\title{
8. MESOZOIC AND CENOZOIC CALCAREOUS NANNOFOSSILS RECOVERED \\ BY DSDP LEG 36 DRILLING ON THE FALKLAND PLATEAU, SOUTHWEST ATLANTIC SECTOR OF THE SOUTHERN OCEAN
}

Sherwood W. Wise, Jr., and Frank H. Wind, Antarctic Marine Geology Research Facility, Department of Geology, Florida State University, Tallahassee, Florida

\begin{abstract}
Three DSDP Leg 36 sites drilled in the high latitudes of the southwestern Atlantic Ocean yielded thick sections of nannofossilbearing sediments of Late Jurassic, Cretaceous, and Tertiary age. Oxfordian, Albian, and Maestrichtian assemblages are diverse and well preserved. Aptian, Cenomanian, and Santonian nannofloras are generally of low diversity and poorly preserved; the result of unfavorable paleoecological and depositional conditions.

High latitude provincial forms are common in the Late Cretaceous and Tertiary sections; these have prompted the proposal of new zones or subzones for the Albian (Biscutum constans, Sollasites falklandensis, and Tranolithus orionatus subzones) and Paleocene (Heliolithus universus Zone). Severe climatic conditions limit post-Eocene coccolith assemblages to fewer than one-dozen species; thus zonations are virtually unworkable for the Neogene section present.

Exceptional preservation of some assemblages, particularly those of the Oxfordian, Maestrichtian, and certain levels of the Aptian permitted the identification of 32 new calcareous nannofossil species as well as 12 new genera (Acuturris, Axopodorhabdus, Boletuvelum, Centosphaera, Misceomarginatus, Monomarginatus, Okkolithus, Orastrum, Phanulithus, Pharus, Seribiscutum, Teichorhabdus).
\end{abstract}

TABLE OF CONTENTS

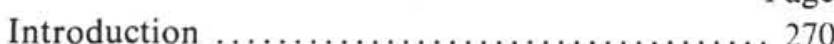

Site Summaries .......................... 270

Zonation ............................ 271

Methods and Procedures ....................... 274

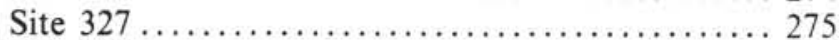

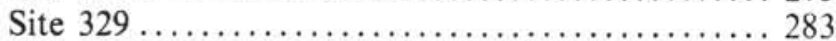

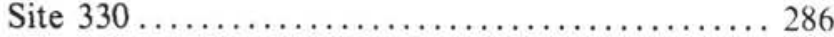

Other DSDP Leg 36 Sites ...................... 289

Paleoecology and Assemblage Characteristics .... 291

Systematic Paleontology ..................... 295

Cenozoic ............................... 295

Genus COCCOLITHUS Schwarz, $1894 \ldots 295$

Genus FASCICULITHUS Bramlette and

Sullivan, 1961 ....................... 295

Genus HELIOLITHUS Bramlette and Sullivan,

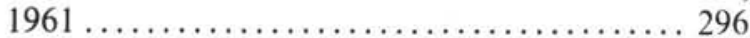

Genus HORNIBROOKINA Edwards, 1973296

Genus TOWEIUS Hay and Mohler, 1967 . 296

Mesozoic............................. 296 Genus ACUTURRIS Wind and Wise, n. gen.296 Genus AXOPODORHABDUS Wind and Wise, n. gen. .......................... 297 Genus BISCUTUM Black, 1959 ......... 297 Genus BOLETUVELUM Wind and Wise, n. gen. ............................ 298 Genus BRONSONIA Bukry, 1969 ....... 299 Genus CENTOSPHAERA Wind and Wise, $n$. gen. ............................... 299
Genus COROLLITHION Stradner, 1961 .. 299 Genus CRETARHABDUS Bramlette and Martini, $1964 \ldots \ldots \ldots \ldots \ldots \ldots \ldots \ldots \ldots \ldots . \ldots \ldots$ Genus ETHMORHABDUS Noel, 1965 ... 300 Genus GARTNERAGO Bukry, $1969 \ldots \ldots .300$ Genus LAGUNCULA Black, $1971 \ldots \ldots . .300$ Genus LAPIDAECASSIS Black, 1971 .... 300 Genus LUCIANORHABDUS Deflandre,

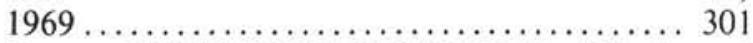
Genus MISCEOMARGINATUS Wind and Wise, n. gen. ..................... 301 Genus MONOMARGINATUS Wind and Wise, n. gen. .......................... 301 Genus OCTOCYCLUS Black, 1972 ...... 302 Genus OKKOLITHUS Wind and Wise, $n$.

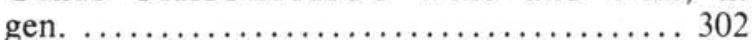
Genus ORASTRUM Wind and Wise, n. gen. Genus OTTARIANUS Risatti, 1973 ...... 303 Genus PALAEOPONTOSPHAERA Noël,

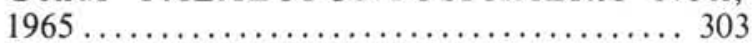
Genus PHANULITHUS Wind and Wise, $\mathrm{n}$. gen. .............................. 304 Genus PHARUS Wind and Wise, n. gen... 304 Genus PODORHABDUS Noël, 1965, emend. Wind and Wise ...................... 305 Genus POLYPODORHABDUS Noël, 1965305 Genus PREDISCOSPHAERA Vekshina,

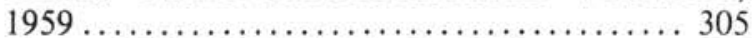
Genus RETECAPSA Black, $1971 \ldots \ldots \ldots . . .305$ Genus RUSSELLIA Risatti, 1973 ....... 306 Genus STEPHANOLITHION Noël, 1956306 
Genus STRIATOMARGINIS Prins ex Rood,

Hay and Barnard, $1973 \ldots \ldots \ldots \ldots \ldots . \ldots 6$

Genus TEICHORHABDUS Wind and Wise, n.

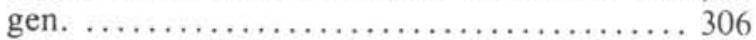

Genus TETRAPODORHABDUS Black,

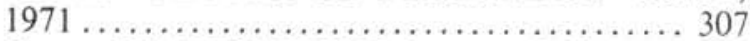

Genus TRANOLITHUS Stover, 1966 .... 307

Genus TUBODISCUS Thierstein, 1973 .. 307

Genus VEKSHINELLA Loeblich and Tappan,

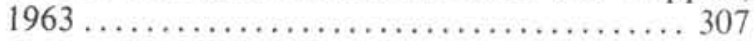

Genus WATZNAUERIA Reinhardt, 1964. 308

Genus ZEUGRHABDOTUS Reinhardt,

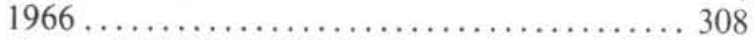

Genus ZYGODISCUS Bramlette and Sullivan,

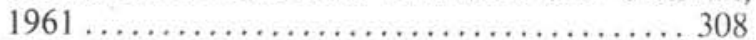

Additional Mesozoic Taxa ............... 310

Genus BRAARUDOSPHAERA Deflandre,

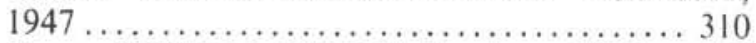

Genus COROLLITHION Stradner, $1961 \ldots 310$

Genus SERIBISCUTUM Filewicz, Wind and

Wise, n. gen. ....................... 310

Genus SOLLASITES Black, $1967 \ldots \ldots \ldots . . .311$

Acknowledgments ....................... 311

References .............................. 311

Plates .................................... 314

\section{INTRODUCTION}

Leg 36 (Southwest Atlantic) of the Deep Sea Drilling Project recovered 108 cores containing 580 meters of sediment taken at six sites from the Drake Passage to the Argentine Basin (Figure 1). Significant numbers of calcareous nannoplankton were recovered only at Sites 327, 329, and 330 located on the Falkland Plateau, an intermediate depth aseismic feature underlain by continental basement which extends east across the Southwest Atlantic from the Falkland Islands near the southern tip of South America. The three closely spaced sites at about $50^{\circ} \mathrm{S}$ latitude on the eastern elevated portion (Maurice Ewing Bank) of the Falkland Plateau, however, provide for this region a most extensive record of calcareous deposition dating back to the Late Jurassic. Sediments recovered provide an excellent opportunity to study the biostratigraphic and biogeographic distribution of older (Mesozoic) calcareous nannofossils from the higher latitudes of the Southern Ocean.

\section{Site Summaries}

A single surface core at Site 326 in the Drake Passage yielded scarce Pleistocene coccoliths, whereas cores taken at the deep-water Sites 328 (Malvinas Outer Basin) and 331 (Argentine Basin) were barren except for rare reworked Mesozoic forms near the base of Site 328.

On the Falkland Plateau, moderately nannoliferous Oxfordian sapropelic clays at Site 330 overlay continental sediments and gneissose basement and underlay disconformably a poorly fossiliferous Aptian sequence of similar lithology. The latter unit grades upsection into a more open marine Albian-Cenomanian nannofossil ooze which was also sampled at Site 327 located about $10 \mathrm{~km}$ away. The separation of Africa and South America via sea-floor spreading caused the plateau to

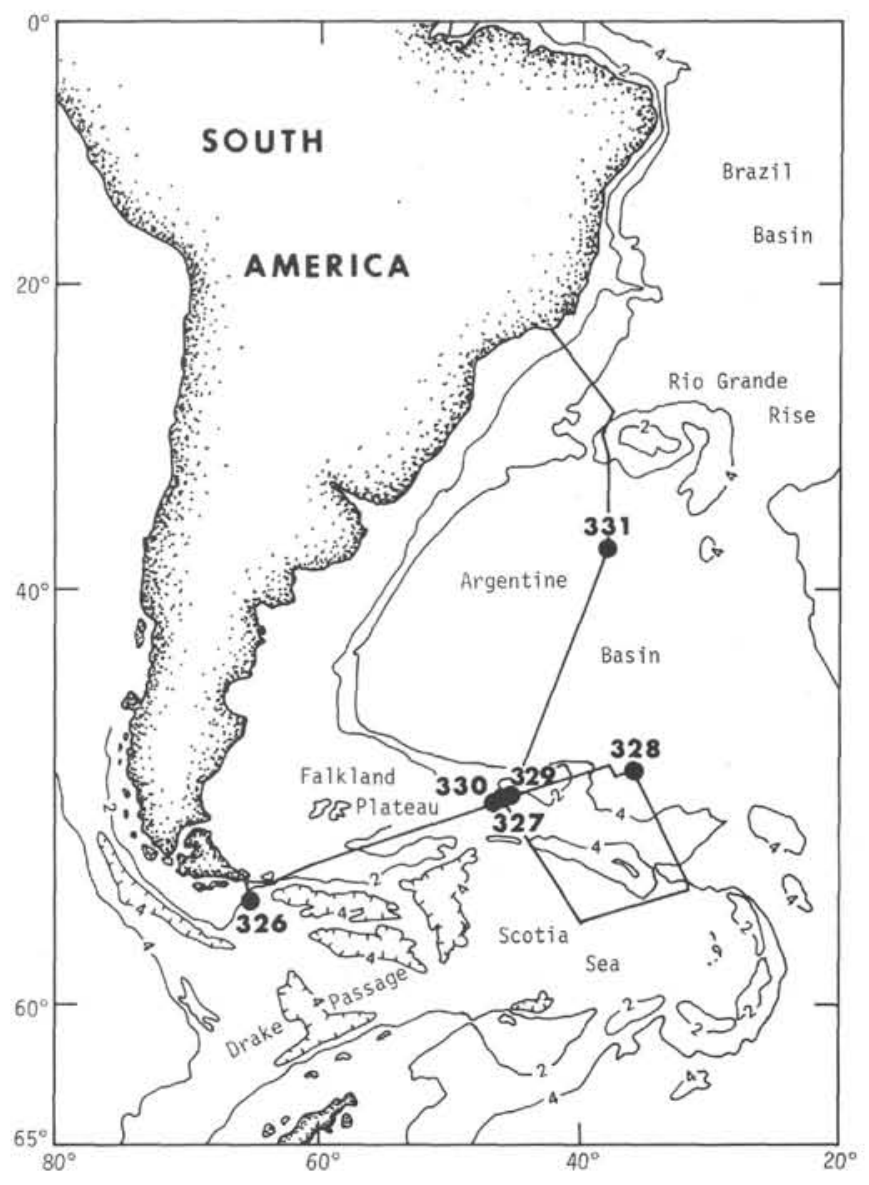

Figure 1. Site locations, DSDP Leg 36.

undergo tectonic subsidence during late AlbianCenomanian times. This was followed by increased bottom current activity and by a relative rise in the carbonate compensation depth which resulted in a sedimentary hiatus representing most of TuronianCenomanian time. Santonian sediments recovered contain only a sparse residual coccolith assemblage deposited near the base of the CCD. Coccolith ooze deposition was renewed at Site 327 during the late Campanian-Maestrichtian interval, but ceased abruptly as the CCD shoaled during the "Terminal Cretaceous Event" (Worsley, 1971) which closed the Mesozoic era. The Maestrichtian coccolith assemblages show definite evidence of climatic cooling.

A hard ground at the top of the Maestrichtian carbonate is overlain disconformably by upper Paleocene zeolitic clays and diatom ooze. The latter contains coccoliths only toward the top of the section where heavily etched specimens were able to accumulate as a result of the gradual descent of the CCD which followed the "Terminal Cretaceous Event." Successive low stands of the CCD during the late Paleocene and mid early Eocene are recorded at Sites 327 and 329.

Site 329 was drilled upslope from Site 327 in a carbonate facies deposited well above the CCD. The Pleistocene to Paleocene section recovered there overlaps stratigraphically the top of the carbonate-poor section drilled at Site 327. A 20-meter sampling gap separates the lower Eocene chalk at Site 329 from 40 
meters of Oligocene chalk above. The only evidence of middle or late Eocene deposition in the area consists of sparse upper Eocene coccoliths in the topmost sediments of Sites 327 and 330. The presence of Discoaster in the Paleocene and Eocene sediments and its absence in the Oligocene indicate further cooling by mid-Tertiary times. The Oligocene is overlain disconformably by a thick Miocene coccolith-diatom ooze which blankets the higher elevations on the Maurice Ewing Bank. Conspicuous reworking of Oligocene coccoliths throughout this sequence indicates the presence of strong bottom currents during the deposition of the unit. Cessation of carbonate deposition at the top of this unit indicates an upward excursion of the CCD which prevented accumulation of coccoliths at Site 329 until latest Pleistocene time as evidenced by an abundance of Emiliania huxleyi at the very top of the section.

Detailed discussion of the biostratigraphy, systematic paleontology, paleoecology, and diagenesis of the material recovered are presented in the following sections of this report. Calcareous nannofossil taxa considered are given in Table 1 (listed in alphabetical order of species epithets). A summary of coccolith occurrences by site measured against a low latitude biostratigraphic zonation (primarily from Bukry, 1973) is provided in Table 2, whereas Table 3 gives a summary of the datum levels and zones adopted in this report for use in the range charts and lithologic logs. Most of these datum levels have been defined during numerous studies conducted over the past 10 years. Those used here are chosen primarily from among those compiled for the Cenozoic by Bukry (1973), for the Cretaceous by Thierstein $(1973,1974)$, and for the Jurassic by Barnard and Hay (1974).

\section{Zonation}

As with other calcareous planktonic organisms, coccoliths attain their maximum diversity in the tropics. Many present-day tropical forms used as guide fossils are neither found in the higher latitudes nor are they systematically replaced poleward by other taxa endemic to cooler waters as is the case with most siliceous planktonic microfossil groups. For this reason, the number of usable coccolith index species decreases with increasing latitude; thus zonal intervals must be expanded poleward with consequent loss of biostratigraphic resolution. As noted by others who have participated on high latitude DSDP legs, this problem is most acute for Neogene coccoliths. The general climatic deterioration which occurred during the late Cenozoic resulted in a contraction of climatic belts and a steepening of temperature gradients poleward. Low latitude coccolith zonations from the Oligocene onwards are essentially useless for Leg 36 material. For most of the long Jurassic-Cretaceous interval, however, during which global climates were generally more equitable, tropical zonations can be applied to the Falkland Plateau sequence without difficulty. The only exception to this is the Campanian-Maestrichtian interval. The temperate upper Paleocene-Eocene section can also be zoned reasonably well since zonal schemes for this interval are based on mid-latitude sections in California (Bramlette and Sullivan, 1961) and France (Hay and Mohler, 1967).
TABLE 1

Calcareous Nannofossil Species Considered in This Report (listed in alphabetical order of the species epithets)

\section{CENOZOIC}

Cyclicargolithus abisectus (Muller) Wise, 1973

Chiasmolithus altus Bukry and Percival, 1971

Markalius astroporus (Stradner) Hay and Mohler, 1967

Hornibrookina australis Edwards and Perch-Nielsen, 1975

Discoaster barbadiensis Tan Sin Hok, 1927

Chiasmolithus bidens (Bramlette and Sullivan) Hay and Mohler, 1967

Zygrhablithus bijugatus (Deflandre) Deflandre, 1959

Reticulofenestra bisecta (Hay, Mohler, and Wade) Roth, 1970

Prinsius bisulcus (Stradner) Hay and Mohler, 1967

Discoaster brouweri Tan Sin Hok, 1927

Toweius craticulus Hay and Mohler, 1967

Chiasmolithus danicus (Brotzen) Bramlette and Martini, 1964

Discoaster deflandrei Bramlette and Riedel, 1954

Neochiastozygus distentus (Bramlette and Sullivan) Perch-Nielsen, 1971

Ellipsolithus distichus (Bramlette and Sullivan) Sullivan, 1964

Zygolithus dubius Deflandre in Deflandre and Fert, 1954

Coccolithus eopelagicus (Bramlette and Riedel) Bramlette and Sullivan, 1961

Toweius eminens (Bramlette and Sullivan) Perch-Nielsen, 1971

Chiasmolithus expansus (Bramlette and Sullivan) Gartner, 1970

Cyclicargolithus floridanus (Roth and Hay) Bukry, 1971

Coccolithus formosus (Kamptner) Wise, 1973

Cyclicargolithus gammation (Bramlette and Sullivan)

Discoaster gemmifer Stradner, 1967

Discoaster germanicus Martini, 1958

Chiasmolithus grandis (Bramlette and Riedel) Gartner, 1970

Thoracosphaera heimi (Lohmann) Kamptner, 1954

Discoaster helianthus Bramlette and Sullivan, 1961

Emiliania huxleyi (Lohmann) Hay and Mohler in Hay et al., 1967

Fasciculithus involutus Bramlette and Sullivan, 1961

Helicopontosphaera kamptneri Hay and Mohler in Hay et al., 1967

Discoasteroides kuepperi (Stradner) Bramlette and Sullivan, 1961

Cyclococcolithina Zeptopora (Murray and Blackmann) Wilcoxon, 1970

Discoaster mediosus Bramlette and Sullivan, 1961

Discoasteroides megastypus Bramlette and Sullivan, 1961

Neochiastozygus modestus Perch-Nielsen, 1971

Sphenolithus moriformis (Brönimann and Stradner) Bramlette and Wilcoxon, 1967

Discoaster multiradiatus Bramlette and Riedel, 1954

Tribrachiatus orthostylus Shamral, 1963

Coccolithus pelagicus (Wallich) Schiller, 1930

Heliolithus perch-nielseni Wind and Wise, n. sp.

Discoaster nobilis Martini, 1961

Gephyrocapsa oceanica Kamptner, 1943

Neococcolithus protens (Bramlette and Sullivan) Hay and Mohler, 1967

Reticulofenestra psuedoumbilica (Gartner) Gartner, 1969

Ismolithus recurvus Deflandre in Deflandre and Fert, 1954

Coccolithus robustus (Bramlette and Sullivan) Wind and Wise n. comb.

Discoaster saipanensis Bramlette and Riedel, 1954

Thoracosphaera saxea Stradner, 1961

Discoaster tani Bramlette and Riedel, 1954

Cruciplacolithus tenuis (Stradner) Hay and Mohler, 1967

Toweius tovae Perch-Nielsen, 1971

Reticulofenestra umbilica (Levin) Martini and Ritzkowski, 1968

Heliolithus universus Wind and Wise, n. sp.

Discoaster varabilis Martini and Bramlette, 1963

\section{MESOZOIC}

Vekshinella aachaena (Bukry) Wind and Wise, $\mathrm{n}$. comb.

Corollithion achylosum (Stover) Thierstein, 1971

Tetralithus aculeus (Stradner) Gartner, 1968

Phanulithus additus Wind and Wise, n. sp.

Braarudosphaera africana Stradner, 1961

Retecapsa angustiformata Black, 1971

Parhabdolithus angustus (Stradner) Stradner, Adamiker, and Maresch, 1968 
Zygodiscus anthophorus (Deflandre) Wind and Wise, $\mathrm{n}$. comb. Lucianorhabdus arborius Wind and Wise, n. sp. Lucianorhabdus arcuatus Forchheimer, 1972

Orastrum asarotum Wind and Wise, n. gen., n. sp. Parhabdolithus asper (Stradner, 1963) Manivit, 1971

Okkolithus australis Wind and Wise, n. gen., n. sp. Centosphaera barbata Wind and Wise, n. gen., n. sp. Watznaueria barnesae (Black) Perch-Nielsen, 1968 Zygodiscus bicrescenticus (Stover) Wind and Wise, n. comb. Flabellites biforaminis Thierstein, 1973

Braarudosphaera bigelowi (Gran and Braarud) Deflandre, 1947 Stephanolithion bigoti Deflandre, 1939

Seribiscutum bijugatum Filewicz, Wind, and Wise, n. gen., n. sp. Watznaueria biporta Bukry, 1969

Biscutum boletum Wind and Wise, n. sp.

Watzmaueria britannica (Stradner) Reinhardt, 1964

Ethmorhabdus sp. aff. E. camaratus Bukry

Boletuvelum candens Wind and Wise, n. gen., n. sp.

Lithraphidites carniolensis Deflandre, 1963

Lucianorhabdus cayeuxi Deflandre, 1959

Cruciellipsis chiasta (Worsley) Thierstein, 1972

Zeugrhabdus choffati Rood, Hay, and Barnard, 1973

Watznaueria communis Reinhardt, 1964

Cretarhabdus conicus Bramlette and Martini, 1964

Biscutum constans (Gorka) Black, 1959

Lapideacassis cornuta Wind and Wise, n. comb.

Cretarhabdus coronadventis Reinhardt, 1966

Biscutum coronum Wind and Wise, n. sp.

Cretarhabdus crenulatus Bramlette and Martini, 1964 emend.

Thierstein, 1971

Prediscosphaera cretacea (Arkhangelsky) Gartner, 1968

Hexapodorhabdus cuvillieri Noèl, 1965

Axopodorhabdus cylindratus (Noel) Wind and Wise, n. comb.

Arkhangelskiella cymbiformis Vekshina, 1959

Tetrapodorhabdus decorus (Deflandre and Fert) Wind and Wise, n. comb.

Micula decussata Vekshina, 1959

Vekshinella dibrachiata Gartner, 1968

Axopodorhabdus dietzmanni (Reinhardt) Wind and Wise, n. comb.

Zygodiscus diplogrammus (Deflandre and Fert) Gartner, 1968

Biscutum dissimilis Wind and Wise, $\mathrm{n}$. $\mathrm{sp}$.

Gartnerago diversum Thierstein in Roth and Thierstein, 1972

Laquncula dorotheae Black, 1971

Palaeopontosphaera dubis Noèl, 1965

Cribrosphaera ehrenbergi (Arkhangelsky) Deflandre, 1952

Vekshinella elliptica Gartner, 1968

Nannoconus elongatus Brönimann, 1955

Parhabdolithus embergeri (Noël) Stradner, 1963

Broinsonia enormis (Shumenko) Manivit, 1971

Zeugrhabdotus erectus (Deflandre) Reinhardt, 1965

Palaepontosphaera erismata Wind and Wise, n. sp.

Polypodorhabdus escaigi Noèl, 1965

Teichorhabdus ethmos Wind and Wise, n. gen., n. sp.

Eiffelithus eximius (Stover) Perch-Nielsen, 1968

Sollasites falklandensis Filewicz, Wind, and Wise, n. sp.

Lithastrinus floralis Stradner, 1962

Scapholithus fossilis Deflandre and Fert, 1954

Corollithion fragilis (Rood and Barnard) Wind and Wise, n. comb. Nephrelithus frequens Gorka, 1957

Ethmorhabdus? frondosus Wind and Wise, n. sp.

Marthasterites furcatus (Deflandre and Fert) Deflandre, 1959

Tranolithus gabalus Stover, 1966

Ethmorhabdus gallicus Noë1, 1965

Chiastozygus garrisonii Bukry, 1969

Braarudosphaera gartneri Filewicz, Wind and Wise, n. sp.

Corollithion geometricum (Gorka) Manivit, 1971

Ottavianus giannus Risatti, 1973

Lapideacassis glans Black, 1971

Tetralithus gothicus Deflandre, 1959

Podorhabdus grassei Noèl emend. Wind and Wise
Corollithion haai Filewicz, Wind, and Wise, n. sp.

Corillithion helotatus Wind and Wise, $\mathrm{n}$. sp.

Micrantholithus hoschulzi (Reinhardt) Thierstein, 1971

Prediscosphaera honjoi Bukry, 1969

Sollasites horticus (Stradner, Adamiker, and Maresch) Black, 1968

Vekshinella imbricata Gartner, 1968

Parhabdolithus infinitus (Worsley) Thierstein, 1974

Stephanolithion laffittei Noèl, 1970

Chiastozygus litterarius (Gorka) Manivit, 1971

Cretarhabdus loriei Gartner, 1968

Sollasites lowei (Bukry) Rood, Hay, and Barnard, 1971

Kamptnerius magnificus Deflandre, 1959

Biscutum magnum Wind and Wise, n. sp.

Cyclagelosphaera margareli Noël, 1965

Lapideacassis mariae Black emend. Wind and Wise

Staurolithites matalosus (Stover) Cepek and Hay, 1969

Braarudosphaera minuta Filewicz, Wind, and Wise, n. sp.

Diadorhombus minutus Rood, Hay, and Barnard, 1971

Nannoconus multicadus Deflandre and Deflandre, 1960

Russellia multiplus (Perch-Nielsen) Wind and Wise, n. comb.

Zeugrhabdotus noeli Rood, Hay, and Barnard, 1971

Dodekapodorhabdus noelii Perch-Nielsen, 1968

Biscutum notaculum Wind and Wise, n. sp.

Gartnerago obliquum (Stradner) Reinhardt, 1970

Phanulithus obscurus (Deflandre) Wind and Wise, n. comb.

Ahmuellerella octoradiata (Gorka) Reinhardt, 1966

Tranolithus orionatus Stover, 1966

Phanulithus ovalis (Stradner) Wind and Wise, n. comb.

Watznaueria ovata Bukry, 1969

Broinsonia parca (Stradner) Bukry, 1969

Vekshinella? parma Wind and Wise, n. sp.

Repagulum parvidentatum (Deflandre and Fert) Forchhelmer, 1972

Monomarginatus pectinatus Wind and Wise, n. gen., n. sp.

Manivitella pemmatoidea (Deflandre ex Manivit) Thierstein, 1971

Misceomarginatus pleniporus Wind and Wise, n. gen., n. sp.

Chiastozygus cf. C. plicatus Gartner, 1968

Seribiscutum primitivum (Thierstein) Filewicz, Wise, and Wind, n. comb.

Chiastozygus propagularia Bukry, 1969

Vekshinella quadriarculla (Noèl) Rood, Hay, and Barnard, 1971

Monomarginatus quaternarius Wind and Wise, n. gen., n. sp.

Octocyclas reinhardtii (Bukry) Wind and Wise, n. comb.

Watznaueria reinhardti Rood, Hay, and Barnard, 1971

Corollithion rhombicum (Stradner and Adamiker) Bukry, 1969

Bidiscus rotatorius Bukry, 1969

Acuturris scotus (Risatti) Wind and Wise, $\mathrm{n}$. comb.

Gartnerago segmentatum (Stover) Thierstein, 1974

Corollithion senarius Wind and Wise, $\mathrm{n}$. $\mathrm{sp}$.

Zygodiscus sigmoides Bramlette and Sullivan, 1961

Broinsonia signata (Noël) Noèl, 1979

Corollithion signum Stradner, 1963

Corollithion silvaradion Filewicz, Wind, and Wise, n. sp.

Pharus simulacrum Wind and Wise, n. gen., n. sp.

Tranolithus skoglundii Forchheimer, 1972

Arkhangelskiella specillata Vekshina, 1959

Prediscosphaera spinosa (Bramlette and Martini) Gartner, 1968

Parhabdolithus splendens (Deflandre) Noèl, 1969

Prediscosphaera stoveri (Perch-Nielsen) Wind and Wise, n. comb.

Vekshinella stradneri Rood, Hay, and Barnard, 1971

Watznaneria supracretacea (Reinhardt) Wind and Wise, n. comb.

Cretarhabdus surrirellis (Deflandre and Fert) Reinhardt, 1979

Sollasites thiersteini Filewicz, Wind, and Wise, n. sp.

Eiffellithus trabeculatus (Gorka) Reinhardt and Gorka, 1967

Lapideacassis tricornus Wind and Wise, n. sp.

Retecapsa tridentata Wind and Wise, n. sp.

Nannoconus truitti Brönnimann, 1955

Eiffellithus turriseiffeli (Deflandre and Fert) Reinhardt, 1965

Broinsonia verecundia Wind and Wise, $n$. $\mathrm{sp}$.

Turbodiscus sp. cf. T. verenae Thierstein, 1973

Heteromarginatus wallacei Bukry, 1969 
TABLE 2

Zonal and Geologic Age Assignments for Calcareous Nannofossil Assemblages in DSDP Leg 36 Cores $^{\mathrm{a}}$

\begin{tabular}{|c|c|c|c|c|c|c|}
\hline \multirow{2}{*}{\multicolumn{2}{|c|}{ Age }} & \multirow[b]{2}{*}{ Zone } & \multicolumn{4}{|c|}{ Site } \\
\hline & & & 326 & 327 & 329 & 330 \\
\hline \multicolumn{7}{|c|}{ CENOZOIC } \\
\hline Holocene & & Emiliania huxleyi & 1 & $1,1 \mathrm{~A}$ & 1 & \\
\hline \multirow{2}{*}{\multicolumn{2}{|c|}{ Pleistocene }} & Gephyrocapsa oceanica & & & & \\
\hline & & Gephyrocapsa doronicoides & & & & \\
\hline \multirow{3}{*}{ Pliocene } & 节 & Discoaster brouweri & & & & \\
\hline & 츨 & Reticulofenestra pseudoumbilica & & & & \\
\hline & 五 & Ceratolithus tricorniculatus & & & s. & \\
\hline \multirow{9}{*}{ Miocene } & $\Xi$ & Discoaster quinqueramus & & & & \\
\hline & 3 & Discoaster neohamatus & & & \multirow{5}{*}{$1-26$} & \\
\hline & \multirow{4}{*}{$\frac{0}{\frac{7}{2}}$} & Discoaster hamatus & & & & \\
\hline & & Catinaster coalitus & & & & \\
\hline & & Discoaster exilis & & & & \\
\hline & & Sphenolithus heteromorphus & & & & \\
\hline & \multirow{7}{*}{ 촘 } & Helicopontosphaera ampliaperta & & & \multirow{3}{*}{$27 ?$} & \\
\hline & & Sphenolithus belemnos & & & & \\
\hline & & Triquetrorhabdulus carinatus & & & & \\
\hline \multirow{4}{*}{ Oligocene } & & Sphenolithus ciperoensis & & & \multirow{2}{*}{$28-29$} & \\
\hline & & Sphenolithus distentus & & & & \\
\hline & & Sphenolithus predistentus & & & \multirow{2}{*}{$30-31$} & \\
\hline & & Helicopontosphaera reticulata & & & & \\
\hline \multirow{7}{*}{ Eocene } & i & Discoaster barbadiensis & & & & $1 \mathrm{~A}$ \\
\hline & \multirow{3}{*}{ 竎 } & Reticulofenestra umbilica & & & & \\
\hline & & Nannotetrina quadrata & & & & \\
\hline & & Discoaster sublodoensis & & & & \\
\hline & \multirow{3}{*}{ 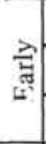 } & Discoaster lodoensis & & & & \\
\hline & & Tribrachiatus orthostylus & & \multirow{2}{*}{$2 \mathrm{~A}$} & \multirow{2}{*}{32} & \\
\hline & & Discoaster diastypus & & & & \\
\hline \multirow{6}{*}{\multicolumn{2}{|c|}{ Paleocene }} & Discoaster multiradiatus & & $3 \mathrm{~A}-4 \mathrm{~A}$ & $32-33$ & \\
\hline & & Discoaster nobilis & & \multirow{4}{*}{$5 \mathrm{~A}-7 \mathrm{~A}$} & & \\
\hline & & Discoaster mohleri & & & & \\
\hline & & Heliolithus kleinpellii & & & & \\
\hline & & Fasciculithus tympaniformis & & & & \\
\hline & & Cruciplacolithus tenuis & & & & \\
\hline & & MESOZC & & & & \\
\hline Maestrichtian & & Nephrolithus frequens & & $10 \mathrm{~A}-12 \mathrm{~A}$ & & \\
\hline 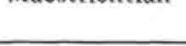 & & Lithraphidites quadratus & & 134 & & \\
\hline Camnanian & & Tetralithus trifidus & & $10 \mathrm{n}$ & & \\
\hline & & Eiffellithus eximius & & & & \\
\hline Santonian & & Marthastenites funcatus & & $14 \mathrm{~A}$ & & \\
\hline Coniacian & & Kamptnerius magnificus & & & & \\
\hline Turonian & & Micula decusata & & & & \\
\hline & & Gartnerago obliquum & & & & \\
\hline
\end{tabular}


TABLE 2 - Continued

\begin{tabular}{|c|c|c|c|c|c|}
\hline \multirow[b]{2}{*}{ Age } & \multirow[b]{2}{*}{ Zone } & \multicolumn{4}{|c|}{ Site } \\
\hline & & 326 & 327 & 329 & 330 \\
\hline \multicolumn{6}{|c|}{ MESOZOIC } \\
\hline Cenomanian & Lithraphidites alatus & & $14 \mathrm{~A}$ & & \multirow{2}{*}{$\begin{array}{c}4 \mathrm{~A}-5 \mathrm{~A}, \\
\text { Bit }\end{array}$} \\
\hline \multirow{2}{*}{ Albian } & Eiffellithus turriseiffeli & & $15 \mathrm{~A}$ & & \\
\hline & Prediscosphaera cretacea & $16 \mathrm{~A}-21 \mathrm{~A}$ & $16 \mathrm{~A}-21 \mathrm{~A}$ & & $1-2$ \\
\hline \multirow{2}{*}{ Aptian } & Parhabdolithus angustus & & $22 \mathrm{~A}-23 \mathrm{~A}$ & & \\
\hline & Chiastozygus litterarius & & $24 \mathrm{~A}-25 \mathrm{~A}$ & & 3 ? \\
\hline Neocomian & & & $26 \mathrm{~A}-27 \mathrm{~A}$ & & 4 \\
\hline \multirow{2}{*}{ Kimmeridgian } & Parhabdolithus embergeri & & & & \\
\hline & Watznaueria communis & & & & \\
\hline \multirow{2}{*}{ Oxfordian } & Vekshinella stradneri & & & & $5-8$ \\
\hline & Corollithion geometricum & & & & $9-14$ ? \\
\hline
\end{tabular}

${ }^{a}$ Measured against standard low or middle latitude zonations for the Cenozoic (Bukry, 1973) and Mesozoic (Thierstein, 1974, 1976; Barnard and Hay, 1974).

A few taxa we studied are endemic to or flourished in cooler waters, and these offer some hope for further refinement of a high latitude coccolith zonation when more is learned of their ranges. At present, cooler water forms such as Isthmolithus recurvus and Nephrolithus frequens are commonly used for high latitude zonations of the upper Eocene and Maestrichtian, respectively. Other such forms which are common to abundant in Leg 36 material and which should be useful southern hemisphere correlations are:

Tertiary: Chiasmolithus altus (Oligocene), Heliolithus universus n.sp. (Paleocene).

Cretaceous: Biscutum dissimilis n.sp., Seribiscutum primitivum, Sollasites falklandensis n.sp.

Heliolithus universus is used to establish new zones for the upper Paleocene of Hole 327A. These zones are based on third-order datum levels which at present should be considered of regional importance only. These new zones are:

\section{Fasciculithus involutus Zone}

Definition: Interval from the first occurrence of Fasciculithus involutus to the first common occurrence of Heliolithus universus.

Reference locality: Hole $327 \mathrm{~A}, 64$ to 42 meters.

Remarks: The true evolutionary first occurrence of Fasciculithus involutus is not observed in Hole $327 \mathrm{~A}$ due to a hiatus.

\section{Heliolithus universus Zone}

Definition: Interval from the first common occurrence of Heliolithus universus to the first occurrence of Discoaster multiradiatus.

Reference locality: Hole $327 \mathrm{~A}, 47$ to 42 meters.

Sollasites falklandensis is used to establish subzones for the early-middle Albian Prediscosphaera cretacea Zone which at Sites 327 and 330 encompasses at least 170 meters of section. These subzones are also based on third-order datum levels which at present should be considered of regional importance only. These new subzones are:

\section{Sollasites falklandensis Subzone}

Definition: Interval from the first occurrence of Prediscosphaera cretacea to the first common occurrence of Tranolithus orionatus.

Reference locality: Hole $327 \mathrm{~A}, 314$ to 230 meters.

\section{Tranolithus orionatus Subzone}

Definition: Interval from the first common occurrence of Tranolithus orionatus to the last occurrence of Sollasites falklandensis.

Reference locality: Hole $327 \mathrm{~A}, 229$ to 223 meters.

\section{Biscutum constans Subzone}

Definition: Interval from the last occurrence of Sollasites falklandensis to the first occurrence of Eiffellithus turriseiffeli.

Reference locality: Hole $327 \mathrm{~A}, 216$ to 185 meters.

In addition to the above, a Corollithion achylosum peak zone is noted in at the base of the Prediscosphaera cretacea Zone ( 314 to $312 \mathrm{~m}$ in Hole 327A). This peak zone is also noted in Core 2 of Site 330.

\section{METHODS AND PROCEDURES}

Selected samples have been studied by electron microscopy using procedures outlined by Wise and Kelts (1972) and Wind (1975). Some specimens were examined both by light and scanning electron microscopy using a method devised by Wind (in preparation).

The abundance of coccolith species in Cenozoic and Cretaceous material examined by light microscopy was tabulated using the method proposed by Hay (1970) and is presented as part of the accompanying range charts. Tabulations were made using standard smearslide preparations examined at a magnification of $\times 1000$. Letters used on the range charts to denote coccolith abundances are keyed to the $\log ($ base $=10)$ of the number of specimens of a particular taxon likely to be observed in any one field of view of the microscope. These and corresponding logs are determined as follows:

$\mathrm{E}=$ extremely abundant, +3 (more than 1000 specimens per field of view at $\times 1000$ ); 
TABLE 3

Calcareous Nannofossil Zones Used in this Report

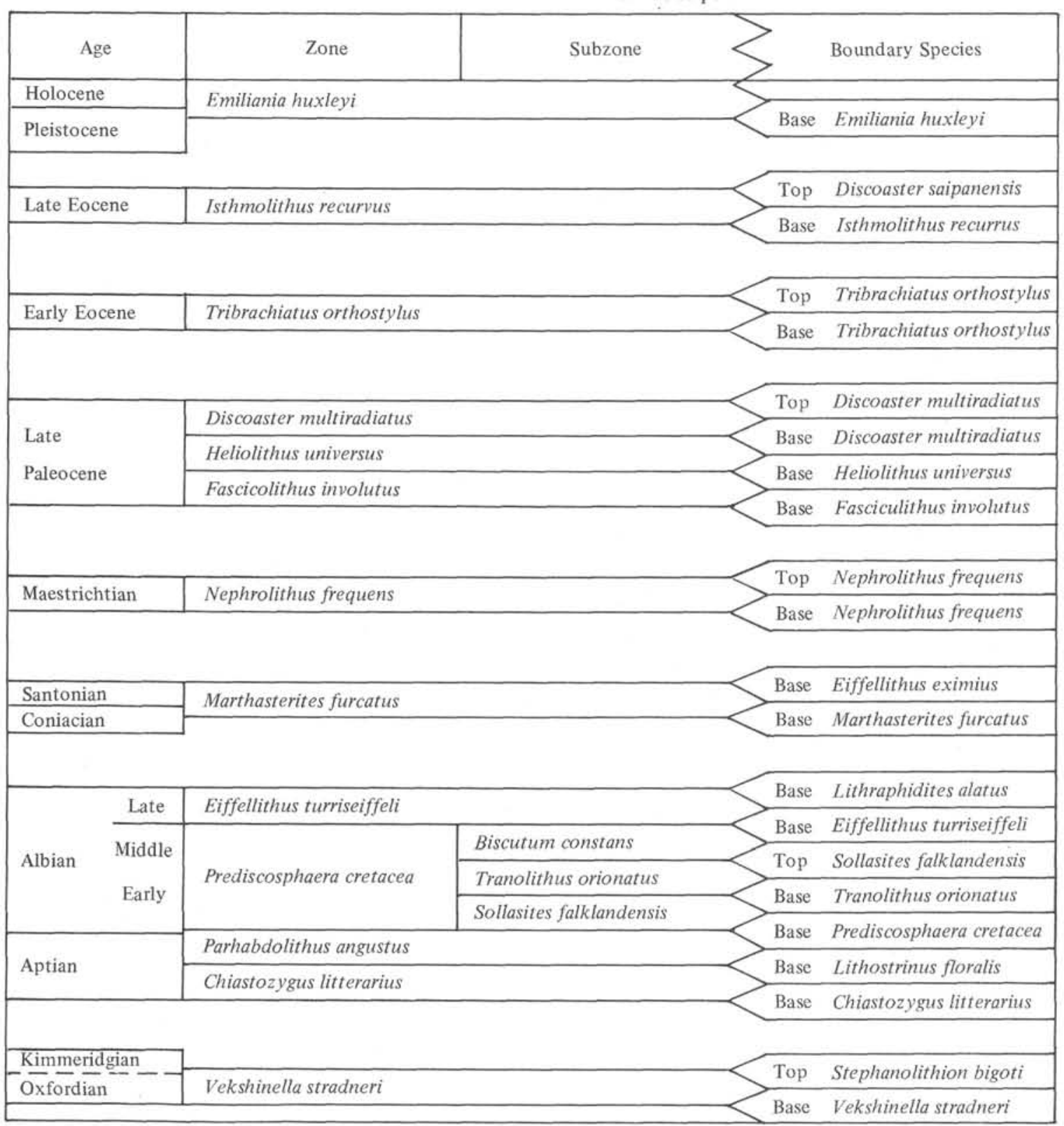

$\mathrm{V}=$ very abundant, +1 (more than 10 specimens per field of view at $\times 1000)$;

$\mathrm{A}=$ abundant, 0 ( 1 to 10 specimens per field of view at $\times 1000)$;

$\mathrm{C}=$ common, -1 ( 1 specimen per 2 to 10 fields of view at $\times 1000)$;

$\mathrm{F}=$ few, $-2(1$ specimen per 11 to 100 fields of view at $\times 1000)$;

$\mathrm{R}=$ rare, -3 (1 specimen per 101 to 1000 fields of view at $\times 1000)$.

Because of their general scarcity, Jurassic samples were concentrated by settling before study by either light or electron microscopy. In order to improve contrast in bright-field and phase-contrast illumination, some Maestrichtian and all Jurassic specimens were prepared for light photomicroscopy by first shadowing lightly with carbon and gold-palladium prior to final preparation with Caedex mounting medium (for example, specimens on Plate 63). Although the coating slightly dims the polarized light figures of most species, much additional information as to species affinity and morphology is obtained when such slides are viewed with plain-light and phase-contrast illumination. Information as to orientation, ultrastructure, and relationships of proximal and distal shields is also more apparent. This reduces the amount of time needed on the scanning electron microscope. The increased resolving power attainable is evident in Jurassic samples, where the precise numbers of perforations in the central area of Polypodorhabdus escaigi can be determined, and in Maestrichtian samples, where the number of elements comprising distal shields of specimens of Watznaueria and Biscutum can be counted.

\section{SITE 327}

\section{$\left(50^{\circ} 52.28^{\prime} \mathrm{S}, 4^{\circ}{ }^{\circ} 47.02^{\prime} \mathrm{W}\right.$; water depth $\left.2400 \mathrm{~m}\right)$}

Site 327 was selected on the western nose of the elevated eastern part of the Falkland Plateau (the 
Maurice Ewing Bank) in order to obtain an older (preNeogene) shallow water reference section for the South Atlantic sector of the Southern Ocean and to date seismic reflectors for regional correlation across this portion of the plateau. The first hole was abandoned in bad weather after recovery of one surface core, but an "A" hole was cored continuously to 113 meters and intermittently to 468.5 meters before excessive ship roll forced abandonment after about half of the sedimentary section was penetrated.

The 28 cores taken at this site penetrated a total of eight distinct lithologic units ranging from Aptian to Pleistocene in age. Calcareous nannofossils are present in nearly all cores, but are abundant only in the Campanian-Maestrichtian, Albian, and minor portions of the Pleistocene. Their abundance and stratigraphic distribution are indicated in Tables 4A and 4B.

Coccolith abundance and diversity in the Aptian was limited by an unfavorable paleoenvironment for their existence and preservation, whereas their accumulation in post-Albian times was controlled primarily by bottom current velocities and by the position of the carbonate compensation level which fluctuated above or below the site of deposition in response to changing paleoclimatic and current circulation patterns.

\section{Biostratigraphy}

The first cores of Holes 327 and 327A recovered Quaternary sands and gravels with interbedded diatomaceous clay. Coccoliths are rare or absent except in a thin lamina of coccolith ooze from Section 327-1-3 that contains abundant small coccoliths (probably the late Pleistocene marker Emiliania huxleyi) as well as common Helicopontosphaera kampteri, Cyclococcolithina leptopora, Coccolithus pelagicus, and rare Gephyrocapsa oceanica.

Cores 2 and 3 penetrated sparsely fossiliferous grayish-orange zeolitic clay of late Paleocene to early Eocene age. Coccoliths in this unit are strongly etched as a result of deposition near the base of the CCD. Rare to common Orthostylus tribrachiatus and rare Chiasmolithus grandis indicate an early Eocene age for the first three sections of Core 2. The lack of other index fossils prevents more precise placement within the early Eocene, therefore these sections are assigned to a rather generalized Orthostylus tribrachiatus Zone.

Also scattered throughout the first three sections of Core 2 are rare to common late Eocene forms such as Discoaster saipanensis, Cyclicargolithus gammation, Reticulofenestra umbilica, and smaller forms of Reticulofenestra. A similar assemblage was encountered at Site 330 drilled nearby. Apparently at Site 327, the upper Eocene material was deposited as a thin veneer over the lower Eocene and was mixed into the latter as the bottom-hole assembly was being spudded in while taking the first two cores.

The bottom 3 meters of Core 327A-2 are barren except for rare contaminants. Core 3 yielded a few heavily etched, dissolution-resistant coccoliths such as Fasciculithus involutus (includes " $F$. tympaniformis"; see Systematic Paleontology) and Discoaster multiradiatus (centers dissolved) which can probably be assigned to the Paleocene Discoaster multiradiatus Zone. D. multiradiatus is known to persist into the lowermost Eocene in other areas, so the Eocene/Paleocene boundary here is picked somewhat arbitrarily. A more diverse flora attributable to this zone is present in the diatom-rich siliceous ooze recovered by the first section and core catcher of Core 4. Included here are forms such as Ellipsolithus disticus along with abundant Chiasmolithus bidens and Toweius eminens. Unfortunately, the other sections of that core contain a slurry of Pleistocene clastics which caved into the hole during drilling and are unsuitable for biostratigraphy.

Discoaster multiradiatus is absent in the siliceous ooze of Core 5; however, the first three sections of that core contain the most abundant and best preserved nannoflora in the Tertiary section. Included there are rather diverse, common to abundant heliolithids, the dominant form of which is described in this report as Heliolithus universus, n.sp. These forms disappear below the top of Section $327 \mathrm{~A}-5-4$, probably due to the increasingly severe dissolution which obliterated all calcareous nannoflora below the second section of Core 7. Only the most dissolution-resistant forms such as Fasciculithus involutus, Chiasmolithus bidens (rims primarily), and various forms of Toweius are consistently present in the lower part of the sequence. For purposes of local correlation, the lower part of the upper Paleocene section is divided into a Fasciculithus involutus Zone and a Heliolithus universus Zone; however, as noted above, the boundary between these may have been controlled largely by dissolution. Overall, the Paleocene-Eocene coccolith flora is somewhat restricted at this site primarily by dissolution and by the high latitude site of deposition; however, rare but wellpreserved taxa such as Discoaster megastypus and Discoaster helianthus indicate occasional influxes of warmer forms into the area.

The siliceous ooze of lithologic Unit 3 gives way to a dark green zeolitic clay (Unit 4) in Cores 9 and 10. Deposited below the CCD, these sediments are barren of all microfossils except for late Paleocene palynomorphs (see Harris, this volume).

Unit 5 consists of Maestrichtian-Campanian foramnanno ooze deposited well above the CCD. Below a meter of chalk hard ground at the top of the section, Unit 5 consists of excellently preserved coccoliths. Their pristine condition is evidenced by the preservation of delicate structures such as large flanges of Kamptnerius magnificus and complete bases and stems of Lucianorhabdus cayeuxi, as well as by a glassy, transparent-translucent low-order gray appearance under crossed nicols. Electron micrographs show that the latter results from the near lack of any secondary calcite overgrowths on the material.

The excellent preservation of the material plus the high latitude location of the drill site account for the large number of new taxa observed in Unit 5. Of the 82 species identified in Maestrichtian and ?late Campanian samples, 19 species are new. Ten new genera are also defined. The new taxa are: 
TABLE 4A

Distribution of Tertiary Calcareous Nannofossils, Holes 327 and 327A

$B=$ barren

$\mathrm{EB}=$ essentially barren

KEY:

$\mathrm{V}=$ very abundan

$\mathrm{A}=$ abundan
$\mathrm{C}=$ common

$F=$ few
$\mathbf{R}=$ rare

reworked (up, down)

$\mathrm{O}=$ overgrown

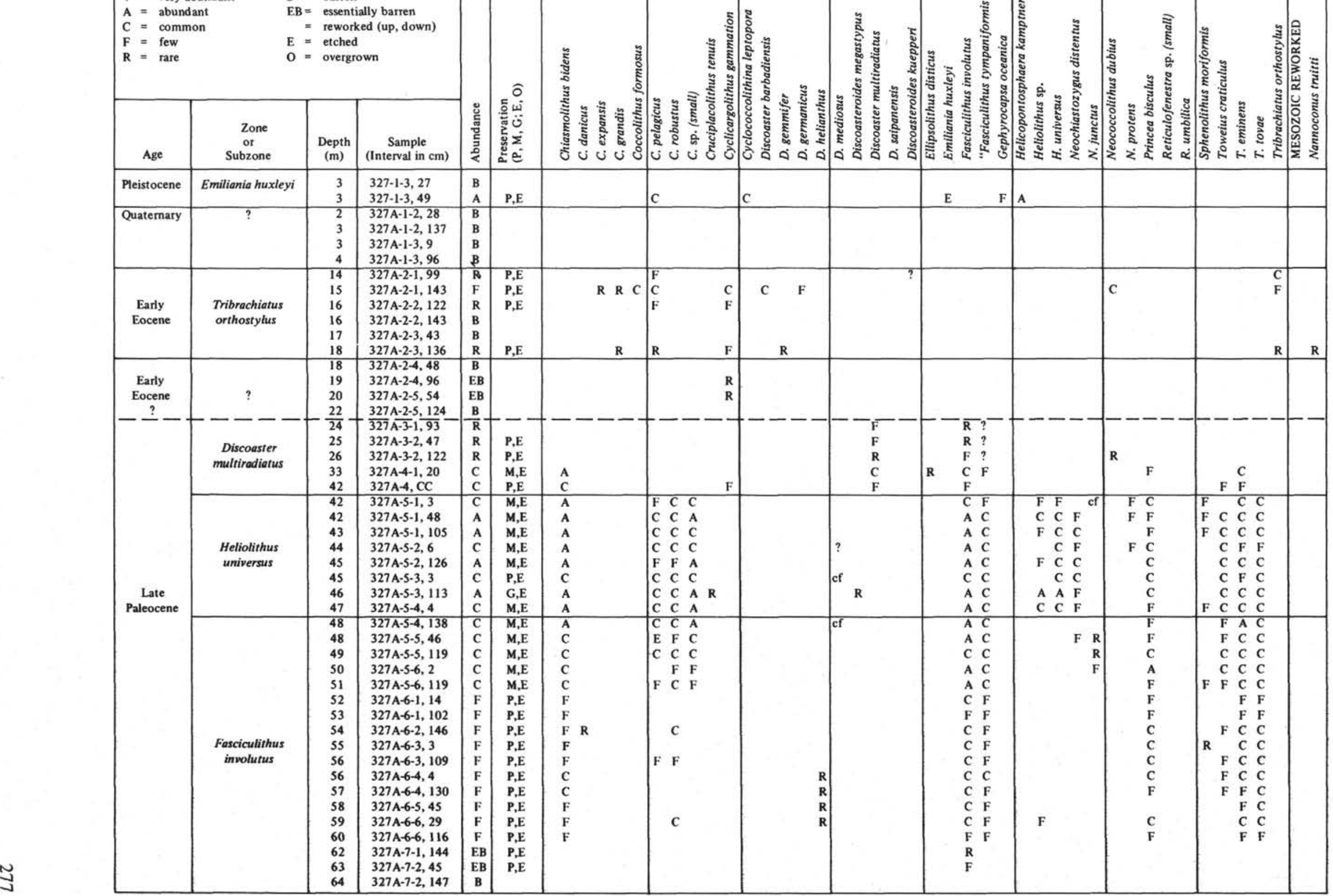


TABLE 4B

Distribution of Santonian to Maestrichtian Calcareous Nannofossils, Hole 327A

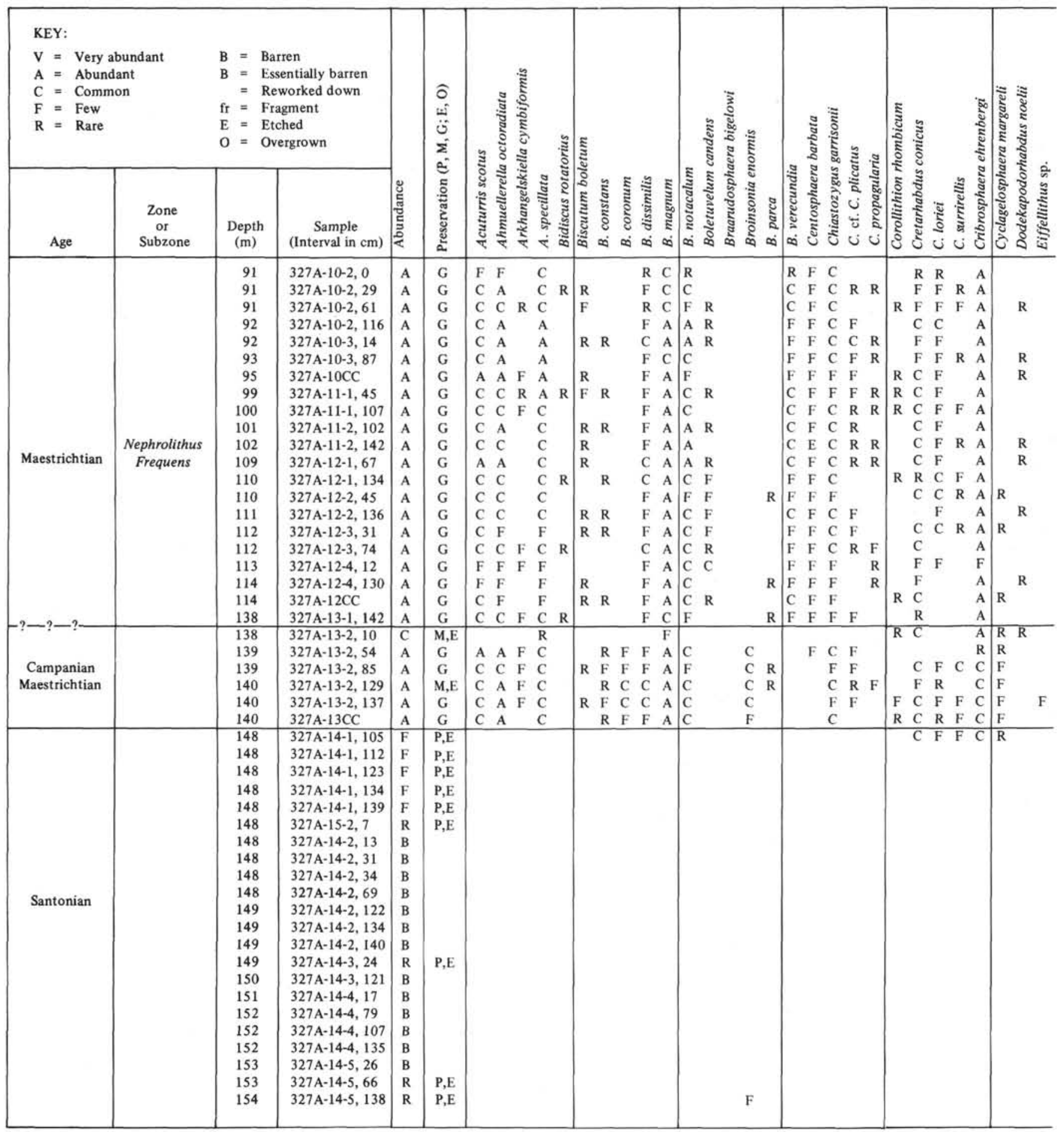


TABLE 4B - Continued

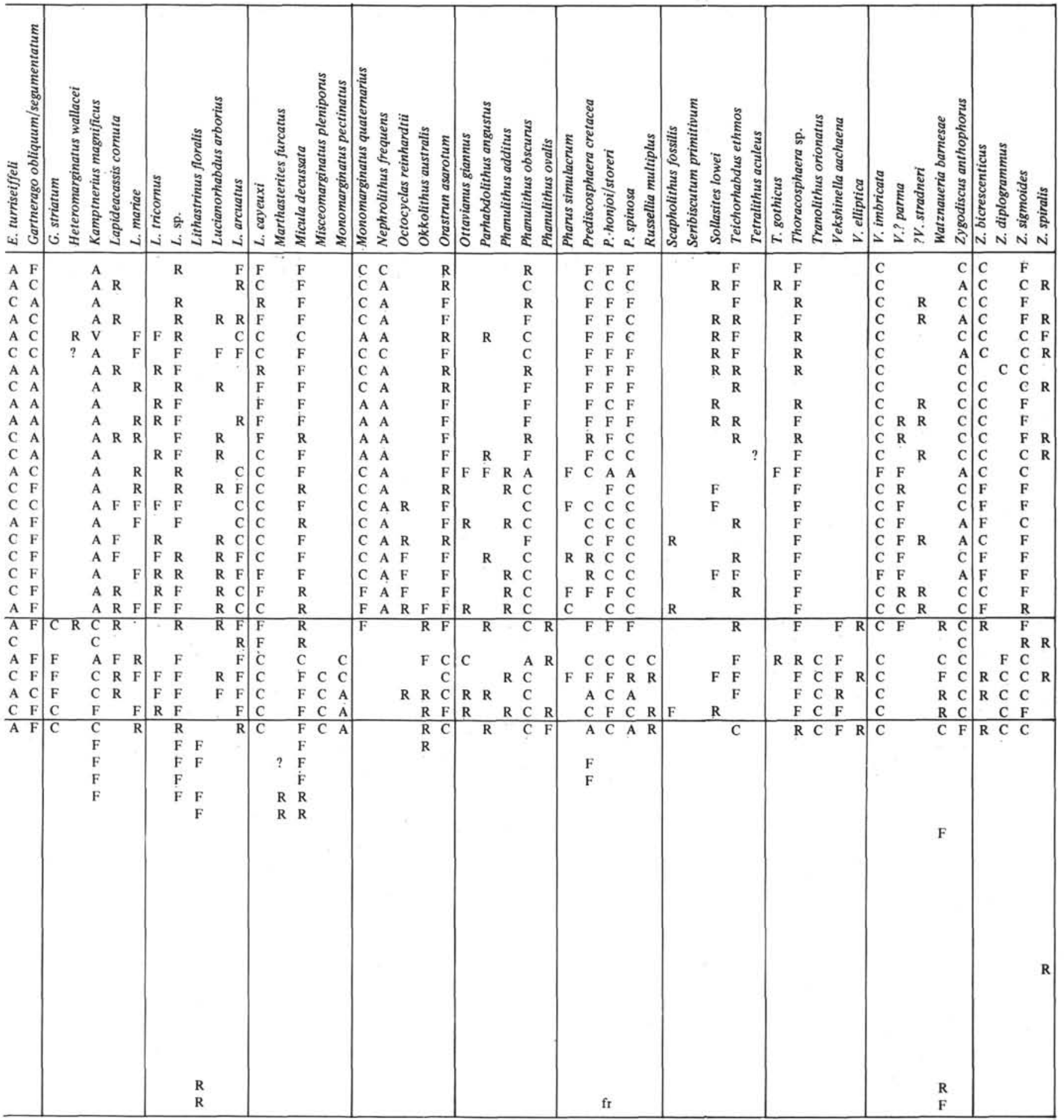


TABLE 4C

Distribution of Aptain to Cenomanian Calcareous Nannofossils, Hole 327A

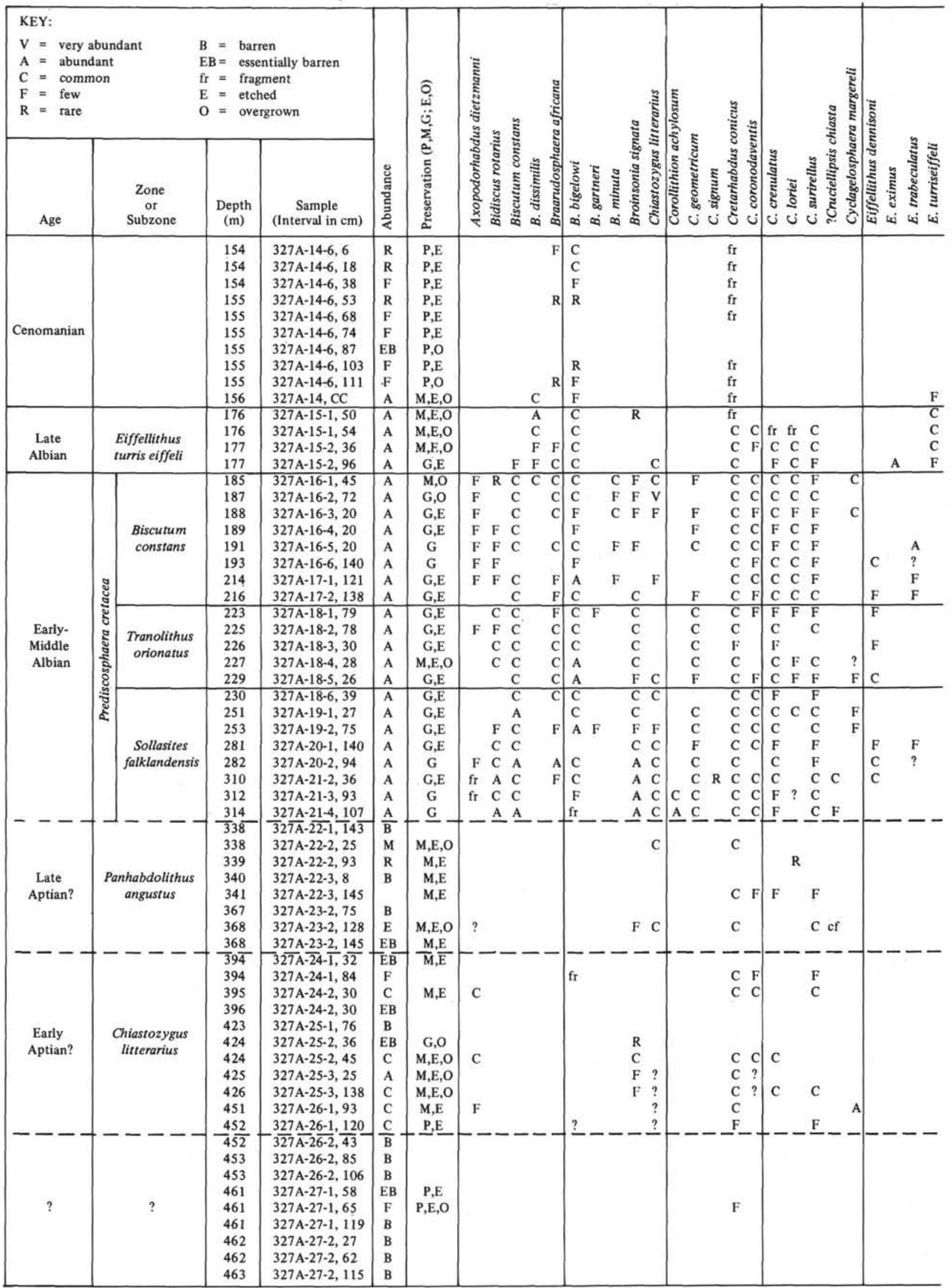


TABLE 4C - Continued

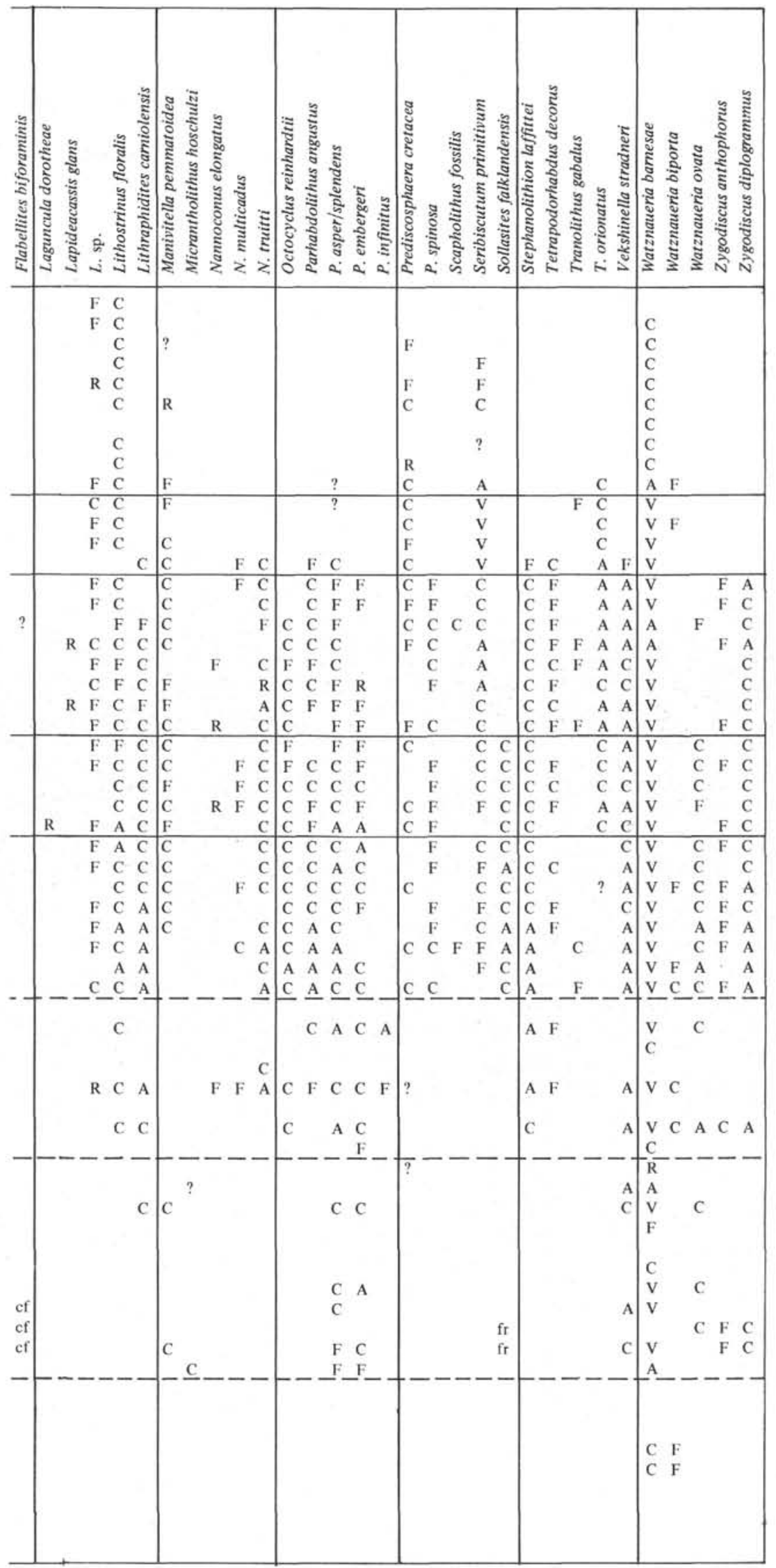




\begin{tabular}{|c|c|c|c|}
\hline New Genera & $\begin{array}{l}\text { Type } \\
\text { Species }\end{array}$ & $\begin{array}{c}\text { Relative } \\
\text { Strati- } \\
\text { graphic } \\
\text { Range }\end{array}$ & $\begin{array}{c}\text { Relative } \\
\text { Abundance }\end{array}$ \\
\hline Acuturris & A. scotos & long & frequent \\
\hline Boletuvelum & B. candens & short & frequent \\
\hline Centosphaera & C. barbata & long & frequent \\
\hline Monomarginatus & M. pectinatus & long & $\begin{array}{l}\text { frequent to } \\
\text { common }\end{array}$ \\
\hline Okkolithus & O. australis & short & rare \\
\hline Orastrum & O. asarotum & long & $\begin{array}{l}\text { rare to } \\
\text { frequent }\end{array}$ \\
\hline Pharus & P. simulacrum & short & rare \\
\hline Phanulithus & P. obscurus & long & frequent \\
\hline Teichorhabdus & T. ethmos & long & $\begin{array}{l}\text { rare to } \\
\text { nearly } \\
\text { frequent }\end{array}$ \\
\hline Misceomarginatus & M. pleniporus & short & frequent \\
\hline \multicolumn{2}{|c|}{ New Species } & $\begin{array}{l}\text { Relative } \\
\text { Strati- } \\
\text { graphic } \\
\text { Range }\end{array}$ & $\begin{array}{c}\text { Relative } \\
\text { Abundance }\end{array}$ \\
\hline \multicolumn{2}{|l|}{ Biscutum boletum } & long & rare \\
\hline \multicolumn{2}{|l|}{ Biscutum coronum } & short & frequent \\
\hline \multicolumn{2}{|l|}{ Biscutum dissimilis } & very & $\begin{array}{l}\text { rare to } \\
\text { nearly } \\
\text { frequent }\end{array}$ \\
\hline \multicolumn{2}{|l|}{ Biscutum magnum } & long & $\begin{array}{l}\text { very } \\
\text { common }\end{array}$ \\
\hline \multicolumn{2}{|c|}{ Biscutum notaculum } & long & $\begin{array}{l}\text { common to } \\
\text { frequent }\end{array}$ \\
\hline \multicolumn{2}{|c|}{ Boletuvelum candens } & short & rare \\
\hline \multicolumn{2}{|c|}{ Broinsonia verecundia } & long & $\begin{array}{l}\text { rare to } \\
\text { common }\end{array}$ \\
\hline \multicolumn{2}{|c|}{ Centosphaera barbata } & long & $\begin{array}{l}\text { frequent } \\
\text { (generally } \\
\text { as frag- } \\
\text { ments }\end{array}$ \\
\hline \multicolumn{2}{|c|}{ Lapideacassis tricornus } & long & rare \\
\hline \multicolumn{2}{|c|}{ Lucianorhabdus arborius } & long & $\begin{array}{l}\text { rare to } \\
\text { frequent }\end{array}$ \\
\hline \multicolumn{2}{|c|}{ Monomarginatus pectinatus } & short & common \\
\hline \multicolumn{2}{|c|}{ Monomarginatus quarternarius } & long & $\begin{array}{l}\text { frequent to } \\
\text { common }\end{array}$ \\
\hline \multicolumn{2}{|l|}{ Okkolithus australis } & short & rare \\
\hline \multicolumn{2}{|l|}{ Orastrum asarotum } & $\begin{array}{l}\text { mod- } \\
\text { erate }\end{array}$ & $\begin{array}{l}\text { rare to } \\
\text { frequent }\end{array}$ \\
\hline \multicolumn{2}{|l|}{ Phanulithus additus } & long & rare \\
\hline \multicolumn{2}{|l|}{ Pharus simulacrum } & short & $\begin{array}{l}\text { rare to } \\
\text { frequent }\end{array}$ \\
\hline \multicolumn{2}{|l|}{ Vekshinella? parma } & long & frequent \\
\hline \multicolumn{2}{|c|}{ Misceomarginatus pleniporus } & short & frequent \\
\hline \multicolumn{2}{|c|}{ Teichorhabdus ethmos } & long & rare \\
\hline
\end{tabular}

Two distinct floral assemblages can be distinguished within Unit 5 . Cores 10,11 , and 12 contain a rather uniform assemblage characterized by large numbers of
Nephrolithus frequens, Biscutum magnum, Kamptnerius magnificus, Eiffellithus turriseiffeli, Arkhangelskiella speciallata, and Cribrosphaerella ehrenbergi. Also common in this assemblage are Zygodiscus anthophorus, $Z$. bicrescenticus, Cretarhabdus loriei, and Monomarginatus quaternarius. Such an assemblage would traditionally be dated as late Maestrichtian due to the presence of Nephrolithus frequens, and it has been so dated for this section by Sliter (this volume) who used planktonic foraminiferal stratigraphy. In a new study based on coccoliths and planktonic foraminifera, however, Smith (1975) places the first occurrence of $N$. frequens in the Alabama section of the Gulf Coast United States in the middle Maestrichtian. Worsley (1974) further suggests that $N$. frequens is time transgressive from higher to lower latitudes, and that its first occurrence should be oldest at sites such as those drilled on the Falkland Plateau. The true first occurrence of $N$. frequens in Hole 327A, however, cannot be determined. It probably falls within the 20 -meter drilling gap between Cores 12 and 13. It is present in the abbreviated Section 1 of Core 13, but this section seems to contain a mixture of material from above and below. It is probable that the occurrence of $N$. frequens there is due to downhole slumping coincident with the interruption of continuous coring between Cores 12 and 13. Thus it appears that the age relationships of the $N$. frequens datum cannot be resolved from study of Hole 327A samples.

The second distinct assemblage in Unit 5 occurs in Core 13, Section 2. It contains most of the common species mentioned above, except that Nephrolithus frequens is absent and Monomarginatus pectinatus and Misceomarginatus pleniporus are present. The age of this material is dated as Campanian to possibly early Maestrichtian by planktonic foraminifers (Sliter, this volume). Due to the drilling gap mentioned above, the relationship between this and the above assemblage cannot be determined although interesting transitions, particularly within the Monomarginatus group, must occur within the gap. These transitions, plus a resolution of the first occurrence of Nephrolithus frequens, should eventually provide a basis for subdividing the upper Campanian-Maestrichtian in the southern high latitudes. Continuous coring of the entire CampanianMaestrichtian section on the Falkland Plateau at some future date would greatly aid such a study.

Core 14 recovered a variegated brown and green mottled zeolitic clay interbedded with diffuse zones of light greenish-gray micrite. Logged as lithologic Unit 6, the sediment contains local accumulations only of sparse, dissolution-resistant coccoliths deposited near the base of the carbonate compensation zone. Sections 1 and 3 contain the Coniacian-Santonian index species Marthasterites furcatus as well as the heavily overgrown Micula decussata and Lithastrinus floralis (see Plate 51). Foraminifers (Sliter, this volume) confirm a Santonian age for the first five sections of the core. Section 6 and the core catcher of Core 14 contain a somewhat more diverse and better preserved nannoflora dated by foraminifers as Cenomanian.

Core 15 penetrated the top of a 170 -meter-thick sequence composed of bioturbated, varicolored nanno ooze, chalk, and claystone (lithologic Unit 7). The core 
contains a moderately diverse flora with the first abundant Watznaueria encountered downhole. Watznaueria barnesae and Seribiscutum primitivum dominate the assemblage. The assemblage is further characterized by common Lithastrinus floralis, Braarudosphaera bigelowi, B. africana, nannoconids such as Nannoconus truitti and $N$. multicadus, few to common Lapideacassis and Biscutum dissimilis, and poorly preserved Eiffellithus turriseiffeli and Prediscosphaera cretacea. Seribiscutum primitivum is especially characteristic of mid Cretaceous high latitude southern hemisphere nannofloras (see also Thierstein, 1975). Foraminifers and micromolluscs indicate a late Albian age for the assemblage which is assigned to the Eiffellithus turriseifelli Zone. An abundance of Eiffellithus eximius at the base of the core (Sample 327A-15-2, $96 \mathrm{~cm}$ ), however, is puzzling since this form has not been reported below the Turonian. Its presence here is believed due to downhole contamination from the 20meter unsampled interval between Cores 14 and 15 . Another puzzle is the presence of a number of elements typical of the Albian flora in the core catcher of Core 14. This suggests the possibility that Albian coccoliths may have been reworked into the younger sediment during Cenomanian deposition.

The remainder of Unit 7 contains a quite diverse and well-preserved nannoflora with most groups represented that are commonly found at lower latitudes. These include members of the genera Cretarhabdus, Bidiscus, Lithraphidites, Manivitella, Parhabdolithus, Stephanolithion, Tranolithus, Zygodiscus, and a variety of podorhabdids. The most common podorhabdid is Octocyclus reinharditii. Nannoconids and braarudosphaerids are common to abundant throughout most but not all of the section. Attention should also be called to several forms originally reported from the Gault Clay of England by Black (1971b), but which have seldom been noted elsewhere in the literature. These are species of Lapideacassis which occur throughout much of the Mesozoic section at Sites 327 and 330 (also reworked [?] into the Paleocene of 329) and Laguncula dorotheae which we noted only in the lower middle Albian of those sites.

The distribution of Prediscosphaera cretacea is somewhat erratic in the sequence. Specimens are generally small (about $5 \mu \mathrm{m}$ in diameter) with centers and stems missing and are thus difficult to see except at high magnification. The last common occurrence downhole of the species is used to mark the base of the Prediscosphaera cretacea Zone between Cores 21 and 22. Questionable isolated specimens (fragments) which may be $P$. cretacea are noted in the more poorly preserved material of Cores 22 and 24, but these may be contaminants. The Aptian/Albian boundary, therefore, is placed between Cores 21 and 22 .

As discussed previously, the long lower-middle $\mathrm{Al}$ bian section is further subdivided here into three subzones based on third-order datum levels which should be considered of regional importance only. In addition, a Corollithion achylosum peak zone is noted at the base of the Prediscosphaera cretacea Zone (314 to $312 \mathrm{~m}$ ).

A coring gap between Cores 21 and 22 spans a lithologic boundary between the coccolith-rich ooze or chalk of Unit 7 and the brownish-black to olive-gray organic-rich claystone of the underlying Unit 8. Sediment induration increases and coccolith preservation decreases markedly across this boundary. As a result, assemblages are much reduced in diversity. Barren intervals are common, particularly in the lower part of the section where organic-rich sapropelic claystones resemble oil shales in character.

Fossiliferous intervals of Core 22 contain Lithastrinus floralis and Parhabdolithus angustus, apparently lack Prediscosphaera cretacea, and are assigned to the Parhabdolithus angustus Zone. Parhabdolithus infinitus was noted only in this core. Cores 23 and 24 lack Lithastrinus floralis, do contain Chiastozygus litterarius, and probably belong to the Chiastozygus litterarius Zone. Cores 26 and 27 are sparsely fossiliferous, but contain no coccoliths unequivocally older than Aptian.

\section{SITE 329}

$\left(5^{\circ} 39.31^{\prime} \mathrm{S}, 4^{\circ} 05.73^{\prime} \mathrm{W}\right.$; water depth $\left.1519 \mathrm{~m}\right)$

Site 329, drilled about $55 \mathrm{~km}$ northeast of Site 327 and at a considerably higher elevation on the Maurice Ewing Bank, was chosen to obtain a shallow-water Neogene biostratigraphic section deposited well above the carbonate compensation depth. The single hole was cored continuously to 179.5 meters and intermittently to 464.5 meters, yielding 33 cores before bottoming in Paleocene chalk. This provides some stratigraphic overlap with the Eocene-Paleocene section deposited in deeper water near the CCD at Site 327 . Recovery of calcareous material was excellent $(69 \%)$, with abundant coccoliths in every core, most of which are calcareous ooze or chalk. The distribution of coccoliths in these cores is shown in Tables $5 \mathrm{~A}$ and $5 \mathrm{~B}$.

Miocene and Oligocene nannofossils are generally well-preserved, cold water forms highly restricted in species diversity as is characteristic of Neogene high latitudinal sites of deposition in the southern hemisphere. Assemblages are dominated by placoliths, particularly Reticulofenestra, Coccolithus, Chiasmolithus, and Cyclicargolithus. Forms such as Chiasmolithus altus are common only in the high latitudes. Warm water genera such as Discoaster, Ceratolithus, Triquetrorhabdulus, and Sphenolithus are essentially absent. Low latitude coccolith zonations based on occurrences of members of these genera are therefore unworkable for this part of the section.

As at Site 327, Eocene and Paleocene nannofloras are more diverse and cosmopolitan than those of younger strata, an indication of milder climatic conditions at this locality during the early Tertiary than subsequently. Thus coccolith zonations developed for low to middle latitude regions such as California and Europe are applicable to the Paleocene/Eocene part of the section. However, the high latitude paleosite of deposition for the Paleocene assemblages is clearly indicated by the paucity of warm water forms such as Discoaster in comparison to the more abundant cool water Chiasmolithus.

The first three sections of Core 1 contain mixed Miocene to Recent diatom ooze rich in ice-rafted clay, silt, and sand. Sections 2 and 3 are essentially barren of coccoliths, but Section 1 contains abundant ( $15 \%$ of the 
TABLE 5A

Distribution of Oligocene to Recent Calcareous Nannofossils, Hole 329

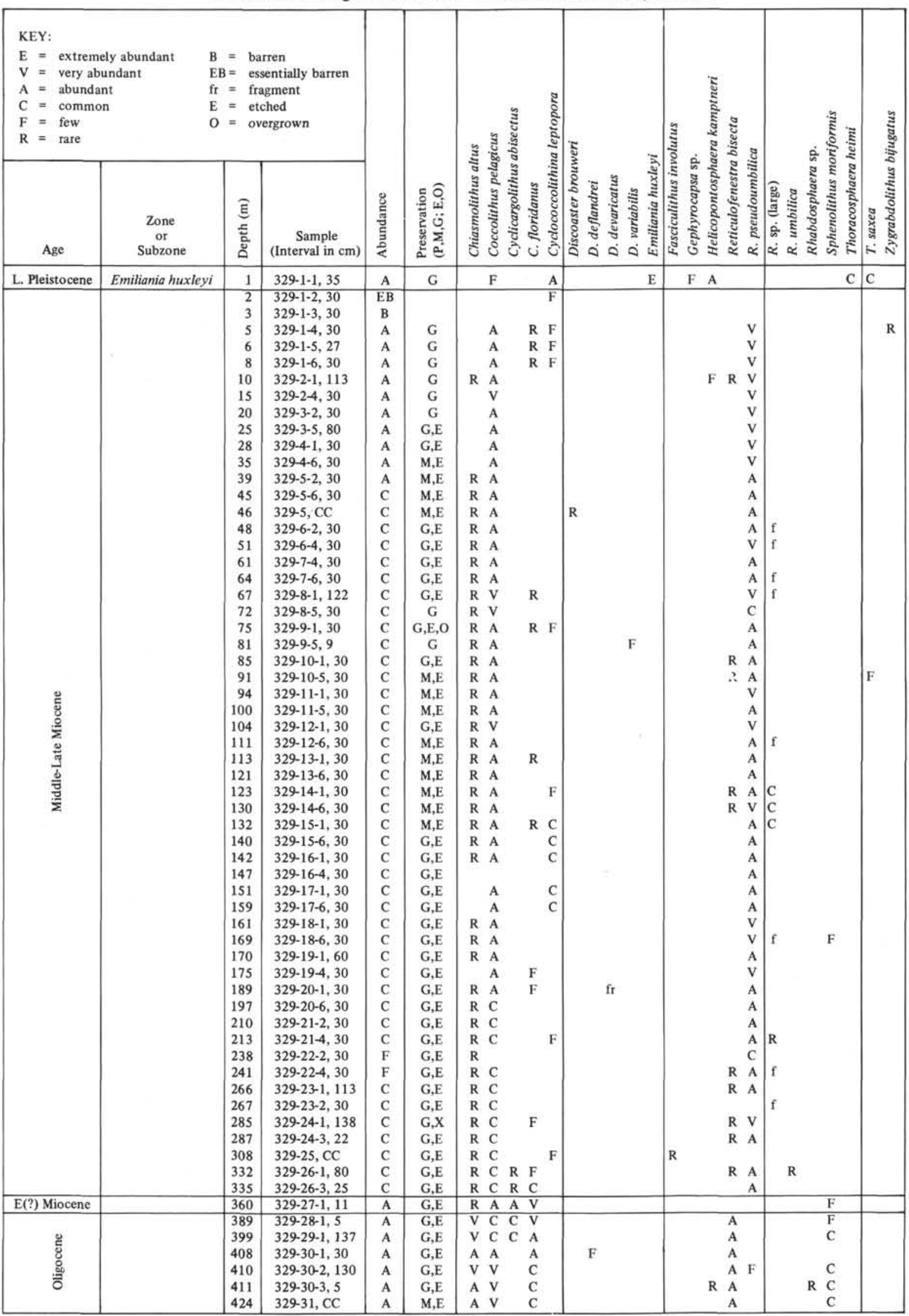


TABLE 5B

Distribution of Paleocene to Eocene Calcareous Nannofossils, Hole 329

\begin{tabular}{|c|c|c|c|c|c|c|c|c|c|c|c|c|c|c|c|c|c|c|}
\hline \multicolumn{4}{|c|}{$\begin{array}{l}\text { KEY: } \\
\mathrm{V}=\text { very abundant } \\
\mathrm{A}=\text { abundant } \\
\mathrm{C}=\text { common } \\
\mathrm{F}=\text { few }\end{array}$} & \multirow[b]{2}{*}{ 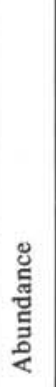 } & \multirow{2}{*}{ 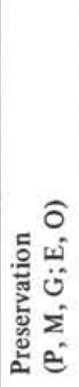 } & \multirow{2}{*}{ 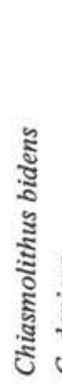 } & \multirow{2}{*}{ 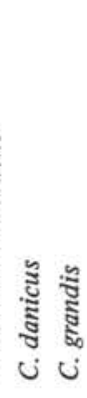 } & \multirow{2}{*}{ 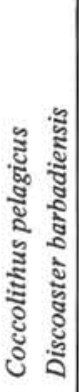 } & \multirow{2}{*}{ 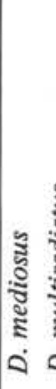 } & \multirow{2}{*}{ 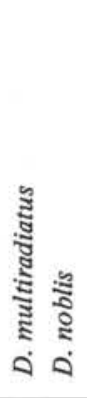 } & \multirow{2}{*}{ 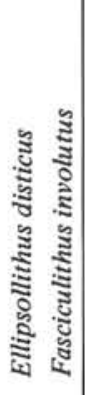 } & \multirow{2}{*}{\multicolumn{3}{|c|}{ 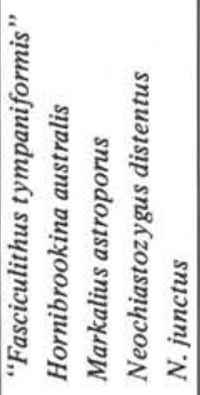 }} & \multirow{2}{*}{\multicolumn{2}{|c|}{ 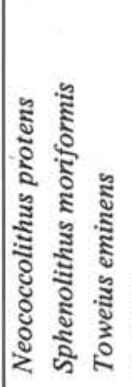 }} & \multirow{2}{*}{ 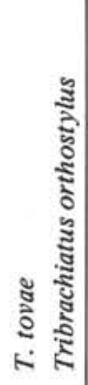 } & \multirow{2}{*}{ 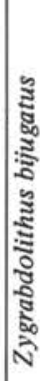 } \\
\hline Age & $\begin{array}{c}\text { Zone } \\
\text { or } \\
\text { Subzone }\end{array}$ & $\begin{array}{l}\text { Depth } \\
\text { (m) }\end{array}$ & $\begin{array}{c}\text { Sample } \\
\text { (Interval in } \mathrm{cm} \text { ) }\end{array}$ & & & & & & & & & & & & & & & \\
\hline E. Eocene & $\begin{array}{l}\text { Tribrachiatus } \\
\text { orthostylus }\end{array}$ & $\begin{array}{l}446 \\
447\end{array}$ & $\begin{array}{l}329-32-1,86 \\
329-32-1,121\end{array}$ & $\begin{array}{l}\mathrm{A} \\
\mathrm{A}\end{array}$ & $\begin{array}{l}\mathrm{M}, \mathrm{O} \\
\mathrm{M}, \mathrm{O}\end{array}$ & $\begin{array}{l}\mathrm{V} \\
\mathrm{C}\end{array}$ & $?$ & \begin{tabular}{ll|}
$\mathrm{V}$ & $\mathrm{C}$ \\
$\mathrm{V}$ & $\mathrm{C}$ \\
\end{tabular} & & $\begin{array}{lll}\mathrm{F} & \mathrm{F} \\
\mathrm{F} & \\
\end{array}$ & $\begin{array}{l}\mathrm{C} \\
\mathrm{C}\end{array}$ & & $\begin{array}{l}\mathrm{C} \\
\mathrm{C}\end{array}$ & & A & & \begin{tabular}{ll|}
$\mathrm{A}$ & $\mathrm{C}$ \\
$\mathrm{A}$ & $\mathrm{C}$ \\
\end{tabular} & \begin{tabular}{|l|l}
$\mathrm{V}$ \\
$\mathrm{V}$ \\
\end{tabular} \\
\hline E. (?) Eocene & $?$ & 447 & $29-32-1,143$ & $\mathrm{~A}$ & $\mathrm{M}, \mathrm{O}$ & $\mathrm{C}$ & & $\mathrm{A}$ & & C & $\mathrm{C}$ & & C F & & $\mathrm{A}$ & & $\mathrm{A}$ & V \\
\hline $\begin{array}{c}\text { Late } \\
\text { Paleocene }\end{array}$ & $\begin{array}{c}\text { Discoaster } \\
\text { multiradiatus }\end{array}$ & $\begin{array}{l}450 \\
451 \\
455 \\
457 \\
458 \\
458 \\
460 \\
461\end{array}$ & $\begin{array}{l}329-32-4,5 \\
329-32-4,87 \\
329-33-1,94 \\
329-33-2,9 \\
329-33-2,125 \\
329-33-3,10 \\
329-33-4,77 \\
329-33-4,135\end{array}$ & $\begin{array}{l}\mathrm{A} \\
\mathrm{A} \\
\mathrm{A} \\
\mathrm{A} \\
\mathrm{A} \\
\mathrm{A} \\
\mathrm{A} \\
\mathrm{A}\end{array}$ & $\begin{array}{l}\mathrm{M}, \mathrm{O} \\
\mathrm{M}, \mathrm{O} \\
\mathrm{M}, \mathrm{O} \\
\mathrm{M}, \mathrm{O} \\
\mathrm{M}, \mathrm{O} \\
\mathrm{M}, \mathrm{O} \\
\mathrm{M}, \mathrm{O} \\
\mathrm{M}, \mathrm{O}\end{array}$ & $\begin{array}{l}\text { V } \\
\text { V } \\
\text { A } \\
\text { A } \\
\text { A } \\
\text { A } \\
\text { C } \\
\text { A }\end{array}$ & $\mathrm{F}$ & $\begin{array}{l}\text { A } \\
\text { A } \\
\text { A } \\
\text { C }\end{array}$ & & $\begin{array}{ll}\text { A } & \text { F } \\
\text { A } & \\
\text { A } & \\
\text { A } & \\
\text { C } & \\
\text { F } & \\
\text { C } & \\
\text { C } & \end{array}$ & $\begin{array}{l}\mathrm{C} \\
\mathrm{A}\end{array}$ & $\begin{array}{lll}\mathrm{A} & & \\
\mathrm{A} & \mathrm{F} & \mathrm{F} \\
\mathrm{A} & \mathrm{A} & \\
\mathrm{A} & & \\
\mathrm{A} & & \mathrm{C} \\
\mathrm{A} & & \\
\mathrm{A} & \mathrm{C} & \mathrm{C} \\
\mathrm{A} & & \end{array}$ & $\begin{array}{ll} & F \\
F & F\end{array}$ & & $\begin{array}{l}\mathrm{C} \\
\mathrm{C}\end{array}$ & $\begin{array}{l}\mathrm{C} \\
\\
\mathrm{C} \\
\mathrm{A} \\
\mathrm{A} \\
\mathrm{A} \\
\mathrm{V} \\
\mathrm{A}\end{array}$ & $\begin{array}{l}\mathrm{A} \\
\mathrm{A} \\
\mathrm{A} \\
\mathrm{A} \\
\mathrm{A} \\
\mathrm{A} \\
\mathrm{A} \\
\mathrm{A}\end{array}$ & \begin{tabular}{|l} 
V \\
V \\
V \\
A \\
A \\
A \\
C \\
C
\end{tabular} \\
\hline
\end{tabular}

sediment) coccoliths of the Emiliania huxleyi Zone $(200,000$ years B.P. to present; see Table 5A and Plate 1). The minute $(3 \mu \mathrm{m})$ Emiliania huxleyi is overwhelmingly dominant with over 100 specimens visible in each field of view of the microscope. Cyclococcolithina leptopora and Heliocopontosphaera kamptneri are abundant, but Gephyrocapsa and Coccolithus pelagicus are rare as would be expected in a cold water assemblage of low diversity.

A sharp lithologic contact separates the coccolithbarren diatom ooze of Section 3 and the coccolith ooze of Section 4 of Core 1. Diversity of this coccolith ooze is extremely low, with assemblages composed almost entirely of Coccolithus pelagicus, Reticulofenestra pseudoumbilica, and related forms. This assemblage is little changed down through a long monotonous sequence ending at Core 26 which is dated as middle or late Miocene by diatoms, foraminifers, and Radiolaria. Reworked Oligocene coccoliths consisting primarily of rims of Chiasmolithus altus are common throughout the sequence, an indication of strong bottom currents during the time of deposition.

The only significant changes in the long middle-late Miocene sequence are rather subtle changes probably indicative of minor climatic fluctuations. A common taxon throughout the sequence is Coccolithus pelagicus, modern forms of which have a temperature preference of about $6^{\circ} \mathrm{C}$ to $14^{\circ} \mathrm{C}$. The highly restricted species diversity of the Miocene section, however, suggests surface water temperatures toward the lower end of this

\footnotetext{
'Among these is Dictyococcites antarcticus Haq, 1976, which was not differentiated on the range chart here, but is plotted in Table 2 of Haq, Lohmann, and Wise (this volume).
}

temperature range. The sudden appearance of common Cyclococcolithina leptopora in Cores 15 to 17 indicates a temporary warming trend (similar evidence is noted in the silicoflagellate floras; see Busen and Wise, this volume).

Reticulofenestra pseudoumbilica is absent in Core 27 which foraminifers suggest is late early Miocene in age. Abundant Cyclicargolithus abisectus in these cores may be reworked from the underlying Oligocene; however, C. floridanus is very abundant and was probably sampled in place. Notably absent in Core 27 are the discoasters which are present in the lower Miocene at these latitudes in the Pacific section of the Southern Ocean (see Burns, 1975; Edwards and Perch-Nielsen, 1975).

The Miocene/Oligocene boundary is placed between Cores 27 and 28 on the basis of abundant Chiasmolithus altus and Reticulofenestra bisecta. This boundary is somewhat difficult to pick due to the intense reworking throughout this section. Common Cyclicargolithus abisectus indicate a latest Oligocene age for Cores 28 and 29. Coccoliths in Cores 30 and 31 do not appear to be lower Oligocene as indicated by the absence of Isthmolithus recurvus or significant numbers of Coccolithus formosus or Reticulofenestra umbilica, but are probably mid-Oligocene in age. Tjalsma (this volume), however, does date Core 30 as early Oligocene on the basis of foraminifers.

Most of the section between Cores 31 and 32 was lost due to drilling difficulties encountered in a cherty part of the Oligocene section. The next sediments recovered were Eocene to Paleocene (Table 5B).

Samples 329-32-1, $86 \mathrm{~cm}$ and 329-32-1, $127 \mathrm{~cm}$ contain a reasonably well preserved (somewhat etched and overgrown) assemblage with lower Eocene forms such as Orthostylus tribrachiatus and Discoaster barbadiensis. Chiasmoliths resemble closely Chiasmolithus bidens. 
Due to heavy overgrowths, it was not possible to ascertain if $C$. grandis is present. No Discoaster lodoensis was noted, and the few $D$. multiradiatus present in these samples are considered reworked. Ellipsolithus distichus was noted only in this section. The assemblage is assigned to the Orthostylus tribrachiatus Zone. $O$. tribrachiatus is absent in the next sample down (329-32$1,143 \mathrm{~cm}$ ) where the absence of Fasciculithus and Toweius eminens suggests that the sample is early Eocene in age.

Fasciculithus and Toweius eminens are present in Section 4 of Core 32 (Sections 2 and 3 of this core contained no sediment) along with abundant Discoaster multiradiatus. This section and the last core from the hole (Core 33) are assigned to the Discoaster multiradiatus Zone. The assemblage is dominated by Chiasmolithus bidens, Fasciculithus, and species of Toweius. The minute Hornibrookina australis originally described from the high latitudes of the Pacific sector of the Southern Ocean is abundant in well-preserved samples of Core 32 .

There are notable differences between the Paleocenelower Eocene assemblages at Site 330 and Site 327 due to the different depositional conditions. Assemblages at Site 329 were deposited well above the CCD. Relatively more soluble forms such as the holococcolith Zygrhabdolithus bijugatus are very abundant at Site 329 and absent at Site 327. A strong change is particularly evident in the character of the fasciculiths between the two sites. A comparison of these differences (Plates 15, 16) calls into question validity of the taxonomic criteria used to differentiate between Fasciculithus involutus and $F$. tympaniformis (discussed in more detail elsewhere in this report).

Another difference between the two sites is the expanded nature of the Discoaster multiradiatus Zone at Site 329 . This may be due partly to lack of recovery in some Cores from Hole $327 \mathrm{~A}$, but it also reflects a higher sedimentation rate at Site 330 as a result of greater accumulation of calcareous material well above the CCD.

\section{SITE 330}

\section{$\left(50^{\circ} 55.19^{\prime} \mathrm{S}, 4^{\circ}{ }^{\circ} 53.00^{\prime} \mathrm{W}\right.$; water depth $\left.2626 \mathrm{~m}\right)$}

This site was drilled about $15 \mathrm{~km}$ east of Site 327 in order to elucidate the pre-Aptian history of the Falkland Plateau and to obtain a biostratigraphic section older than that cored at Sites 327 and 329. This was accomplished by Hole 330 which was cored discontinuously from 129 meters to basement $(575.5 \mathrm{~m})$. The drill string was then raised to the sediment surface and Hole $330 \mathrm{~A}$ was begun in order to sample the top of the section. This effort was largely unsuccessful because pieces of basement rock from Hole 330 lodged in the bottom-hole assembly, preventing proper functioning of the coring apparatus. Core $330 \mathrm{~A}-1$ did recover sediments; Cores 2 and 3 were empty, whereas Cores 4 , 5 , and the drill bit yielded traces of nanno-rich clay. The hole was abandoned due to coring difficulties.

Core 330A-1 recovered diatom ooze with a few etched nannofossils of late Eocene age scattered throughout (Table 6A). These include Discoaster saipanensis and Isthmolithus recurvus which allow assignment of the assemblage to a generalized Isthmolithus recurvus Zone.

Cores $330 \mathrm{~A}-4$ and 5 recovered muddy water which contained a mixture of diverse, moderately well preserved late Albian, Cenomanian, and possibly younger Mesozoic coccoliths (see Table 6B). Sparse Gartnerago segmentatum indicate a late Cenomanian or younger age whereas Eiffellithus eximius appears to be exotic to the rest of the flora which, according to foraminifers (Sliter, this volume), is predominantly Cenomanian in age. A pinkish nannofossil ooze which adhered to the drill bit after the drilling tools were retrieved from the hole yielded a well-preserved assemblage with common to abundant Seribiscutum primitivum, Biscutum dissimilis, and Eiffellithus turriseiffeli.

Cores 1 and 2, taken over 100 meters below the top of the section, recovered an assemblage equivalent in age to those of the lower part (Sollasites falklandensis Subzone of the Prediscosphaera cretacea Zone of Site 327. The assemblage at Site 330 , however, is better preserved. Sollasites falklandensis is present throughout these cores, but Tranolithus orionatus is absent. The Corollithion achylosum peak zone is represented at the base of Core 2.

Core 3, taken in the Aptian sapropelic claystone unit sampled previously at Site 327 , contains a few assemblages highly restricted in diversity, with nannoliths abundant only in portions of Section 330-3-2 which contains floods of braarudosphaerid and microantholith remains. Lithastrinus floralis is absent, and the assemblage is considered early Aptian in age (Chiastozygus litterarius Zone) due to the absence of any pre-Aptian forms such as Nannoconus colomi.

Some lithified braarudosphaerid/micrantholithid chalk laminae within the second section of Core 3 contain exceptionally well preserved, delicately constructed coccoliths deposited essentially intact, often as entire coccospheres. Fragile forms such as Corollithion have been preserved undistorted primarily due to early cementation of the chalk laminae. This provided a framework sufficiently rigid to prevent compaction and further diagenesis of the material. The chalk laminae are composed primarily of disaggregated segments of Micrantholithus hoschulzi with common Vekshinella stradneri. Three delicate species of Corollithion are also common, including $C$. silvaradion n.sp. Other forms described as new from the material are $C$. perch-nielseni and Seribiscutum bijugum. Several sollasitids, including Sollasites falklandensis n.sp., S. thiersteini n. sp., and $S$, horticus are present.

Core 4, taken near the base of the Cretaceous section, is sparsely nannoliferous. Many of the specimens such as Watznaueria communis and Zeugrhabdotus erectus seem to have been reworked from underlying Jurassic units, an inference supported by palynomorph studies (see Harris, this volume). No diagnostic lowermost Cretaceous (Berriasian to Barremian) coccoliths were observed in this core; however, pollen studies indicate an Aptian to Neocomian age. Thus a sharp biostratigraphic discontinuity separates Core 4 from Core 5 which is Late Jurassic in age. This, in addition to the apparent reworking of Jurassic fossils into Core 4, suggests the presence of an erosional disconformity between Cores 4 and 5 . 
TABLE 6A

Distribution of Tertiary Calcareous Nannofossils, Hole 330A

\begin{tabular}{|c|c|c|c|c|c|c|c|c|c|c|c|c|c|c|}
\hline \multicolumn{2}{|c|}{$\begin{array}{l}\text { KEY: } \\
\mathrm{C}=\text { common } \\
\mathrm{F}=\text { few } \\
\mathrm{R}=\text { rare }\end{array}$} & \multicolumn{2}{|c|}{$\begin{array}{l}\mathrm{B}=\text { barren } \\
\mathrm{E}=\text { etched } \\
\mathrm{O}=\text { overgrown }\end{array}$} & \multirow[b]{2}{*}{ 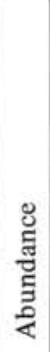 } & \multirow{2}{*}{ 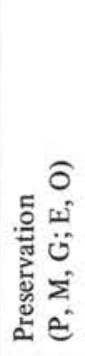 } & \multirow{2}{*}{ 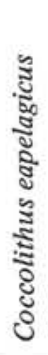 } & \multirow[b]{2}{*}{ 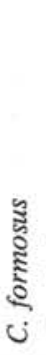 } & \multirow{2}{*}{\multicolumn{2}{|c|}{ 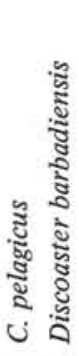 }} & \multirow{2}{*}{ 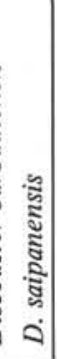 } & \multirow{2}{*}{\multicolumn{2}{|c|}{ ڤ్ }} & \multirow{2}{*}{ 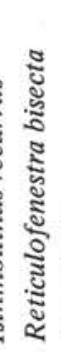 } & \multirow[b]{2}{*}{ 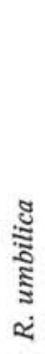 } \\
\hline Age & $\begin{array}{c}\text { Zone } \\
\text { or } \\
\text { Subzones }\end{array}$ & $\begin{array}{c}\text { Depth } \\
\text { (m) }\end{array}$ & $\begin{array}{c}\text { Sample } \\
\text { (Interval in } \mathrm{cm} \text { ) }\end{array}$ & & & & & & & & & & & \\
\hline $\begin{array}{c}\text { Late } \\
\text { Eocene }\end{array}$ & $\begin{array}{l}\text { Isthmolithus } \\
\text { recurvus }\end{array}$ & $\begin{array}{r}6 \\
7 \\
7 \\
8 \\
9 \\
10\end{array}$ & $\begin{array}{l}330 \mathrm{~A}-1-1,28 \\
330 \mathrm{~A}-1-1,128 \\
330 \mathrm{~A}-1-2,29 \\
330 \mathrm{~A}-1-2,55 \\
330 \mathrm{~A}-1-3,24 \\
330 \mathrm{~A}-1-3,103\end{array}$ & $\begin{array}{l}\text { B } \\
\text { F } \\
\text { F } \\
\text { F } \\
\text { F } \\
\text { F }\end{array}$ & $\begin{array}{l}\mathrm{M}, \mathrm{E} \\
\mathrm{P}, \mathrm{E} \\
\mathrm{P}, \mathrm{E} \\
\mathrm{M}, \mathrm{E} \\
\mathrm{M}, \mathrm{E}\end{array}$ & $\begin{array}{l}F \\
F \\
F \\
F \\
F\end{array}$ & $\begin{array}{l}\text { F } \\
\text { F } \\
\text { F } \\
\text { F }\end{array}$ & $\begin{array}{l}\text { F } \\
F \\
F \\
F \\
F\end{array}$ & $\begin{array}{l}\mathrm{R} \\
\mathrm{R}\end{array}$ & $\begin{array}{l}\text { F } \\
\text { F } \\
\text { F } \\
\text { F } \\
\text { F }\end{array}$ & $\mathrm{R}$ & & $\begin{array}{l}\mathrm{C} \\
\mathrm{C} \\
\mathrm{C} \\
\mathrm{C}\end{array}$ & $\begin{array}{l}\mathrm{C} \\
\mathrm{C} \\
\mathrm{C} \\
\mathrm{C}\end{array}$ \\
\hline
\end{tabular}

Cores 5 to 8 contain a rather sparse, but wellpreserved Late Jurassic assemblage. Despite the scarcity of specimens in smear-slide preparations, it was found that these coccoliths could be concentrated easily by settling techniques. Due to their excellent preservation in the organic-rich fine clays, they are quite suitable for electron microscope examination. The assemblage is dominated by species of Watznaueria, Zeugrhabdotus, and Cyclagelosphaera with rare to few Ethmorhabdus gallicus, Vekshinella stradneri, V. quadriarculla, Stephanolithion bigoti, Hexapodorhabdus cuvillieri, and several forms of Axopodorhabdus, n. gen. (Table 6C). In addition to the above forms observed in the light microscope, this material has yielded the following species described herein as new: Ethmorhabdus? frondosus, Retecapsa tridentata, Palaeopontosphaera erismata, Corollithion senarius, and $C$. helotatus. The assemblage in Cores 5 to 8 is assigned to the Vekshinella stradneri Zone of Barnard and Hay (1974) which is defined as the interval between the lowest (first) stratigraphic occurrence of the name species to the highest (last) stratigraphic occurrence of Stephanolithion bigoti. Although Meed (1971) and Rood and Barnard (1972) concluded that $S$. bigoti is probably confined to Callovian and Oxfordian strata of England and Northern France, the absence of coccoliths in the lowermost Kimmeridgian of northern Europe leaves open the possibility that this zone may extend as high as lower Kimmeridgian in other areas.

In addition to the presence of Vekshinella stradneri, the absence of Discorhabdus tubus supports a late Oxfordian to early Kimmeridgian age for the assemblage. Barnard and Hay (1974) illustrate in their fig. 4 the range of Zeugrhabdotus noeli as terminating in the midOxfordian. However, specimens of this species illustrated by Noël (1965) are late Oxfordian in age as are specimens observed in the present study. In the same figure Barnard and Hay (1974) illustrate Crepidolithus cavus as persisting to near the end of the Oxfordian. However, with the exception of one late Oxfordian sample, the previous continuous occurrence of the species is in the Bathonian. The presence of specimens of C. cavus in the Oxfordian is possibly the result of reworking, and its absence in Hole 330 samples is not considered to be a factor in age determination of that material. We also confirm the presence of Podorhabdus grassei (=Discorhabdus biperforatus) in the Oxfordian as originally reported by Noël for northern France. In England, Barnard and Hay (1974) find this species only in the Bajocian and Bathonian.

Cores 9 to 13 contain fewer and less diagnostic coccoliths than Cores 5 to 8 , and no precise age determination can be made. Palynomorphs do suggest an Oxfordian age for these as well (see Harris, this volume). A correlation between calcareous nannofossil assemblages recovered at Sites 327 and 330 is given in Figure 2.

\section{OTHER DSDP LEG 36 SITES}

Three sites drilled at abyssal depths in areas neighboring the Falkland Plateau yielded few coccoliths and are listed here only in passing.

\section{Site $326\left(5^{\circ} 35.00^{\prime} \mathrm{S}, 6^{\circ} 18.20^{\prime} \mathrm{W}\right.$; water depth $\left.3812 \mathrm{~m}\right)$}

The one surface core taken at this site in the Drake Passage recovered clayey and sandy silts of Quaternary age. Rare calcareous nannofossils recovered from a sandy silt at $118 \mathrm{~cm}$ in Section 1, Core 1, include Coccolithus pelagicus, Cyclococcolithina leptopora, and small forms which may be Emiliania huxleyi.

\section{Site $328\left(4^{\circ} 48.67^{\prime} \mathrm{S}, 36^{\circ} 39.53^{\prime} \mathrm{W}\right.$; water depth $\left.5059 \mathrm{~m}\right)$}

Cores at this site located in the Malvinas Outer Basin east of the Falkland Plateau penetrated 471 meters of siliceous ooze and zeolitic claystone deposited well below the CCD. All cores were barren of nannoliths except for one in the lower part of the section (Core 11, Section 6 and core catcher) where rare but wellpreserved Mesozoic forms had been reworked into a zeolitic claystone dated by palynomorphs at preCampanian in age (see Harris, this volume). These coccoliths are Watznaueria barnesae, a taxon common only in pre-Maestrichtian sediments of the Falkland Plateau. 
TABLE 6B

Distribution of Cretaceous Calcareous Nannofossils, Holes 330 and 330A

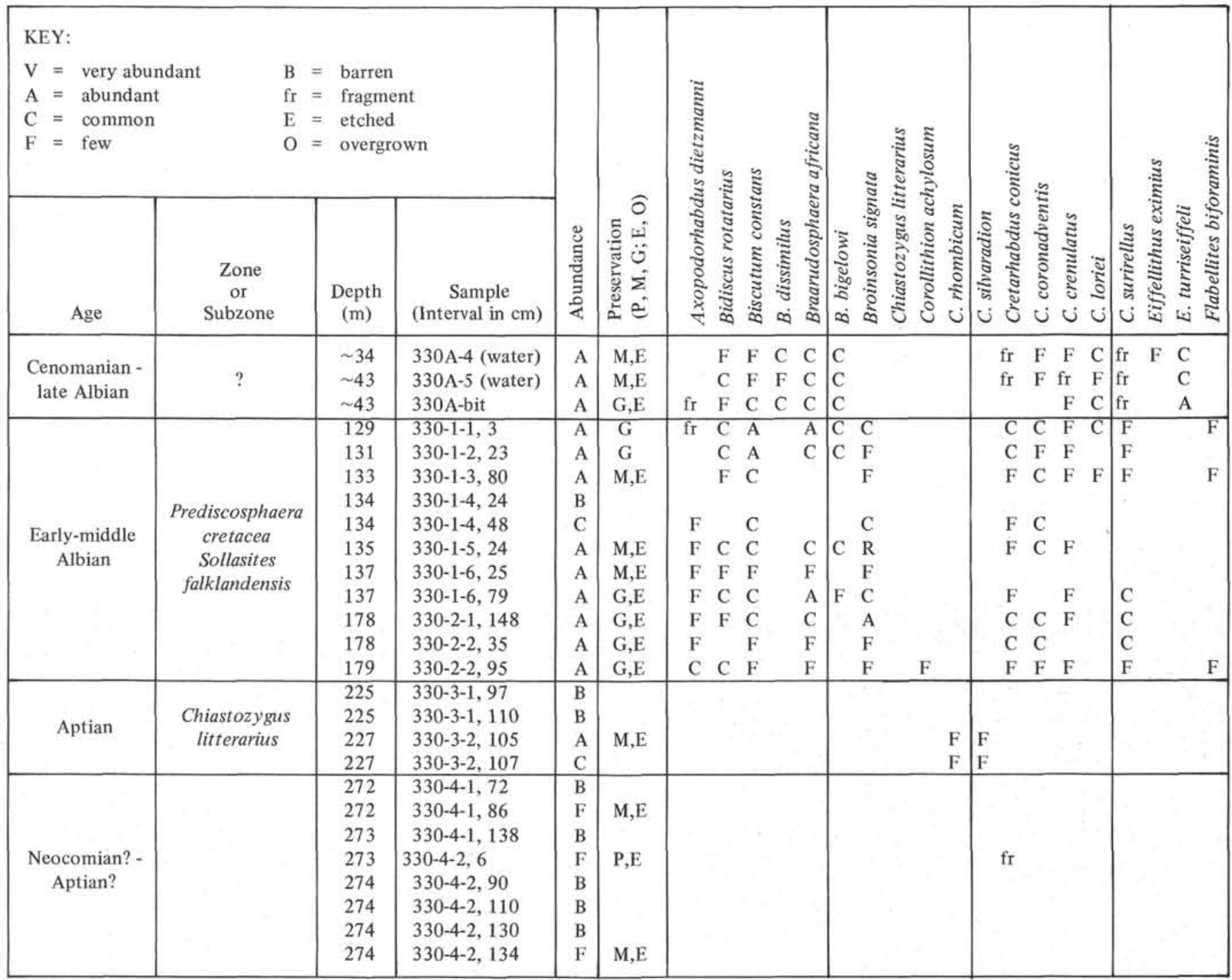

\section{Site $331\left(37^{\circ} 53.00^{\prime} \mathrm{S}, 38^{\circ} 06.92^{\prime} \mathrm{W}\right)$}

Only one surface core composed entirely of Quaternary clay and silt deposited well below the CCD recovered a significant amount of sediment at this site which was located in the Argentine basin. Neither it nor the second core attempted recovered calcareous nannofossils.

\section{PALEOECOLOGY AND ASSEMBLAGE CHARACTERISTICS}

Coccoliths at Sites 327, 329, and 330 on the Falkland Plateau accumulated intermittently over a period of 150 m.y. at a depositional site which experienced an apparently complex tectonic history that included displacements between shelfbreak and bathyal depths as well as significant latitudinal and longitudinal displacements via sea-floor spreading. Diversity and preservation of the coccolith assemblages recovered varies radically as a function of paleodepth of deposition, paleodepth of the lysocline and $C C D$, planktonic productivity, latitude of deposition, proximity to the basinal margin, lithology, paleocirculation patterns, and postdiagenetic dissolution. The following is a brief summary of factors which seemed important in determining the character of the coccolith assemblages encountered. More detail as to the structural framework and sedimentary regime of the plateau may be found in the Site Report chapters, Cruise Synthesis, and those individual chapters in this volume which deal with regional sedimentation and correlation (see, particularly, chapters by Barker and Thompson).

\section{Jurassic}

The initial marine deposition at Site 330 began in a restricted Jurassic basin where coccoliths were able to flourish only during the latter stages of the basin life when more open marine conditions prevailed. Diversity of the Oxfordian assemblages, however, reached about 20 species which compares favorably with the diversity of assemblages of equivalent age reported from the 


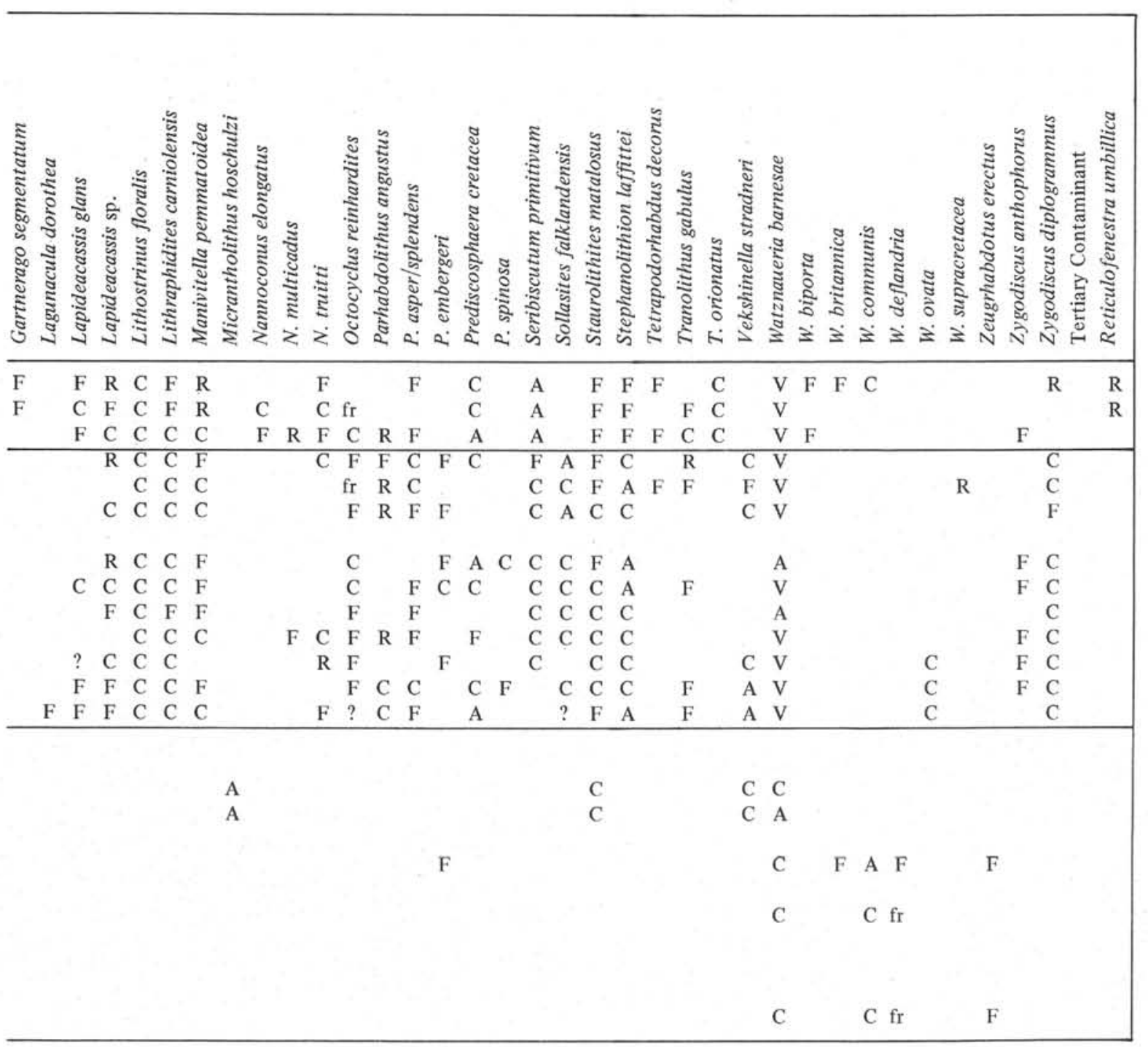

classic Jurassic localities of England and northern France. Medd (1971) considers the English Jurassic assemblages boreal in nature.

A predominance of fine clays in the Oxfordian units precluded fluid migration and assured excellent preservation of delicate forms such as the several species of Corollithion. Each coccolith was apparently sufficiently "insulated" by the fine clay particles to prevent largescale dissolution, diffusion, and reprecipitation of the carbonate by way of the interstitial pore fluids; thus the nannofossils show virtually no signs of etching or calcite overgrowth.

\section{?Neocomian-Aptian}

A disconformity representing up to $50 \mathrm{~m} . \mathrm{y}$. of time is suggested by the ?Neocomian-Aptian age assigned to Core 330-4. Most samples in that core are barren or contain a number of reworked Jurassic forms such as Watznaueria communis and Zeugrhabdotus erectus (not seen in the other Cretaceous cores). The lack of other coccoliths in the core is attributed to the absence of open marine conditions. Core 330-3 (Aptian in age) represents fluctuations between restricted and normal marine depositional conditions. A veritable flood of braarudosphaerid and micrantholith pentalith segments in the second section of that core attests to a sustained incursion of marine waters of normal or perhaps slightly less than normal marine salinities. Abundant pentalith fragments were also noted locally in the Aptian of Hole 327A. Braarudosphaerids and the closely related micrantholiths are generally found in nearshore shallow environments such as those represented by the Lisbon Formation of Alabama (Bybell and Gartner, 1972) or the Quaternary of the Black Sea (Bukry, 1974). Bukry (1974) attributes their abundance in near-shore areas to the slightly reduced salinities often encountered along continental margins.

A most unusual feature of the micrantholith ooze of Section 330-3-2 is the presence of thin, well-cemented chalk laminae which contain exceptionally well preserved coccospheres of a variety of forms including delicate species of Corollithion (see Plates 61 to 66). 
TABLE 6C

Distribution of Jurassic Calcareous Nannofossils, Site 330

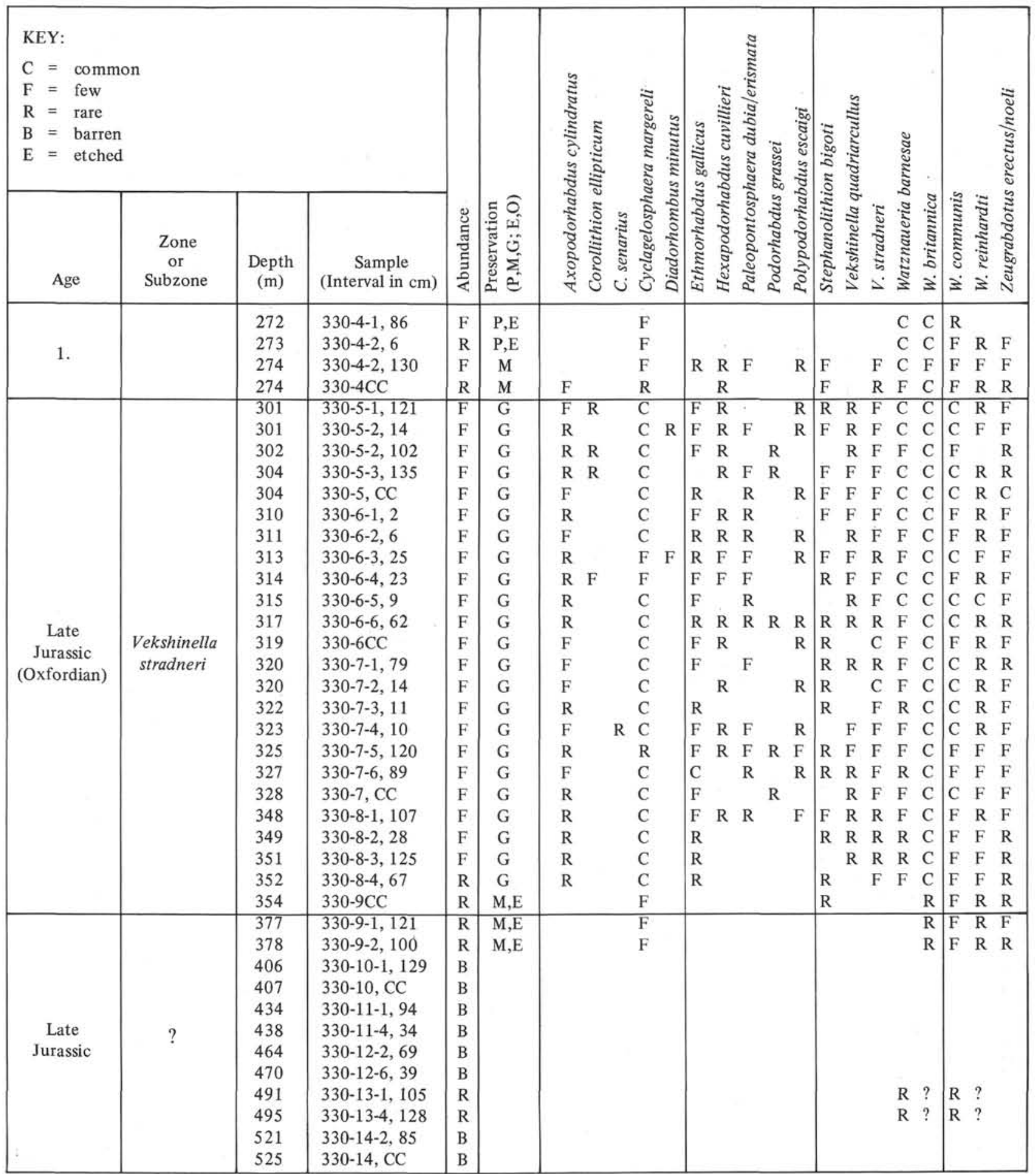

These chalks are quite porous and show no evidence of compaction, whereas other limestones in the sections are quite dense with no visible porosity. Although impurities make it difficult to ascertain the mode of cementation of the chalk laminae, they resemble in many ways Oligocene braarudosphaerid chalks described from the South Atlantic by Wise and Kelts (1972). These latter were cemented during early diagenesis by selective dissolution and reprecipitation of calcite from the relatively soluble pentalith segments. Early cementation provided sufficient structural sup- port to the constituent particles of the Oligocene chalk to enable it to withstand compaction when buried at moderate depths in the sediment. Our micrographs indicate that the Aptian chalk in Core 330-3 also underwent cementation during early diagenesis as well. This allowed it to achieve sufficient competence to withstand compaction under moderate sediment loading, thus preserving the many delicate coccoliths and coccospheres observed on fracture surfaces.

Except for local occurrences, nannoliths in the Aptian of both Sites 327 and 330 are sparse and poorly 


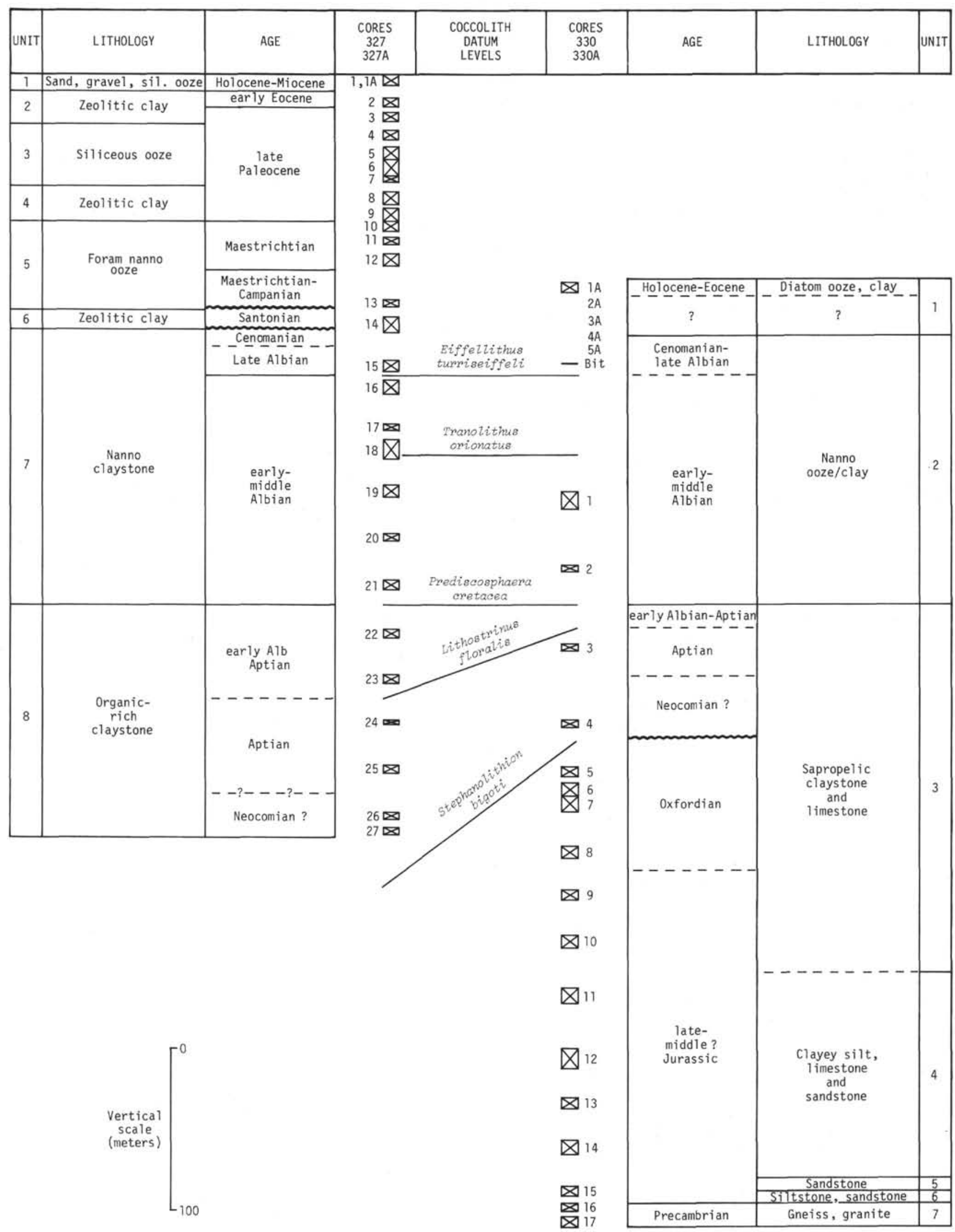

Figure 2. Coccolith correlations, Sites $327 A$ and 330. 
preserved. This is probably due partly to the poor circulation of normal marine waters in the restricted basin and perhaps to postdepositional alterations. The Aptian sediments are extremely rich in organic matter. It has been suggested that the Lower Cretaceous sapropelic claystones of the Atlantic basin are unfavorable for the preservation of coccoliths due to their low $p \mathrm{H}$. Indeed, the range charts for Sites 327 and 330 (Tables 4 and 5) both show a dramatic increase in the abundance and preservation of coccoliths at the Aptian/Albian boundary, which is placed at the facies change between the sapropelic claystones and the overlying nanno ooze/claystones.

\section{Lower-middle Albian}

The Albian sediments are well oxidized as evidenced by increased bioturbation and by the absence of carbonaceous fossils or even pollen and spores which are quite abundant in the Aptian (see Harris, this volume). This change to open ocean conditions was probably effected as the Falkland Plateau cleared the tip of Africa via sea-floor spreading, thereby establishing a deep ocean seaway which allowed circulation from the south or east into the incipient South Atlantic basin. The well-preserved nannofloras compare favorably in diversity with those reported from other northern and southern hemisphere localities (Table 7). The variety of forms present attests to the more equitable global climates which prevailed during the Jurassic and the earlier stages of the Cretaceous than during later earth history. Some forms common at low latitudes such as Cruciellipsis chiasta, Eiffellithus trabeculatus, Flabellites biforaminis, and Parhabdolithus infinitus, however, are absent or only sparsely represented at the Falkland Plateau sites. In addition, some forms are present which appear to be more temperate in nature. These may be considered somewhat provincial or in some cases even endemic to higher latitudes. They include Sollasites falklandensis, Seribiscutum primitivum, Biscutum dissimilis, Octocyclus reinhardtii, and Lapideacassis. The rare Laguncula dorotheae may also be a temperate form.

Other forms abundant in the Albian such as Braarudosphaera africana and the nannoconids of the Nannoconus truitti-N. multicadus plexus appear to be near-shore forms. Although common in most samples, Nannoconus truitti and Braarudosphaera africana are both conspicuously absent or rare in others such as $327 \mathrm{~A}-16-4,20 \mathrm{~cm}, 327 \mathrm{~A}-16-6,140 \mathrm{~cm}$, and 327A-20-1, $140 \mathrm{~cm}$. This indicates that the distribution of both may be effected by similar environmental conditions, such as fluctuations in salinity conditions or the existence of sedimentary environments which promote their dissolution. The occurrence of Nannoconus, however, in our samples clearly shows that the genus was not restricted to the tropics or to the Tethyan region during the Late Cretaceous.

The shallow water $(100-400 \mathrm{~m}$; see Sliter, this volume) continental margin environment which existed at the sites throughout most of the Albian provided optimum conditions for the accumulation and preservation of coccolith assemblages of maximum diversity. Site 330, which apparently lay seaward of Site 327, yielded the richest nannofossil oozes. Dissolution was negligible, and high sedimentation rates assured rapid burial of the material.

TABLE 7

Comparison of Recorded Coccolith Occurrences in Samples From

the Albian Prediscosphaera cretacea Zone, Northern and Southern Hemisphere localities

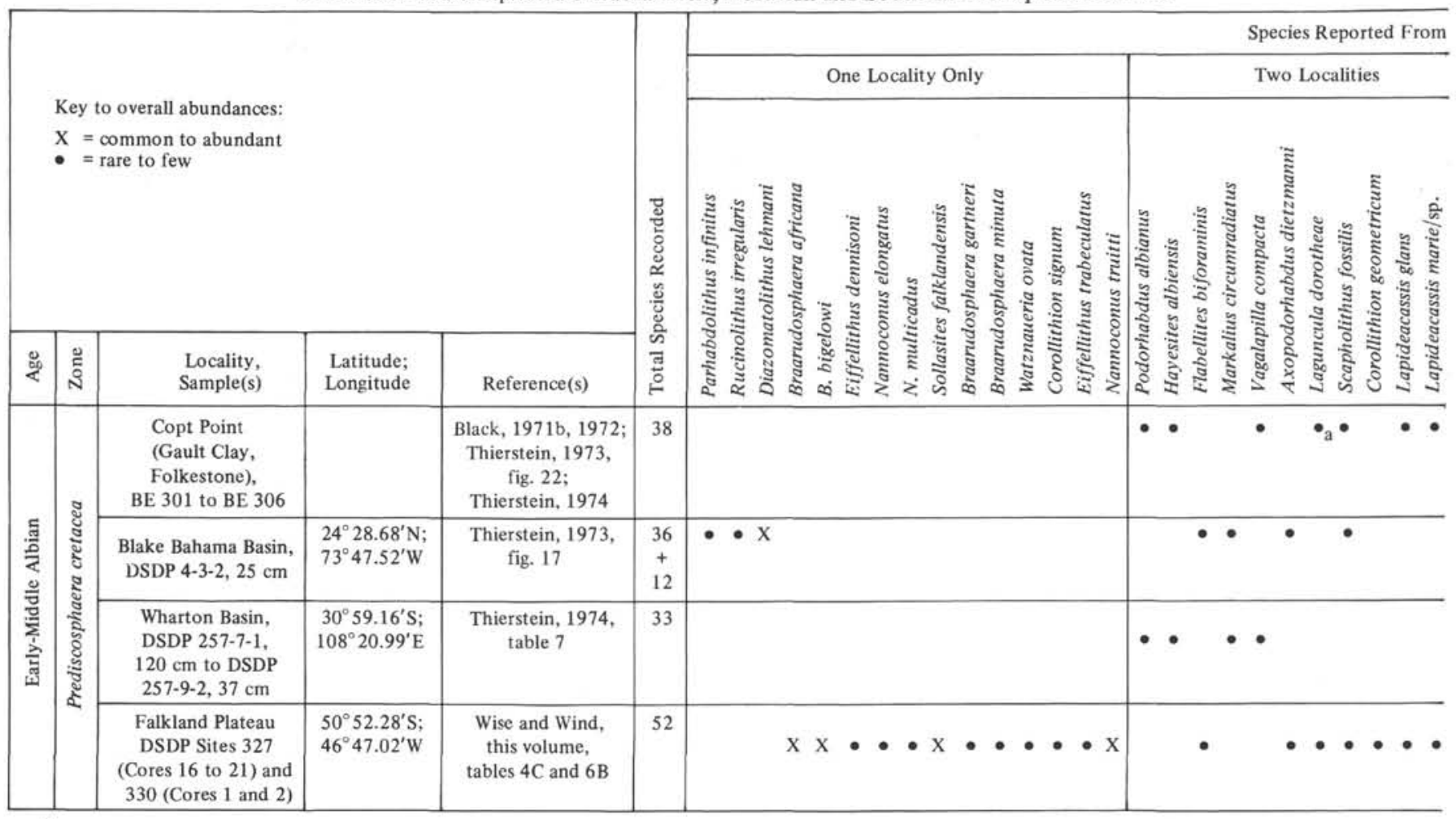

${ }^{\mathrm{a}}$ Gault Clay, Suffolk (Black, 1971b). 


\section{Upper Albian to Maestrichtian}

Preservation of upper Albian coccoliths diminishes going up section with more dissolution evident, particularly in Hole 327A. Only the most dissolutionresistant groups such as Watznaueria and Lithastrinus are present in the Cenomanian of that hole, and the entire upper Albian-Cenomanian interval is greatly reduced in thickness compared to the long lower-middle Albian section. A most prominent biostratigraphic hiatus separates the Cenomanian from the overlying Santonian. The latter contains an even more restricted assemblage of dissolution-resistant coccoliths deposited near the CCD. Cold deep water $(3000 \mathrm{~m})$ benthonic foraminifers are also present (see Sliter, this volume). These faunas and floras provide strong evidence for a rapid subsidence beginning in late Albian. This subsidence event, so well documented by the microfossil fauna and flora, reflects major tectonic activity. It corresponds closely in time to the final opening of the South Atlantic and could be related to the final passage of the southern extremity of the South American continental mass past the southern tip of Africa. This explanation assumes that the configuration of the Falkland Plateau was then much as it is now, and that the Maurice Ewing Bank was the last portion of the plateau to clear the tip of South Africa. The tectonic subsidence would then result as the continental fragment was carried by spreading down the ridge flank.

Two difficulties arise, however, with this explanation. The late Albian-Santonian subsidence is too rapid if calculated against the "Sclater curve" (see Site 327 Site Chapter, this volume). Secondly, one has great dif- ficulty in accounting for the thick $(50 \mathrm{~m})$ sequence of well-preserved coccolith ooze deposited at Site 327 during the Campanian-Maestrichtian. Maestrichtian benthonic foraminifers indicate a paleodepth of about 2000 meters (Sliter, this volume). The pristine preservation of the coccoliths and the presence of rather soluble forms (Lucianorhabdus group) support a paleodepth of deposition well above that recorded for the Santonian. Thus, an apparent re-elevation of the site of deposition is indicated if the paleontologic evidence alone is considered. At present, however, no regional evidence supports a suitable Campanian-Maestrichtian tectonic event which would accomplish this (see Barker, this volume). On the other hand, the regional tectonic history of the basins adjacent to the Falkland Plateau is little understood, so the problem in interpreting the Site 327 sequence is hindered by the lack of sufficient data.

One can seek to explain the sedimentologic and paleontologic evidence by a circulation model used in conjunction with tectonic evidence rather than invoking a purely paleontologic or tectonic model. Assume that the original configuration of the plateau during the initial separation of South America and Africa was much as it is today, with the Maurice Ewing Bank forming the eastern extremity. As such, the plateau would have formed a partial barrier to the free circulation of waters between the Atlantic and Indian ocean regions even after its eastern extremity had cleared the southern tip of Africa and had begun its descent down the ridge flank. It is possible that return bottom waters could have moved over low sills along the plateau as surface communication of ocean waters was established between the expanding major ocean

TABLE 7 - Continued

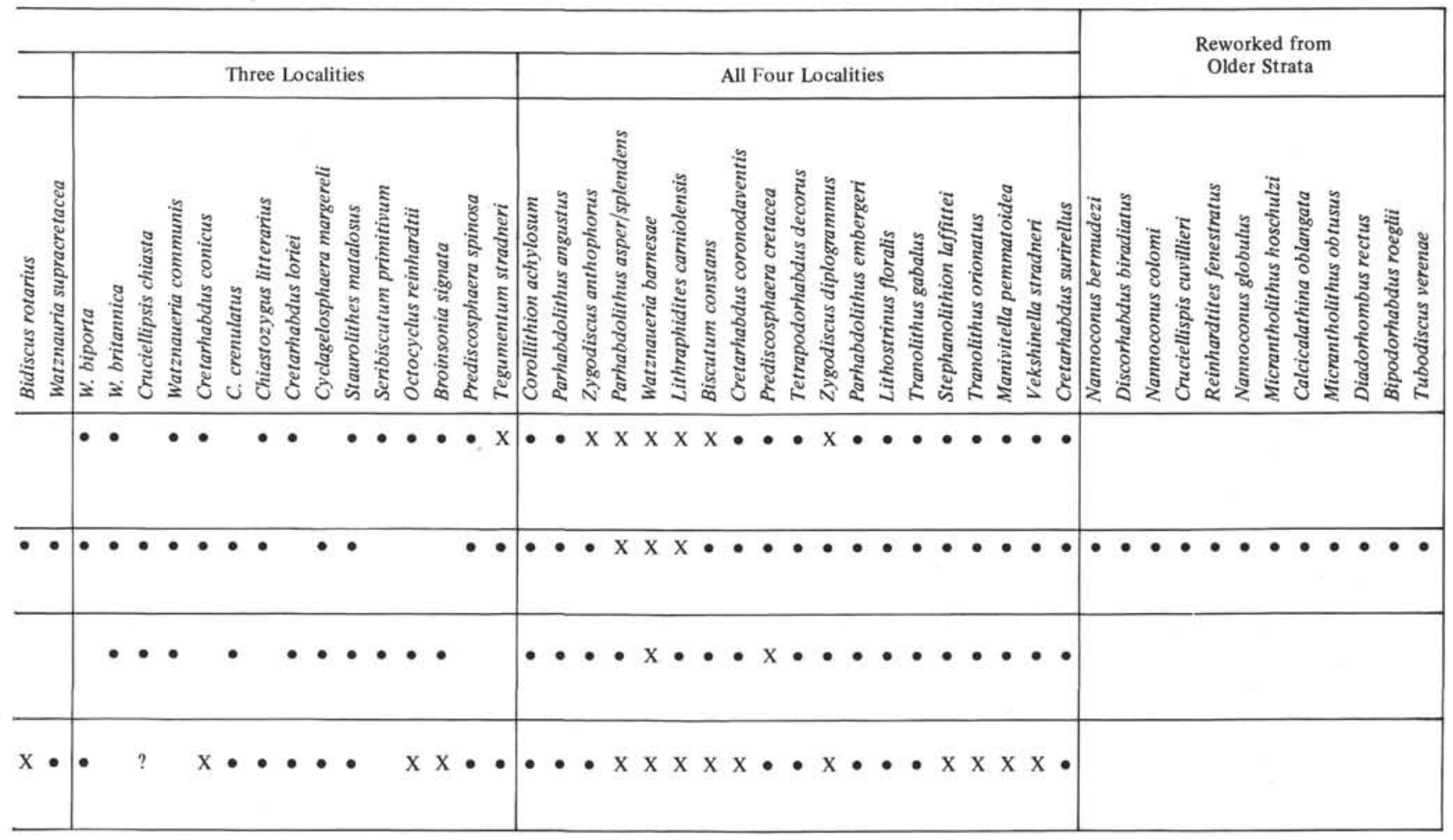


basins. Strong current movement would explain the virtual absence of Turonian-Coniacian sediments in any of the sections drilled. A similar hiatus is present at other high latitude sites in the Indian Ocean (Veevers and Heirtzler, 1974), an indication that sharp changes in current patterns were felt in various sectors of the Atlantic-Indian ocean systems as these basins were enlarged sufficiently to allow broad circulation patterns to become established in the higher latitudes of the southern hemisphere during mid-Cretaceous times. Bottom current flow at the site would have become sufficiently slow by Santonian times to allow accumulation of mottled orange and green clays. Their carbonate-poor oxidized condition might indicate movement of cold (polar?), carbonate-deficient waters over this area of the plateau, the net effect of which would be to raise the local carbonate compensation depth close to abnormally high levels. Variation in the numbers of coccoliths preserved in the mottled Santonian sediments indicates that the CCD fluctuated above and below the site of deposition, possibly in response to fluctuations in the movements of bottom currents. The end result would be the formation of a sediment type analogous in some respects to the well-known Ammonitico Rosso limestones of the Tethyan region of southern Europe (see Bosellini and Winterer, 1975). Those sediments also formed during high stands of the compensation levels for calcite and aragonite as ocean currents moved over promontories formed along rifted continental margins while communication was being established between major ocean basins.

Further expansion of the seaway connecting the South Atlantic to major oceans of the Indian-Southern ocean region would have eventually reduced the velocity of current moving over the plateau. With the depression of the CCD to more normal levels, a thick sequence of pelagic carbonate could accumulate on the plateau during the Late Cretaceous. The CampanianMaestrichtian coccolith assemblages are exceptionally well preserved due to their comparatively shallow site of deposition well above the CCD. The light overburden at Site 327 and the rather high clay and silica content of the nanno ooze also served to prevent the mobilization of calcite through dissolution-diffusionreprecipitation processes. As a result, even the more soluble species such as the holococcoliths of the Lucianorhabdus plexus (see Wind and Wise, 1976) are immaculately preserved.

The scenario outlined above assumes the operation at the cooler, higher latitudes of conditions not normal in other regions during the Late Cretaceous. While circulation factors seem to have modified the distribution of high latitude sediments and biota somewhat during this interval, a more satisfactory explanation of the Albian-Maestrichtian sequence drilled on the plateau must await more precise reconstruction of the tectonic history of the region.

The opening of the Atlantic basin and the establishment of efficient north-south circulation patterns contributed to a more efficient heat transfer system between the poles and equator, thereby steepening temperature gradients and allowing the establishment of well-defined climatic belts as well as faunal and floral provinces by the end of the Cretaceous (see Hammond, 1976). The effects of global cooling are quite noticeable in the Maestrichtian coccolith floras which are dominated by the provincial Nephrolithus frequens along with abundant Kamptnerius magnificus (large flange), Monomarginatus, Eiffellithus turriseiffeli, species of Biscutum, and members of the Lucianorhabdus plexus. The composition of these assemblages stands in marked contrast to low latitude assemblages of the Nephrolithus frequens Zone (compare our Table 4B and fig. 11 of Worsley [1974]). Important index species abundant at low latitudes such as Tetralithus nitidus and $T$. aculeus are extremely rare at Site 327 . Other genera such as Lithraphidites are not represented at all.

The first occurrence of Nephrolithus frequens in our section cannot be determined precisely due to a drilling gap. Its long range in the section (about $50 \mathrm{~m}$ ) indicates, however, that in the high latitudes, $N$. frequens may not be confined to the uppermost Maestrichtian as is often assumed. Instead, its initial occurrence is probably time transgressive toward the equator as suggested by Worsley (1974).

The Maestrichtian nanno ooze is capped by a "hard ground" similar to those found at the top of the Cretaceous chalk in many parts of the world. According to Worsley (1974), the CCD rose sharply near the end of the Maestrichtian causing cessation of carbonate deposition in many parts of the oceans and promoting carbonate dissolution and hard-ground formation at the top of the chalk. The sequence at Site 327 is quite similar to those described by Worsley (1974) in the South Atlantic (DSDP Leg 3 sites). At Site 327, however, the CCD did not descend again to the site of deposition until late in the Paleocene (as recorded in Core 327A-6).

\section{Cenozoic}

Although Sites 327 and 329 are located only about 50 $\mathrm{km}$ apart, Paleocene sediments at Site 329 accumulated at an elevation over 460 meters above those at Site 327. Further upslope east of Site 329 and toward the crest of the Maurice Ewing Bank, a Lamont piston core (RC 15-84) recovered Paleocene sediments at a topographic elevation of 970 meters above the same stratigraphic level equivalent to that penetrated at Site 327. Coccoliths at Site 327 accumulated close to the base of the CCD. They consist primarily of etched, dissolutionresistant forms in a clay or siliceous ooze matrix whereas those at the other two localities form a chalk. The most obvious difference in the assemblages is the high abundance of Zygrhabdolithus bijugatus at Site 329 and its absence at Site 327. This places the CCD for this relatively more soluble holococcolith between 2000 and 2400 meters for the Paleocene-Eocene in this area. Edwards and Perch-Nielsen (1974) note a similar distribution for $Z$. bijugatus in the Pacific sector of the Southern Ocean. Z. bijugatus, however, is absent in the Oligocene at Site 329, probably as a result of cooler surface water temperatures rather than of dissolution effects.

An unexpected observation in comparing the three Paleocene localities is the obvious change in the 
appearance of the fasciculiths. At Site 327 most fasciculiths are heavily etched and are identified as Fasciculithus involutus (see Plates 15 and 16). At the other sites few $F$. involutus were noted, but forms traditionally identified as $F$. tympaniformis are very abundant. The latter forms show some evidence of secondary calcite overgrowths, but there can be little doubt that they are merely well preserved or somewhat overgrown specimens of $F$. involutus. We therefore placed $F$. tympaniformis in synonomy with $F$. involutus (see Systematic Paleontology).

The distribution of the Paleogene coccolith assemblages in relation to those of the rest of the Atlantic are discussed in Haq, Lohmann, and Wise, this volume, and will not be elaborated on here. As noted in their table 3 , and in the range charts of this paper, the Chiasmolithus/Discoaster ratios are generally much higher at the Falkland Plateau sites than at lower latitudes, a phenomenon discussed in considerable detail by Bukry (1973c) and Edwards and Perch-Nielsen (1975) for the Pacific sector of the Southern Ocean. The ratio fluctuates rather widely at Site 329 , however, due to fluctuations in the surface water temperature possibly modulated strongly by surface currents. These fluctuations, which seem to be accentuated at the high latitude Falkland Plateau sites, make it difficult to read general trends. Such a wide variation in the ratios also cautions against the selection of single samples from any given locality for estimations of climatic conditions or paleolatitudes of deposition.

The general paucity of tropical index species and the difficulty their absence presents in establishing biostratigraphic zones at high latitudes have been discussed in detail in previous sections of this report as well as by others who have participated on or studied material from DSDP cruises into the higher latitudes (Perch-Nielsen, 1972; Bukry, 1972, 1973b; Wise, 1973; Edwards and Perch-Nielsen, 1975; Burns, 1975). The fact that sufficient zonal markers are present to allow reasonable resolution of the Paleocene-early Eocene interval at Leg 36 sites does attest to the more equitable global climates which prevailed during that time compared to the Neogene. The warmest peaks in the Paleogene recorded at the Leg 36 sites apparently coincide with the two maxima of carbonate deposition which occurred during the late Paleocene (Heliolithus universus Zone-Discoaster multiradiatus Zone) and the mid-early Eocene (Orthostylus tribrachiatus Zone). This is best seen in the record of Site 327 where fluctuations in the CCD can be noted with greatest precision. Although the drilling record is incomplete, no carbonate appears to have been deposited at Sites 327 or 329 between the early and late Eocene, probably due to a rise of the CCD in relation to the sites of deposition and/or to increased bottom current activity. The few recoveries of late Eocene coccoliths at Sites 327 and 330 are most interesting, however, because a few discoasters are still present at both localities. Thus by late Eocene times climates had not deteriorated to the extent evident during the Oligocene.

No discoasters are present in the Oligocene of Site 329 , an indication of considerably reduced surface water temperatures compared to the early Eocene.
Although the Oligocene floras are highly restricted in their diversity, the Miocene assemblages are even more so, and consist only of a half dozen species or less. The hiatus at Site 329 between the Oligocene and Miocene coincides with the suspected ultimate opening of the Drake Passage and the establishment of a Circumpolar Current (Barker, this volume). Indeed the Miocene carbonate oozes contain a remarkable number of reworked Oligocene coccoliths, and their distribution in accumulations which drape the higher elevations of the plateau attest to the action of extraordinarily strong bottom currents. The cessation of Miocene coccolith deposition and the sharp hiatus between the older sediments and the overlying Pliocene/Pleistocene siliceous oozes and ice-rafted sediments at all sites probably indicate a sharp northward shift in the center of carbonate productivity and a concomitant rise in the local CCD following Miocene times. This was accompanied by increased bottom current activity which eroded older sediments.

This event would coincide with the onset of severe glacial conditions on the Antarctic continent (Hayes, Frakes, et al., 1974) and the firm establishment of a polar front. With this sharp change in paleoenvironmental conditions, coccolith deposition on the Maurice Ewing Bank virtually ceased until 200,000 years ago. At that point, the evolution of Emiliania huxleyi, a form tolerant of cold water down to $2^{\circ} \mathrm{C}$, raised the calcareous phytoplankton productivity in the region to a level sufficient to allow the accumulation of some coccolith-rich sediment on the higher elevations of the plateau.

\section{SYSTEMATIC PALEONTOLOGY}

Species considered in this study are listed in Table 1. Most bibliographic references for these taxa are provided by Loeblich and Tappan (1966, 1968, 1969, 1970a, 1970b, 1972, 1973); any not included there are given in the references. Type specimens of new taxa are deposited in the U.S. National Museum, Washington, D.C. All taxa in the following sections are arranged alphabetically by generic epithets.

\section{CENOZOIC}

(F.H. Wind and S.W. Wise, Jr.)

Genus COCCOLITHUS Schwarz, 1894

Coccolithus robustus (Bramlette and Sullivan) Wind and Wise, n. comb.

Cyclolithus? robustus Bramlette and Sullivan, 1961, p. 141, pl. 2, fig. $7 \mathrm{a}-\mathrm{c}$.

\section{Genus FASCICULITHUS Bramlette and Sullivan, 1961}

Fasciculithus involutus Bramiette and Sullivan, 1961 (Plate 14, Figure 12; Plate 15, Figures 1-6; Plate 16, Figures 1-6) Fasciculithus involutus Bramlette and Sullivan, 1961, p. 164, pl. 14, fig. 1a-c, 2a, b, 3a, b, 4a, b, 5a, b.

Fasciculithus tympaniformis Hay and Mohler, 1967, p. 1537, pl. 204, fig. 10-15, pl. 205, fig. 4, 5, 7, 8 .

Remarks: Fasciculithus involutus was described from California where it occurred consistently in the Paleocene of the Lodo Formation in units which are now assigned to the Heliolithus riedeli and Discoaster multiradiatus zones. F. tympaniformis was described from slightly older units at Pont Labau, France, which were assigned to the Fasciculithus tympaniformis. Heliolithus kleinpelli, and Discoaster gemmeus zones (Hay and Mohler, 1967). F. tympaniformis has since been reported frequently from younger Paleocene sections up 
through the Discoaster multiradiatus Zone, so that in the Paleocene, its recorded range overlaps that of $F$. involutus except in the Fasciculithus tympaniformis Zone (see Gartner, 1971; Perch-Nielsen, 1971; Bukry, 1973). The primary difference detween the two species is that in $F$. involutus, the outer cylindrical surface is deeply fluted whereas in $F$. tympaniformis, it is smooth.

At our Falkland Plateau sites, we find that the predominant occurrence of one species over the other in sections of equivalent age correlates strongly with the carbonate content of the host rock lithology. F. tympaniformis is predominant in chalks and coccolith oozes (Hole 329; Conrad Core 15-84) which were deposited well above the carbonate compensation zone, whereas $F$. involutus is predominant in siliceous sections deposited near the base of the CCD (Hole 327A). In the carbonate-rich sections, specimens are somewhat overgrown with secondary calcite; in the zeolitic clays and diatomaceous oozes of the deeper water sections, specimens are moderately to heavily etched. Attempts to differentiate the two species on the basis of element count were unsuccessful since the number of segments making up the cylinders is highly variable in both groups. We conclude that in the sections we studied, the predominant form of Fasciculithus present is a function of the preservation of the material, and that Fasciculithus involutus is probably an etched form of $F$. tympaniformis. For this reason, we place $F$. tympaniformis in synonymy with $F$. involutus.

\section{Genus HELIOLITHUS Bramlette and Sullivan, 1961}

Heliolithus universus Wind and Wise, new species (Plate 12, Figures 1-6; Plate 13, Figures 1, 2; Plate 14, Figures 1-3)

Description: A species of Heliolithus consisting of two partial cones flaring outwards and composed of 30 or more elements. A relatively narrow intermediate ring of elements is usually visible along the outer circumference at the junction of the two partial cones.

Remarks: In outline, this species resembles Heliolithus riedeli Bramlette and Sullivan, but differs in having a greater number of elements (ranging up to about 60). Topotype specimens of $H$. riedeli have 30 or less elements, averaging about 20 (Plate 11, Figures 1,2). Forms of $\mathrm{H}$. universus having low element counts are probably transitional between the two species (Plate 12, Figures 1-3). H. universus is readily distinguished from the more discoidally shaped $H$. kleinpelli (Plate 11, Figures 3-5) by its double-cone appearance.

Opinions among nannofossil specialists differ widely as to the occurrence and range of the various Heliolithus species in deep-sea sediments. For instance, Bukry (1972, p. 1075) recorded $H$. riedeli as present in DSDP Hole 119, but Perch-Nielsen (1971) found it to be absent there. The difficulty in distinguishing between members of this group lies in the variety of forms present within most deep-sea assemblages and in the extreme differences produced by diagenetic alteration. Most specimens observed in DSDP Leg 36 material have high element counts and were etched to some degree.

Occurrence: Common to abundant in Paleocene sediments of the Falkland Plateau below the Discoaster multiradiatus Zone.

Size: 6 to $11 \mu \mathrm{m}$; average $8 \mu \mathrm{m}$.

Holotype: USNM 385453 (Plate 12, Figures 4, 5).

Paratypes: USNM 385452, 385454 (Plate 12, Figures 1-3, 6); USNM 385455, 385456 (Plate 13, Figures 1-2); USNM 385457, 385458 (Plate 14, Figures 1-3).

Type locality: Sample 327A-5-1, $48 \mathrm{~cm}$.

Heliolithus sp. A Wind and Wise, n. sp.

(Plate 13, Figures 3, 4; Plate 14, Figures 7, 8, 9?, 10?)

Diagnosis: Relatively flat heliolithid with large central area bounded by three narrow closely appressed cycles of elements of approximately equal width.

Description: The heliolith is composed of three tiers of approximately 50 to 60 elements. Those in the proximalmost cycle are imbricated along the inner margin in a clockwise direction. Elements of the prominent middle cycle of elements are inclined strongly counterclockwise when viewed proximally. The open central area generally spans at least half the diameter of the coccolith.

Remarks: This form is distinguished from others assigned to the genus by its large central area, high element count, short height, and the presence of a prominent set of elements which compose an intermediate cycle. It appears to be closely related to $H$. universus as evidenced by the high element count and the presence of a middle cycle of elements. The forms illustrated here appear to be end members of a rather discrete taxonomic group. However, the lack of an adequate number of well-preserved specimens precludes the definition of a new species at present. The specimen in Plate 14, Figures 9 and 10 is obscured by debris so its true dimensions cannot be determined with certainty.

Occurrence: Few in the Heliolithus universus Zone of the Paleocene section of Hole 327A on the Falkland Plateau.

Size: $10-11 \mu \mathrm{m}$.

\section{Genus HORNIBROOKINA Edwards, 1973}

\section{Hornibrookina australis Edwards and Perch-Nielsen, 1974} (Plate 7, Figures 2-6)

Hornibrookina sp., Edwards, 1973a, p. 77, fig. 82.

Hornibrookina n. sp., Edwards, 1973b, pl. 9, fig. 1-3.

Hornibrookina australis Edwards and Perch-Nielsen, 1974, p. 485, pl. 2, fig. $1-3,6,9,12$; pl. 5 , fig. $6,9,12$.

Remarks: First described from the Pacific sector of the Southern Ocean by Edwards and Perch-Nielsen, this small but distinct species is here recorded from the Atlantic sector where it is few to abundant in upper Paleocene samples from the Discoaster multiradiatus Zone of the carbonate-rich section at Site 329 .

\section{Genus TOWEIUS Hay and Mohler, 1967}

\section{Toweius eminens (Bramlette and Sullivan, 1961)}

(Plate 5, Figures 1-3)

Coccolithus eminens Bramlette and Sullivan, 1961, p. 139, pl. 1, fig. 3 .

Cruciplacolithus eminens Hay and Mohler, 1967, p. 1527, pl. 196, fig. 26-28.

Toweius eminens Perch-Nielsen 1971, p. 360, pl. 13, fig. 4, 6; pl. 14, fig. 3,4 .

Remarks: Our SEM micrographs of this species reveal a grill on the proximal side which covers the central area. The grill is sometimes visible in distal as well as proximal view.

Toweius tovae Perch-Nielsen, 1971

(Plate 5, Figure 6; Plate 6, Figure 1)

Remarks: Specimens listed on the range charts as Toweius tovae exhibited 5 to 7 perforations in the light microscope rather than the six originally defined for the species. This may have been due in part to diagenetic overgrowth, or to intraspecific variation. The taxon served as a convenient designation for all such forms.

\section{MESOZOIC}

(F.H. Wind and S.W. Wise, Jr.)

\section{Genus ACUTURRIS Wind and Wise, n. gen.}

Type species: Eurhabdus scotus Risatti, 1973.

Diagnosis: Elongate forms constructed of three calcite laths rising from a thin basal disk marked by three sutures radiating from a central pore on the proximal surface.

Remarks: The generic name is from the Latin acus, a pin, needle; turris, a spire. Specimens of Eurhabdus scotus Risatti from Hole 327A illustrate 3-fold symmetry of both base and spire. Parallel observations have been made on Upper Cretaceous samples from Alabama. Acuturris Wind and Wise differs from Lucianorhabdus Deflandre, 1959 (=Eurhabdus Reinhardt, 1965; see Wind, 1975) in that the latter forms are characterized by 4 -fold symmetry.

\section{Acuturris scotus (Risatti) emend. Wind and Wise, n. comb.}

(Plate 33, Figures 1-3; Plate 36, Figure 3)

Eurhabdus scotus Risatti, 1973, p. 29, pl. 7, fig. 9, 10.

Description: Narrow, elongate spines projecting from small round or elliptical basal disc; spine and disc constructed of three identical components. Sutures isolating each third of a specimen are continuous between spine and base.

Basal disc between 0.8 and $1.0 \mu \mathrm{m}$ thick and generally between 4.5 and $5.5 \mu \mathrm{m}$ in diameter. Spine length generally between 10 and $20 \mu \mathrm{m}$. Outer surface of spine blocky, inner surface relatively smooth. Narrow triangular tunnel is formed at the junction of the three com- 
ponent parts. Percentage of any given specimen remaining bright in polarized light depends upon orientation of specimen within polarizing field and position of sutures.

Remarks: Risatti (1973, p. 29) describes this form as "shaped like an alchemists cap or a 'dunce cap' ... The edges are rugose and a straight suture perpendicular to the base divides the specimen into two parts." Risatti's investigation was restricted to the study of light microscope slides, and he was therefore unable to observe the 3 -fold symmetry of this form evident in the scanning electron microscope.

Incomplete specimens ( $1 / 3$ of a whole specimen) are dark gray in phase contrast illumination and not visible in polarized light. This species is rarely seen in proximal or distal view.

\section{Genus AXOPODORHABDUS Wind and Wise, n. gen.}

Type species: Podorhabdus cylindratus Noël, 1965

Description: Forms with a podorhabdid rim and hollow spine supported by four wide bars aligned parallel to the major and minor axes of the coccolith.

Remarks: In 1965, Noël intended to erect the genus Podorhabdus, with the type species $P$. grassei, for specimens which possessed a spine supported by four large pillars. Although the holotype of $P$. grassei is described by Noël (1965, p. 103) as being constructed of four large pillars separated from each other by raised arches, our examination of the electron micrographs of the holotype (Noël, 1965, pl. 9, fig. 1, 2) reveals the presence of only two pillars and arches. The holotype and original description are therefore not in agreement.

We have, therefore, in this report, redefined the genus Podorhabdus Noèl to include forms with two broad pillars separated by arched excavations. The new genus, Axopodorhabdus, is proposed for those species bearing four spine-supporting struts aligned parallel to the axes of greatest and least dimension. We designate $P$. cylindratus Noël, 1965, p. 103-104, fig. 30, pl. 9, fig. 3, 7 as the type of this new genus.

This genus can be distinguished from Podorhabdus Noël, 1965 , emend. Wind and Wise, in that the latter genus possesses only two bars supporting a central stem (and only two perforations), and from Tetrapodorhabdus Black, 1971a, in which the four perforations, and not the bars supporting the stem, are aligned along the ellipse axes. The distinguishing features of these three genera are illustrated in Figure 3.

The following species validly described under Podorhabdus are here included under the new genus Axopodorhabdus.

Axopodorhabdus cylindratus (Noël) Wind and Wise n. comb. (Plate 80, Figures 5, 6; Plate 81, Figures 1-4; Plate 88, Figures 5, 6)

$=$ Podorhabdus cylindratus Noël, 1965, p. 103-104, fig. 30, pl. 9, fig. 3,7 .

Axopodorhabdus albianus (Black) Wind and Wise, n. comb.

$=$ Rhabdosphaera $\mathrm{sp}$. Black, 1965, p. 133, fig. 10.

=Podorhabdus albianus Black, 1967, p. 143-144.

$=$ Podorhabdus orbiculofenestratus (Gartner) Thierstein, 1971, p. 478, pl. 8, fig. 9-17.

Axopodorhabdus dietzmanni (Reinhardt) Wind and Wise, n. comb. (Plate 58, Figures 3, 4)

$=$ Ahmuellerella dietzmanni Reinhardt, 1965, p. 30, pl. 1, fig. 1, text fig. 1.

$=$ Cretarhabdus dietzmanni (Reinhardt) Reinhardt, 1966, p. 27, pl. 22, fig. 1; fig. 23.

=Podorhabdus dietzmanni (Reinhardt) Reinhardt, 1967, p. 169 , fig. 4 .

Axopodorhabdus fusiformis (Black) Wind and Wise, n. comb.

$=$ Podorhabdus fusiformis Black, 1972, p. 34-35, pl. 7, fig. 3, 6-9, text-fig. 34 .

Axopodorhabdus gracilis (Black) Wind and Wise, n. comb. $=$ Podorhabdus gracilis Black, 1972, p. 35, pl. 13, fig. 4 .

Axopodorhabdus gorkae (Reinhardt) Wind and Wise, n. comb. =Podorhabdus gorkae Reinhardt, 1969, p. 933, pl. 1, fig. 1, 2 .

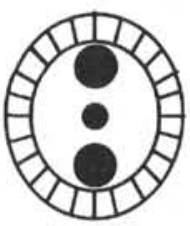

Podorhabdus

Noët emend.

Wind and Wise

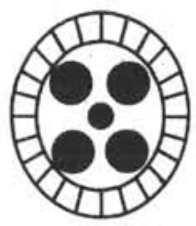

Axopodorhabdus Wind and Wise

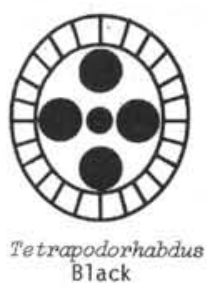

Black
Figure 3. Comparison of symmetry exhibited by Podorhabdus, Axopodorhabdus, and Tetrapodorhabdus.

\section{Genus BISCUTUM Black, 1959}

Remarks: In addition to the shield configuration of this genus described by Black (see Black and Barnes, 1959, p. 325) and the central area characteristics described by Gartner (1968, p. 18), a modification of distal shield element design is noted for those species which have been viewed in the scanning electron microscope. When viewed from the distal side, the distal rim of specimens so observed is characterized by interelemental sutures modified into a dovetail tongue-and-groove configuration. The counterclockwise edge of each element forms a short, often wide appendage with rounded corners, which is inserted in a corresponding similarly shaped depression on the clockwise edge of the adjacent shield element. These tabs are well developed on Biscutum magnum n. sp. (see Plate 20, Figure 4; Plate 21 , Figure 2) and are evident, although not as well developed in micrographs of Biscutum constans (Gorka) $(=B$. blacki and B. testudinarium) (see Bukry, 1969, pl. 8, fig. 7, 9, 10, 12). Smaller triangular tabs are visible on Biscutum multiforme Bukry (1969, pl. 8, fig. 5). Distal element tabs are also present in modified form in B. dissimilis $\mathrm{n}$. sp. (pl. 23, fig. 1-5). This modification of the distal shield elements is not restricted to species of Biscutum as it is also well developed in Prediscosphaera cretacea (see Bukry, 1969, pl. 16, fig. 12; pl. 17, fig. 1, 3, 7-10, 12), and Seribiscutum Filewicz, Wind, and $W$ ise.

Biscutum boletum Wind and Wise, $n$. sp.

(Plate 21, Figure 1; Plate 23, Figures 6, 7)

Diagnosis: Species of Biscutum with a small proximal shield surrounding an elongated collar and central area.

Description: Distal shield constructed of 17 to approximately 24 elements. Proximal shield consists of a narrow band of approximately 24 elements surrounding a central area collar which projects proximally from the distal shield. Proximal surface of the central area is slightly depressed, caused by sloping of proximal shield elements towards the central groove. Proximal shield elements are continuous with the intershield tube elements and project as a single unit proximally.

Remarks: The species name is from the Latin, meaning mushroom. It is distinguished from other species of Biscutum by its laterally restricted, proximally extended proximal shield and central area.

Occurrence: Maestrichtian of Hole 327A, Falkland Plateau.

Size: Holotype-distal shield $5.8 \mu \mathrm{m} \times 4.7 \mu \mathrm{m}$; proximal shield $2.9 \mu \mathrm{m} \times 2.0 \mu \mathrm{m}$. Paratype-distal shield, $5.8 \mu \mathrm{m} \times 4.3 \mu \mathrm{m}$; proximal shield, $2.5 \mu \mathrm{m} \times 1.7 \mu \mathrm{m}$.

Holotype: USNM 239488 (Plate 23, Figures 6, 7).

Paratype: USNM 239479 (Plate 21, Figure 1).

Type locality: Sample 327A-12-2, $45 \mathrm{~cm}$.

\section{Biscutum coronum Wind and Wise, n. sp.} (Plate 24, Figures 10-12)

Diagnosis: Species of Biscutum characterized by a bright ring surrounding an elliptical area in both phase-contrast and crossedpolarized light.

Description: This large species has a central area covering approximately $20 \%$ of the placolith. Distal shield elements are dextrally oriented; proximal shield elements appear to be radial. The number of distal shield elements appears to exceed 24. In crossed-polarized light, the narrow ring or collar-like feature and the central area, is bright. The inner part of the central area elements may be slightly 
thickened, however, individual central area elements are not discernible in the light microscope. This species has not yet been studied in the scanning electron microscope.

Remarks: The species name is Latin, meaning halo. This form is approximately equal in size to Biscutum magnum $\mathrm{n}$. $\mathrm{sp}$. It is distinguished from other species of the genus by the presence of the bright ring adjacent to the central area.

Occurrence: Maestrichtian of Hole 327A, Falkland Plateau.

Size: Holotype $8.0 \mu \mathrm{m}$.

Holotype: USNM 239491 (Plate 24, Figures 10-12).

Type locality: Sample 327 A-13-2, $137 \mathrm{~cm}$.

\section{Biscutum dissimilis Wind and Wise, $n$. sp.}

(Plate 23, Figures 1-5; Plate 24, Figures 3-6)

Lithastrinus sp. Forchheimer, 1968, p. 58, text-fig. 2 (p. 17), fig. 1, pl. 9 , figs. la-b, 5 .

Diagnosis: Strongly elliptical species of Biscutum with thick massive distal plates and thin, small proximal shield. Long axis extremities are usually dominated by one or two exceptionally broad, massive elements.

Description: Large elongate form constructed of between 7 and 11 radial, slightly imbricate and massively constructed distal shield elements and a similar number of thin radial nonimbricate elements in the proximal shield. Largest dimension of specimens varies between 8.5 and $11 \mu \mathrm{m}$; ellipticity ranges from 1.3 to 1.5 . The thin proximal shield has dimensions generally only one-half that of the proximal shield. Distal shield elements may exceed $1.0 \mu \mathrm{m}$ in thickness; proximal shield elements are more uniform in thickness, generally about $0.1 \mu \mathrm{m}$ thick. Although the arrangement of elements is variable, one or two large crystalline elements may dominate one or both ends of the distal shield.

Lateral distal shield elements have modified dovetail tabs and sockets characteristic of several species of this genus (see Plate 23 , Figures 2,3). Proximal surfaces of distal shield elements exhibit a pitted appearance; this feature is most evident on the large polar elements, and is present to a lesser degree on the distal surface as well.

The small central area appears to be lined with a small number of thick plates. Central area is similar in appearance in both proximal and distal view.

Remarks: The proximal shield is generally not completely preserved, and in those samples which have been subjected to even moderate dissolution, the shield is completely removed. While the proximal shield is one of the features of the flora most susceptible to dissolution, the distal shield is one of the most resistant.

Occurrence: Upper Albian to Maestrichtian, Holes 327A and 330, Falkland Plateau.

Size: $8.5-11 \mu \mathrm{m}$.

Holotype: USNM 239484 (Plate 23, Figure 1).

Paratypes: USNM 239485-239487 (Plate 23, Figures 2-5); USNM 239480 (Plate 24, Figures 3, 6); USNM 239490 (Plate 24, Figures 4, 5).

Type locality: Sample 327A-12, CC.

Biscutum magnum Wind and Wise, n. sp.

(Plate 20, Figures 4-6; Plate 21, Figure 2; Plate 24, Figures 1, 2; Plate 30, Figure 1; Plate 50, Figure 1)

Diagnosis: Large form of Biscutum with shields constructed of about 17 elements surrounding a central area representing $20 \%$ to $30 \%$ of area of placolith.

Description: Distal shield larger than proximal. Each shield usually consists of 17 elements; the largest elements are situated along the long axis. Distal shield elements oriented slightly dextrally; proximal shield elements radial and nonimbricate. Imbrication of the distal shield elements forms broad dovetail extensions on the counterclock wise edge of each element; these are positioned over corresponding depressions on adjacent elements. These tabs are broadest (longest radial length) on the narrowest elements.

The central area is occupied by approximately 15 inwardly projecting elements; most of these elements give the appearance of being a continuation of distal rim elements; however, along the long axis, elements of the ends of the central area vary in shape and size, probably due to crowding. In well-preserved specimens, central area elements have pronounced outer thickening and centralmost area thinning. During early diagenesis, the thin central area is dissolved and the outer area becomes overgrown.
Remarks: The large size of this species exceeds that of all other species of Biscutum characterized by similar symmetry, with the exception of some specimens of $B$. coronum. The holotype of $B$. castorum Black ( $=B$. constans $)$ is $4.1 \mu \mathrm{m}$. The holotype of $B$. testudinarium Black $(=B$. constans) is $3.7 \mu \mathrm{m}$, and the holotype of $B$. blacki Gartner $(=$ B. constans) is $5.0 \mu \mathrm{m}$. Bukry $(1969$, p. 29$)$ states that $B$. testudinarium Black has a maximum diameter of $6.6 \mu \mathrm{m}$, but according to the micrograph dimensions and magnifications given, his specimens range in size from 4.5 to $7.7 \mu \mathrm{m}$.

Coccolithites polycingulatus Reinhardt $(1965$, p. $39-40$, pl. 3 , fig. 4) has a central area similar to that of $B$. magnum, but has a size range of 5 to $7 \mu \mathrm{m}$. Distal shield element tabs are radically different in construction, being more similar in their design to species of Seribiscutum.

Cribrosphaerella tectiforma Reinhardt (1964, p. 758, pl. 2, fig. 4) has a maximum diameter of $6 \mu \mathrm{m}$.

Occurrence: Maestrichtian of Hole 327A, Falkland Plateau.

Size: Holotype $8.4 \mu \mathrm{m}$; Paratypes $8.1 \mu \mathrm{m}$ to $9.0 \mu \mathrm{m}$.

Holotype: USNM 239476 (Plate 21, Figure 2).

Paratypes: USNM 239473-239475 (Plate 20, Figures 4-6); USNM 239489 (Plate 24, Figures 1, 2); USNM 239512 (Plate 30, Figure 1a); USNM 239527 (Plate 50, Figure 1a).

Type locality: Sample 327A-12, CC.

\section{Biscutum notaculum Wind and Wise, n. sp.}

(Plate 26, Figure 4; Plate 30, Figure 1b)

Diagnosis: Small species of Biscutum whose central area presents an image in polarized light that resembles a figure " $\mathrm{H}$ " when oriented parallel to the polarizing axes.

Description: Small specimens constructed of approximately 17 slightly imbricate elements in distal shield, and approximately the same number of radial, nonimbricate elements in the proximal shield. In proximal view, central area is surrounded by narrow rim of crystals. Central area is filled with approximately 24 radiating tabular composite rays.

In polarized light, central area generates an " $\mathrm{H}$ " or deformed " $\mathrm{S}$ " figure depending upon orientation with respect to the polarizing axes. The crossbar on the " $\mathrm{H}$ " figure often bears a small central pore.

Remarks: The species name is Latin, meaning a letter, character, distinguishing mark. This form is distinguished from all other species of Biscutum on the basis of its small size and appearance in polarized light. The greatest dimension of this species is smaller than the central area of Biscutum magnum Wind and Wise, n. sp. and approximately equal to the size of the central area of Biscutum constans (Gorka). The precise size of Watznaueria ? minima Reinhardt and Gorka (1967) cannot be determined. Reinhardt and Gorka (1967, p. 248) state that the length is 4 to $6 \mu \mathrm{m}$. However, the two specimens as illustrated (Plate 31, Figure 24; Plate 33, Figure 6) have greatest dimensions of 2.95 and $2.50 \mu \mathrm{m}$, respectively.

Occurrence: Maestrichtian of Hole 327A, Falkland Plateau.

Size: Holotype $3.4 \mu \mathrm{m} \times 2.8 \mu \mathrm{m}$; central area $1.4 \mu \mathrm{m} \times 0.9 \mu \mathrm{m}$.

Holotype: USNM 239517 (Plate 30, Figure 1b).

Paratype: USNM 239526 (Plate 26, Figure 4).

Type locality: Sample 327A-12, CC.

\section{Biscutum virginica (Bukry) Wind and Wise, n. comb. (Not illustrated)}

Watznaueria virginica Bukry, 1969, p. 34, pl. 13, fig. 4-6.

Remarks: Elements at the ends of this elongate coccolith are much wider than those along the sides, a construction exhibited by members of the genus Biscutum. Although the median suture and the regular alignment of elements in the central area is reminiscent of Watznaueria, the slight degree of imbrication of adjacent elements and the disparity in size between the proximal and distal shields seems more typical of Biscutum.

\section{Genus BOLETUVELUM Wind and Wise, n. gen.}

Type species: Boletuvelum candens Wind and Wise, n. sp.

Diagnosis: Rhabdolith consisting of broad-based flaring hollow stem terminating in a massive, totally enclosed distal bulb.

Remarks: The genotype resembles the Jurassic species Discorhabdus jungi Noël, 1965. The holotype of $D$. jungi is illustrated with a nondecalcified transmission electron micrograph. Subsequently illustrated specimens are probably specimens of Podorhabdus grassei 
Noël emend. Wind and Wise whose orientation in micrographs obscures the two small arched perforations which characterize the species.

Derivation of name is from the Latin boletus (a mushroom) and velum (a sail).

\section{Boletuvelum candens Wind and Wise, $\mathbf{n}$. sp.}

(Plate 21, Figure 6; Plate 22, Figures 1-7)

Diagnosis: A rhabdolith constructed of a two-shield base and a wide, hollow distal projection terminating in an inflated and closed bulb. The greatest diameter of the bulbous terminus is greater than the corresponding dimension of the distal shield.

Description: The hollow stem projects distally from a base constructed of a broad distal shield and a smaller proximal shield. Distal shield composed of approximately 35 radial, nonimbricate or slightly imbricate elements. The main trunk of the stem is constructed of approximately 24 ribs and is occasionally reinforced by internal supporting cross-struts. Closing seam parallels the lateral elongation of the bulbous terminus. Proximal and distal shields generally elongated in one direction.

Remarks: Species name is from the Latin candens (incandescent). The holotype bears a conspicuous perforation of the base outside of the tubular stem. It is not known whether this feature, which has been observed on several specimens, is characteristic of the species or merely an individual variation. Similarly, the number of elements forming the proximal shield could not be determined. However, the tubular stem appears to arise from the proximal shield, therefore the shield probably contains elements equal in number to the elongate laths constructing the tube.

Occurrence: Maestrichtian of Hole $327 \mathrm{~A}$ on the Falkland Plateau.

Size: Holotype-maximum diameter of proximal shield $4.5 \mu \mathrm{m}$; maximum diameter of distal shield $6.0 \mu \mathrm{m}$; total length $10 \mu \mathrm{m}$; diameter of tubular base $2.5 \mu \mathrm{m}$; maximum dimension of bulb 7.5 $\mu \mathrm{m}$.

Holotype: USNM 239478 (Plate 22, Figures 1-4).

Paratypes: USNM 239481-239483 (Plate 22, Figures 5-7); USNM 239477 (Plate 21, Figure 6).

Type locality: Sample 327A-12, CC.

\section{Genus BROINSONIA Bukry, 1969}

Broinsonia verecundia Wind and Wise n. sp. (Plate 28, Figures 1-3)

Diagnosis: Small specimens of Broinsonia with major portion of inner area filled by flat elliptical platform. Platform connected to rim by approximately 14 to 16 radiating spokes and four slightly larger axial or subaxial bars.

Description: Specimens generally under $4 \mu \mathrm{m}$ in greatest diameter, with distal rim of approximately 22 radial and nonimbricate elements. All distal rim elements are approximately the same size. Central area of holotype represents about $47 \%$ of distal surface area. Long axis bridges connecting central area and rim are only slightly larger than accessory spokes. Two supports connecting the inner platform to the rim are oriented at between $10^{\circ}$ and $30^{\circ}$ to the short axis of the ellipse. The two pairs of axial or subaxial supports are often indistinguishable from accessory spokes in distal view, but are clearly discernible in proximal view as being the only rays connecting the central platform to the proximal shield. The accessory spokes are confined to the distal shield and parallel neither major nor minor ellipse axis.

Remarks: Species name is Latin, meaning bashfulness. This species differs from other forms of Broinsonia in its small size and the similarity in size of principal and accessory supporting spokes. All other species of Broinsonia contain either perpendicular sets of accessory rays, or thinner, more numerous rays parallel to the short axis of the ellipse. Orientation of accessory rays is similar to that found in Zygolithus flabellosus Stradner, Adamiker, and Maresch, but the latter species is characterized by a different rim structure, smaller central platform, and more pronounced short axis support strut.

Occurrence: Maestrichtian of Hole 327A, Falkland Plateau

Size: Holotype, $3.6 \mu \mathrm{m} \times 2.8 \mu \mathrm{m}$; central area $2.6 \mu \mathrm{m} \times 1.8 \mu \mathrm{m}$; rim diameter $0.5 \mu \mathrm{m}$. Paratypes, $4.0 \mu \mathrm{m} \times 2.6 \mu \mathrm{m}, 3.8 \mu \mathrm{m} \times 2.7 \mu \mathrm{m}$.

Holotype: USNM 239501 (Plate 28, Figure 1).

Paratypes: USNM 239502-239503 (Plate 28, Figures 2, 3).

Type locality: Sample 327A-12, CC.
Genus CENTOSPHAERA Wind and Wise, n. gen.

Type species: Centosphaera barbata Wind and Wise, n. sp.

Diagnosis: Large calcareous spheres constructed of hour-glassshaped blocks arranged in patchwork pattern. The sphere is ringed with one or more keels composed of needle-like crystals.

Description: See characteristics of type species.

Remarks: The genus name is from the Latin centos, pattern, and sphaera. This genus differs from the genus Thoracosphaera in the mode of construction of the sphere wall and in the presence of large structures modifying the exterior.

\section{Centosphaera barbata Wind and Wise, n. sp.}

(Plate 25, Figures 1-6; Plate 26, Figures 1-3; Plate 27, Figures 1-7)

Diagnosis: Large calcareous spheres constructed in patchwork pattern of hour-glass-like crystals. Keels of needle-like crystals circle the sphere.

Description: Complete specimens may be perfectly spherical or slightly laterally compressed. A moderately large aperture is present in all of the specimens whose orientation permitted viewing from several directions. The holotype possesses two parallel large fibrous keels which project approximately $4.5 \mu \mathrm{m}$ outward from the sphere. Flattening of the main body parallels the major keels, and the aperture is located at one end, between the two keels. Short fibrous processes connect the two major keels. These features have been observed in light-microscope mobile mounts on specimens identical to the holotype.

The inner surface of the main body is lined with interlocking seemingly dendritic crystals (see Plate 25 , Figures 5,6 ), which are either features of the proximal surface of the hour-glass-shaped crystals, or are related in morphology to the fibers constructing the fringes. One paratype (Plate 26, Figures 1, 3) appears to possess only one very prominent keel, which circles the sphere at its greatest diameter, terminating at the aperture. It is not known at the present time whether this variation in keel morphology is intraspecific in nature or whether this paratype should serve as the type for a second species. Individual hour-glass-shaped crystals $2.7 \mu \mathrm{m} \times 1.6 \mu \mathrm{m}$ are readily identifiable in the light microscope, and their presence was often used to indicate the presence of this species in the smear slides studied.

Remarks: The species name is Latin, meaning bearded.

Occurrence: Maestrichtian of Hole 327A, Falkland Plateau.

Size: Holotype maximum dimension including fringe, $30 \mu \mathrm{m}$; maximum dimension of spherical body, $21.5 \mu \mathrm{m}$.

Holotype: USNM 239492 (Plate 25, Figures 1-3).

Paratypes: USNM 239493 (Plate 25, Figure 4); USNM 239494 (Plate 25, Figures 5, 6); USNM 239495 (Plate 26, Figures 1, 3); USNM 239496 (Plate 26, Figure 2); USNM 239497 (Plate 27, Figure 1); USNM 239498 (Plate 27, Figure 2); USNM 239499 (Plate 27, Figures 3-5); USNM 239500 (Plate 27, Figures 6, 7).

Type locality: Sample 327A-10-3, $14 \mathrm{~cm}$.

\section{Genus COROLLITHION Stradner, 1961}

(For descriptions of other Corollithion species in addition to those listed below, see next section)

Corollithion fragilis (Rood and Barnard) Wind and Wise, n. comb. (Plate 60, Figures 5-7; Plate 61, Figure 2)

Actinozygus fragilis Rood and Barnard, 1972, p. 334, pl. II, fig. 9.

Remarks: Rood and Barnard named this species for an eightrayed Jurassic form which shows a slight asymmetry of the radial bars. They considered it to be an intermediate form between the genera Actinozygus and Diadozygus which they differentiated on the basis of cross-bar symmetry. Thierstein (1973) placed Diadozygus in synonymy with Corollithion due to similar shield construction which he considered of more taxonomic importance than the geometric arrangement of the cross bars. Forms observed in the Aptian of Hole 330 show only slight asymmetry and some variation in bar spacing (compare Plate 60, Figures 6, 7).

\section{Corollithion helotatus Wind and Wise, n. sp. (Plate 85, Figures 1-5)}

Description: Species of Corollithion constructed of an elliptical base and four arched struts supporting an elongate, straight spine. The base consists of a single thin proximal layer of crystals support- 
ing a tall $(0.8 \mu \mathrm{m})$ vertical wall. The proximal surface curves convexly and the basal wall projects slightly inward. The spine, when present, is constructed of vertical laths of calcite approximately $1 \mu \mathrm{m}$ in length. Total length of the spine is approximately $7.0 \mu \mathrm{m}$. The four struts curve towards the short axis, and join to form a broad platform. Ellipticity of base is approximately 1.22 .

Remarks: Species name is from the Greek helotos, meaning nailshaped. The four struts project distally and merge to form the base of the spine. The presence of a small hole on the proximal side of the junction of the four struts suggests that at least the lower part of the spine may be hollow. Edges of the basal layer of flat crystals project beyond the edge of the wall of overlying vertical plates. Sutures between individual plates constructing the wall alternate in position with those of the basal layer. The specimen in Plate 85, Figure 5 appears to be a specimen of $A$. helotatus without a long spine. When viewed from the dorsal side, such forms resemble specimens of Stephanolithion bigoti without lateral processes.

This form differs from other species of Corollithion in the number of struts present and the convex nature of the base and the resulting inward projection of the basal wall. In proximal view it is probably similar to Chiastozygus primitus Prins (Rood et al., 1973, pl. 1, fig. 8), but the species of Chiastozygus in this view exhibits no arching of the cross bars and no evidence of the existence of a hollowbased spine.

Occurrence: Oxfordian of Hole 330 on the Falkland Plateau.

Size: Holotype: base $4 \mu \mathrm{m}$ wide, $0.8 \mu \mathrm{m}$ high; spine $0.8 \mu \mathrm{m}$ wide, total height of specimen $7 \mu \mathrm{m}$. Paratype: base $3.2 \mu \mathrm{m}$ wide, $0.8 \mu \mathrm{m}$ high: spine $0.7 \mu \mathrm{m}$ wide, total height of specimen approximately 5.5 $\mu \mathrm{m}$. Paratype (Plate 9, Figure 5) base $3.4 \mu \mathrm{m} \times 2.8 \mu \mathrm{m}$.

Holotype: USNM 239535 (Plate 85, Figures 1-3).

Paratype: USNM 239541-239542 (Plate 85, Figures 4, 5).

Type locality: Sample 330-8-1, $107 \mathrm{~cm}$.

Corollithion senarius Wind and Wise, $\mathrm{n}$. sp. (Plate 78, Figures 2, 3; Plate 89, Figures 10,11)

Description: A species of Corollithion with six bars extending from an enlarged central platform to a thin rim. Two bars form a strut which bisects the specimen. The rim exhibits pronounced flaring around the medial set of perforations. The angle between adjacent sides is between $75^{\circ}$ and $80^{\circ}$.

Remarks: Species name is Latin, meaning "consisting of six." In the evolutionary and stratigraphic study of Diadozygus and related genera by Rood and Barnard, 1972, p. 339, fig. 2, Corollithion senarius could probably be placed in the "transition to rhomboidal outline" interval linking Diadozygus escovillensis to Diadorhombus minutus. This interval represents the time interval from latest Bajocian to early Oxfordian. This transitional zone is characterized by a reduction in the number of bars (from 8 to 4 ) and change from elliptical to rhombic periphery.

Occurrence: Oxfordian of Hole 330 on the Falkland Plateau.

Size: Holotype: $4.3 \mu \mathrm{m} \times 3.0 \mu \mathrm{m}$; Paratypes: $4.0 \mu \mathrm{m} \times 3.0 \mu \mathrm{m}$.

Holotype: USNM 239537 (Plate 78, Figure 3).

Paratypes: USNM 239544, 240450 (Plate 89, Figures 10, 11).

Type locality: Sample $330-7-5,120 \mathrm{~cm}$.

\section{Genus CRETARHABDUS Bramlette and Martini, 1964}

\section{Cretarhabdus sp.}

(Plate 70, Figures 1, 2)

Diagnosis: A species of Cretarhabdus with approximately six perforations arranged asymmetrically with respect to the major and minor axes of the ellipse.

Remarks: Only two proximal views of specimens are available. One has six well-defined perforations, the other five. Both, however, exhibit a pronounced asymmetry of perforations within a central area platform composed of granular and elongate elements. The taxonomic importance of the asymmetrical arrangement at present is unclear.

\section{Genus ETHMORHABDUS Noël, 1965}

\section{?Ethmorhabdus sp. aff. E. camaratus Bukry}

$$
\text { (Plate 26, Figure 5) }
$$

Description: Specimen of Ethmorhabdus consisting of wide shield surrounding central area containing 33 holes situated between diagonally arranged cross bars. The central area is highly inflated.
The four quadrants are slightly unequal in size, containing 7, 10, 9, and 7 holes, respectively.

Remarks: This specimen contains far more than the 9 to 18 polygonal openings in the central area of Ethmorhabdus camaratus Bukry (1969, p. 37, pl. 15, fig. 10-12). With the exception of the orientation of the cross bars, this specimen is quite similar to one specimen of Cretarhabdus conicus Bramlette and Martini illustrated by Bukry (1969, pl. 13, fig. 10). This specimen bears intra-elemental sutures on the distal surface of the rim, a feature seen on many species of Cretarhabdus. However, Cretarhabdus possesses a two-cycle distal shield. Marked differences in rim appearance between this specimen and Jurassic representatives of Ethmorhabdus suggest that this form may represent an ethmorhabdid taxon derived from Cretarhabdus.

\section{Ethmorhabdus ? frondosus Wind and Wise, n. sp.} (Plate 76, Figures 1, 2)

Diagnosis: Central area paved with a field of small randomly oriented petal-like crystals, superimposed upon which is a cross constructed of narrow, elongate crystals.

Description: The central cross is oriented at approximately $10^{\circ}$ to $15^{\circ}$ to the axes of the coccolith. The arms of the cross do not extend to the rim, but are confined to only the inner portion of the central area.

Remarks: The species name is from the Latin frondosus (full of leaves). This species differs from $E$. gallicus Noël in the generally random orientation of petal-like crystals filling the central area and the presence of the cross-structure.

Occurrence: Oxfordian of Hole 330 on the Falkland Plateau.

Size: Holotype length $5.4 \mu \mathrm{m}$, width $4.3 \mu \mathrm{m}$; Paratype length 5.2 $\mu \mathrm{m}$, width $4.4 \mu \mathrm{m}$.

Holotype: USNM 239530 (Plate 76, Figure 1).

Paratype: USNM 239531 (Plate 76, Figure 2).

Type locality: Sample 330-8-1, $107 \mathrm{~cm}$.

Genus GARTNERAGO Bukry, 1969

\section{Gartnerago segmentatum (Stover) Thierstein}

(Plate 52, Figures 2,3)

Gartnerago segmentatum (Stover) Thierstein, 1974, p. 640, pl. 5, fig. 1, 2; pl. 6, fig. 1, 3-10; pl. 7, fig. 6. (for pre-1974 synonymy, see Thierstein, 1974).

Remarks: The species concepts employed by Thierstein (1974) in his revision of Gartnerago are followed to distinguish this somewhat rare and poorly preserved form we found in the Cenomanian of Holes $327 \mathrm{~A}$ and 330 .

Genus LAGUNCULA Black, 1971

\section{Laguncula dorotheae Black}

(Plate 73, Figures 3-7)

Laguncula dorotheae Black, 1971b, p. 327, pl. 2.

Remarks: Reported to date only from the Gault Clay of England by Black (1971 b) who illustrated this uncommon form in transmission electron micrographs. Transmitted light reveals that the specimens are composed of very thin walls with a hollow interior. Intergrowths of wall elements produce a cancellate pattern visible in polarized light.

Occurrence: Few in the Prediscosphaera cretacea Zone (lower and middle Albian) of Holes 327A and 330 of the Falkland Plateau and in the Gault Clay (middle to upper Albian) of England. This species may prefer high latitude environments.

\section{Genus LAPIDEACASSIS Black, 1971}

\section{$(=$ Scampanella Forcheimer and Stradner $)$}

Type species: Lapideacassis mariae Black, 1971

\section{Lapideacassis cornuta (Forcheimer and Stradner) Wind and Wise, n. comb. \\ (Plate 48, Figures 9-12; Plate 49, Figures 3-8)}

Scampanella cornuta Forchheimer and Stradner, 1973, p. 285-287, fig. 1-9.

Description: Hollow cylindrical calcareous objects bearing small tabular dentation at one end, with two similar diverging processes at 
the opposite end. Cylindrical wall is constructed of between one and three tiers of laths.

Remarks: This species is distinguished from other species of Lapideacassis on the basis of the presence of the two diverging spines.

Occurrence: Coniacian (Forchheimer and Stradner); Leg 36: Poorly preserved forms, possibly identifiable as this species, are present in Albian, and Cenomanian samples. It also is reworked into Eocene samples of Hole 329.

\section{Lapideacassis glans Black, 1971}

(Plate 46, Figures 5, 6; Plate 47, Figures 5, 6)

Remarks: The present authors include in the species all short, nearly hemispherical specimens of this genus observed in Leg 36 samples. Black (1971b, p. 326-327) describes this form as a species with roughly sculptured calcite plates having no visible perforations.

This species is similar in size and shape to the holotype of Hayella situliformis Gartner (1969, p. 32, 34, pl. 1, fig. 4-7) from the upper Eocene of the Mississippi.

Occurrence: Albian of Holes 327A and 330A.

Lapideacassis mariae Black, 1971 emend. Wind and Wise Plate 46, Figures 1-3; Plate 47, Figures 1, 2; Plate 49, Figures 1, 2) Lapideacassis mariae Black, 1971b, p. 326, pl. 1, fig. b, d.

Description: Tapering cylinders constructed of two tiers of rectangular calcite laths. The apertural end is ornamented with approximately 10 square projecting tabs which are aligned with the laths of the adjacent tier. A thin skirt projects laterally from the base of the lowermost tier of laths. The abapertural tier is tapered and terminates in a small cap from which a long, straight spine extends. The spine is constructed of tabular extensions of laths of the upper tier. The spine may bifurcate at its terminus. Each tier of the body cylinder is constructed of between 8 and 10 laths. Laths of the adjacent tiers alternate in position, and a small pore may be present near the abapertural terminus of each lath.

Remarks: No clearly discernible spines are visible on the holotype of this species (Black, 1971b, pl. 1, fig. b), and the existence of same is not mentioned by the original author. The general dimensions of the holotype, however, most nearly correspond to those specimens from the Falkland Plateau which bear single axial spines.

Occurrence: Middle and upper Albian (Black) to Maestrichtian (this report). Questionable specimens have also been observed in Albian and Cenomanian samples from Leg 36, Hole 327A.

\section{Lapideacassis tricornus Wind and Wise, n. sp.}

(Plate 46, Figure 4; Plate 48, Figures 1-8)

?Lapideacassis mariae Black, $1971 \mathrm{~b}$, pl. 1, fig. a.

Diagnosis: A species of Lapideacassis bearing three similar abaperturally projecting spines.

Description: Two-tiered hollow calcareous cylinder terminating in three symmetrically disposed parallel or slightly flaring blade-like spines. The apertural end is ornamented with approximately 10 short tabular projections and a short laterally flaring skirt. The cylinder is constructed of two tiers of calcite laths; the three spines are extensions of the approximately nine laths comprising the second tier. A low, rounded cap seals the cylinder beneath the spines. A small pore is present in the abapertural portion of each of the lower tier laths.

Remarks: In the light microscope, well-preserved forms of this species exhibit an appearance reminiscent of the carapace and anterior appendages of a lobster or crayfish (see Plate 48, Figures 110). Reduction in length of spines is generally accompanied by corresponding reduction in definition of apertural dentition and reduction in degree of development of skirt.

Size: Holotype: total length $9.2 \mu \mathrm{m}$; length of cylindrical body 5.8 $\mu \mathrm{m}$; greatest width $4.2 \mu \mathrm{m}$.

Holotype: USNM 239522 (Plate 48, Figures 4-8).

Paratypes: USNM 239524 (Plate 46, Figure 4); USNM 239525 (Plate 48, Figures 1-3).

Type locality: Sample $327 \mathrm{~A}-10-3,14 \mathrm{~cm}$.

\section{Genus LUCIANORHABDUS Deflandre, 1959}

\section{Lucianorhabdus arborius Wind and Wise, n. sp.} (Plate 32, Figures 3, 5)

Diagnosis: A species of Lucianorhabdus with spine characterized by tree-like appearance. Thickened spine core curves laterally and may not follow center of frondose structure.
Description: Elliptical base supports slightly fluted distally projecting fan-like fringe arising from thickened spine core. Spine core may not constitute axis of fan-like structure; it may curve laterally and represent one margin of the spine complex. Spine fringe may nearly equal the greatest diameter of the base. Spine complex is laterally compressed and parallels the long axis of the base.

Remarks: Species name is Latin, arborius (tree-like). This species is distinguished from other species of Lucianorhabdus by the presence of a fan-like spine complex. Lucianorhabdus arcuatus Forchheimer also possesses a curved spine, but one which has a curved terminus deflected from a primarily vertical spine.

Occurrence: Maestrichtian of Hole 327A, Falkland Plateau.

Size: Holotype - maximum diameter of base $7.6 \mu \mathrm{m}$; height of spine above base $8.6 \mu \mathrm{m}$; greatest diameter of spine complex $7.1 \mu \mathrm{m}$.

Holotype: USNM 239506 (Plate 32, Figures 3, 5).

Type locality: Sample $327 \mathrm{~A}-12, \mathrm{CC}$.

Genus MISCEOMARGINATUS Wind and Wise, n. gen.

Type species: Misceomarginatus pleniporus Wind and Wise, n. sp. Diagnosis: Species with rim of narrow outer, highly imbricate elements and inner cycle of vertically oriented narrow tabular crystals. Fibrous cross bars and faint diamond-shaped inner structure ornament central area. One series of small round or square holes is present in the central area adjacent to the rim. Several similar perforations are present between the crossbar junction and the diamondshaped inner frame.

Description: The outer imbricate rim is constructed of approximately 70 elements. The occasionally obscured inner rim cycle is constructed of, or is adjacent to, crystals which serve to separate adjacent outer perforations. The nature of the crystals paving the area between the outer pores and diamond-shaped inner structure is not understood, but it appears to be constructed of blocky plates in a radial arrangement. The innermost region has a similar appearance. No specimens with spines have been observed.

Remarks: The generic name is from the Latin misceo (mixture) and marginatus (border). Misceomarginatus differs from Monomarginatus Wind and Wise, n. gen., in the presence in the former genus of a two-cycle rim and a greater number of central perforations. Heteromarginatus wallacei Bukry has a wider rim of outer radial elements and an inner cycle of strongly imbricate elements. The inner cycle of elements in Heteromarginatus wallacei Bukry is recessed below the outer cycle, while in Misceomarginatus the two cycles are approximately of equal height. Misceomarginatus has two to three times as many elements in its rim as does Heteromarginatus.

\section{Misceomarginatus pleniporus Wind and Wise, n. sp. (Plate 18, Figures 1-8)}

Diagnosis: A species of Misceomarginatus with approximately 20 outer perforations and approximately 8 central perforations.

Description: Rim constructed of approximately 70 outer imbricate elements and an inner ring of vertical tabular plates. Two axial and perpendicular fibrous cross bars terminate in the inner ring of rim plates. No spine has been observed. The area central to the diamond-shaped inner framework is constructed of tabular crystals similar to those constructing the outer portion of the central area.

Remarks: This species is distinguished from species of Monomarginatus by differences in rim construction and in the similarity of design of the inner and outer portions of the central area of this species. Heteromarginatus wallacei Bukry is quite smaller in size, has fewer pores, and a radically different rim structure.

Occurrence: Maestrichtian of Hole 327A, Falkland Plateau.

Size: Holotype (Plate 18, Figure 1), $9.1 \mu \mathrm{m} \times 6.4 \mu \mathrm{m}$; Paratype (Plate 18, Figure 2), $8.8 \mu \mathrm{m} \times 6.3 \mu \mathrm{m}$; Paratype (Plate 18, Figure 3), $9.2 \mu \mathrm{m} \times 6.8 \mu \mathrm{m}$; Paratype (Plate 18, Figure 4), $9.2 \mu \mathrm{m} \times 6.8 \mu \mathrm{m}$; Paratype (Plate 18, Figure 5 left), $8.6 \mu \mathrm{m} \times 6.7 \mu \mathrm{m}$; Paratype (Plate 18, Figure 6), $9.1 \mu \mathrm{m} \times 7.1 \mu \mathrm{m}$.

Holotype: USNM 239459 (Plate 18, Figure 1).

Paratypes: USNM 239460-239464 (Plate 18, Figures 2-8).

Type locality: Sample $327 \mathrm{~A}-13-2,137 \mathrm{~cm}$.

\section{Genus MONOMARGINATUS Wind and Wise, n. gen.}

Type species: Monomarginatus pectinatus Wind and Wise, n. sp. Diagnosis: Large eiffellithid-rimmed specimens bearing two cross bars which are parallel or subparallel to the major and minor axes of the ellipse. Straight or slightly curved multicrystalline bars extend in 
each quadrant from the points of juncture of axial bars and rim elements. Four large holes are present at the center, and one or more smaller holes are present between the diamond-shaped structure defined by the secondary bars and the rim.

Description: Rim is constructed of between 50 and 75 narrow, overlapping elements. Major cross bars which are parallel or nearly parallel to ellipse axes are arched and are constructed of many long, needle-like crystals. A long composite spine is present in many specimens; the spine may be greater in length than the maximum dimension of the base. Spineless specimens bear a jagged depression in the cross-bar junction. Fibrous straight or outwardly bowed bars form a diamond-shaped structure within the central area. One large round or triangular perforation is located in the inner part of each quadrant, defined by the axial and diagonal cross bars. From one to approximately four smaller holes are present between the diagonal cross bar of each quadrant and the rim. In proximal view, specimens are divisible into the rim and eight central area regions: four central triangular sections bounded by medial sutures on the primary and secondary cross bars; and four outer regions defined by the medial suture of the minor cross bar and a suture marking the inner limit of the rim. The four central areas each contain one round or triangular hole; the four outer regions each contain between one and four or five holes, depending upon the species and individual specimens. Axial cross bars and rim are bright in phase-contrast illumination and polarized light.

Remarks: Species of this genus are defined by the number of outer perforations. This genus differs from Misceomarginatus Wind and Wise, n. gen. and Heteromarginatus Bukry, which possess two-cycle rims.

Monomarginatus pectinatus Wind and Wise, n. sp. (Plate 18, Figure 5; Plate 19, Figures 5, 6; Plate 20, Figures 1, 2)

Diagnosis: Large specimens of Monomarginatus with 8 to approximately 16 perforations between diamond-shaped inner frame and outer rim.

Description: Specimens divided into four quadrants by prominent cross bars which parallel ellipse axes and are inserted at points level with distal surface of rim. Rim constructed of between 50 and $75 \mathrm{im}$ bricate elements. Eccentricity of specimens approximately 1.2 to 1.25 . The number of perforations between diamond-shaped inner frame and rim varies from specimen to specimen and often is not constant in all quadrants of any given individual. Perforations may be round, square, or rectangular in shape; adjacent perforations may coalesce. The four inner perforations are round or triangular in shape and are generally smaller than adjacent cross bars. Cross bars often extend onto distal surface of rim. A spine may be present, rising distally from the junction of the cross bars. The distal surface of cross-bar junction in spineless specimens is marked by a small depression constructed of radially disposed grooves marking the ends of cross-bar crystals.

Remarks: The species name is Latin meaning comb-like, toothed. Monomarginatus pectinatus differs from $M$. quaternarius Wind and Wise, n. sp. by the presence of more than four outer region perforations. This species has a size range and rim element distribution similar to those of $M$. quaternarius Wind and Wise, n. sp. and twice those of Heteromarginatus wallacei Bukry. It differs from Misceomarginatus pleniporus $\mathrm{Wind}$ and $\mathrm{Wise}, \mathrm{n}$. gen., $\mathrm{n}$. $\mathrm{sp}$., which generally possesses more outer perforations, a two-cycle rim, and many small central perforations.

Occurrence: Maestrichtian of Hole 327A, Falkland Plateau.

Size: Holotype: $11.0 \mu \mathrm{m} \times 8.9 \mu \mathrm{m}$; Paratypes: $9.3 \mu \mathrm{m} \times 7.8 \mu \mathrm{m}$; $11.5 \mu \mathrm{m} \times 8.7 \mu \mathrm{m} ; 12 \mu \mathrm{m} \times 8.7 \mu \mathrm{m}$.

Holotype: USNM 239469 (Plate 19, Figure 5)

Paratypes: USNM 239504 (Plate 18, Figure 5 [right]); USNM 239470 (Plate 19, Figure 6); USNM 239471-239472 (Plate 20, Figures $1,2)$.

Type locality: Sample $327 \mathrm{~A}-13-2,54 \mathrm{~cm}$.

\section{Monomarginatus quaternarius Wind and Wise, n. sp.} (Plate 19, Figures 1-4)

Diagnosis: Specimens of Monomarginatus characterized by four large triangular central perforations and four outer elliptical perforations surrounded by a rim constructed of between 50 and 75 elements.

Description: Specimens are divided into four quadrants by prominent cross bars which parallel ellipse axes. Cross bars generally do not extend onto the distal surface of the rim. Rim constructed of between
50 and 75 imbricate elements. Eccentricity of specimens approximately 1.2 to 1.25 . Four inner perforations are triangular in outline and are generally larger than the adjacent cross bars. One elliptical perforation is present in the outer region of each quadrant, situated at the center of a large rectangular tablet which occupies the entire area between the diamond-shaped inner frame and the rim. Median sutures are visible on the proximal surface of both the diamondshaped inner frame panels and axial cross bars. A solid spine which may project as much as $15 \mu \mathrm{m}$ is present on many specimens. Specimens without spines bear a jagged excavation which extends as deep grooves onto the adjacent portions of all four cross bars.

Remarks: Species name is Latin, meaning consisting of four. Monomarginatus quaternarius is distinguished from Heteromarginatus wallacei Bukry by its larger size, greater rim element counts, larger size of the four inner perforations, and the more equidimensional proportions of the four outer perforations. M. pectinatus Wind and Wise, n. sp. is characterized by many more outer area perforations. Ellipticity of Heteromarginatus wallacei Bukry is 1.4 to 1.5, as compared with 1.20 to 1.25 for $M$. quaternarius Wind and Wise, n. sp.

Occurrence: Maestrichtian of Hole 327A, Falkland Plateau.

Size: Holotype: $8.6 \mu \mathrm{m} \times 6.8 \mu \mathrm{m}$; Paratypes: $8.3 \mu \mathrm{m} \times 5.9 \mu \mathrm{m}$; $8.8 \mu \mathrm{m} \times 5.6 \mu \mathrm{m} ; 8.6 \mu \mathrm{m} \times 6.9 \mu \mathrm{m}$.

Holotype: USNM 239465 (Plate 19, Figure 1).

Paratypes: USNM 239466-239468 (Plate 19, Figures 2-4).

Type locality: Sample 327A-12, CC.

\section{Genus OCTOCYCLUS Black, 1972}

\section{Octocyclus reinhardtii (Bukry) Wind and Wise, n. comb.} (Plate 57, Figure 6; Plate 58, Figures 1, 2)

non Discolithus decussatus Manivit, 1959 (1961), p. 14, pl. 1, fig. 7. Rhabdolithus decussatus (Manivit) Stradner, 1963, p. 175, pl. 5, fig. $8,8 \mathrm{a}$.

Zygolithus variradiatus Stover, 1965, (partium), pl. 9, fig. 1 (non pl. 4 , fig. $15,=$ holotype of $Z$. variradiatus).

Cretarhabdus decussatus (Manivit) Stradner, in Stradner et al., 1968, p. 27, pl. 13.

Podorhabdus reinhardtii Bukry, 1969, p. 38, pl. 16, fig. 7.

Octopodorhabdus decussatus (Manivit) Rood et al., 1971, p. 262, pl. III, fig. 4.

Octocyclus magnus Black, 1972, p. 38, pl. 8, fig. 1-5, pl. 9, fig. 6-9. Remarks: It is questionable that Manivit's Discolithus decussatus is this species. Her illustration of the holotype for Discolithus decussatus shows no indication of a central process.

Occurrence: Consistently common throughout the Albian at Sites 327 and 330 of the Falkland Plateau although often observed with the central area missing. This species seems to prefer cooler latitudes. It is widely dispersed throughout the Gault (middle and upper Albian) (Black, 1972) and the Bajocian-Oxfordian (Rood et al., 1971) of England, the lower and middle Albian of Holland (Stradner, 1963; Stradner in Stradner et al., 1968), but rare (reworked?) in the Santonian of Texas (Bukry, 1969).

\section{Genus OKKOLITHUS Wind and Wise, n. gen.}

Type species: Okkolithus australis Wind and Wise, n. sp.

Diagnosis: Elliptical coccoliths constructed of a broad rim of approximately 20 trapezoidal elements surrounding a large elliptical central area filled with two or more trapezoidal or triangular elements. Dark sutures outline the central area and occasionally mark the contacts of adjacent rim elements. Maximum dimension of coccolith generally between 5.0 and $6.0 \mu \mathrm{m}$.

Remarks: The generic name is from the Greek okkos (eye) and lithus (stone). This genus is similar in construction to Russellia Risat$\mathrm{ti}$, but the latter genus is typified by a small monocrystalline central area. Behavior of the rim of Okkolithus in polarized light is similar to that of Ottavianus Risatti, which has a central area occupied by two large perforations.

Okkolithus australis Wind and Wise, n. sp. (Plate 37, Figures 1, 2)

Diagnosis: Species of Okkolithus with a broad outer rim of constant width surrounding a central area constructed of two triangular and two trapezoidal elements.

Description: The periphery of specimens of this species is crenulate, with crenulations corresponding to the individual elements 
of the outer rim. In polarized light, specimens exhibit a cross when aligned parallel to the optical axis. The cross follows the major and minor axes of the rim; the cross along the shorter axis is generally much broader, as the long axis extinction line appears to follow interelemental sutures. When the specimen is oriented at $45^{\circ}$ to the optical axes, a dark chevron is present at each end of the long axis. Extinction lines do not extend across the central area, although the larger crystals of the central area appear to possess the same crystallographic orientation as the adjacent rim elements.

Remarks: The holotype (Plate 37, Figure 1) appears to possess a central area consisting of two triangular and two trapezoidal or rectangular elements. The larger trapezoidal or rectangular elements parallel the long axis of the coccolith, while the two triangular elements are situated at the ends of the central area. The number and geometry of elements constituting the central area of the paratype (Plate 37, Figure 2) is not known with certainty.

Occurrence: Maestrichtian of Hole 327A, Falkland Plateau.

Size: Holotype: $5.1 \times 3.6 \mu \mathrm{m}$; Paratype: $4.9 \times 3.5 \mu \mathrm{m}$.

Holotype: USNM 239518 (Plate 37, Figure 1).

Paratype: USNM 239519 (Plate 37, Figure 2).

Type locality: Sample 327A-12, CC.

\section{Genus ORASTRUM Wind and Wise, $\mathrm{n}$. gen.}

Type species: Orastrum asarotum Wind and Wise, n. sp.

Diagnosis: Elliptical coccoliths consisting of one or more calcite plates surrounded by a thin partial or complete composite calcite rim. A round pore or small elongate slit may be present along a suture between major plates at the center of the coccolith. Boundaries between adjacent component plates are marked by dark sinuous sutures.

Remarks: Generic name is from the Latin ora (rim) and astrum (star). Basic geometry of this genus is similar to that of Ottavianus Risatti, Phanulithus obscurus (Deflandre), and P. ovalis (Stradner).

Thin partial or complete rims have also been noted on some specimens of Phanulithus obscurus (see Plate 34, Figures 2, 4, 5), Lucianorhabdus quadratus Forchheimer (1972), and specimens of Acuturris scotus (Risatti) Wind and Wise, n. comb.

\section{Orastrum asarotum Wind and Wise, n. sp.$$
\text { (Plate 35, Figures 1-3) }
$$

Diagnosis: Rimmed elliptical form constructed of four principal central calcite segments and several smaller outer segments. Generally one or two pairs of segments fill most of the central area.

Description: Centers of specimens constructed of two pairs of segments; one large pair forms a diagonal bridge across the central area. Suture between these two segments passes through the center of the specimen and at the midpoint is enlarged by an elongate slit or larger circular perforation. Smaller segments lie on either side of this broad diagonal bridge, between the two massive segments and the rim structure. Elements of the second principal pair may be nearly equal in size to the larger pair or be extremely reduced.

Remarks: Species name is Latin asarotum (floor laid in mosaic). Although the relative dominance of principal component plates varies from specimen to specimen, the basic model is always followed; variation in appearance is viewed as intraspecific variation.

The complexity of construction and the resulting characteristic appearance in polarized light distinguishes this species. Orastrum asarotum Wind and Wise, n. sp. differs from Orastrum campanensis (Cepek) Wind and Wise, n. comb. in the near-equal size and symmetrical deployment of major component plates in the latter species.

Occurrence: Maestrichtian of Hole 327A, Falkland Plateau.

Size: Holotype: $4.7 \mu \mathrm{m}$ maximum diameter; Paratypes: 4.4 to 5.6 $\mu \mathrm{m}$ maximum diameter.

Holotype: USNM 239509 (Plate 35, Figure 1).

Paratypes: USNM 239510-239511 (Plate 35, Figures 2, 3).

Type locality: Sample 327A-12, CC.

Orastrum campanensis (Cepek) Wind and Wise, n. comb. (Not illustrated)

Tetralithus campanensis Cepek, 1970, p. 246-247, pl. 25, fig. 1, 2.

Remarks: Sinuous sutures, accessory plates, and presence of at least a partial rim place this species in the genus Orastrum Wind and Wise. The symmetry of its construction distinguishes it from $O$. asarotum Wind and Wise, n. sp.

Occurrence: Upper Campanian

\section{Orastrum sp.}

(Plate 35, Figure 4)

Description: Elliptical crystallographically continuous central plate with no sutures or evidence of central pore or spine. Thin rim plates of varying length surround central crystal. Portions of rim structure along major and minor axes have similar crystallographic orientation.

Remarks: The presence of a single central crystal distinguishes this form from other species of Orastrum.

Size: Maximum length $4.2 \mu \mathrm{m}$.

\section{Genus OTTAVIANUS Risatti, 1973}

Type species: Ottavianus giannus Risatti 1973

Remarks: Study of specimens from the Falkland Plateau shows that Risatti's suggestion that the "bridge" between the two perforations is constructed of two elements growing from opposite sides of the coccolith is correct. In crossed-polarized light, three distinct views characterize this species. When oriented parallel to the polarizing direction, thin suture lines are seen paralleling the major and minor axes; the short axis line does not extend across the "bridge," but is deflected into one of the two perforations. When specimens are oriented at approximately $45^{\circ}$ to the polarizing direction, the central portion with the exception of the two perforations is bright. Dark chevrons extend from near the outer edges of the perforations to points on both sides of the ends of the specimens; these chevrons correspond to prominent sutures which are conspicuous in phase contrast illumination. At $10^{\circ}$ to $15^{\circ}$ to the polarizing direction, extinction of one or more elements on one side of each perforation combines with the dark perforations to create a bright S-shaped figure which characterizes this species. The tips of the $\mathrm{S}$ are crossed by thin dark suture lines.

Occurrence: Risatti (1973) reports that this species ranges from the Demopolis Chalk through the middle of the Ripley Formation of the U.S. Gulf Coast. Smith (1975) dates this same interval as latest Campanian through early Maestrichtian.

\section{Genus PALAEOPONTOSPHAERA Noël, 1965}

\section{Palaeopontosphaera erismata Wind and Wise, n. sp.} (Plate 78, Figures 4-6)

?Palaeopontosphaera dubia Noël, 1965, pl. 7, fig. 6, 8, 9, 13. Palaeopontosphaera veterna Prins, 1969 (invalid), p. 554, pl. 2, fig. 9.

Diagnosis: A species of Palaeopontosphaera with a single cycle distal shield, narrow tube cycle, and central area characterized by a short hollow spine rising from the junction of a low, broad crossstructure whose arms parallel the axes of the coccolith.

Description: Proximal and distal shield both consist of approximately 20 nonimbricate, nearly radial elements. Distal shield is considerably larger than proximal shield. Tube cycle outlining the central area flares outward slightly on distal side. The spine consists of a short circular cluster of rounded particles. Each arm is constructed of two broad, partially overlapped and fused laths. The cross occupies approximately $90 \%$ of the central area.

Remarks: Species name from the Latin erisma; buttress, support. We cannot with complete assuredness identify specimens of this species oriented in proximal view. One specimen (Plate 78, Figure 6) embodies many characteristics which suggest that it is a representative of this species. Element count and configuration, and size and proportion of the two shields are similar to corresponding values for distal views of the holotype and the paratype shown in Plate 78, Figure 5. In addition, a small perforation is present at the center of the central area. The central area is paved with randomly oriented calcite blocks, but electron microscope beam penetration of the specimen reveals the presence of a possible partial cross-structure on the distal side.

The synonymy listed above is similar to that included in Palaeopontosphaera veterna Prins by Rood et al. (1973, p. 378). The holotype of $P$. veterna clearly possesses distal shields constructed of a tube cycle and two shield cycles. In contrast, $P$. dubia (Noël, 1965, pl. 7, fig. 13) possesses only one shield cycle of elements. Although such a structure is not visible in the holotype of $P$. dubia, tube cycle elements are present in several of the specimens illustrated by Noël (1965, pl. 7, fig. 6, 8, and 9). The presence of an inner area crossstructure is suggested in Noël's pl. 7, fig. 13, but no tube cycle appears to be present.

Occurrence: Oxfordian of Hole 330 on the Falkland Plateau. 
Size: Holotype $3.5 \mu \mathrm{m} \times 2.3 \mu \mathrm{m}$; Paratype $3.9 \mu \mathrm{m} \times 2.8 \mu \mathrm{m}$ (Plate 78, Figure 5).

Holotype: USNM 239538 (Plate 78, Figure 4).

Paratypes: USNM 239539-239540 (Plate 78, Figures 5, 6).

Type locality: Sample $330-7-5,120 \mathrm{~cm}$.

\section{Parhabdolithus infinitus (Worsley, 1971) Thierstein, 1972}

(Plate 56, Figures 4-6)

Mitosia infinitae Worsley, 1971, p. 1311, pl. 1, fig. 48-50.

Parhabdolithus infinitus (Worsley, 1971) Thierstein, in Roth and Thierstein, 1972, p. 437, pl. 8, fig. 1-12.

Remarks: The specimen illustrated by the SEM (Plate 56, Figures $5,6)$ is surmounted by a large flaring rhabdolith composed of overlapping laths. The presence of this feature confirms Thierstein's transfer of this species to the genus Parhabdolithus.

\section{Genus PHANULITHUS Wind and Wise, n. gen.}

Type species: Tetralithus obscurus Deflandre, 1955

Diagnosis: Elliptical coccoliths constructed of three or more calcite segments which exhibit high birefringence in polarized light. The elliptical forms may support short fluted stems similar to Lucianorhabdus.

Description: Elliptical specimens generally between 5.0 and 7.0 $\mu \mathrm{m}$ in greatest diameter constructed of three or more calcite segments of varying crystallographic orientation. Sutures separating individual calcite segments may correspond to the axes of the ellipse. Ellipticity of specimens varies from 1.4 to 1.6. Specimens are concave on proximal side and may be sculptured on the distal side by circular excavations ringing a short central hollow-cored spine. Fluting on the spine exterior extends downward onto the surface of the disc between the excavations and some of the flutings coincide with intercrystalline sutures.

Remarks: The name for this genus is from the Greek phanus (luminous) and lithus (stone). This genus resembles Lucianorhabdus and Acuturris, but the latter genera possess a well-developed spine. Phanulithus is similar in shape and size to Orastrum Wind and Wise, n. gen., Okkolithus, Wind and Wise, n. gen. and Ottavianus Risatti, 1973 , but is constructed of fewer, larger segments and often has a well-developed short spine.

\section{Phanulithus additus Wind and Wise, n. sp.}

(Plate 30, Figure 2; Plate 34, Figure 5)

Tetralithus ovalis Stradner. Cepek 1970, pl. 23, fig. 4, 5a-c.

Diagnosis: Elliptical species of Phanulithus constructed of five crystallographically independent areas separated by sutures.

Description: Large, elliptical specimens constructed of five plates of varying size. Orientation of sutures with respect to axes of the ellipse varies from specimen to specimen. Centers of some specimens resemble abbreviated spines of species of Lucianorhabdus, with central canal and external fluting. Sutures coincide with some of the radiating ridges which extend over the distal surface of specimens.

Remarks: Species name is Latin, additus (additional). The presence of five plates on forms of this species distinguishes it from all other species of Phanulithus. The variable orientation of sutures with respect to ellipse axes prevents determination as to whether this species arose from $P$. obscurus (Deflandre) or $P$. ovalis (Stradner) The presence of a well-developed spine and characteristic external fluting demonstrate the affinity of species of Phanulithus and Lucianorhabdus previously observed in Wind (1975). It is not known whether any of the abundant specimens of Lucianorhabdus cayeuxi Deflandre, $L$ arcuatus Forchheimer, and $L$. arborius Wind and Wise, n. sp. identified in lateral view possess five-part basal discs similar to those of this species.

Size: Holotype, dimensions of base $7.0 \mu \mathrm{m} \times 5.0 \mu \mathrm{m}$; height of spine above base approximately $3.0 \mu \mathrm{m}$.

Occurrence: Maestrichtian of Hole 327A, Falkland Plateau.

Holotype: USNM 239505 (Plate 30, Figure 2).

Paratype: USNM 239507 (Plate 34, Figure 5).

Type locality: Sample $327 \mathrm{~A}-11-3,113 \mathrm{~cm}$.

Phanulithus obscurus Wind and Wise, $n$, comb.

(Plate 31, Figure 5; Plate 33, Figures 2-6; Plate 34, Figures 2, 4; Plate 36, Figure 6)

Tetralithus obscurus Deflandre, 1959, p. 138, fig. 26-29.

Tetralithus obscurus Deflandre, Martini, 1961, p. 3, pl. 1, fig. 2.
Tetralithus obscurus Deflandre, Bramlette and Martini, 1964, p. 320, pl. 4 , fig. $26-28$.

Tetralithus obscurus Deflandre, Bukry, 1969, p. 63, pl. 37, fig. 11, 12.

Tetralithus obscurus Deflandre, Perch-Nielsen, 1968, p. 87-88, textfig. 44 , pl. 31 , fig. $6-8,10,11$

Tetralithus obscurus Deflandre, Manivit, 1971, p. 144-145, pl. 25 , fig. 3-5.

Tetralithus obscurus Deflandre, Risatti, 1973, p. 32, pl. 5, fig. 5-12. Tetralithus ovalis Stradner, Risatti, 1973, p. 32, pl. 5, fig. 3, 4.

Tetralithus obscurus Deflandre, Wind, 1975, pl. 2, fig. 4, 6; pl. 3, fig. 11,15 .

Description: Elliptical coccoliths constructed of four crystal segments separated by sutures aligned at an angle to the axes of the ellipse. A short, stout, hollow-cored spine may be present on the distal surface, with external fluting of the spine extending over much of the dorsal surface. Some of the fluting corresponds to the four sutures. Sutures may either cross at the center or be arranged as similar V-shaped traces connected by a bar of varying length parallel to the longest dimension of the ellipse. A narrow rim surrounding all or part of the object may be present.

Remarks: P. obscurus represents a short-spined or spineless form of one of the three variants of Lucianorhabdus: L. cayeuxi Deflandre, $L$. arcuatus Forchheimer, and $L$. arborius Wind and Wise, n. sp. (see the discussion affinity of Lucianorhabdus and species of Tetralithus in Wind, 1975).

Risatti (1973, p. 32) distinguished Tetralithus ovalis from $T$. obscurus by the failure of the sutures to meet in the central area, while the true distinguishing feature between the two species is the orientation of the sutures with respect to the elliptical axes.

The relative size of the four crystal quadrants varies from specimen to specimen. In some specimens, all four sutures meet at or near the center, with all four quadrants of nearly equal size. Other specimens, such as that illustrated in Plate 34 , Figure 3, have greatly asymetrical quadrants, with the two portions along the greater ellipse axis representing only approximately $15 \%$ of the total area. This variation may be related to the presence and degree of development of the distal spine (see Plate 33, Figure 6). Specimens with prominent spines generally have sutures which cross or which are connected by a short line parallel to the long axis. Plate 31 , Figure 5, and Plate 33 , Figures 2 (left), 4, 5, 6 (left) illustrate specimens with well-developed short spines. The specimen illustrated in Plate 33, Figure 4 has lost the two smaller quadrants and illustrates the mode of construction of this species.

\section{Phanulithus ovalis (Stradner) Wind and Wise, n. comb.} (Plate 34, Figure 1)

Tetralithus ovalis Stradner, 1963, p. 178, pl. 6, fig. 7, 7A non Tetralithus ovalis Stradner, Risatti, 1973, p. 32, pl. 5, fig. 3, 4

Remarks: Stradner (1963, p. 178) defined this species as "flat tetraliths consisting of four sectors fitting closely together to form a plate with an oval circumference. The suture lines may lie in the main axes or diagonally or in between." His holotype (pl. 6, fig. 7, 7a) is characterized by sutures nearly aligned with the ellipse axes. The specimen illustrated by Risatti $(1973$, pl. 5, fig. 3, 4) is Phanulithus obscurus (Deflandre).

\section{Genus PHARUS Wind and Wise, n. gen.}

Type species: Pharus simulacrum Wind and Wise, n. sp.

Diagnosis: Elliptical coccoliths constructed of one or two symmetrical crystallographically continuous plates pierced by two round holes. A short spine may be present between the two holes.

Description: See characteristics of type species.

Remarks: Genus name is Latin meaning a beacon, lighthouse. The single or bielemental construction of this genus distinguishes it from Ottavianus Risatti, which also is biperforate.

Pharus simulacrum Wind and Wise, n. sp. (Plate 35, Figures 5, 6; Plate 36, Figures 1, 2)

Diagnosis: Specimens constructed of two calcite plates of nearly identical crystallographic orientation; separated by a subtle suture along which two perforations and central short spine are situated.

Description: Specimens of this species bear two symmetrically placed $1 \mu \mathrm{m}$ wide perforations along the long axis. A short narrow or bulbous spine is situated between the two perforations. In polarized 
light, specimens show nearly uniform optical characteristics. An often indistinct suture along the long axis of the ellipse divides specimens into two identical halves. The suture runs between the two perforations and goes around the spine, if one is present. When rotated in polarized light, extinction is initiated at the suture line between one hole and the periphery and proceeds around the specimen. tion.

Remarks: The species name is Latin, meaning ghost or appari-

Occurrence: Maestrichtian of Hole 327A, Falkland Plateau.

Size: Holotype maximum diameter $4.3 \mu \mathrm{m}$; Paratypes 4.1 to 4.7 $\mu \mathrm{m}$ maximum diameter.

Holotype: USNM 239515 (Plate 36, Figure 1).

Paratypes: USNM 239513, 239514 (Plate 35, Figures 5, 6); USNM 239516 (Plate 36, Figure 2).

Type locality: Sample 327A-12, CC.

Genus PODORHABDUS Noël, 1965, emend. Wind and Wise Wise.

Type species: Podorhabdus grassei Noël, 1965 emend. Wind and

Description: Forms with a podorhabdid rim (two closely appressed single cycle shields constructed of nonimbricate or slightly imbricate elements; having characteristically darker appearance in phase-contrast illumination as compared with the mounting medium), and a large hollow spine bearing two arched and opposed perforations.

Remarks: As discussed under the genus Axopodorhabdus n. gen., emendation of Podorhabdus is necessary to resolve discrepancies between descriptions of the genus Podorhabdus Noël and features visible on the holotype of the type species, $P$. grassei Noël.

\section{Podorhabdus grassei Noël emend. Wind and Wise}

(Plate 79, Figures 4-6; Plate 80, Figures 1-4)

Podorhabdus grassei Noël, 1965, p. 103, pl. 9, fig. 1, 2. Discorhabdus biperforatus Rood et al., 1973, p. 381, pl. 3, fig. 7. ?Discorhabdus jungi Noël, 1965, p. 144-145, pl. 22, fig. 5 .

Description: Hollow stem of small, distinct crystallites arising from nearly circular podorhabdid base. Stem tapers gradually in distal direction, but becomes greatly expanded before ending approximately $5.5 \mu \mathrm{m}$ above base. Distal edge of stem generally uneven. Two arched or hemispherical perforations are situated at the base of the stem, aligned along the major axis of the base. In some specimens, a narrow groove marks the boundaries of rim and stem. Distal shield constructed of between 30 and 38 elements; proximal shield constructed of approximately the same number of elements. Elements of both shields are nonimbricate and radial.

Remarks: The genus and species are emended to conform to features of the holotype. Rather than being constructed of four buttresses supporting a hollow stem, the holotype consists of only two broad stem supports. Transmission electron microscope illustrations of the holotype (Noël, 1965, pl. 9, fig. 1,2) offer a confused picture of characteristics of the species, as it is only with great difficulty that the illustrations can be viewed as a stereo-pair. Dr. W.W. Hay (1975, personal communication) found that the images could be viewed stereoscopically if they are first cut out of the original publication and manipulated under a large stereoscope. By this procedure he confirmed that only two perforations are present at the base of the stem. Dr. Hay has also concluded, based upon these observations, that Discorhabdus biperforatus Rood et al., 1973, is a junior synonym of Podorhabdus grassei holotype as emended.

The holotype of Discorhabdus jungi Noël (1965, p. 144-145, pl. 22, fig. 5) is a transmission electron microscope photograph of a specimen which was not decalcified during sample preparation. As a result, the only information supplied by the holotype is the lateral profile, dimension, and mode of construction of the distal portion of the stem. The opacity of the specimen to the electron beam obscures all other detail.

Subsequent illustration of $D$. jungi by Rood et al. (1971, pl. 4 , fig. 5, 6), and Barnard and Hay (1974, pl. 3, fig. 5; pl. 6, fig. 4) generally offer little evidence of the presence of perforations at the base of the stem. The lateral profile of specimens of $D$. jung $i$ by these authors, as well as the profile of the holotype are quite similar to corresponding views of specimens of $P$. grassei. Resolution of this problem of possible synonymy depends upon the location of perforate forms similar to $P$. grassei on the scanning electron microscope.
Size: Plate 79, Figure 5, height $6.5 \mu \mathrm{m}$, width of shield $4.3 \mu \mathrm{m}$; Plate 79, Figure 6 , height $6.6 \mu \mathrm{m}$, width of shield $4.3 \mu \mathrm{m}$; Plate 80 Figures 1,2 , height approximately $6.7 \mu \mathrm{m}$, width of shield $5.1 \mu \mathrm{m}$; Plate 80 , Figures 3,4 , width of shield $5.8 \mu \mathrm{m}$.

\section{Genus POLYPODORHABDUS Noël, 1965}

\section{Polypodorhabdus aff. P. escaigi, Noël, 1965} (Plate 77, Figure 4)

Remarks: Although nearly all of the specimens of Polypodorhabdus from Site 330 samples agree with the definition and subsequent illustrations of $P$. escaigi Noël, the specimen illustrated in Figure 4 of Plate 77 exhibits morphological features which prevent its placement in any presently recognized species.

The specimen, visible only in proximal view, is approximately 6.5 $\mu \mathrm{m}$ long and $5.0 \mu \mathrm{m}$ wide. The large central area contains between 18 and 20 radially disposed elongate perforations. The perforations originate adjacent to the outer margin of the central area, but rather than extending to near the center of the specimen, as would be the case in $P$. escaigi, the perforations terminate after only approximately $0.4 \mu \mathrm{m}$ of length. The central portion of the inner area of the specimen is a solid wall of calcite with the exception of one round perforation in each quadrant. This round hole appears to be aligned with the second elongate perforation from the minor axis of the ellipse. A depression corresponding to a spine on the distal side of the specimen is present.

We are faced with three options regarding the affinity of this form: we may emend the species $P$. escaigi to include such variants or we may erect a new species or subspecies. Inasmuch as only one illustration of this morphotype is presently available, this being a specimen in proximal view, we have elected to refer to this specimen as Polypodorhabdus sp. aff. P. escaigi to await the acquisition of additional photomicrographs for final evaluation of this form.

Size: Approximately $6.5 \mu \mathrm{m} \times 5.1 \mu \mathrm{m}$.

\section{Genus PREDISCOSPHAERA Vekshina, 1959}

\section{Prediscosphaera stoveri (Perch-Nielsen)} (Plate 42, Figure 3)

Deflandrius stoveri Perch-Nieisen 1968, p. 66-67, pl. 16, figs. 11-13. Prediscosphaera germanica Bukry, 1969, p. 39, pl. 18, fig. 1-3.

Remarks: This species is difficult to distinguish from Prediscosphaera honjoi Bukry on the light microscope. The central area of $P$. honjoi is smaller, more angular, and the cross bars are often broken.

\section{Genus RETECAPSA Black, 1971}

Retecapsa angustiformata Black, 1971

$$
\text { (Plate 76, Figure 6) }
$$

Retecapsa angustiformata Black, 1971a, p. 409, pl. 33, fig. 4 . Retecapsa brightoni Black, 1971a, p. 409, pl. 33, fig. 3. Retecapsa levis Black, 1971a, p. 410, pl. 33, fig. 1. Retecapsa neocomiana Black, $1971 \mathrm{a}$, p. 410 , pl. 33, fig. 2 .

Description: Elliptical coccolith with podorhabdid rim and central area characterized by eight perforations formed by three cross bars parallel to the short axis and perpendicular to a thick cross bar parallel to the long axis. The median short axis cross bar is as massive as the long axis cross bar and broadens where it intercepts the rim. The four central perforations are equal in size and larger than the outer two pairs of holes. The inner four and outer four perforations may differ in shape; the inner four tend to be nearly square or round, while the outer four are generally triangular. A short, narrow spine may be present. A narrow complete or incomplete cycle of elements may line the outer rim of the central area. Similar elements may be found at the tips of the rim elements.

Remarks: Features discussed by Black, 1971a, to distinguish among the four species of Retecapsa proposed are too restrictive to allow for variation within a given species. One specimen of $R$. levis Black (1972, pl. 10, fig. 3) embodies both the cross bar to windowsize relationship of $R$, levis and the presence of an inner cycle of accessory elements of $R$. brightoni.

One specimen from DSDP Site 330 (Plate 76, Figure 6) bears characteristics of both $R$. brightoni (accessory cycle of elements) and $R$. angustiforata (four nearly circular windows). 
No outer rim accessory crystals are readily visible on specimens illustrated by Black $(1971 ; 1972)$ and no mention is made of them by the author. There is a slight suggestion of the presence of such a feature on the holotype of Retecapsa brightoni Black (1971a, pl. 33, fig. 2). Unfortunately, detail of the outer portion of the rim is almost completely obscured by the presence of relict nonskeletal debris between the rim and substratum. This undissolved material prevented transmission of the electron beam through this region.

Retecapsa tridentata Wind and Wise, n. sp.

(Plate 76, Figures 3-5; Plate 88, Figure 12)

Diagnosis: A species of Retecapsa with a central area divided into quadrants by broad, nearly flat cross bars which parallel the major and minor axes of the coccolith. The shorter cross bar flares slightly where it intersects the rim; each half of the longer cross bar abruptly divides into three equal processes shortly before it meets the rim. Two small triangular perforations may be present between the diverging processes of the long axis cross bar.

Description: The symmetrical lateral processes of the long axis cross bar curve and eventually parallel the short axis cross bar where they intersect the rim. A low, narrow secondary rim of elements may line the inner margin of the rim, and a similar set of crystals may be situated along the outer edge of portions of the rim.

Remarks: The species name refers to the three-prong nature of the major axis cross bar ends. This species differs from $R$. angustiformata in the extreme diminutive nature of the outer pairs of perforations which are often obscured by overgrowths and detritus. In addition, the orientation of the long axis lateral processes at the point of junction with the rim differs between the two species of Retecapsa. This species is distinguished from Cretarhabdus schizobrachiatus (Gartner) Bukry by the presence of two well-developed distal rim cycles and more similar morphology of major and minor axis cross bars in the latter species.

Occurrence: Oxfordian of Hole 330 on the Falkland Plateau.

Size: Holotype: $7.5 \mu \mathrm{m} \times 5.8 \mu \mathrm{m}$; Paratypes: $6.5 \mu \mathrm{m} \times 5.0 \mu \mathrm{m}$.

Holotype: USNM 239532 (Plate 76, Figure 3).

Paratypes: USNM 239533-239534 (Plate 76, Figures 4, 5); USNM 239543 (Plate 88, Figure 12)

Type locality: Sample $330-8-1,107 \mathrm{~cm}$.

\section{?Retecapsa sp.}

(Plate 78, Figure 1)

Description: Central area constructed of large crystals arranged in the shape of a four-armed cross. The terminus of each arm flares as it meets the distal shield, a feature more pronounced on the ends of the long axis arms. The long axis of the cross is positioned approximately $10^{\circ}$ to $15^{\circ}$ to the long axis of the coccolith. Arms support a short, generally inconspicuous spine; large, broad crystals forming the arms define four hexagonal open areas which expose similar crystals below.

Remarks: This form differs from E.? frondosus in its central area construction of larger crystals, extension of the arms of the cross to the inner area margin, and the division of the central area into a prominent cross-structure and paved interarm areas, the orientation of the cross-structure with respect to the geometry of the rim and mode of filling of the central area.

Occurrence: Oxfordian (Sample 330-8-1, $107 \mathrm{~cm}$ ).

Size: $6.0 \mu \mathrm{m} \times 4.3 \mu \mathrm{m}$.

\section{Genus RUSSELLIA Risatti, 1973}

\section{Russellia multiplus (Perch-Nielsen) Wind and Wise, n. comb.}

$$
\text { (Plate 37, Figures 5, 6) }
$$

Tetralithus multiplus Perch-Nielsen, 1973, p. 326-327, pl. 9, fig. 6, 7; pl. 10 , fig. 17,18

Russellia laswelli Risatti, 1973, p. 31, pl. 8, fig. 1-3.

Description: Elliptical forms constructed of approximately 12 wedge-shaped elements of similar size. A central pore may or may not be present. In phase contrast illumination, a dark suture is visible running along the long axis and bifurcating at the ends. When oriented parallel to the polarizing axes, dark straight or undulating sutures are aligned with the major and minor axes of the specimen. When the specimen is oriented at $45^{\circ}$ to the polarizing axes, dark chevrons are visible, coincident with the suture bifurcations visible in phase-contrast illumination.
Remarks: This species differs from Russellia bukryi Risatti which has additional sutures visible in phase-contrast illumination and a less regular periphery. Russellia multiplus and Ottavianus giannus Risatti produce similar figures in polarized light, but the latter species possesses two well-developed perforations.

Occurrence: Maestrichtian of the U.S. Gulf Coast (Risatti, 1973), Falkland Plateau, and Madagascar (Perch-Nielsen, 1973).

\section{Genus STEPHANOLITHION Noël, 1956}

Stephanolithion laffittei Noël, 1956

(Plate 70, Figures 5, 6; Plate 71, Figures 1-6)

Stephanolithion laffittei Noël, 1956, p. 318, pl. 2, fig. 5 .

Remarks: Specimens from the Albian of Holes 327A and 330 are strongly elliptical, particularly in proximal view.

\section{Genus STRIATOMARGINIS Prins ex Rood et al., 1973}

Remarks: Neither Prins (1969) nor Rood et al. (1973) mention the presence of a two-cycle distal shield (in addition to the tube cycle). This feature is visible in the type species, $S$. primitivus Rood, Hay, and Barnard and Palaeopontosphaera veterna Prins. Both species have central areas consisting of broad radiating bars in the four quadrants separated by a wide-armed cross-structure. This genus is strikingly similar to Lotharingius Noël, 1973, and the holotypes of the two genera are exceedingly similar. The inner cycle of elements on the distal shield of $L$. barozi Noël, 1973 flare and project distally. If this feature is later shown to be an overgrowth phenomenon, $L$. barozi Noël and $S$. primitivus are cospecific.

\section{Striatomarginis veterna (Prins ex Rood et al.) Wind and Wise n. comb.} (Not illustrated)

Palaeopontosphaera veterna Prins, 1969 (invalid), p. 554, pl. 2, fig. 9. Palaeopontosphaera veterna Prins, Rood et al., 1973, p. 378-379, pl. 3, fig. 2, 3 .

Description: In distal view, specimens have an elliptical central area with a broad cross-structure and indistinct radial bars; central area surrounded by a tube cycle of elements and a two-cycle distal shield. Radial bars are set beneath cross-structure and are more visible in proximal view.

Remarks: Rood et al. (1973, p. 378$)$ place one specimen of Palaeopontosphaera dubia Noël $(1965$, pl. 7 , fig. 13) in synonymy with $S$. veterna. However, Noël's specimen bears a single-cycle distal shield and not the two-cycle distal shield typical of Striatomarginis.

\section{Genus TEICHORHABDUS Wind and Wise, n. gen.}

Type species: Teichorhabdus ethmos Wind and Wise, n. sp.

Diagnosis: Large rhabdoliths consisting of a two-level rim and large, elevated central area containing a massive hollow granular stem and more than 12 round perforations.

Description: Rim constructed of narrow band of approximately 50 radial, slightly imbricate elements. A wall of blocky crystals extends distally from the rim elements, forming a prominent collar from which the cribrate central area extends. Small granular crystals construct the broad hollow stem and remainder of the central area which may contain as many as 35 or more round perforations.

Remarks: The genus name is from the Greek teichos, wall around a city; rhabdos, rod, staff. This genus is distinguished from other podorhabdid genera and Cretarhabdus by the presence of the massive inner cycle of crystals. Dodekapodorhabdus Perch-Nielsen, by definition, possesses only 12 central area perforations.

\section{Teichorhabdus ethmos Wind and Wise, n. sp.} (Plate 44, Figure 6)

Diagnosis: Forms with a narrow radial outer rim cycle and a massive blocky inner cycle of crystals which serves as the point of attachment for a large granular cribrate central area dominated by a large hollow spine.

Description: Large specimens consisting of a two-level rim and arched granular cribrate central area. The thin outer rim is constructed of approximately 50 thin, radial, slightly imbricate elements. A tall (approximately $1.0 \mu \mathrm{m}$ high) wall of crystals is situated between the thin rim elements and the central area proper. The crystals form a level or slightly inwardly sloping surface approximately $1 \mu \mathrm{m}$ wide. 
The central area is constructed of small granular crystals which form a wide, high, hollow stem around which are situated approximately 30 to 35 round holes. The central area proper represents $55 \%$ of the distal area of the holotype. Central area perforations appear to be randomly distributed, but are not present on a narrow band aligned parallel to the short axis of the specimen. The crystalline inner wall is bright in both phase-contrast illumination and polarized light.

Remarks: The species name is Greek, meaning a sieve, strainer. Teichorhabdus ethmos differs from Dodekapodorhabdus noelli in having a central area marked by more than 12 perforations. The holotype of $D$. noelli has a maximum length of approximately $18.0 \mu \mathrm{m}$. The specimen of $D$. noelli from Site 327 A (Plate 44, Figure 4) has a maximum length of $11.6 \mu \mathrm{m}$.

Occurrence: Maestrichtian of Hole 327A, Falkland Plateau.

Size: Holotype-maximum dimension $16.0 \mu \mathrm{m}$.

Holotype: USNM 239523 (Plate 44, Figure 6).

Type locality: Sample $327 \mathrm{~A}-10-3,14 \mathrm{~cm}$.

\section{Genus TETRAPODORHABDUS Black, 1971}

Tetrapodorhabdus decorus (Deflandre and Fert) Wind and Wise, $n$. comb.

(Plate 59, Figures 3-6)

Rhabdolithus decorus Deflandre and Fert, 1954, p. 159, text-fig. 87; pl. 13, fig. 4-6.

Cretarhabdus? decorus (Deflandre and Fert) Bramlette and Martini, 1964 , p. 300 , pl. 3, fig. 9-12.

Ahmuellerella granulata Reinhardt, 1965, p. 39, pl. 3, fig. 2 .

Cretarhabdus? (Reinhardt) Reinhardt, 1966a, p. 27, pl. 8, fig. 1

Cretarhabdus decorus (Deflandre and Fert) Gartner, 1968, p. 22, pl. 4, fig. 15, 16; pl. 11, fig. 13, 14

Podorhabdus gramulatus (Reinhardt) Bukry, 1969, p. 37, pl. 16, fig. 4-6.

Tetrapodorhabdus coptensis Black, 1971a, p. 411, pl. 31, fig. 7.

Podorhabdus decorus (Deflandre and Fert) Thierstein, in Roth and Thierstein, 1972, pl. 4, fig. 7, 8, 10-13.

Remarks: The element count within this species is somewhat variable and increases with increasing size of the coccolith.

\section{Genus TRANOLITHUS Stover, 1966}

\section{Tranolithus orionatus (Reinhardt) Reinhardt, 1966 (Plate 57, Figures 1-4)}

Discolithus orionatus Reinhardt, 1966a, p. 42, pl. 23, fig. 22, 31-33. Tranolithus exiguus Stover, 1966, p. 146, pl. 4, fig. 19-21; pl. 9, fig. 3,4 .

Tranolithus orionatus (Reinhardt) Reinhardt, 1966b, p. 522.

Tranolithus cf. exiguus Stover, Forchheimer, 1968, p. 49, pl. 5, fig. 2 .

Tranolithus cf. manifestus Stover, Noël, 1970, p. 44, pl. 9, fig. 3, 5, 7; pl. 10, fig. 1-4.

Zygostephanos orionatus (Reinhardt) Hoffmann, 1970, p. 178, pl. 1, fig. 5 ; pl. 2 , fig. 3 .

Remarks: The central area of Tranolithus orionatus is composed of four large crystals which can serve as efficient calcite acceptors during early postdepositional diagenesis of carbonate sediment (see Wise [in press] for a discussion of the dissolution-diffusionprecipitation process involved). The secondary overgrowths produced can greatly enlarge the central area elements and thereby produce a wide range of gradational morphologies and sizes for the central area structure. These, however, are not original features secreted by the organism. Once overgrown by a thick accumulation of calcite, the central elements became more stable within the sedimentary environment and are thus protected from subsequent dissolution which may destroy the remaining elements of the coccolith secreted at different environmenta! temperatures and pressures. Thus it is not uncommon to find heavily overgrown but isolated central area structures in slide preparations (for example, Plate, 57, Figure 4). Such isolated sets of overgrown crystals resemble superficially some species of Tetralithus such as $T$. pyramidus. The isolated crystal sets are readily distinguished from Tetralithus, however, because their adjacent crystals are somewhat imbricate. Thus when one focuses up and down on such a specimen, the suture lines between crystals migrate laterally so that the adjacent crystals appear to "scissor" as the plane of focus is changed. $T$. exiguus and $T$. orionatus are here considered one species. The first appearance of this species in the Albian section of Hole 327A is used to mark the base of the Tranolithus orionatus Subzone of the Prediscosphaera cretacea Zone.

\section{Genus TUBODISCUS Thierstein, 1973}

\section{Tubodiscus sp. cf. T. verenae}

(Plate 67, Figures 5, 6)

Description: The rudimentary central tube projects only a short distance above the featureless intermediate shield. The central tube and the large shield consist of about 50 elements inclined counterclockwise when viewed from the tube side.

Remarks: This form differs from described forms of Tubodiscus by the counterclock wise inclination of the elements of the central tube and of the large shield. It differs from Manivitella pemmatoidea (Deflandre ex Manivit) by its more rounded outline and the presence of a rudimentary central tube. Thierstein (1976, personal communication) has observed a rather varied plexus of forms of this general type in Lower Cretaceous samples; however, their taxonomic placements are at present unclear.

Occurrence: Albian of Holes 327A and 330, Falkland Plateau. Size: $10 \mu \mathrm{m}$ to $11 \mu \mathrm{m}$.

\section{Genus VEKSHINELLA Loeblich and Tappan, 1963}

\section{Vekshinella aachena (Bukry) Wind and Wise, n. comb.} (Plate 42, Figure 4)

Vagalapilla aachena Bukry, 1969, p. 55-56, pl. 31, fig. 6-9.

Vagalapilla aachena Bukry, Thierstein, 1974, pl. 3, fig. 1-4.

Remarks: The most characteristic features of this species are the shape of the four central openings and the mode of insertion of the cross bars in the rim below the plane of the distal surface.

The holotype of Vekshinella, Ephippium acutiferrus Vekshina, 1959 , is described as possessing a short, blunt proximally projecting spine extension. Bukry (1969, p. 55) proposed the genus Vagalapilla for species of Vekshinella and Staurolithites which bear no proximal spine extension. The present authors agree with Rood et al. (1971) who view the proximal spine extension as an artifact of preservation or slide preparation and not of systematic and taxonomic validity.

\section{Vekshinella? parma Wind and Wise, n. sp.}

(Plate 42, Figures 1, 2)

Diagnosis: Small elliptical form with imbricate rim and blocky central area. Cross bars are coincident with the ellipse axes. A diamond-shaped depression marked by four small pores occupies the central area adjacent to the cross bars.

Description: Rim is constructed of approximately 40 small imbricate elements. Cross bars are paired lineations of elongate crystals. Cross bars do not intersect the rim and form a star-shaped depression at the center of the specimen. The central area is constructed of flat crystals of varying size and is divided into two concentric regions by straight or inwardly curved composite crystal margins of the outer area. The inner central area, adjacent to the cross bars, bears one small perforation between adjacent crystals in each quadrant. No spine has been observed.

Remarks: The species name is Latin, meaning a small, light shield.

Occurrence: Maestrichtian of Hole 327A, Falkland Plateau.

Size: Holotype maximum dimension $4.8 \mu \mathrm{m}$; Paratype maximum dimension $4.6 \mu \mathrm{m}$.

Holotype: USNM 239521 (Plate 42, Figure 2).

Paratype: USNM 239520 (Plate 42, Figure 1).

Type locality: Sample $327 \mathrm{~A}-13-1,142 \mathrm{~cm}$.

Vekshinella quadriarculla (Noël) Rood et al., 1971

(Plate 83, Figures 3, 4; Plate 84, Figures 2, 4)

Discolithus quadriarcullus Noël, 1965, p. 74-75, fig. 7, pl. 1, fig. 14, 15 ; pl. 2, fig. 1, 2.

Vekshinella quadriarculla (Noël) Rood et al., 1971, p. 250, pl. 1, fig. 1 .

Staurorhabdus quadriarculus (Noël) Noël 1972 (1973), p. 101-102, pl. 1, fig. 5, 6; pl. 2, fig. 1-5.

Description: A species of Vekshinella with short hollow spine filling approximately half of central area. Cross bars broaden as they approach spine base. Four narrow elliptical perforations are visible between the rim and spine in both proximal and distal views. A large 
diamond-shaped depression on the proximal side underlies the stem and inner portion of supporting cross bars. The diamond-shaped central hole is separated from the four elliptical perforations by arcuate partitions. A sheet of thin crystals occasionally paves the proximal surface of parts of the elliptical perforations, but apparently never extends to the central hole. In distal view, the four arcuate partitions defining the perforations are slightly recessed when compared with the rim elements.

Remarks: This species differs from $V$. stradneri in the presence of a wide hollow spine and radically different proximal surface construction. It may be difficult to distinguish between these two species when distal surfaces are partially obscured.

The similarity of rim construction, cross-bar features, and presence of proximal surface paving illustrate the close phylogenetic relationship of $V$. quadriarculla and $V$. stradneri. Stradner et al. (1968, p. 37) concluded that the central cross-structure of Zygolithus crux (Deflandre and Fert) Bramlette and Sullivan (=Vekshinella stradneri Rood, Hay, and Barnard) is derived from four separate arches such as those present in Zygolithus quadriarcullus ( $=V$. quadriarculla) and Z. octoradiatus.

Size: Plate 83 , Figure 3, $3.2 \mu \mathrm{m} \times 1.8 \mu \mathrm{m}$; Plate 83 , Figure 4, 4.0 $\mu \mathrm{m} \times 3.2 \mu \mathrm{m}$; Plate 84 , Figure 2, $2.9 \mu \mathrm{m} \times 2.2 \mu \mathrm{m}$; Plate 84, Figure 4, $3.9 \mu \mathrm{m} \times 2.6 \mu \mathrm{m}$.

Vekshinella stradneri Rood et al., 1971

(Plate 83, Figure 6; Plate 84, Figures 1, 3, 5, 6; Plate 89, Figure 7)

Remarks: Transmission electron microscope (TEM) study of this species (then identified as Zygolithus crux [Deflandre and Fert] Bramlette and Sullivan) by Stradner et al., 1968, yields much information concerning species ultrastructure. The specimen from Site 330 illustrated in proximal view (Plate 84 , Figure 5) is nearly identical to the TEM micrograph of an Albian specimen shown in Plate 29 of Stradner et al. (1968).

Scanning electron microscope study of some specimens assigned to this species shows that they bear a partial calcite proximal sheet which extends inward from rim elements and obscures outer portions of the cross bars (for example, Plate 84, Figure 5). The specimen in Plate 84, Figure 6 appears to represent a proximal view of this form in which the proximal sheet is complete, with the exception of four relatively small angular perforations. This calcareous membrane paving the proximal surface of the coccolith is not always present, but when present, may be visible even in distal view. Figures 1 and 3 of Plate 84 illustrate two specimens of $V$. stradneri in distal view. The specimen in Figure 1 reveals no trace of proximal sheet, whereas in Figure 3, the sheet is nearly complete. The specimen of $V$. stradneri illustrated in Plate 83, Figure 6, contains only a partial proximal sheet and is probably the distal view equivalent of Figure 5 of Plate 84.

The distal surfaces of the cross bars and spine of $V$. stradneri are constructed of parallel small elongate crystallites which give the entire central area of the species a ropey appearance. This feature of the surface of the cross bars and spine is not as well preserved on the specimen illustrated as in the holotype of this species (Rood et al., 1971, pl. 1, fig. 2).

Unfortunately, the range in size of the central spine and resulting modification of the cross-bar junction has never been studied in detail. In this study, forms described above with small spines have been identified as $V$. stradneri, while similar forms with wider hollow spines (see Plate 83, Figure 4; Plate 84, Figure 2) have been identified as $V$. quadriarcullus (Noël). These two species are easily discernible in proximal view because of the presence of a large diamond-shaped perforation in the central area below the hollow spine in $V$. quadriarcullus. The presence of a proximal sheet cannot be used to identify $V$. stradneri, as this sheet appears to be also present in $V$. quadriarcullus, and may in fact, characterize well-preserved specimens of many allied species in this genus.

Size: Plate 84 , Figure 1, $4.9 \mu \mathrm{m} \times 3.6 \mu \mathrm{m}$; Plate 84 , Figure 3, 3.1 $\mu \mathrm{m} \times 2.2 \mu \mathrm{m}$; Plate 84 , Figure 5, $3.8 \mu \mathrm{m} \times 2.8 \mu \mathrm{m}$.

\section{Vekshinella sp. aff. V. stradneri Rood et al., 1971}

$$
\text { (Plate 83, Figure 5) }
$$

Description: A specimen of Vekshinella with a long tapering spine constructed of spiral-tiered vertical crystallites. Specimen rim dimensions $5.0 \mu \mathrm{m} \times 3.3 \mu \mathrm{m}$. Spine is approximately $1.7 \mu \mathrm{m}$ tall, $0.7 \mu \mathrm{m}$ in diameter at base, and is constructed of crystals $0.08 \mu \mathrm{m}$ in diameter whose distal faces form a series of stepped ramps that spiral counterclockwise in the distal direction. A nearly complete proximal surface sheet is present.
Remarks: This specimen of Vekshinella differs from the holotype and other illustrations of $V$. stradneri in surface ornamentation and mode of construction of the central spine.

\section{Genus WATZNAUERIA Reinhardt, 1964}

\section{Watznaueria supracretacea (Reinhardt) Wind and Wise, n. comb.} (Plate 50, Figure 8)

Coccolithites supercretaceus Reinhardt, 1965, p. 40, pl. 2, fig. 7, 8 . Biscutum? supracretaceum (Reinhardt) Perch-Nielsen, 1968, p. 80, pl. 23, fig. 9-12

Watznaueria bayacki Worsley, 1971, p. 23, pl. 1, fig. 21-23.

"Coccolithites" supracretaceus Reinhardt, Manivit, 1971, p. 137, pl. 5, fig. 14-18.

Remarks: The entire coccolith of the holotype and most of the other forms which have been attributed to this species are highly birefringent in polarized light. This is an attribute of Watznaueria rather than Biscutum. In the latter the shields are only weakly birefringent.

There is some question, however, as to whether $W$. supracretacea is a legitimate species or merely an isolated shield of another taxon. Forms observed in our material were too few in number to allow a satisfactory determination to be made.

\section{Genus ZEUGHRABDOTUS Reinhardt, 1965}

Zeugrhabdotus noeli Rood, 1971

(Plate 82, Figures 1-4, 6; Plate 83, Figure 1; Plate 89, Figure 12)

Zygolithus erectus Deflandre, in Deflandre and Fert, 1954, textfig. 62 .

Zygolithus erectus Deflandre, 1954, Noël, 1965, p. 62-64, fig. 2, pl. I, fig. 3,4 .

Zygolithus erectus Deflandre, 1954, Stradner et al., 1968, p. 34-35, pl. 25; pl. 26, fig. 1, 2.

Zeugrhabdotus noeli Rood et al,, 1971, p. 252-253, pl. 1, fig. 4.

Remarks: Primarily as a result of differences in preservation, specimens from Site 330 are more similar to those illustrated by Stradner et al. (1968) than to the holotype of Rood et al. (1971). The species appears to be most easily distinguished in proximal view.

?Zeugrhabdotus choffati Rood, Hay, and Barnard, 1973 (Choffati, Rood, Hay, and Barnard, 1971) (Plate 82, Figure 5)

Remarks: The presence of a large hollow spine on the cross bar of this specimen suggests affinity to $Z$. choffati. Uncertainty exists due to the lack of knowledge of the range of distal morphology of $Z$. noeli and because of differences in size and age between this specimen and the holotype.

$Z$. choffati has only been reported from the Bathonian of Normandy. The holotype is $2.4 \mu \mathrm{m} \times 1.8 \mu \mathrm{m}$ in dimension, as compared with corresponding values of $4.0 \mu \mathrm{m}$ and $2.5 \mu \mathrm{m}$ for the Oxfordian specimen. The accompanying specimens of $Z$. noeli are generally approximately the same size as the specimen illustrated in Plate 7, Figure 5. However, the specimens of $Z$. noeli have two or three calcite crystals extending from the cross bar and overlying the inner portion of several rim elements. This phenomenon is not evident on the specimen under consideration.

Although the general appearance of this specimen suggests affinity with $Z$. choffati, the relatively large size with respect to the holotype and uncertainty as to the total range of $Z$. choffati prevents a more definite identification.

\section{Zeugrhabdotus erectus (Deflandre) Reinhardt, 1965}

(Plate 81, Figure 6; Plate 83, Figure 2)

Remarks: These specimens are similar to the holotype and previous illustrations of $Z$. erectus, but show no evidence of a spine on the cross bar. No finely perforated sheet masking the proximal surface such as that noted by Rood et al. (1971) was observed.

\section{Genus ZYGODISCUS Bramlette and Sullivan, 1961}

\section{Zygodiscus anthophorus (Deflandre) Wind and Wise, n. comb.} (Plate 43, Figures 1-4)

Rhabdolithus anthophorus Deflandre, 1959, p. 137, pl. 1, fig. 21, 22. Cretarhabdus? anthophorus (Deflandre) Bramlette and Martini, 1964, p. 299 , pl. 3, fig. 1-4 
Zygodiscus elegans Gartner, 1968, p. 32, pl. 10, fig. 3-6; pl. 12, fig. 3a-c, 4a-c; pl. 27, fig. 1.

?Chiastozygus anthophorus (Deflandre) Gartner, 1968, pl. 15, fig. 5a, b, 6, 7a-c; non pl. 11, fig. 5a, b, 6a-c; non pl. 14, fig. 6 .

Reinhardtites anthophorus (Deflandre) Perch-Nielsen, 1968, p. 38-39, text-fig. 13, 14; pl. 5, fig. 1-8.

non Zygodiscus elegans Gartner emend. Bukry, 1969, p. 59, pl. 34, fig. 6-8.

Zygodiscus meudini Bukry, 1969, p. 61-62, pl. 35, fig. 5-8.

Reinhardtites anthophorus (Deflandre) Perch-Nielsen, 1968. Reinhardt, 1971, p. 20, text-fig. 3, 4.

non Glaukolithus elegans (Gartner, 1968 emend. Bukry, 1969) Roth and Thierstein, 1972, p. 437, pl. 10, fig. 16-20.

Zygodiscus sp. Risatti, 1973, p. 21, pl. 10, fig. 18, 19.

Remarks: Deflandre (1959, p. 137, pl. 1, fig. 21, 22) described and illustrated in plan view an intact rhabdolith characterized by a wide, relatively thin distally flaring base, and long striate stem terminating in a large petaloid structure. The holotype (loc. cit., fig. 22) appears to be constructed of between 40 and 45 rim elements. Unfortunately, no proximal or distal views of the holotype were illustrated, and no mention is made of base-plate characteristics.

Bramlette and Martini (1964, p. 299, pl. 3, fig. 1-4) note that "the basal plate arches up from the low peripheral rim to a small elliptical opening at the center, which is largely covered or obscured by the complexly constructed base of the central knob or stem. Alternate radial segments of the basal plate are relatively thin."

Gartner (1968, p. 32) defines his new species Zygodiscus elegans as a species with a flat disc with submarginal notches and ridges. He (loc. cit.) notes that Rhabdolithus anthophorus Deflandre has Xshaped cross bars and a more distinct flare on the distal end of the stem. Gartner (1968, p. 26) remarks that his new combination Chiastozygus anthophorus (Deflandre) has no trace of the submarginal notches found on the disc of Zygodiscus elegans.

Gartner illustrates three specimens of the form he refers to as Chiastozygus anthophorus (Deflandre). Light micrographs (his pl. 11, fig. $5 a, b, 6 a-c)$ are interpreted by him as lateral and proximal views of the same specimen with a distally tapering spine terminating in a petaloid structure, and a base dominated by a well-formed cross whose arms are oriented at approximately $45^{\circ}$ to the base axes. A similar specimen, viewed on the TEM (Gartner, 1968, pl. 14, fig. 6) also has a high, distally flaring base. The stem of this specimen also tapers distally and terminates in a petaloid structure.

The specimens illustrated in Gartner's pl. 11 and 14 are clearly the same species; however, this species does not appear to be the taxon named by Deflandre. Features of the stem and height of the base do not agree with corresponding parts of the holotype. The fact that Deflandre gave both major axis and minor axis dimensions of the specimens studied indicates that he viewed specimens in proximal and/or distal, as well as plan view. The presence of a feature as characteristic as a well-developed basal cross would surely have prompted him to mention this feature, had it been present.

Only Gartner's pl. 15, fig. 5a, b; 6; 7a-c illustrate a specimen whose appearance approaches that of the holotype of Rhabdolithus anthophorus Deflandre. The absence of submarginal notching on this specimen can be attributed to what appears to be a filling of the concave proximal surface of the base and the presence of a large nonskeletal grain which obscures much of the proximal view of the specimen.

Gartner's (1968) transmission electron microscope and light microscope illustrations of Zygodiscus elegans Gartner are nearly identical to Cretarhabdus? anthophorus (Deflandre) Bramlette and Martini and specimens from Hole 327A on the Falkland Plateau (Plate 43, Figures 1-4). This species is quite common throughout the Maestrichtian section on the Falkland Plateau and common to abundant in the early Maestrichtian samples studied by Bramlette and Martini (1964). As listed in Gartner (1968), Zygodiscus elegans is "abundant" in the one sample (late Campanian) in which it is present, while Chiastozygus anthophorus (Deflandre) is "rare" or "few" in the three Campanian samples in which it was found. It appears reasonable to assume that the form described by Deflandre would be the more common of these two species.

Gartner has attributed to Deflandre's species ( $R$. anthophorus) morphological features not described or mentioned by the original author. The present authors consider the forms Gartner described as Zygodiscus elegans Gartner and one specimen he described as Chiastozygus anthophorus (Deflandre) (Gartner, 1968, pl. 15, fig. 5a- c, 6a-c) to be cospecific with the holotype of Rhabdolithus anthophorus Deflandre. The remaining two specimens identified as $C$. anthophorus (Deflandre) by Gartner (1968) are here considered to be species of Chiastozygus.

Zygodiscus bicrescenticus (Stover) Wind and Wise, n. comb. (Plate 38, Figures 4-7; Plate 39, Figures 1,2)

Discolithus bicrescenticus Stover, 1966, p. 142, pl. 2, fig. 5-7, pl. 8, fig. 11.

Zygolithus stenopous Stover, 1966, p. 148, pl. 4, fig. 6-9; pl. 8, fig. 25 ,

Zygodiscus compactus Bukry, 1969, p. 59, pl. 34, fig. 1, 2.

Zygolithus compactus (Bukry) Noël, 1970, p. 26-28, fig. 2, 3; pl. 2, fig. 2-8; pl. 3, fig. 1-3.

Description: Elliptical specimens constructed of rim of approximately 30 imbricate elements and multicrystalline broad cross bar which may represent as much as $1 / 3$ of length of specimen. Rim elements are approximately $1.0 \mu \mathrm{m}$ wide, but several bear broad, thin inward extensions which restrict central area perforations to two small triangular or semicircular openings. In proximal view, the cross bar is defined as two parallel thick cross bars lying just below the plane of the proximal surface. The two small perforations are visible at the bottom of the large cavities situated between the cross bars and the proximal rim.

Remarks: In polarized and phase-contrast illumination the central cross bar appears as two mirror-image trapezoids joined along the longest common side by a dark suture. Viewing of individual specimens on both the scanning electron microscope and the light microscope illustrates the synonymy of Discolithus bicrescenticus, Zygodiscus compactus, and Zygolithus stenopous. Z. compactus Bukry (1969, p. 59) has a maximum dimension of $7.0 \mu \mathrm{m} ; D$. bicrescenticus Stover (1966, p. 142) has a length of 6.0 to $8.0 \mu \mathrm{m} ; Z$. stenopous Stover (1966, p. 148) has a length ranging from 7.0 to $10.0 \mu \mathrm{m}$; and specimens from Hole 327A all have lengths of approximately $7.2 \mu \mathrm{m}$. Specimens of Zygodiscus diplogrammus from Sample 327A-13-2, 137 $\mathrm{cm}$ range in length from 8.5 to $9.6 \mu \mathrm{m}$.

Manivit (1971, p. 81) placed Discolithus bicrescenticus Stover in synonymy with Glaukolithus diplogrammus. Thierstein (1973, p. 36) placed Zygolithus stenopous Stover and Zygodiscus compactus Bukry in synonymy with Zygodiscus diplogrammus.

Occurrence: Cenomanian to Campanian (Stover, 1966); Maestrichtian (this report).

\section{Zygodiscus sigmoides Bramlette and Sullivan, 1961} (Plate 43, Figures 5, 6)

Zygodiscus sigmoides Bramlette and Sullivan, 1961, p. 149, pl. 4, fig. 11a-d (non fig. 11e).

Zygodiscus simplex Bramlette and Sullivan, 1961, p. 151, pl. 6, fig. 19, 20a, b, 21, 22.

Zygodiscus sigmoides Bramlette and Sullivan, Bramlette and Martini, 1964 , p. 303 , pl. 4 , fig. 3-5.

non Zygodiscus sp. aff. Z. sigmoides Bramlette and Sullivan; Bukry, 1969 , p. 61, pl. 36, fig. 1, 2 .

?Glaukolithus elegans (Gartner, 1968 emend. Bukry, 1969) Thierstein; Roth and Thierstein, 1972, p. 437, pl. 10, fig. 16-20.

Remarks: Appearance of specimens of Zygodiscus sigmoides Bramlette and Sullivan, 1961, in light microscope slide preparations of samples from Hole 327A is identical to the micrographs of the holotype (Bramlette and Sullivan, 1961, pl. 4, fig. 11a, d) and micrographs in subsequent publications. The drawing in distal view of the holotype by Bramlette and Sullivan (pl. 4, fig. 1le) does not correspond to the accompanying micrographs, in particular, the polarized light micrograph (pl. 4, fig. 11d).

Bukry (1969) appears to have misinterpreted the sigmoid light microscope appearance of specimens of this species as the result of distal surface structures. SEM and light microscope analysis of specimens from Hole 327A has shown that the sigmoid figure present in the central portion of this species is generated by the symmetrical flaring aprons which extend from the spine base to the rim and skeletal material situated beneath the central spine. To the authors' knowledge, this is the first observation of $Z$. sigmoides in Maestrichtian samples.

Occurrence: Paleocene and Danian (Bramlette and Martini, 1964); Maestrichtian (this report). 


\section{ADDITIONAL MESOZOIC TAXA}

(M.V. Filewicz, F.H. Wind, and S.W. Wise, Jr.)

Most of the new taxa described in this section are from an Aptian shallow water (100 to $400 \mathrm{~m}$ ) micrantolith-braarudosphaerid chalk lamina which formed in such a way that even the most delicate nonarticulated coccospheres are preserved relatively intact. For further discussion of the depositional and diagenetic characteristics of this material, see p. 289 of this report and Wise (in press).

\section{Genus BRAARUDOSPHAERA Deflandre, 1947}

\section{Braarudosphaera gartneri, Filewicz, Wind and Wise, n. sp.} (Plate 74, Figures 4, 5)

Diagnosis: A moderate-sized species of Braarudosphaera with prominent radial ridges extending down the center of each segment of the pentalith.

Description: The ridges stand high above the plane of the solid portion of the pentalith and represent about half the total thickness of the coccolith.

Remarks: The ridges are readily discernible in the light microscope and serve to distinguish $B$. gartneri from all other species of Braarudosphaera. Ridges occur on some species of Micrantolithus, but only along the margins of the pentalith segments. It is conceivable that the ridge features could be produced by dissolution; however, this is not believed to be the case because dissolution should not affect all segments of the pentaliths in such a uniform manner. In other units where dissolution of Braarudosphaera has been intense (for example, Sample 330-3-2, $115 \mathrm{~cm}$; see also Wise and Kelts, 1972), no such ridge features are seen.

Occurrence: Few in two Albian samples of Hole 327A, Falkland Plateau.

Size: $6-7 \mu \mathrm{m}$

Holotype: USNM 240473 (Plate 74, Figure 4).

Paratype: USNM 240474 (Plate 74, Figure 5).

Type locality: Sample 327 A-19-2, $120 \mathrm{~cm}$.

Braarudosphaera minuta Filewicz, Wind, and Wise, n. sp. (Plate 73, Figures 9-11)

Diagnosis: A small species of Braarudosphaera with exceptionally long pentalith segments.

Description: The length of each segment if measured from the center of the pentalith is approximately twice the width of the segment at its widest point. Diameter of the pentaliths averages about 5 $\mu \mathrm{m}$. In the samples studied, the pentalith segments are somewhat irregular in shape, probably due to secondary calcite overgrowth.

Remarks: Though somewhat overgrown, specimens illustrated here are readily distinguished from those of other members of the genus by their small size and long pentalith segments. The stratigraphic range of the taxon is restricted to a short interval at Site 327.

Occurrence: Few to common in the Biscutum constans Subzone of the Albian Prediscosphaera cretacea Zone of Hole 327A, Falkland Plateau.

Size: $5-7 \mu \mathrm{m}$

Holotype: USNM 240472 (Plate 73, Figure 11).

Paratypes: USNM 240470, 240471 (Plate 73, Figures 9, 10).

Type locality: Sample $327 \mathrm{~A}-21-2,36 \mathrm{~cm}$.

Genus COROLLITHION Stradner, 1961

(Other species of this genus are discussed in the preceding section)

Corollithion perch-nielseni Filewicz, Wind, and Wise, n. sp. (Plate 61, Figure 3)

Diagnosis: An elliptical species of Corollithion with a large diamond-shaped central area platform attached to the rim by four radial bars in the major and minor axes.

Description: The central platform is composed of a thin framework of bars which describe a diamond-shaped base. The radial bars are doubled in the minor axes and probably rise to the center of the platform to support a spine. A spine, however, has not been observed in our specimens; instead, the central structure is broken away to leave the central portion of the platform void. The bars which attach the platform to the rim appear to lie slightly asymmetric to the major and minor axes of the ellipse.
Remarks: Only two specimens, both probably part of the same coccosphere, have been observed. The fragile nature of this species makes its observation in even well-preserved material fortuitous.

Size: $3-5 \mu \mathrm{m}$.

Occurrence: Rare in the Aptian braarudosphaerid-micrantholithid chalk laminae of Site 330, Falkland Plateau.

Holotype: USNM 240456 (Plate 61, Figure 3, upper specimen).

Paratype: USNM 240457 (Plate 61, Figure 3, lower specimen).

Type locality: Sample $330-3-2,115 \mathrm{~cm}$.

Corollithion silvaradion Filewicz, Wind, and Wise, n. sp. (Plate 62, Figures 2-6; Plate 63, Figures 5, 6)

Diagnosis: A species of Corollithion with elliptical outline and approximately 22 radially disposed bars.

Description: The bars extend to the periphery from a broad central platform which is peaked slightly to form a spine. The platform occupies over $75 \%$ of the central area and is composed of extensions of the bars plus shorter elements inserted between the bars. The bars are composed of long laths, often paired (for example, Plate 62, Figure 5), and usually jointed where the bars intersect the central platform.

Remarks: The trivial name is from the Latin meaning "forest of spokes." This species is readily distinguished by the large number of central area bars. Other members of the genus have only about half as many bars or less. This delicate form is best preserved in chalk laminae which were cemented during early diagenesis at Site 330 .

Occurrence: Few to common in braarudosphaerid-micrantholithid chalk laminae and adjacent oozes in the Aptian of Site 330, Falkland Plateau.

Size: $3-5 \mu \mathrm{m}$.

Holotype: USNM 240455 (Plate 62, Figure 6)

Paratypes: USNM 240451-240454 (Plate 62, Figures 2-5), USNM 240475, 240476 (Plate 63, Figures 5, 6).

Type locality: Sample $330-3-2,115 \mathrm{~cm}$.

Genus SERIBISCUTUM Filewicz, Wind, and Wise, n. gen. $\mathrm{sp}$.

Type species: Seribiscutum bijugum Filewicz, Wind, and Wise, n.

Diagnosis: Elliptical coccoliths with two monocyclic shields composed of nonimbricate to slightly imbricate elements surrounding a central area partially closed by large blocky elements and granules.

Remarks: The name is from the Latin Sera meaning bar. The rim is similar to that of Biscutum from which Seribiscutum differs in having a perforated central area which is partially closed by large blocky elements as well as granules. As in some specimens of Biscutum, the elements of the distal shields may develop tabs which overlap adjacent elements in the sinistral direction. The two species assigned to this genus may form an evolutionary series.

Seribiscutum bijugum Filewicz, Wind, and Wise, n. sp. (Plate 63, Figures 7, 8; Plate 65, Figures 3-6; Plate 66, Figures 1-3)

Diagnosis: A small species of Seribiscutum with the central area partially filled by two bars parallel to but offset on either side of the minor axis so as to partition the central area into three roughly equalsized perforations. The inner margin of the central area on the proximal side is surrounded by granules of assorted size.

Description: The shields consist of 17 to 21 radially arranged elements. In distal view, lath-shaped elements along the inner margin of the central area serve as buttresses into which the two parallel bars are emplaced at right angles. In proximal view, only granules are seen along the inner margin of the central area.

Remarks: Coccospheres are composed of 16-20 coccoliths. The species is distinguished from $S$. primitivum by its smaller size and by the two central area bars which are parallel to and separate from one another.

Occurrence: Common in the Aptian chalk laminae sampled at Site 330, Falkland Plateau.

Size: $3-4 \mu \mathrm{m}$.

Holotype: USNM 240466 (Plate 66, Figure 2).

Paratypes: USNM 240468, 240469 (Plate 63, Figures 7, 8); USNM 240461-240464 (Plate 65, Figures 3-6); USNM 240465, 240467 (Plate 66, Figures I, 3).

Type locality: Sample $330-3-2,115 \mathrm{~cm}$. 
Seribiscutum primitivum (Thierstein) Filewicz, Wind, and Wise, n. comb.

(Plate 66, Figures 4-6; Plate 67, Figures 1-4)

Tremalithus cf. cretaceus (Deflandre) Forchheimer, 1968, p. 36, pl. III, fig. 6a, b; text-fig. $3(10), 14$.

Cribrosphaerella primitiva Thierstein, 1974, p. 637, pl. 1, fig. 1-3).

Remarks: Tabs are prominent on the distal shields of some specimens (for example, Plate 67, Figure 2), but not so well developed on others. The central area is nearly completely filled by granules, four of the largest of which join to form a zig-zag line along the long axis. In some specimens, the four large granules seem to form two closely appressed parallel bars (Plate 66, Figure 6); in others the bars are somewhat separated as in Plate 66, Figures 4 and 5 . The latter two specimens may be forms transitional between $S$. primitivum and $S$. bijugum.

Occurrence: Originally described from Albian through Cenomanian DSDP cores from the southern part of the Indian Ocean, this species seems to prefer a cool water high latitude habitat. It is one of the more abundant species through much of the Albian section of the Falkland Plateau, but is not found above the Cenomanian there due to unsuitable facies conditions in the Upper Cretaceous section. Specimens illustrated by Forchheimer (see synonymy) are from the Albian-Cenomanian of southern Sweden.

\section{Genus SOLLASITES Black, 1967}

\section{Sollasites falklandensis Filewicz, Wind, and Wise, n. sp.} (Plate 50, Figures 6, 7; Plate 64, Figures 2-4)

Diagnosis: A large species of Sollasites with a solid oval-shaped central platform. On the proximal surface of the platform can be traced the outline of one cross bar in the minor axis of the ellipse and one in the major axis. The latter is flanked on either side by two cross bars subparallel to the major axis which bend outwards along the platform margin. The extremities of the cross bars intersect the rim along prominent sutures visible in the light microscope.

Description: The monocyclic distal shield is composed of 50 to 60 radial and slightly imbricate elements. On the proximal surface, the traces of the cross bars of the central platform consist of a double row of granules. The extremities of the two outer cross bars turn out sharply where they intersect the rim so that their outlines are similar to a recurved archer's bow. The distal surface of the platform is covered by long laths parallel to the long axis of the coccolith.

Remarks: $S$. falklandensis is readily distinguished from $S$. horticus (Stradner, Adamiker, and Maresch) (see our Plate 64, Figure 1) by its larger size and larger number of elements (50-60 as opposed to 32-44 for $S$. horticus [see Bukry, 1969]), the solid platform, the recurved outer cross bars, and the prominent sutures visible in the light microscope where the cross bars join the shields.

Occurrence: Common to abundant in the lower part of the early. middle Albian of Holes 327A and 330 on the Falkland Plateau where the presence of this species marks the Sollasites falklandensis Subzone of the Prediscosphaera cretacea Zone.

Size: $10 \mu \mathrm{m}$.

Holotype: USNM 240459 (Plate 64, Fígure 3).

Paratypes: USNM 239528, 239529 (Plate 50, Figures 6, 7); USNM 240458, 240460 (Plate 64, Figures 2, 4).

Type locality: Sample $327 \mathrm{~A}-19-2,15 \mathrm{~cm}$.

Sollasites thiersteini Filewicz, Wind, and Wise, n. sp. (Plate 64, Figures 5, 6; Plate 65, Figures 1, 2)

Diagnosis: A species of Sollasites with a solid central platform connected to the rim at four points which lie roughly along the major and minor axes of the ellipse.

Description: The monocyclic distal shield is composed of approximately 40 slightly imbricate radial elements. The platform covers most of the central area with only four narrow slits separating it from the rim. The distal surface of the platform is composed of thin laths, the arrangement of which is not well defined, although triangular-shaped laths extend from the rim toward the center of the platform at the point of juncture of those two structures. The two shields are joined by a relatively wide inner cycle of subvertical elements visible on the proximal surface only. The proximal surface of the platform is composed of granules arranged in no discernible order. No traces of cross bars on the platforms are visible.

Remarks: S. thiersteini is similar to $S$. loweii (Bukry) in size and in the shape of the central area structure. Unlike $S$. loweii, however, the central area structure is solid with no evidence of cross bars or slits between cross bars. The preservation of the several specimens observed is sufficiently good to discount the possibility that the solid central area platform resulted from diagenetic overgrowths which obscured an original bar structure thereby giving the appearance of an original solid platform. $S$. thiersteini is distinguished from $S$. falklandensis by its smaller size.

Occurrence: Observed only in the Aptian braarudosphaeridmicrantholith chalk Sample 330-3-2, $115 \mathrm{~cm}$.

Size: $3.5-5 \mu \mathrm{m}$.

Holotype: USNM 240477 (Plate 64, Figures 5, 6; two views of same coccosphere).

Paratypes: USNM 240478, 240479 (Plate 65, Figures 1, 2).

Type locality: Sample 330-3-2, $115 \mathrm{~cm}$, Falkland Plateau.

\section{ACKNOWLEDGMENTS}

We are grateful to numerous friends and colleagues aboard ship and on shore for aid in preparing this report. Drs. Stephan Gartner (Texas A \& M University), William W. Hay (University of Miami, Florida), Katharina Perch-Nielsen (Swiss Federal Institute, Zurich), and Hans R. Thierstein (Scripps Institution of Oceanography) provided valuable discussion and review of various portions of the coccolith taxonomy. F.H. Wind prepared the range chart and the bulk of the systematics for the Campanian-Maestrichtian interval. Richard E. Constans, Mark V. Filewicz, and Marianne Trinchitella assisted with the electron microscopy. We thank Yang-Ja P. Chung, LaVerne Lamb, Dennis S. Cassidy, and Trudy Wood for their valuable assistance with sample and manuscript preparation. The dedicated efforts of Provost Robert A Spivey and the FSU Committee on Electron Microscope Facilities enabled acquisition of the ISI SuperMini I scanning electron microscope used throughout this study. Examination of a piston core (RC-15-84) from the Lamont-Doherty Geological Observatory core collection supported by NSF Grant DES72-01568 and ONR Grant N00014-75-0210 was helpful. Primary support was provided by an FSU Faculty Research Grant (COFRS). Laboratory facilities and valuable new core material helpful to the study were provided by National Science Foundation Grant OPP 74-20109 and Islas Orcadas Cruise 7-75 to the Falkland Plateau and Malvinas Outer Basin.

\section{REFERENCES}

Barnard, R. and Hay, W.W., 1974. On Jurassic coccoliths: a tentative zonation of the Jurassic of Southern England and North France: Eclog. Geol. Helv., v. 67, p. 563-585.

Black, M., 1971a. Coccoliths of the Specton Clay and Sutterby Marl: Yorkshire Geol. Soc. Proc., v. 38, p. 381-424. 1971b. Problematical microfossils from the Gault Clay: Geol. Mag., v. 108, p. 325-327.

1972. British Lower Cretaceous Coccoliths. I. Gault Clay. Part 1: Palaeontol. Soc. Monogr., p. 1-48.

Black, M. and Barnes, B., 1959. The structure of coccoliths from the English Chalk: Geol. Mag., v. 96, p. 321-328.

Bosellini, A. and Winterer, E.L., 1975. Pelagic limestone and radiolarite of the Tethyan Mesozoic: a genetic model: Geology, v. 3, p. 279-282.

Bramlette, M.N. and Martini, E., 1964. The great change in calcareous nannoplankton fossils between Maestrichtian and Danian: Micropaleontology, v. 10, p. 291-322.

Bramlette, M.N. and Sullivan, F.R., 1961. Coccolithophorids and related nannoplankton of the early Tertiary in California: Micropaleontology, v. 7, p. 129-188.

Bukry, D., 1969. Upper Cretaceous coccoliths from Texas and Europe: Univ. Kansas Paleont. Contrib., Art. 51 (Protista 2), p. 1-79.

1972. Further comments on coccolith stratigraphy, Leg 12, Deep Sea Drilling Project. In Laughton, A.S., Berggren, W.A., et al., Initial Reports of the Deep Sea 
Drilling Project, Volume 12: Washington (U.S. Government Printing Office), p. 1071-1083.

1973a. Coccolith stratigraphy, eastern equatorial Pacific, Leg 16 DSDP. In van Andel, T.H., Heath, G.R., et al., Initial Reports of the Deep Sea Drilling Project, Volume 16: Washington (U.S. Government Printing Office), p. 653-711.

1973b. Coccolith and silicoflagellate stratigraphy, Deep Sea Drilling Project Leg 18, Eastern North Pacific. In Kulm, L. D., von Huene, R., et al., Initial Reports of the Deep Sea Drilling Project, Volume 18: Washington (U.S. Government Printing Office), p. 817-831.

1973c. Coccolith and silicoflagellate stratigraphy, Tasman Sea and Southwestern Pacific Ocean, Deep Sea Drilling Project Leg 21. In Burns, R.E., Andrews, J.E., et al., Initial Reports of the Deep Sea Drilling Project, Volume 21: Washington (U.S. Government Printing Office), p. 885-893.

1973d. Low-latitude coccolith biostratigraphic zonation. In Edgar, N.T., Saunders, J.B., et al., Initial Reports of the Deep Sea Drilling Project, Volume 15: Washington (U.S. Government Printing Office), p. 685703.

1974. Coccoliths as paleosalinity indicators-evidence from Black Sea: Am. Assoc. Petrol. Geol. Mem. 20, p. 353-363.

Burns, D.A., 1975. Nannofossil biostratigraphy for Antarctic sediments, Leg 28, Deep Sea Drilling Project. In Hayes, D.E., Frakes, L.A., et al., Initial Reports of the Deep Sea Drilling Project, Volume 28: Washington (U.S. Government Printing Office), p. 589-598.

Bybell, L. and Gartner, S., 1972. Provincialism among midEocene calcareous nannofossils: Micropaleontology, v. 18 , p. $319-336$

Cepek, P., 1970. Zur Vertikalverbreitung von CoccolithenArten in der Oberkreide NW-Deutschlands: Geol. Jb., v. 88 , p. $235-264$

Deflandre, G., 1959. Sur les nannofossiles calcaires et leur systématique: Rev. Micropal., v. 2, p. 127-152.

Edwards, A.R., 1973a. Calcareous nannofossils from the southwest Pacific, Deep Sea Drilling Project, Leg 21. In Burns, R.E., Andrews, J.E., et al., Initial Reports of the Deep Sea Drilling Project, Volume 21: Washington (U.S. Government Printing Office), p. 641-691.

1973b. Key species of New Zealand calcareous nannofossils: New Zealand J. Geol. Geophys., v. 16, p. 68-89.

Edwards, A.R. and Perch-Nielsen, K., 1975. Calcareous nannofossils from the southern southwest Pacific: Deep Sea Drilling Project, Leg 29. In Kennett, J.P., Houtz, R.E., et al., Initial Reports of the Deep Sea Drilling Project, Volume 29: Washington (U.S. Government Printing Office), p. 469-539.

Forchheimer, S., 1972. Scanning electron microscope studies of Cretaceous coccoliths from the Koepsingberg Borehole No. 1, SE Sweden: Sver. Geol. Undersok., Arsbok., v. 65, Ser. C., p. 1-141.

Forchheimer, S. and Stradner, H., 1973. Scampanella, eine neue gattung kretazischer nannofossilien: Verh. Geol. B.A., no. 2, p. 285-289.

Gartner, S., 1968. Coccoliths and related calcareous nannofossils from upper Cretaceous deposits of Texas and Arkansas: Univ. Kansas Paleont. Contrib., Protista, Art. 1.

1971. Calcareous nannofossils from the JOIDES Blake Plateau cores, and revision of Paleogene nannofossil zonation: Tulane Stud. Geol. Paleontol., v. 8, p. 101-121.

Hammond, A.L., 1976. Paleoceanography: sea floor clues to earlier environments: Science, v. 191, p. 168-170, 208.
Haq, B.U., 1976. Coccoliths in cores from the Bellingshausen Abyssal Plain and Antarctic Continental Rise (DSDP Leg 35). In Hollister, C.D., Craddock, C., et al., Initial Reports of the Deep Sea Drilling Project, Volume 35: Washington (U.S. Government Printing Office), p. $557-568$.

Hay, W.W., 1970. Calcareous nannofossils from cores recovered on Leg 4. In Bader, R.G., et al., Initial Reports of the Deep Sea Drilling Project, Volume 4: Washington (U.S. Government Printing Office), p. 455-501.

Hay, W.W. and Mohler, H.P., 1967. Calcareous nannoplankton from early Tertiary rocks at Pont Labau, France, and Paleocene-early Eocene correlations: J. Paleontol., v. 41, p. $1505-1541$.

Hayes, D.E. and Frakes. L.A., 1975. General synthesis, Deep Sea Drilling Project, Volume 28: Washington (U.S. Government Printing Office), p. 919-942.

Loeblich, A.R., Jr. and Tappan, H., 1966. Annotated index and bibliography of the calcareous nannoplankton: Phycologia, v. 5, p. 81-216.

1968. Annotated index and bibliography of the calcareous nannoplankton II: J. Paleontol., v. 42 , p. 584 598.

1969. Annotated index and bibliography of the calcareous nannoplankton III: Paleontol., v. 43, p. $568-$ 588.

1970a. Annotated index and bibliography of the calcareous nannoplankton IV: J. Paleontol., v. 44, p. 558574.

1970b. Annotated index and bibliography of the calcareous nannoplankton V: Phycologia, v. 9, p. 157 174.

1972. Annotated index and bibliography of the calcareous nannoplankton VI: Phycologia, v. 10, p. 309 339.

1973. Annotated index and bibliography of the calcareous nannoplankton VII: J. Paleontol., v. 47, p. 715-759.

Manivit, H., 1971. Nannofossiles calcaires du Crétacé francais (Aptien-Maestrichtien). Essai de Biozonation appuyée sur les Stratotypes: Thèse, $187 \mathrm{p}$.

Medd, A.W., 1971. Some middle and upper Jurassic Coccolithophoridae from England and France. In Farinacci, A. (Ed.), Plankt. Conf. Proc., Second: Rome (Tecnozcienza), v. 11 , p. $821-846$

Noël, D., 1965. Sur les coccolithes du Jurassic Europeen et d'Afrique du Nord: C.N.R.S., Paris, p. 1-209.

1972 (1973). Nannofossiles calcaires de sediments jurassiques finement lamines: Mus. Nat. d'Hist. Nat. Bull., ser. 3 , v. 75 , p. $95-155$

Perch-Nielsen, K., 1971. Einige neue Coccolithen aus dem Paleozän der Bucht von Biskaya: Denmark Geol. Soc. Bull., v. 20, p. 347-361.

1972. Remarks on Late Cretaceous to Pleistocene Coccoliths from the North Atlantic: In Laughton, A.S., Berggren, W.A., et al., Initial Reports of the Deep Sea Drilling Project, Volume 12: Washington (U.S. Government Printing Office), p. 1003-1069.

1973. Neue coccolithen aus dem Maastrichtien von Danemark, Madagaskav und Agypten: Geol. Soc. Denmark Bull., v. 22, p. 306-333.

Prins, B., 1969. Evolution and stratigraphy of coccolithinids from the lower and middle Lias. In Brönnimann, P. and Renz, H.H. (Eds.), Proc. 1st Internat. Conf. Plank. Microfossils: Geneva (Brill) v. 2, p. 547-558.

Reinhardt, P., 1971. Synopsis der Gatturgen und arten der mesozoischen Coccolithen und anderer kalkiger Nannofossilien, Teil III: Sonder. Forschungs. C267, p. 19-41. 
Reinhardt, P. and Górka, H., 1967. Revision of some upper Cretaceous coccoliths from Poland and Germany: N. Jb. Geol. Pal. Abh., v. 129 , p. $240-255$.

Risatti, J.B., 1973. Nannoplankton biostratigraphy of the upper Bluffport Marl-lower Prairie Bluff Chalk interval (Upper Cretaceous), in Mississippi. In Smith, L.A. and Hardenbol, J., (Eds.), Symp. Calcareous Nannofossils Proc.: Houston (Gulf Coast Section, Soc. Econ. Paleontol. Min.), p. 8-57.

Rood, A.P. and Barnard, T., 1972. On Jurassic coccoliths: Stephanolithion, Diadozygus and related genera: Eclog. Geol. Helv., v. 65, p. 327-342.

Rood, A.P., Hay, W.W., and Barnard, T., 1971. Electron microscope studies of Oxford clay 'coccoliths: Eclog. Geol. Helv., v. 64 , p. $245-272$. 1973. Electron Microscope Studies of Lower and Middle Jurassic Coccoliths: Eclog. Geol. Helv., v. 66, p. 365-382.

Roth, P.H. and Thierstein, H.R., 1972. Calcareous nannoplankton: Leg 14 of the Deep Sea Drilling Project. In Hayes, D.E., Pimm, A.C., et al., Initial Reports of the Deep Sea Drilling Project, Volume 14: Washington (U.S. Government Printing Office), p. 421-485.

Smith, C.C., 1975. Upper Cretaceous calcareous nannoplankton zonation and stage boundaries: Gulf Coast Assoc. Geol. Soc. Trans., v. 25, p. 263-278.

Stover, L.E., 1966. Cretaceous coccoliths and associated nannofossils from France and the Netherlands: Micropaleontology, v. 12, p. 133-167.

Stradner, H., 1963. New contributions to Mesozoic stratigraphy by means of nannofossils: Sixth World Petrol. Congr. Proc. (Frankfurt a. M.), Sect. 1, Paper 4, 16 p.

Stradner, H., Adamiker, D., and Maresch, O., 1968. Electron microscope studies on Albian calcareous nannoplankton from the Delft 2 and Leidschendam 1 Deepwells, Holland: Verh. Nederl. Akad. Weetensch., Afd. Natururk., Eerste Reeks, Deel, v. 24, p. 51-157.

Thierstein, H.R., 1973. Lower Cretaceous calcareous nannoplankton biostratigraphy: Abh. Geol. B. A. (Wein), v. 29, p. $1-52$.
1974. Calcareous nannoplankton-Leg 26, Deep Sea Drilling Project. In Davies, T.A., Luyendyk, B.P., et al., Initial Reports of the Deep Sea Drilling Project, Volume 26: Washington (U.S. Government Printing Office), p. 619-667.

, in press. Biostratigraphy of marine Mesozoic sediments by calcareous nannoplankton: Marine Micropaleontol.

Veevers, J.J. and Heirtzler, J.R., 1974. Tectonic and paleographic synthesis of Leg 27. In Veevers, J.J., Heirtzler, J.R., et al., Initial Reports of the Deep Sea Drilling Project, Volume 27: Washington (U.S. Government Printing Office), p. 523-534.

Wind, F.H., 1975. Affinity of Lucianorhabdus and species of Tetralithus in late Cretaceous Gulf Coast samples: Gulf Coast Assoc. Geol. Soc. Trans., v. 25, p. 350-361.

Wind, F.H. and Wise, S.W., 1976. Mesozoic origin of holococcoliths: Am. Assoc. Petrol. Geol. Bull., v. 60, p. 733-734.

Wise, S.W., 1973. Calcareous nannofossils from cores recovered during Leg 18, Deep Sea Drilling Project: biostratigraphy and observations of diagenesis. In Kulm, L.O., von Huene, R., et al. Initial Reports of the Deep Sea Drilling Project, Volume 18: Washington (U.S. Government Printing Office), p. 569-615.

in press. Deep sea carbonate sediment: early diagenesis and the fate of fossil fuel $\mathrm{CO}_{2}$ : Proc. ONR Conf. on Fate of Fossil Fuel CO 2 (Hawaii, 1976).

Wise, S.W. and Kelts, K.R., 1972. Inferred diagenetic history of a weakly silicified deep sea chalk: Gulf Coast Assoc. Geol. Soc. Trans., v. 22, p. 177-203.

Worsley, T.R., 1971. Terminal Cretaceous event: Nature, v. 230 , p. $318-320$.

1974. The Cretaceous-Tertiary boundary event in the oceans. In Hay, W.W. (Ed.), Studies in paleooceanography: Soc. Econ. Paleont. Mineral., Spec. Publ., v. 20 , p. $94-125$. 


\section{PLATE 1}

(Pleistocene; Sample 329-1-1, $120 \mathrm{~cm}$ )

Figures 1-5 Emiliania huxleyi (Lohman). Series showing range of dissolution effects; all distal views.

1. $\times 13,000$.

2. $\times 16,000$.

3. $\times 13,500$.

4. $\times 13,500$.

5. $\times 14,500$.

Figures 6,7 Helicopontosphaera kamptneri Hay and Mohler.

6. Distal view, $\times 5500$.

7. Proximal view, $\times 5000$.

Figure $8 \quad$ Helicopontosphaera wallichi (Lohman), proximal view, $\times 6000$.

Figure 9 Coccolithus pelagicus (Wallich), proximal view, $\times 3500$.

Figures 10,11 Cyclococcolithina leptopora (Murray and Blackman).

10. Proximal view, $\times 8000$.

11. Proximal view of isolated distal shield, $\times 7500$.

Figure $12 \quad$ Gephyrocapsa sp., proximal view, $\times 15000$. 
PLATE 1
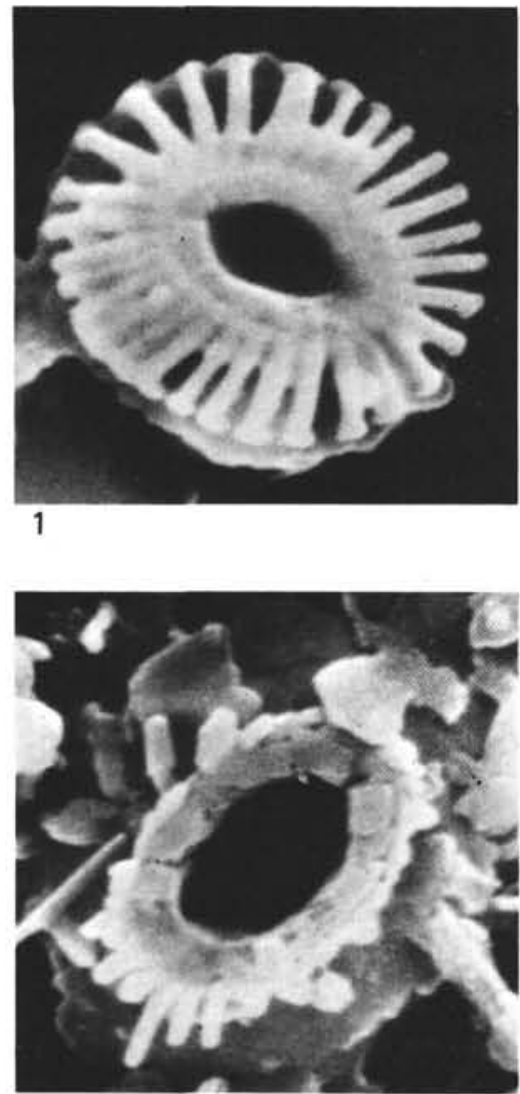

4

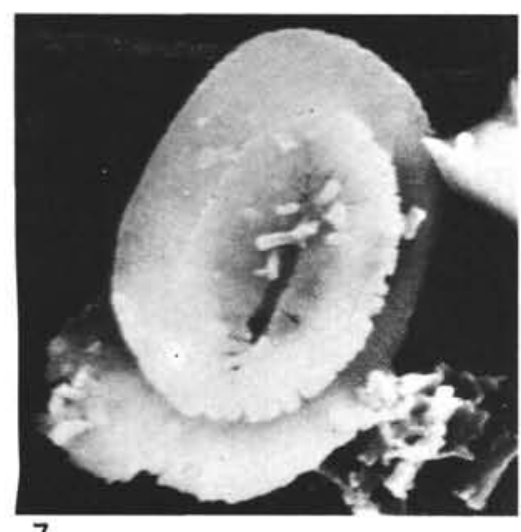

7

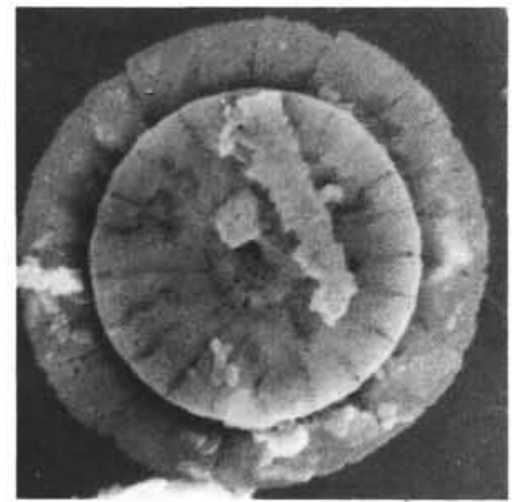

10
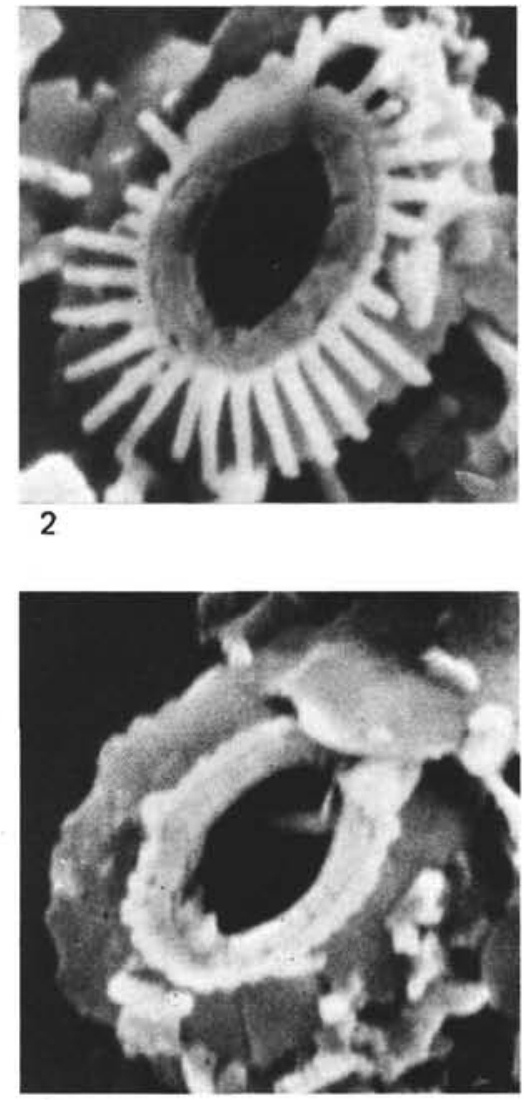

5

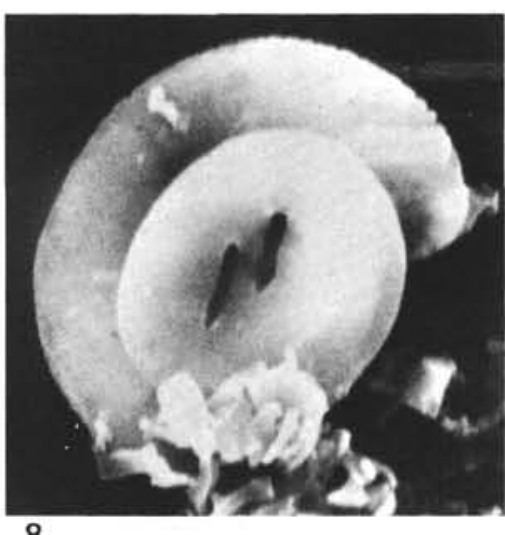

8

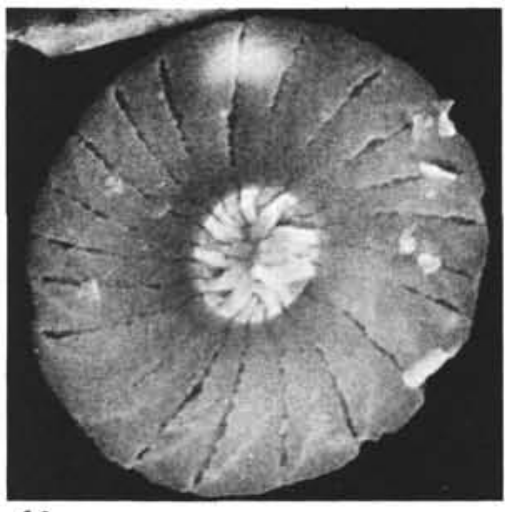

11

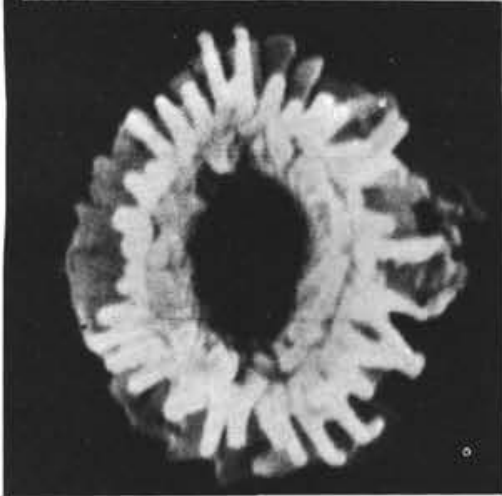

3

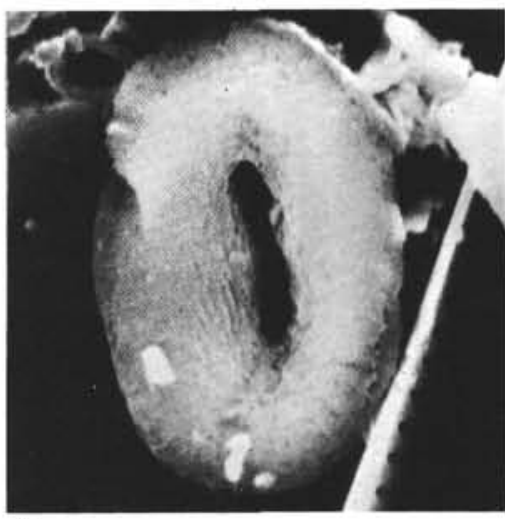

6
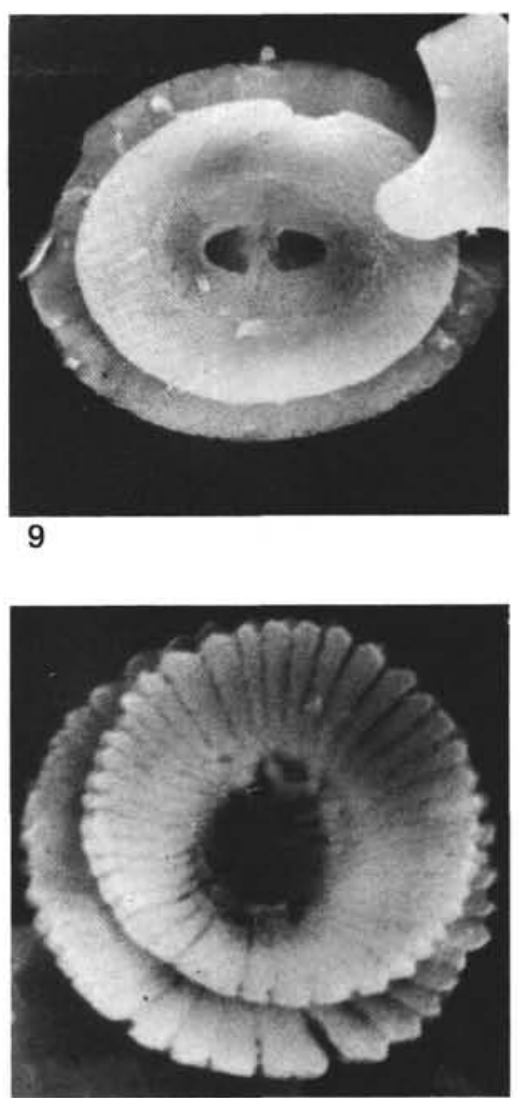

12 


\section{PLATE 2}

(Miocene, Sample 329-7-5, $120 \mathrm{~cm}$ )

Figures 1-3 Reticulofenestra pseudoumbilica (Gartner).

1. Proximal view, $\times 8000$.

2. Proximal view, $\times 12,000$.

3. Distal view, $\times 9000$.

Figure 4 ?Reticulofenestra $\mathrm{sp}$., distal view, $\times 11,000$.

Figure 5 Coccolithus eopelagicus (Bramlette and Riedel), proximal view, $\times 10,500$. 


\section{PLATE 2}
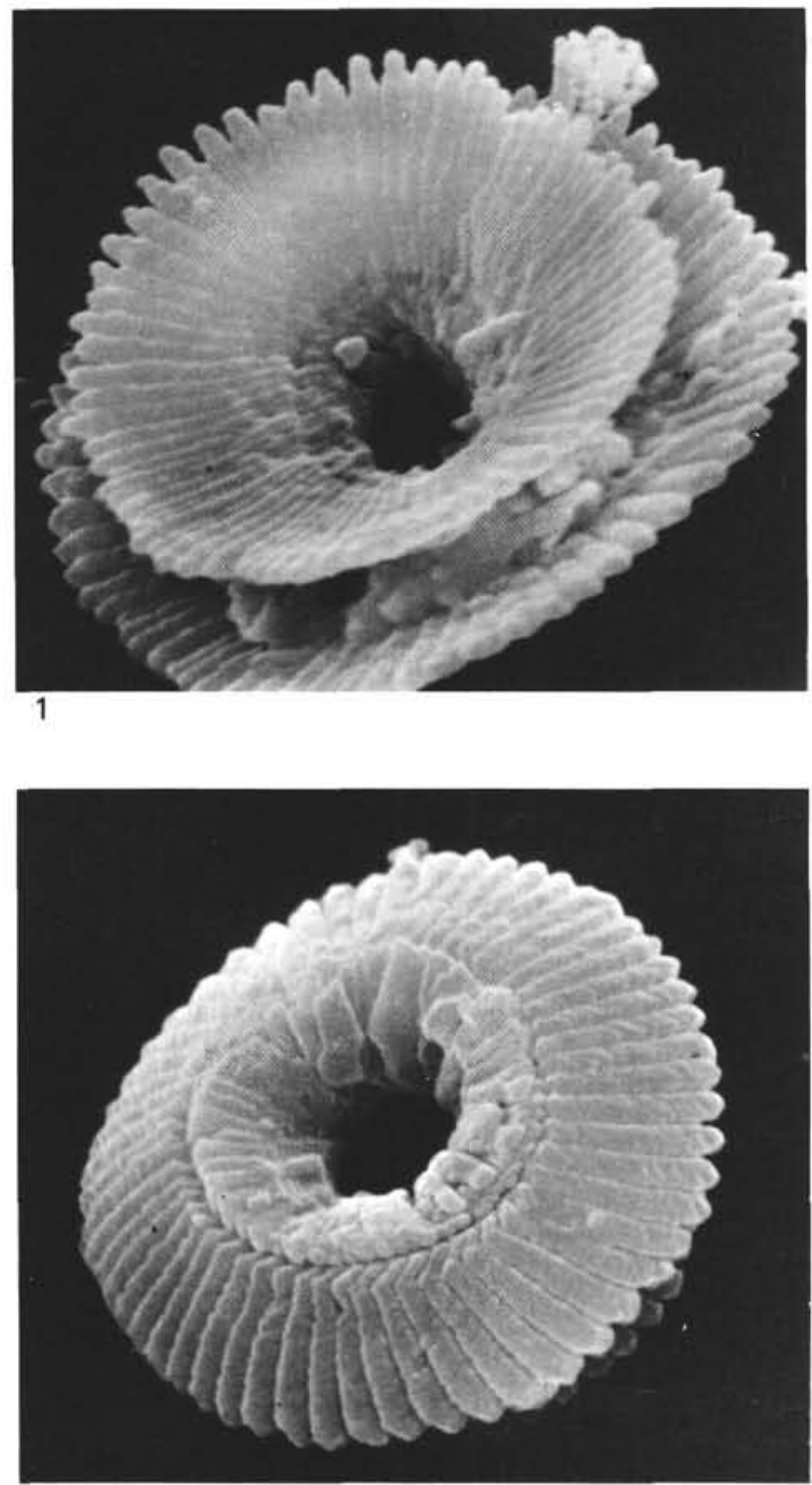

3
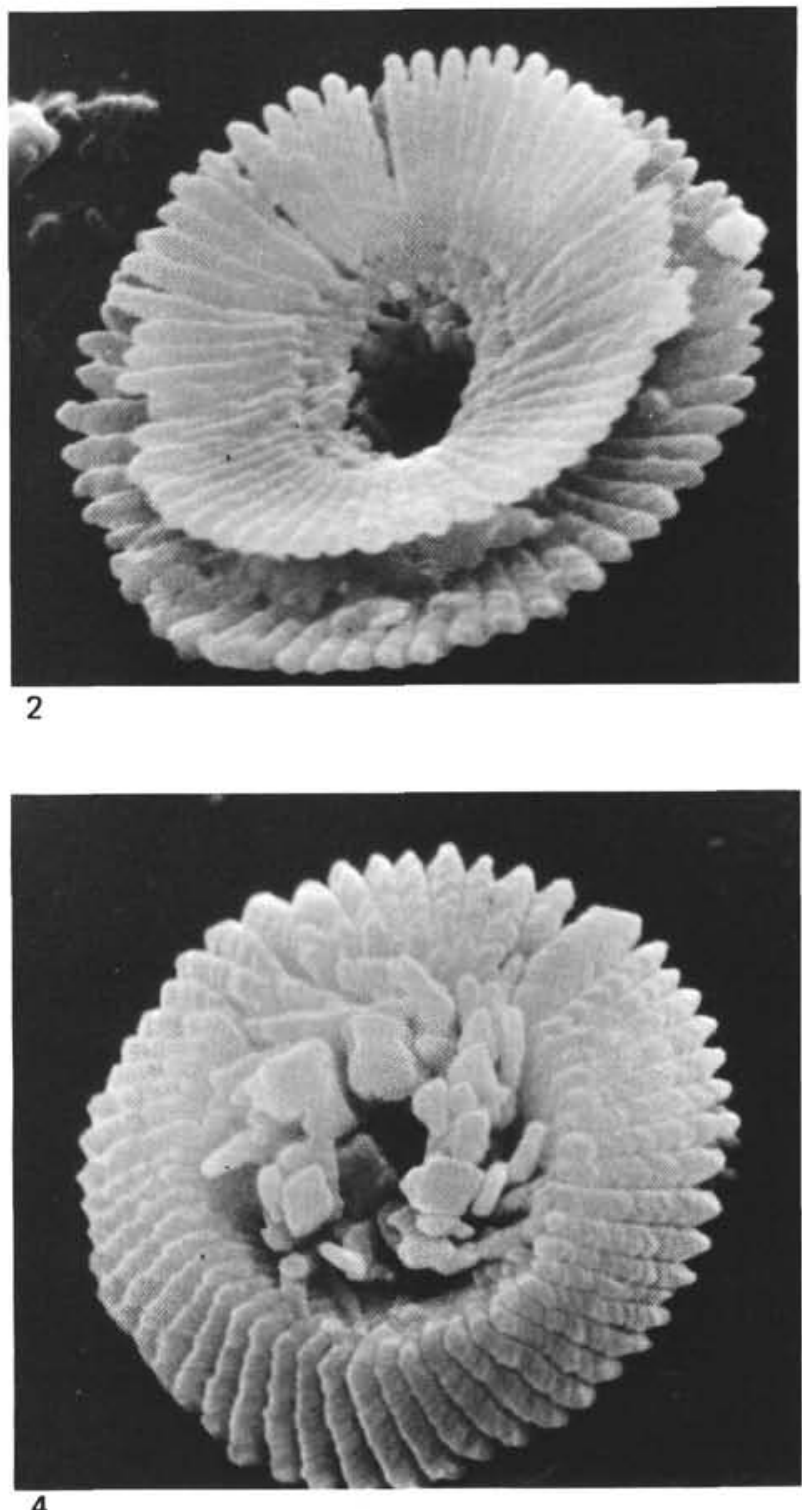

4

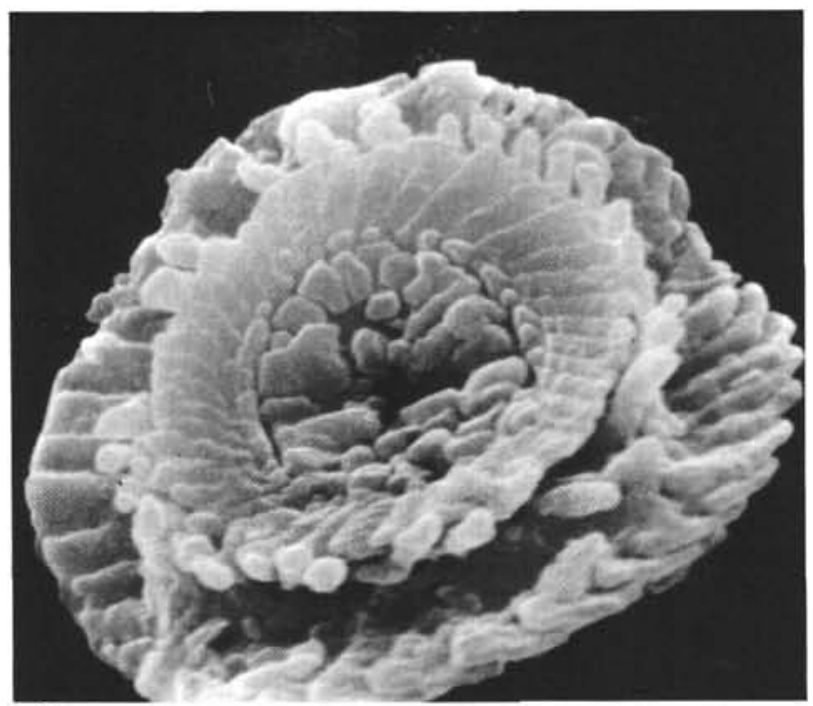

5 


\section{PLATE 3}

(Oligocene)

Figures 1-4 Chiasmolithus altus Bukry and Percival.

1. Distal view, Sample 329-29-1, $60 \mathrm{~cm}, \times 5500$.

2. Distal view, Sample $329-29-1,60 \mathrm{~cm}, \times 5500$.

3. Distal view, Sample 329-30-1, $62 \mathrm{~cm}, \times 5500$.

4. Proximal view, Sample $329-29-1,60 \mathrm{~cm}, \times 7500$.

Figures 5,6 Coccolithus pelagicus (Wallich).

5. Distal view, Sample $329-29-1,60 \mathrm{~cm}, \times 7000$.

6. Distal view, Sample 329-30-1, $82 \mathrm{~cm}, \times 17,000$. 
PLATE 3

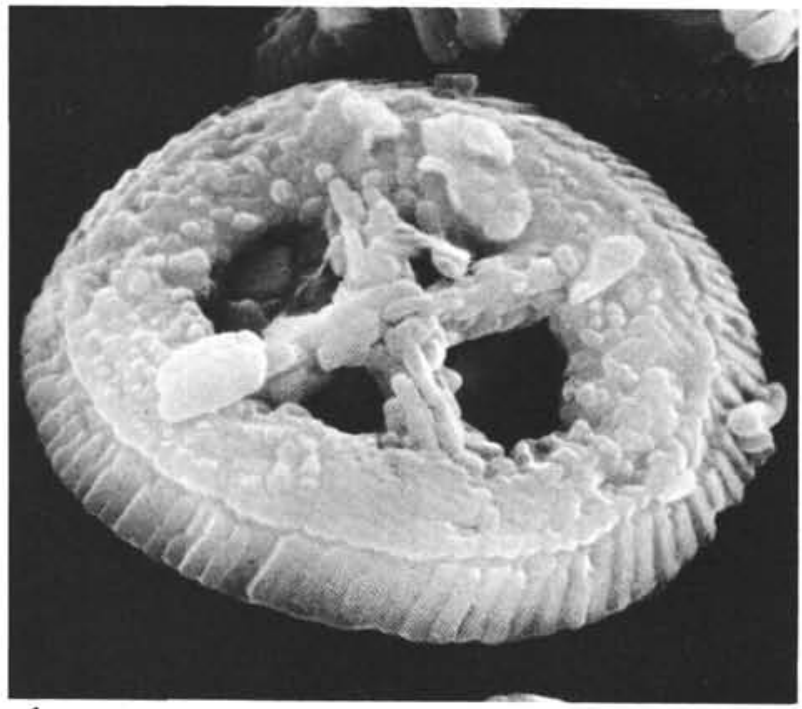

1
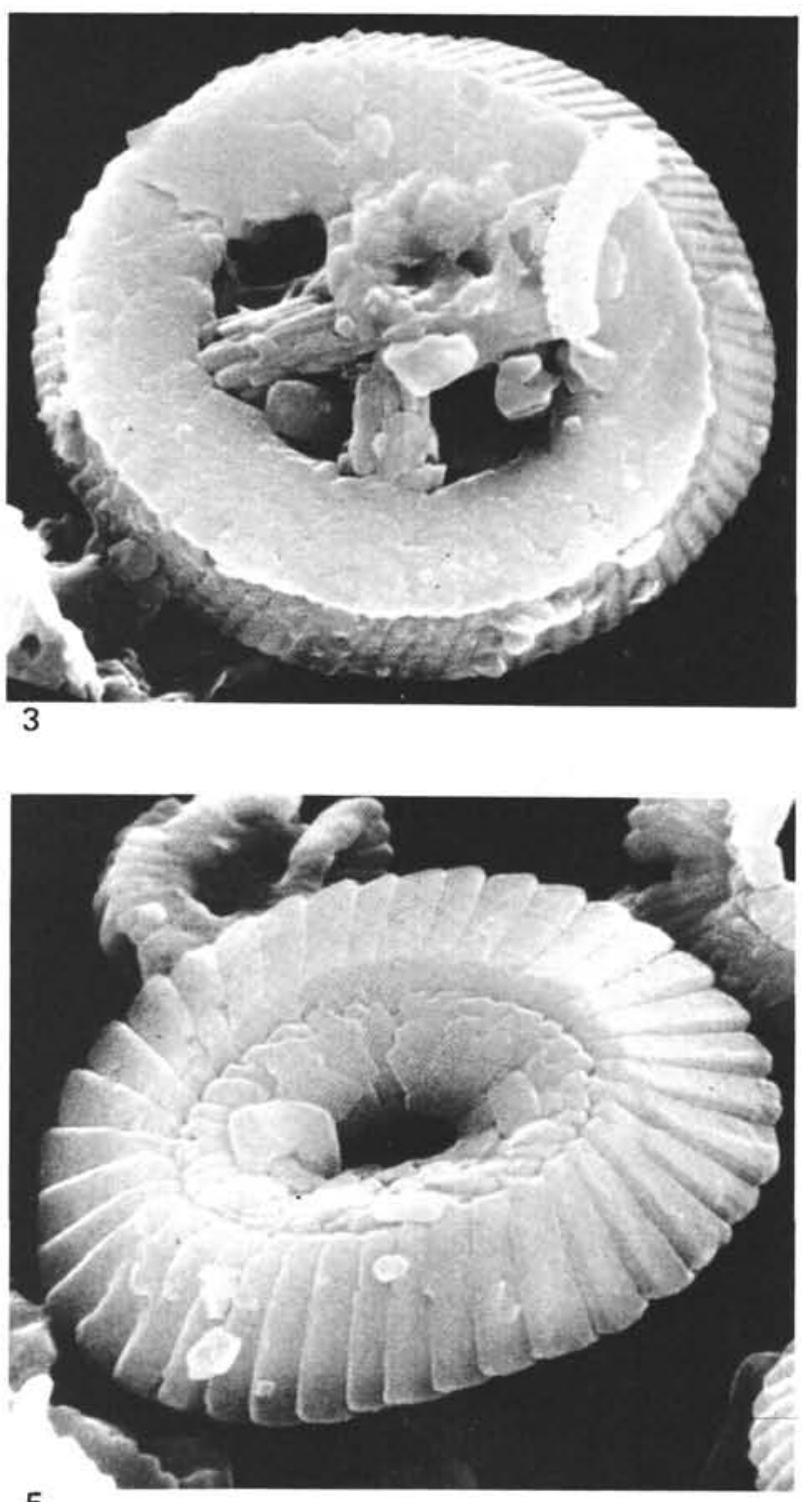

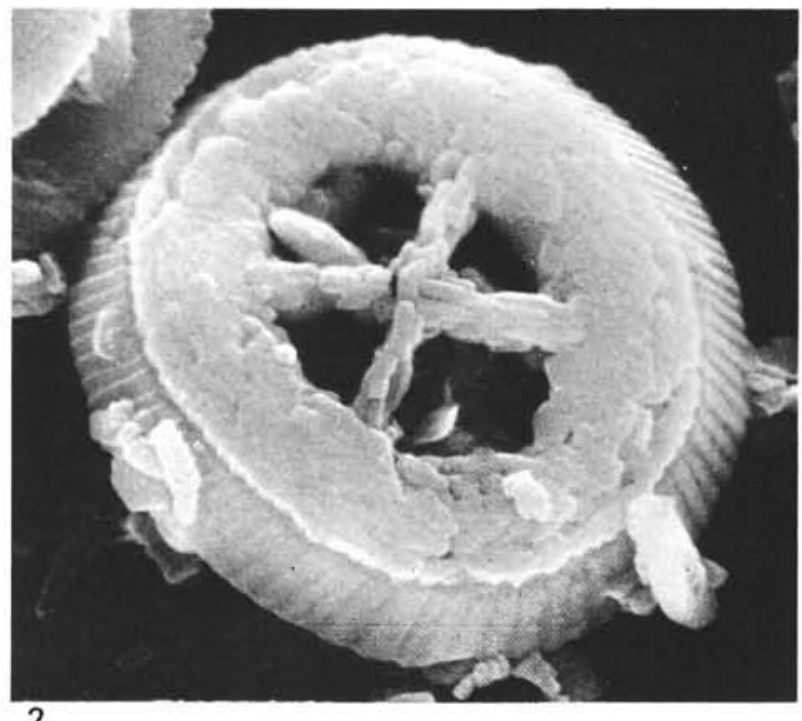

2
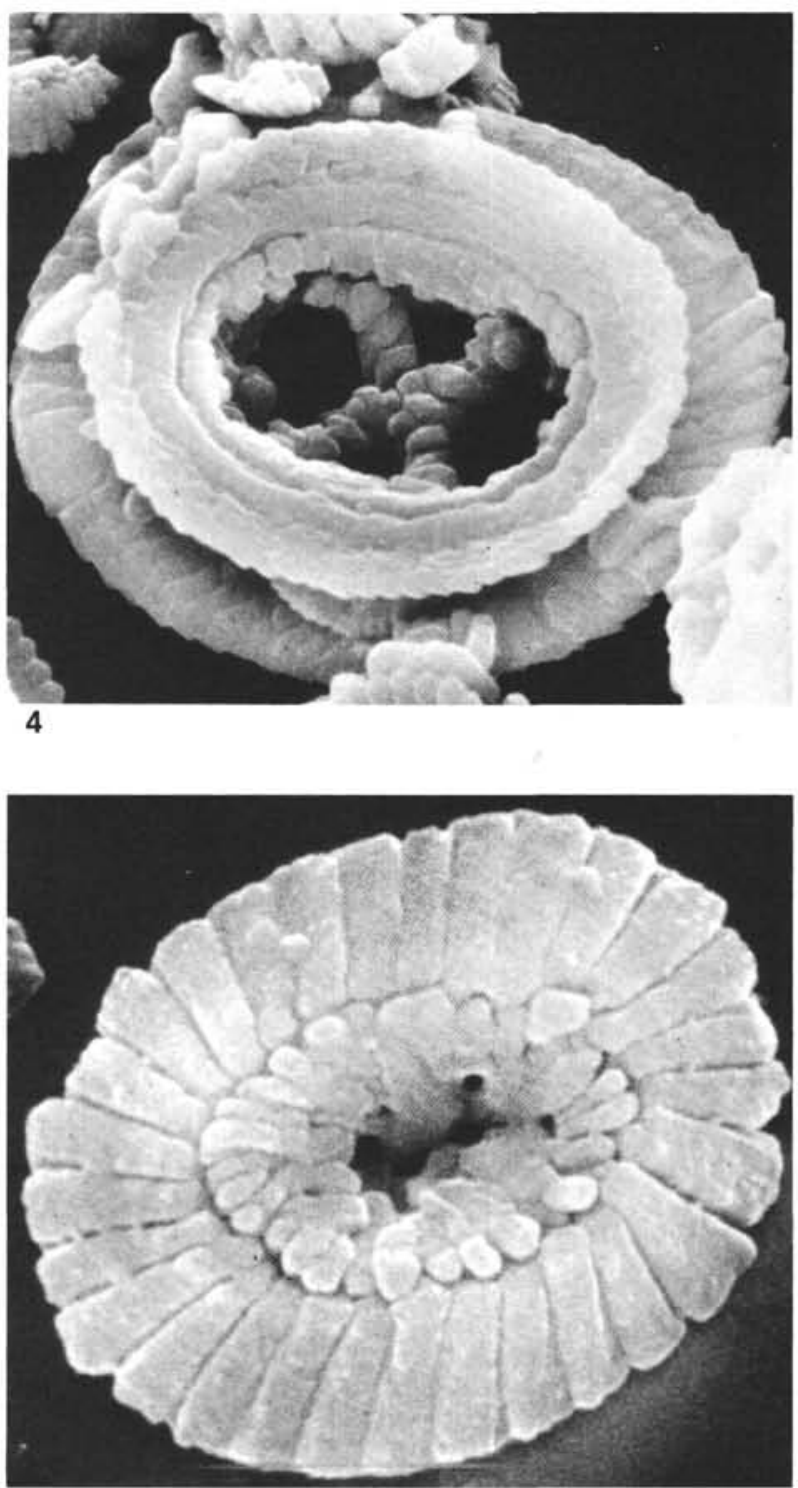

6 


\section{PLATE 4}

(Oligocene)

Figure 1

Reticulofenestra sp., distal view, Sample 329-30-1, $82 \mathrm{~cm}, \times 11,500$.

Figures 2-4 Reticulofenestra bisecta (Hay, Mohler, and Wade).

2. Distal view, Sample 329-29-1, $60 \mathrm{~cm}, \times 5500$.

3. Proximal view, Sample 329-29-1, $62 \mathrm{~cm}, \times 5000$.

4. Proximal view, Sample $329-29-1,60 \mathrm{~cm}, \times 7000$.

Figures 5,6 Cyclicargolithus floridanus (Roth and Hay).

5. Distal view, Sample 329-29-1, $60 \mathrm{~cm}, \times 9000$.

6. Distal view, Sample $329-28-1,43 \mathrm{~cm}, \times 9000$. 
PLATE 4

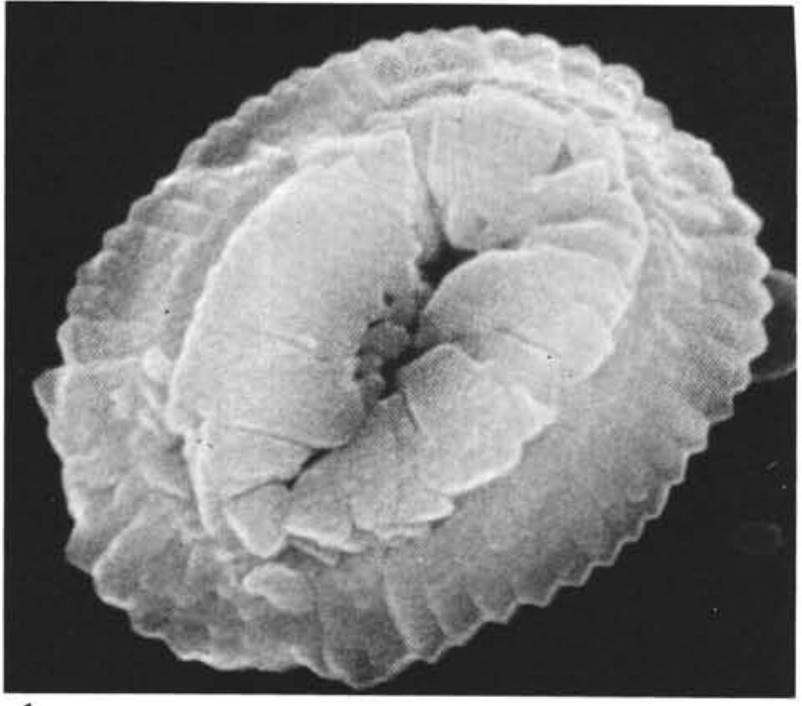

1

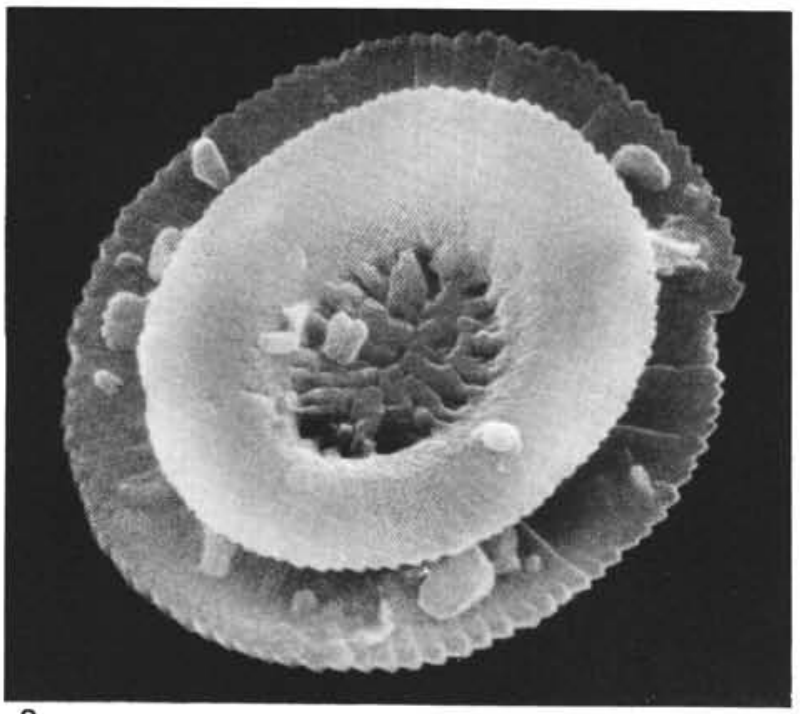

3

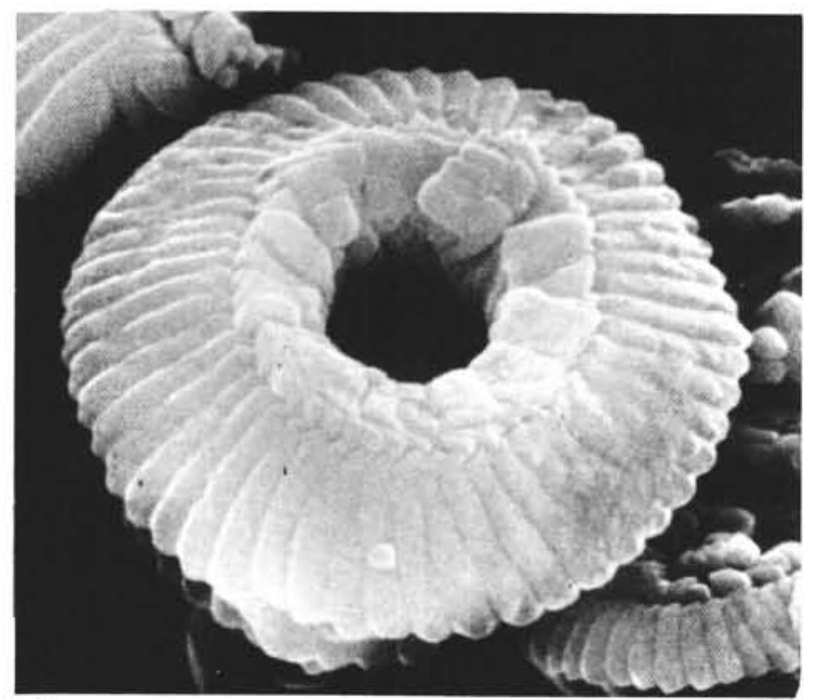

5
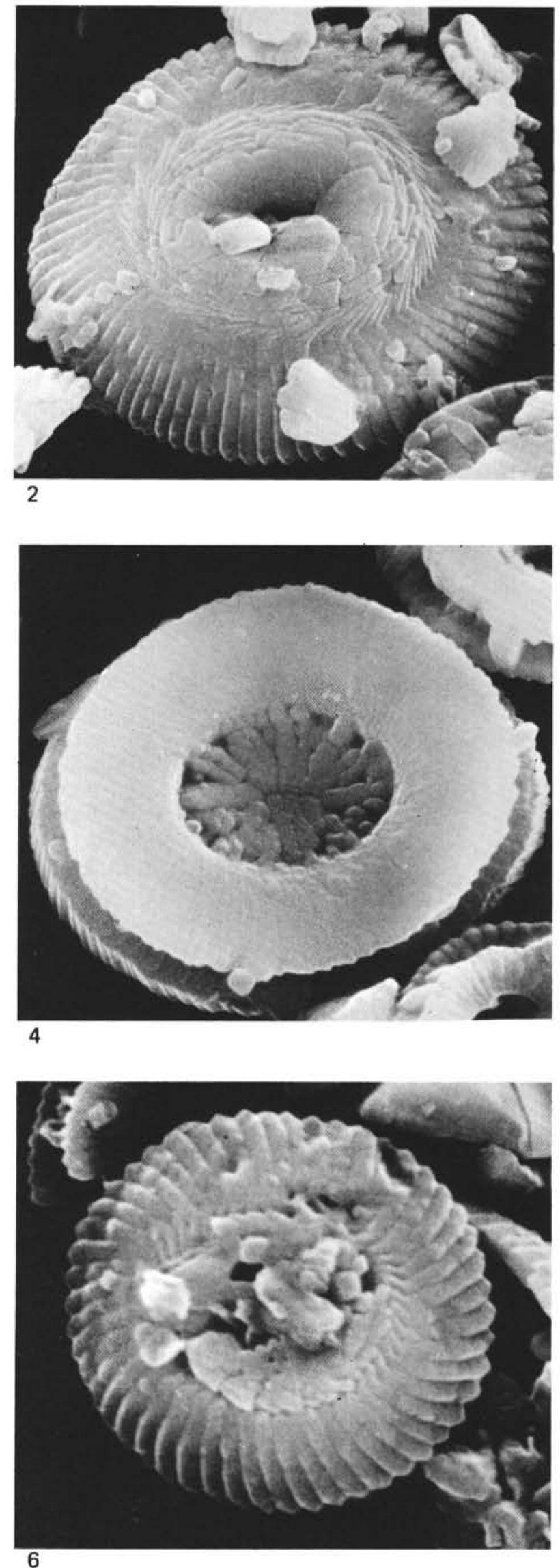


\section{PLATE 5}

\section{(Paleocene)}

Figures 1-5 Toweius eminens (Bramlette and Sullivan). Note grill in Figures 1-3.

1. Distal view, Sample 327A-5-2, $83 \mathrm{~cm}, \times 12,000$.

2. Proximal view, Sample 327 A $-5-2,83 \mathrm{~cm}$, $\times 12,000$.

3. Proximal view, Sample 327A-5-2, $83 \mathrm{~cm}$, $\times 12,000$.

4. Distal view, Sample $329-33-4,100 \mathrm{~cm}, \times 9000$.

5. Distal view, Sample RC-15-84, $350 \mathrm{~cm}, \times 7500$.

Figure 6 Toweius tovae Perch-Nielsen, distal view, Sample $327 \mathrm{~A}-5-1,133 \mathrm{~cm}, \times 13,500$. 


\section{PLATE 5}
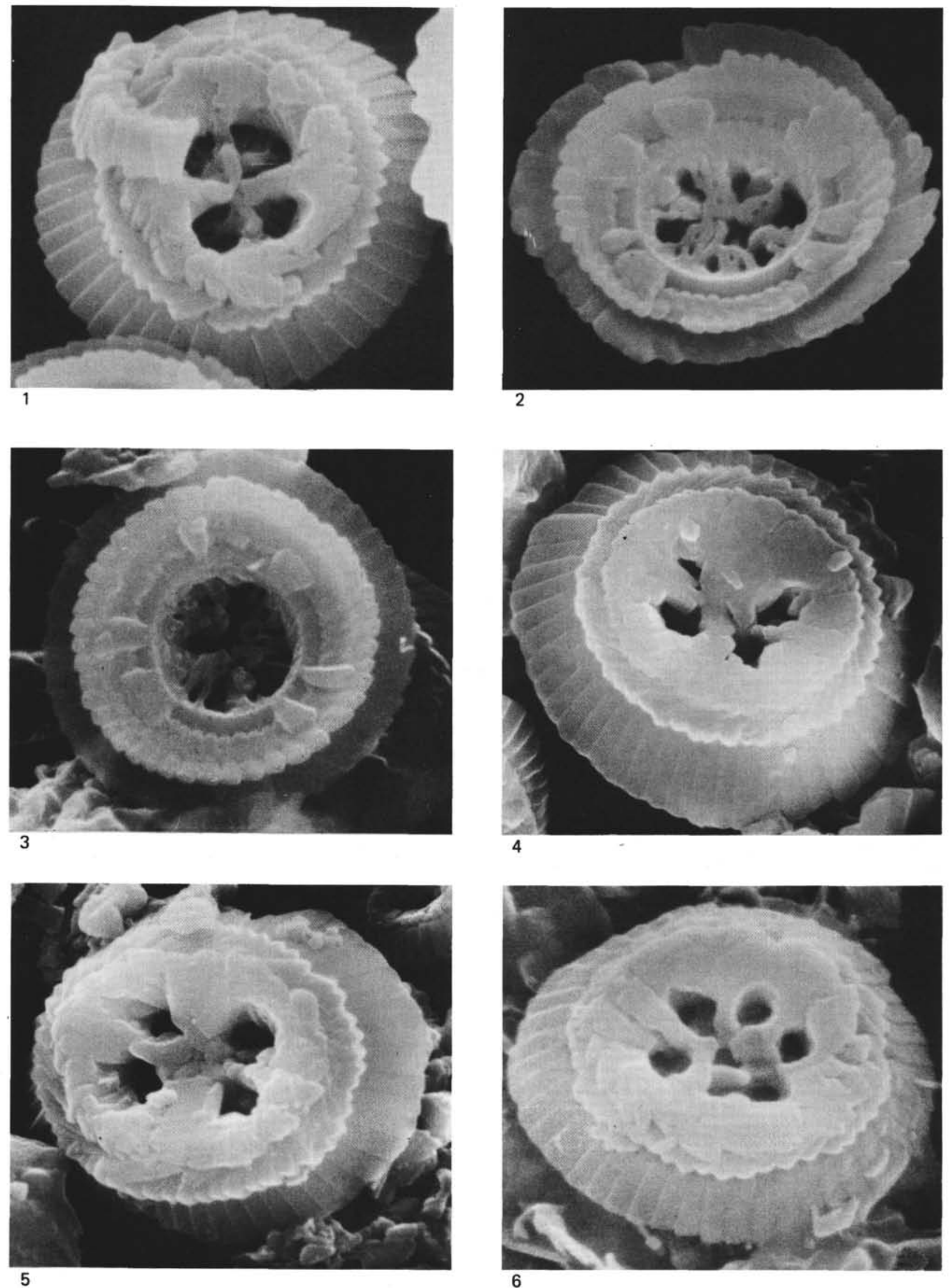


\section{PLATE 6}

(Paleocene)

Figure 1 Toweius tovae Perch-Nielsen, distal view, Sample $329-33-2,70 \mathrm{~cm}, \times 7000$.

Figure 2 Toweius craticulus Hay and Mohler, distal view, Sample 327 A-5-2, $83 \mathrm{~cm}, \times 7200$.

Figures 3-6 Prinsius bisulcus (Stradner).

3. Distal view, Sample RC-15-84, $350 \mathrm{~cm}$, $\times 14,500$.

4. Distal view, Sample RC-15-84, $350 \mathrm{~cm}, \times 7500$.

5. Distal view, Sample 327A-5-1, $133 \mathrm{~cm}$, $\times 15,500$.

6. Distal view, Sample $329-33-4,77 \mathrm{~cm}, \times 9500$. 
PLATE 6
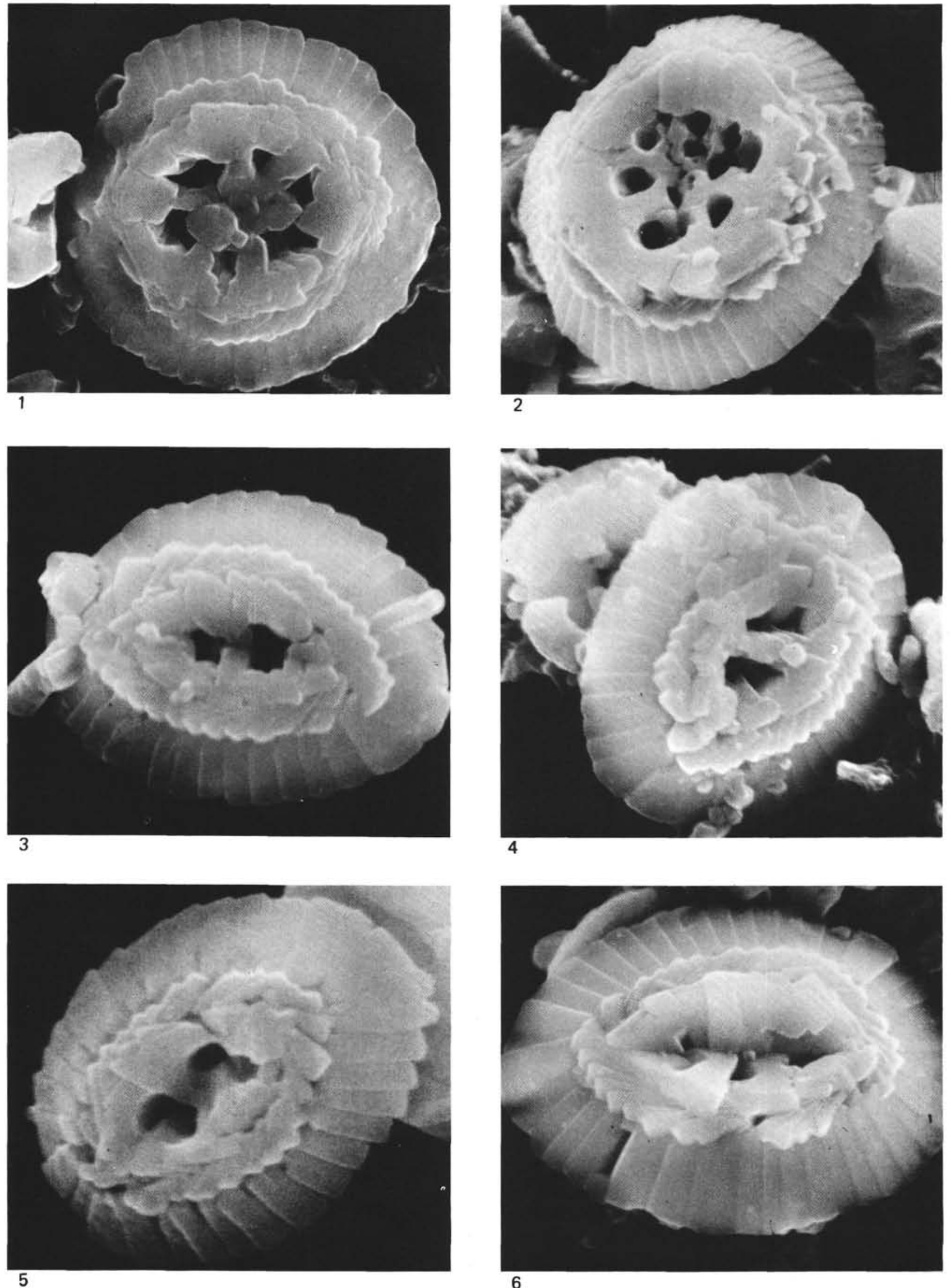


\section{PLATE 7}

(Paleocene, Eocene)

Figure 1 Toweius sp., proximal view, Paleocene Sample $327 \mathrm{~A}-5-1,3 \mathrm{~cm}, \times 14,000$.

Figures 2-6 Hornibrookina australis Edwards and PerchNielsen.

2. Distal view, Paleocene Sample 329-33-4, 134 $\mathrm{cm}, \times 12,500$.

3. Distal view, Eocene Sample 329-32-1, $86 \mathrm{~cm}$, $\times 18,000$.

4. Distal view, Paleocene Sample 329-33-4, $77 \mathrm{~cm}$, $\times 15,500$.

5. Phase contrast, Paleocene Sample 329-33-4, 134 $\mathrm{cm}, \times 3200$.

6. Same specimen as above, cross-polarized light at $45^{\circ}, \times 3200$.

Figures 7,8 Chiasmolithus grandis (Bramlette and Riedel), Eocene Sample 327A-2-1, $143 \mathrm{~cm}, \times 1800$.

7. Phase contrast.

8. Sample specimen, polarized light at $0^{\circ}$. 
PLATE 7

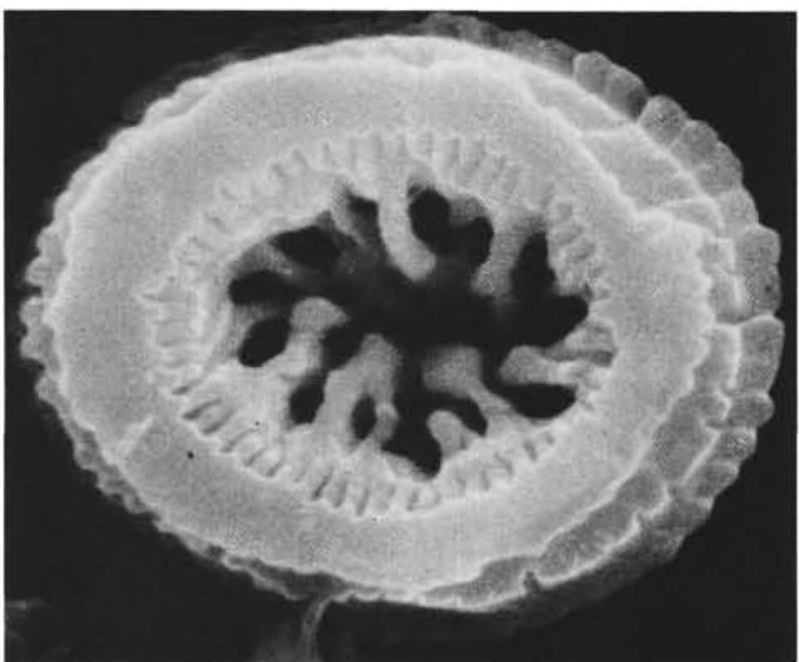

1

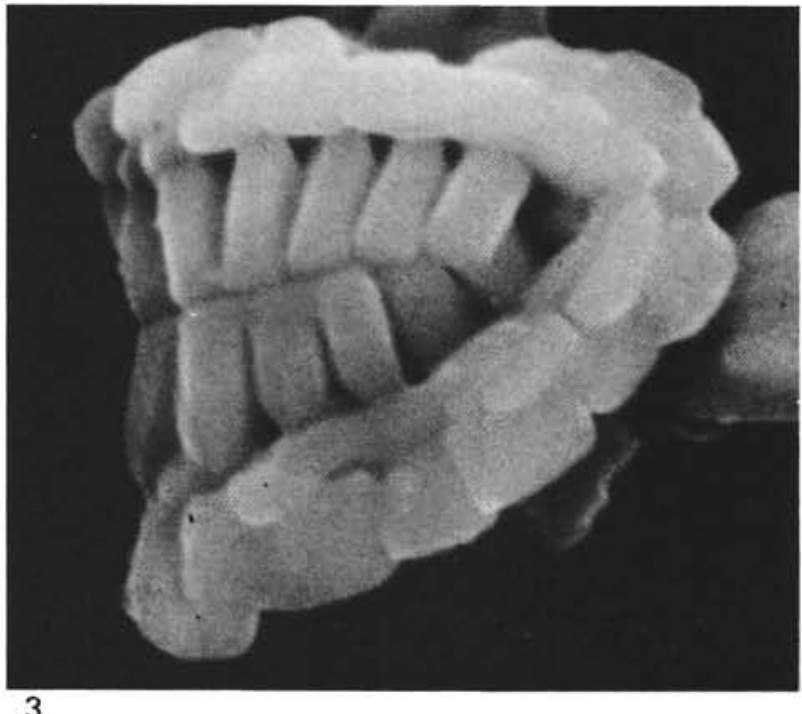

3

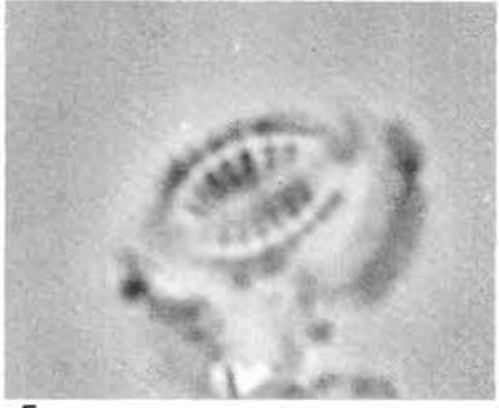

5

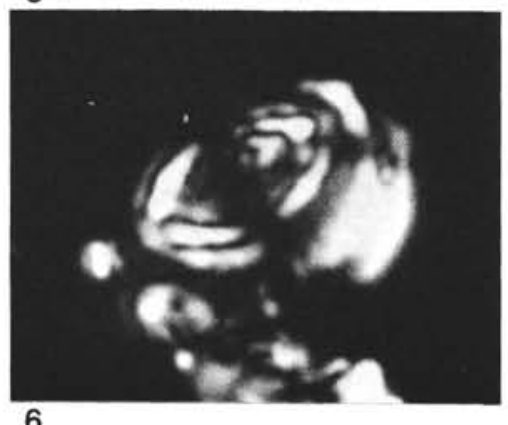

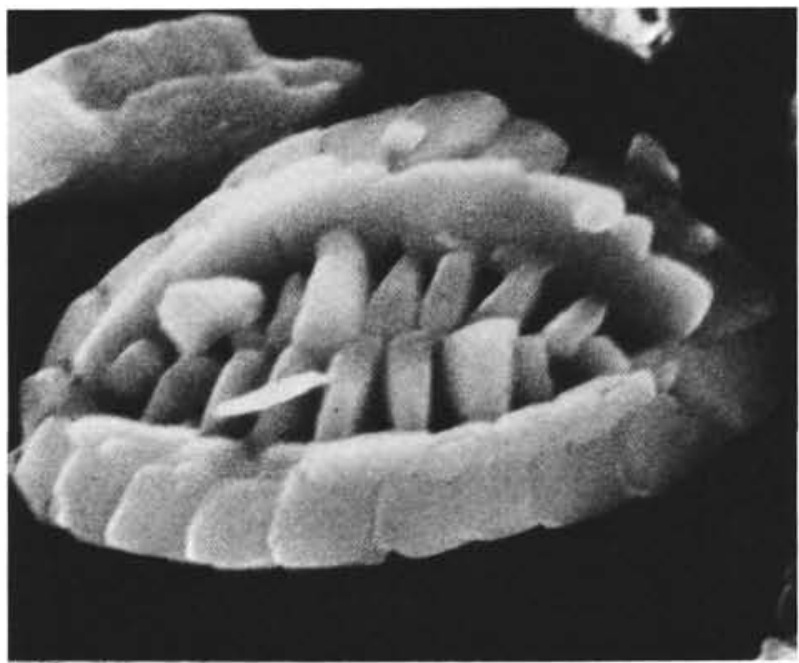

2

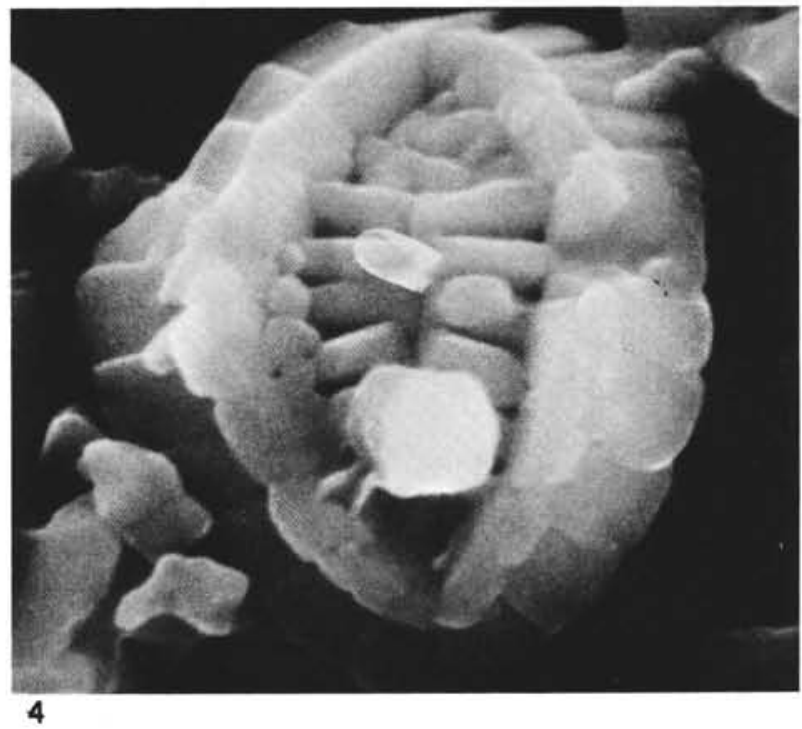

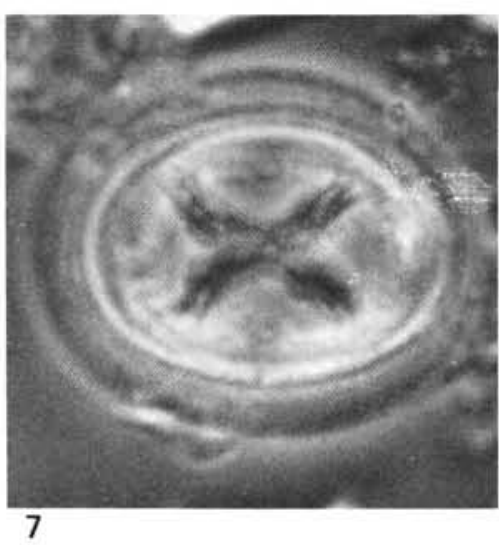

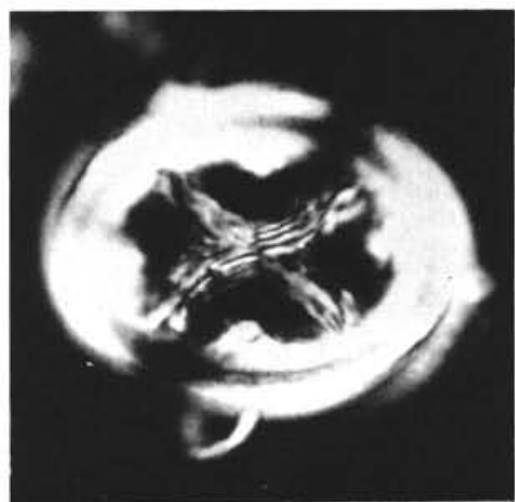

8 


\author{
PLATE 8 \\ (Paleocene, Eocene)
}

Figure 1 Chiasmolithus sp., distal view, Eocene Sample 329$32-1,142 \mathrm{~cm}, \times 8500$.

Figures 2-6 Chiasmolithus bidens (Bramlette and Sullivan). 2. Distal view, Eocene Sample 329-32-1, $142 \mathrm{~cm}$, $\times 7000$.

3. Distal view, Paleocene Sample 329-33-4, $\times 6500$.

4. Distal view, Paleocene Sample 329-32-1, 142 $\mathrm{cm}, \times 7000$.

5. Distal view, Paleocene Sample 327A-5-1, 133 $\mathrm{cm}, \times 7500$.

6. Distal view, Paleocene Sample 327A-5-2, 83 $\mathrm{cm}, \times 8000$. 
PLATE 8

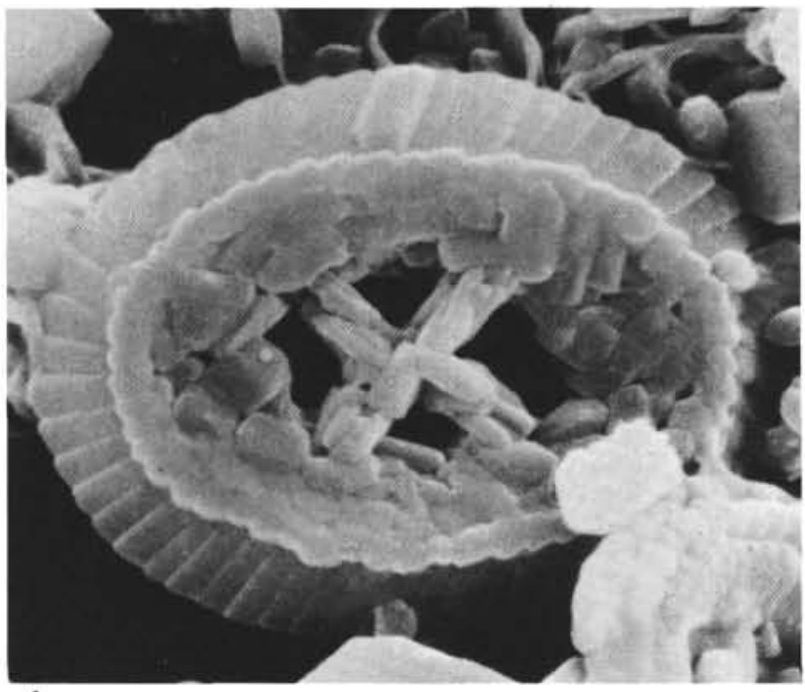

1

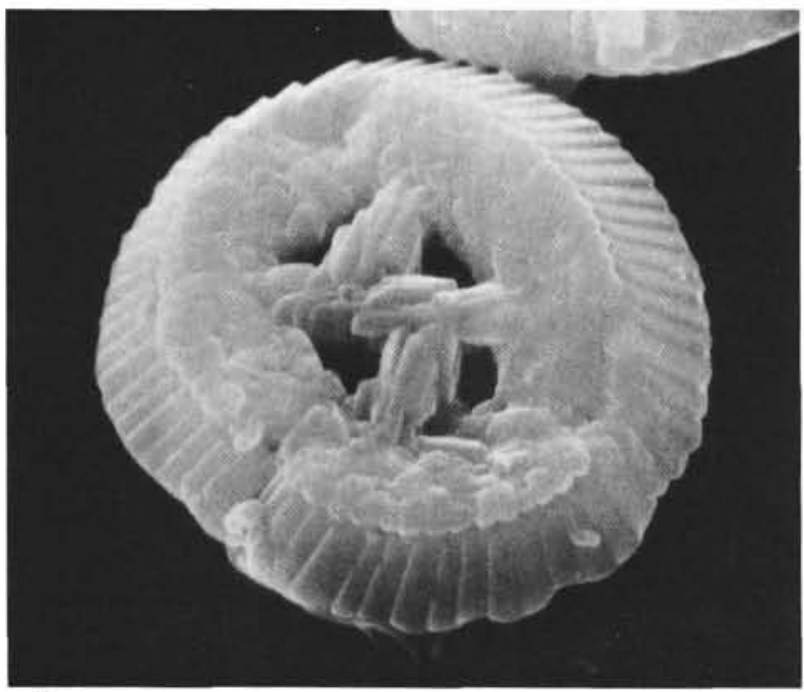

3

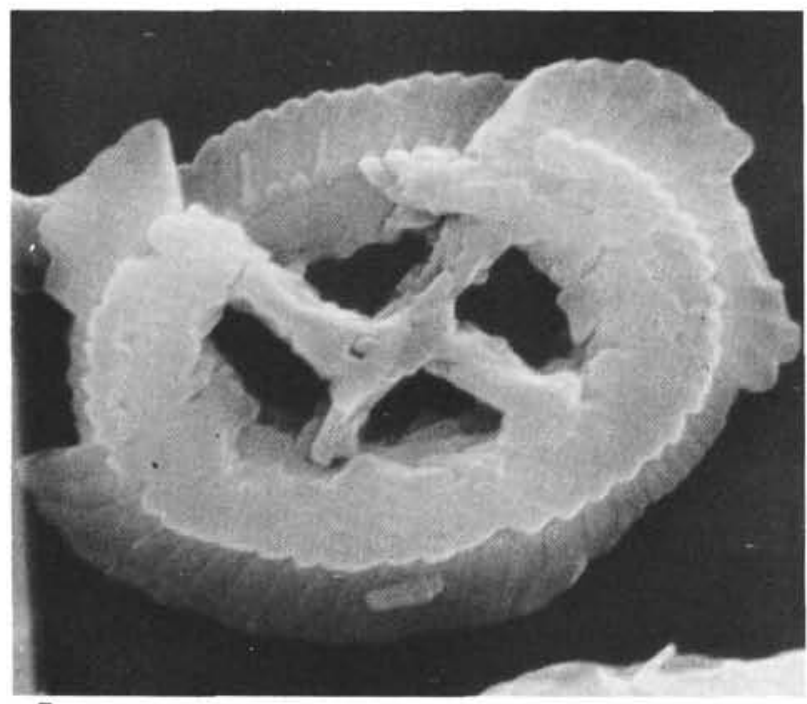

5

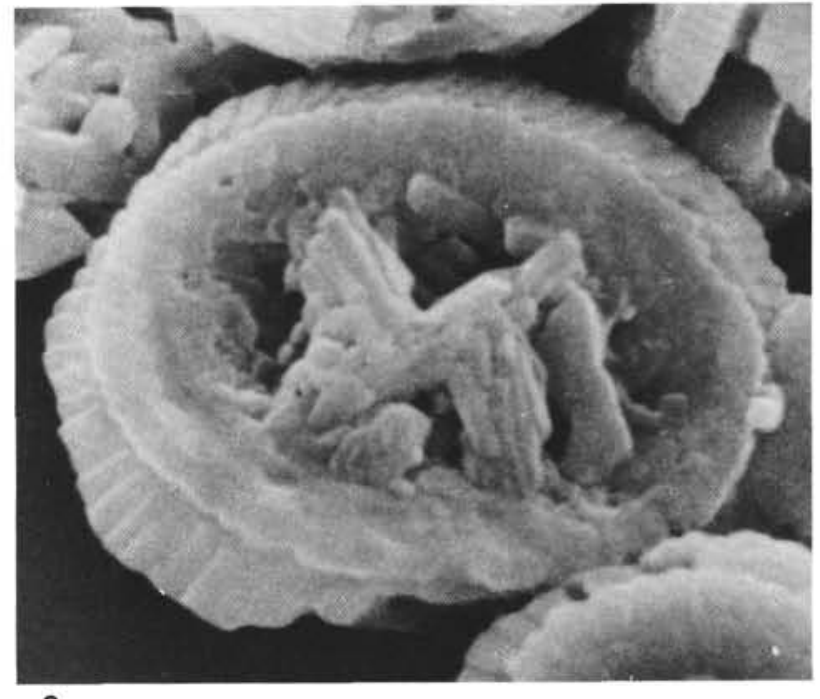

2

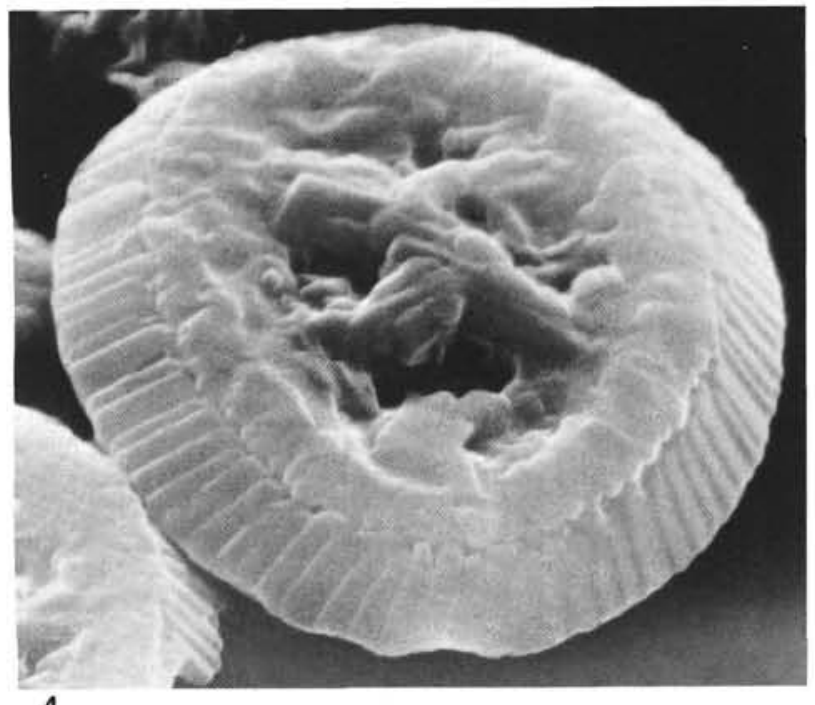

4

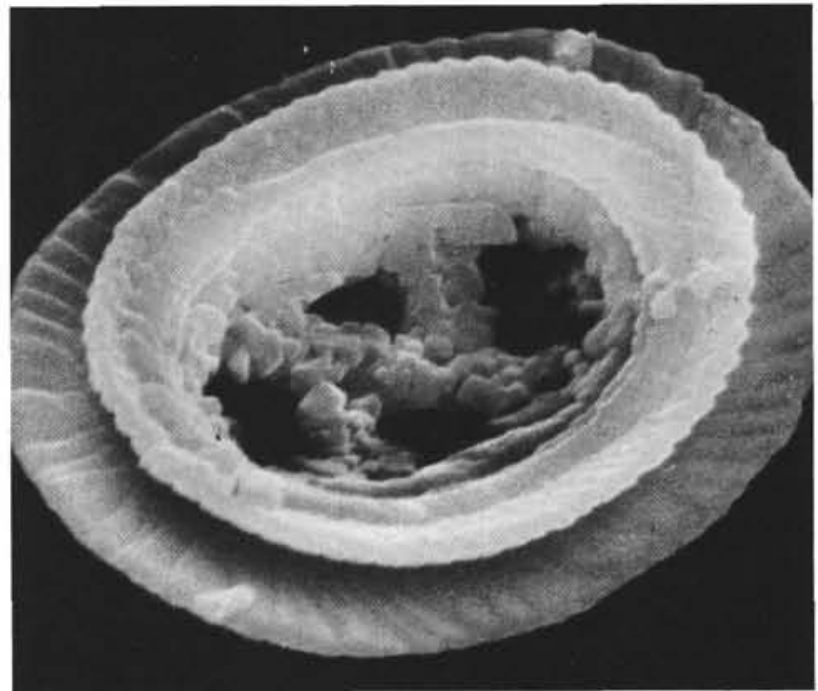

6 


\section{PLATE 9 \\ (Paleocene, Eocene)}

Figure 1 Chiasmolithus bidens (Bramlette and Sullivan), proximal view, Paleocene Sample 327A-5-1, 133 $\mathrm{cm}, \times 6000$.

Figures 2, 3 Chiasmolithus sp. cf. C. eograndis Perch-Nielsen. 2. Proximal view, Paleocene Sample 329-33-4, 134 $\mathrm{cm}, \times 5000$.

3. Proximal view, Eocene Sample 329-32-1, 143 $\mathrm{cm}, \times 5000$.

Figure $4 \quad$ Zygrhablithus bijugatus (Deflandre), specimen heavily overgrown, Eocene Sample 329-32-1, 143 $\mathrm{cm}, \times 6700$.

Figures 5, 6 Coccolithus pelagicus (Wallich).

5. Distal view, Paleocene Sample 329-33-4, $77 \mathrm{~cm}$, $\times 12,500$.

6. Proximal view, etched specimen, Paleocene Sample 327A-5-1, $3 \mathrm{~cm}, \times 13,000$. 


\section{PLATE 9}
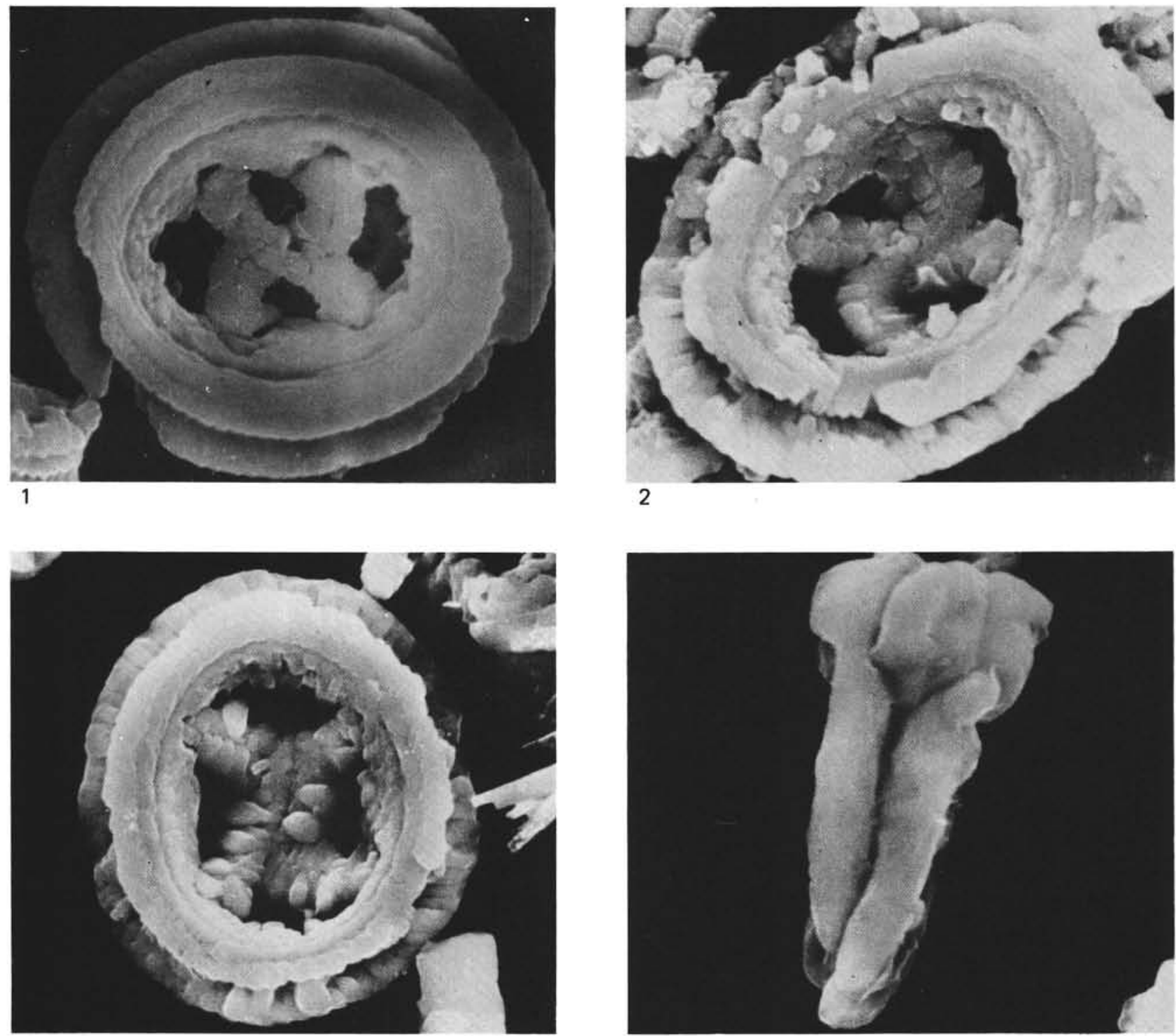

3
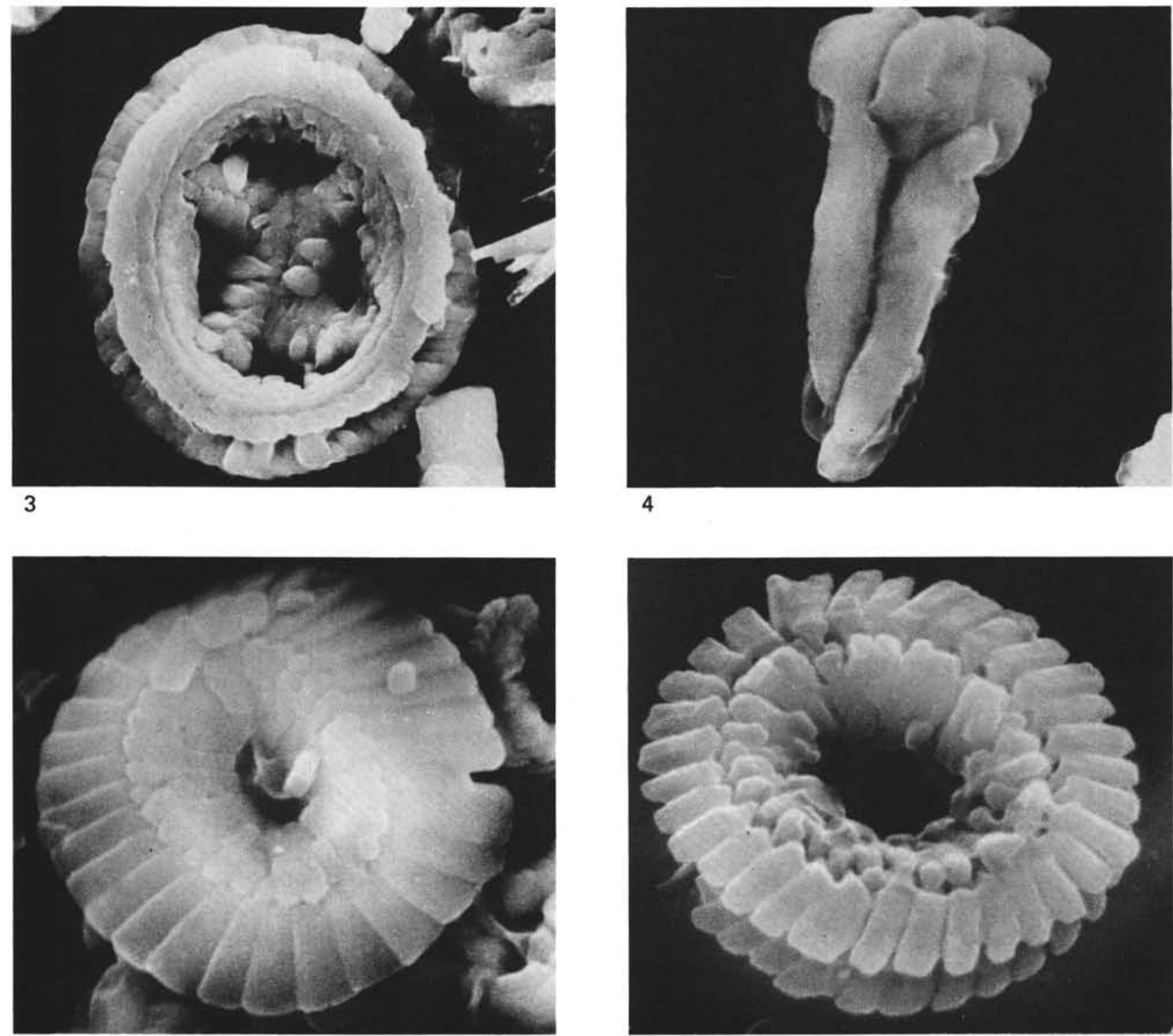

4

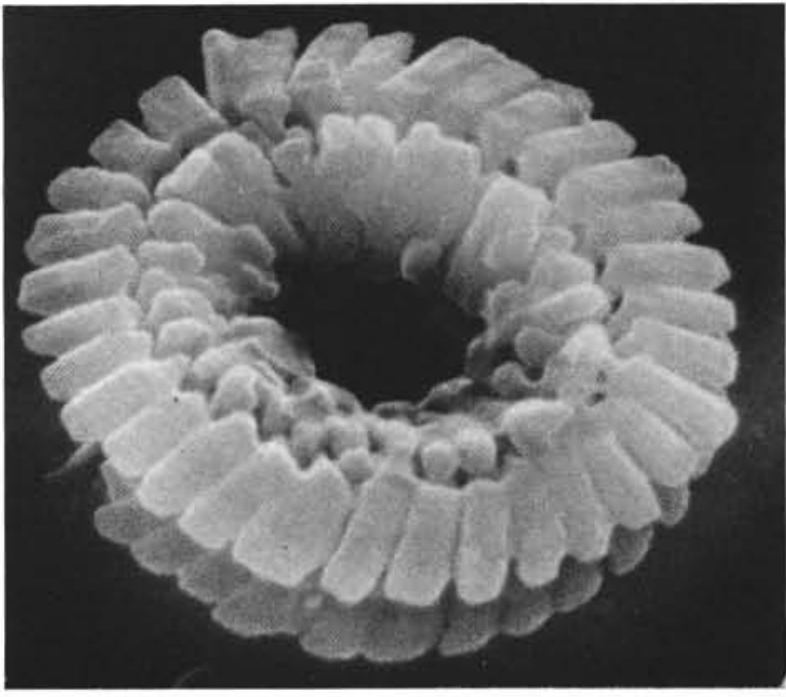


PLATE 10

(Paleocene, Eocene)

Figure $1 \quad$ Neochiastozygus modestus Perch-Nielsen. Distal view, Paleocene Sample RC-15-84, $350 \mathrm{~cm}$, $\times 11,000$.

Figures 2, $3 \quad$ Neochiastozygus junctus (Bramlette and Sullivan). 2. Proximal view, Paleocene Sample 329-33-4, 77 $\mathrm{cm}, \times 9000$.

3. Distal view, Paleocene Sample 327A-5-2, 83 $\mathrm{cm}, \times 9000$.

Figures 4, $6 \quad$ Neococcolithus dubius (Deflandre).

4. Distal view, Paleocene Sample 329-33-2, $70 \mathrm{~cm}$, $\times 12,000$.

6. Distal view, Eocene Sample 329-32-1, $86 \mathrm{~cm}$, $\times 14,000$.

Figure $5 \quad$ Neococcolithus protenus (Bramlette and Sullivan), distal view, Eocene Sample 329-32-1, $142 \mathrm{~cm}$, $\times 11,000$. 
PLATE 10
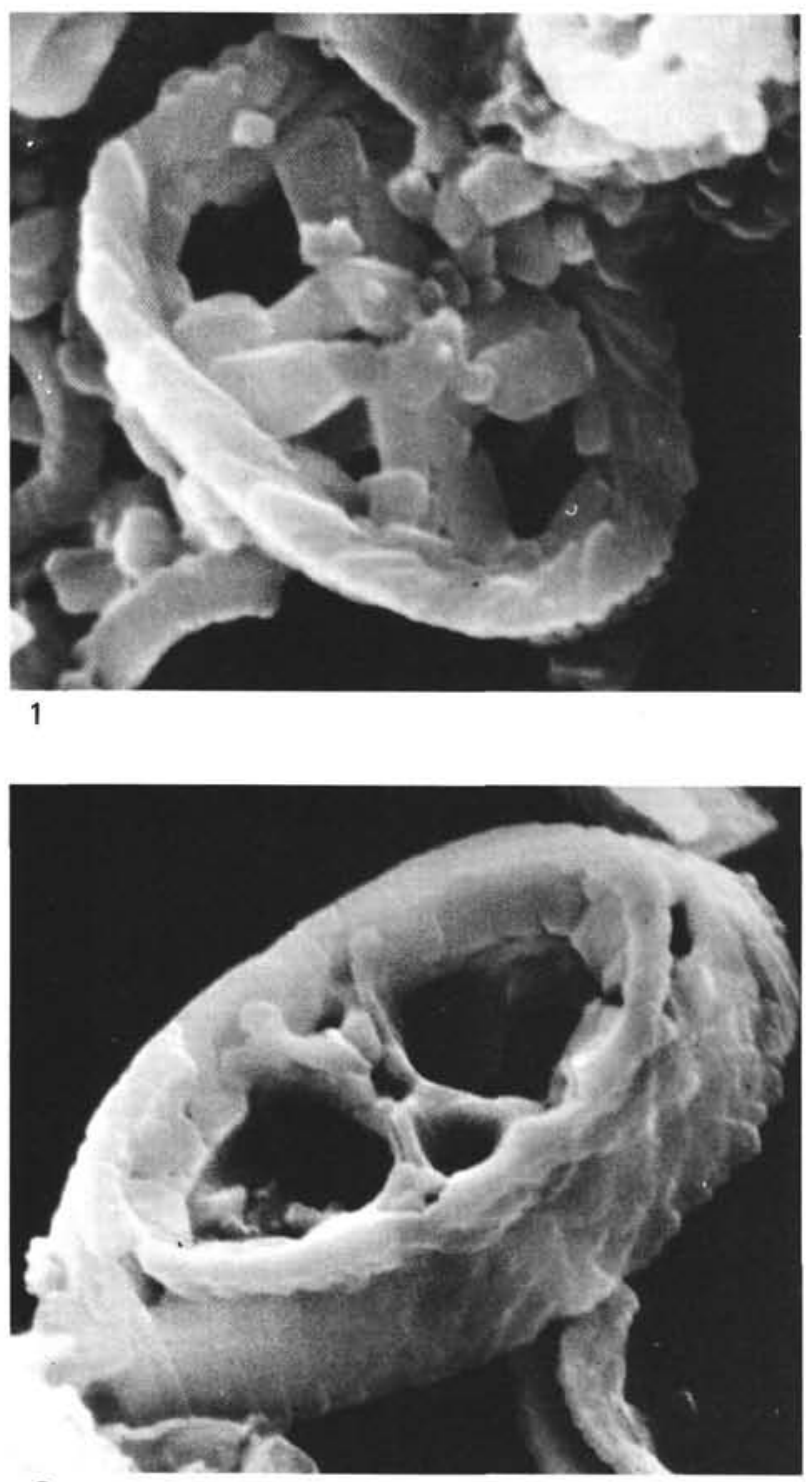

3

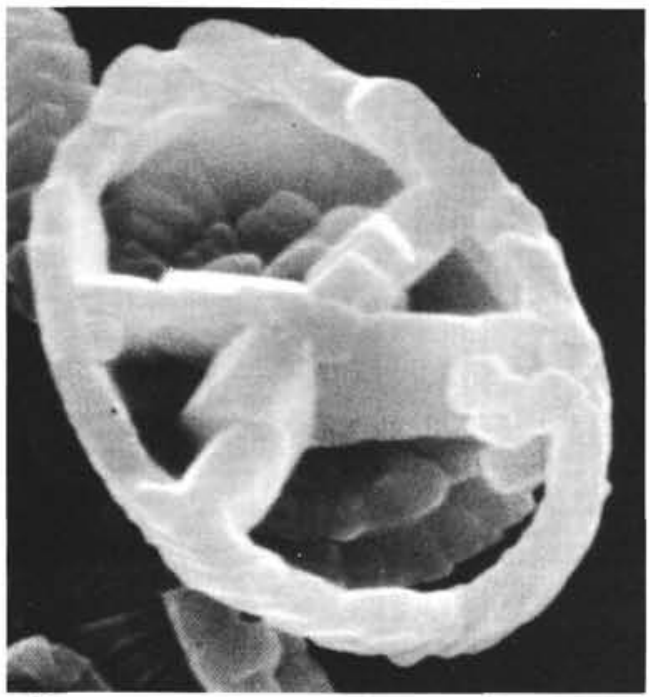

5

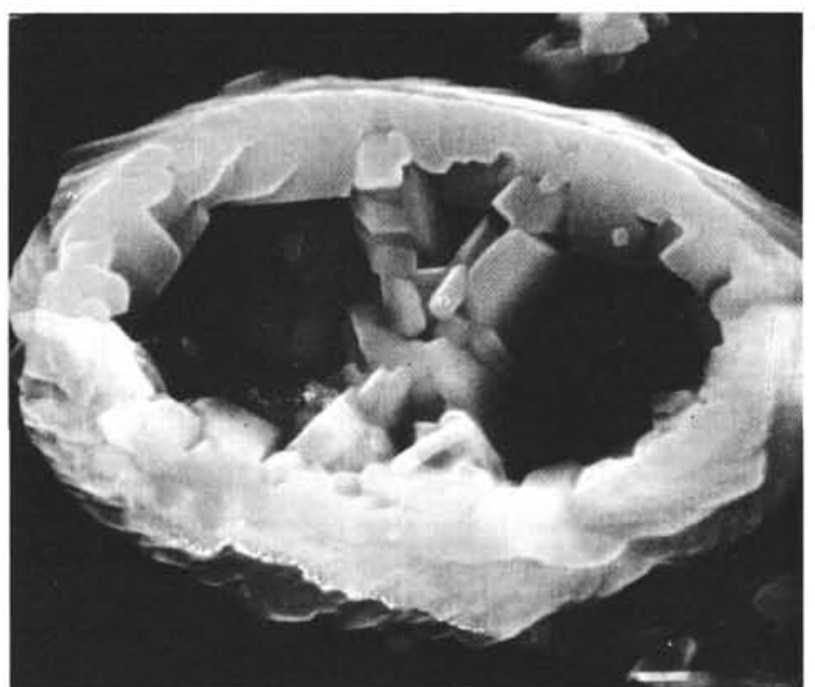

2

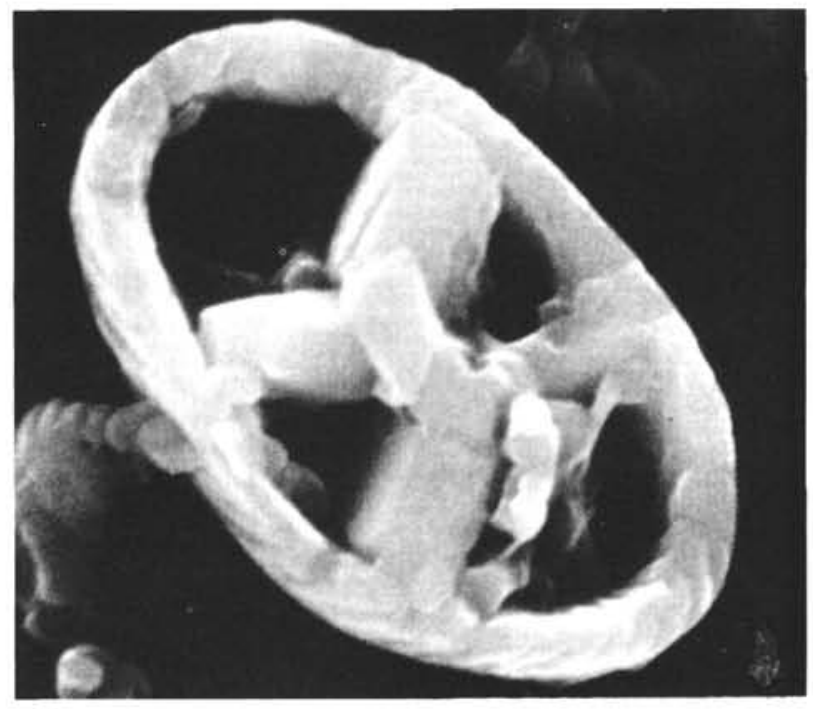

4

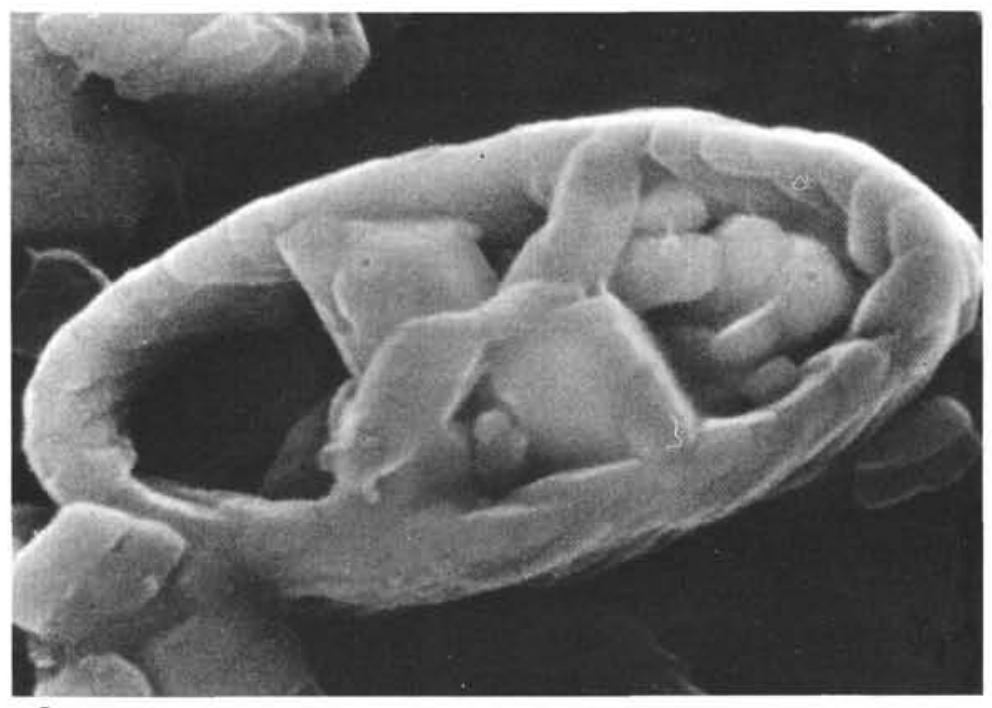


PLATE 11

(Paleocene)

Figures 1,2 Heliolithus riedeli Bramlette and Sullivan, topotype Sample LODO $6+1$.

1. Distal view, $\times 8000$.

2. Side view, $\times 10,500$.

Figures 3-5 Heliolithus kleinpelli Sullivan, oblique distal views, Pont Labau Sample 815 (reference: Hay and Mohler, 1967).

3. $\times 6500$.

4. $\times 6000$.

5. $\times 7000$. 


\section{PLATE 11}

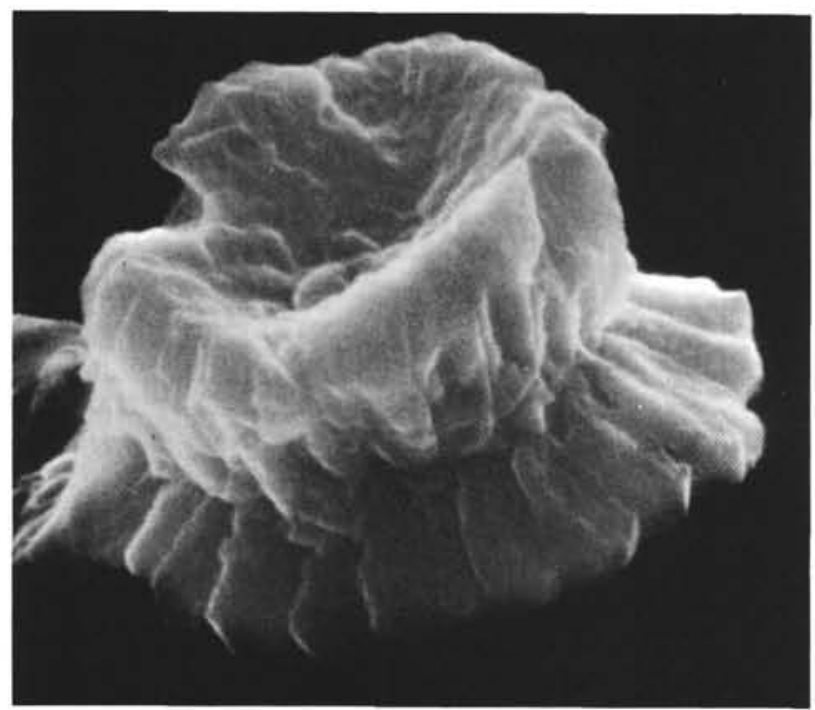

1

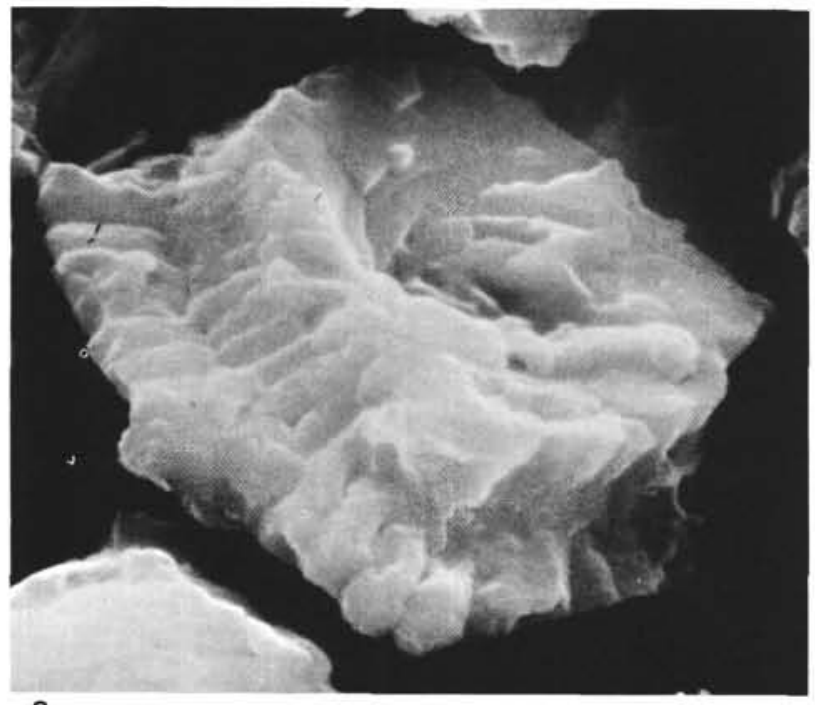

3
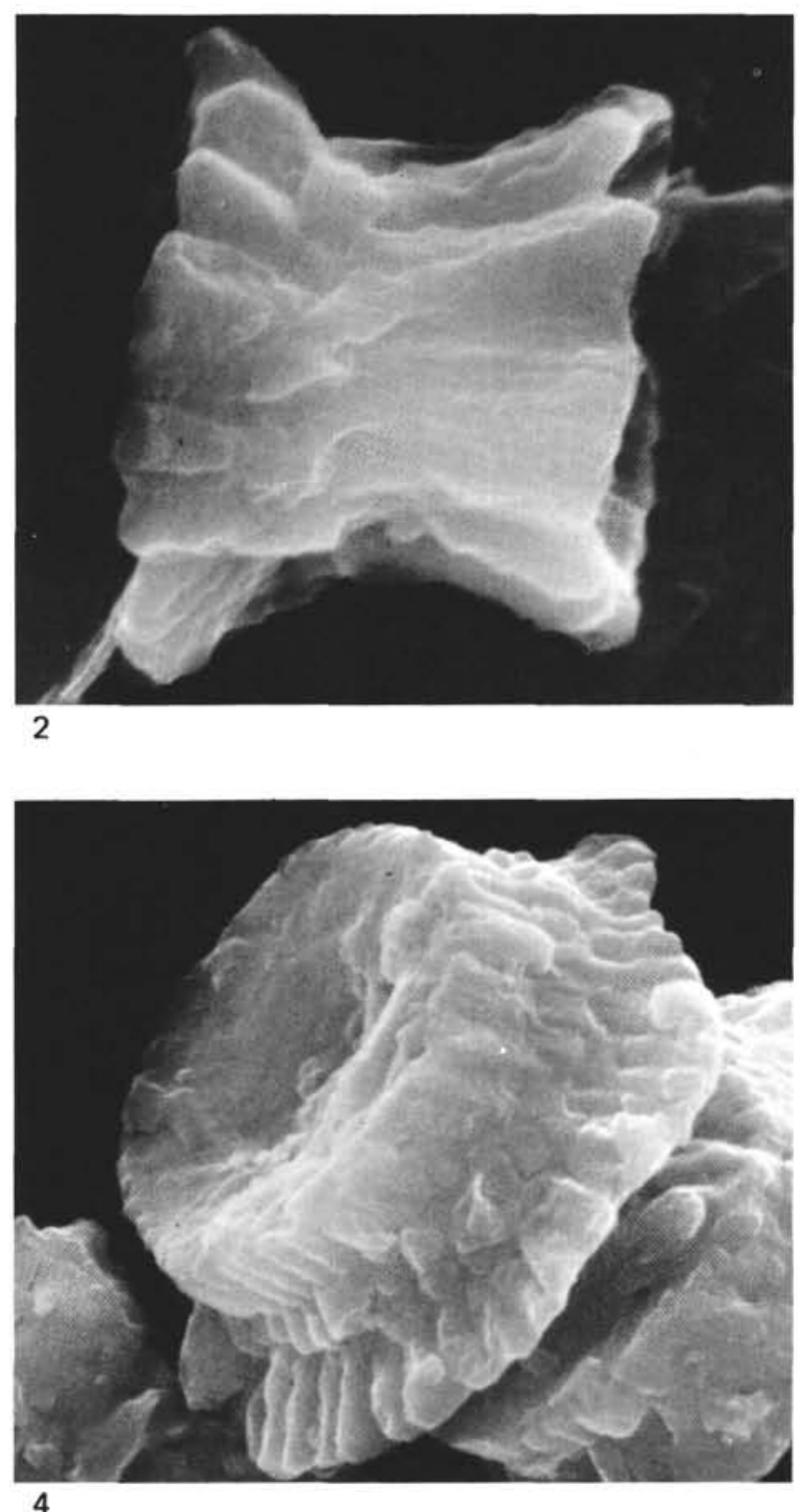

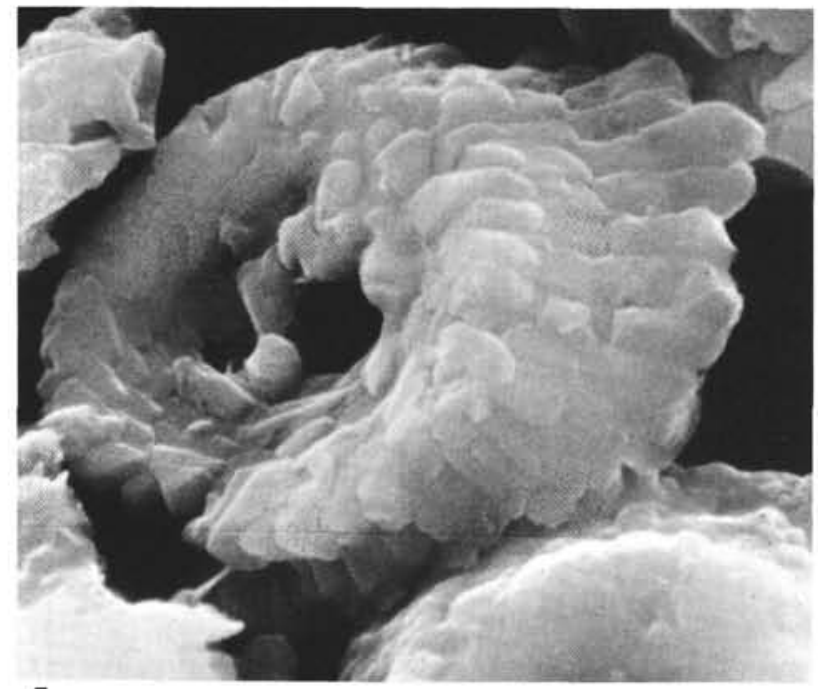


PLATE 12

(Paleocene)

Figures 1-6 Heliolithus universus Wind and Wise, n. sp. 1-3. Paratype USNM 385452, three views of specimen which is transitional to $H$. riedeli Bramlette and Sullivan. Sample 327A-5-1, $133 \mathrm{~cm}$, $\times 10,500$.

4. 5. Holotype USNM 385453, proximal and oblique proximal views of specimen, Sample $327 \mathrm{~A}-5-1,48 \mathrm{~cm}, \times 7000$.

6. Paratype USNM 385454, Sample 327A-5-1, 48 $\mathrm{cm}, \times 6500$. 
PLATE 12

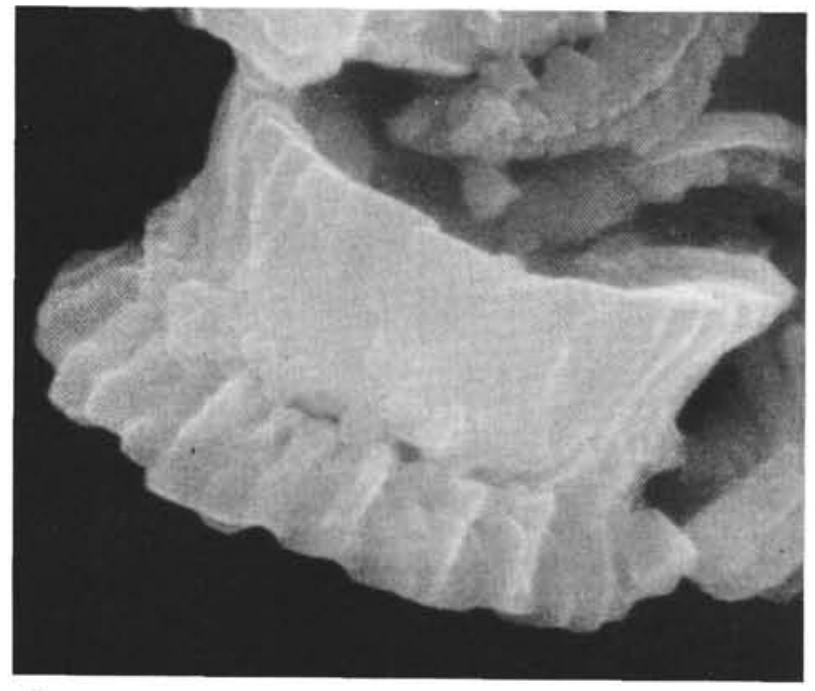

1

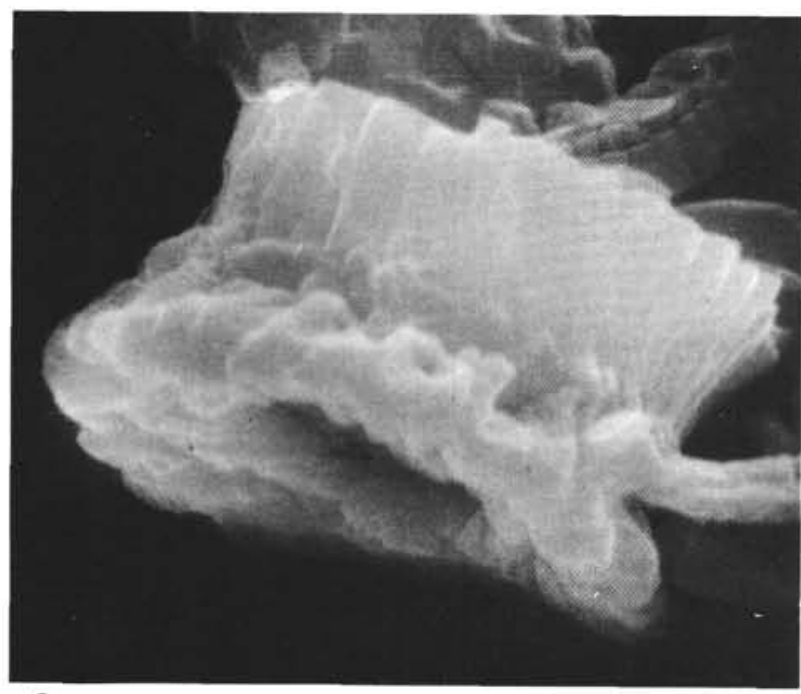

2

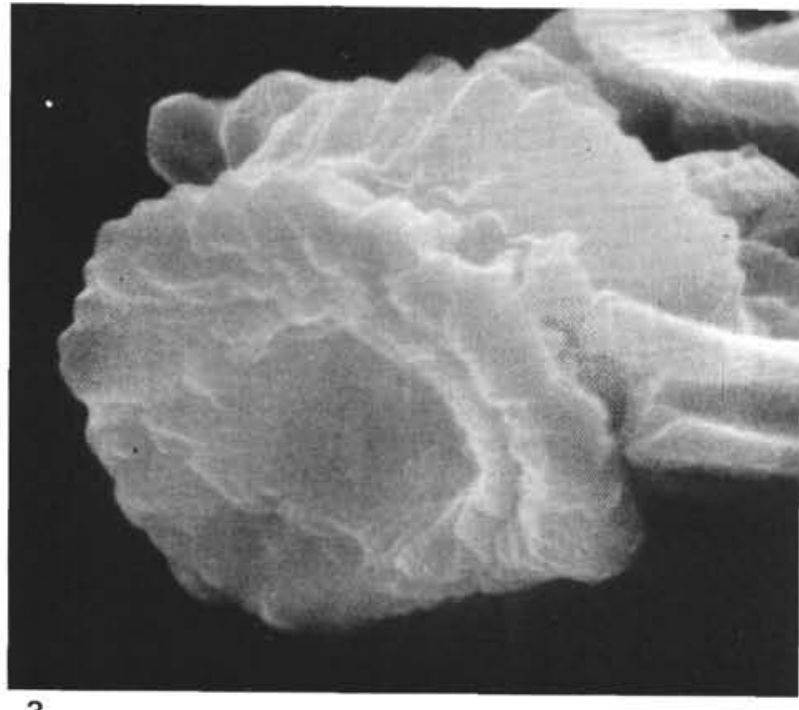

3

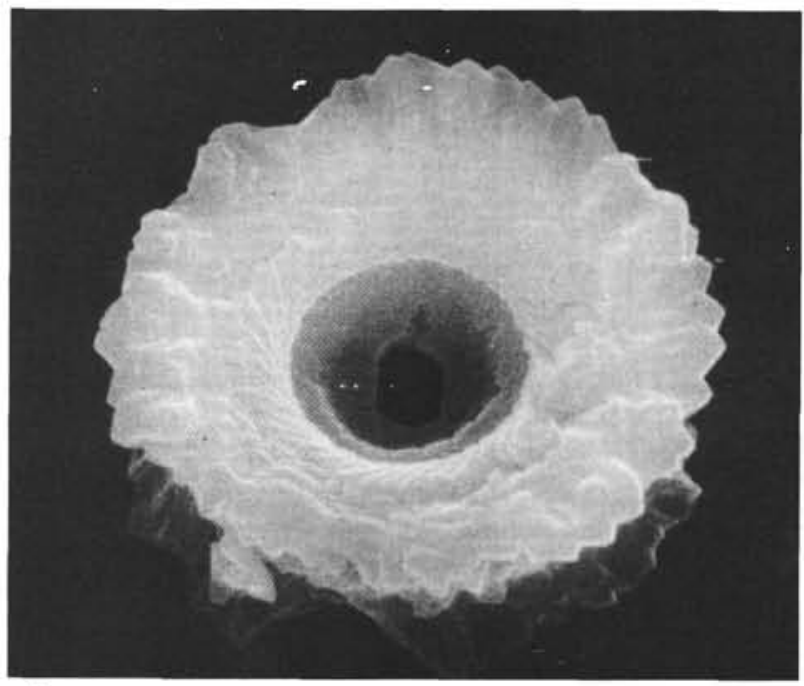

4
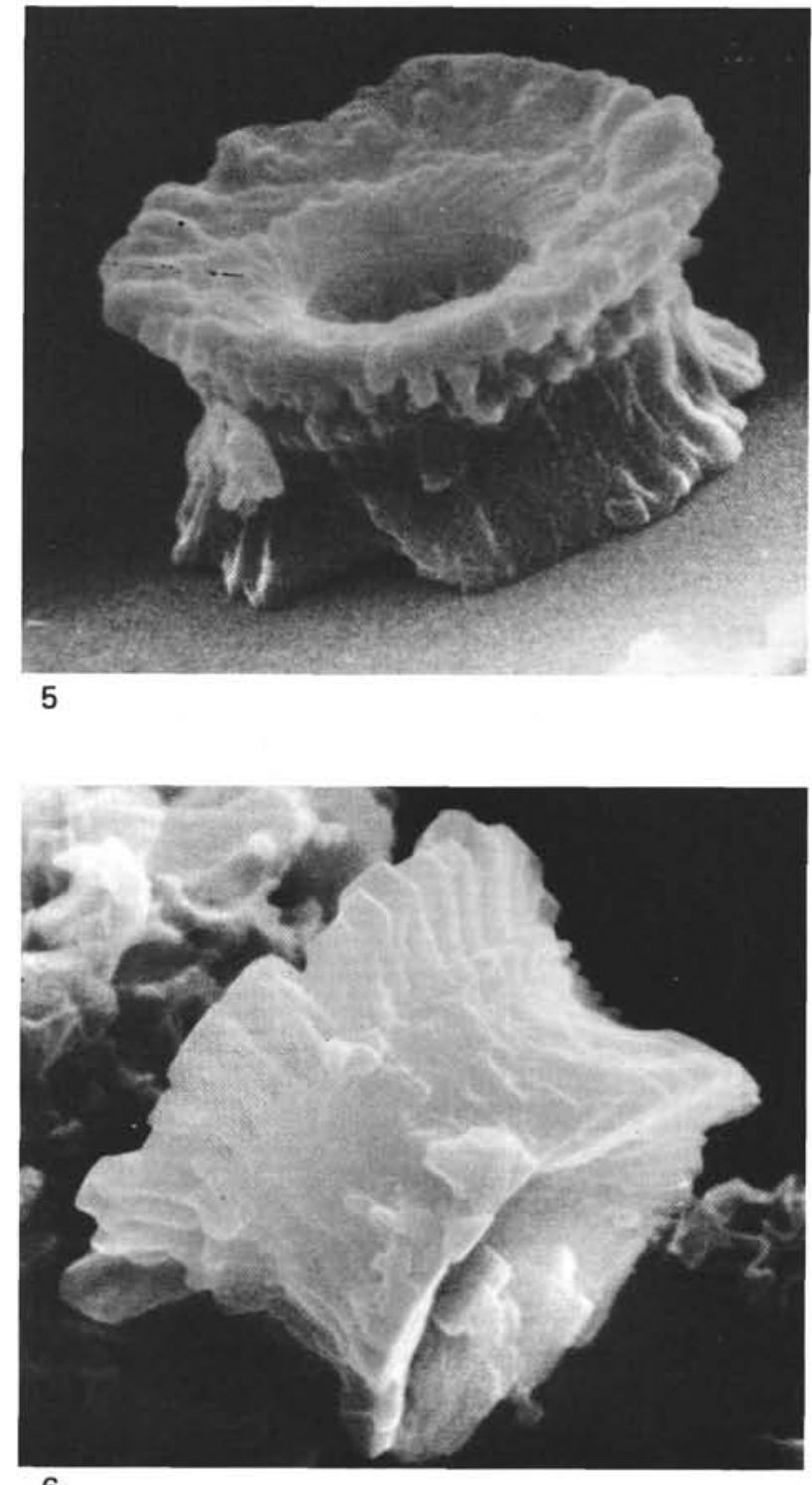

6 


\section{PLATE 13 \\ (Paleocene)}

Figures 1, 2 Heliolithus universus Wind and Wise, n. sp.

1. Paratype USNM 385455, Sample 327A-5-1. 48 $\mathrm{cm} . \times 9000$.

2. Paratype USNM 385456, Sample 327A-5-1, 83 $\mathrm{cm}, \times 8000$.

Figures 3,4 Heliolithus sp. A, Sample 327A-5-1, $3 \mathrm{~cm}$.

3. $\times 8000$.

4. Same specimen, $\times 5500$.

Figures 5, 6 Heliolithus sp., Sample 327A-5-1, $133 \mathrm{~cm}$, $\times 11,000$.

5. $\times 11,000$.

6. Same specimen, $\times 11,000$. 
PLATE 13

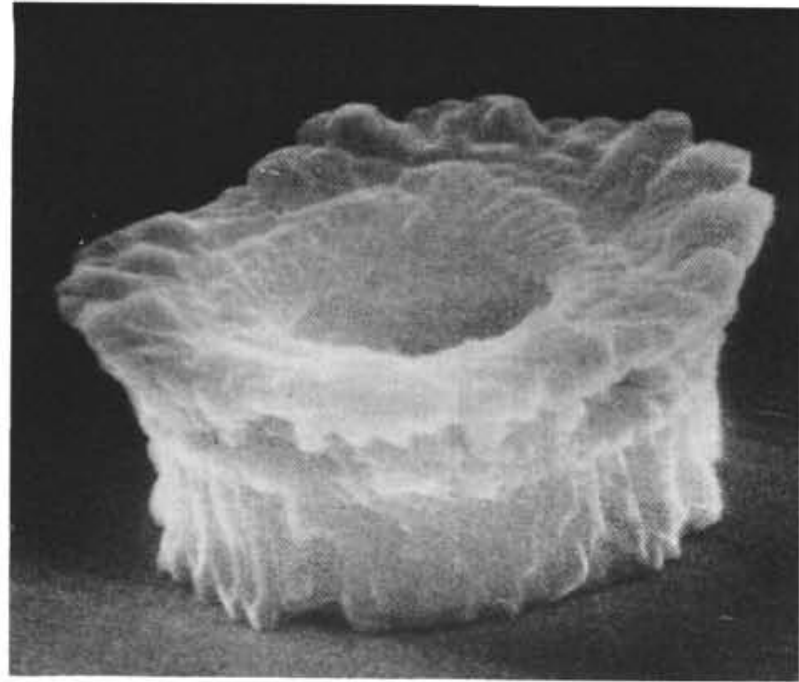

1

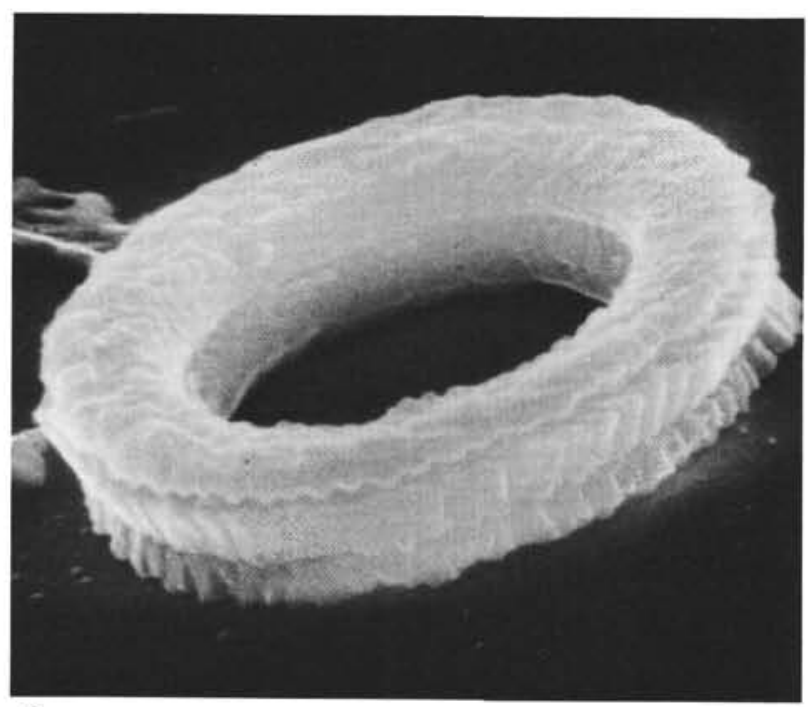

3

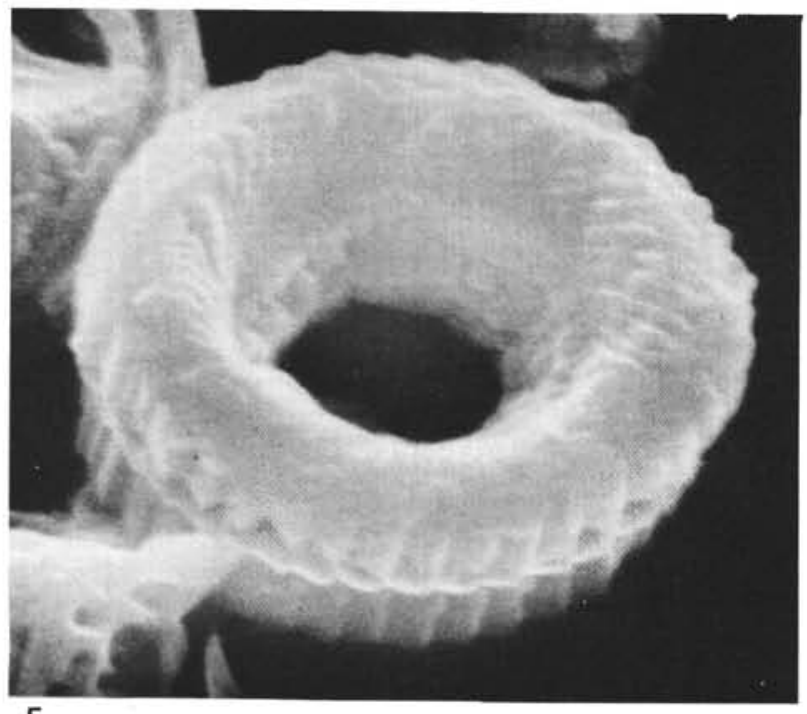

5

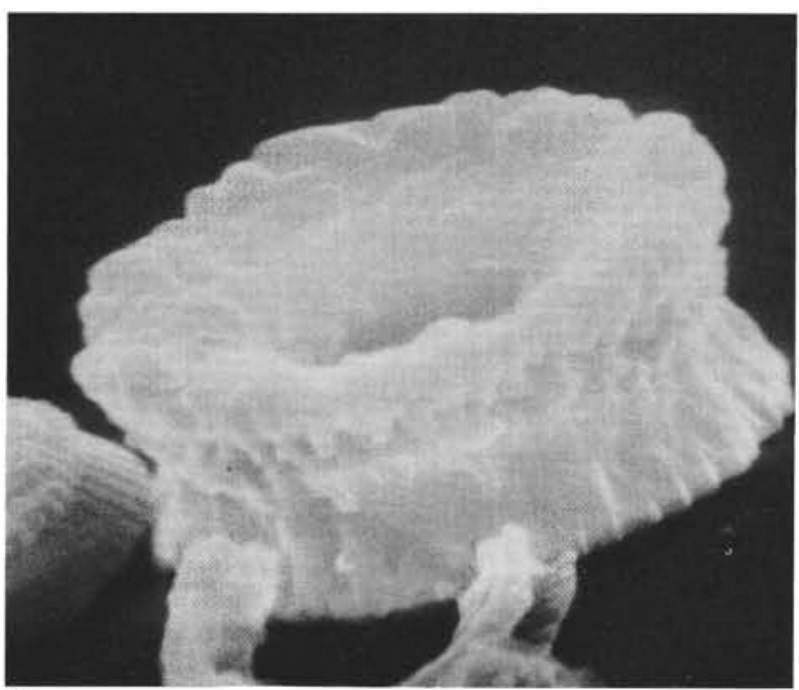

2

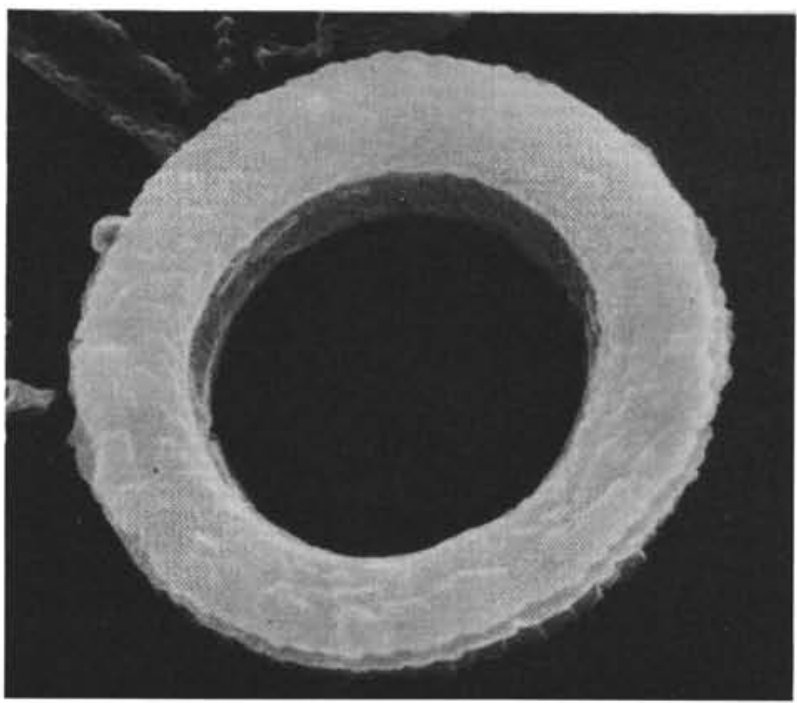

4

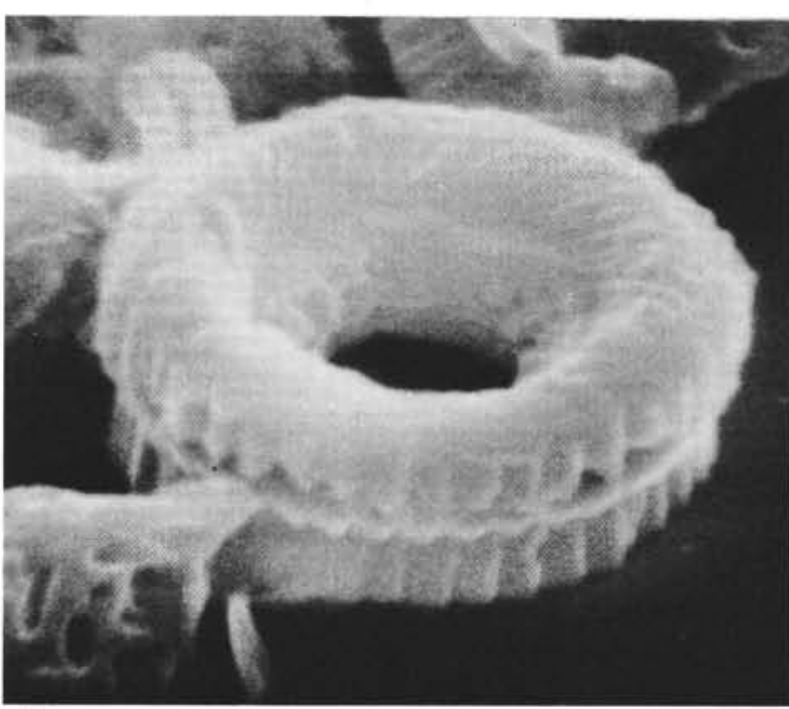

6 


\author{
PLATE 14 \\ (Paleocene, Eocene)
}

Figures 1-3 Heliolithus universus Wind and Wise, n. sp., paratype USNM 385457, Sample 327A, 5-1, 133 $\mathrm{cm}$.

1. Side view, $\times 4000$.

2. Paratype USNM 385458 , plan view of etched specimen, phase contrast, $\times 4000$.

3. Same specimen, crossed-polarized light, $\times 4000$.

Figures 4-6 Heliolithus sp., etched specimens.

4. Oblique distal view, Sample $327 \mathrm{~A}-5-1,133 \mathrm{~cm}$, $\times 5000$.

5. Distal view, Sample 327A-5-1, $3 \mathrm{~cm}, \times 5000$.

6 . Same specimen, oblique distal view, $\times 5500$.

Figures 7, 8 Heliolithus sp. A, paratype USNM 240452, Sample $327 \mathrm{~A}-5-1,3 \mathrm{~cm}$.

7. Distal view, $\times 7000$.

8. Same specimen, oblique distal view, $\times 6000$.

Figures 9, 10 ?Heliolithus sp. A.

9. Proximal view, Sample $327 \mathrm{~A}-5-1,3 \mathrm{~cm}, \times 4100$.

10. Same specimen, oblique view, $\times 3900$.

Figure 11 Isthmolithus recurvus Deflandre and Fert, plan view, phase contrast, Sample 330A-1-3, $24 \mathrm{~cm}$, $\times 4000$.

Figure 12 Fasciculithus involutus Bramlette and Sullivan, axial view of etched specimen, Sample 327A-5-3, 3 $\mathrm{cm}, \times 4000$. 
PLATE 14

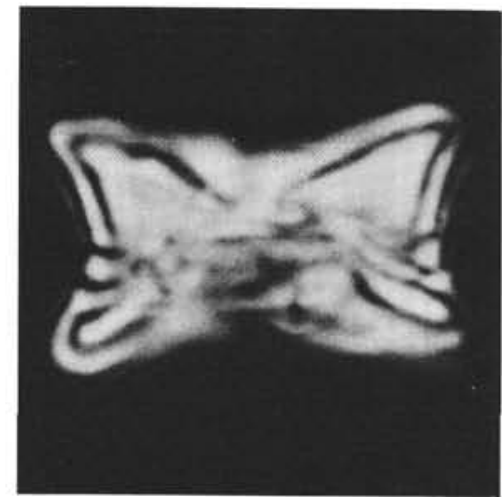

1

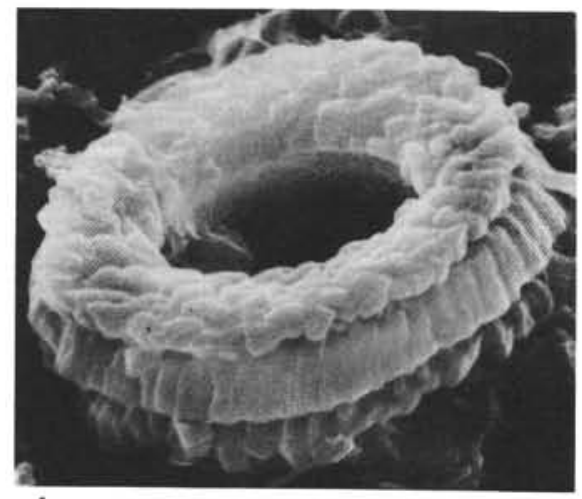

4

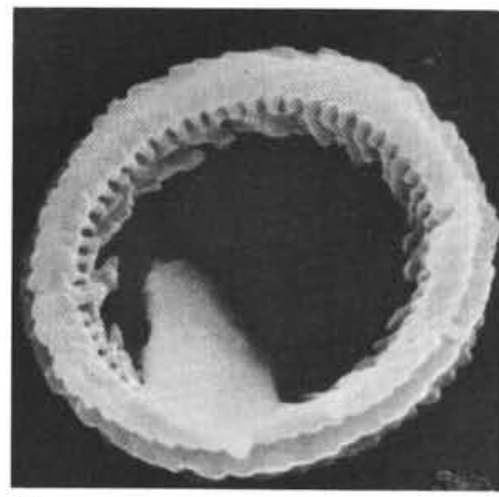

7

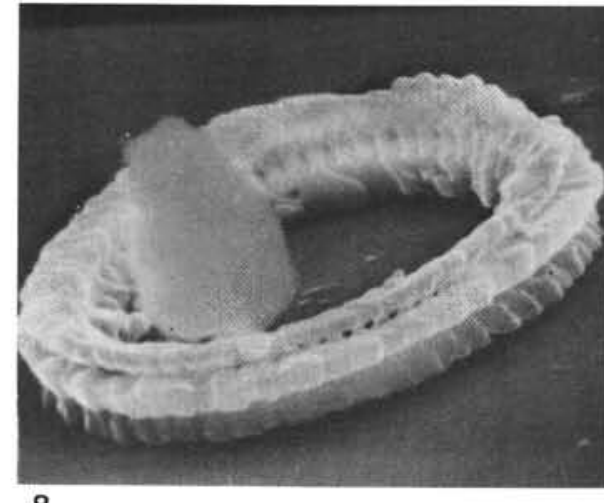

8

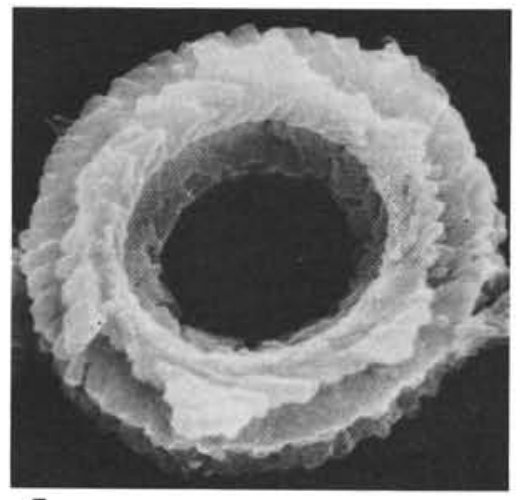

5
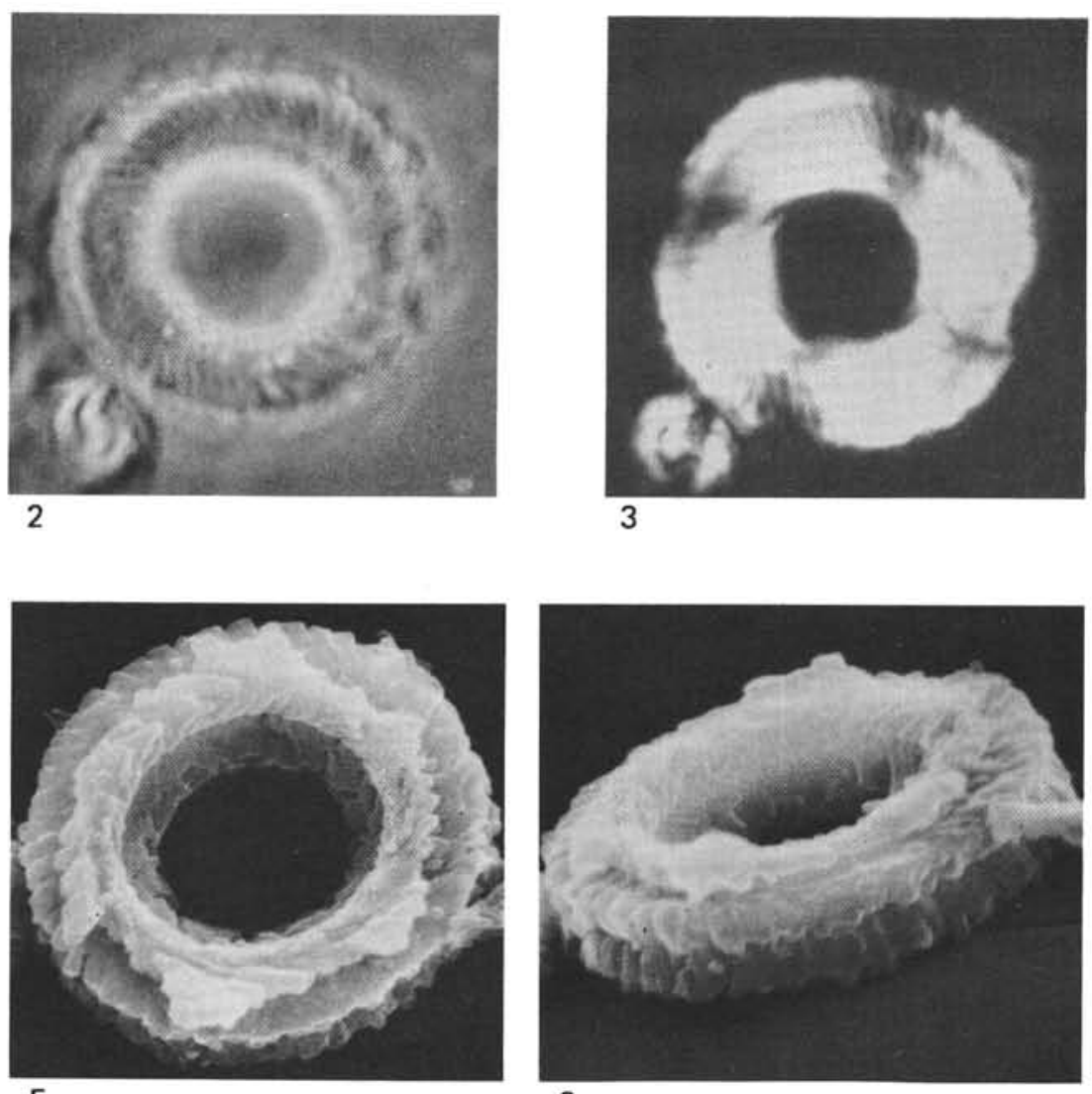

6

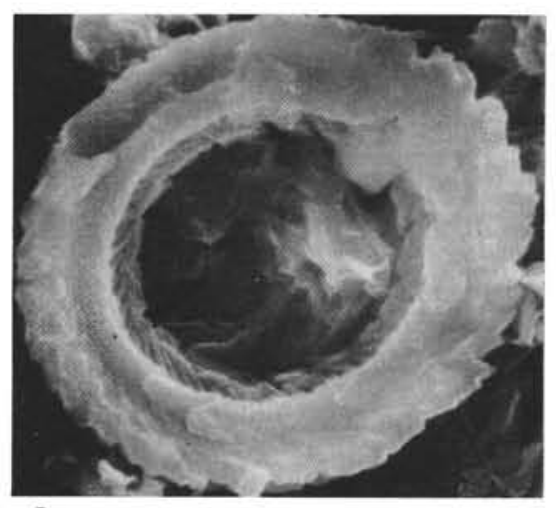

9

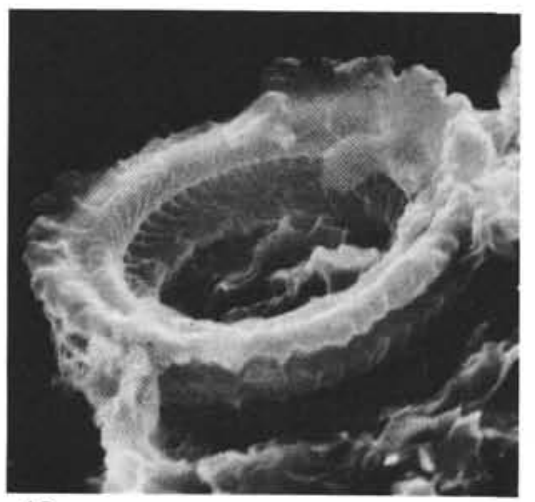

10
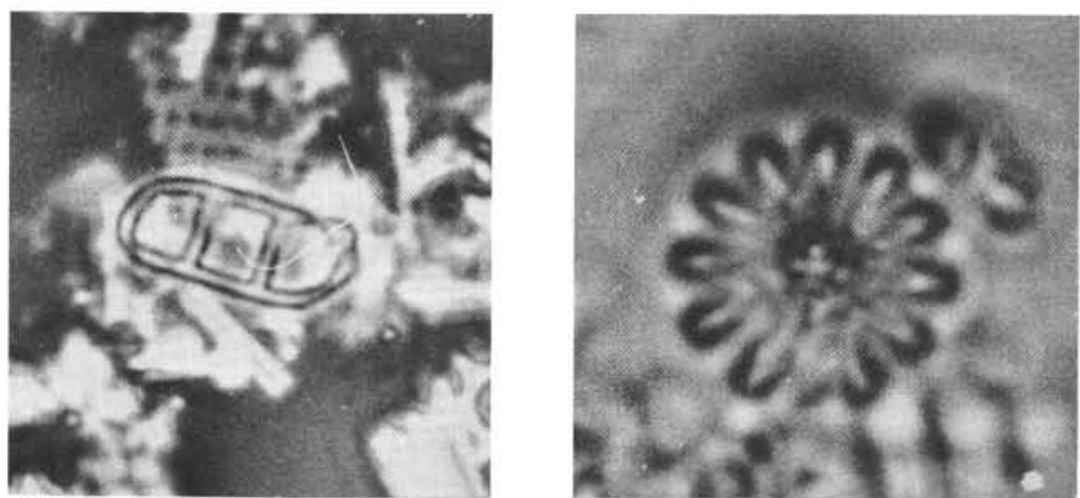

12 


\section{PLATE 15}

(Paleocene)

Figures 1-6 Fasciculithus involutus Bramlette and Sullivan. Figures shown here and on Plate 16 show etched and nonetched (or overgrown) specimens of this taxon. The etched specimens (right-hand column of each plate) have usually been assigned to $F$. involutus whereas the nonetched forms (left-hand column of each plate) are often referred to $F$. tympaniformis Hay and Mohler. Comparison of Falkland Plateau specimens from the same biostratigraphic levels (Heliolithus universus and Discoaster multiradiatus zones) but from contrasting facies (carbonate-rich vs. carbonate-poor) indicate that all specimens belong to the same biological species although diagenesis (etching or overgrowth) has produced as an artifact two distinct morphotypes. Specimens from the carbonaterich facies are in the left-hand column; those from carbonate-poor facies are in the right-hand columns.

1. Side view Pont Labau Sample 815 (reference: Hay and Mohler, 1967), $\times 7000$.

2. Oblique distal view, Lodo Sample 6+1 (reference, Bramlette and Sullivan, 1961), $\times 10,000$.

3. Distal view, Sample 329-33-2, $70 \mathrm{~cm}, \times 10,000$.

5. Axial view of fractured specimen, Sample 329$33-4,77 \mathrm{~cm}, \times 10,000$.

6. Oblique distal view, Sample $327 \mathrm{~A}-5-1,48 \mathrm{~cm}$, $\times 7000$. 
PLATE 15
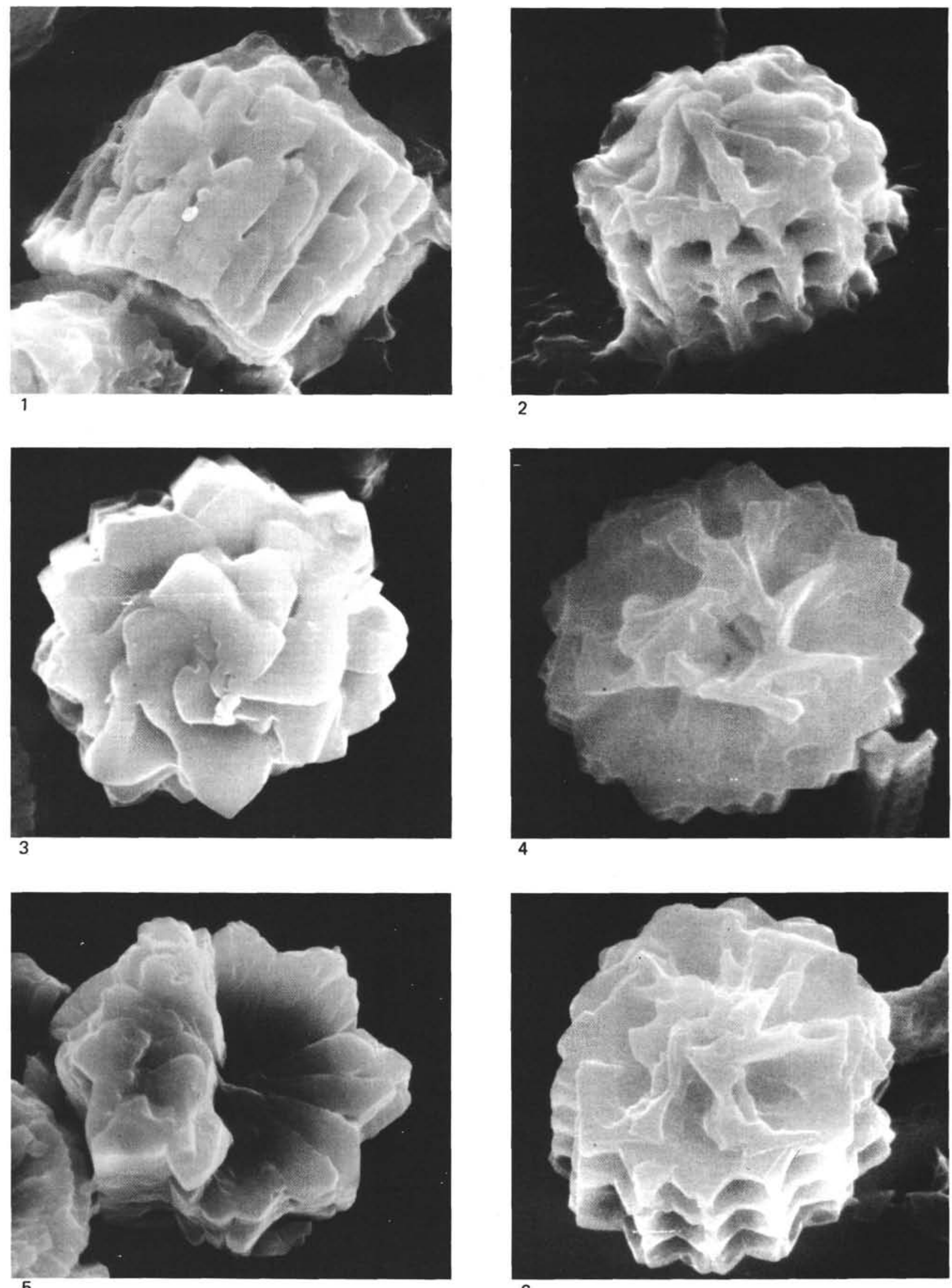

6 


\section{PLATE 16}

(Paleocene; see Plate 15 for detailed explanation)

Figures 1-6 Fasciculithus involutus Bramlette and Sullivan.

1. Oblique proximal view, Sample RC-15-84, 425 $\mathrm{cm}, \times 7000$.

2. Oblique proximal view, Sample $327 \mathrm{~A}-5-1,3$ $\mathrm{cm}, \times 8000$.

3. Proximal view, Sample RC-15-84, $425 \mathrm{~cm}$, $\times 11,000$.

4. Oblique proximal view, Sample 327A-5-1, 3 $\mathrm{cm}, \times 9000$.

5. Side view, Sample RC-15-84, $425 \mathrm{~cm}, \times 9000$.

6. Side view, Sample 327 A $-5-1,3 \mathrm{~cm}, \times 7000$. 
PLATE 16

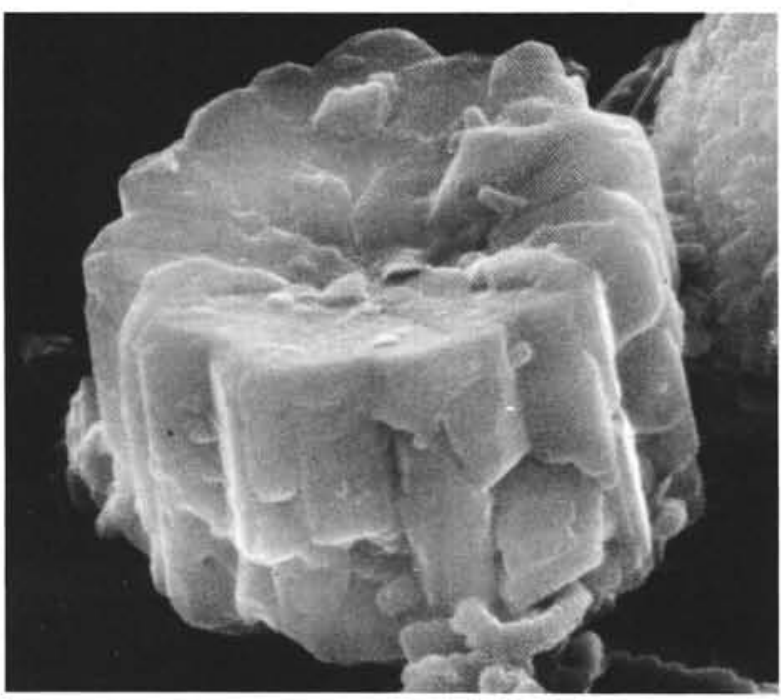

1

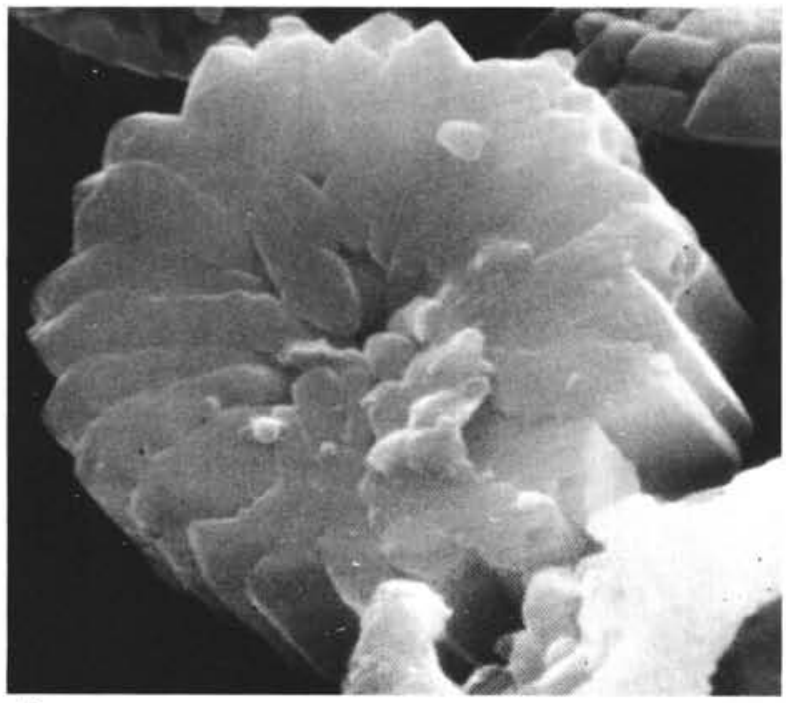

3

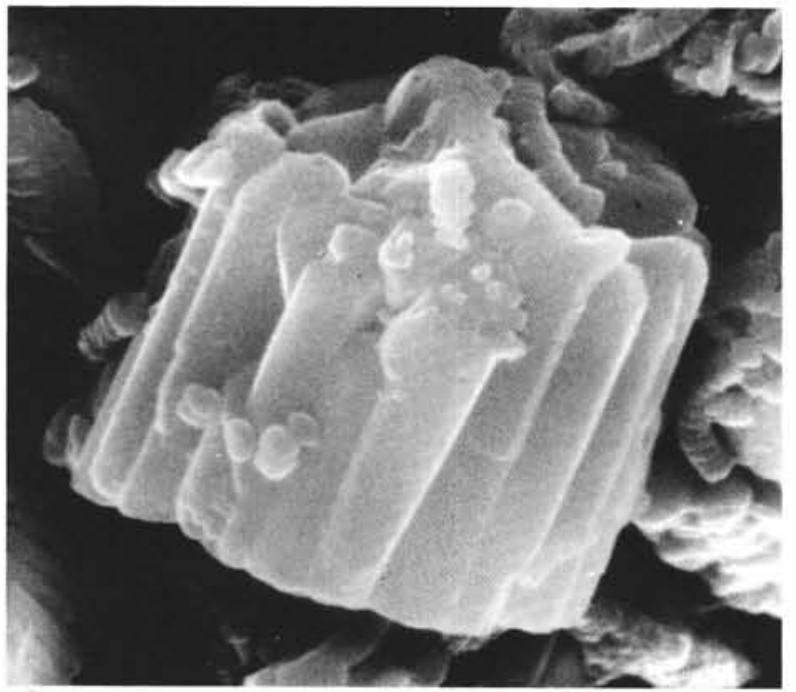

5

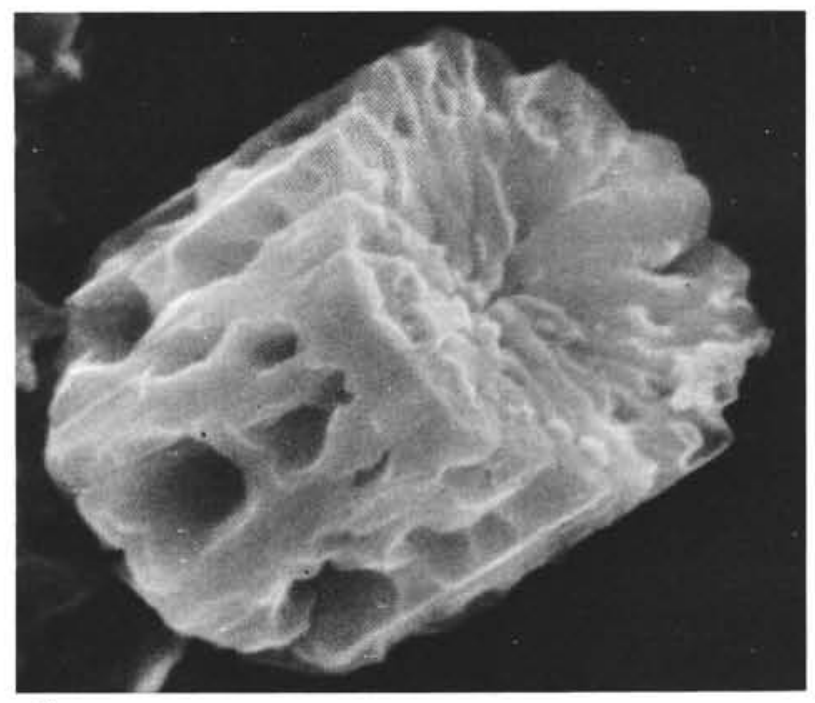

2
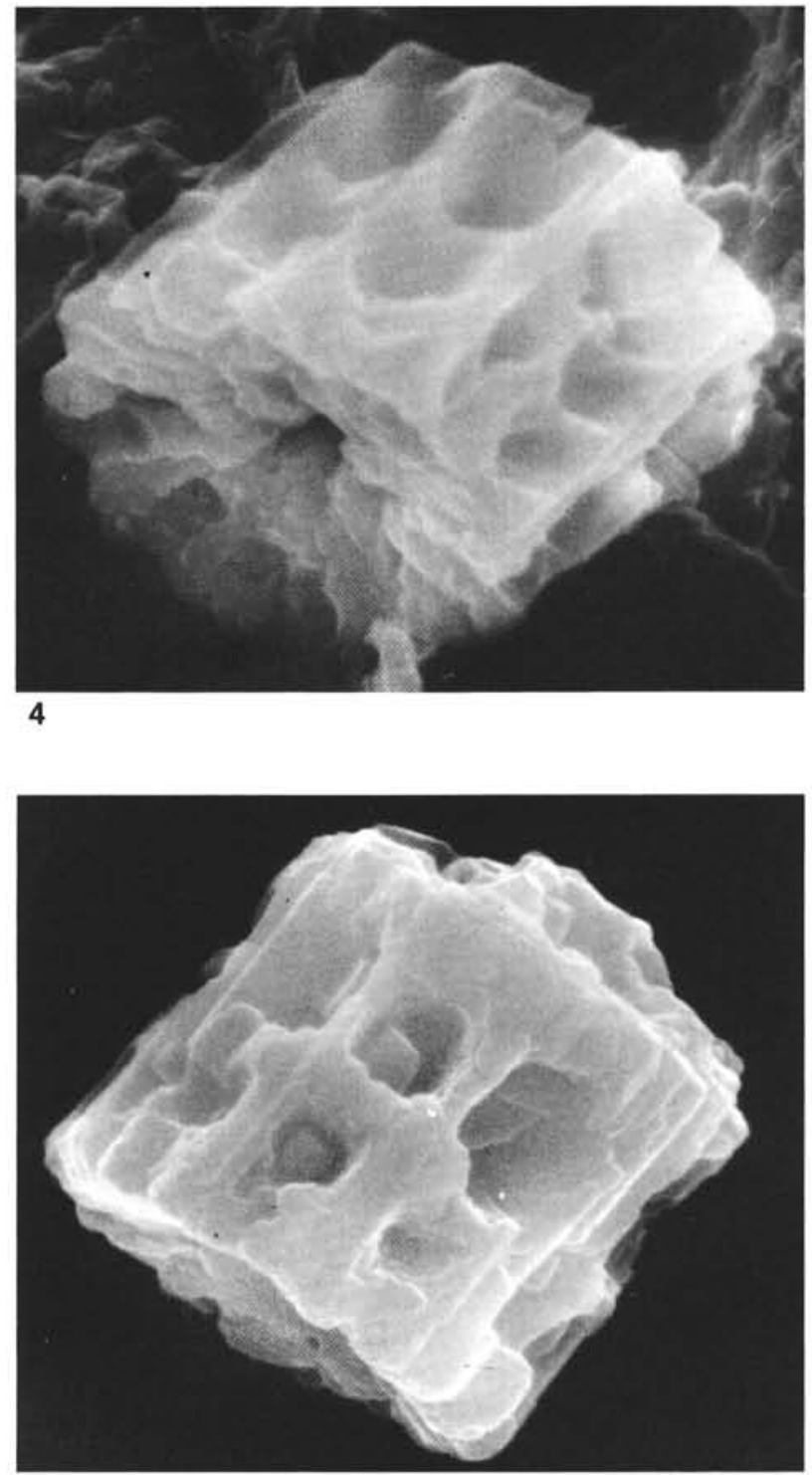


\section{PLATE 17}

(Paleocene, Eocene)

Figure 1 Discoaster robustus Haq, oblique distal view, Sample $329-32-1,142 \mathrm{~cm}, \times 7500$.

Figure 2 Discoaster multiradiatus Bramlette and Riedel, distal view, Sample 329-33-2, $70 \mathrm{~cm}, \times 7000$.

Figures 3-5 Discoaster saipanensis Bramlette and Riedel, Sample $330 \mathrm{~A}-1-1,128 \mathrm{~cm}$.

3. $\times 4000$.

4. $\times 4000$.

5. $\times 3000$.

Figure 6 Discoaster helianthus Bramlette and Sullivan, Sample $327 \mathrm{~A}-5-3,3 \mathrm{~cm}, \times 2400$.

Figure 7 Discoaster mediosus Bramlette and Sullivan, Sample $327 \mathrm{~A}-5-3,3 \mathrm{~cm}, \times 3000$.

Figure $8 \quad$ Tribrachiatus orthostylus (Bramlette and Riedel) Shamrai, Sample 327A-2-1, $99 \mathrm{~cm}, \times 2000$. 
PLATE 17

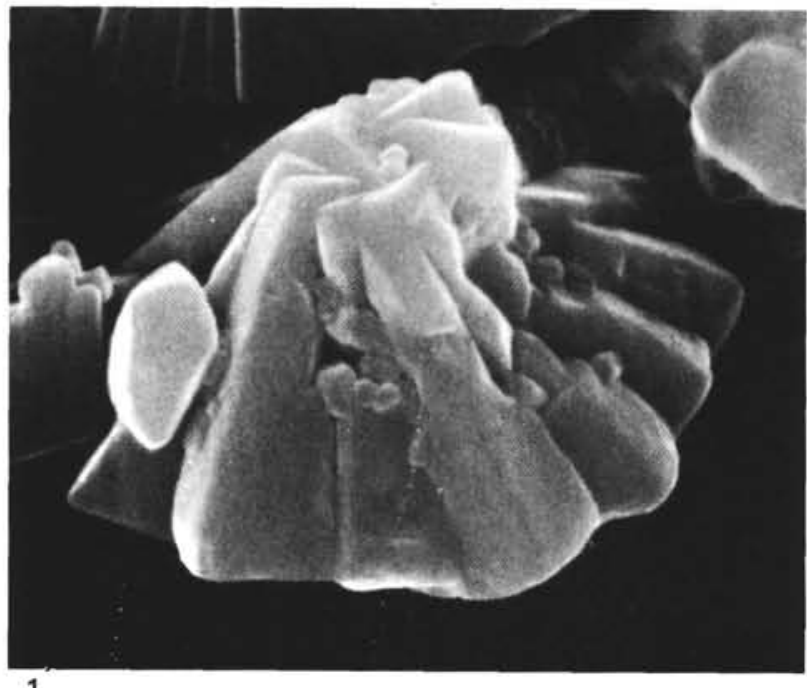

1

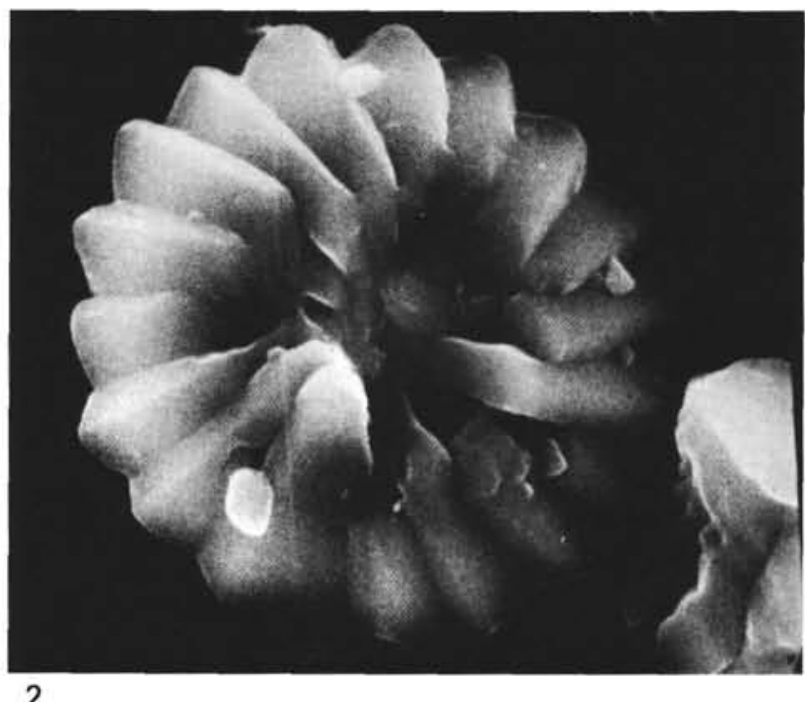

2
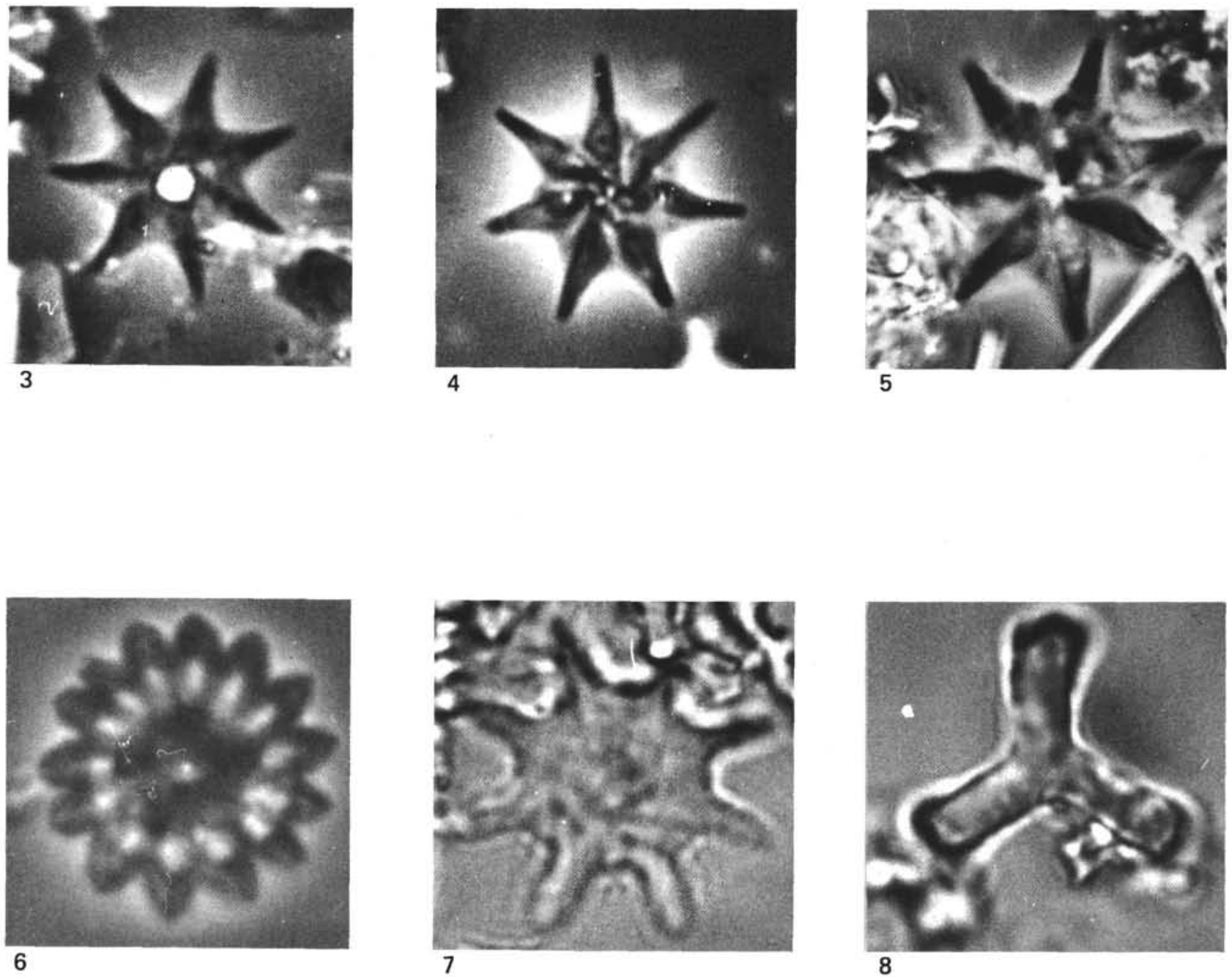
PLATE 18

(Maestrichtian-Campanian)

Figures 1-8 Misceomarginatus pleniporus Wind and Wise, $\mathrm{n}$. gen., n. sp., Sample $327 \mathrm{~A}-13-2,137 \mathrm{~cm}$.

1. Holotype USNM 239459, distal view, $\times 8500$.

2. Paratype USNM 239460, distal view, $\times 8800$.

3. Paratype USNM 239461, distal view, $\times 8200$.

4. Paratype USNM 239462, distal view, $\times 8400$.

5, 6. Misceomarginatus pleniporus $\mathrm{n}$. sp. paratype USNM 239463 (left), and Monomarginatus pectinatus n. sp. paratype USNM 239504 (right).

5. Phase-contrast illumination.

6. Polarized light, $\times 3400$.

7, 8. Paratype USNM 239464, $\times 4300$.

7. Phase-contrast illumination.

8. Polarized light. 
Plate 18
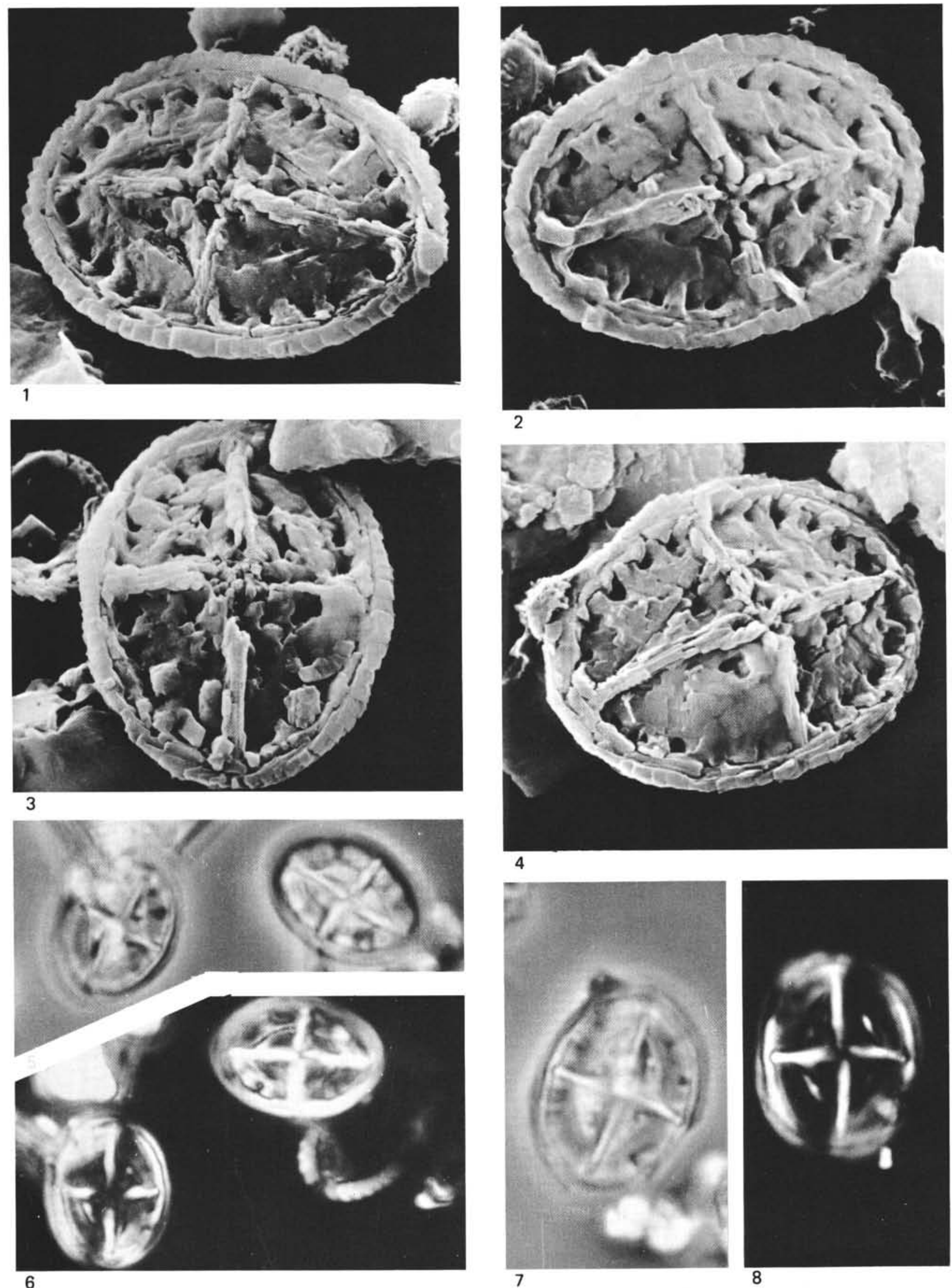
PLATE 19

(Maestrichtian-Campanian)

Figures 1-4 Monomarginatus quaternarius Wind and Wise, $\mathrm{n}$. sp.

1. Holotype USNM 239465, distal view, Sample $327 \mathrm{~A}-12, \mathrm{CC}, \times 8100$.

2. Paratype USNM 239466, proximal view, Sample $327 \mathrm{~A}-12, \mathrm{CC}, \times 8700$.

3. Paratype USNM 239467, distal-lateral view, Sample 327A-13-2, $45 \mathrm{~cm}, \times 11,000$.

4. Paratype USNM 239468 , proximal view, Sample $327 \mathrm{~A}-12, \mathrm{CC}, \times 8800$.

Figures 5,6 Monomarginatus pectinatus Wind and Wise, n. sp. 5. Holotype USNM 239469, distal view, Sample $327 \mathrm{~A}-13-2,45 \mathrm{~cm}, \times 7500$.

6. Paratype USNM 239470, proximal view, Sample $327 \mathrm{~A}-13-2,45 \mathrm{~cm}, \times 7000$. 
PLATE 19

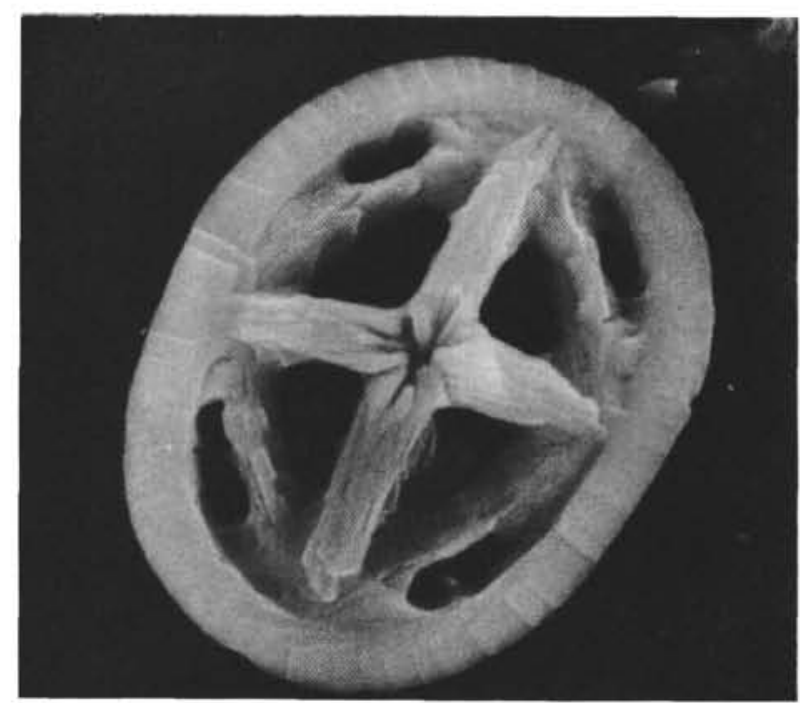

1

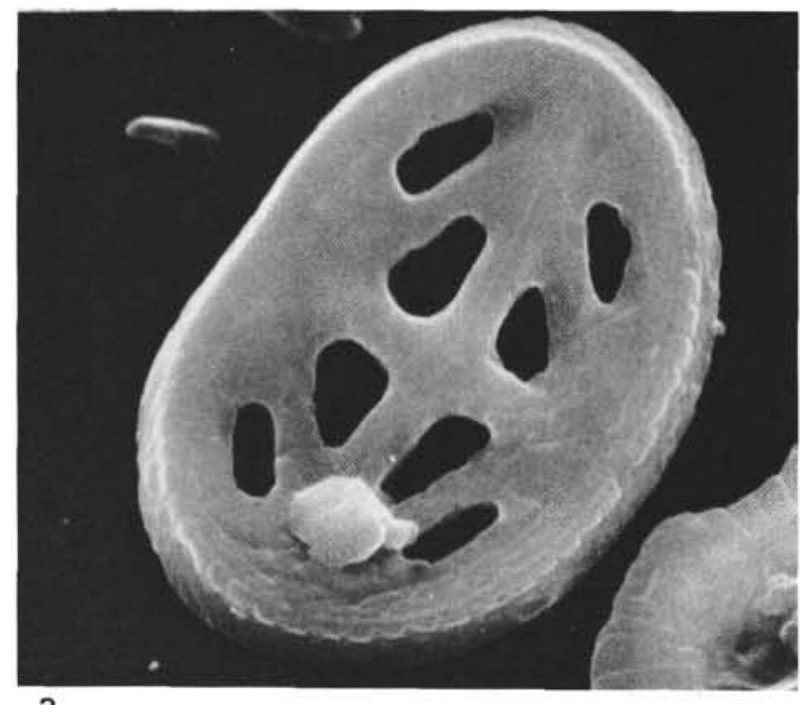

2

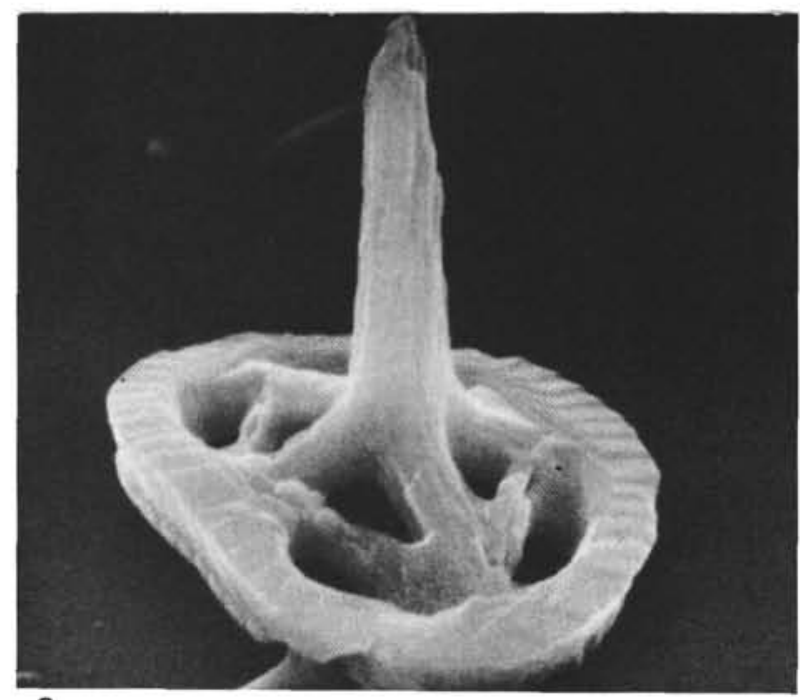

3

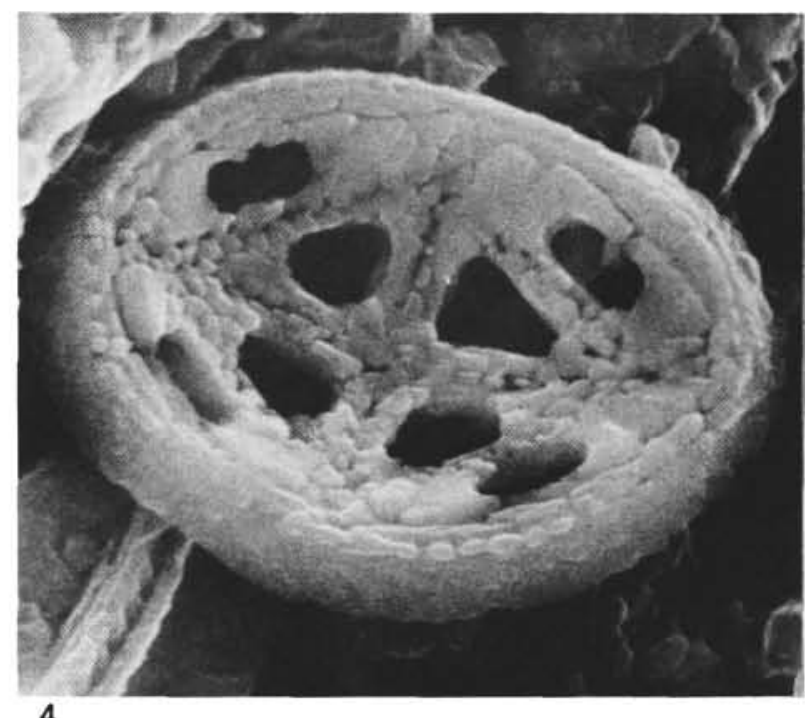

4

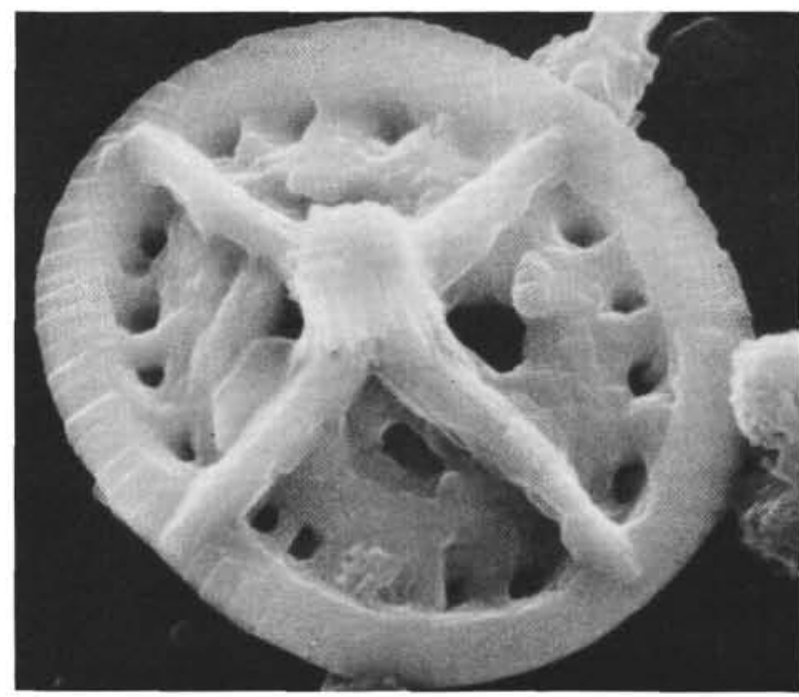

5

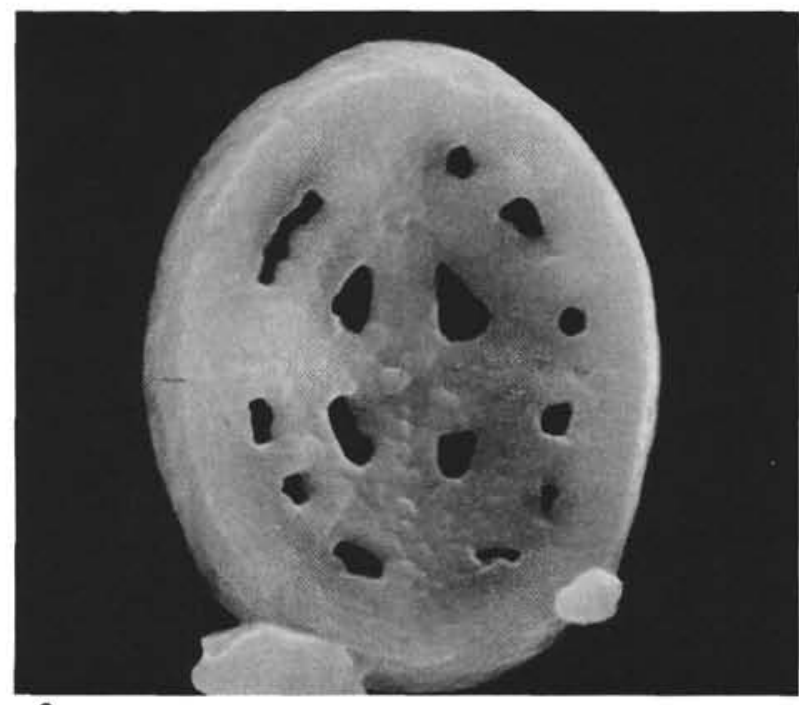

6 


\section{PLATE 20}

(Maestrichtian-Campanian)

Figures 1,2 Monomarginatus pectinatus Wind and Wise, n. sp. 1. Paratype USNM 239471, proximal (left) and distal (right) views, Sample 327A-13-2, $54 \mathrm{~cm}$, $\times 4700$.

2. Paratype USNM 239472, distal view, Sample $327 \mathrm{~A}-13-2,54 \mathrm{~cm}, \times 6300$.

Figure 3 Nephrolithus frequens Gorka; with spine, Sample $327 \mathrm{~A}-12, \mathrm{CC}, \times 7000$.

Figure 4-6 Biscutum magnum Wind and Wise, n. sp.

4. Paratype USNM 239473, proximal view of two attached coccoliths, Sample 327A-12, CC, $\times 7000$. 5. Paratype USNM 239474, proximal view showing proximally-projecting inner extensions of distal shield, Sample 327A-13-2, $45 \mathrm{~cm}, \times 8700$.

6. Paratype USNM 239475, distal-lateral view of slightly overgrown specimen, Sample 327A-10-3, $14 \mathrm{~cm}, \times 9000$. 
PLATE 20
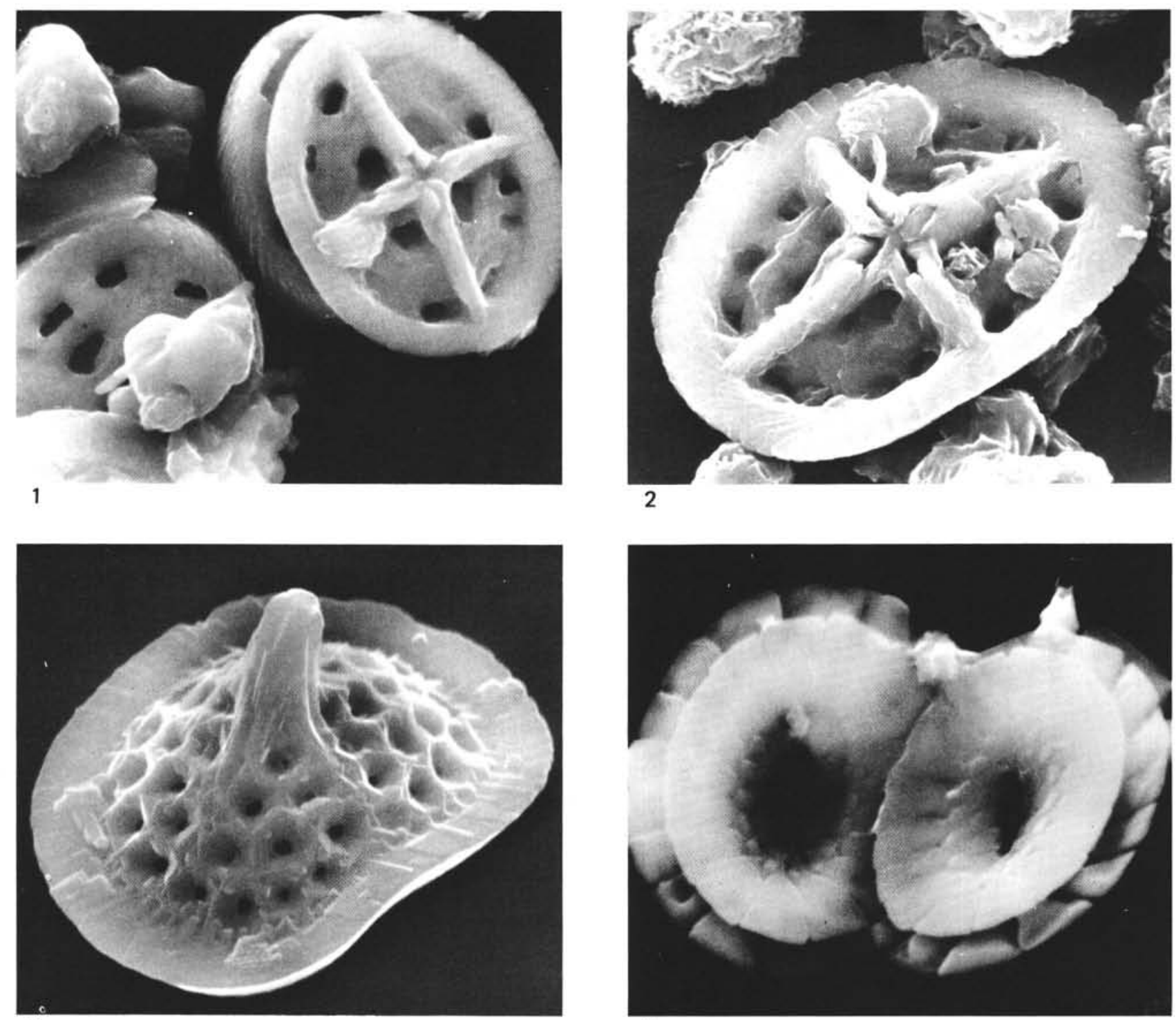

3

4
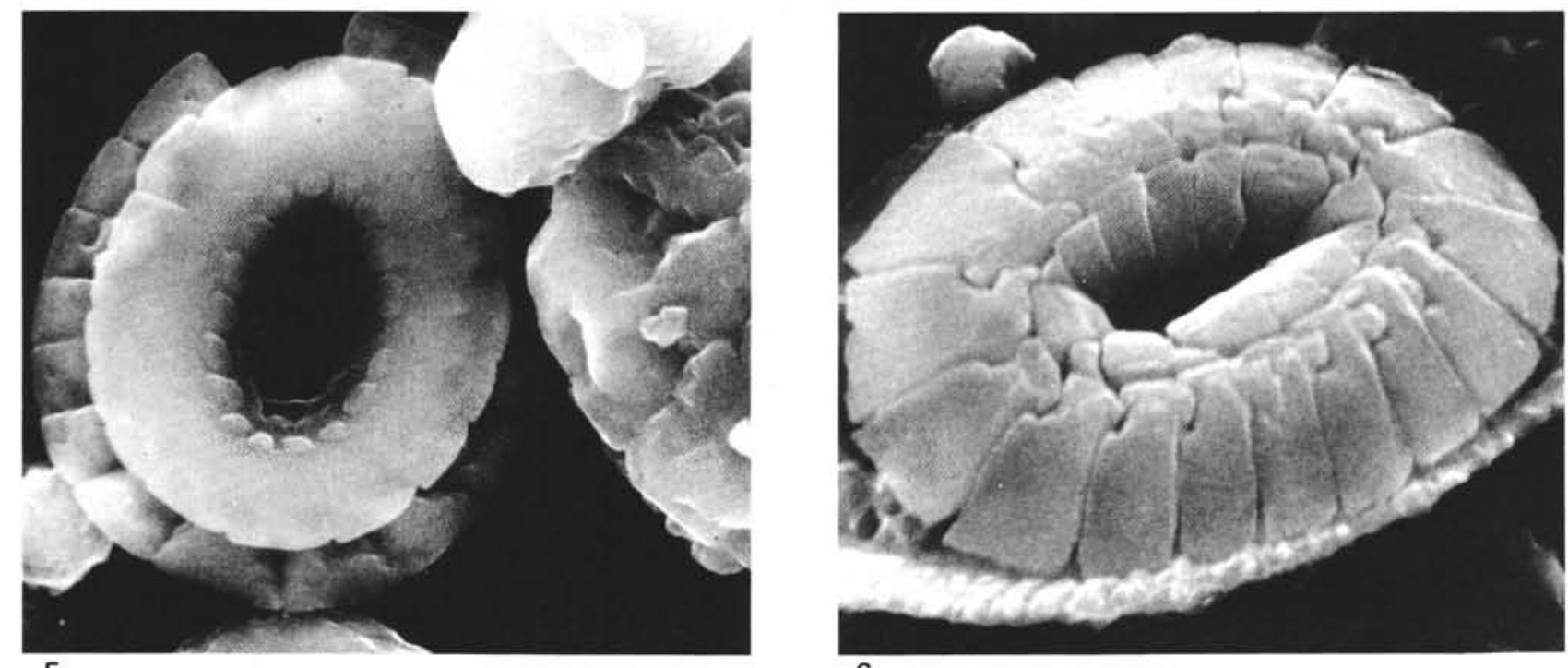


\section{PLATE 21}

(Maestrichtian)

Figure 1 Biscutum boletum Wind and Wise, n. sp., Paratype USNM 239479, proximal view, Sample 327A-12, $\mathrm{CC}, \times 13,000$.

Figure 2 Biscutum magnum Wind and Wise, n. sp., Holotype USNM 239476, distal view, Sample $327 \mathrm{~A}-12, \mathrm{CC}, \times 8700$.

Figures 3, 4 Ahmuellerella octoradiata (Gorka) Reinhardt.

3. Distal view, Sample 327A-12, CC, $\times 8700$.

4. Proximal view, Sample 327A-12, CC, $\times 14,000$.

Figure 5 ?Rucinolithus sp., Sample 327A-12, CC, $\times 13,000$.

Figure 6 Boletuvelum candens Wind and Wise, n. gen., n. sp., paratype USNM 239477, lateral view, Sample $327 \mathrm{~A}-12, \mathrm{CC}, \times 8000$. 
PLATE 21

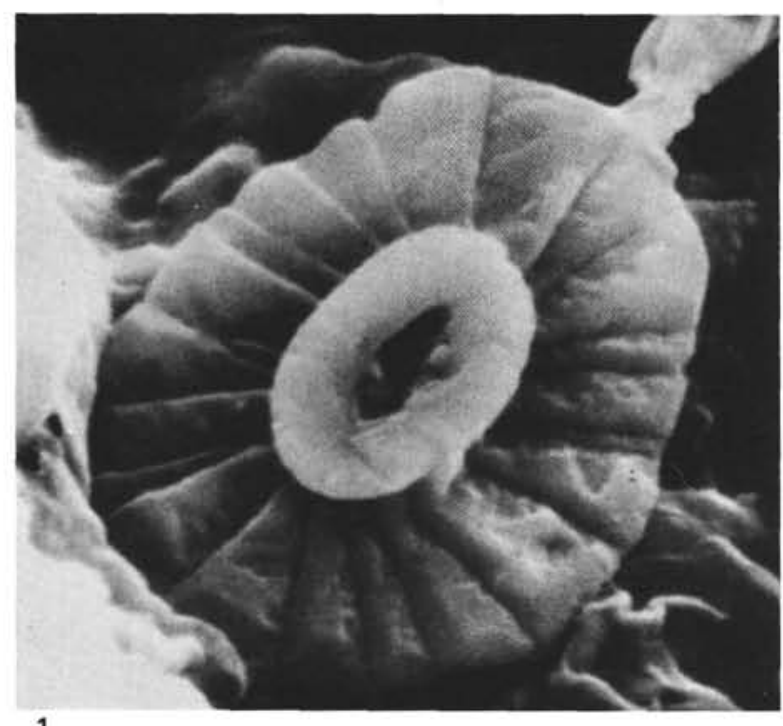

1

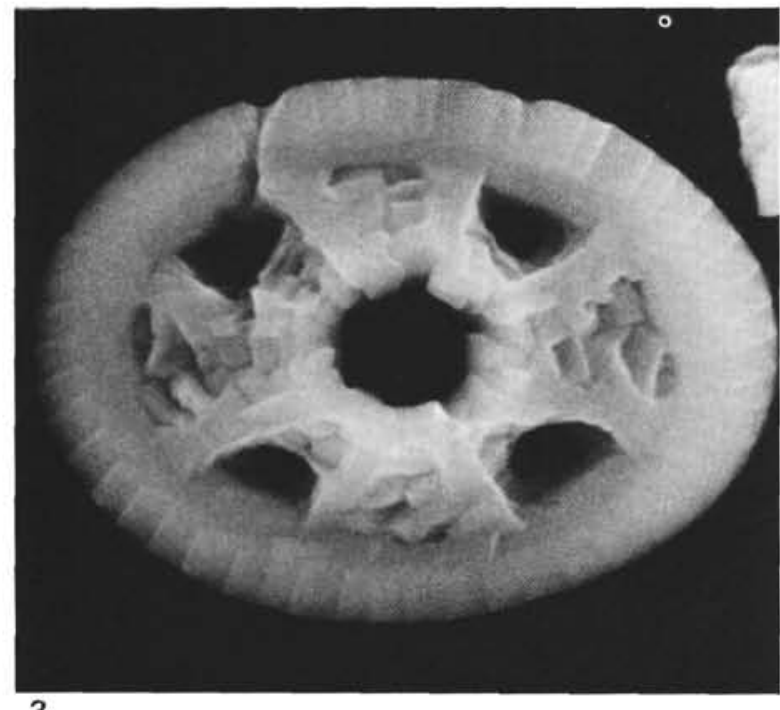

3

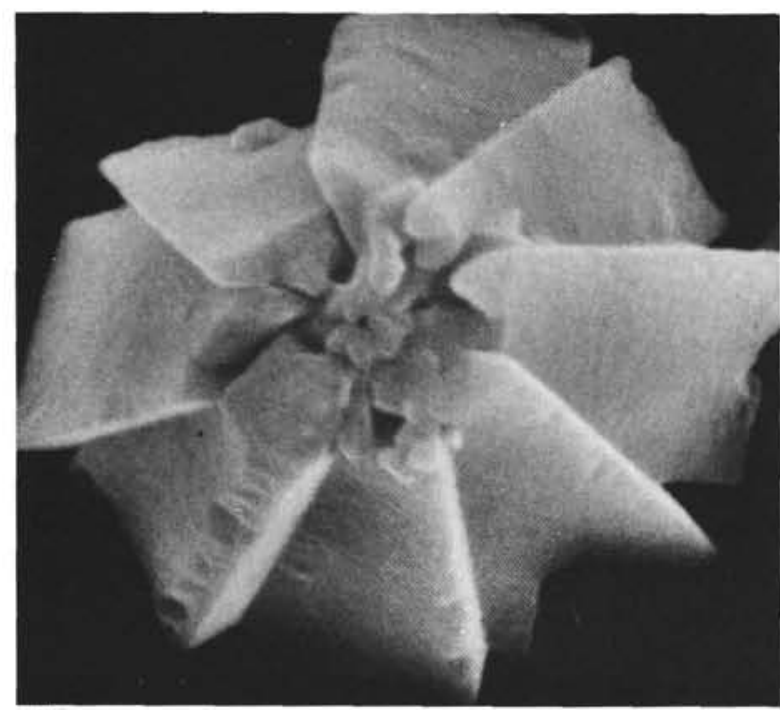

5
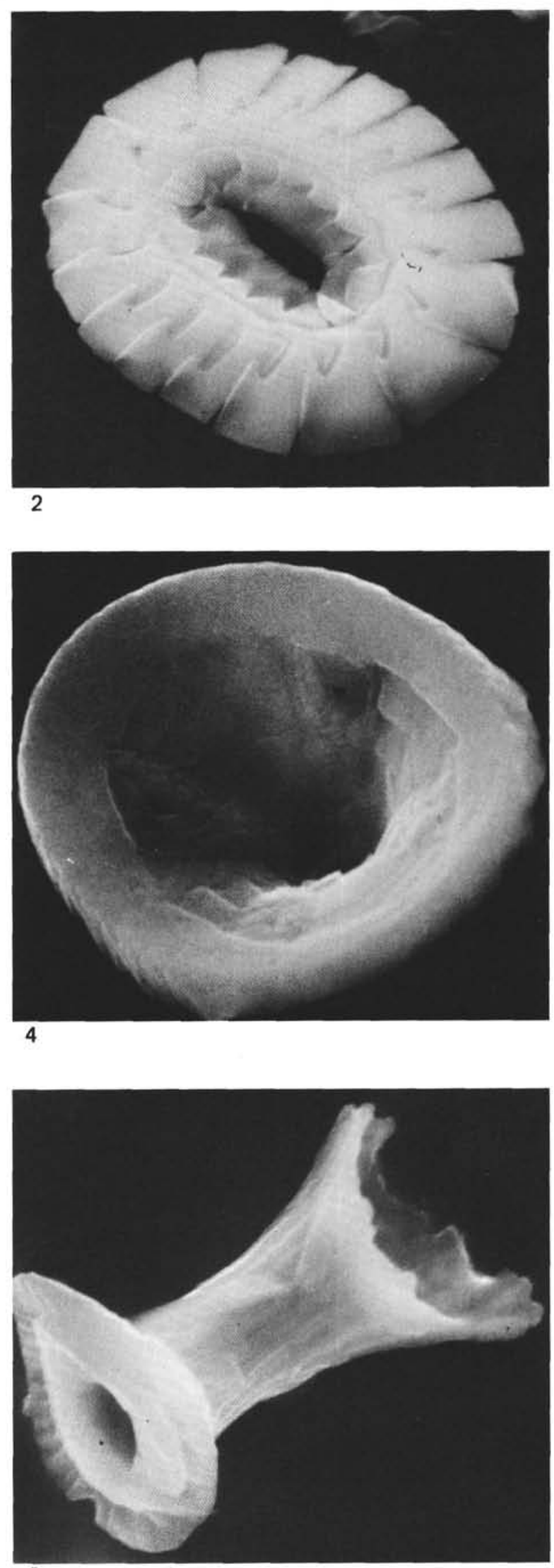

6 
PLATE 22

(Maestrichtian)

Figures 1-7 Boletuvelum candens Wind and Wise, n. gen., n. sp. 1-4. Holotype USNM 239478, Sample 327A-12, CC.

1. Proximal view, $\times 6500$.

2. Same specimen, proximal view in phase contrast (a), crossed-polarized light (b), and transmitted light (c), illumination, $\times 1600$.

3. Same specimen, lateral view, $\times 7000$.

4. Same specimen, detail of proximal surface, $\times 15,000$.

5. Paratype USNM 239481, Sample 237A-12, CC, $\times 8700$.

6. Paratype USNM 239482, lateral view, Sample 327A-12, CC, $\times 7000$.

7. Paratype USNM 239483, lateral view, Sample 327A-12, CC, $\times 10,000$. 
PLATE 22

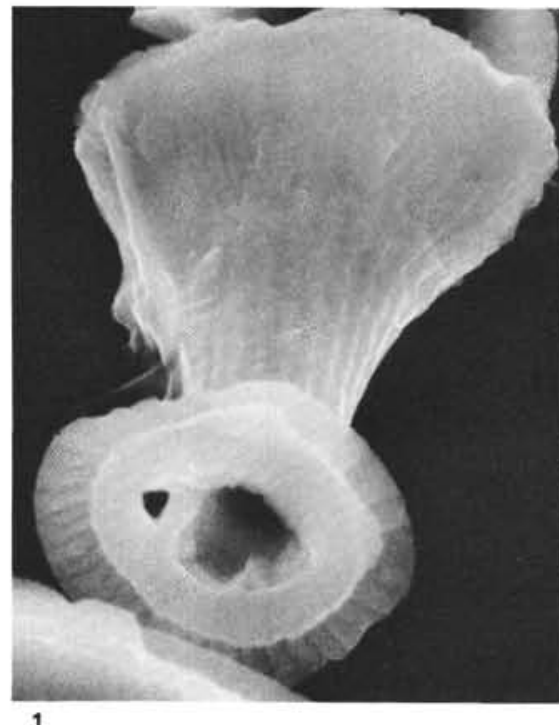

1

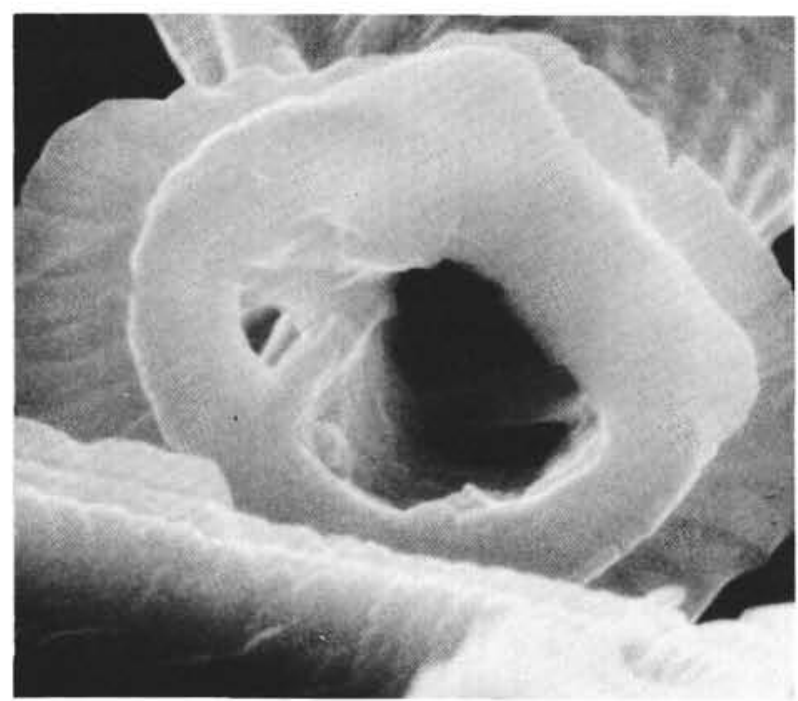

4

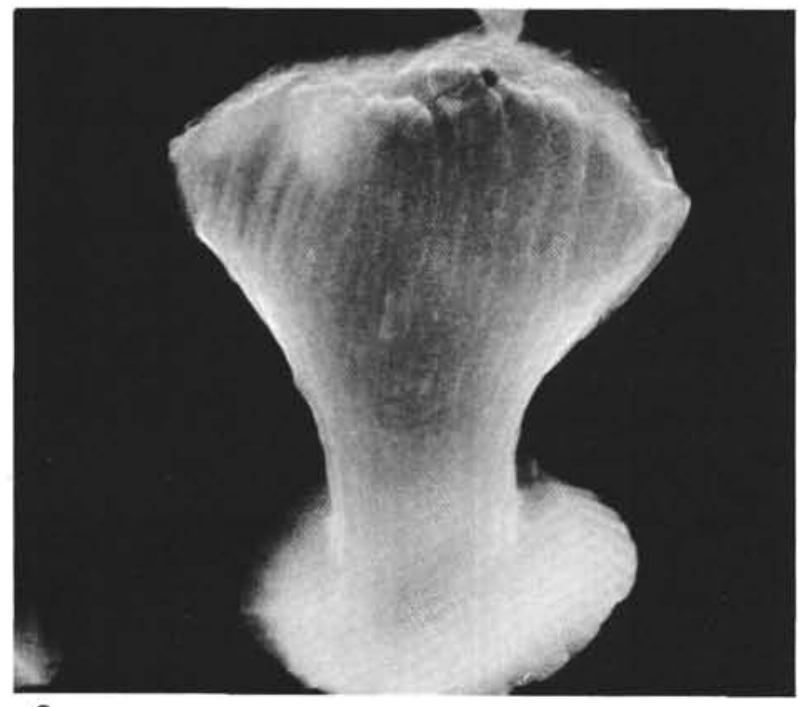

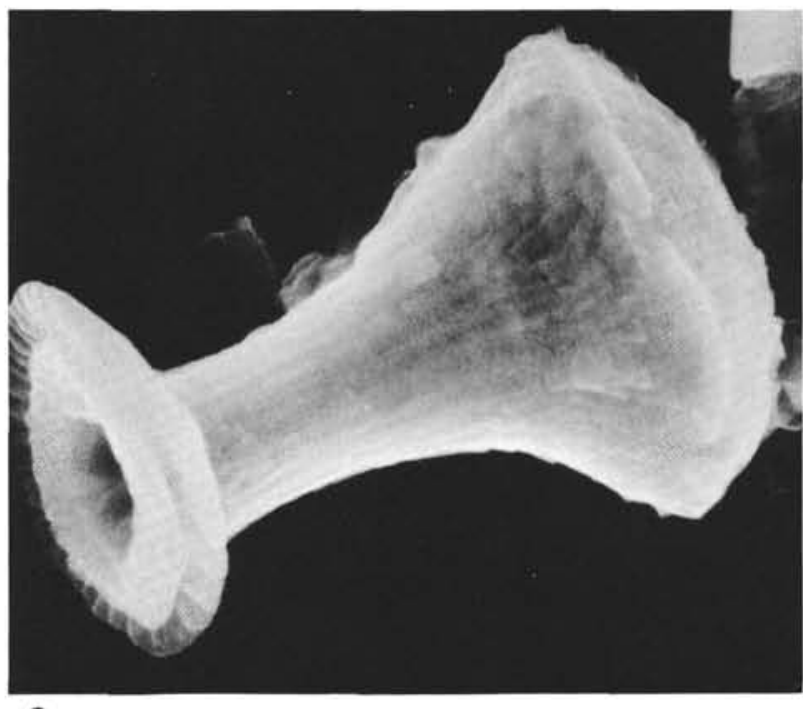

3

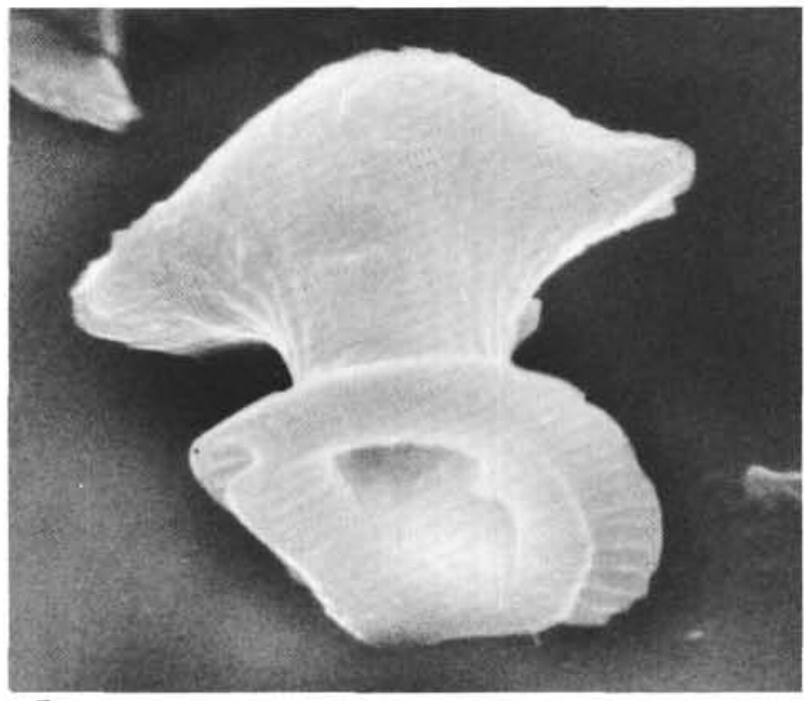

5

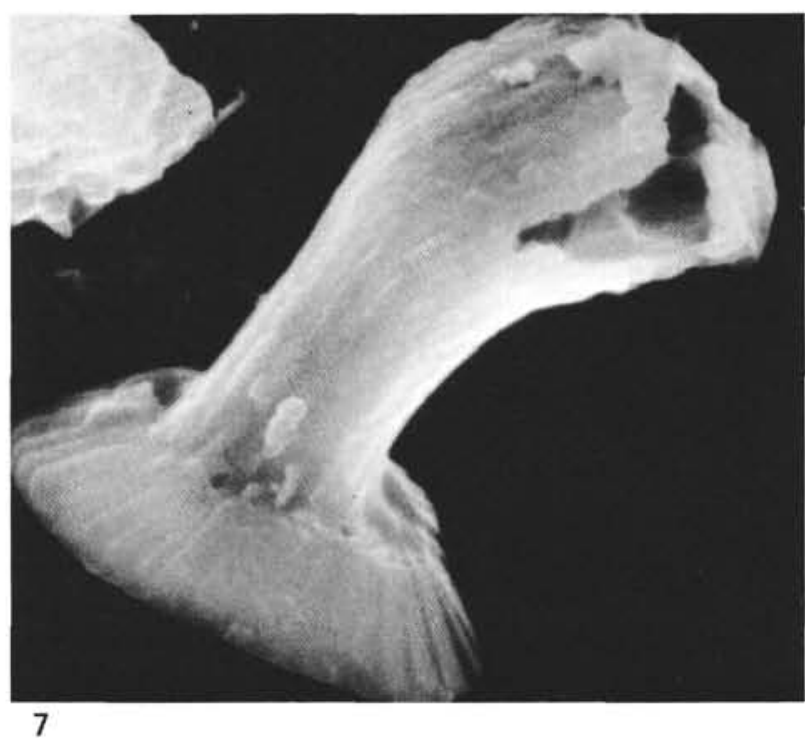




\section{PLATE 23}

(Maestrichtian)

Figures 1-5 Biscutum dissimilis Wind and Wise, n. sp.

1. Holotype USNM 239484, proximal-lateral view, Sample 327A-12, CC, $\times 9800$.

2, 3. Paratype USNM 239485, distal and lateral views, Sample 327A-12, CC, $\times 7300$.

4. Paratype USNM 239486, lateral view illustrating relative thickness of proximal (lower) and distal (upper) shields, Sample 327A-12, CC, $\times 9700$.

5. Paratype USNM 239487, proximal view of elongate specimen, Sample 327A-12, CC, $\times 9000$.

Figures 6, 7 Biscutum boletum Wind and Wise, n. sp., Holotype USNM 239488, proximal and lateral views, Sample $327 \mathrm{~A}-12-2,45 \mathrm{~cm}$.

6. $\times 15,000$.

7. $\times 17,500$. 


\section{PLATE 23}
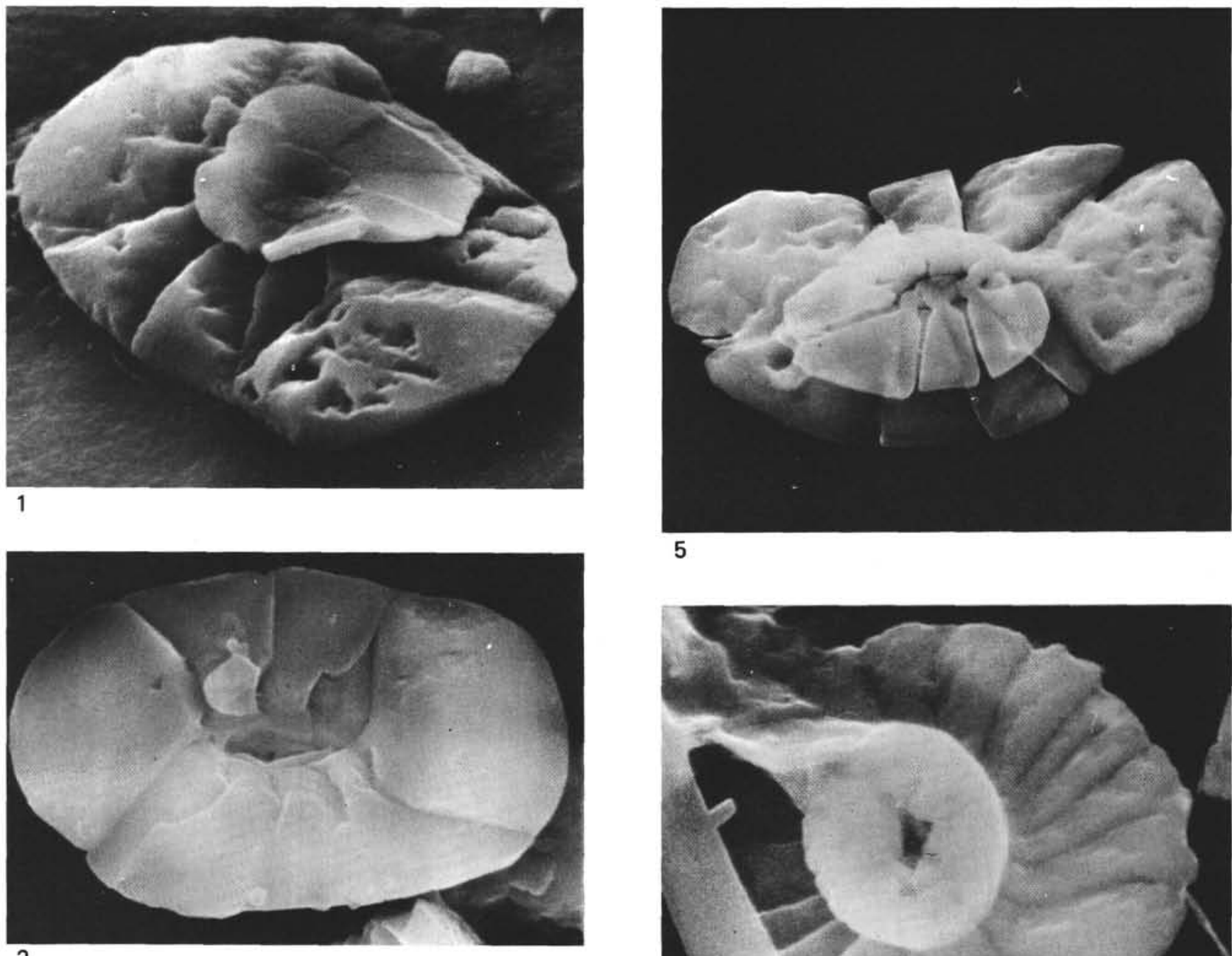

5

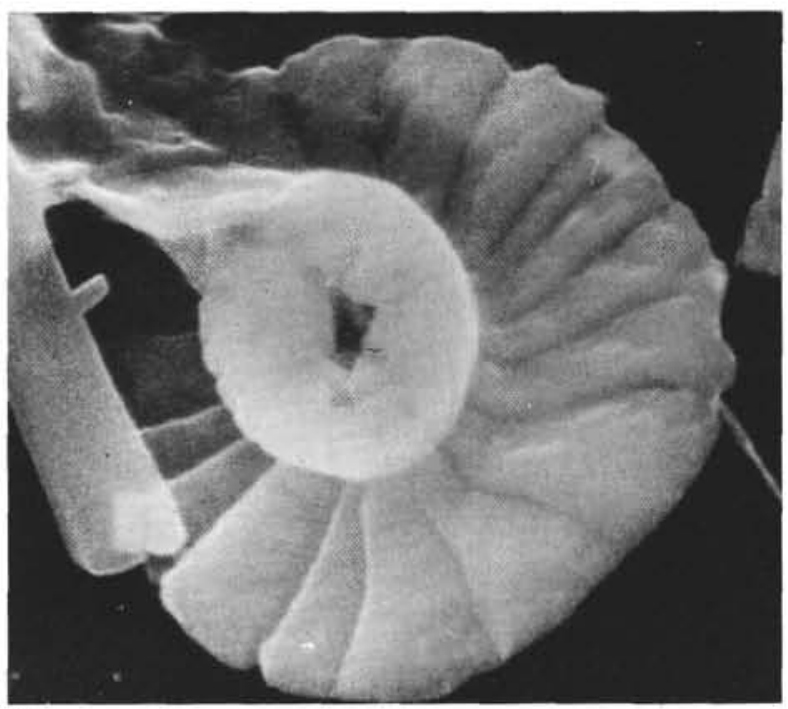

6

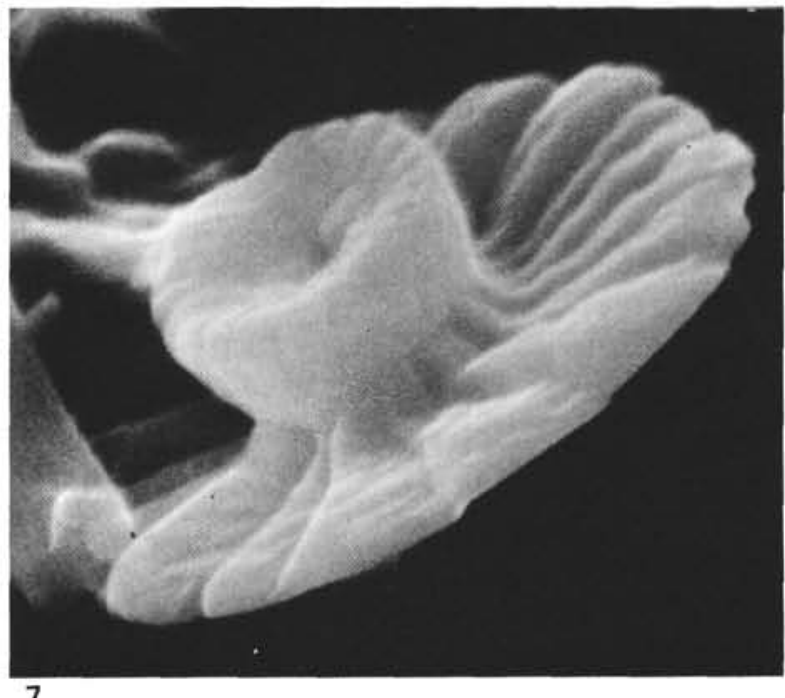




\section{PLATE 24}

(Maestrichtian-Campanian; polarizing directions for crossedpolarized light are parallel to the plate

$$
\text { margin) }
$$

Figures 1,2 Biscutum magnum Wind and Wise, n. sp., paratype USNM 239489, crossed-polarized light and phase contrast, Sample 327A-12, CC, $\times 3700$.

Figures 3-6 Biscutum dissimilis Wind and Wise, n. sp. 3, 6. Paratype USNM 239480, phase-contrast and crossed-polarized light, Sample 327A-12, CC, $\times 4200$.

4, 5. Paratype USNM 239490, crossed-polarized light and phase-contrast illumination, Sample $327 \mathrm{~A}-12, \mathrm{CC}, \times 4200$.

Figures 7-9 Biscutum sp. aff. B. dissimilis Wind and Wise, $\mathrm{n}$. sp., phase-contrast and crossed-polarized light, Sample 327A-13-2, $54 \mathrm{~cm}, \times 3200$.

Figures 10-12 Biscutum coronum Wind and Wise, n. sp., holotype USNM 239491, phase-contrast and crossedpolarized light illumination, Sample 237A-13-2, $137 \mathrm{~cm}, \times 4200$. 
PLATE 24

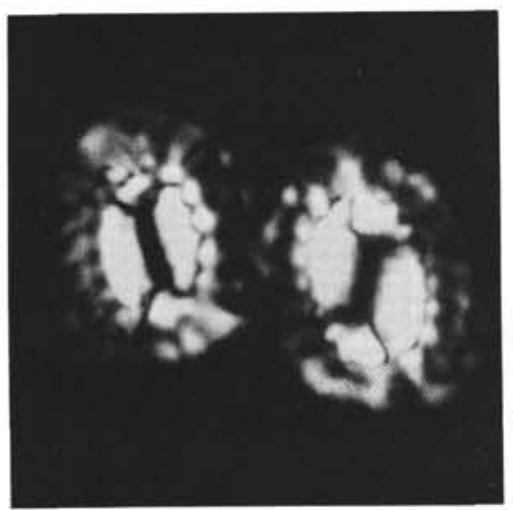

1

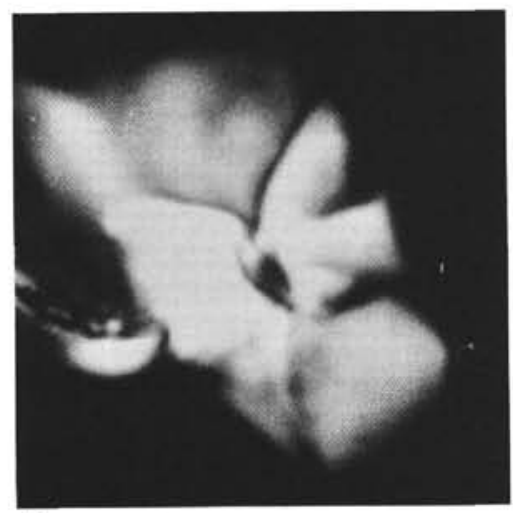

4
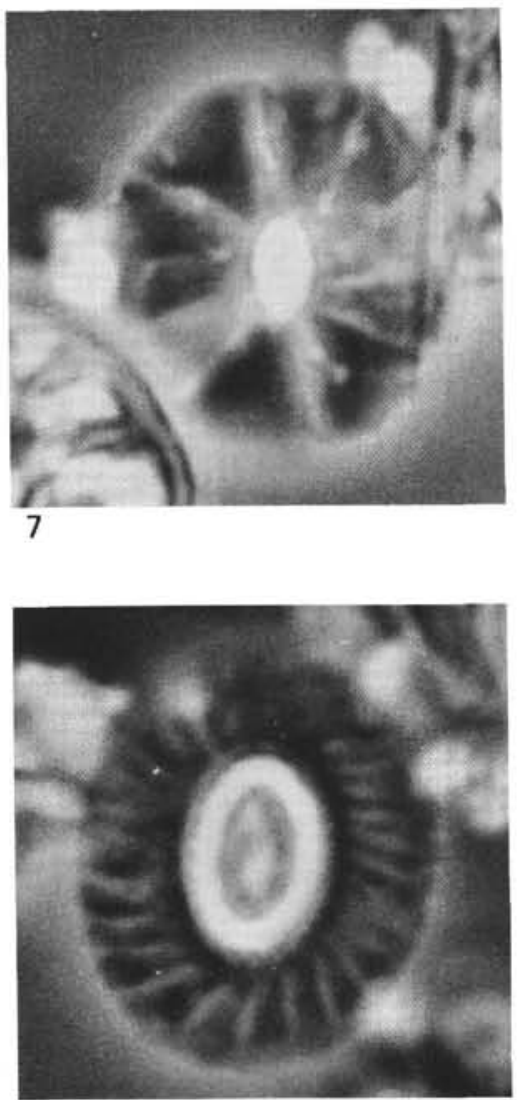

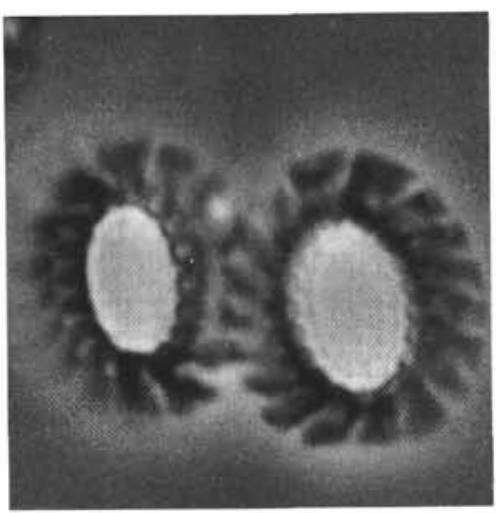

2

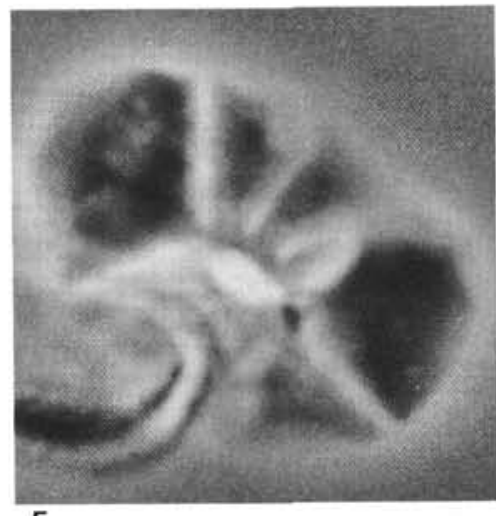

5
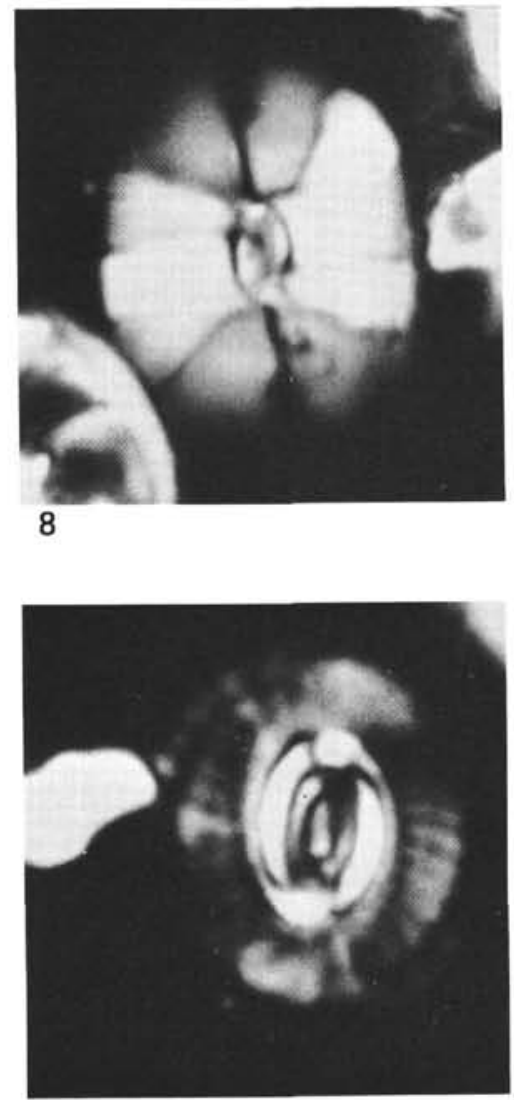

11
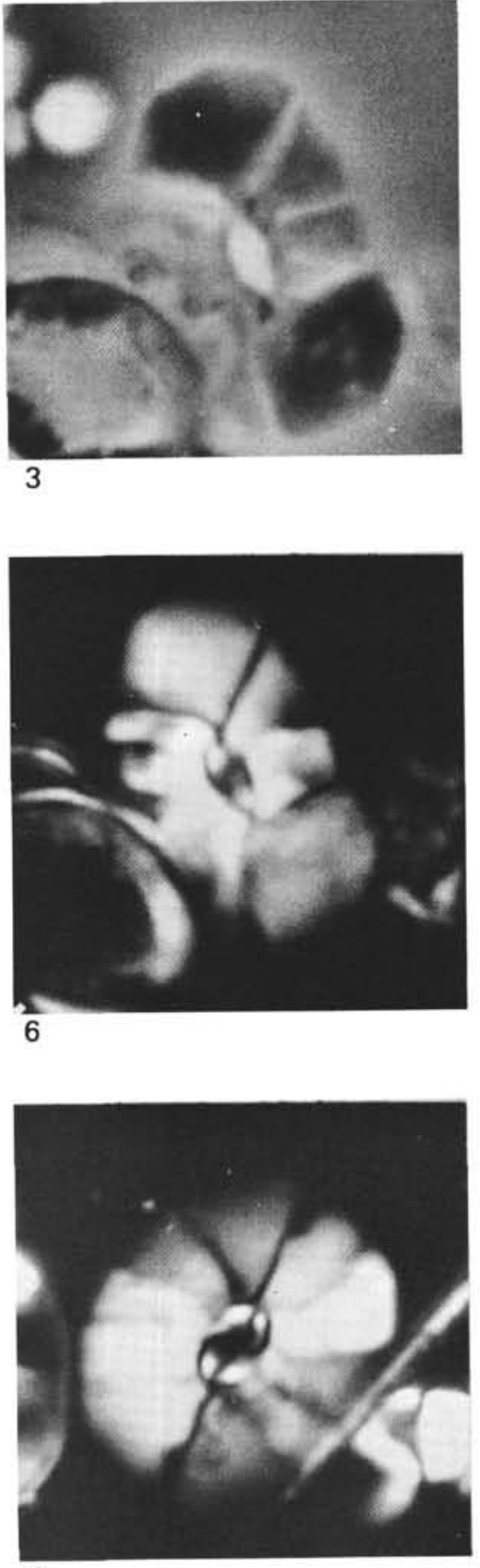

9

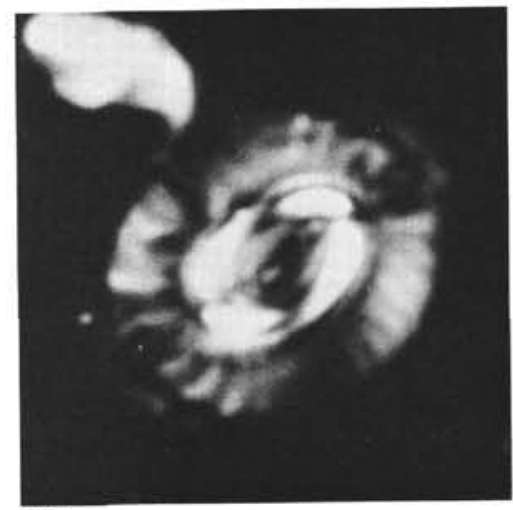

12 


\section{PLATE 25}

\section{(Maestrichtian)}

Figures 1-6 Centosphaera barbata Wind and Wise, n. gen., n. sp.

1-3. Holotype USNM 239492, Sample 327A-10-3, $14 \mathrm{~cm}$.

$1,2 . \times 2280$.

3. Detail of surface, $\times 6300$.

4. Paratype USNM 239493; single skeletal element of Centosphaera barbata, Sample 327A-12, CC, $\times 20,000$.

5, 6. Paratype USNM 239494, view of interior of broken specimen, Sample 327A-13-1, $142 \mathrm{~cm}$.
5. $\times 2800$
6. $\times 10,000$. 


\section{PLATE 25}

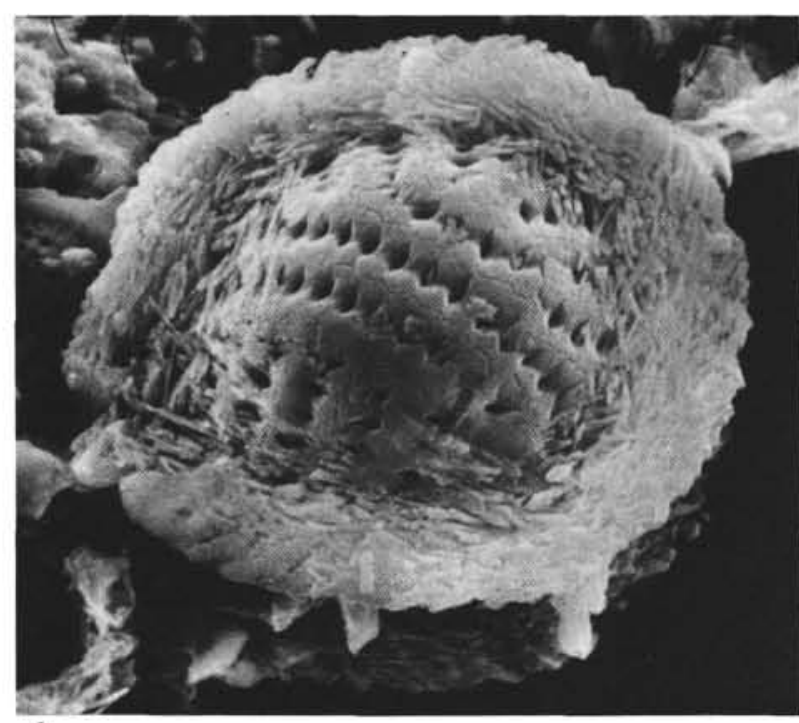

1

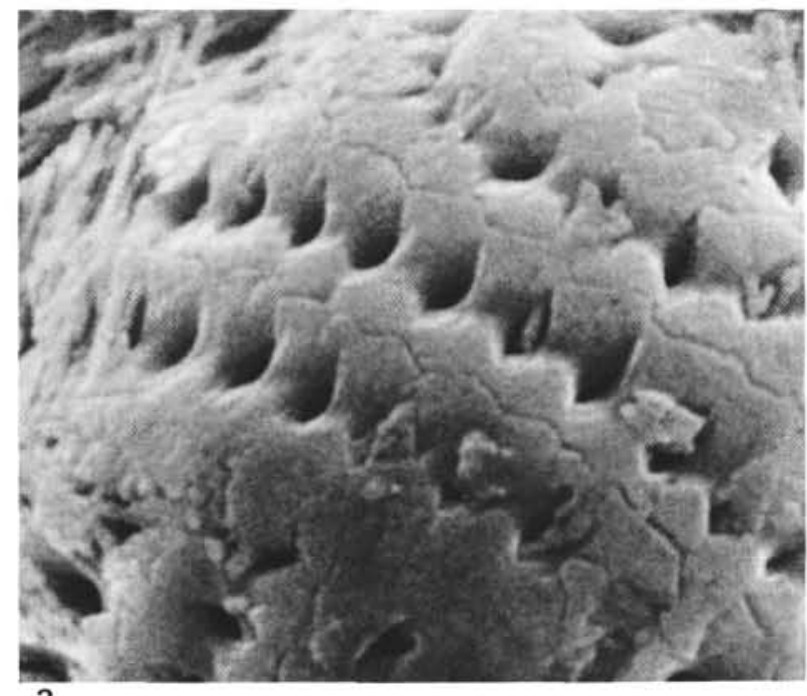

3

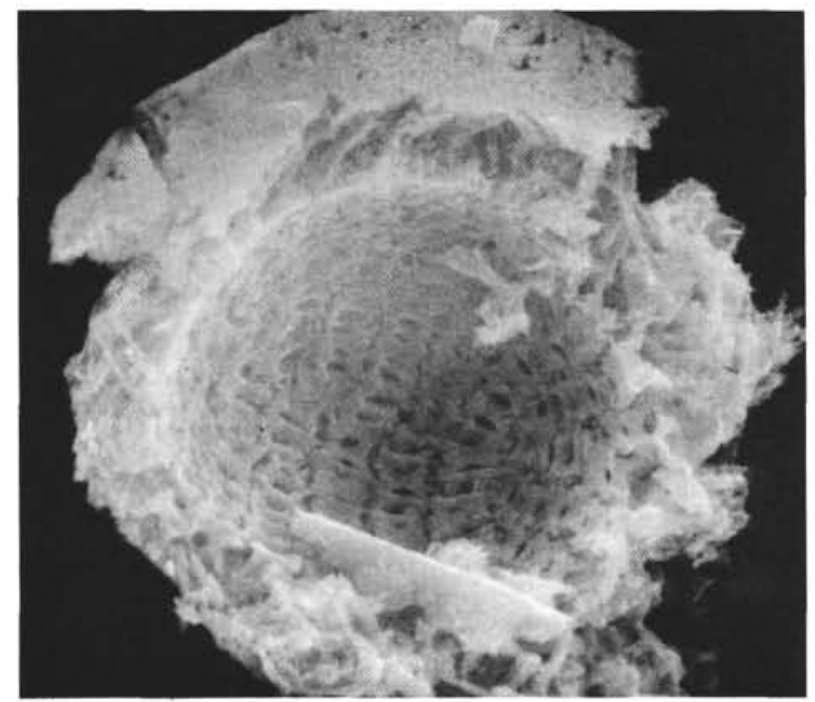

5

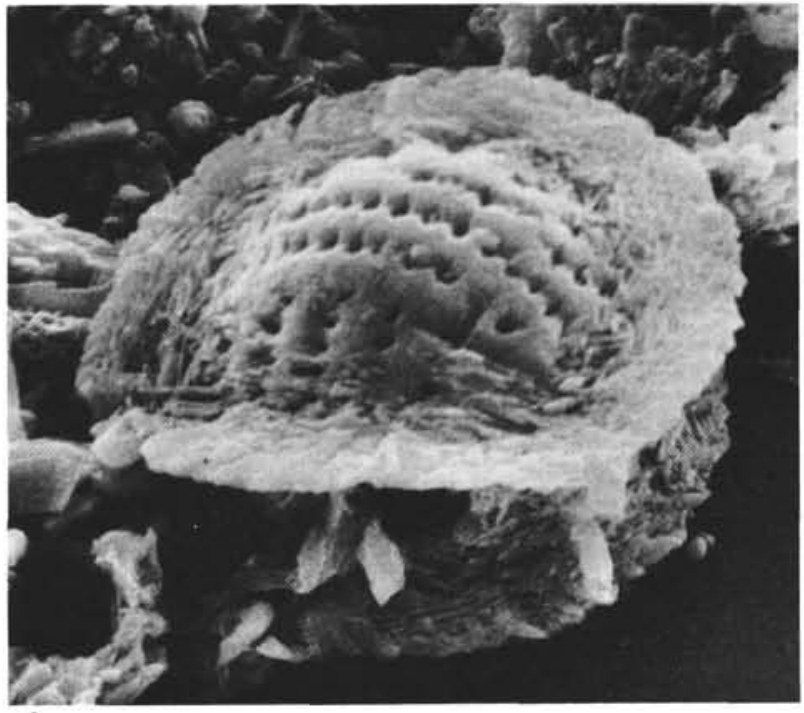

2

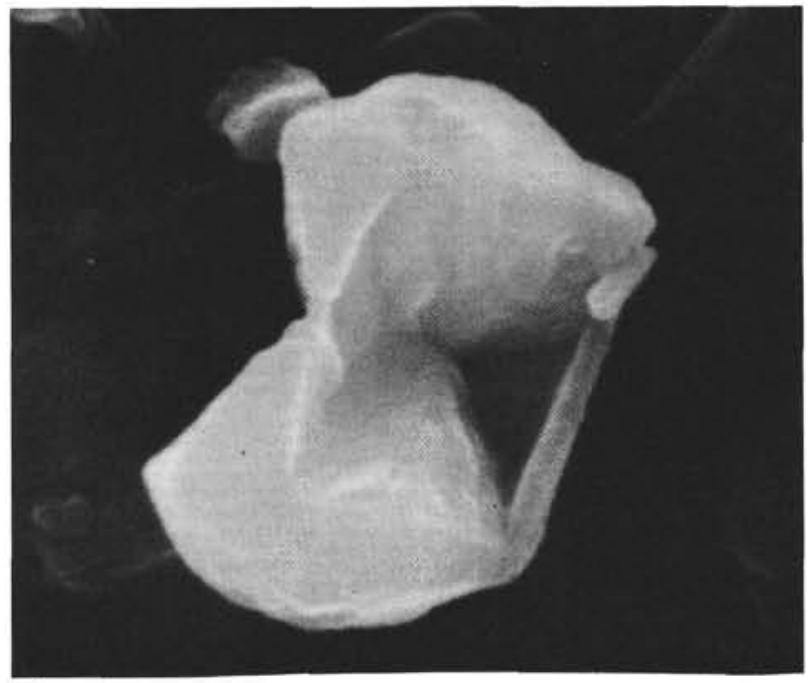

4

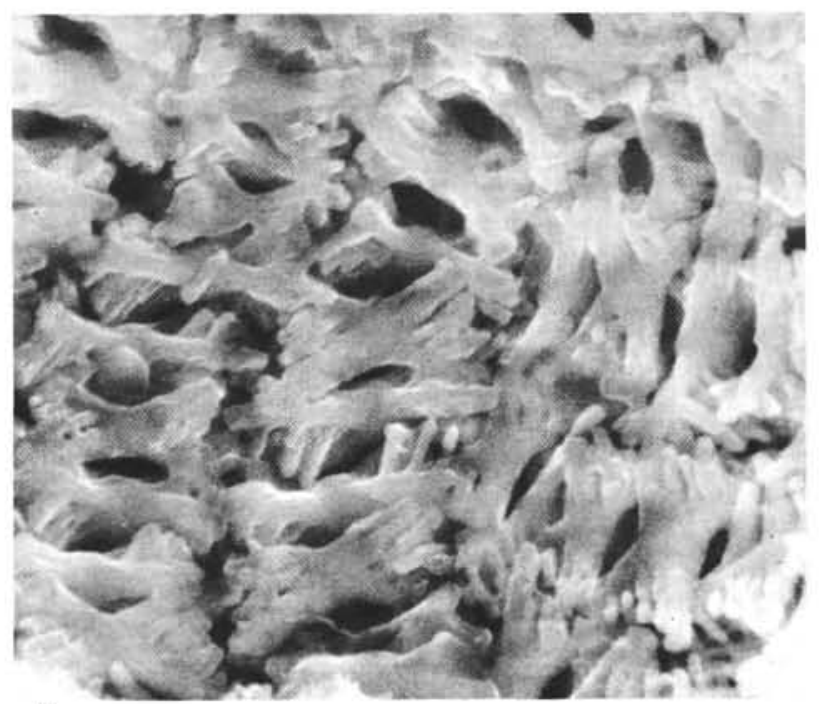

6 
PLATE 26

(Maestrichtian-Campanian)

Figures 1-3 Centosphaera barbata Wind and Wise, n. gen., n. sp.

1, 3. Paratype USNM 239495, Sample 327A-12, CC, $\times 2400$.

2. Paratype USNM 239496, Sample 327A-10-3, $14 \mathrm{~cm}, \times 2800$.

Figure 4 Biscutum notacutum Wind and Wise, n. sp., proximal view, USNM 239526, Sample 327A-12, CC, $\times 21,000$.

Figure 5 ?Ethmorhabdus sp. aff. E. camaratus Bukry, distal view, Sample $327 \mathrm{~A}-13-2,45 \mathrm{~cm}, \times 8000$.

Figure 6 Arkhangelskiella cymbiformis Vekshina, coccosphere illustrating pattern of arrangement and variation in size of component coccoliths, Sample $327 \mathrm{~A}-10-3,14 \mathrm{~cm}, \times 4000$. 
PLATE 26
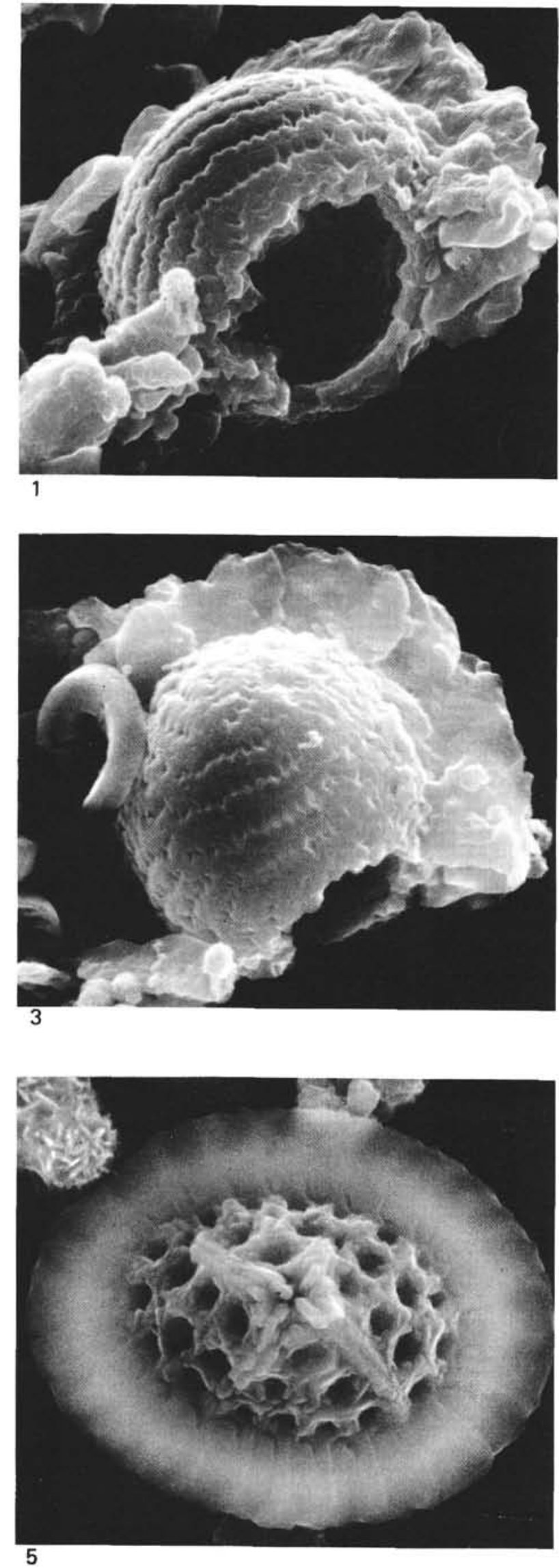

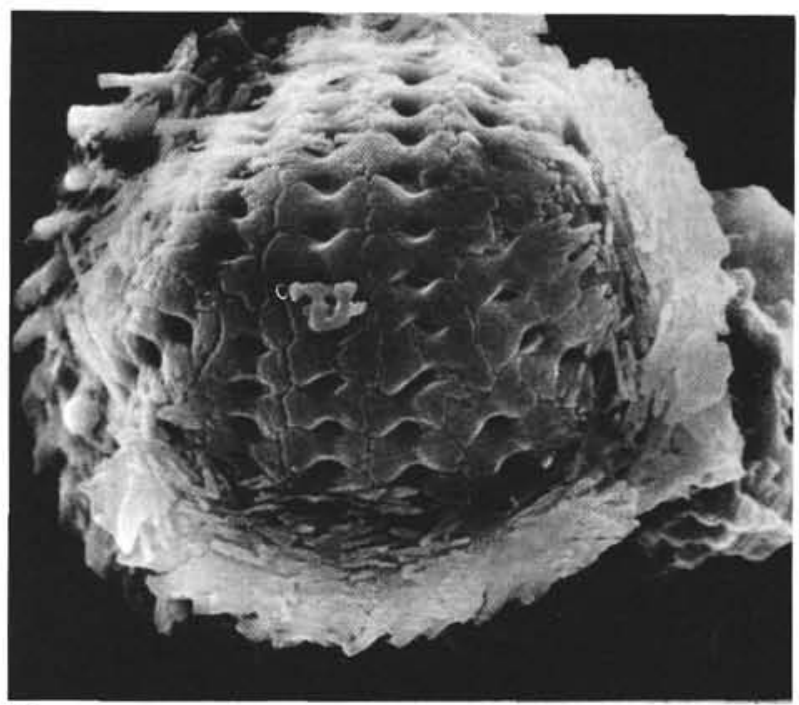

2

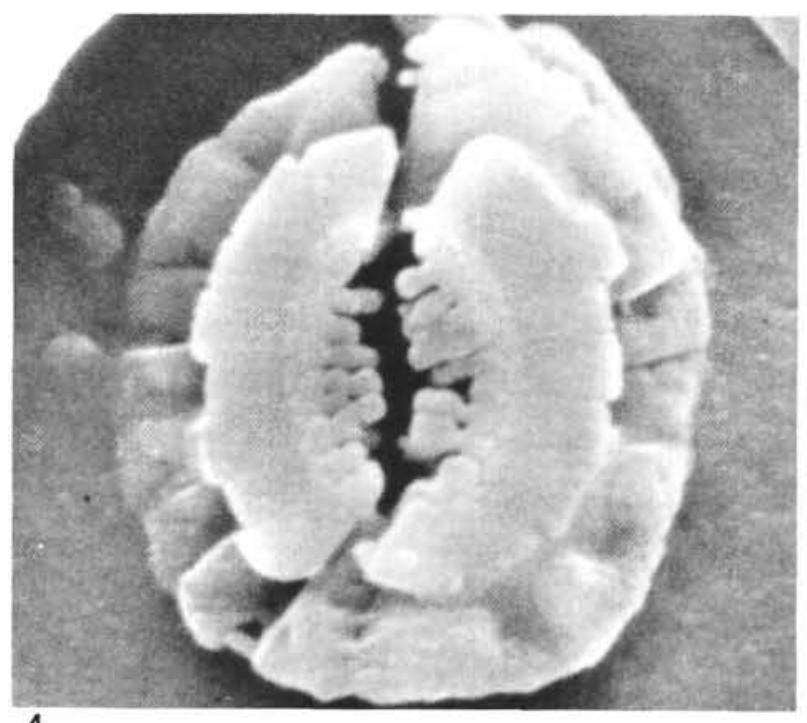

4

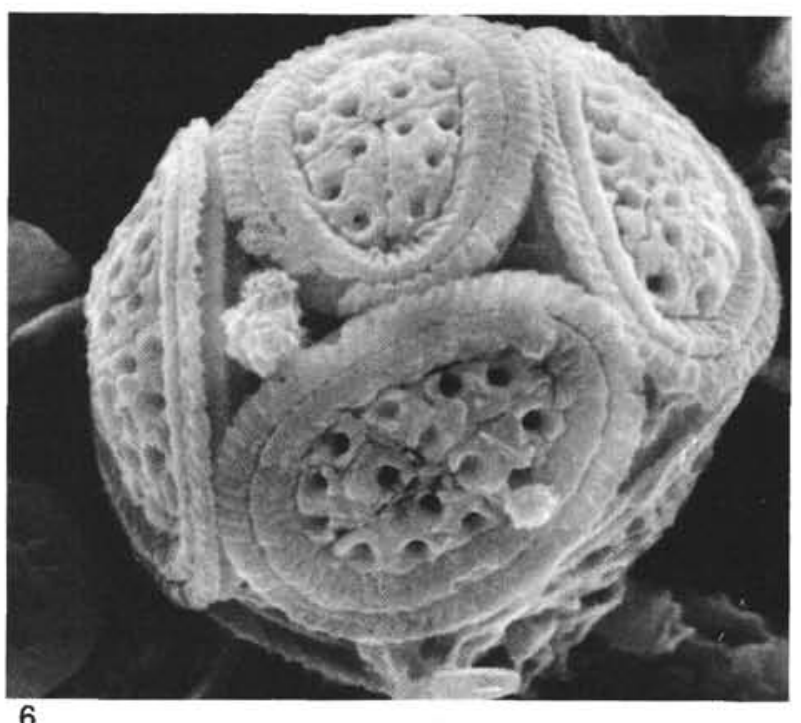




\section{PLATE 27}

(Maestrichtian: Sample 327A-12, CC; polarizing directions for crossed-polarized light are parallel to the plate margin)

Figures 1-7 Centosphaera barbata Wind and Wise, n. sp.

1. Paratype USNM 239497, phase-contrast illumination, $\times 4000$.

2. Paratype USNM 239498, phase-contrast illumination, $\times 4000$.

3-5. Paratype USNM 239499, crossed-polarized light and phase-contrast illumination; $\times 4000$.

6, 7. Paratype USNM 239500, crossed-polarized light and phase-contrast illumination; $\times 4000$.

Figures 8-12 Chiastozygus garrisonii Bukry.

8 , 9. Crossed-polarized light and phase-contrast illumination, $\times 5000$.

10-12. Crossed-polarized light and phase-contrast illumination, $\times 5200$. 
PLATE 27
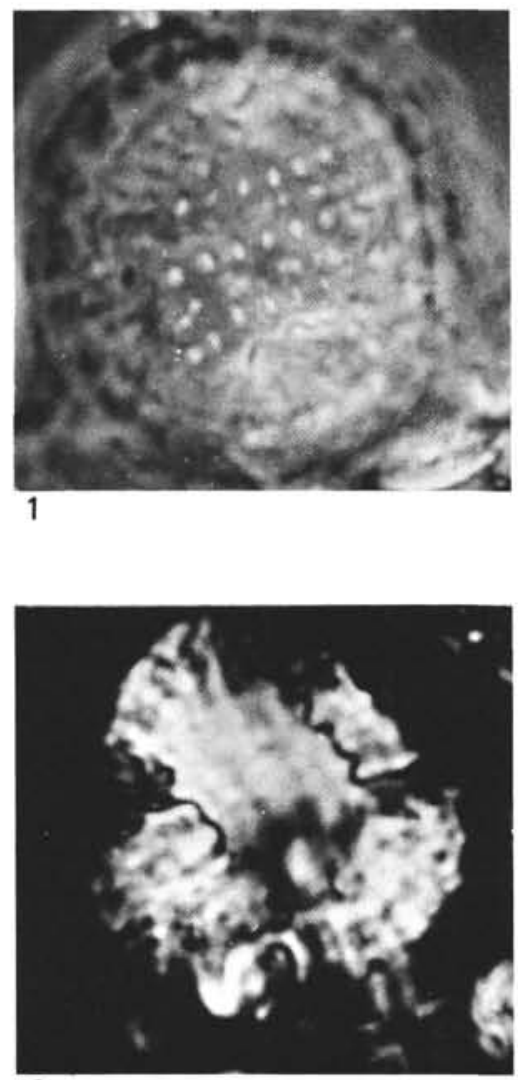

6

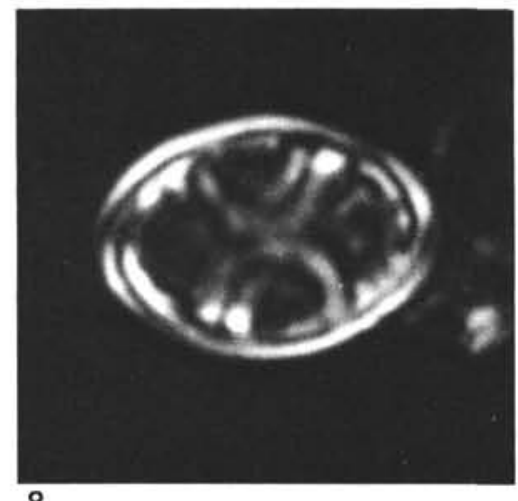

8

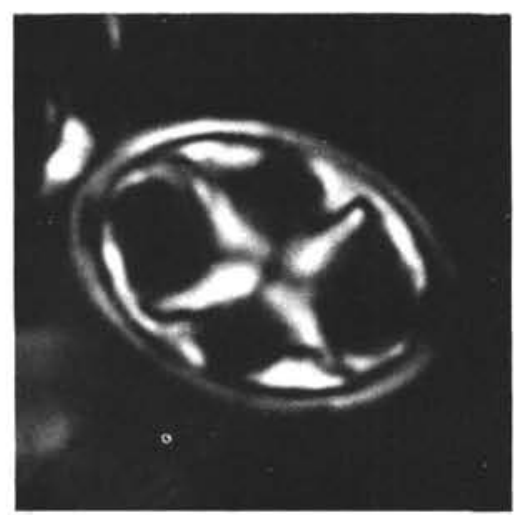

10
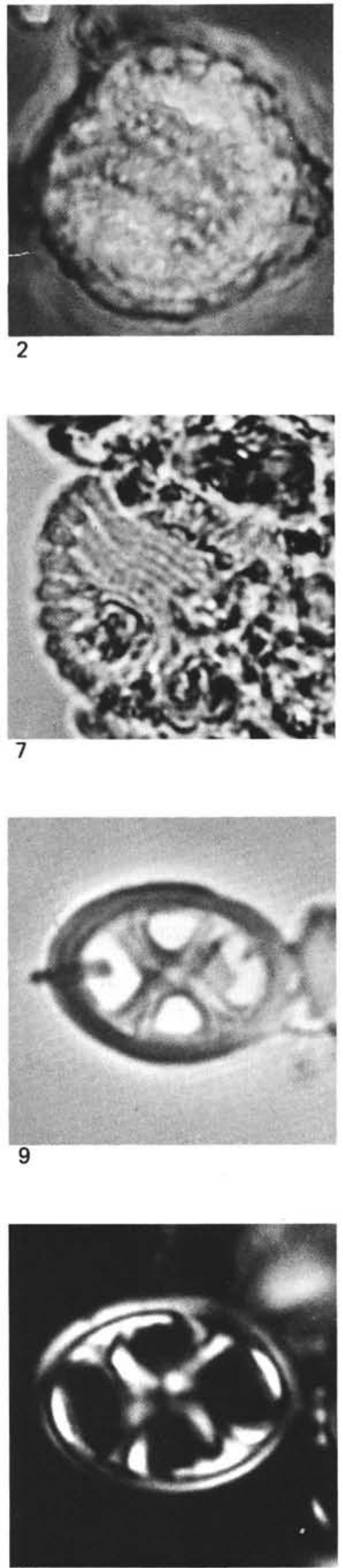

11

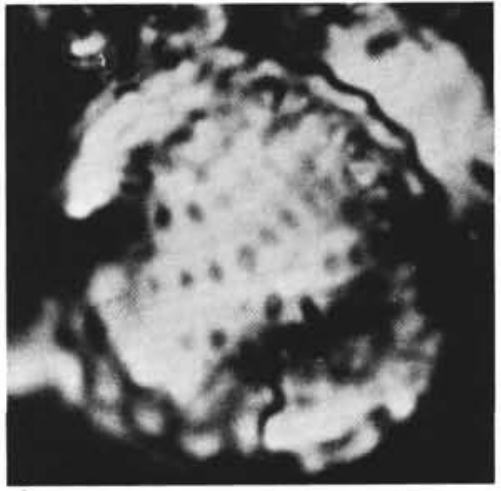

3

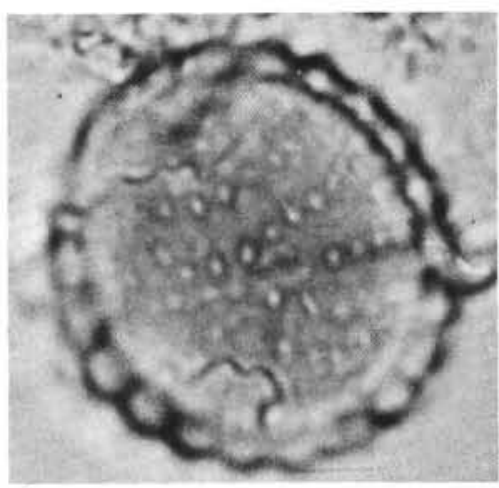

4
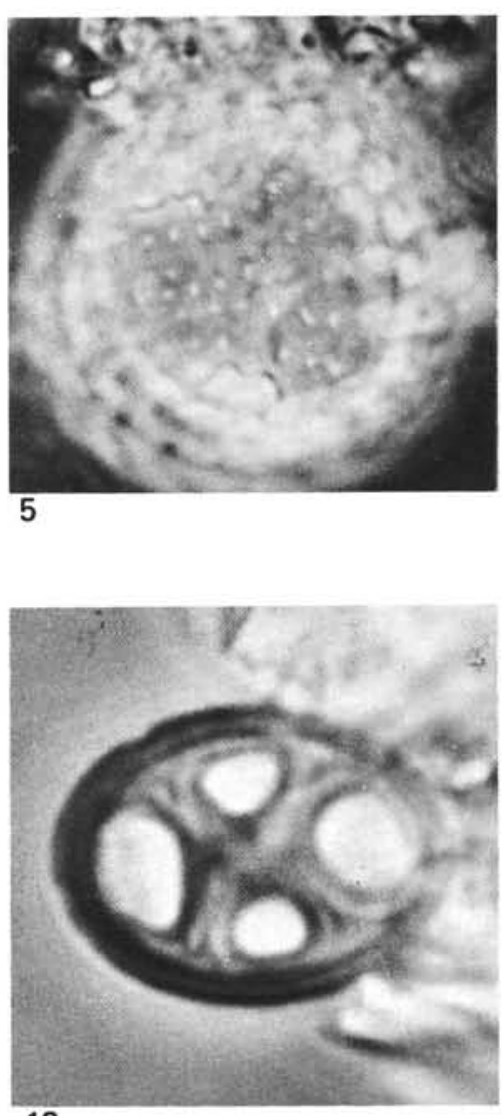


\section{PLATE 28}

\section{(Maestrichtian)}

Figures 1-3 Broinsonia verecundia Wind and Wise, n. sp.

1. Holotype USNM 239501, distal view, Sample $327 \mathrm{~A}-12, \mathrm{CC}, \times 18,000$.

2. Paratype USNM 239502, proximal view, Sample $327 \mathrm{~A}-12$, CC, $\times 20,000$.

3. Paratype USNM 239503, distal view, Sample $327 \mathrm{~A}-12, \mathrm{CC}, \times 17,000$.

Figures 4, 5 Chiastozygus garrisonii Bukry, lateral-distal and distal views, Sample 327A-12, CC.

4. $\times 11,000$.

5. $\times 10,000$.

Figure 6 Genus and species indet., distal view, Sample $327 \mathrm{~A}-12, \mathrm{CC}, \times 19,000$. 
PLATE 28
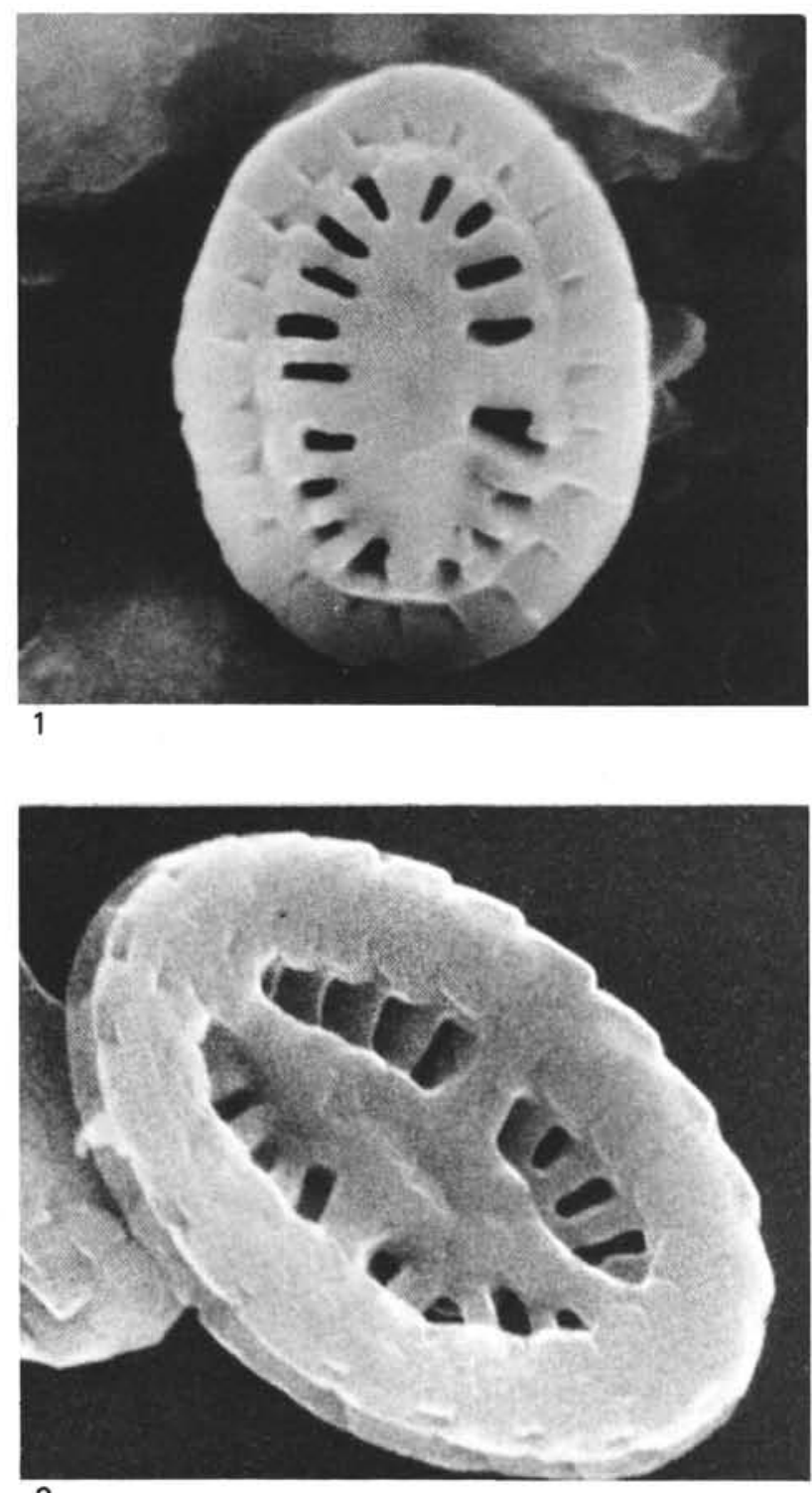

2

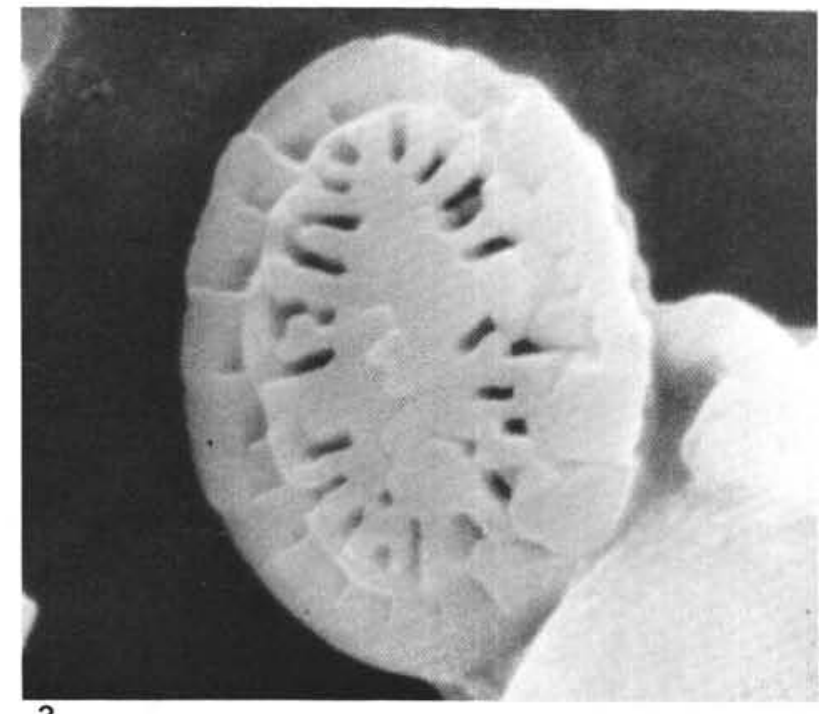

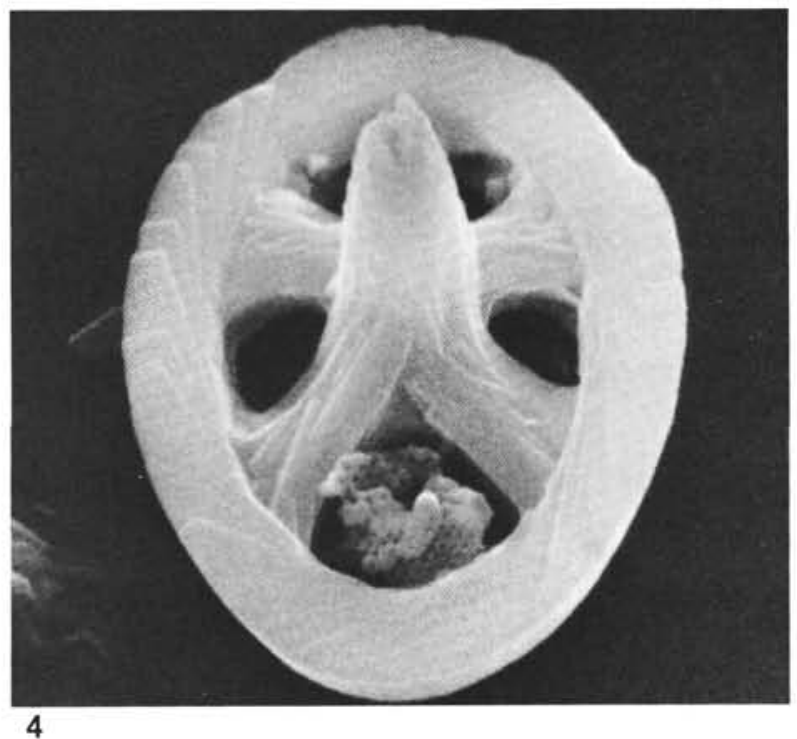

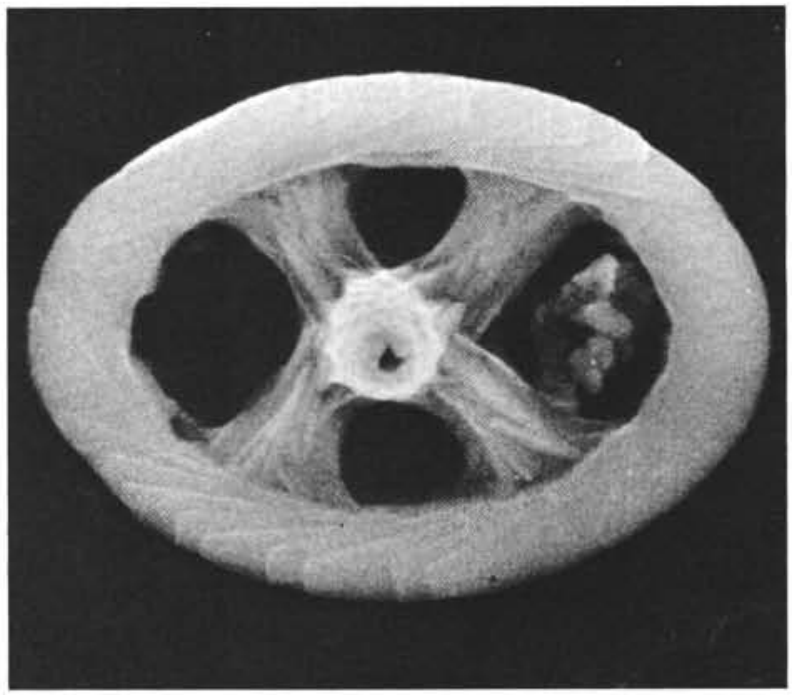

5

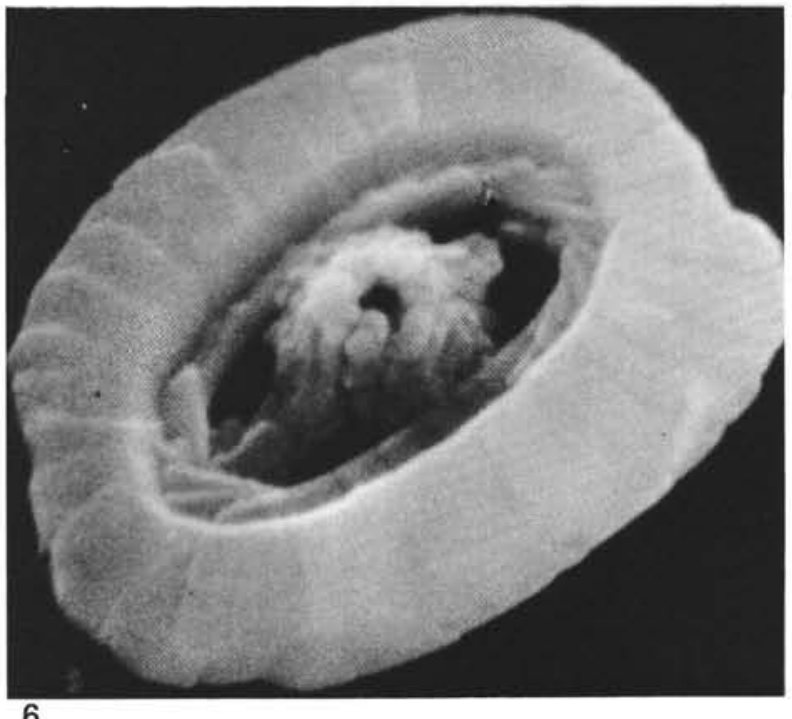

6 


\section{PLATE 29}

(Maestrichtian)

Figures 1, 2 Gartnerago diversum Thierstein, 1972, Sample 327A-13-1, $142 \mathrm{~cm}$.

1. Proximal view, $\times 7000$.

2. Distal view, $\times 7700$.

Figure 3 ?Broinsonia sp., distal view, Sample 327A-13-1, $142 \mathrm{~cm}, \times 7000$. This specimen resembles several specimens described by Bukry (1969) as $B$. parca (Stradner).

Figures 4-6 Arkhangelskiella specillata Vekshina.

4. Distal view, Sample 327A-13-1, $142 \mathrm{~cm}, \times 8000$.

5. Distal view (with Zygodiscus sp.), Sample 327A-12, CC, $\times 6000$.

6. Proximal view, Sample $327 \mathrm{~A}-13-1,142 \mathrm{~cm}$, $\times 7000$. 


\section{PLATE 29}

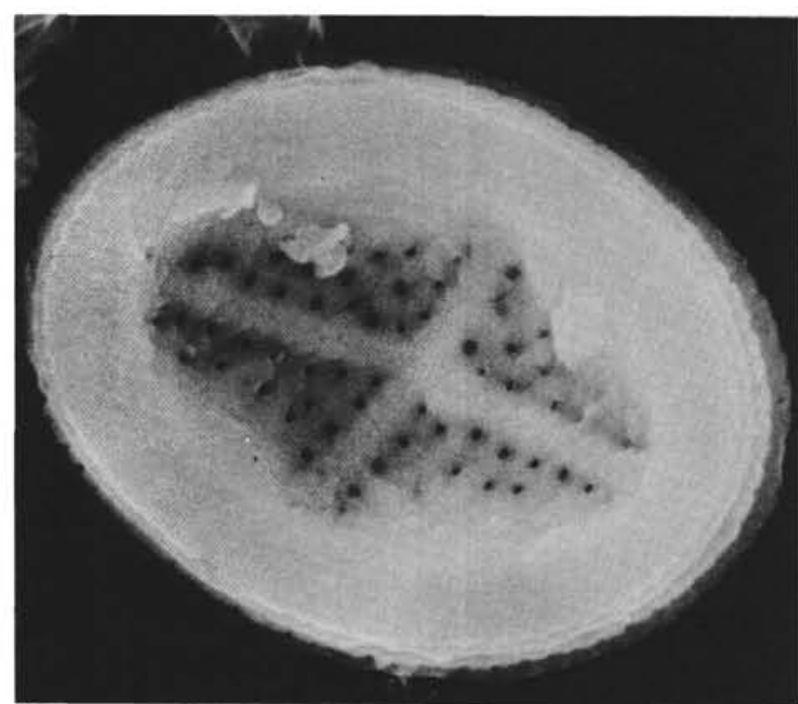

1

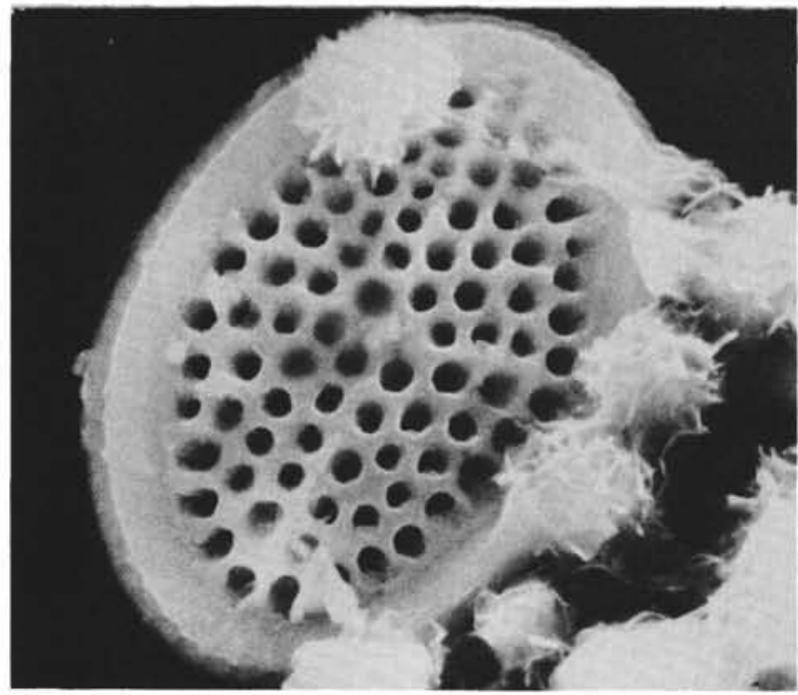

3

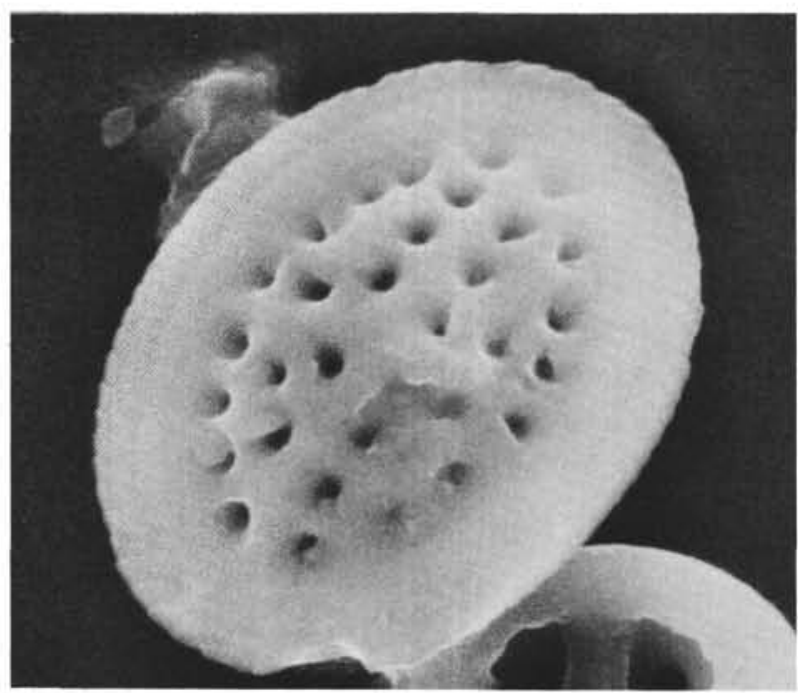

5

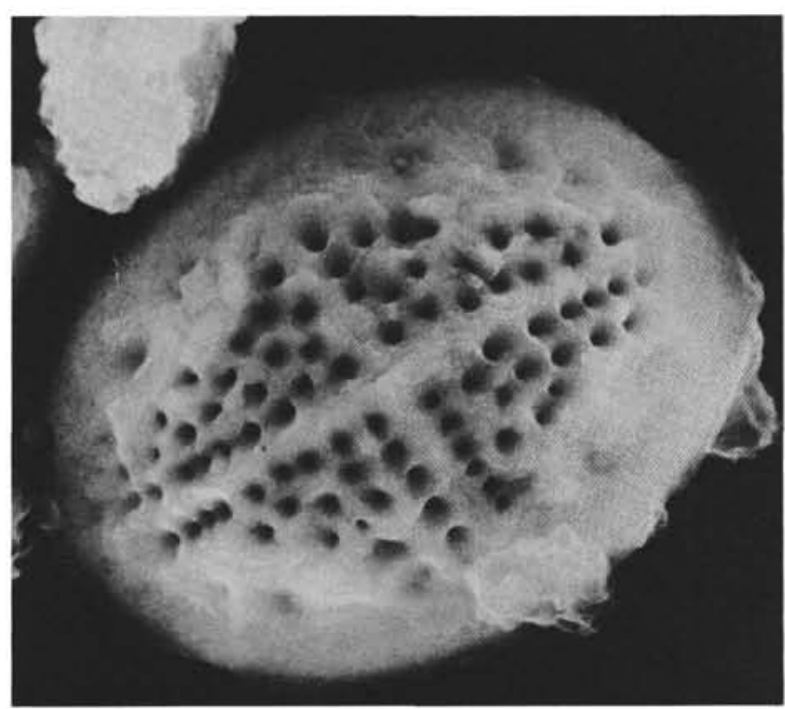

2

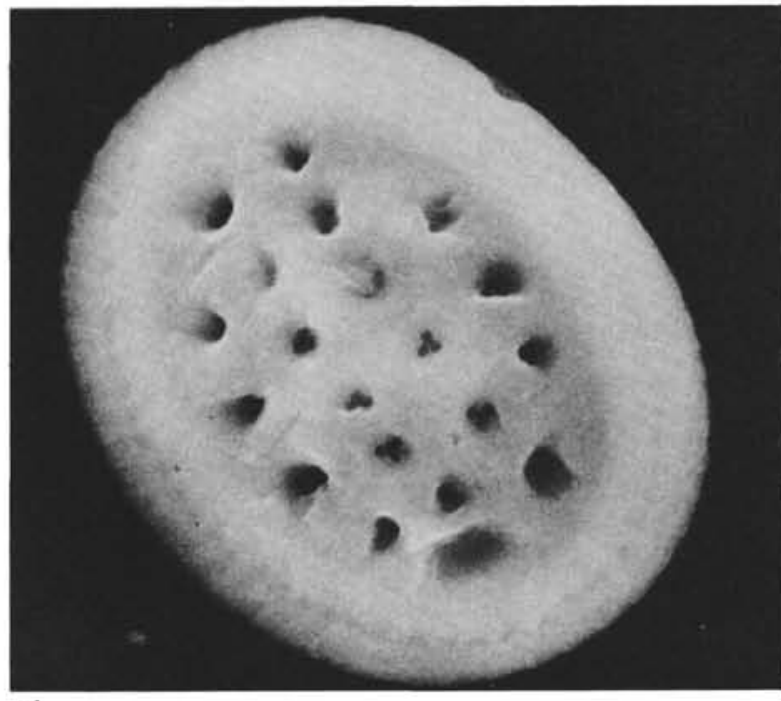

4

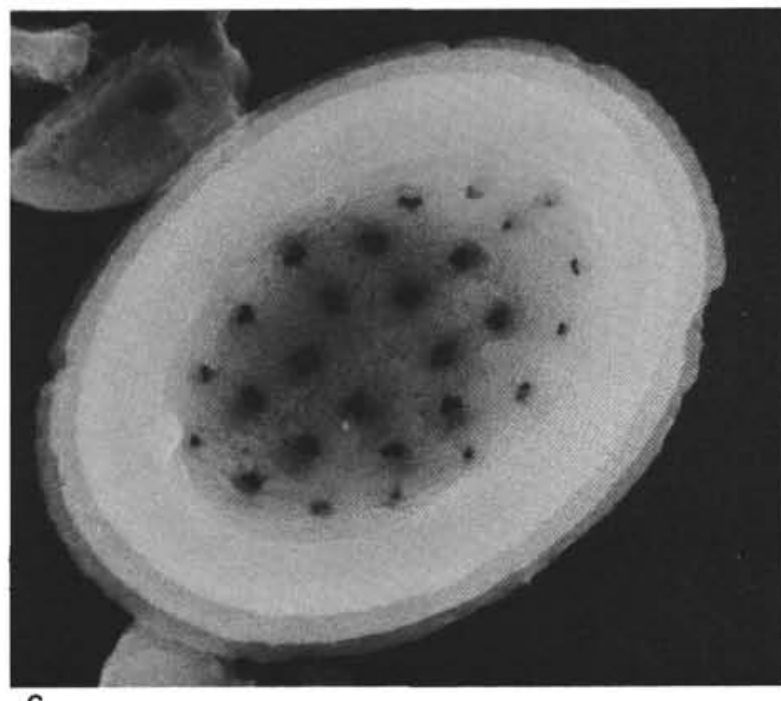

6 
PLATE 30

(Maestrichtian; polarizing directions for crossed-polarized light are parallel to the plate margins)

Figure 1 Biscutum magnum Wind and Wise, n. sp. (a) and B. notaculum Wind and Wise, n. sp. (b) phasecontrast and crossed-polarized light, Sample $327 \mathrm{~A}-12, \mathrm{CC}, \times 3800$.

1a. Paratype USNM 239512.

1b. Holotype USNM 239517.

Figure 2 Phanulithus additus Wind and Wise, n. sp. holotype USNM 239505, crossed-polarized light (a), phase-contrast illumination (b), scanning electron micrographs; distal-lateral view; (c), and distal view (d); Sample 327A-12, CC; light micrographs $\times 4200$, electron micrographs $\times 10,000$. 
PLATE 30
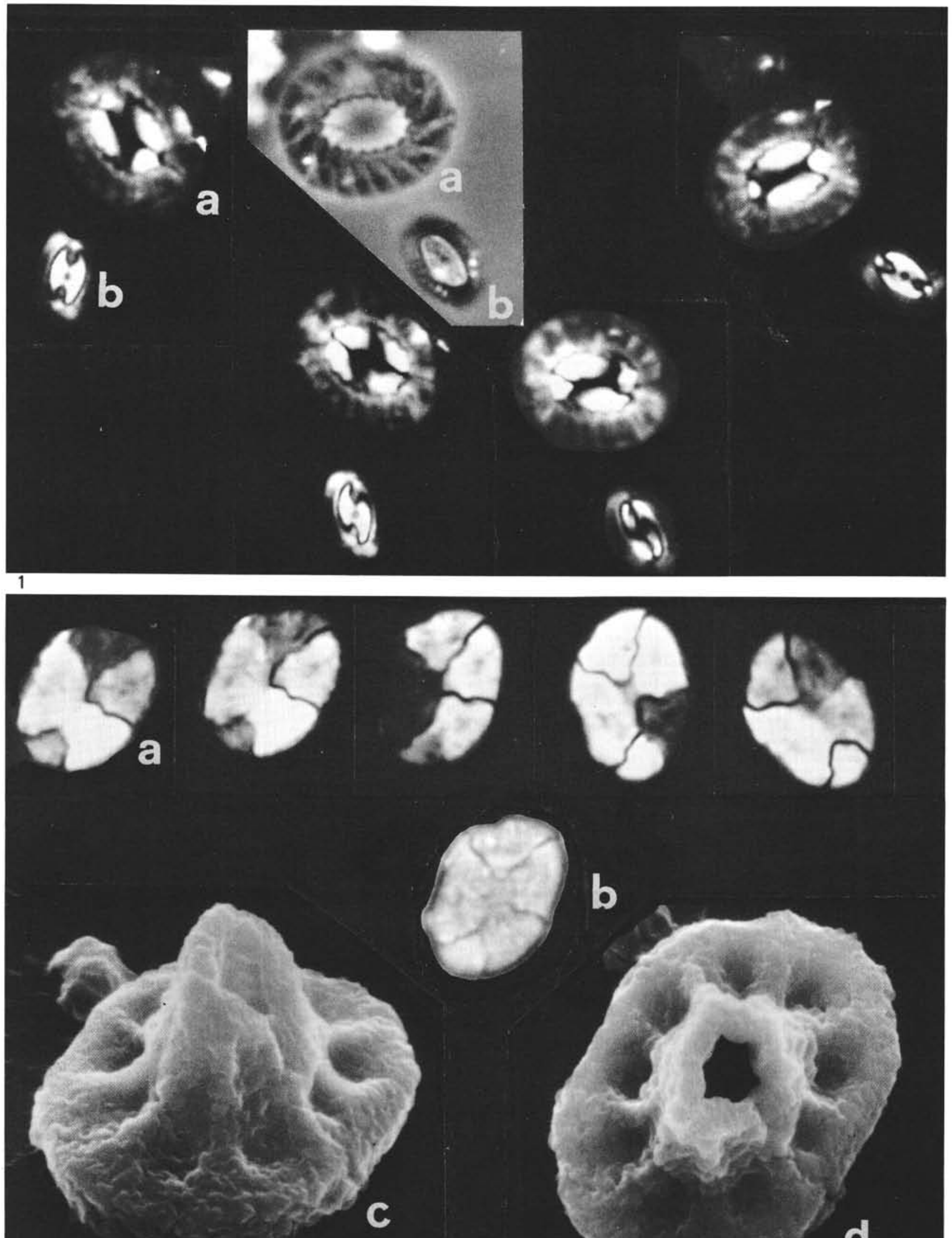

e

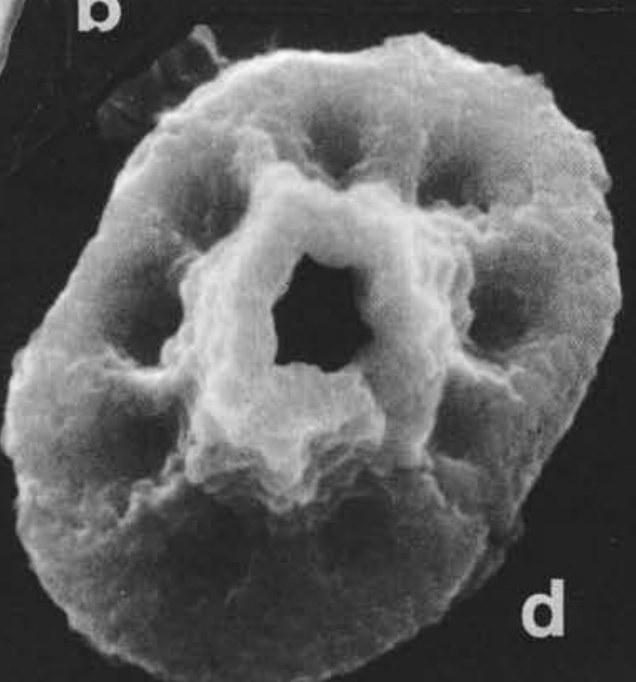


PLATE 31

(Maestrichtian-Campanian)

Figures 1,2 Cyclagelosphaera margareli Noël, lateral-distal and distal views, Sample 327A-13-2, $54 \mathrm{~cm}$.

1. $\times 17,500$.

2. $\times 16,000$.

Figure 3 Thoracosphaera sp., Sample $327 \mathrm{~A}-13-2,54 \mathrm{~cm}$, $\times 4000$.

Figure $4 \quad$ Corollithion rhombicum (Stradner and Adamiker), Sample 327A-12, CC, $\times 15,000$.

Figure 5 Phanulithus sp., distal views, Sample 327A-12, CC, $\times 10,300$. Inability to identify suture positions prevents determination of species affinity. 


\section{PLATE 31}

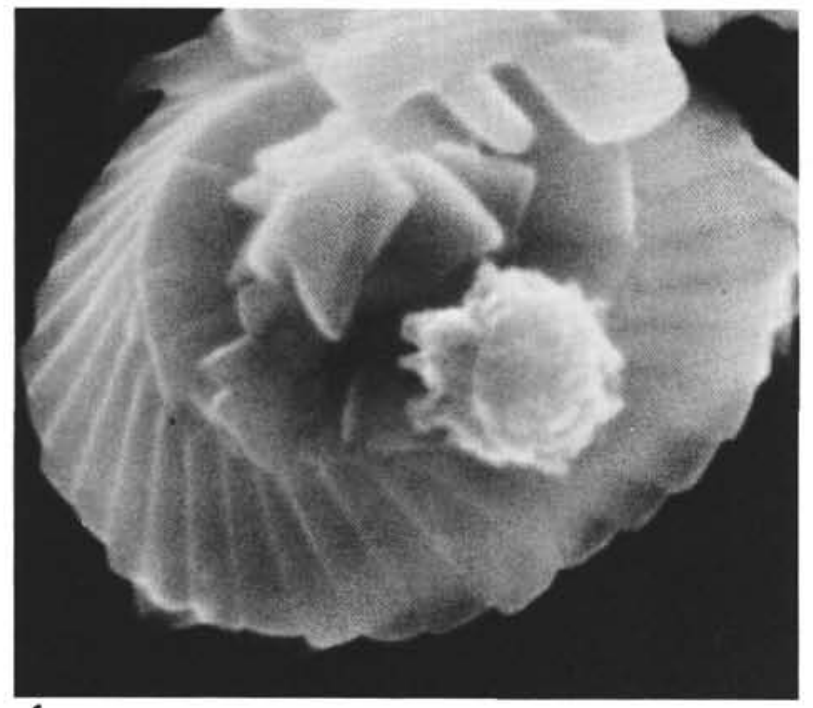

1

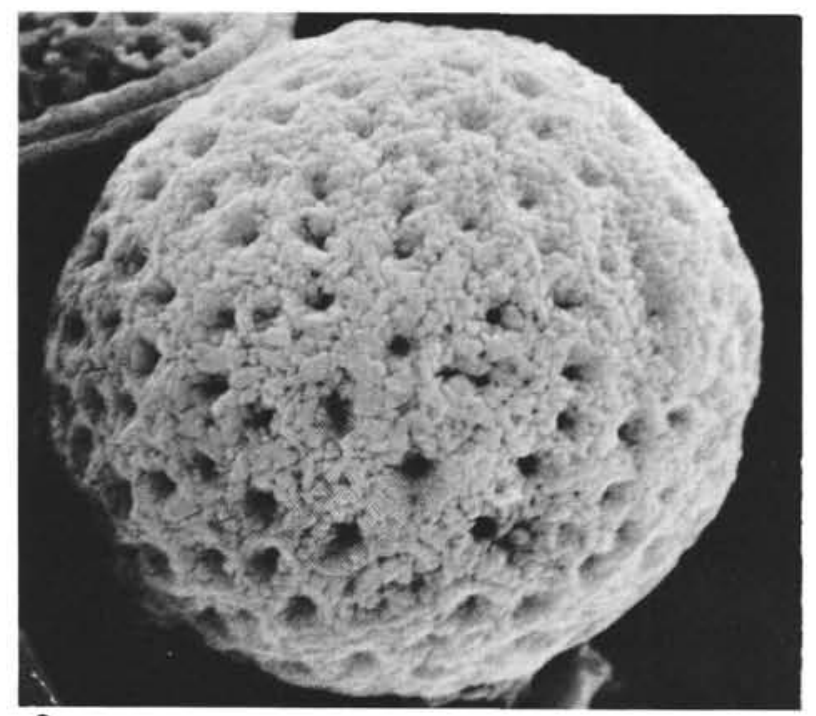

3

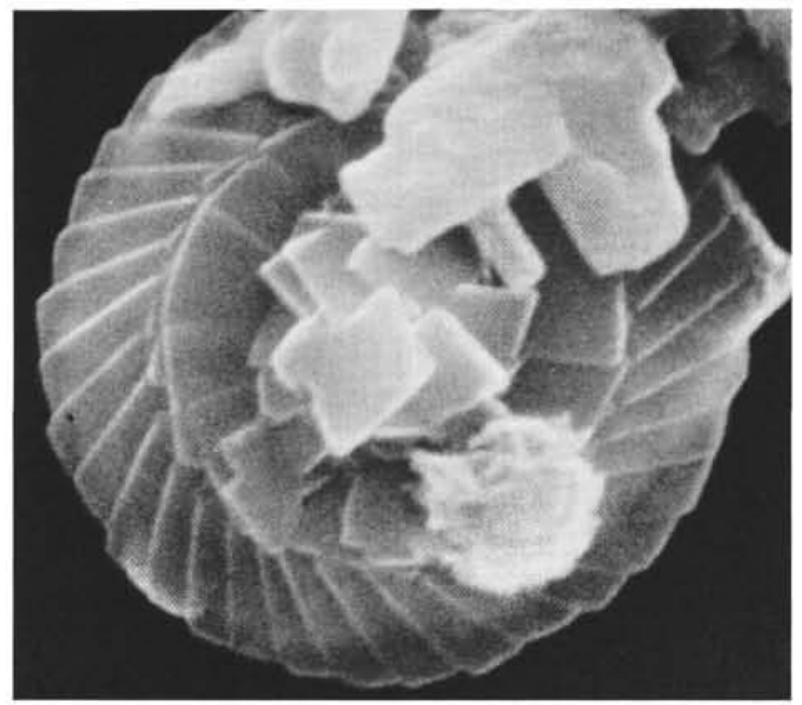

2

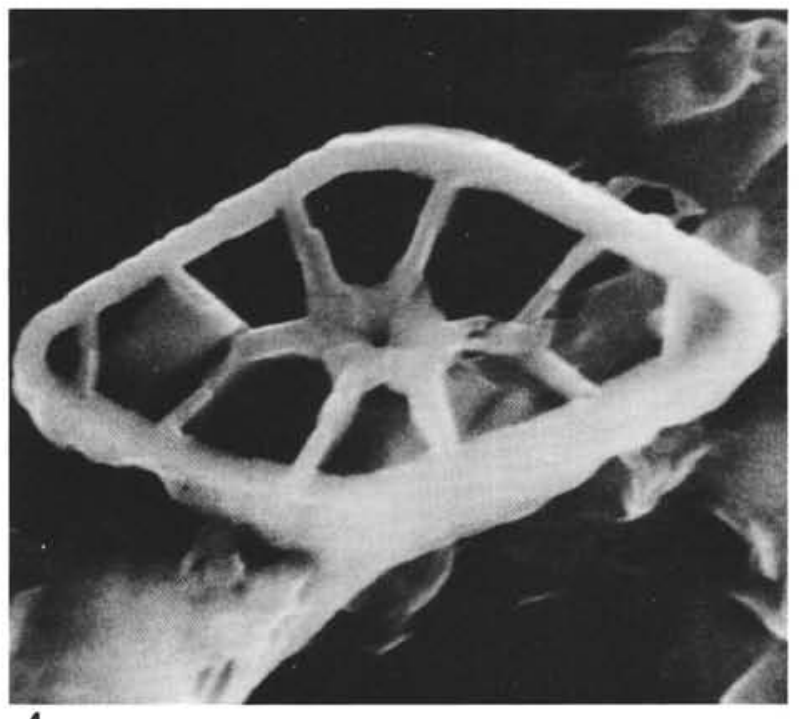

4

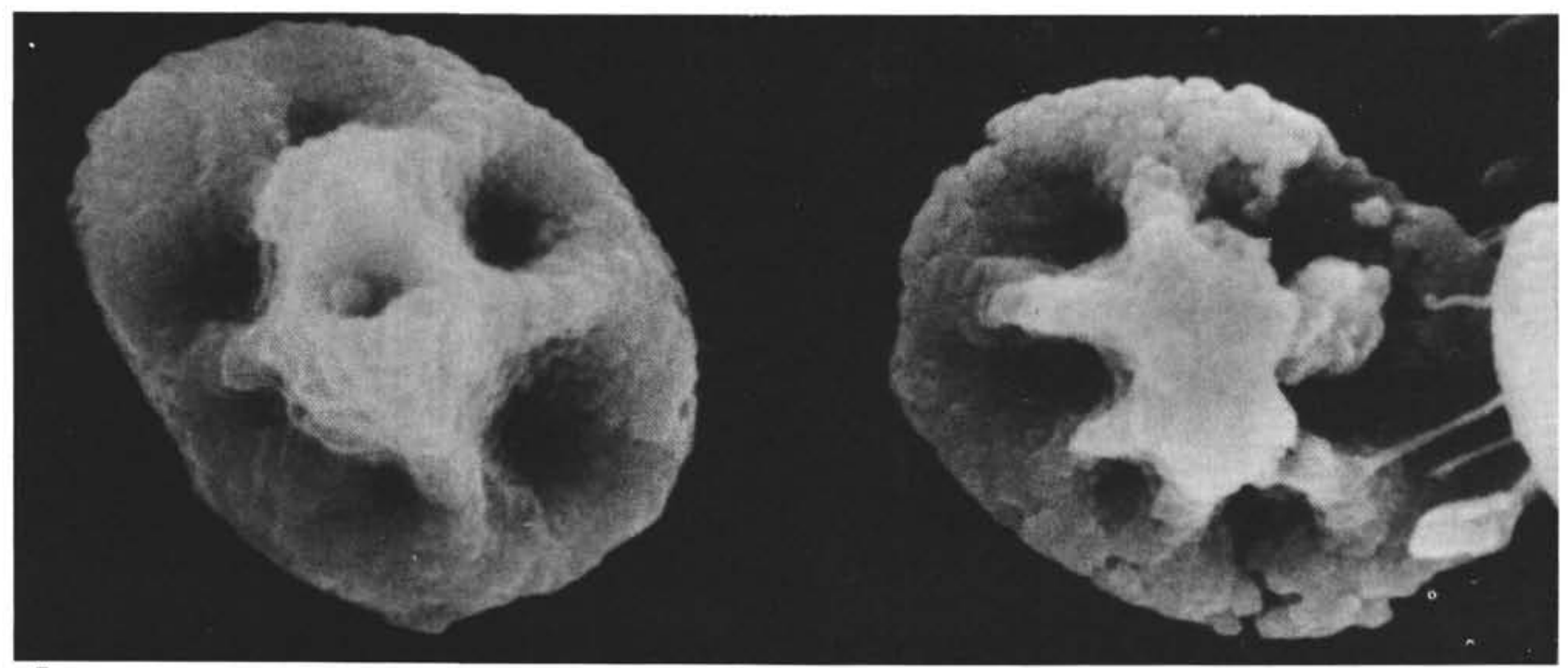




\section{PLATE 32}

\section{(Maestrichtian)}

Figures 1,2 Lucianorhabdus arcuatus Forchheimer, Sample 327A-12, CC.

1. $\times 4800$.

2. $\times 5000$.

Figures 3,5 Lucianorhabdus arborius Wind and Wise, n. sp., holotype USNM 239506, lateral and lateral-distal views, Sample 327A-12, CC, $\times 7000$.

Figure 4 Lucianorhabdus sp., lateral view, Sample 327A-11$1,107 \mathrm{~cm}, \times 7100$.

Figure 6 Lucianorhabdus sp., proximal-lateral view illustrating tetralithic nature of base, Sample 327A$10-3,14 \mathrm{~cm}, \times 7000$. 
PLATE 32
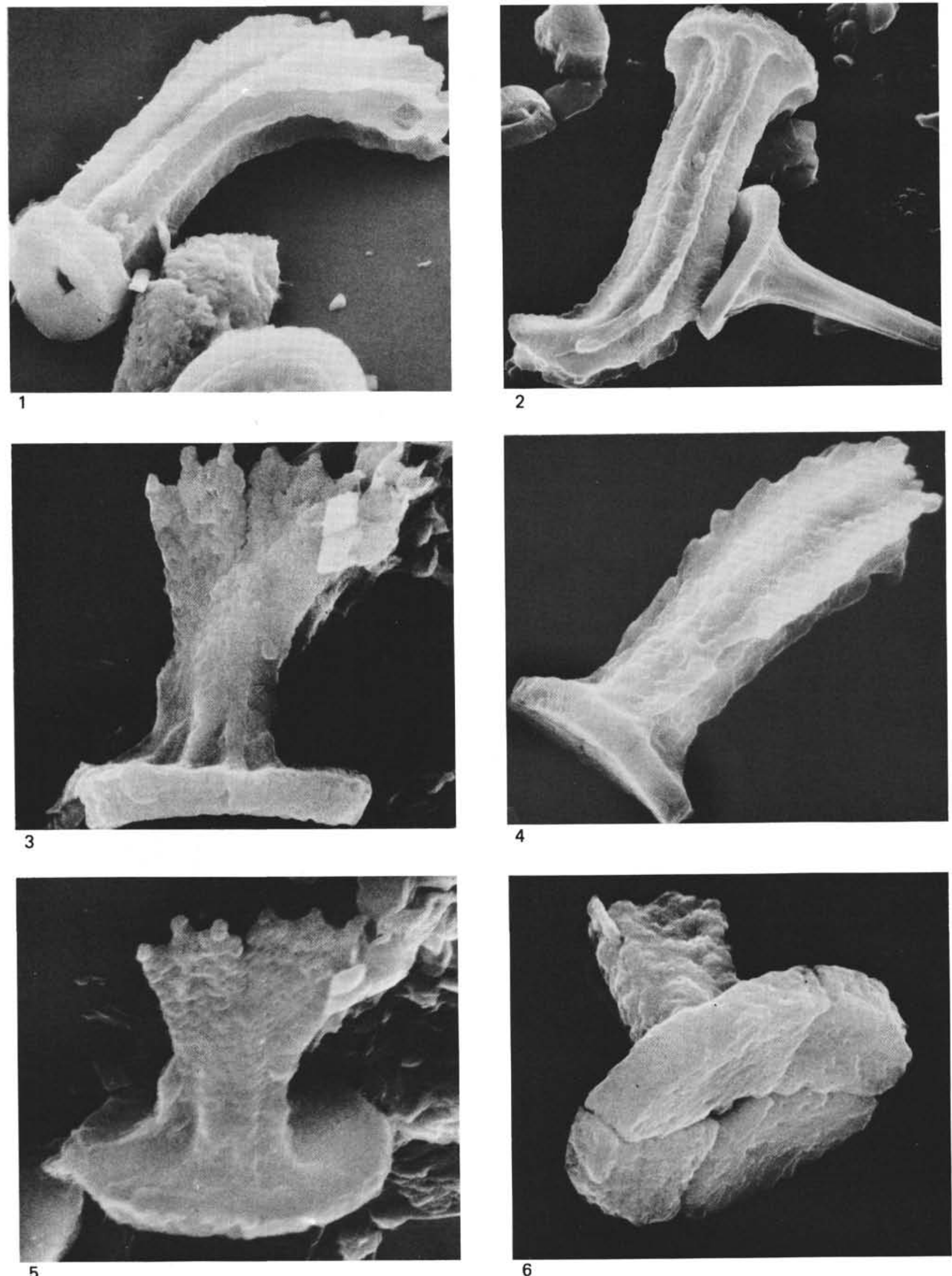


\section{PLATE 33}

(Maestrichtian)

Figures 1-3 Acuturris scotus (Risatti) Wind and Wise, n. comb., Sample 327A-12, CC.

1. $\times 7600$.

2. (Right) with Phanulithus obscurus (Deflandre) (left); $\times 5300$.

3. Specimen partially disarticulated, illustrating three-part construction, $\times 7300$.

Figures 4-6 Phanulithus obscurus (Deflandre) Wind and Wise, n. comb.; Sample 327A-12, CC.

4. Distal view of the two larger quadrants of wellsculptured specimen, $\times 14,000$.

5. $\times 10,000$.

6. Three short-spined or spineless specimens, $\times 7200$. The central specimen is seen in proximal view. The spineless specimen at right, seen in distal view, bears more subdued sculpturing than the short spine-bearing specimen (left). The tetralithic nature of these three specimens is evident when they are viewed with crossed-polarized light (insert). 


\section{PLATE 33}

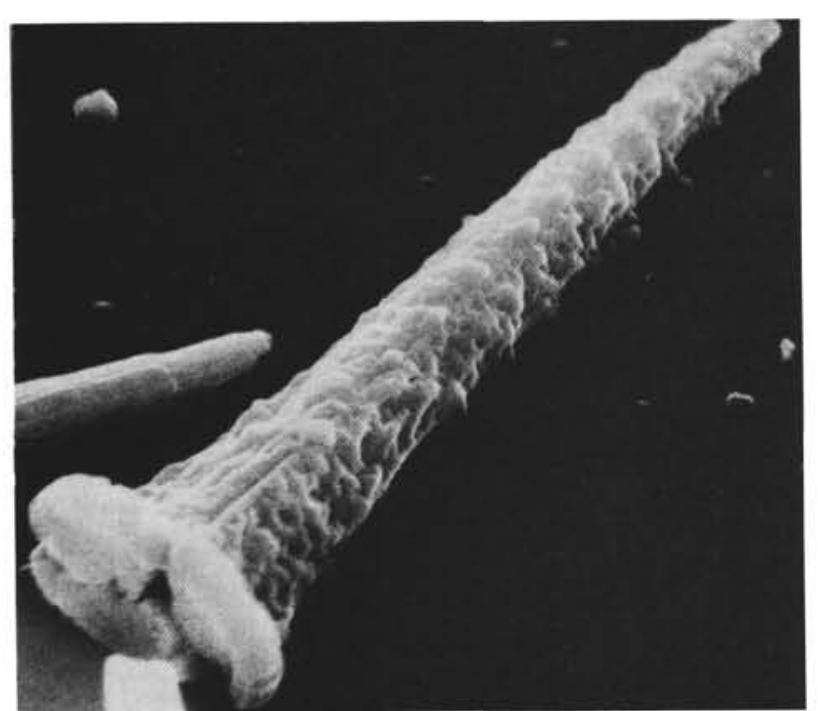
1

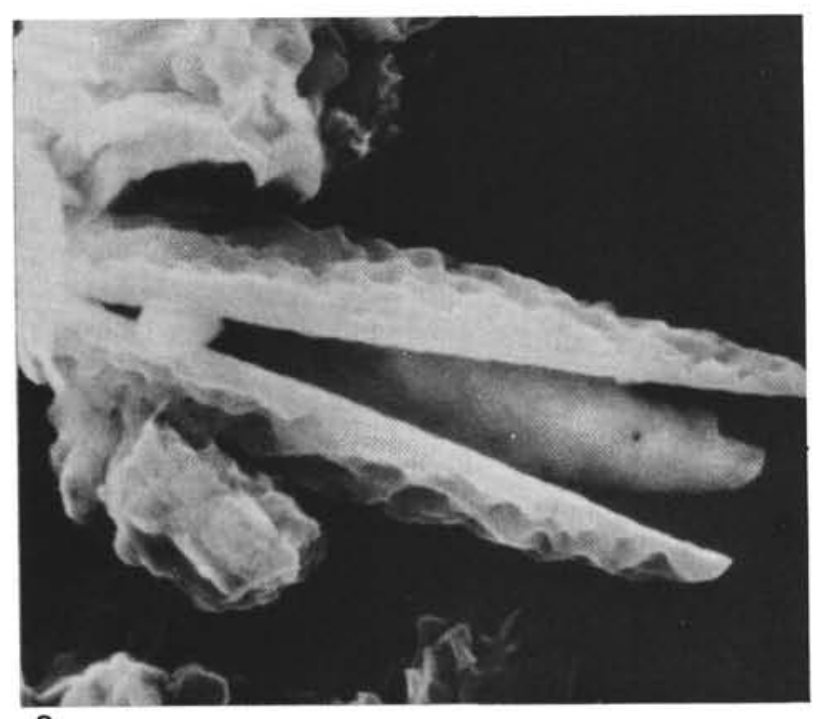

3

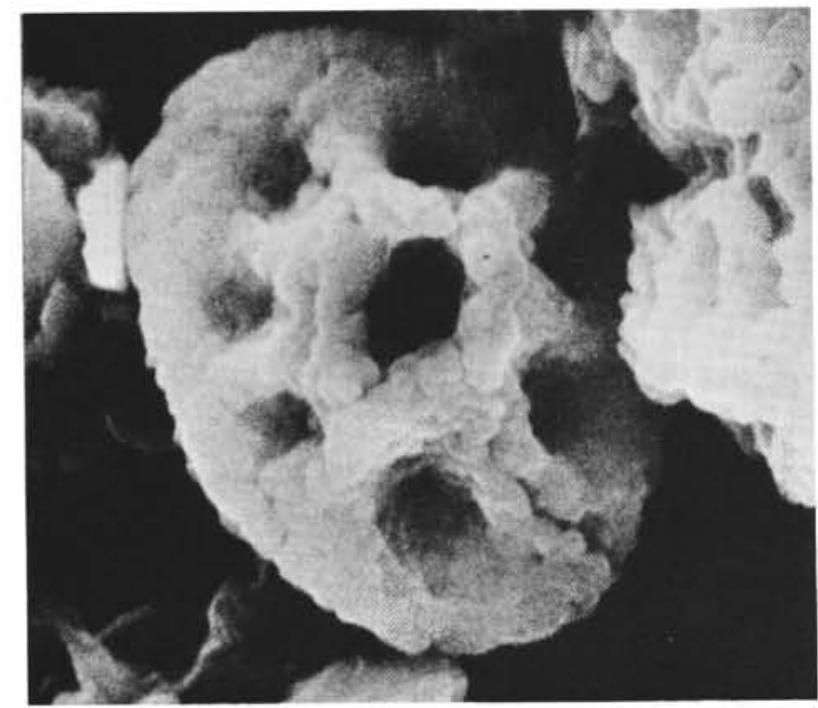

5
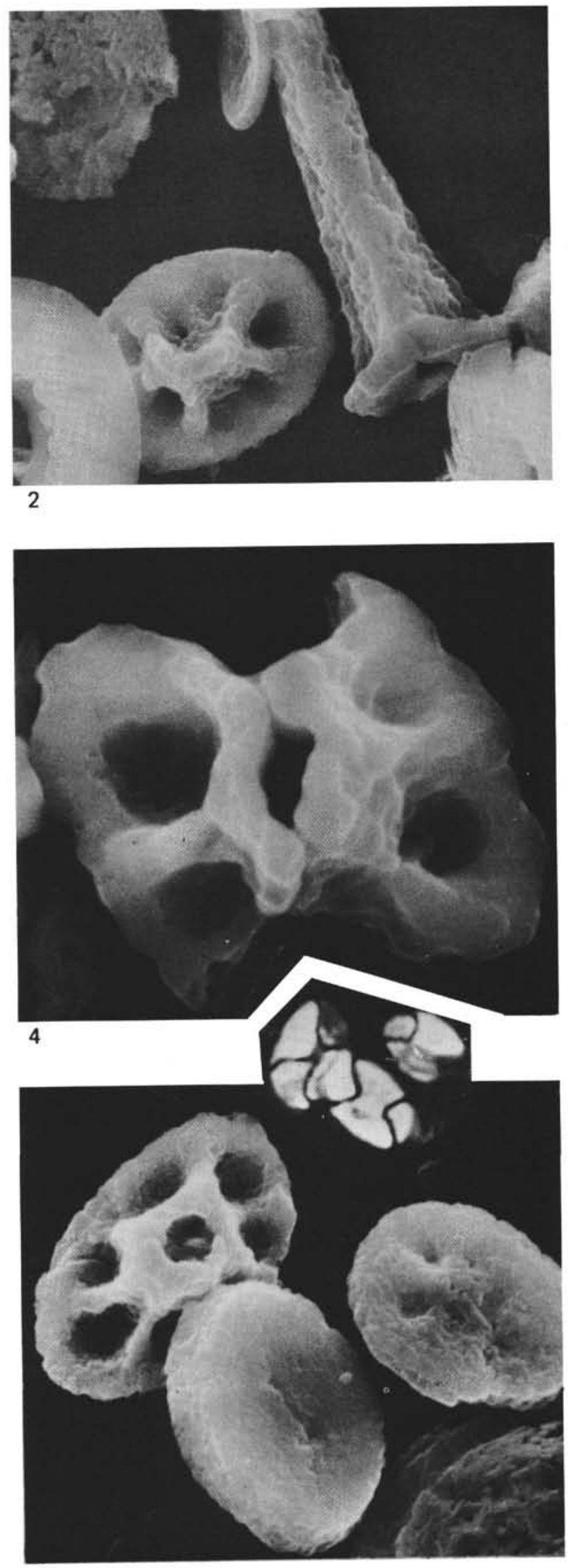

6 


\section{PLATE 34}

(Maestrichtian; polarizing directions for crossed-polarized light are parallel to the plate margin)

Figure $1 \quad$ Phanulithus ovalis (Stradner) Wind and Wise, n. comb., phase-contrast (a) and crossed-polarized light (b), Sample 327A-12, CC, $\times 4300$.

Figures 2-4 Phanulithus obscurus (Deflandre) Wind and Wise, n. comb. Specimens illustrated in phase-contrast (a) and crossed-polarized light (b), Sample 327A12, CC.

2. Specimen with well-developed rim, $\times 4300$.

3. Specimen with extremely small minor segments, $\times 3700$.

4. Specimen with partial rim, $\times 4900$.

Figure 5 Phanulithus additus Wind and Wise, n. sp., paratype USNM 239507, phase-contrast (a) and crossed-polarized light (b), Sample 327A-12, CC, $\times 3700$.

Figure 6 Phanulithus sp. aff. P. obscurus, Sample 327A-12, $\mathrm{CC}, \times 4300$. 
PLATE 34
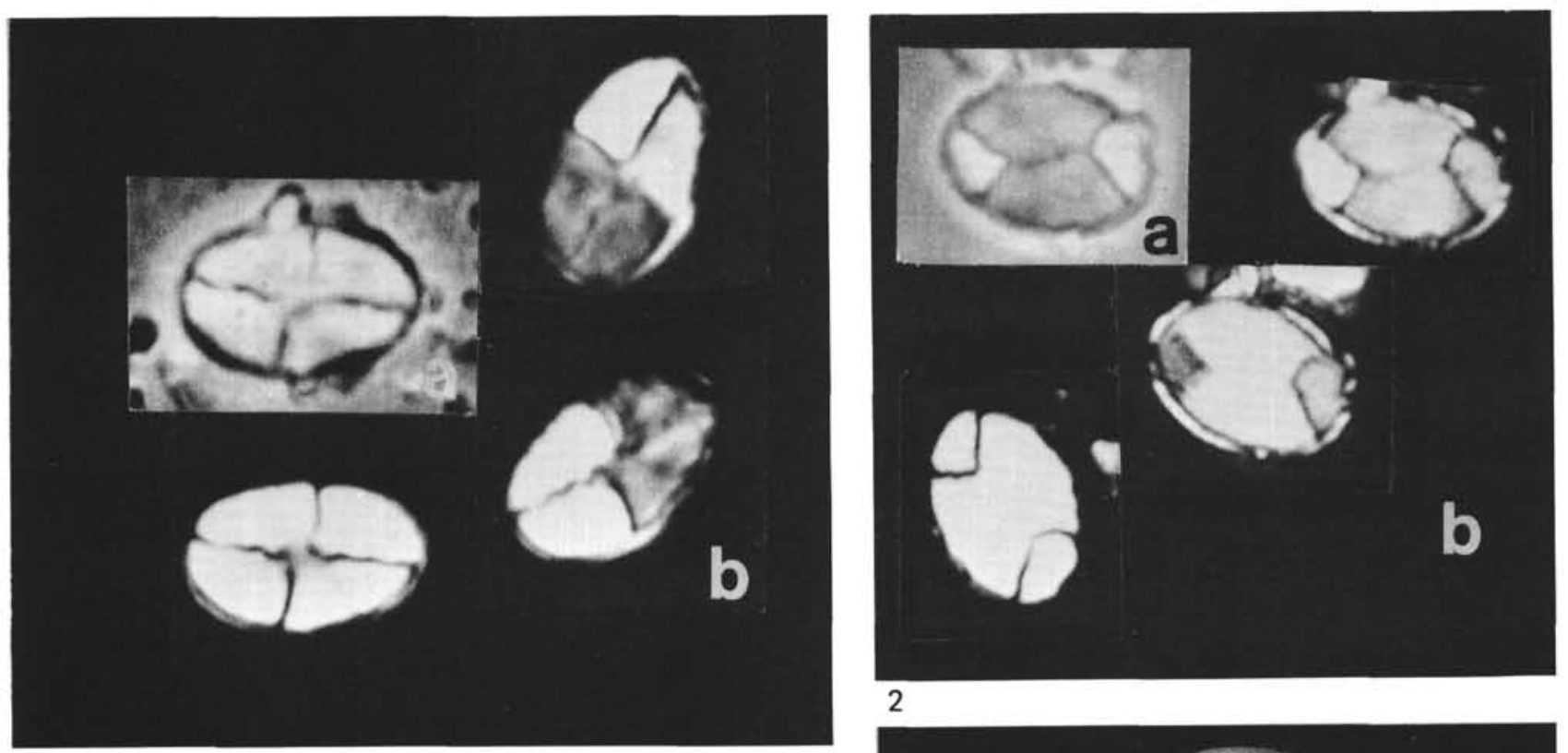

$$
1
$$

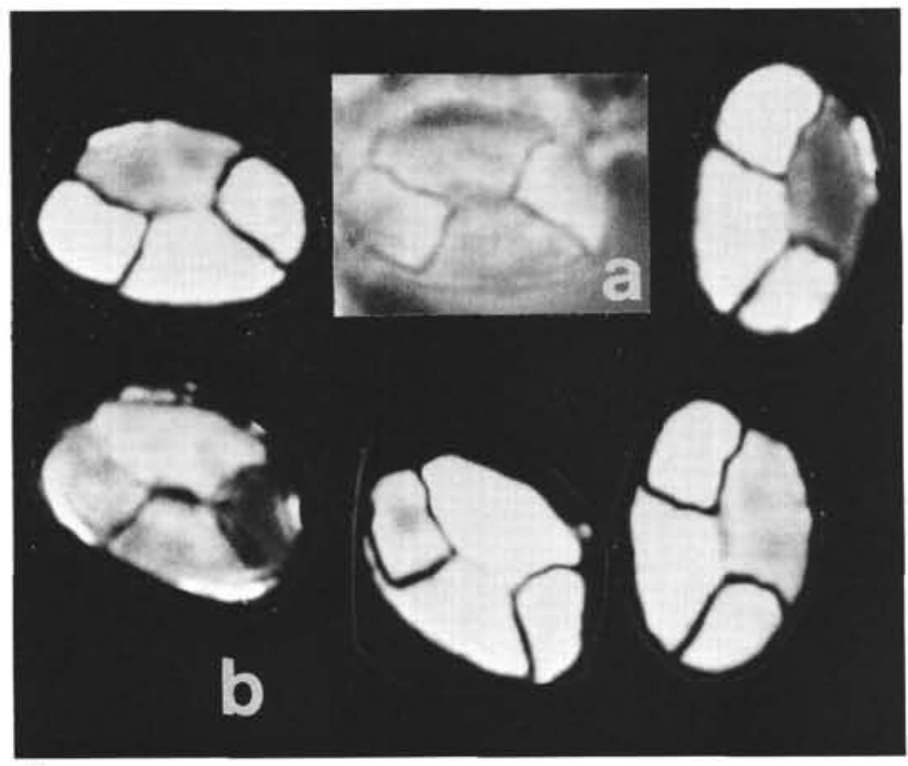

4
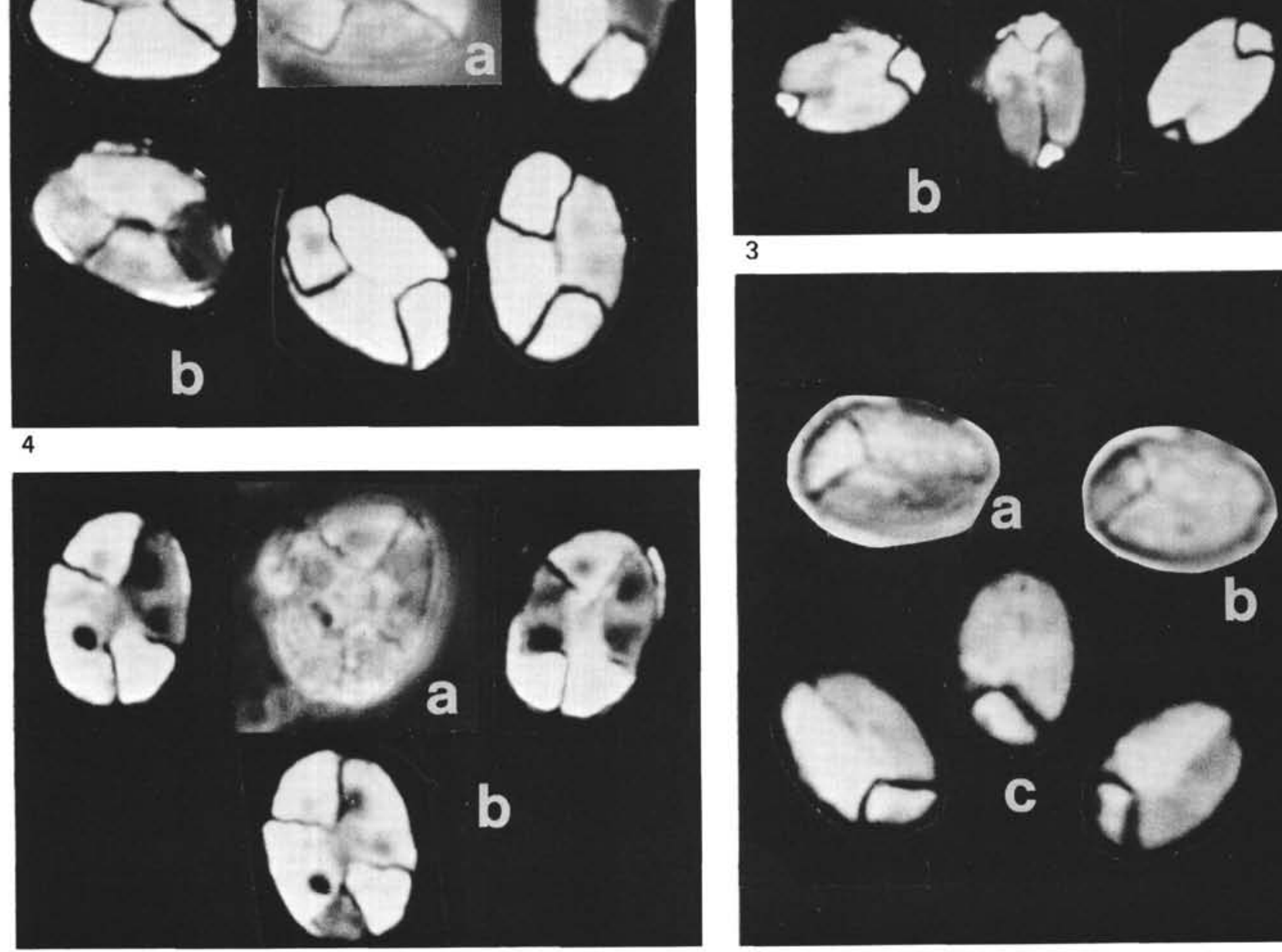

b

3

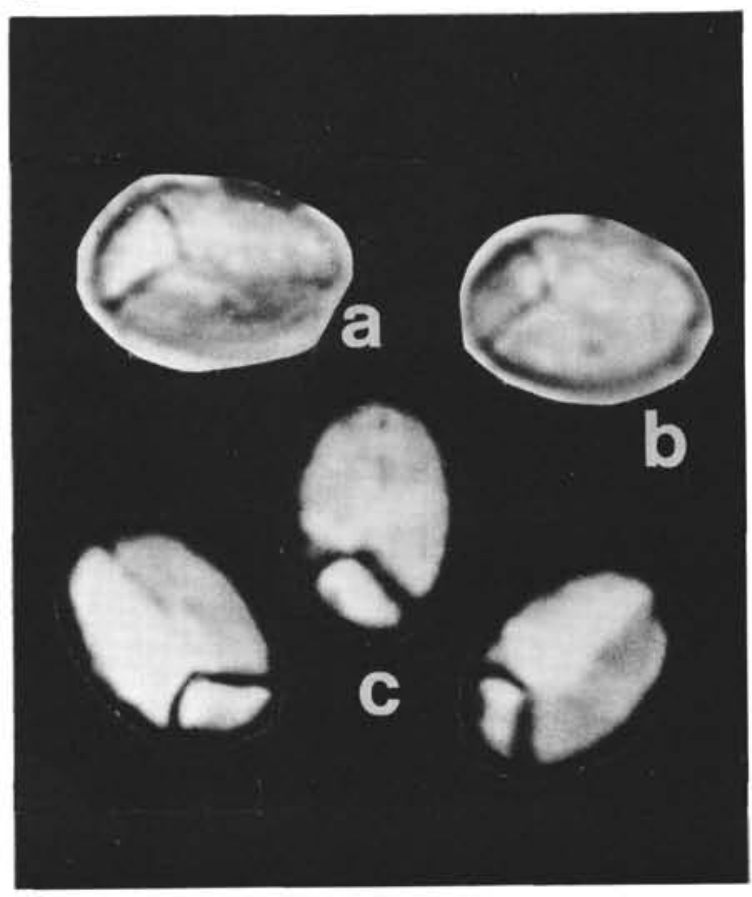




\section{PLATE 35}

(Maestrichtian; polarizing directions for crossed-polarized light are parallel to the plate margin)

Figures 1-3 Orastrum asarotum Wind and Wise, n. gen., n. sp., phase-contrast (a) and crossed-polarized light (b), Sample 327A-12, CC, $\times 3800$.

1. Holotype USNM 239509.

2. Paratype USNM 239510.

3. Paratype USNM 239511.

Figure 4 Orastrum sp., phase-contrast (a) and crossedpolarized light (b), Sample 327A-12, CC, $\times 4200$.

Figures 5, 6 Pharus simulacrum Wind and Wise, n. gen., n. sp., Sample 327A-12, CC.

5. Paratype USNM 239513, crossed-polarized light, $\times 4600$.

6. Paratype USNM 239514 in lateral view $\left({ }^{*}\right)$ and distal view $\left({ }^{* *}\right)$. Phase-contrast illumination (a) and crossed-polarized light (b), $\times 3000$. 


\section{PLATE 35}
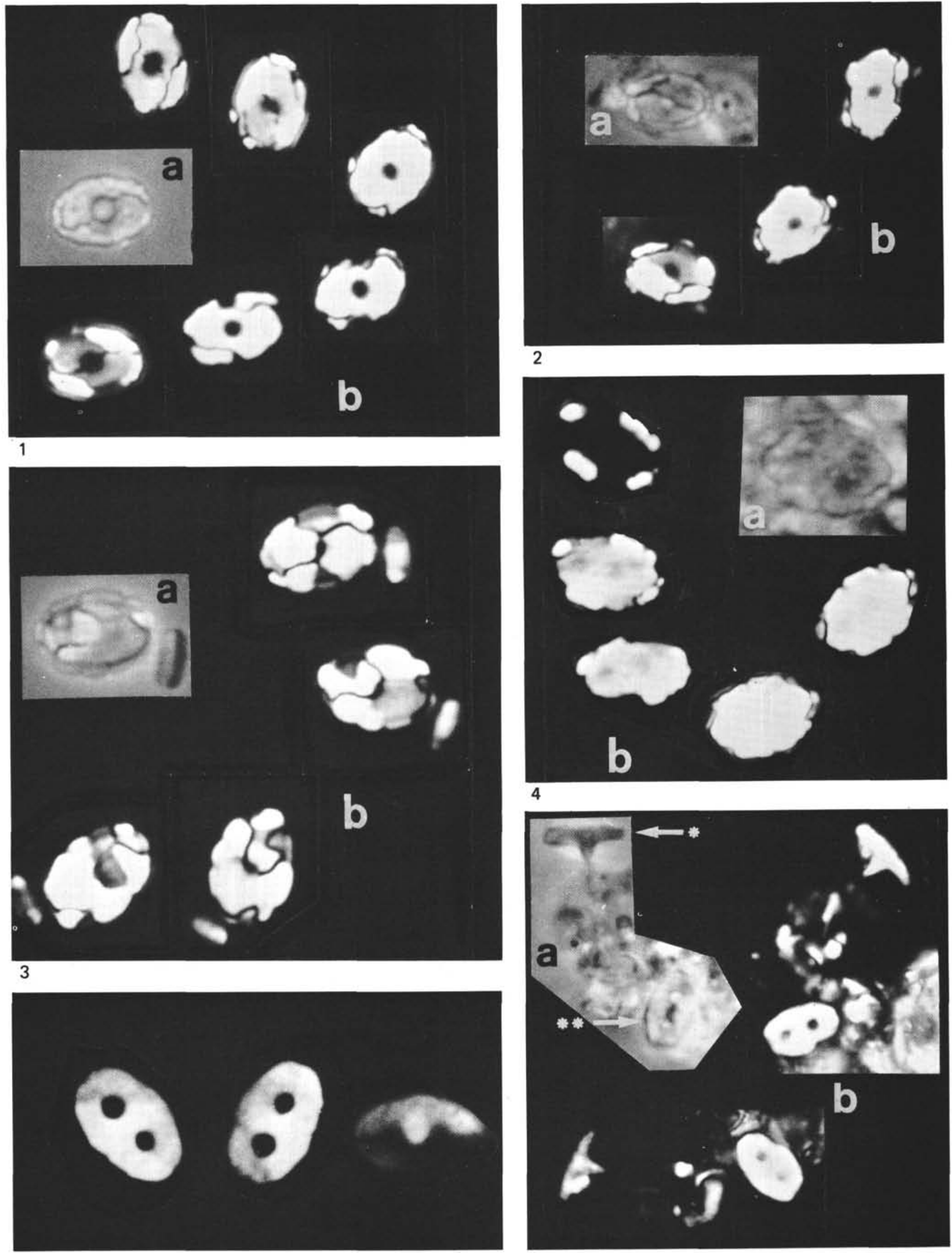

6 


\section{PLATE 36}

(Maestrichtian; Sample 327A-12, CC; polarizing directions for crossed-polarized light are parallel to the plate margin)

Figures 1,2 Pharus simulacrum Wind and Wise, n. gen., n. sp.; phase-contrast (a) and crossed-polarized light (b). 1. Holotype USNM 239515, lateral-distal view; $\times 5500$.

2. Paratype USNM 239516 , distal view, $\times 5000$.

Figure 3 Acuturris scotus (Risatti) Wind and Wise, $\mathrm{n}$. comb., phase-contrast (a) and crossed-polarized light (b), $\times 3000$.

Figure 4 Lucianorhabdus arcuatus Forchheimer, phasecontrast (a) and crossed-polarized light (b), $\times 3300$.

Figure 5 Lucianorhabdus sp. cf. L. cayeuxi Deflandre, phase-contrast (a) and crossed-polarized light (b); slight curvature of terminus of spine suggests that this specimen may be intermediate form between L. cayeuxi and $L$. arcuatus, $\times 3000$.

Figure 6

Phanulithus sp. aff. P. ovalis (Stradner), phasecontrast (a) and crossed-polarized light (b); presence of suture coincident with long axis of ellipse indicates that this specimen is a 3-part variant of $P$. ovalis (Stradner), $\times 3000$.

Figure $7 \quad$ Phanulithus obscurus Deflandre, phase-contrast (a) and crossed-polarized light (b), $\times 3000$. 
PLATE 36
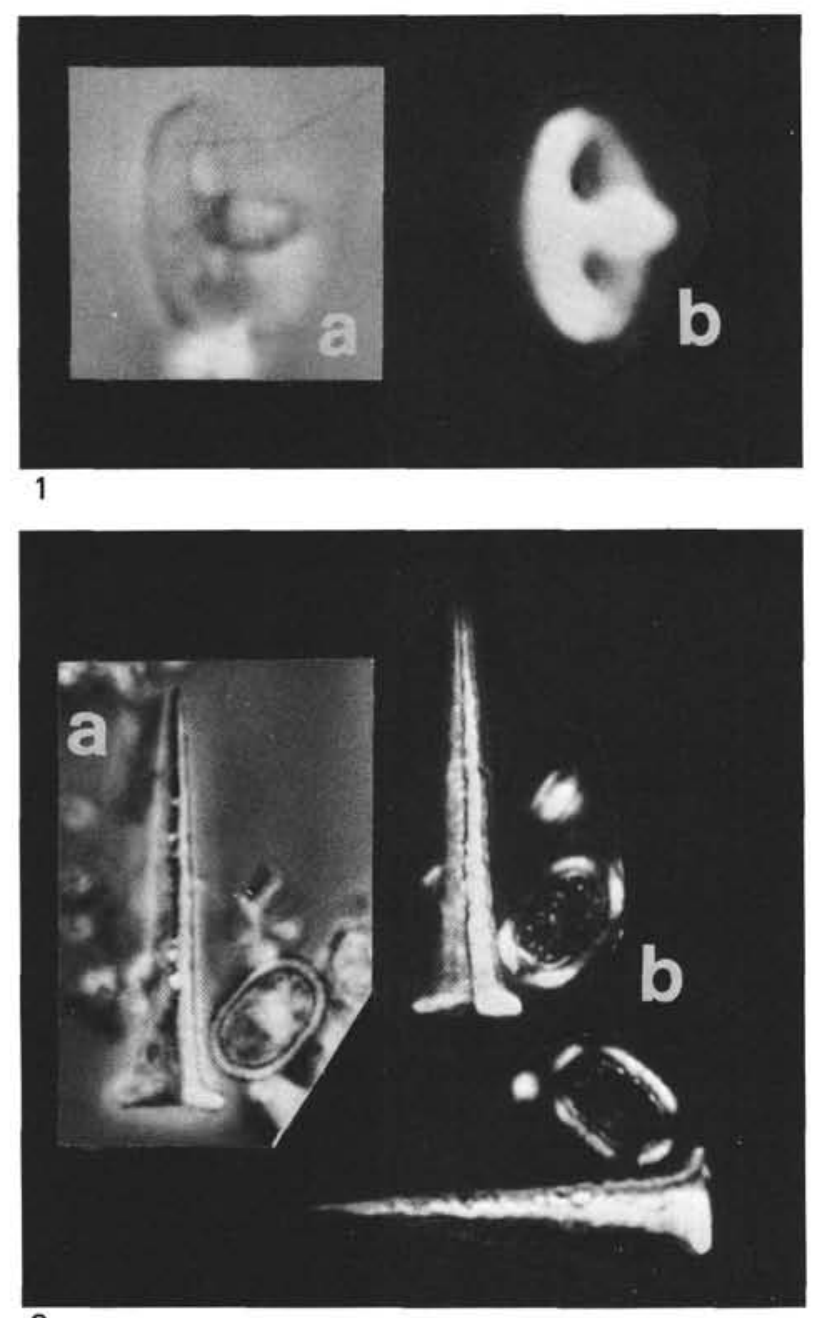

3

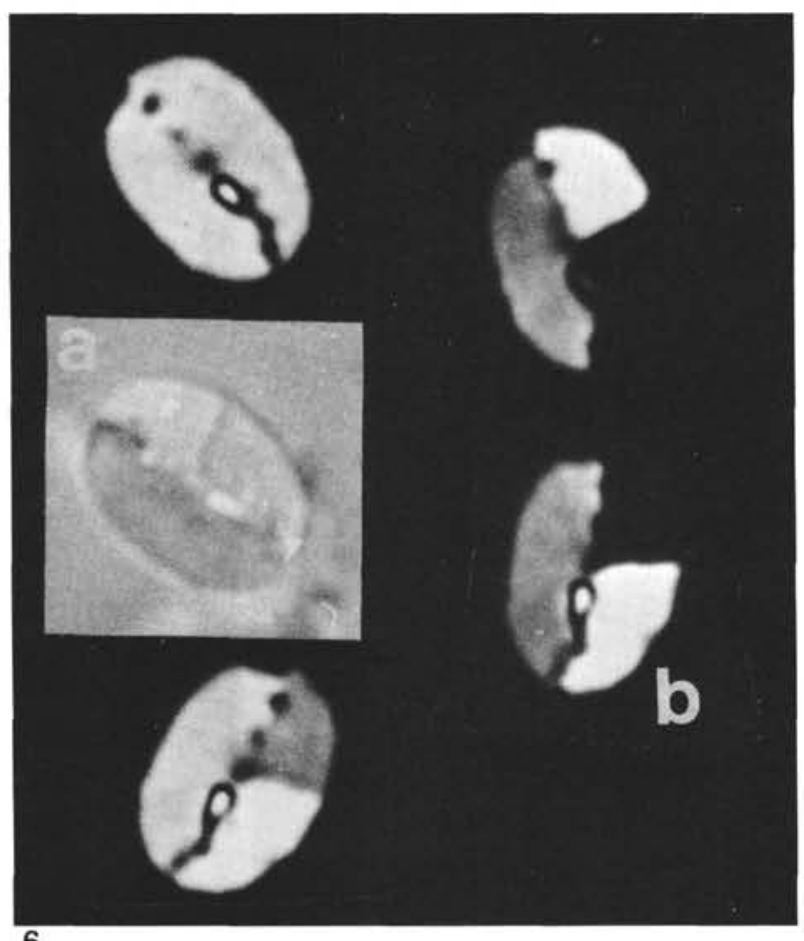

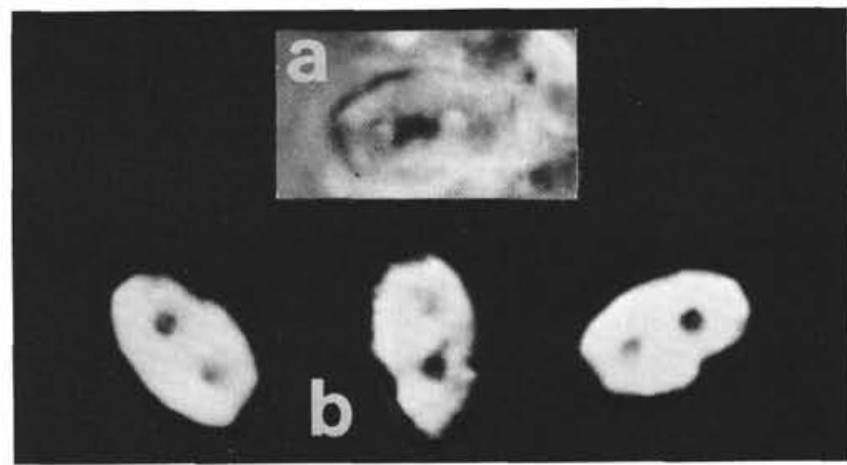

2

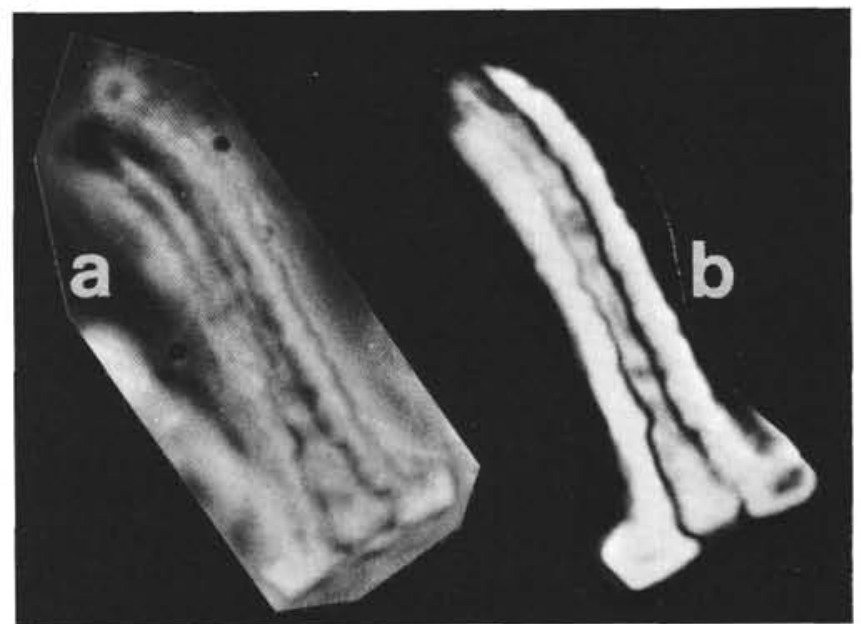

5

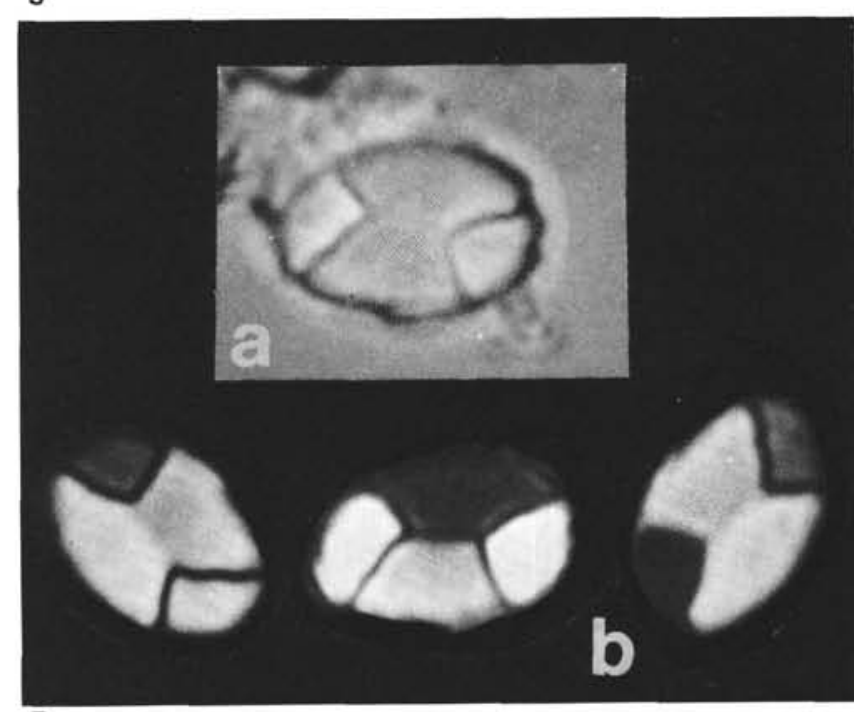

7 


\section{PLATE 37}

(Maestrichtian; Sample 327A-12, CC; polarizing directions for crossed-polarized light are parallel to the plate margin; all figures $\times 5000$ )

Figures 1,2 Okkolithus australis Wind and Wise, n. gen., n. sp. 1. Holotype USNM 238518, phase-contrast (a) and crossed-polarized light (b).

2. Paratype USNM 239519, phase-contrast (a) and crossed-polarized light (b).

Figures 3, 4 Ottavianus giannus Risatti, phase-contrast (a) and crossed-polarized light (b).

Figures 5,6 Russellia multiplus (Perch-Nielsen) Wind and Wise, n. comb.

5. Specimen with central pore, phase-contrast (a) and crossed-polarized light (b).

6. Specimen without central pore, phase-contrast ( $a$ and $b$ ) and crossed-polarized light (c). 


\section{PLATE 37}
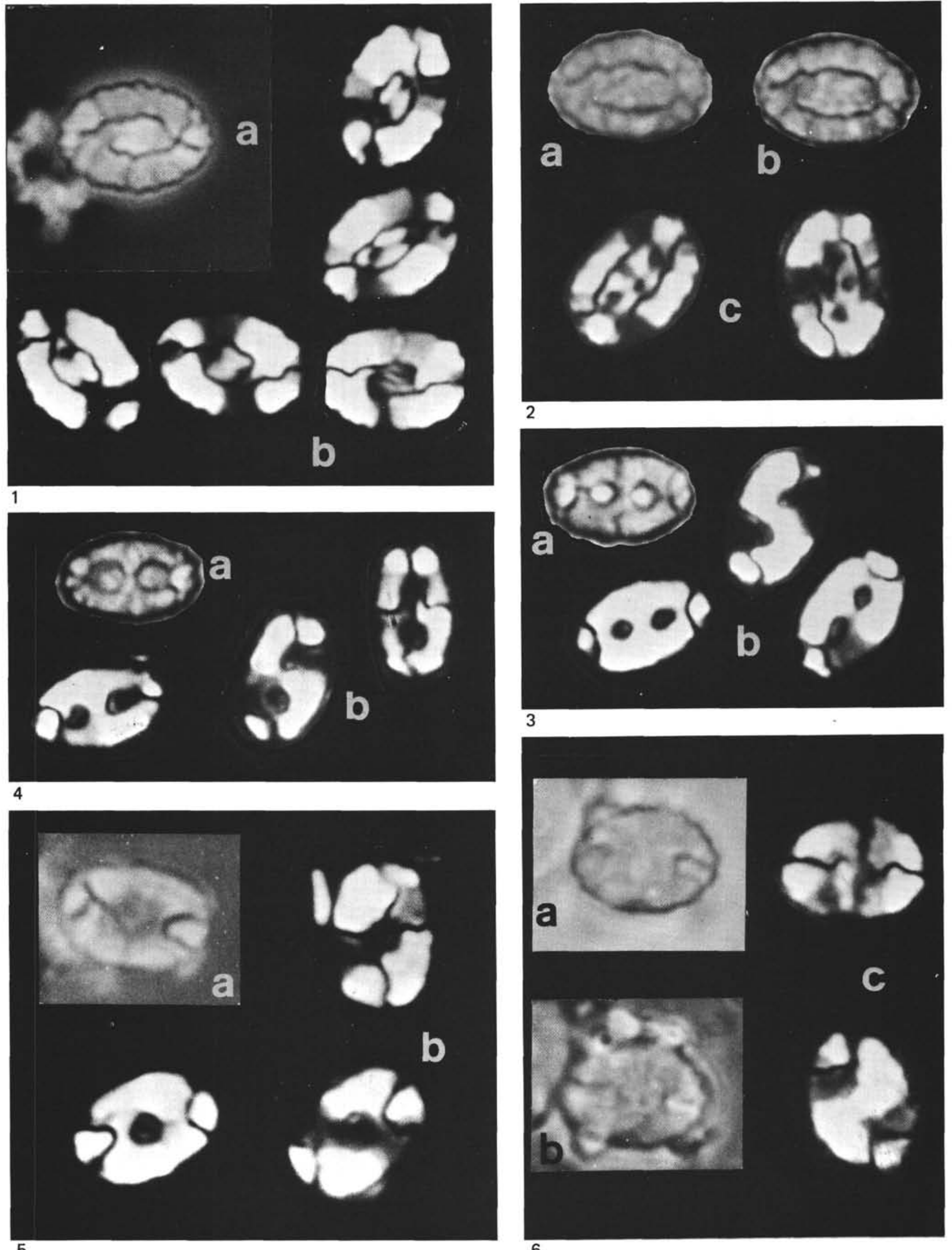

3

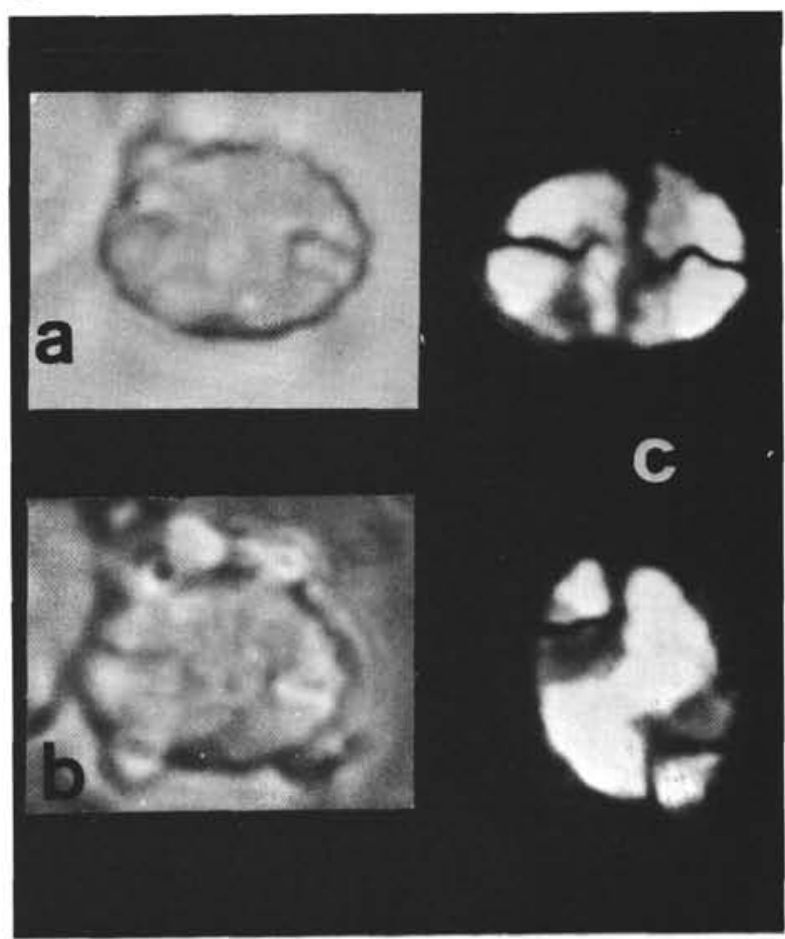




\section{PLATE 38}

(Maestrichtian-Campanian; polarizing directions for crossedpolarized light are parallel to the plate margin)

Figures 1-3 Micula decussata Vekshina.

1. Sample 327A-13-2, $54 \mathrm{~cm}, \times 8700$.

2, 3. Sample $327 \mathrm{~A}-12, \mathrm{CC}, \times 8500$.

Figures 4-7 Zygodiscus bicrescenticus (Stover) Wind and Wise, n. comb.

4, 5. Scanning electron micrograph and light microscope photographs of specimen in distal view; Sample 327A-12, CC.

4. $\times 3000$.

5. Phase-contrast and crossed-polarized light illumination, $\times 9000$.

6, 7. Scanning electron micrograph and light microscope photographs of specimen in proximal view, Sample 327A-12, CC.

6. Phase-contrast and crossed-polarized light illumination, $\times 3000$.

7. $\times 9000$. 
PLATE 38

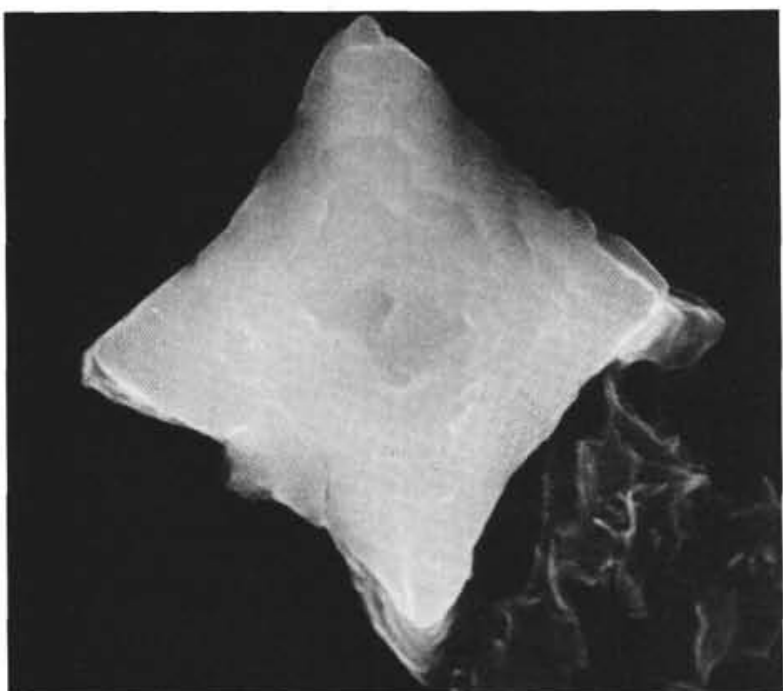

1
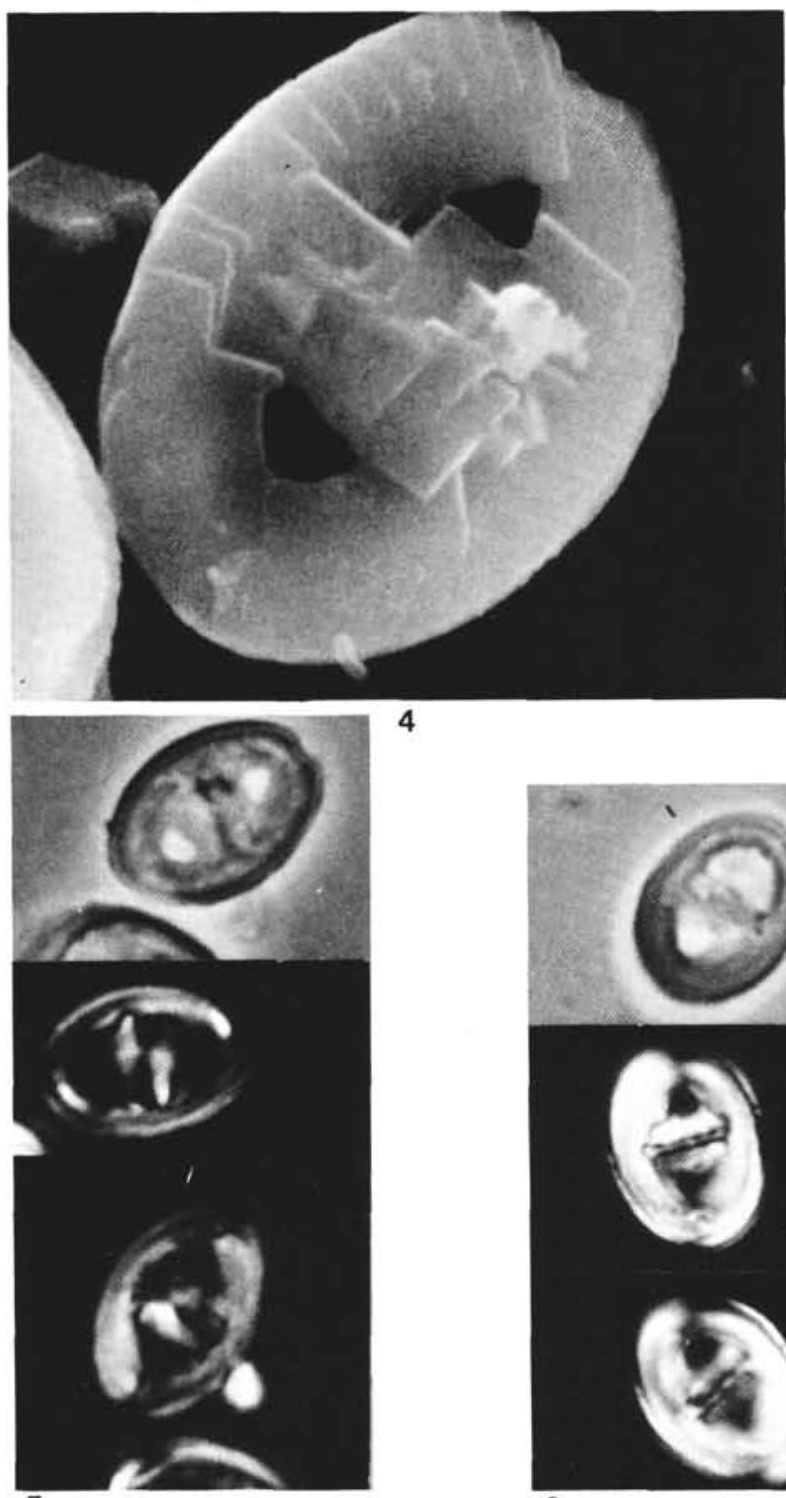

5 4

6
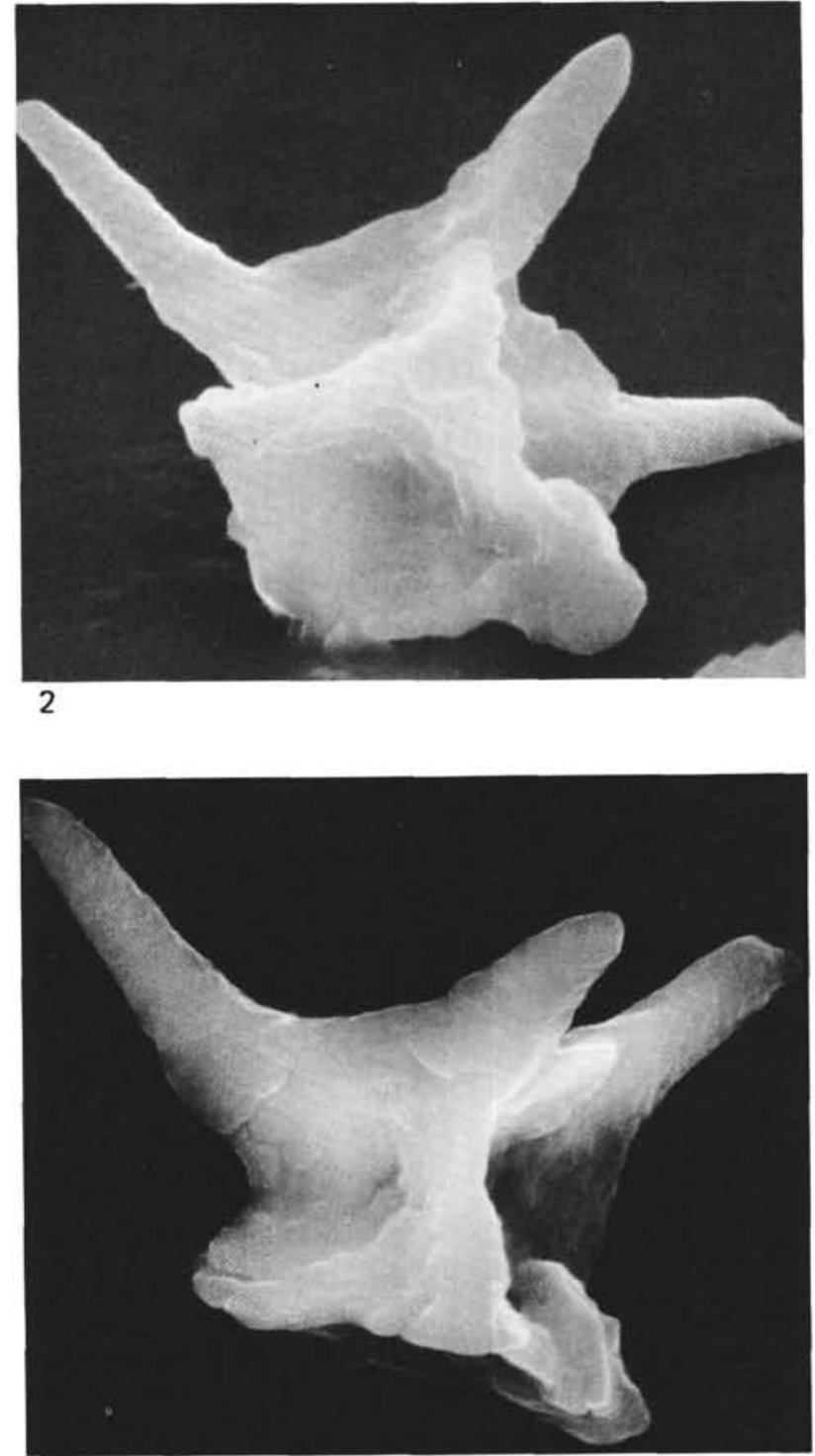

3
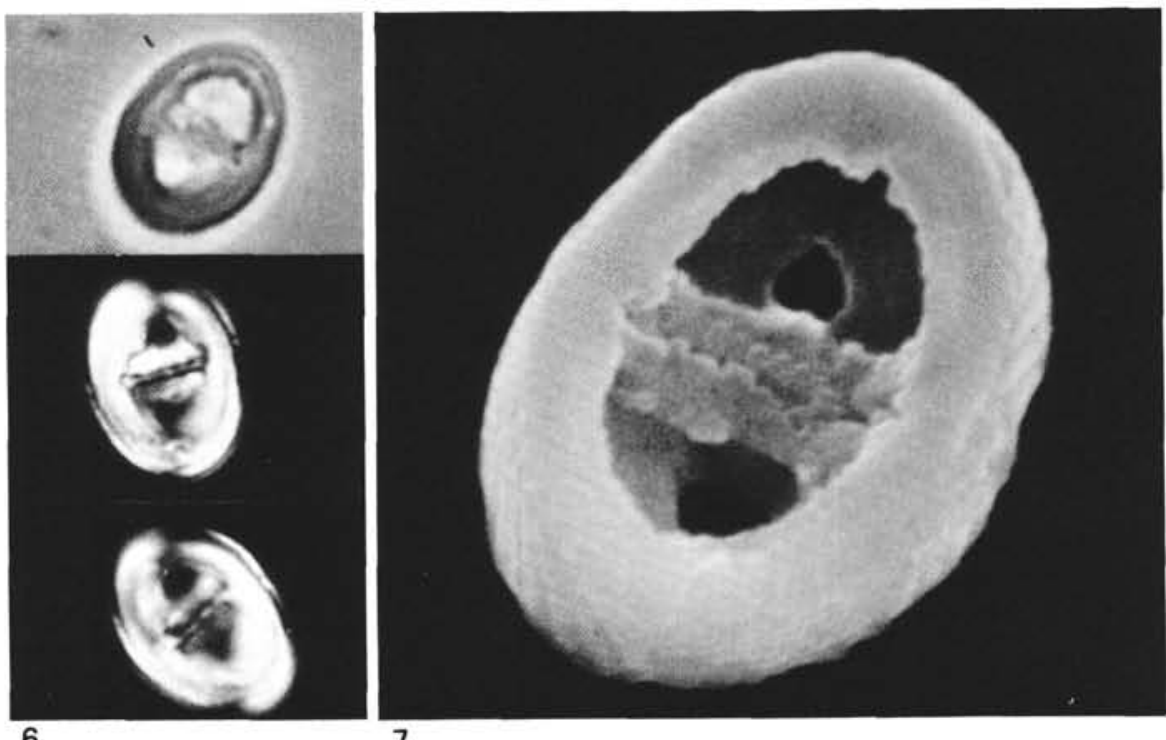
PLATE 39

(Maestrichtian-Campanian)

Figures 1,2 Zygodiscus bicrescenticus (Stover) Wind and Wise, n. comb.

1. Distal view, Sample 327A-12, CC, $\times 10,000$.

2. Proximal-lateral view, Sample $327 \mathrm{~A}-11,107$ $\mathrm{cm}, \times 10,400$.

Figure 3 Chiastozygus propagulis Bukry, proximal view, Sample 327A-12, CC, $\times 17,000$.

Figure 4 Tranolithus skoglundii Forchheimer, distal view, Sample 327A-13-2, $45 \mathrm{~cm}, \times 9500$.

Figures 5,6 Tranolithus sp., two specimens in proximal view.

5. Sample $327 \mathrm{~A}-12-3,45 \mathrm{~cm}, \times 10,000$.

6. Sample $327 \mathrm{~A}-13-1,113 \mathrm{~cm}, \times 8000$. 


\section{PLATE 39}

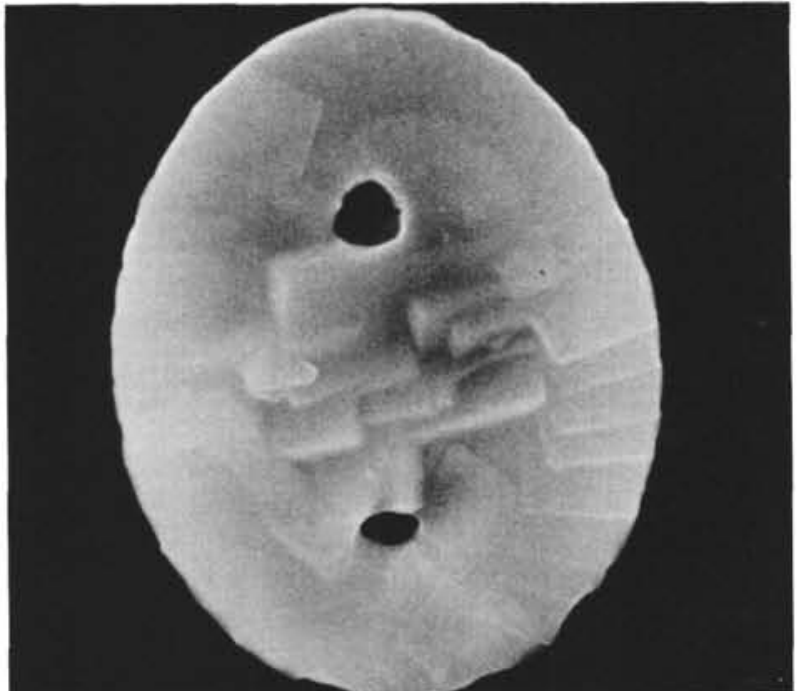

1

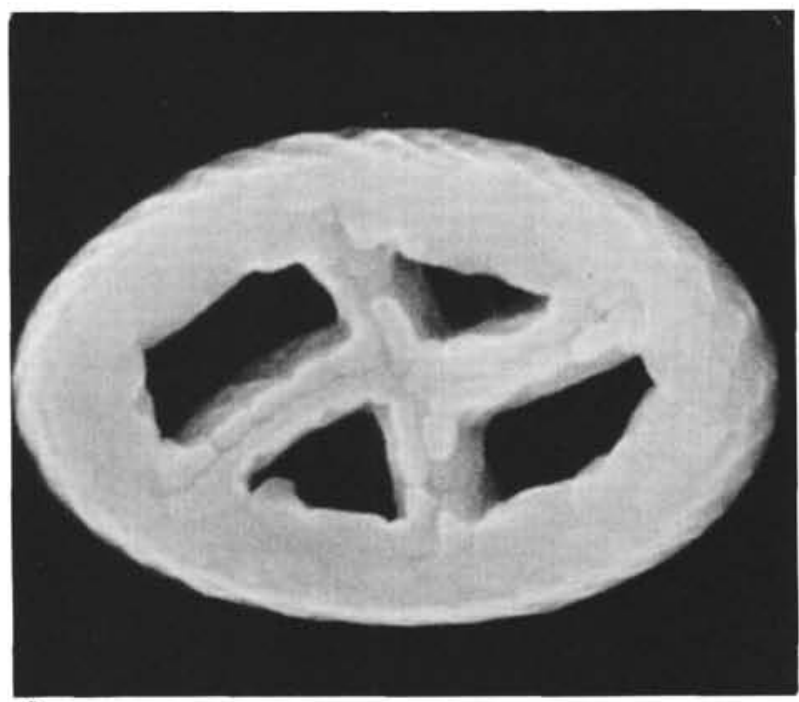

3

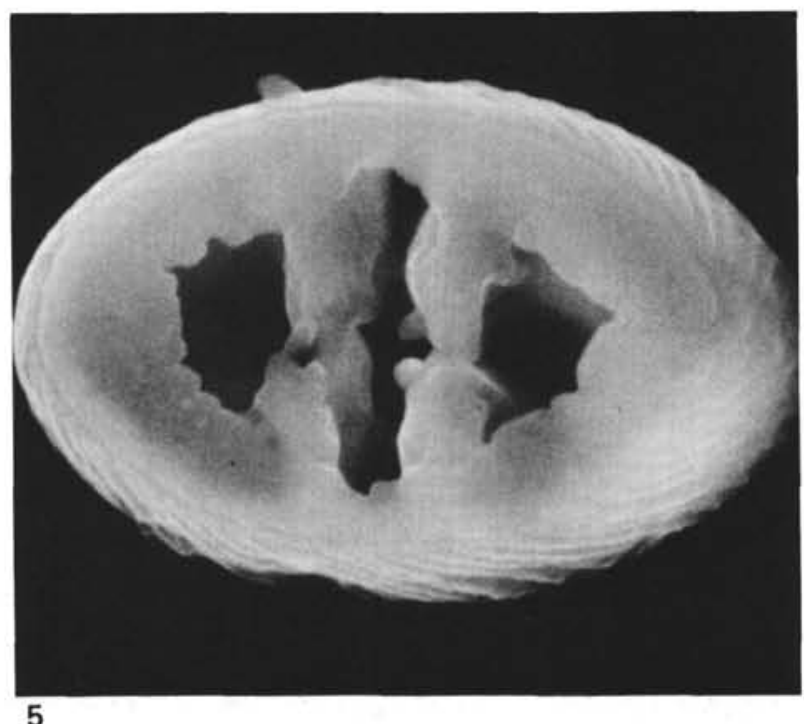

5
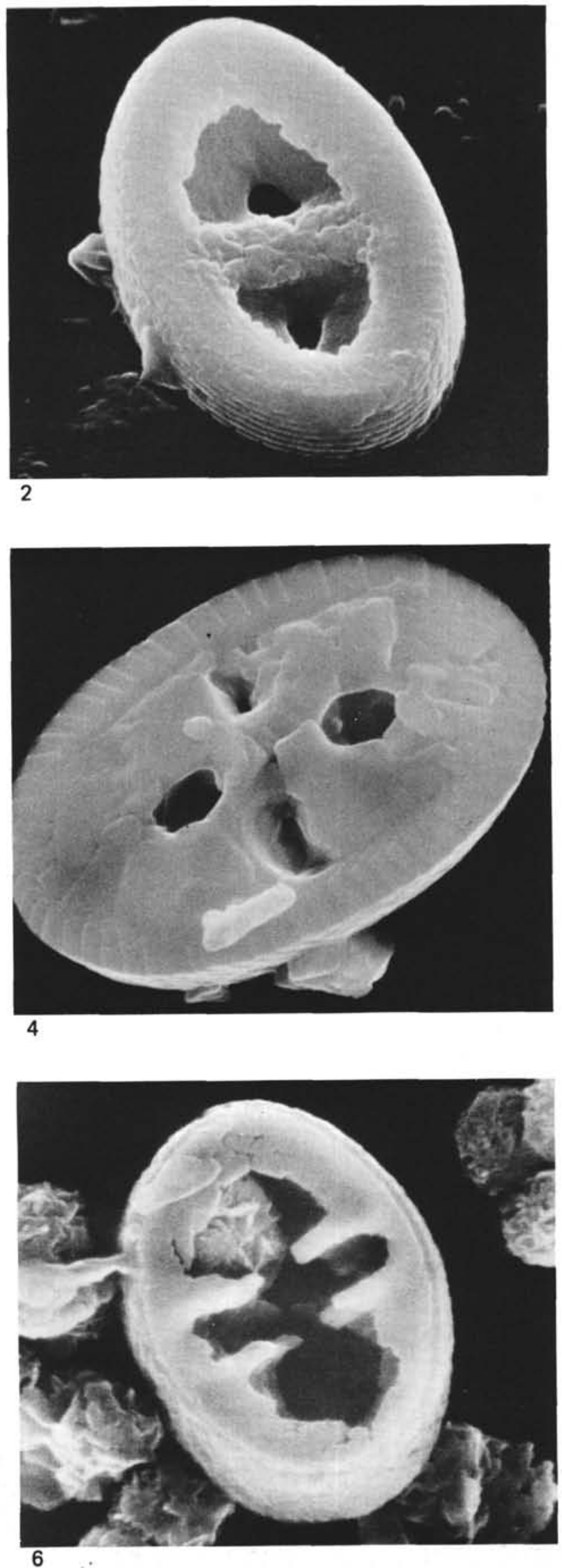
PLATE 40

(Maestrichtian-Campanian)

Figures 1-6 Eiffellithus turriseiffeli (Deflandre) Reinhardt; Figures 1, 2, 3, 5 proximal views, Figures 4, 6 distal views.

1. Sample $327 \mathrm{~A}-12-2,45 \mathrm{~cm}, \times 10,000$.

2. Sample $327 \mathrm{~A}-11-1,107 \mathrm{~cm}, \times 6000$.

3. Sample $327 \mathrm{~A}-12, \mathrm{CC}, \times 11,500$.

4. Sample 327A-12, CC, $\times 13,500$.

5. Specimen with spine supports removed; Sample $327 \mathrm{~A}-13-2,45 \mathrm{~cm}, \times 10,000$.

6. Sample $327 \mathrm{~A}-10-3,14 \mathrm{~cm}, \times 8000$. 
PLATE 40
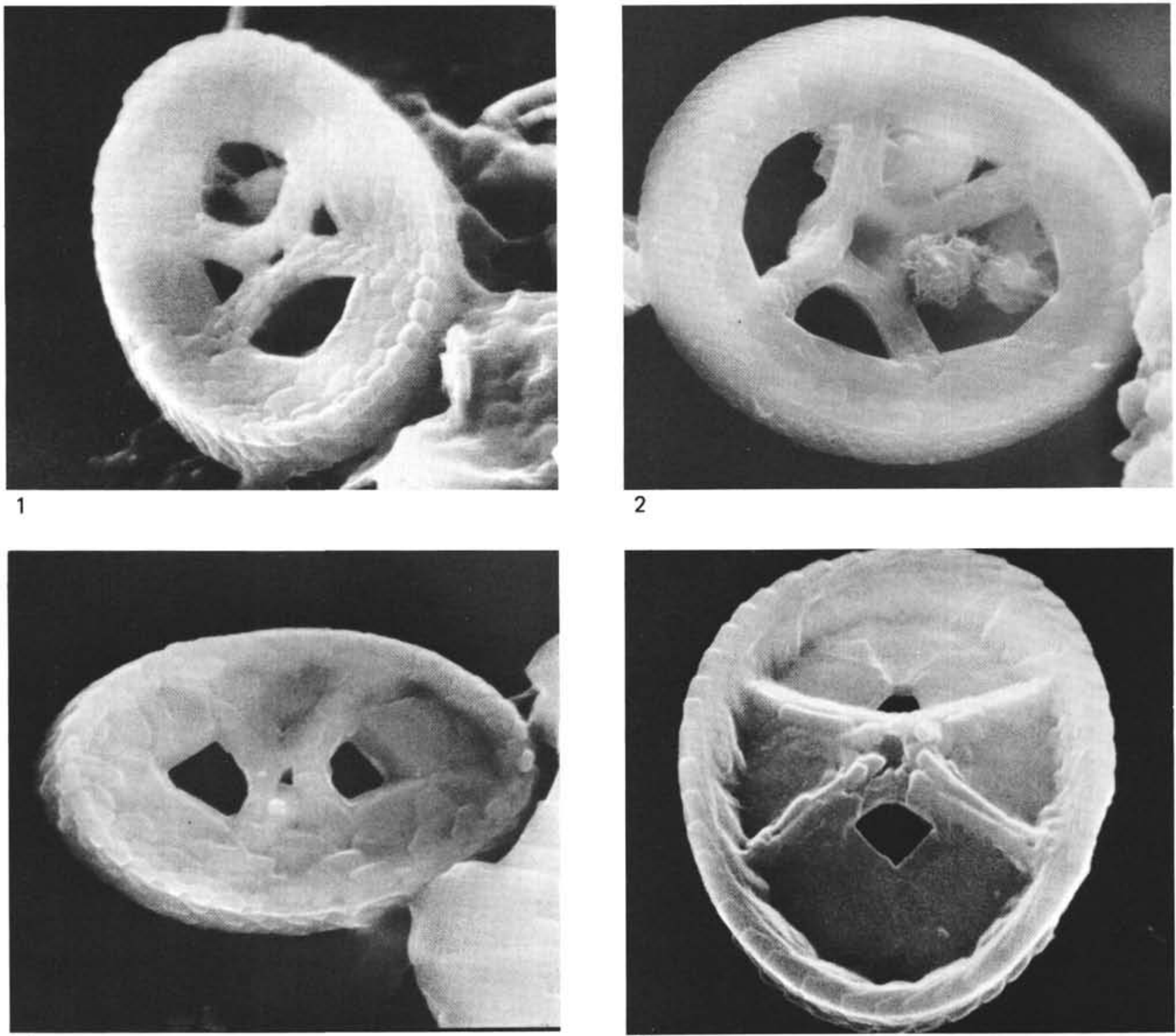

3

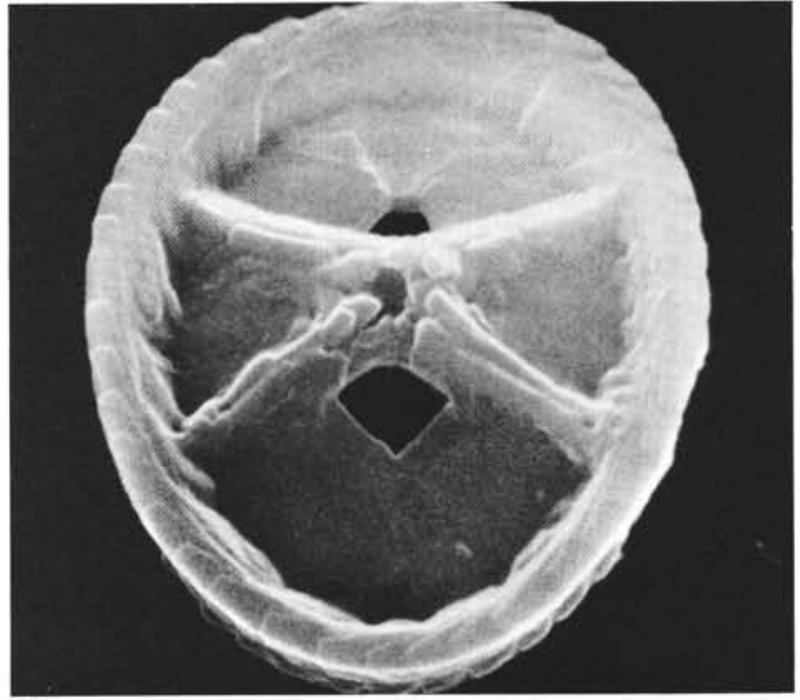

4
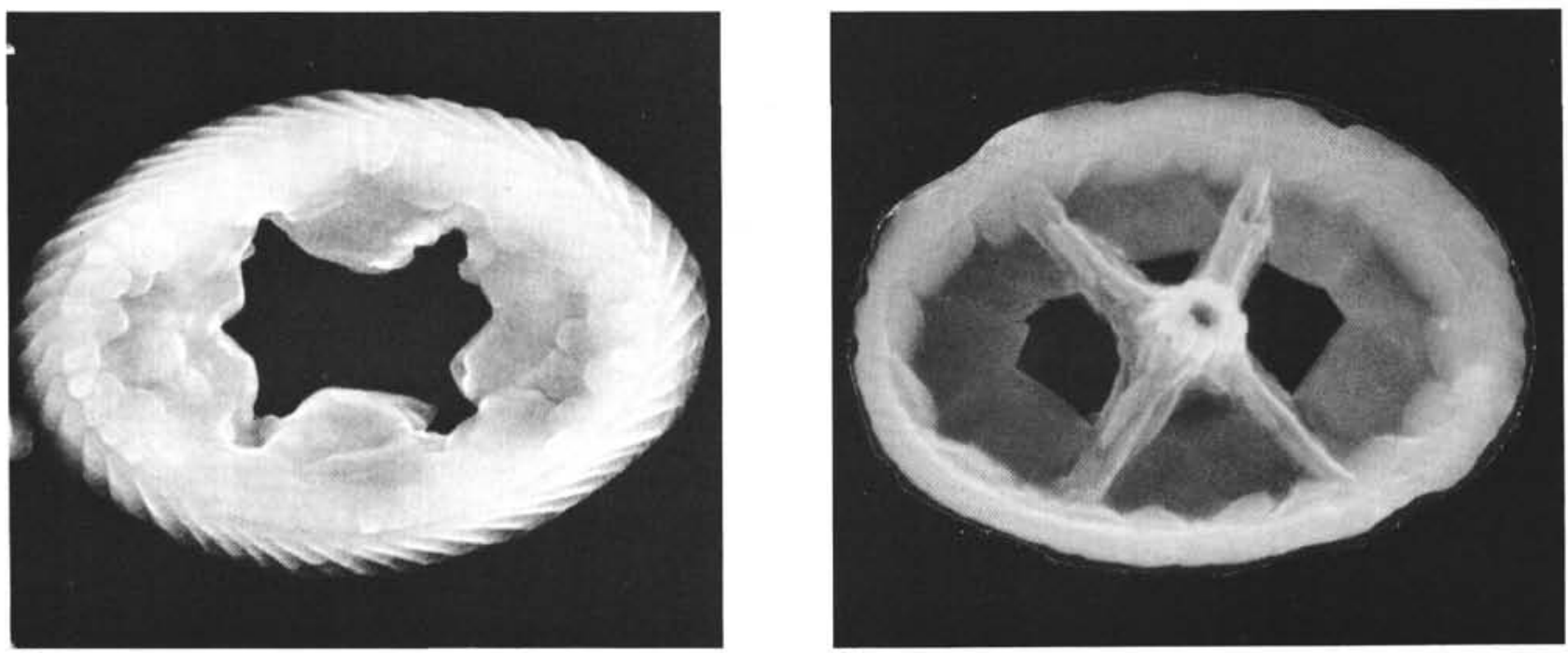
PLATE 41

(Maestrichtian-Campanian)

Figures 1, 2 Vekshinella dibrachiata Gartner, proximal views. 1. Sample 327A-13-2, $137 \mathrm{~cm}, \times 9000$.

2. With Zygodiscus sp. (lower left), Sample 327A$13-2,137 \mathrm{~cm}, \times 5000$.

Figures 3, $4 \quad$ Prediscosphaera spinosa (Bramlette and Martini) Gartner.

3. Distal view, Sample 327A-11-1, $107 \mathrm{~cm}, \times 8000$.

4. Proximal view, Sample $327 \mathrm{~A}-12, \mathrm{CC}, \times 9000$.

Figure 5 Prediscosphaera cretacea (Arkhangelsky) Gartner, distal view, Sample 327A-13-2, $45 \mathrm{~cm}, \times 8000$.

Figure 6 Species indet. Specimen is possibly central area and tube of Biscutum magnum Wind and Wise, $\mathrm{n}$. sp. in proximal view, Sample 327A-12, CC, $\times 15,000$. 
PLATE 41
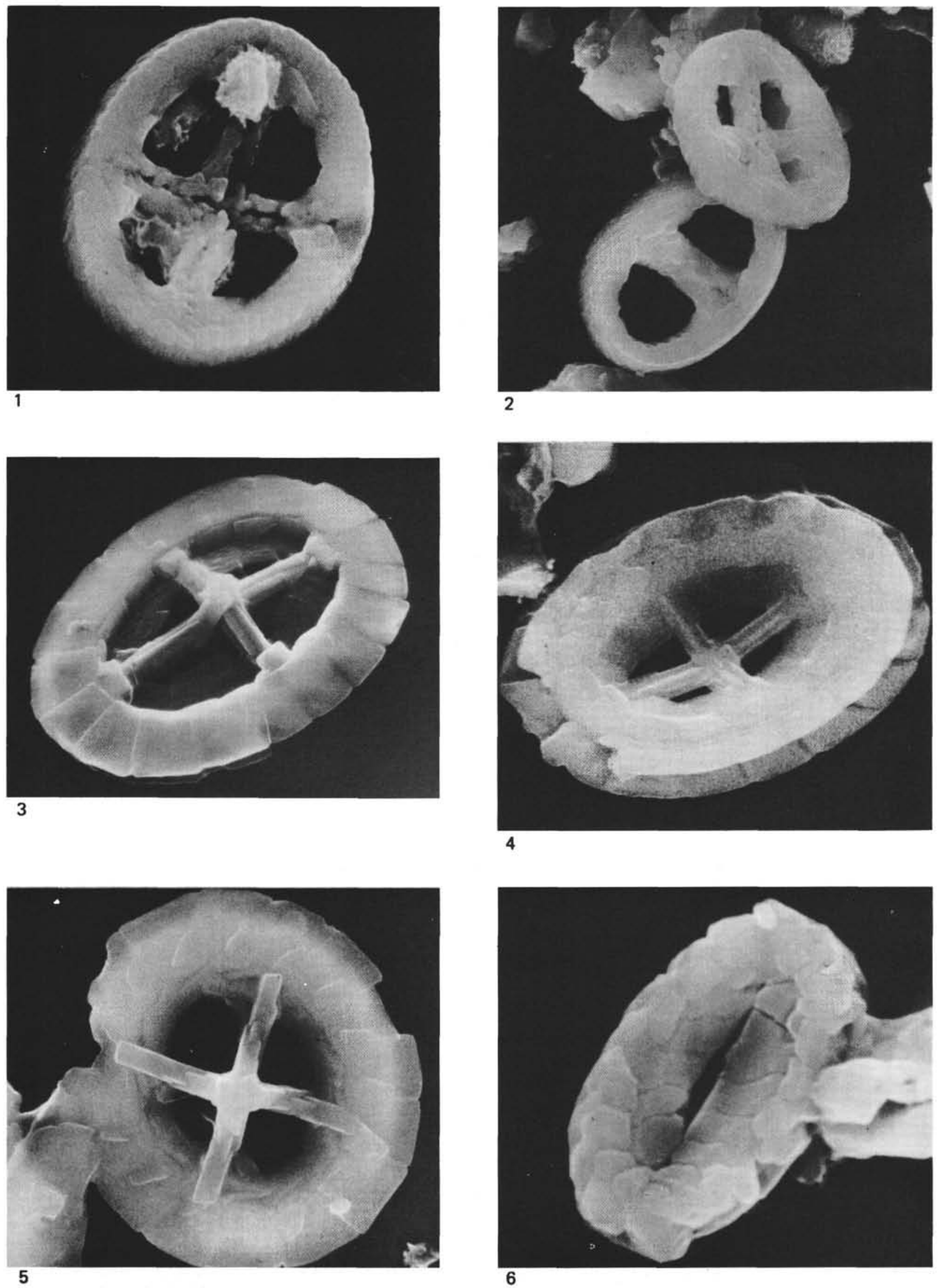


\section{PLATE 42}

(Maestrichtian-Campanian)

Figures 1,2 Vekshinella? parma Wind and Wise, n. sp.

1. Paratype USNM 239520, distal view, Sample $327 \mathrm{~A}-13-1,142 \mathrm{~cm}, \times 12,800$.

2. Holotype USNM 239521, distal view, Sample $327 \mathrm{~A}-13-1,142 \mathrm{~cm}, \times 12,800$.

Figure 3 Prediscosphaera stoveri (Perch-Nielsen) Wind and Wise, n. comb., distal view, Sample 327A-13-2, $142 \mathrm{~cm}, \times 15,700$.

Figure $4 \quad$ Vekshinella aachena (Bukry) Wind and Wise, n. comb., distal view; Sample 327A-13-1, $142 \mathrm{~cm}$, $\times 11,500$.

Figures 5,6 Vekshinella dibrachiata Gartner.

5. Distal view, Sample 327A-12-3, $31 \mathrm{~cm}$, $\times 13,000$.

6. Distal view, Sample $327 \mathrm{~A}-12-3,31 \mathrm{~cm}$, $\times 12,000$. 
PLATE 42

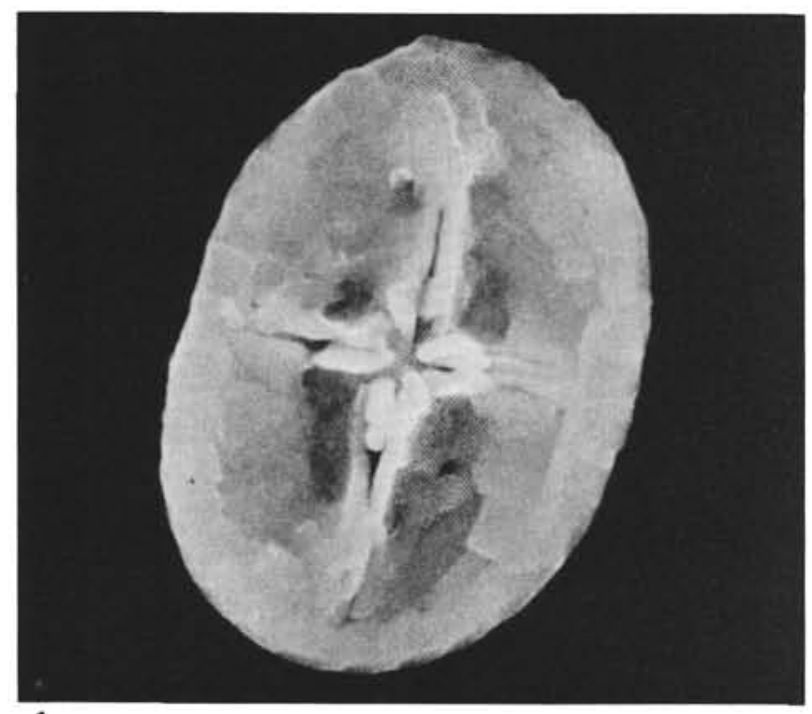

1

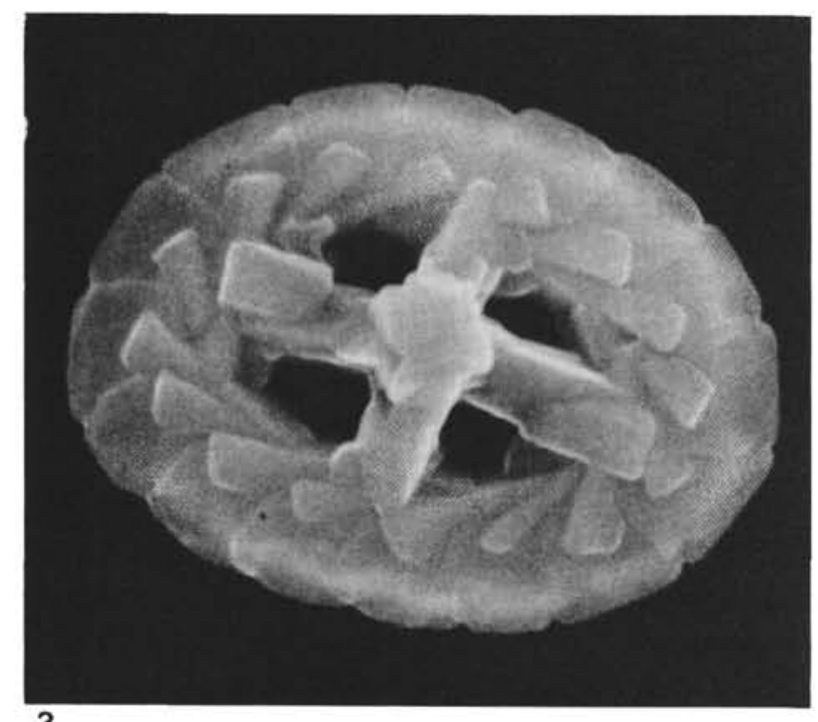

3

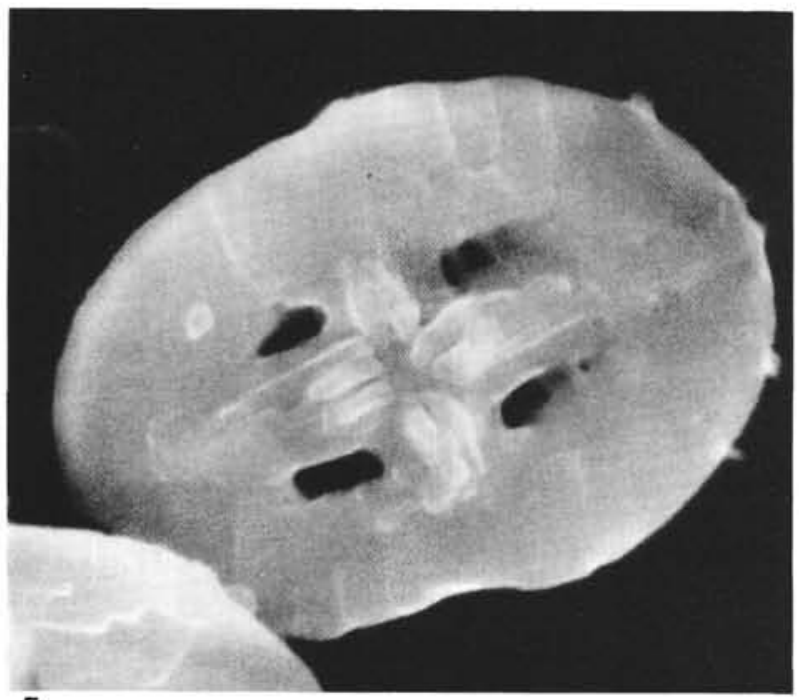

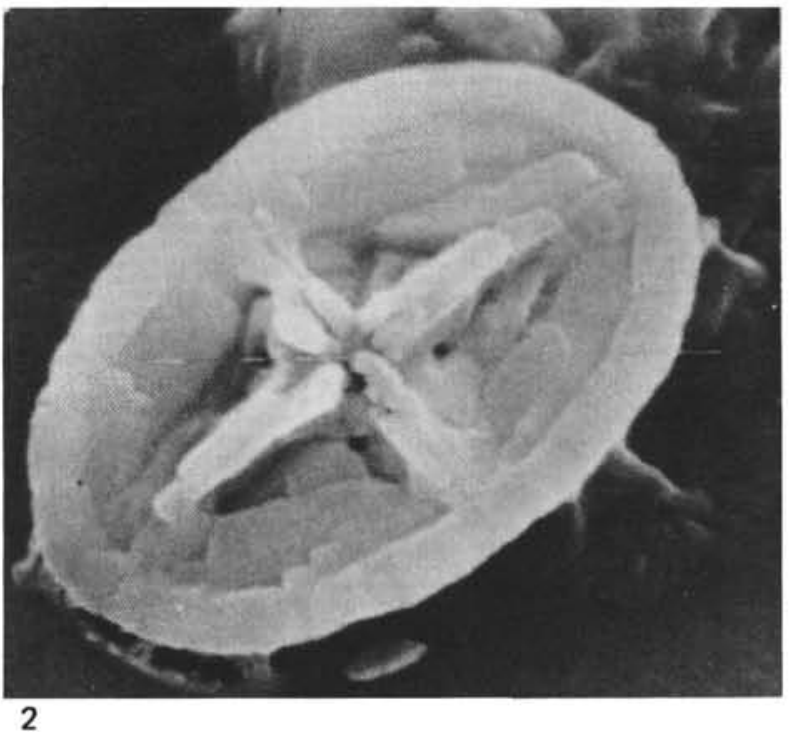

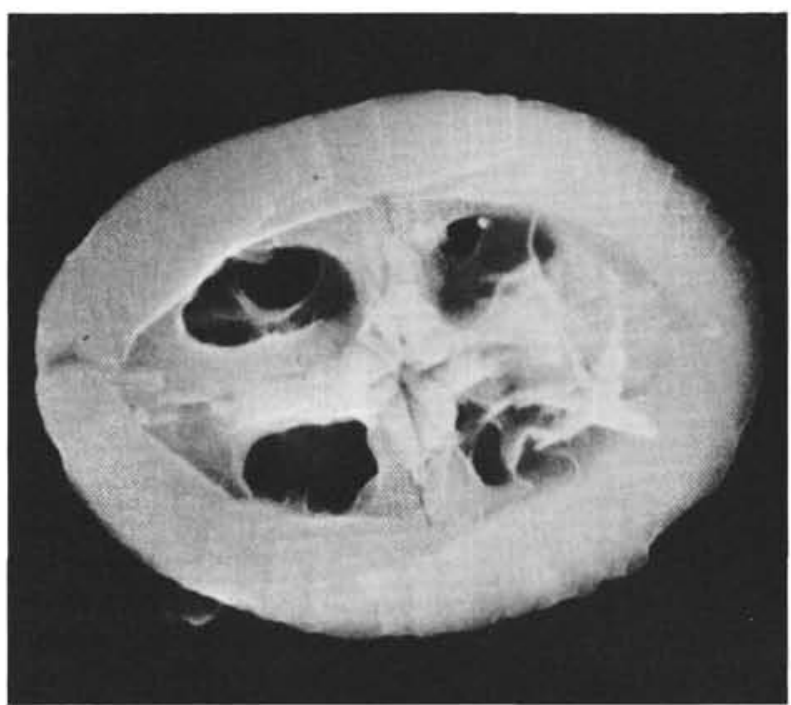

4

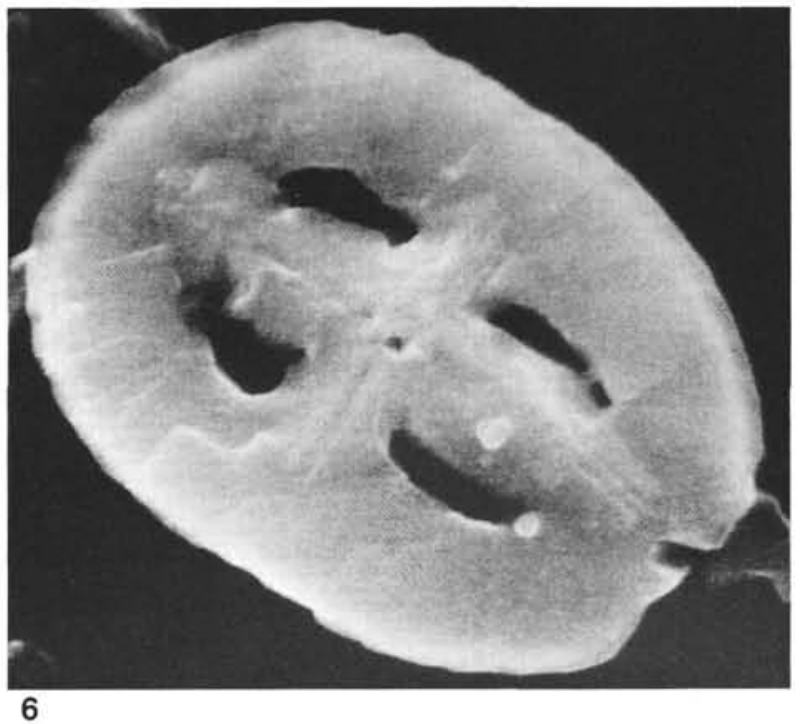




\section{PLATE 43}

(Maestrichtian-Campanian)

Figures 1-4 Zygodiscus anthophorus (Deflandre) Wind and Wise, n. comb.

1. Distal-lateral view showing well-developed surface sculpturing, Sample 327A-13-1, $142 \mathrm{~cm}$, $\times 9750$.

2. Distal view, Sample 327A-12, CC, $\times 7800$.

3. Distal view, Sample $327 \mathrm{~A}-13-2,45 \mathrm{~cm}, \times 7700$.

4. Lateral view of specimen with complete spine, Sample 327 A-10-3, $14 \mathrm{~cm}$. This specimen appears to be identical to the holotype of $Z$. anthophorus (Deflandre).

Figures 5,6 Zygodiscus sigmoides Bramlette and Sullivan.

5. Distal view, Sample 327A-12, CC, $\times 8000$.

6. Distal view, Sample 327A-13-2, $45 \mathrm{~cm}, \times 6000$. 
PLATE 43
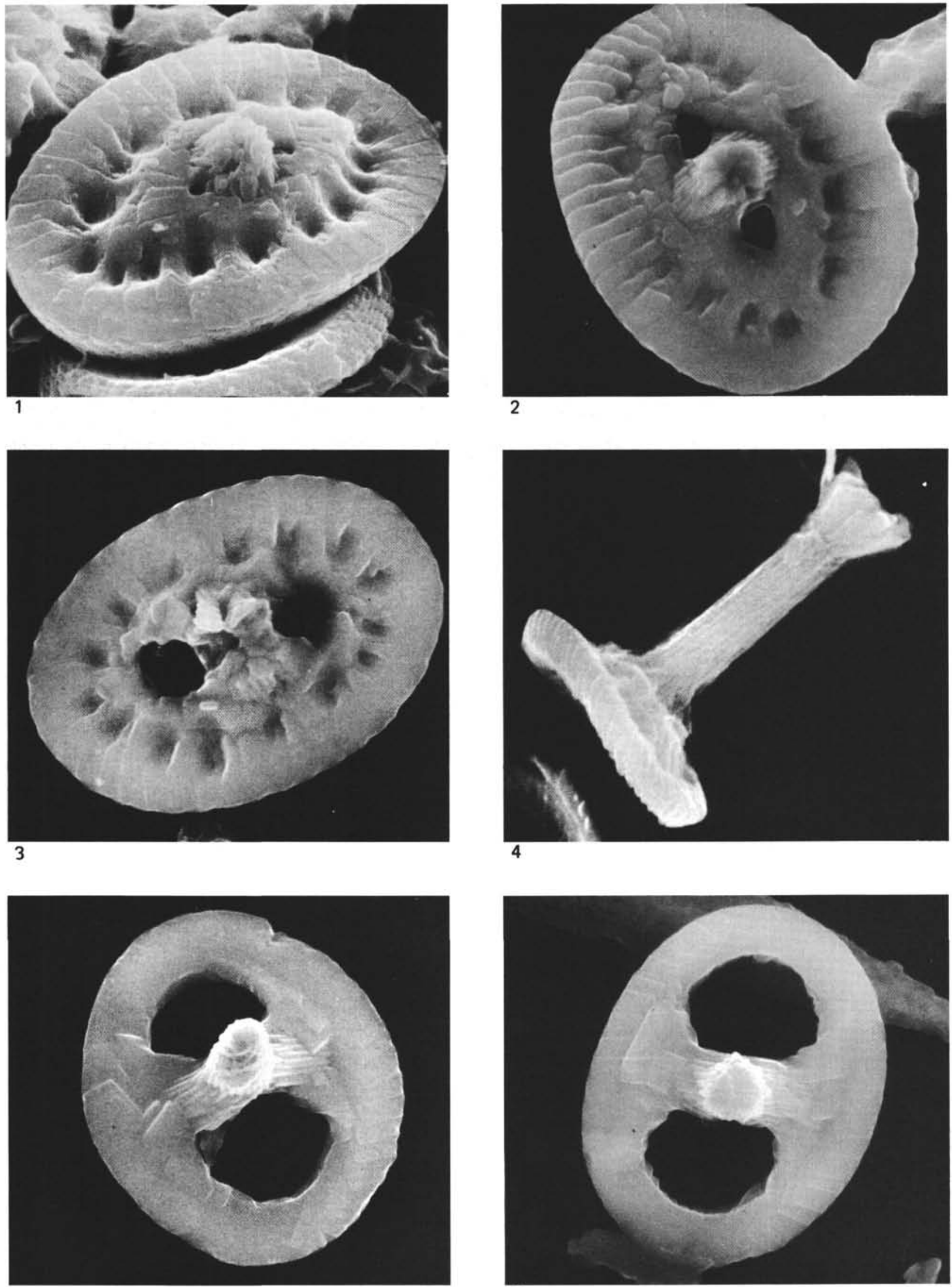


\section{PLATE 44}

(Maestrichtian-Campanian)

Figures 1-3 Octocyclas reinhardtii (Bukry) Wind and Wise, $\mathrm{n}$. comb.

1. Distal view, with Arkhangelskiella sp., Sample $327 \mathrm{~A}-12, \mathrm{CC}, \times 5000$.

2. Distal view, with Monomarginatus pectinatus Wind and Wise, n. sp. (left), Sample 327A-13-2, 45 $\mathrm{cm}, \times 5000$.

3. Proximal-lateral view, Sample 327A-12, CC, $\times 5500$.

Figure 4 Dodekapodorhabdus noelii Perch-Nielsen, distal view, Sample 327A-13-2, $45 \mathrm{~cm}, \times 6800$.

Figure 5 Cretarhabdus sp. cf. C. conicus Bramlette and Martini, distal view, Sample 327A-13-1, $142 \mathrm{~cm}$, $\times 7500$.

Figure 6 Teichorhabdus ethmos Wind and Wise, n. gen., n. sp., holotype USNM 239523, Sample 327A-10-3, $14 \mathrm{~cm}, \times 5100$. 


\section{PLATE 44}
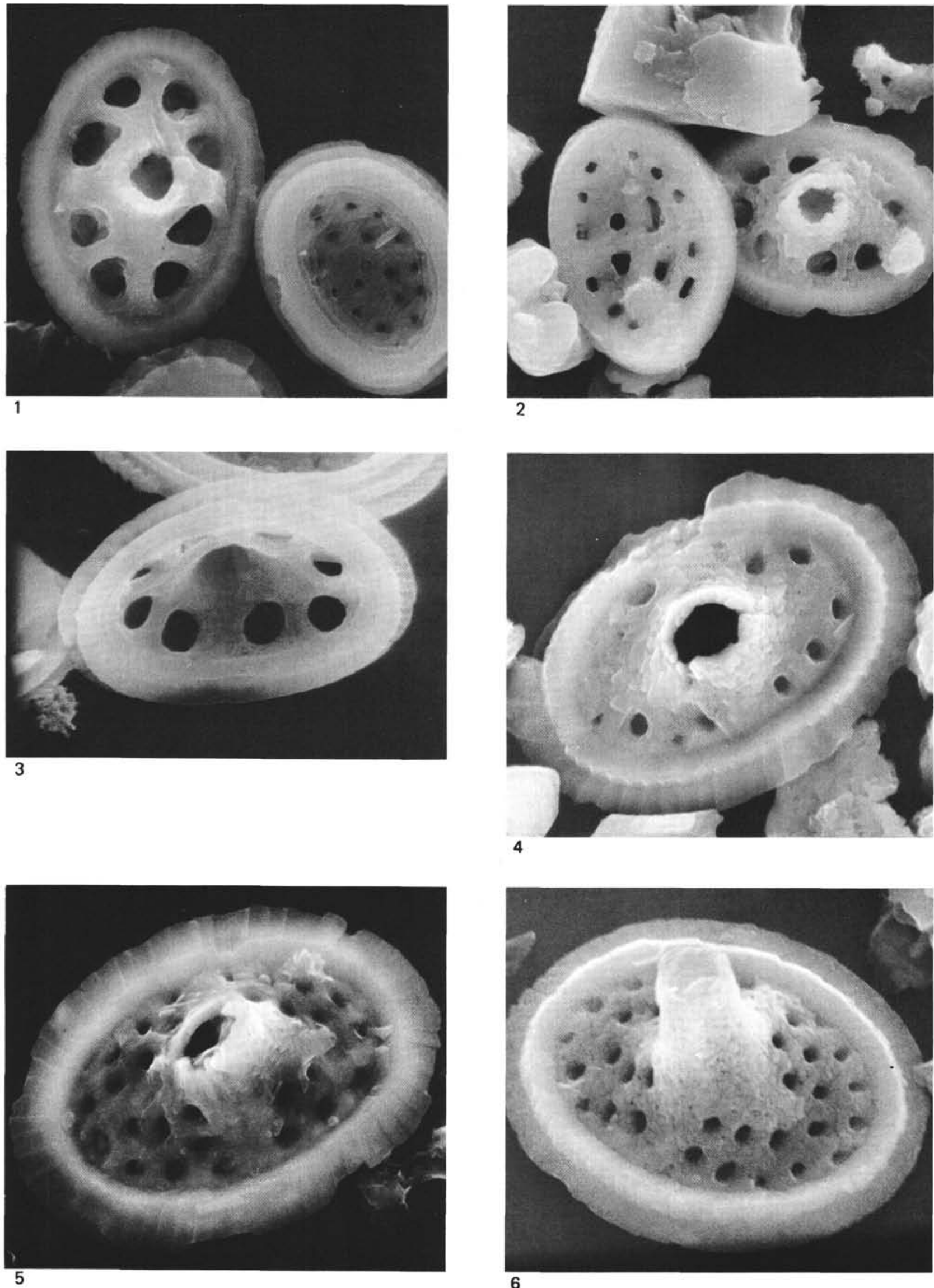


\section{PLATE 45}

(Maestrichtian-Campanian)

Figures 1-6 Kamptnerius magnificus Deflandre.

1. Proximal view, Sample 327A-10-3, $14 \mathrm{~cm}$, $\times 5200$.

2. Proximal view, Sample 327A-13-2, $45 \mathrm{~cm}$, $\times 7000$.

3. Proximal view, Sample 327A-13-2, $45 \mathrm{~cm}$, $\times 7000$.

4. Proximal view, Sample 327A-12, CC, $\times 7000$.

5. Distal view, Sample 327A-11-1, $107 \mathrm{~cm}, \times 5600$.

6. Proximal view, Sample $327 \mathrm{~A}-10-3,14 \mathrm{~cm}$, $\times 5000$. 
PLATE 45
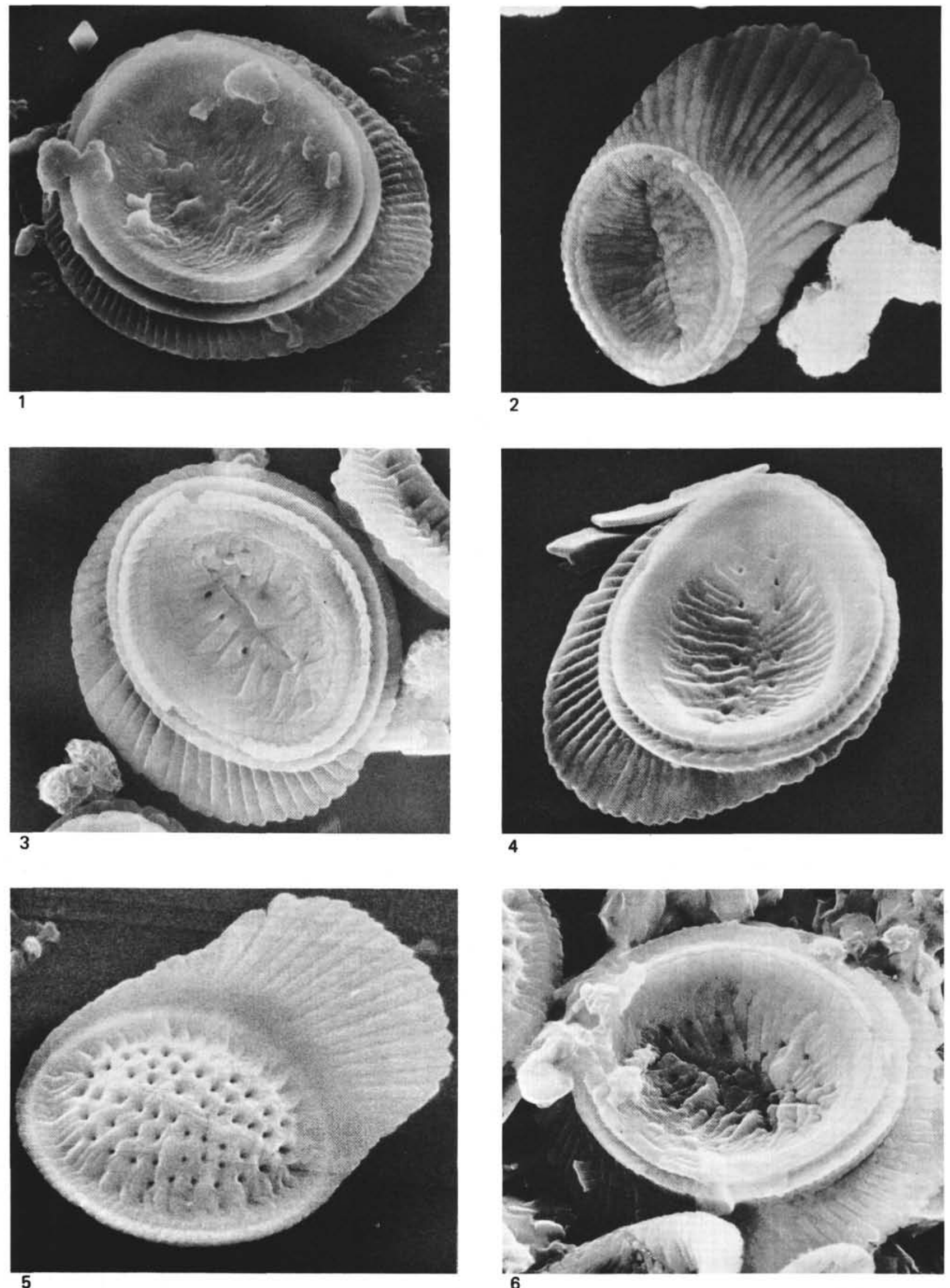


\section{PLATE 46}

(Maestrichtian-Campanian)

Figures 1-3 Lapideacassis mariae Black emend. Wind and Wise. Sample 327A-11-1, $107 \mathrm{~cm}$.

1, 2. Lateral, proximal views, $\times 6500, \times 10,600$.

3. Lateral view, $\times 6000$.

Figure 4 Lapideacassis tricornus Wind and Wise, n. sp. Paratype USNM 239524, lateral view; Sample $327 \mathrm{~A}-11-1,107 \mathrm{~cm} ; \times 5300$.

Figures 5,6 Lapideacassis glans Black, lateral and lateralproximal views, Sample 327 A-13-2, $56 \mathrm{~cm}, \times 8000$. 


\section{PLATE 46}
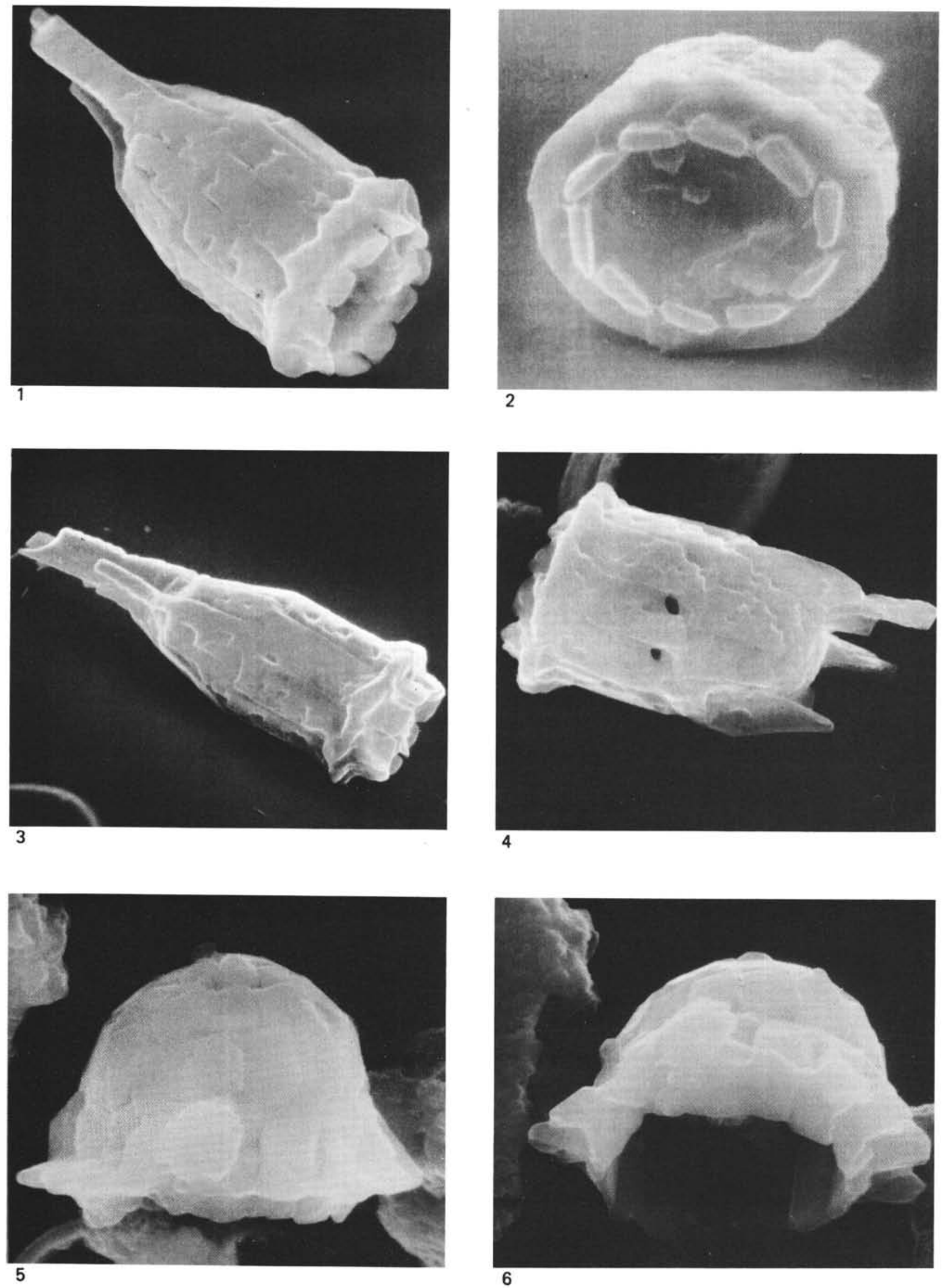


\section{PLATE 47}

(Maestrichtian [Figures 1, 2, 4] and Albian [Figures 3, 5, 6])

Figures 1,2 Lapideacassis mariae Black, emend. Wind and Wise.

1. Sample $327 \mathrm{~A}-13-1,142 \mathrm{~cm}, \times 5600$.

2. Sample 327A-12, CC, $\times 4000$.

Figures 3, $4 \quad$ Lapideacassis sp.

3. Sample $327 \mathrm{~A}-19-2,14 \mathrm{~cm}, \times 5700$.

4. Sample 327A-12, CC, $\times 5000$.

Figures 5,6 Lapideacassis glans Black.

5. Sample $330-2-1,130 \mathrm{~cm}, \times 8800$.

6. Sample $330 \mathrm{~A}-4, \mathrm{CC}, \times 7000$. 


\section{PLATE 47}
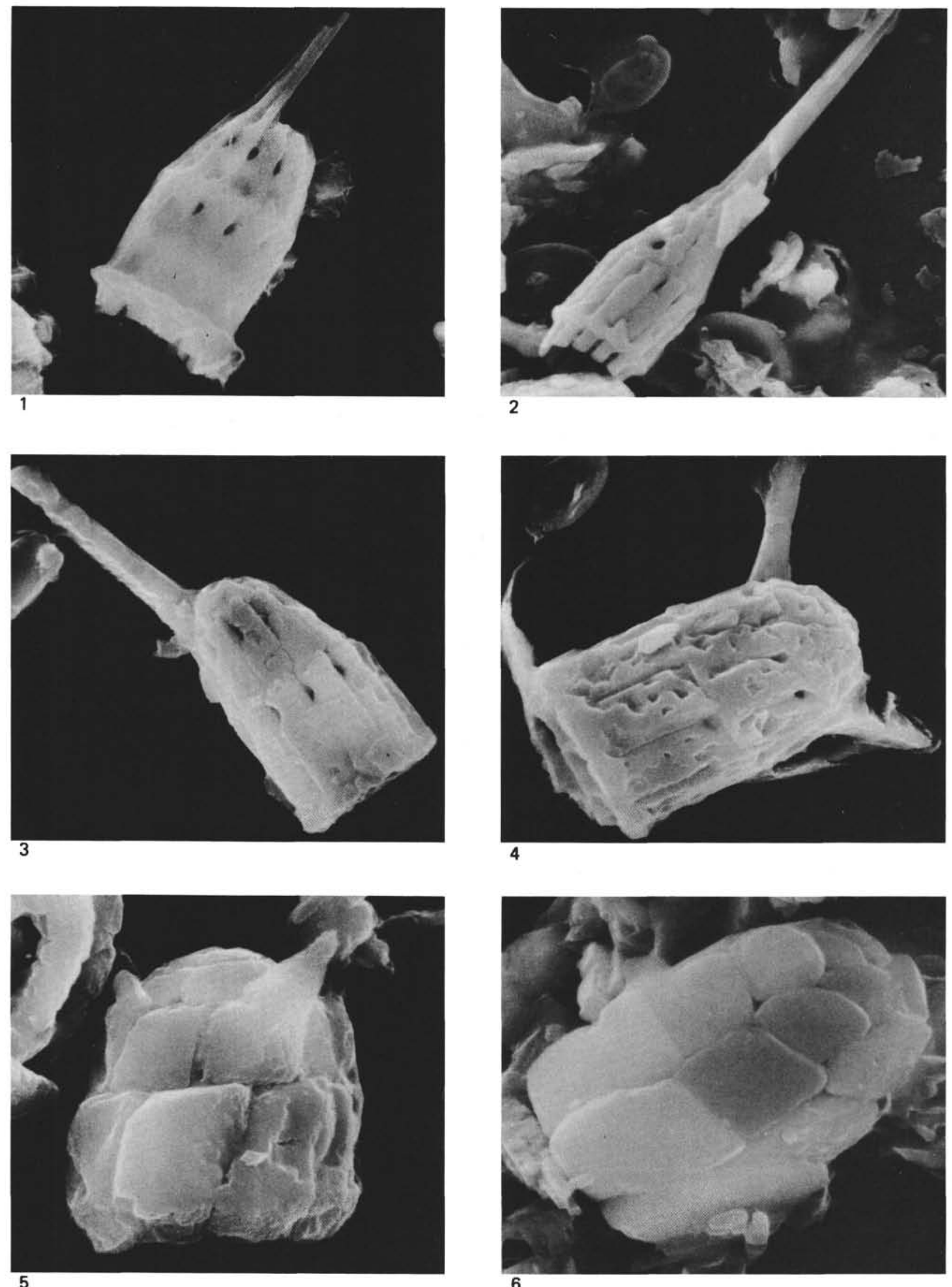


\section{PLATE 48}

(Maestrichtian and Cenomanian; polarizing directions for crossed-polarized light are parallel to the plate margin)

Figures 1-8 Lapideacassis tricornus Wind and Wise, n. sp. 1-3. Paratype USNM 239525; phase-contrast illumination and crossed-polarized light; Sample $327 \mathrm{~A}-10-3,14 \mathrm{~cm}, \times 3000$.

4-8. Holotype USNM 239522; phase-contrast illumination, crossed-polarized light and plain light; Sample 327A-10-3, $14 \mathrm{~cm}, \times 3000$.

Figures 9-12 Lapideacassis sp. aff. L. cornuta Forchheimer and Stradner.

9, 10. Phase-contrast illumination and crossedpolarized light, Sample 327A-14, CC, $\times 4000$.

11,12 . Phase-contrast illumination and crossedpolarized light, Sample 327A-14, CC, $\times 3100$. 
PLATE 48
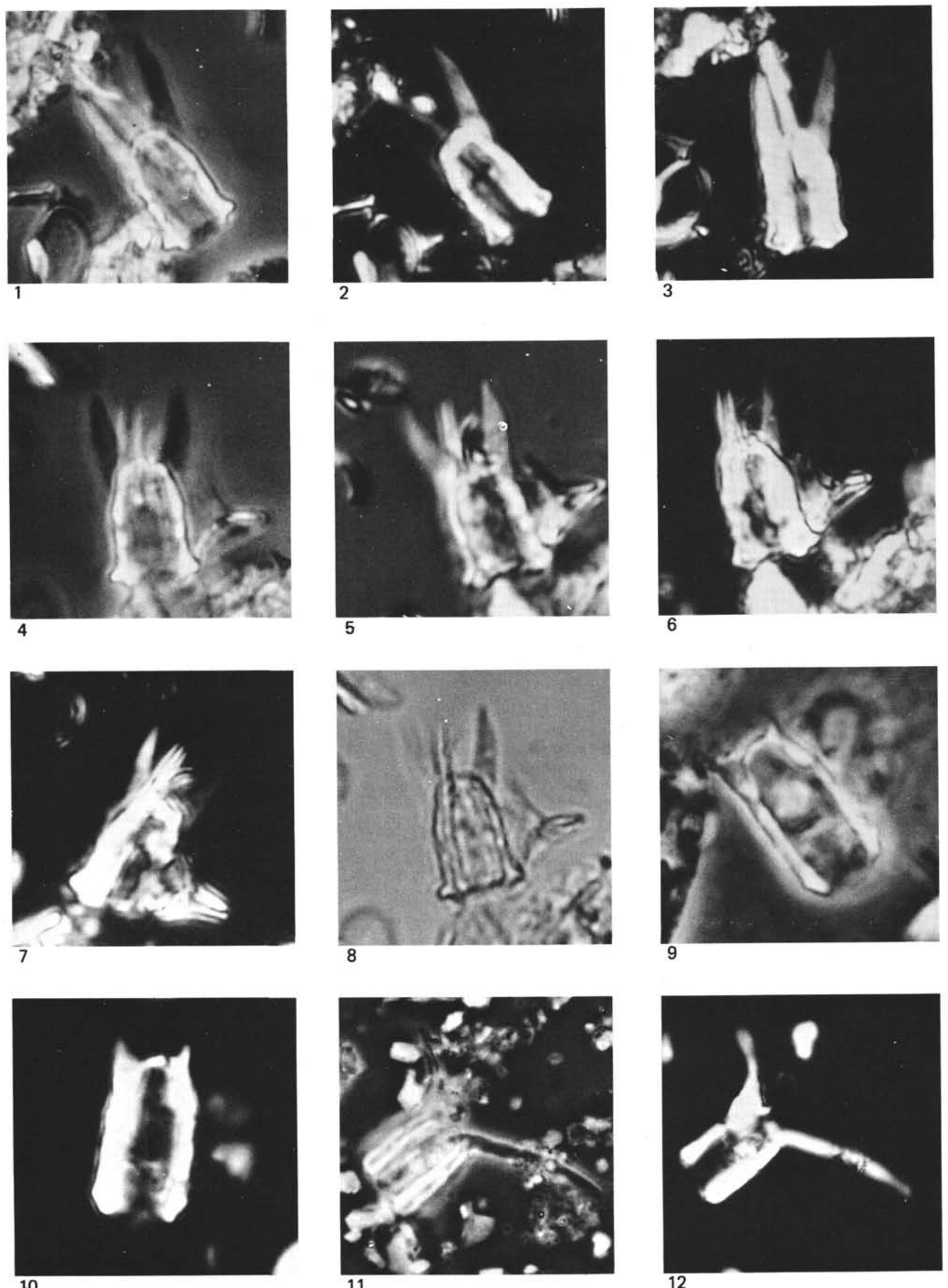


\section{PLATE 49}

(Maestrichtian and Tertiary [reworked?]; polarizing directions for crossed-polarized light are parallel to the plate margin)

Figures 1,2 Lapideacassis mariae Black emend. Wind and Wise, phase contrast illumination and crossedpolarized light, Sample 327A-12, CC, $\times 4700$.

Figures 3-8 Lapideacassis cornuta (Forchheimer and Stradner) Wind and Wise, n. comb.

3-5. Phase-contrast illumination and crossedpolarized light; Sample 329-32-1, $143 \mathrm{~cm}, \times 3700$. 6-8. Phase-contrast illumination and crossedpolarized light, Sample 329-32-1, $143 \mathrm{~cm}, \times 3700$.

Figures 9-11 Lapideacassis sp. phase-contrast illumination and crossed-polarized light, Sample 329-32-1, $143 \mathrm{~cm}$, $\times 3400$. 


\section{PLATE 49}
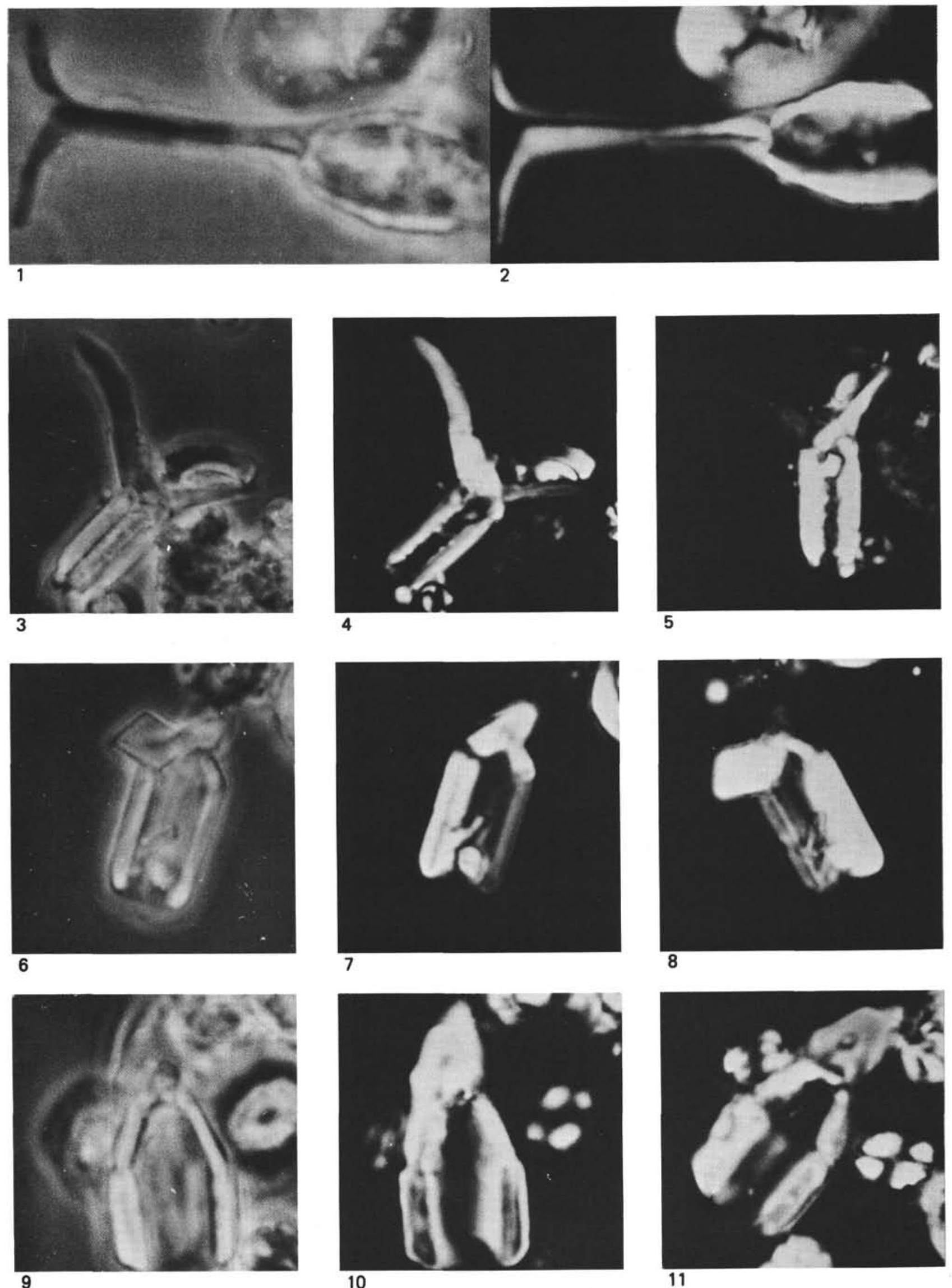


\section{PLATE 50}

(Maestrichtian-Campanian [Figures 1-5] and Albian [Figures 6-8]; Polarizing directions for crossed-polarized light are parallel to the plate margin)

Figure 1

(a) Biscutum magnum Wind and Wise, n. sp., paratype USNM 239527 and (b) B. constans (Gorka); phase-contrast (left) and crossedpolarized light (right); Sample 327A-12, CC; $\times 4600$.

Figure 2 ?Eiffellithus sp. phase-contrast and crossedpolarized illumination, Sample 327A-13-2, 137 $\mathrm{cm}, \times 4200$.

Figure 3 Tetralithus gothicus Deflandre, crossed-polarized and phase-contrast illumination, Sample 327A-13$1,142 \mathrm{~cm}, \times 4500$.

Figure 4 Broinsonia enormis (Shumenko), phase-contrast and crossed-polarized light, Sample 327A-13-2, 54 $\mathrm{cm}, \times 4600$.

Figure $5 \quad$ Broinsonia parca (Stradner), phase-contrast and crossed-polarized light, Sample 327A-13-2, $54 \mathrm{~cm}$, $\times 4000$.

Figures 6,7 Sollasites falklandensis Filewicz, Wind, and Wise, n. sp., phase-contrast and crossed-polarized light, Sample 327A-19-2, $15 \mathrm{~cm}, \times 3200$.

6. Paratype USNM 239528.

7. Paratype USNM 239529.

Figure $8 \quad$ Watznaueria supracretacea (Reinhardt) Wind and Wise, n. comb., phase-contrast and crossedpolarized light, Sample 330-1-2, $21 \mathrm{~cm}, \times 4000$. 
PLATE 50
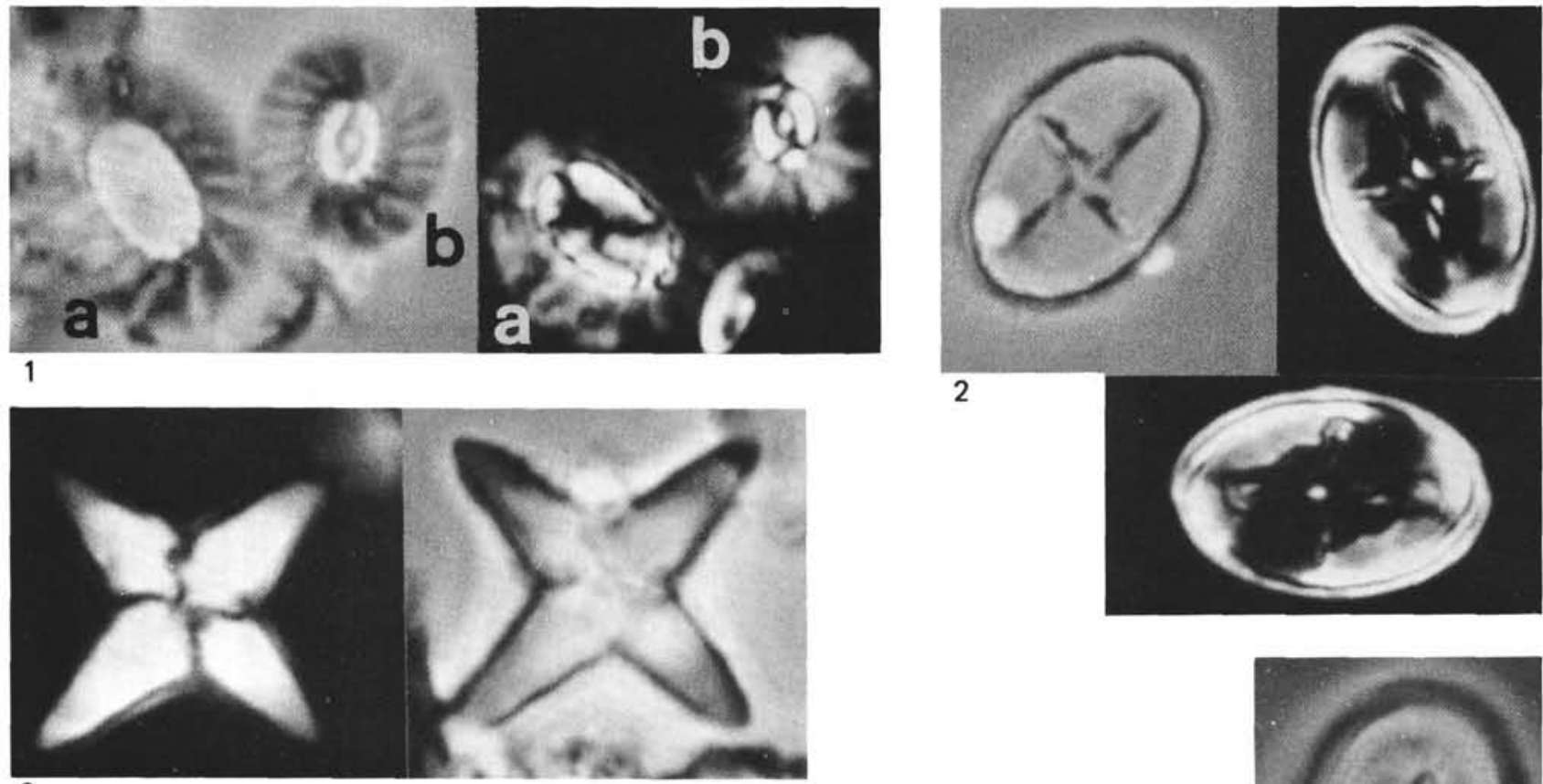

3
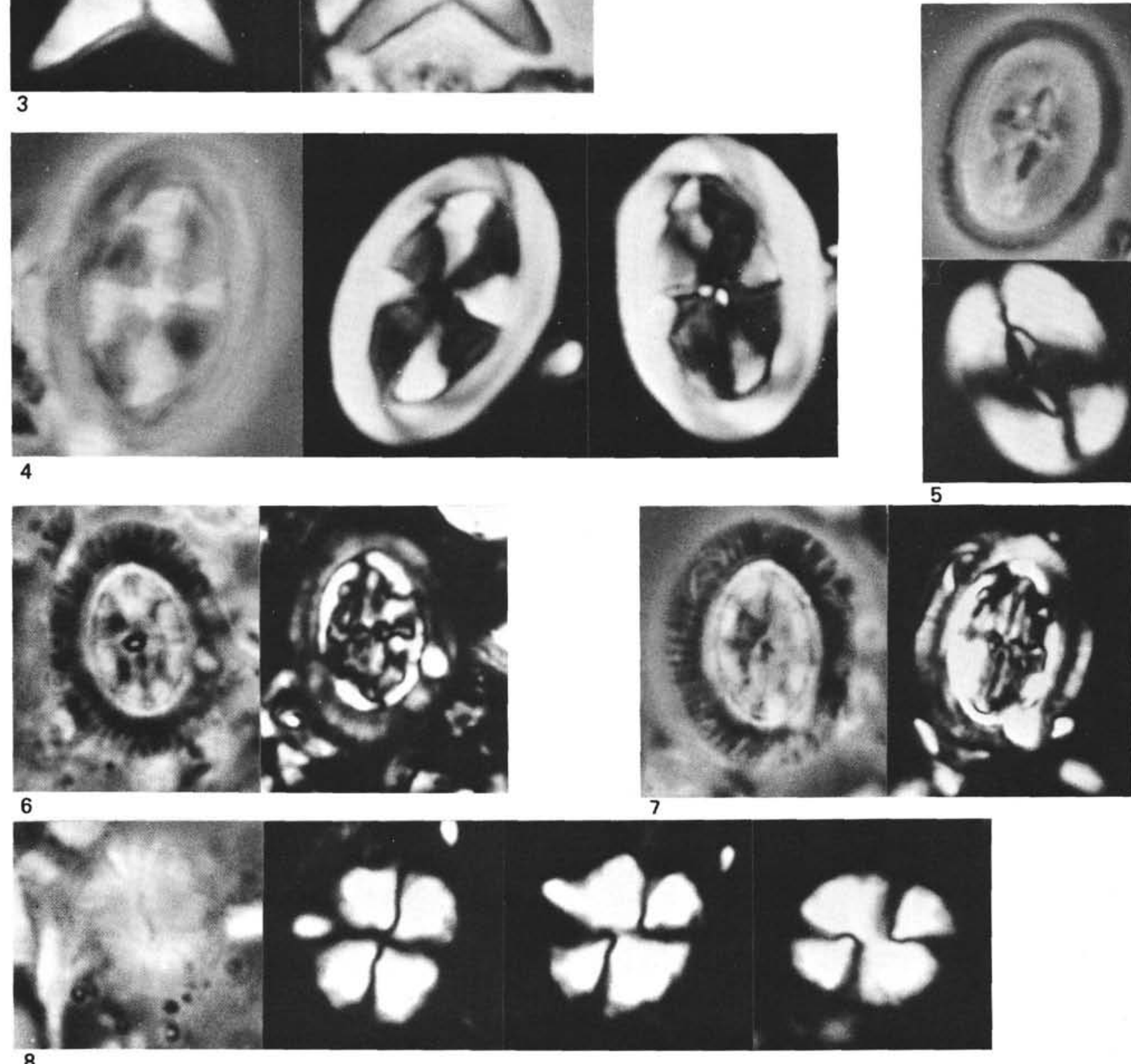

7
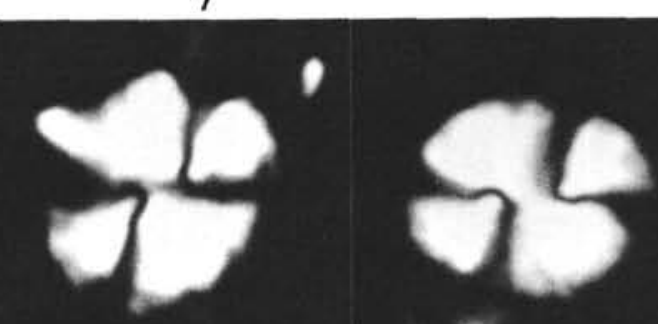


\section{PLATE 51}

(Santonian, late Albian)

Figures 1-4 Marthasterites furcatus (Deflandre and Fert), Santonian Sample 327A-14-3, $24 \mathrm{~cm}$.

1. $\times 8000$. This and the following two specimens are somewhat overgrown.

2. $\times 10,200$.

3. $\times 8000$.

4. $\times 14,500$. Tips of arms rounded by dissolution.

Figure $5 \quad$ Micula decussata Vekshina. Santonian Sample 327 A-14-3, $24 \mathrm{~cm}, \times 5300$. Specimen heavily overgrown.

Figure $6 \quad$ Eiffellithus turriseiffeli (Deflandre and Fert), late Albian Sample 327-15-1, $148 \mathrm{~cm}, \times 10,000$. Specimen heavily etched and overgrown. 


\section{PLATE 51}
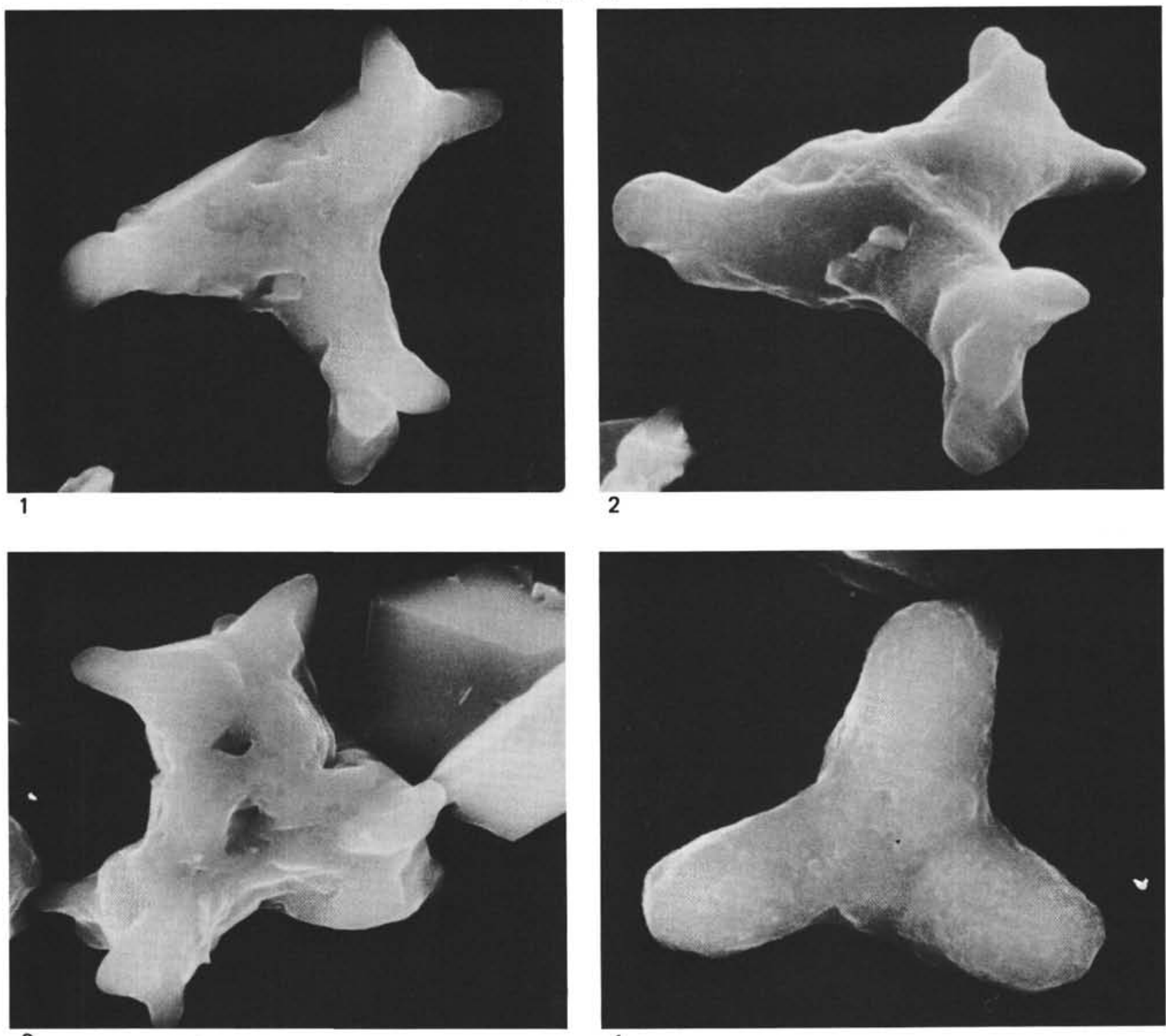

3

4
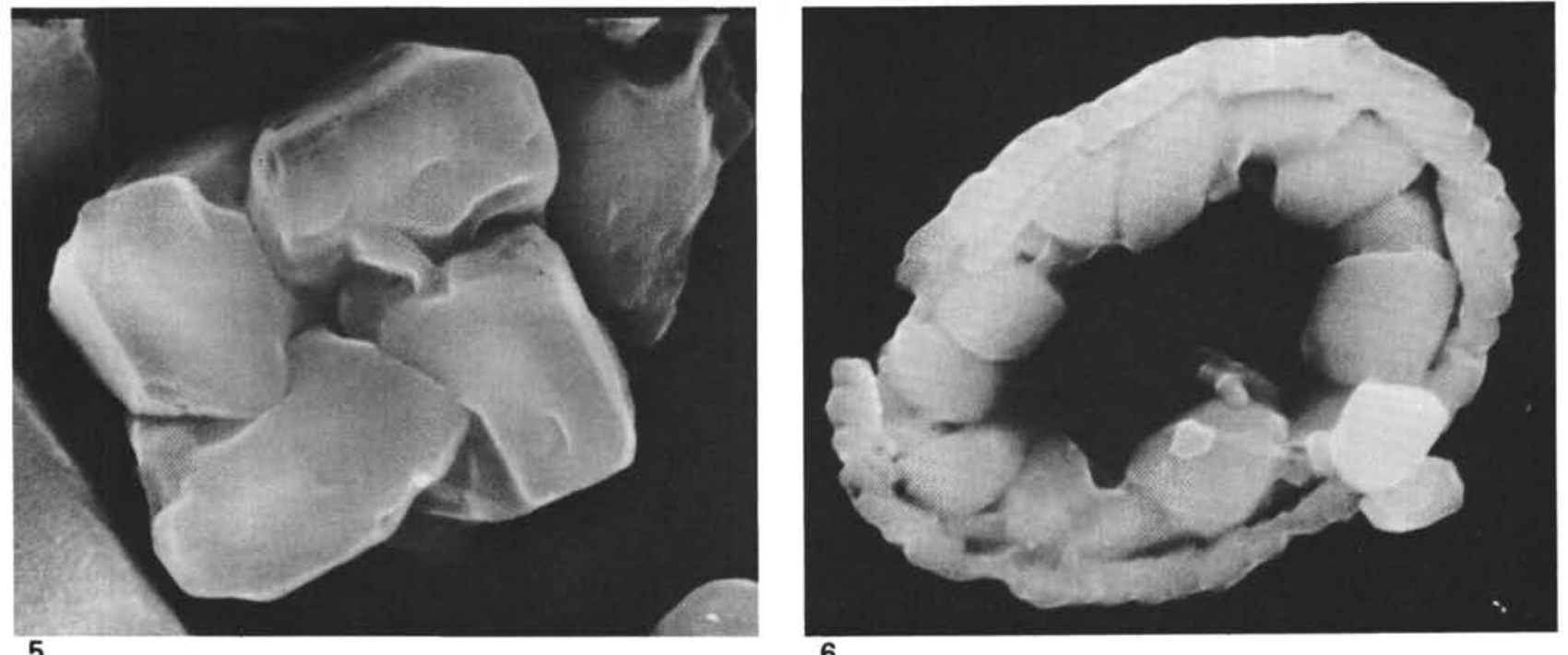

6 


\section{PLATE 52}

(Albian [Figures 1, 4-6]; Albian-Cenomanian [Figures 2, 3])

Figure 1 Broinsonia enormis (Shumenko), distal view, Sample $327 \mathrm{~A}-16-5,20 \mathrm{~cm}, \times 13,500$.

Figures 2, 3 Gartnerago segmentatum (Stover). Both specimens etched and overgrown, Sample 330A-4, CC.

2. $\times 7000$.

3. $\times 11,000$.

Figures 4-6 Broinsonia signata (Noël).

4. Distal view, Sample $330-2-1,130 \mathrm{~cm}, \times 11,430$.

5. Proximal view, Sample $330-2-1,130 \mathrm{~cm}, \times 8500$.

6. Distal view, Sample 330-2-2, $26 \mathrm{~cm}, \times 9500$. 
PLATE 52
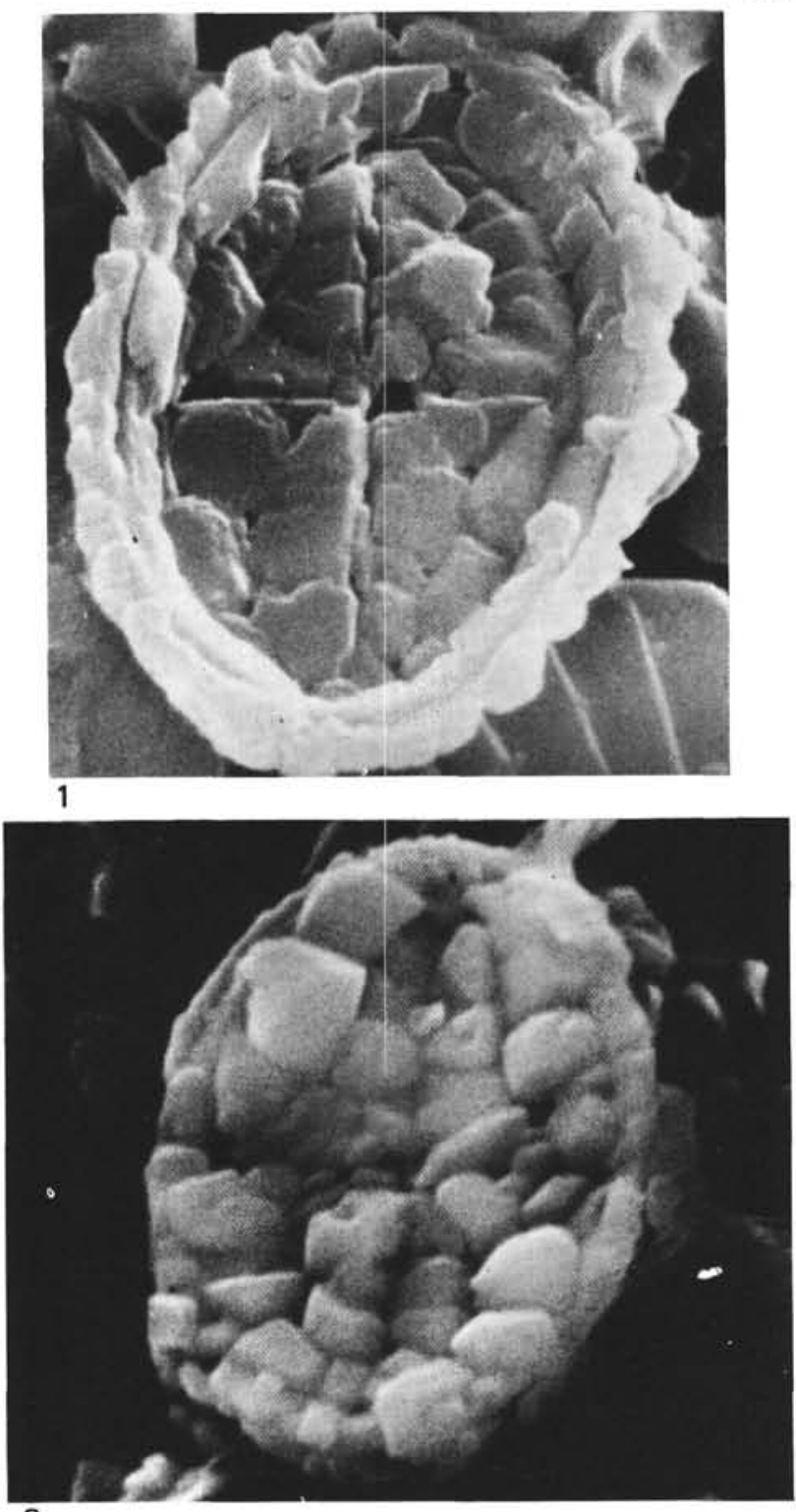

3

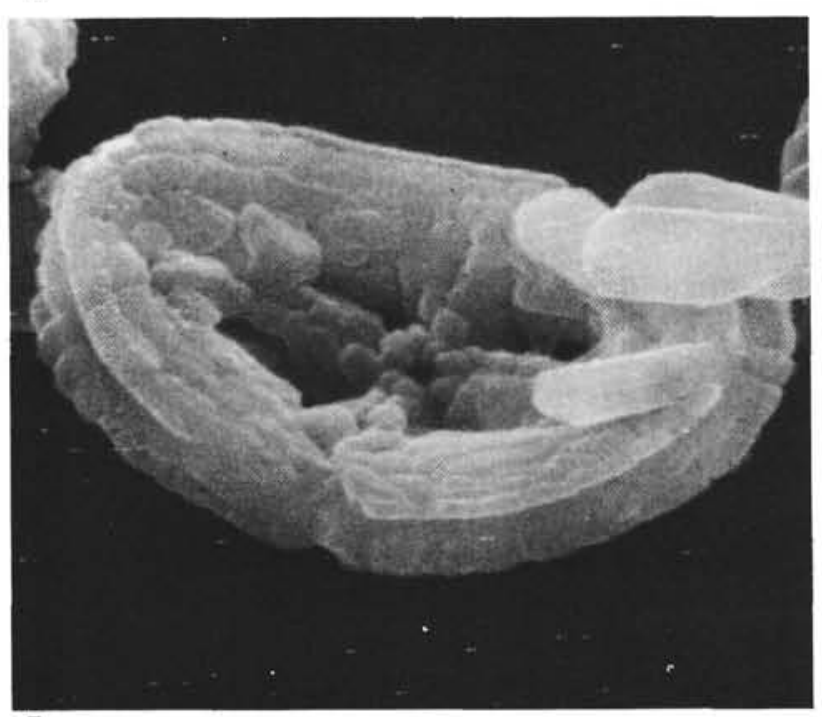

5
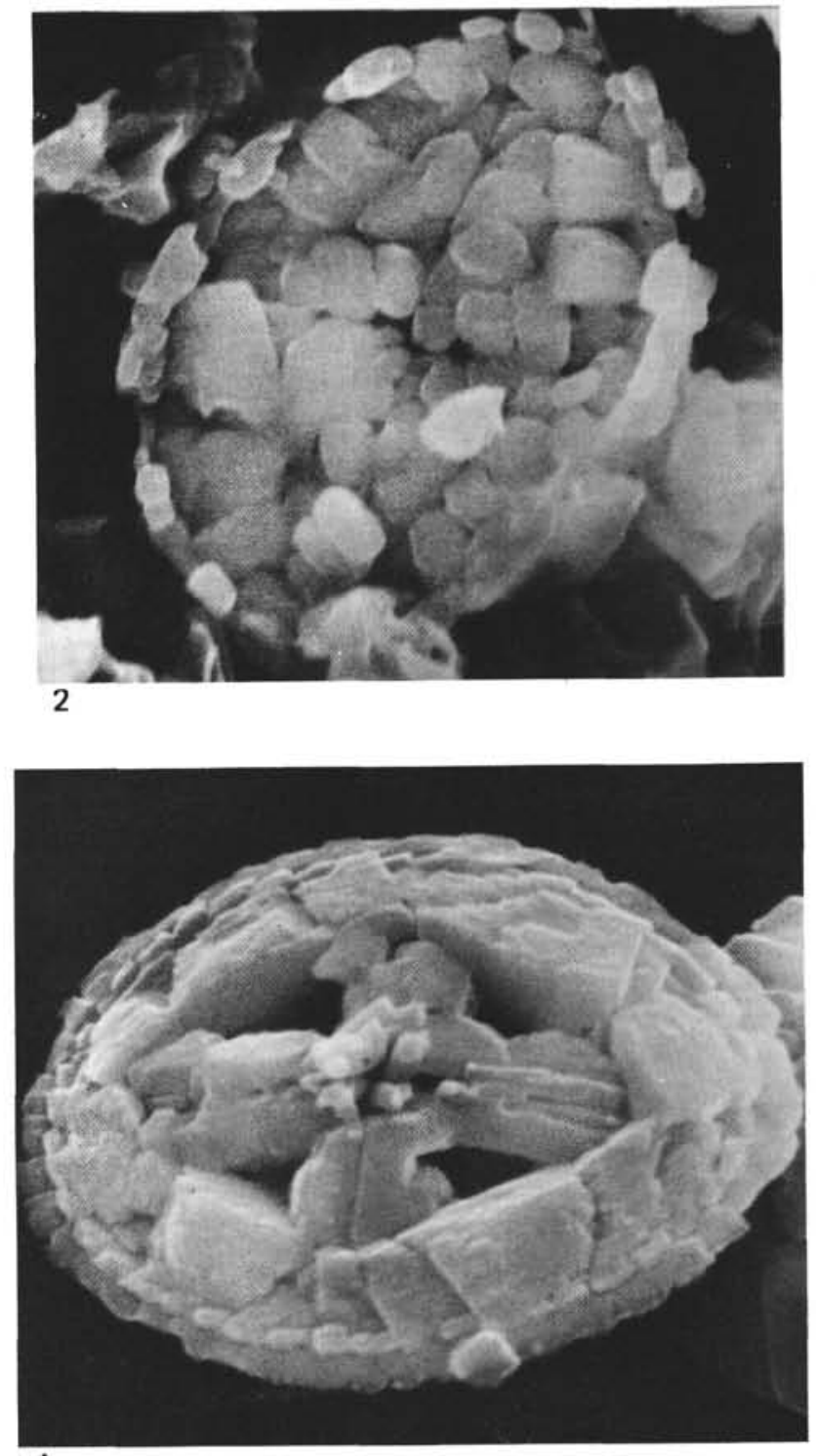

4

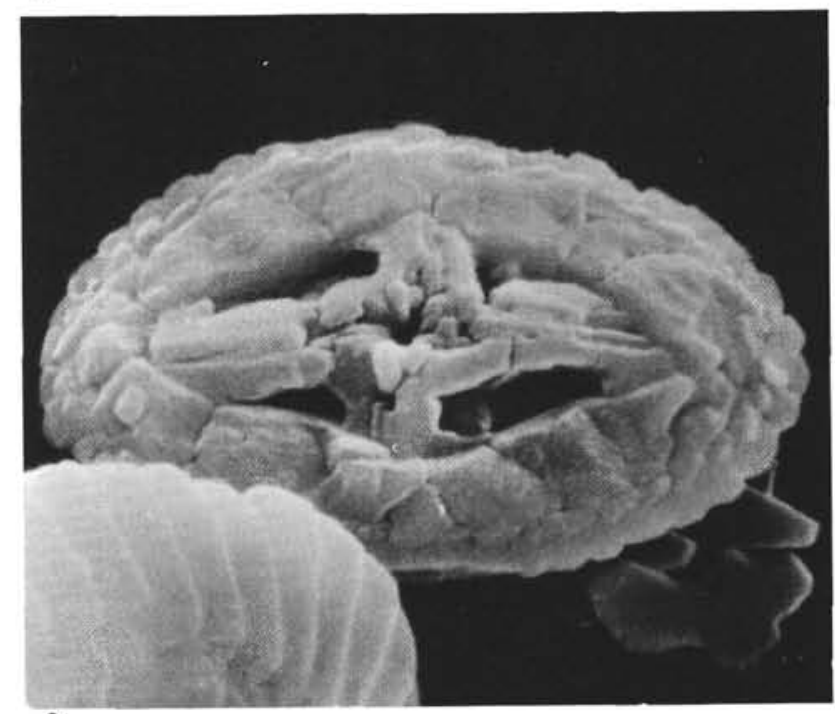

6 


\section{PLATE 53}

(Albian)

Figures 1-3 Chiastozygus litterarius (Gorka).

(upper), 4 1. Distal view, Sample $330-2-2,26 \mathrm{~cm}, \times 8000$.

2. Distal view, Sample 330-2-1, $130 \mathrm{~cm}, \times 10,000$.

3. Top-C. litterarius distal view; lower left-Watznaueria sp., proximal view; lower right-Zygodiscus sp. Gartner, distal view, Sample 327 A-19-2, $120 \mathrm{~cm}, \times 5000$.

4. Proximal view, Sample 330-1-1, $70 \mathrm{~cm}$, $\times 10,000$.

Figures 5,6 Vekshinella stradneri Rood, Hay and Barnard. 5. Proximal view, Sample 330-3-2, $105 \mathrm{~cm}$, $\times 16,000$.

6. Proximal view, Sample 327A-19-2, $120 \mathrm{~cm}$, $\times 13,000$. 


\section{PLATE 53}
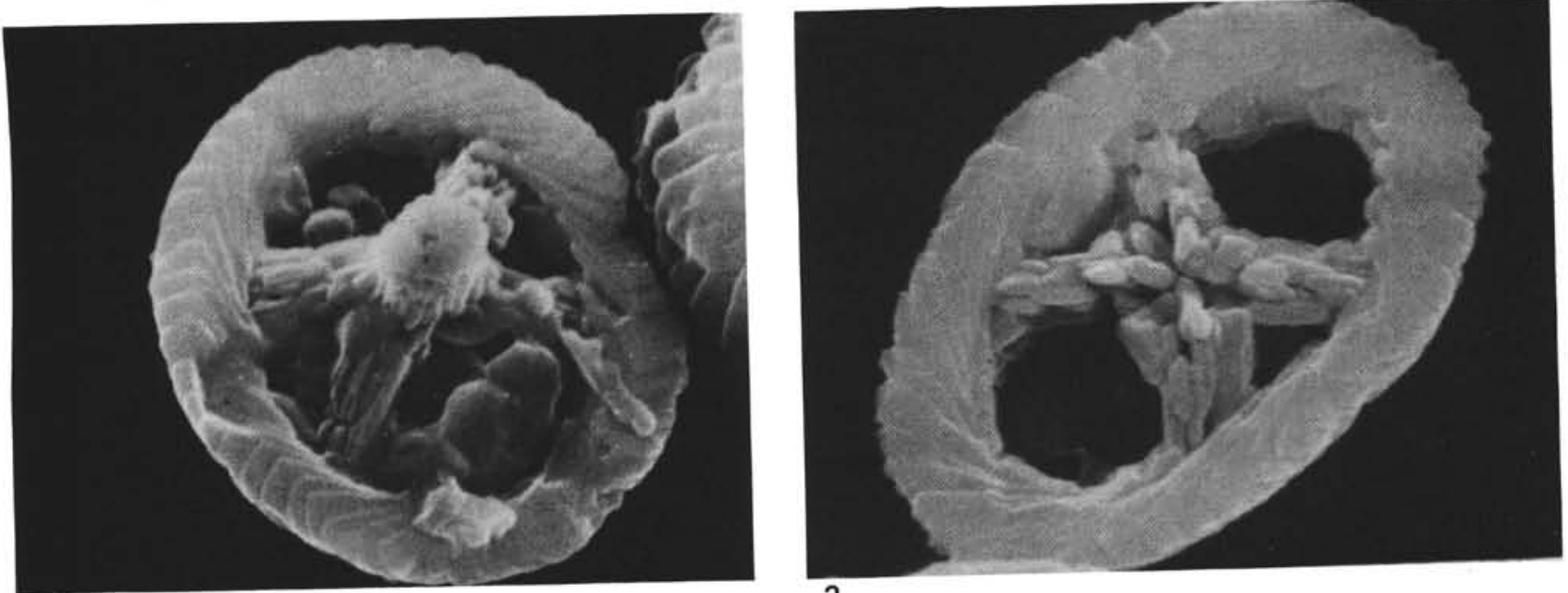

2

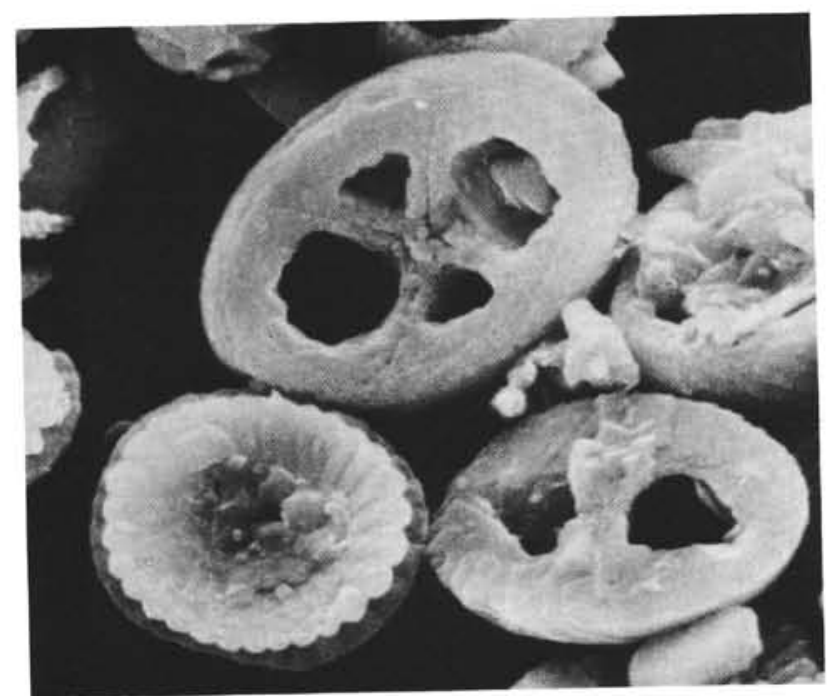

3

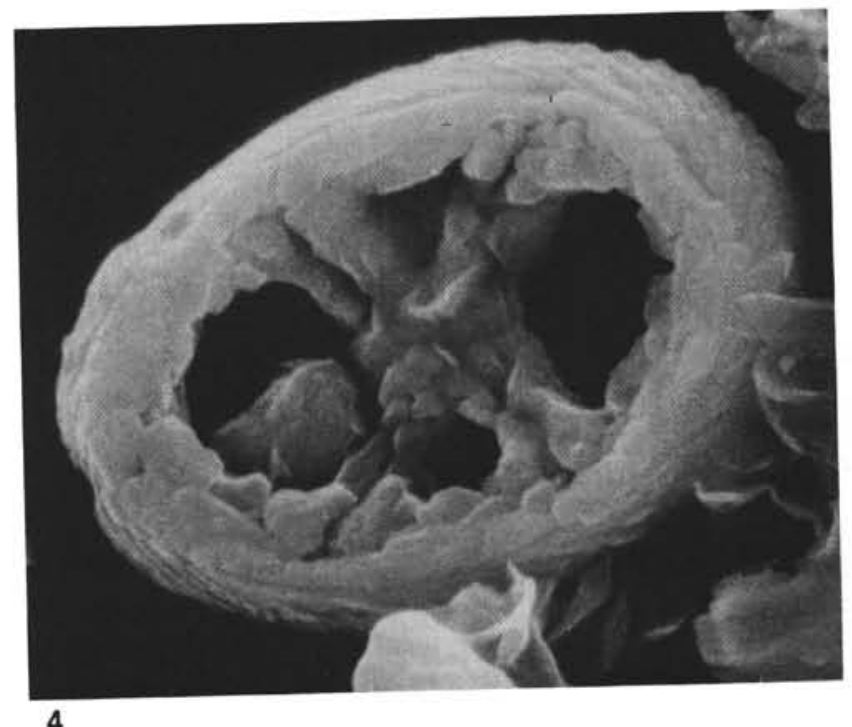

4
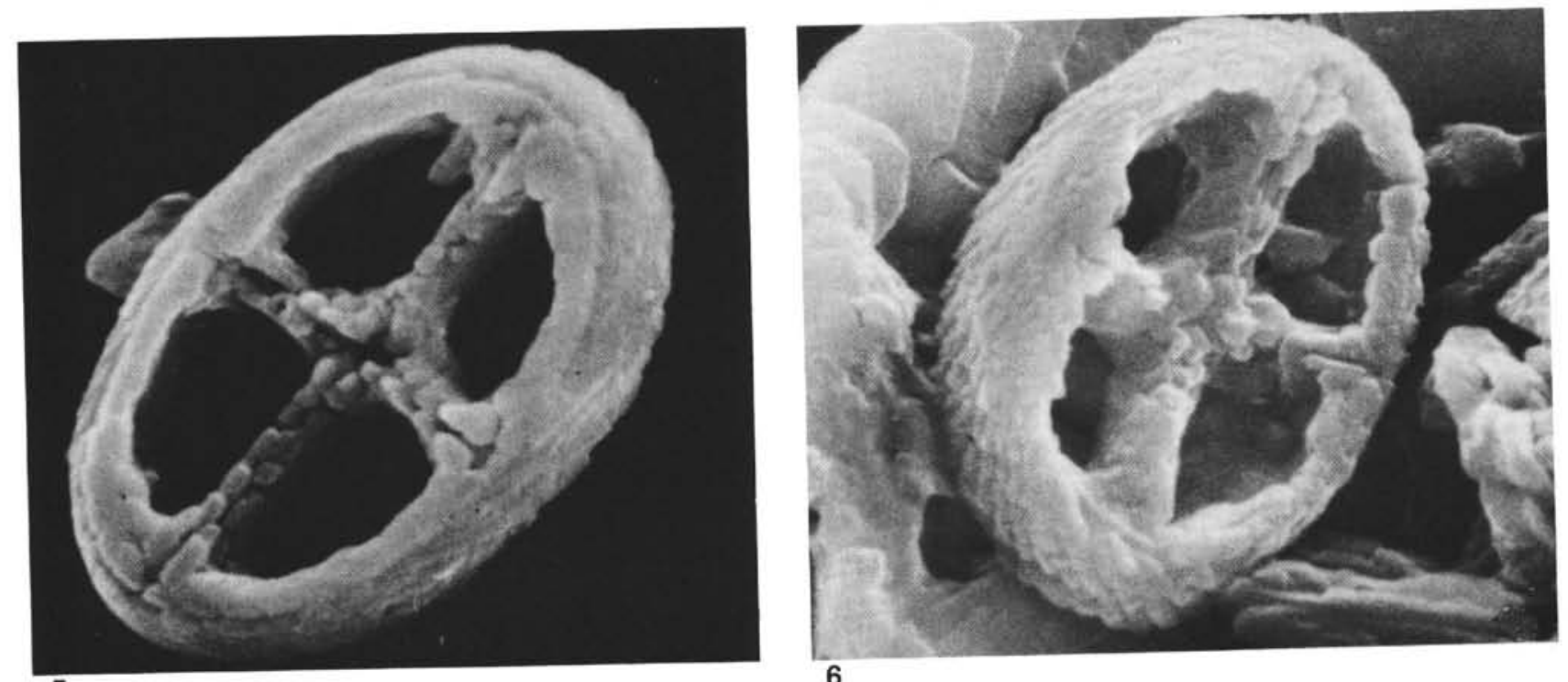
PLATE 54

(Aptian, Albian)

Figures 1-3, Vekshinella stradneri Rood, Hay, and Barnard. 4 (part) 1. Proximal view, Sample 330-3-2, $115 \mathrm{~cm}$, $\times 14,000$.

2. Proximal, side, and distal views, Sample 330-3-

$2,115 \mathrm{~cm}, \times 7000$.

3. Distal view, Sample $330-3-2,115 \mathrm{~cm}, \times 24,000$. 4. Bottom-V. stradneri, distal view; TopParhabdolithus angustus (Stradner), proximal view, Sample 330-2-2, $141 \mathrm{~cm}, \times 5900$.

Figure 5 ?Vekshinella sp., Sample 327A-16-5, $20 \mathrm{~cm}$, $\times 16,000$.

Figure 6 Eiffellithus sp. cf. E. dennisoni Worsley (=Vekshinella quadriarculla [Noël]?), distal view, Sample $327 \mathrm{~A}-19-2,120 \mathrm{~cm}, \times 15,000$. 
PLATE 54
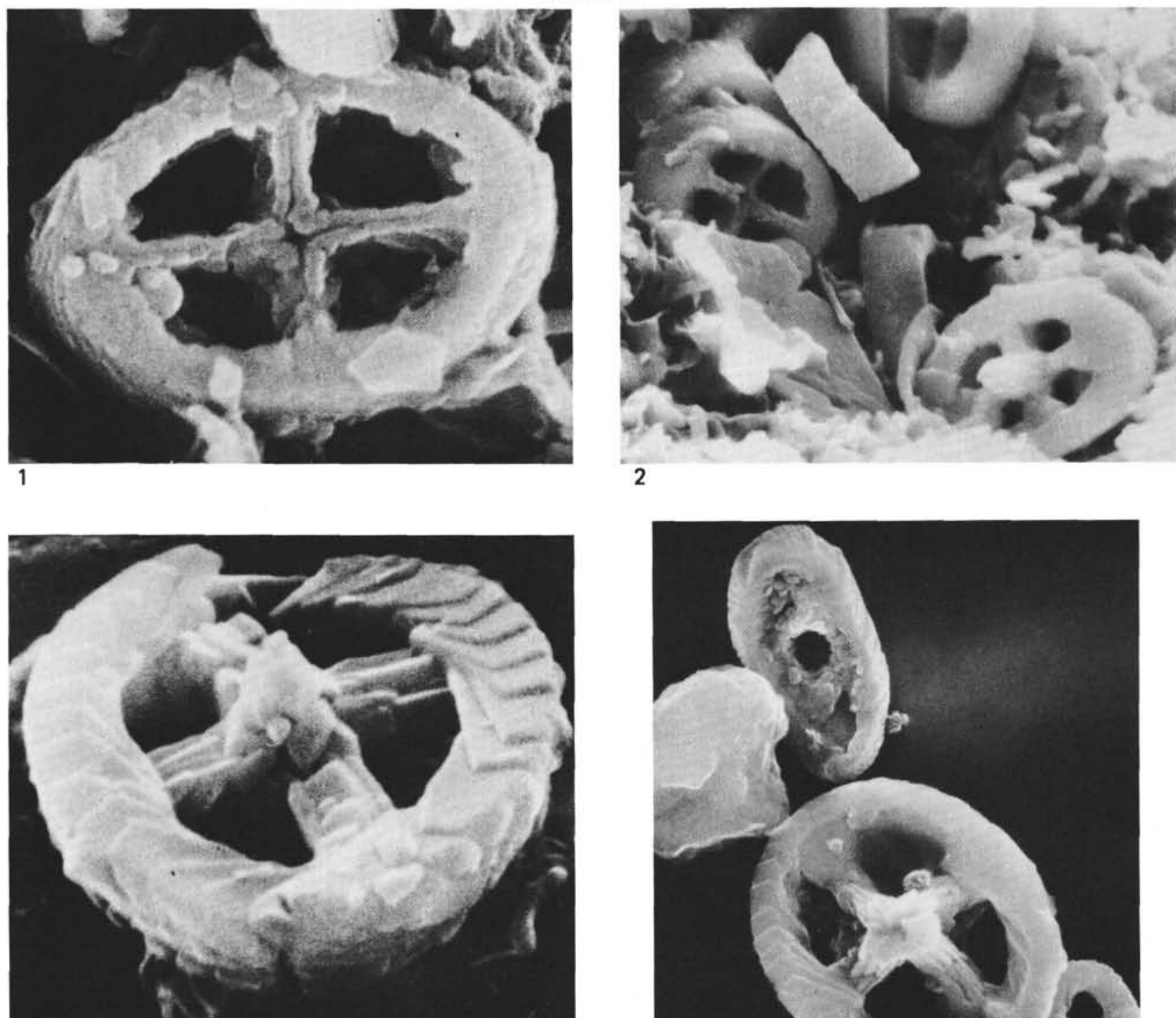

3
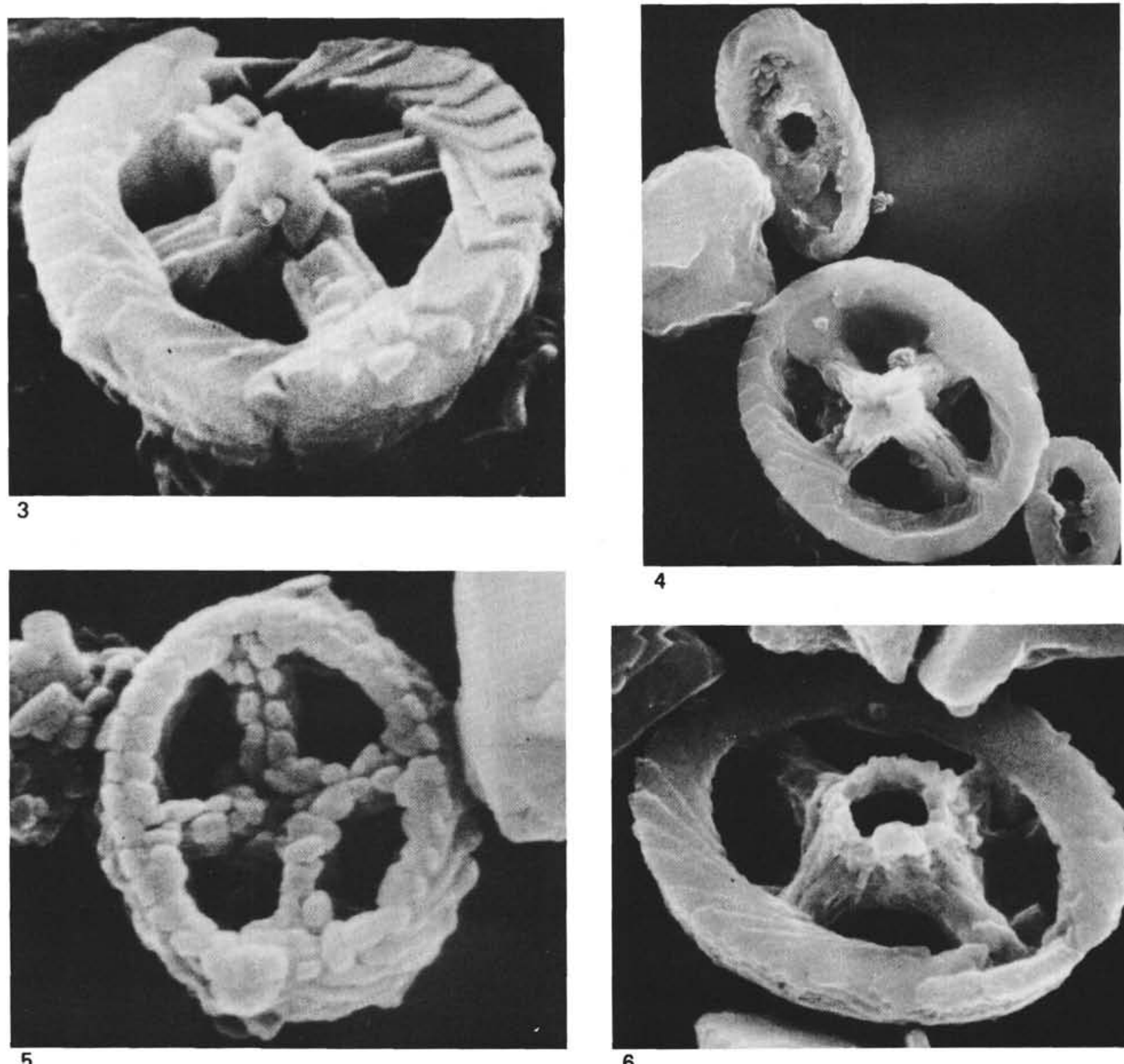

4

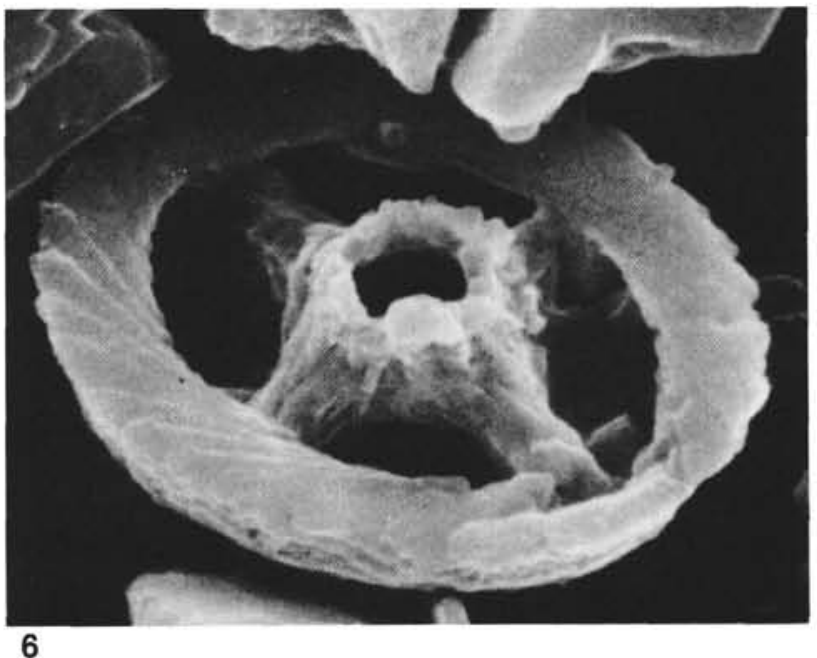




\section{PLATE 55}

(Aptian, Albian-Cenomanian)

Figures 1-3 Eiffellithus dennisoni? Worsley (=Vekshinella quadriarculla [Noël]?).

1. Proximal view, Sample 327A-16-5, $20 \mathrm{~cm}$, $\times 16,000$.

2. Proximal view, Sample 327A-19-2, $75 \mathrm{~cm}$, $\times 15,000$.

3. Phase-contrast, Sample 327A-21-3, $93 \mathrm{~cm}$, $\times 4000$.

Figure $4 \quad$ Zygodiscus sp., proximal view, Sample 330A-4, CC, $\times 16,000$.

Figure $5 \quad$ Zygodiscus sp., proximal view, Sample 330-2, 26 $\mathrm{cm}, \times 9400$.

Figure $6 \quad$ Zygodiscus sp., distal view, Sample 330-3-2, 115 $\mathrm{cm}, \times 13,000$.

Figure 7 Zygodiscus diplogrammus (Deflandre and Fert), distal view, Sample 327A-19-2, $120 \mathrm{~cm}, \times 12,000$. 


\section{PLATE 55}
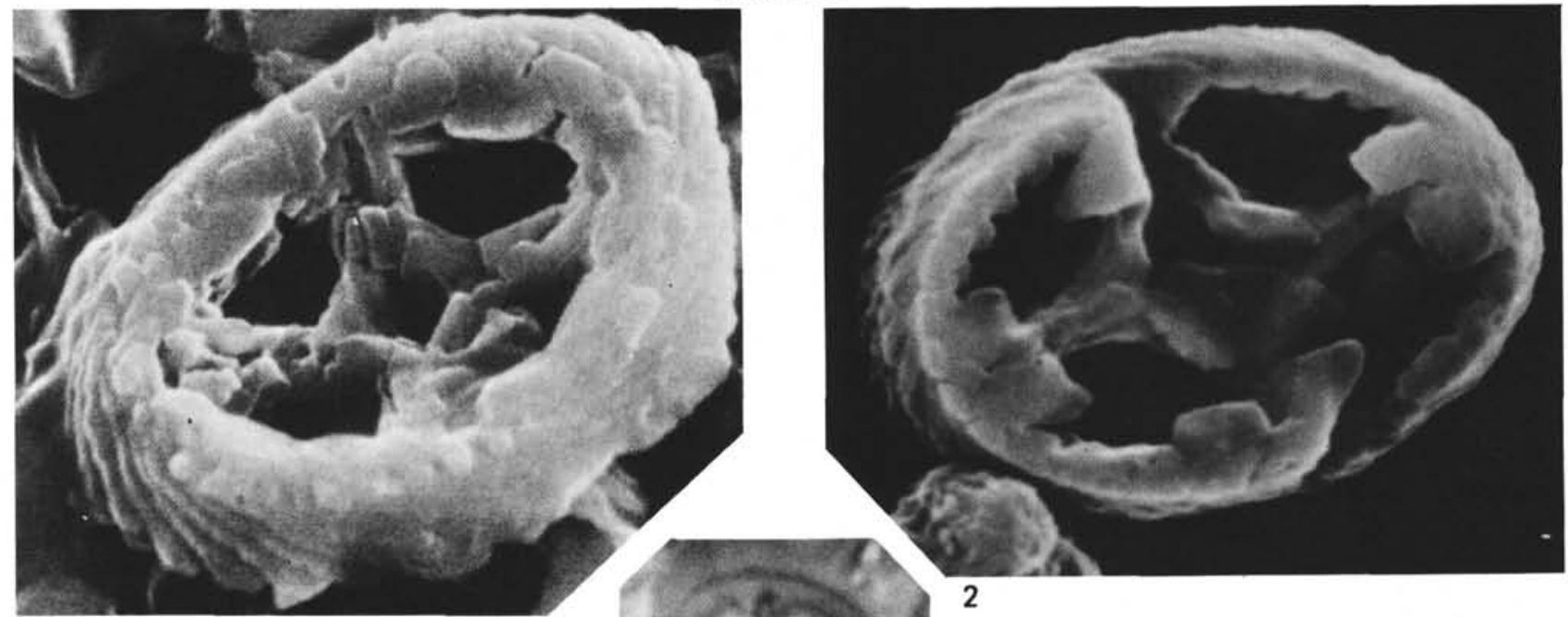

1
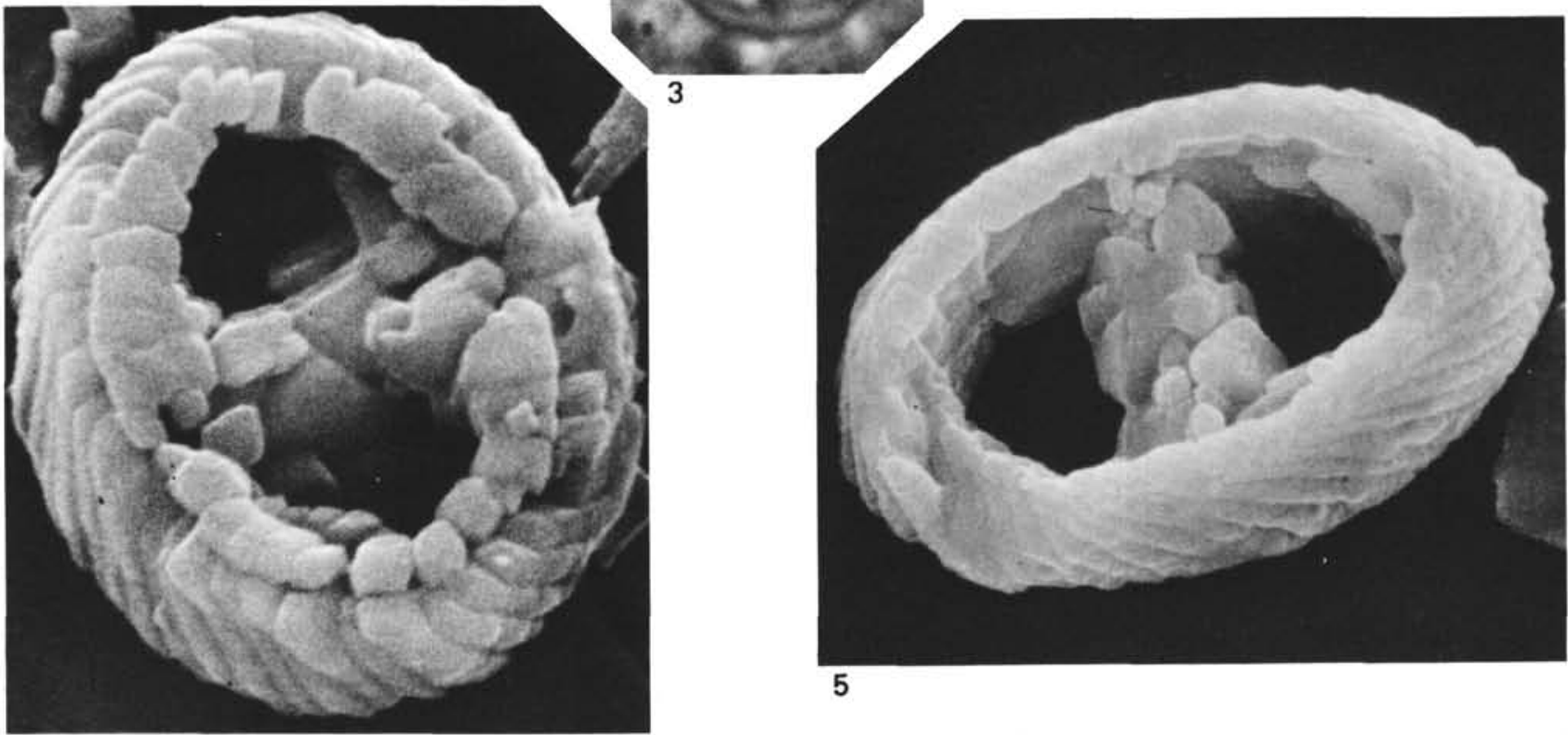

4
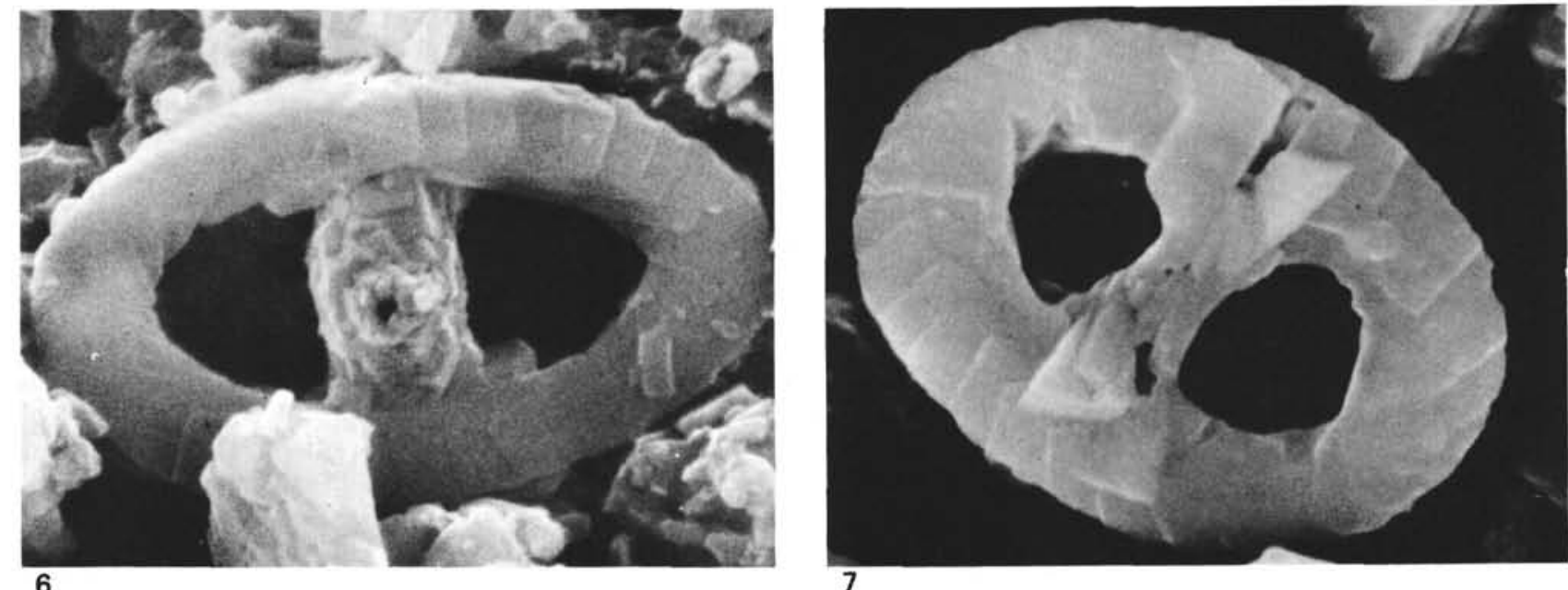


\section{PLATE 56}

(Aptian, Albian)

Figures 1, 2 Parhabdolithus splendens (Deflandre).

1. Distal view, Sample $330-2-2,26 \mathrm{~cm}, \times 9000$.

2. Distal view, Sample $330-2-1,130 \mathrm{~cm}, \times 7500$.

Figure 3 Parhabdolithus asper (Stradner) ?, proximal view, Sample 330-2-2, $26 \mathrm{~cm}, \times 7500$.

Figures 4-6 Parhabdolithus infinitus (Worsley).

4. Proximal view (phase-contrast), Sample 327A$22-2,27 \mathrm{~cm}, \times 4000$.

5. Proximal view, Sample $327 \mathrm{~A}-21-3,31 \mathrm{~cm}$, $\times 8500$.

6. Side view, Sample 327 A-21-3, $31 \mathrm{~cm}, \times 7300$. 


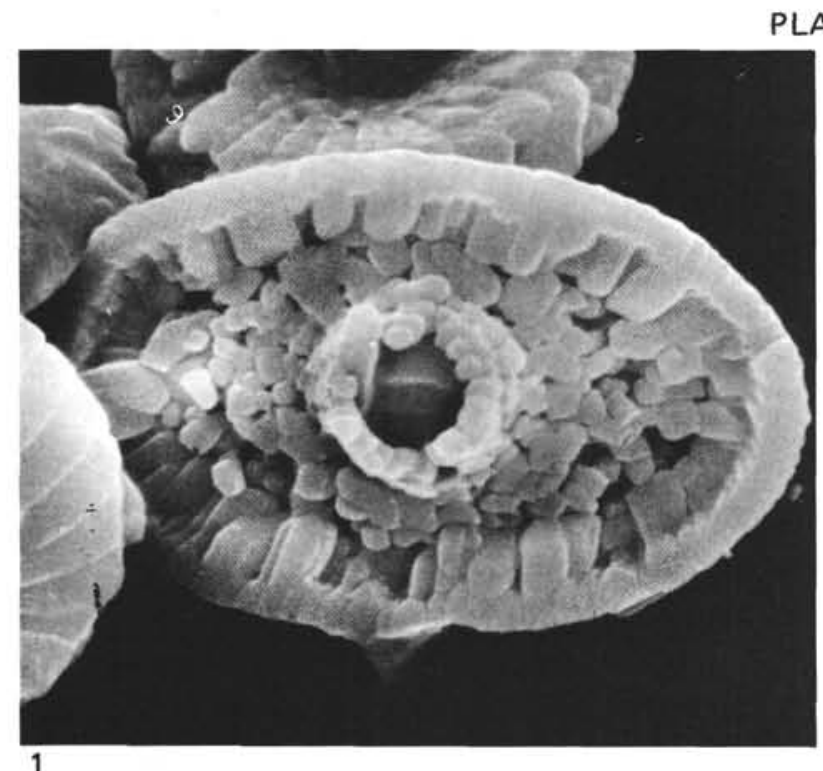

PLATE 56
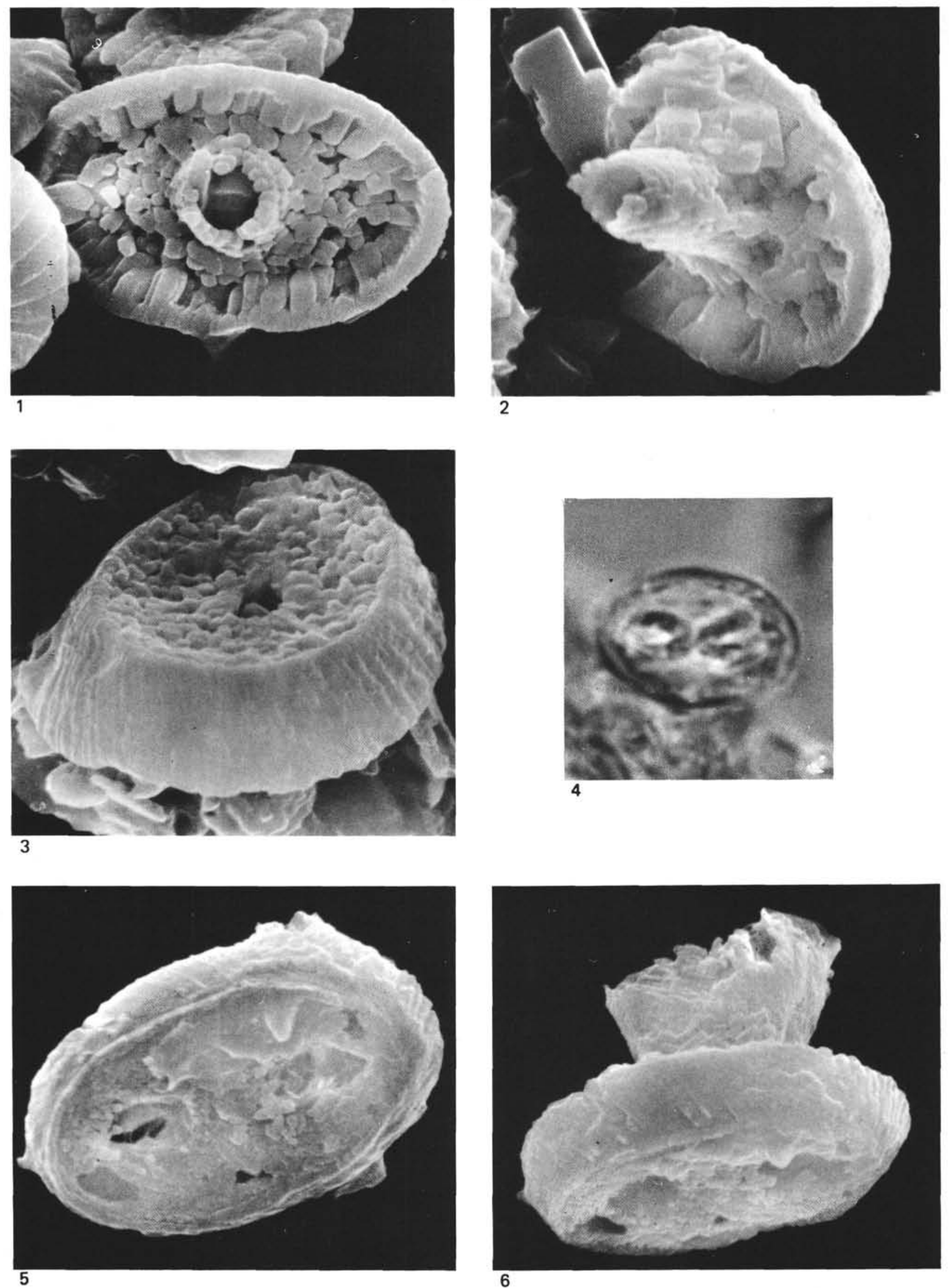


\section{PLATE 57}

(Albian, Albian-Cenomanian)

Figures 1-4 Tranolithus orionatus (Reinhardt) Reinhardt.

1. Distal view, Sample 327A-15-1, $146 \mathrm{~cm}$, $\times 11,000$.

2. Distal view, Sample 327A-15-1, $146 \mathrm{~cm}$, $\times 11,500$.

3. Distal view, Sample $330 \mathrm{~A}-4, \mathrm{CC}, \times 20,000$.

4. Isolated central area structure, Sample 327-14, $\mathrm{CC}, \times 15,000$.

Figure 5 Tranolithus gabalus Stover, distal view, Sample $327 \mathrm{~A}-14, \mathrm{CC}, \times 9000$.

Figure 6 Octocyclus reinhardtii (Bukry) Wind and Wise, $\mathrm{n}$. comb., distal view, Sample 327A-19-2, $15 \mathrm{~cm}$, $\times 5000$. 


\section{PLATE 57}
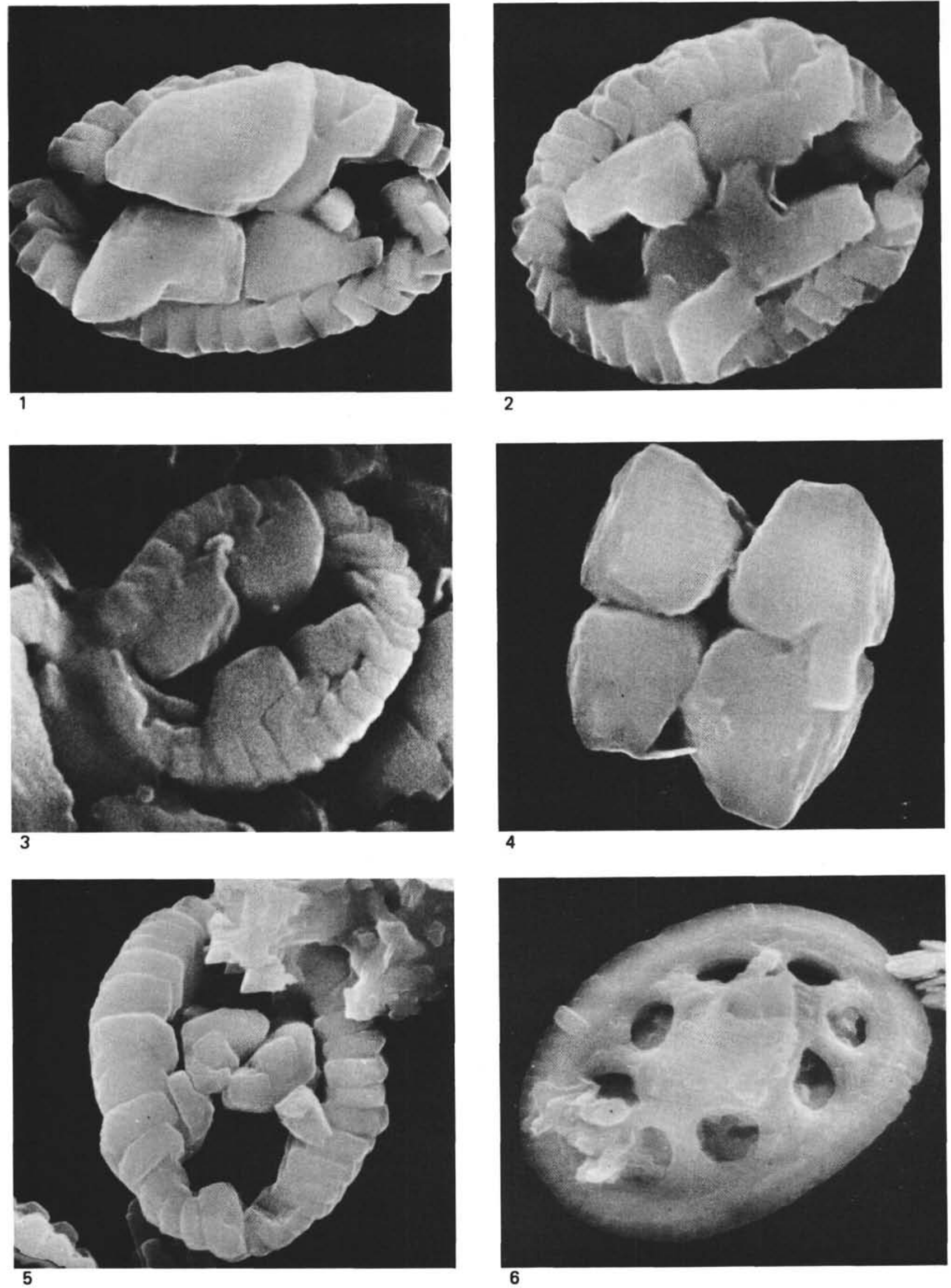


\section{PLATE 58}

(Albian)

Figures 1, 2 Octocyclus reinhardtii (Bukry) Wind and Wise, n. comb.

1. Distal view, Sample 327A-21-3, 31, CC, $\times 8000$. 2. Proximal view, Sample $327 \mathrm{~A}-21-3,31 \mathrm{~cm}$, $\times 8000$

Figures 3,4 Axopodorhabdus dietzmanni (Reinhardt) Wind and Wise, n. comb.

3. Distal view, Sample 327A-21, CC, $\times 10,000$.

4. Distal view, Sample 327A-16-5, 20, CC, $\times 9500$.

Figures 5,6 Prediscosphaera cretacea (Arkhangelsky).

5. Three specimens, proximal and side views, Sample $327 \mathrm{~A}-19-2,15 \mathrm{~cm}, \times 6000$.

6. Distal view, Sample $327 \mathrm{~A}-15-1,148 \mathrm{~cm}$, $\times 10,000$. 
PLATE 58
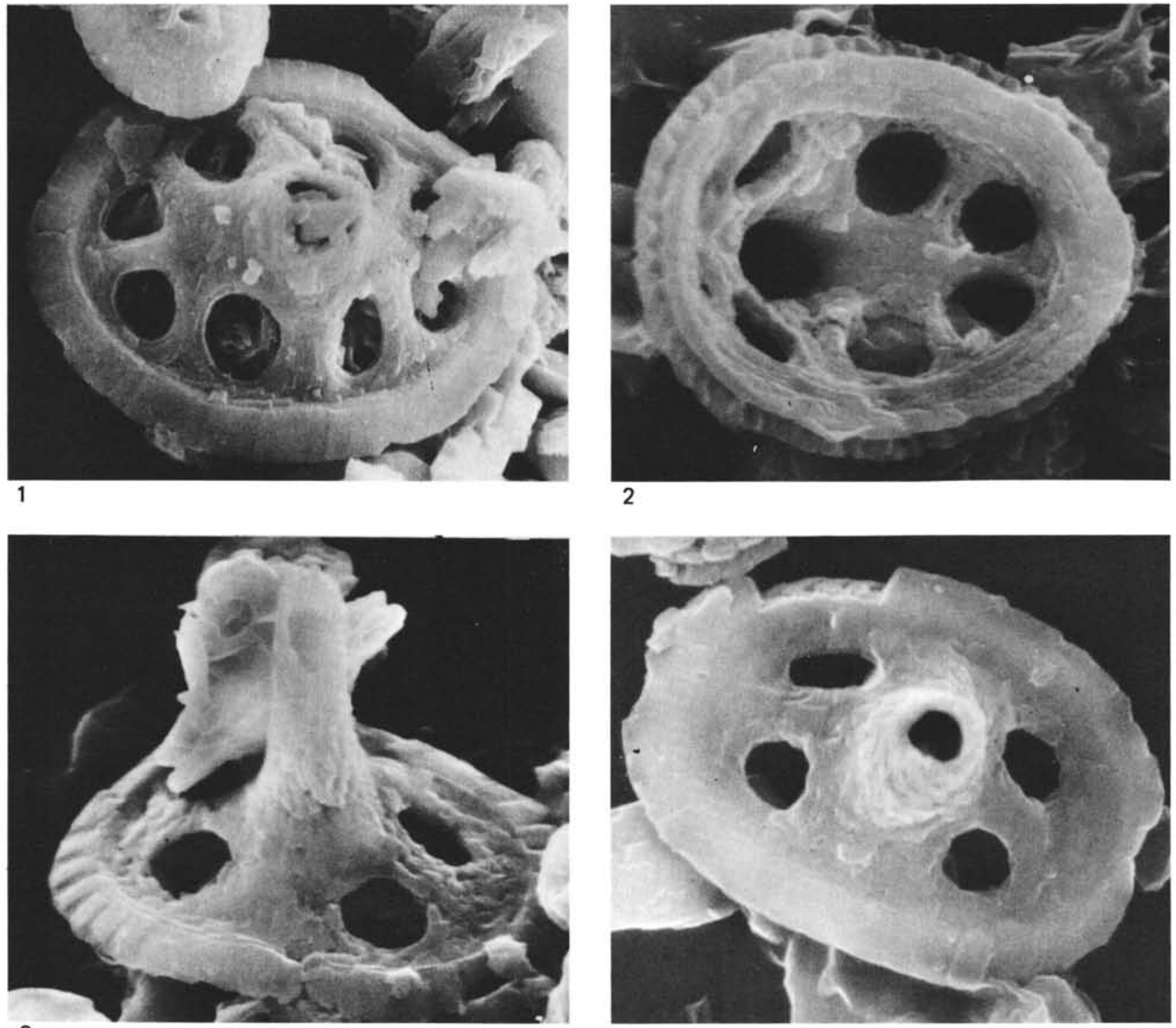

3
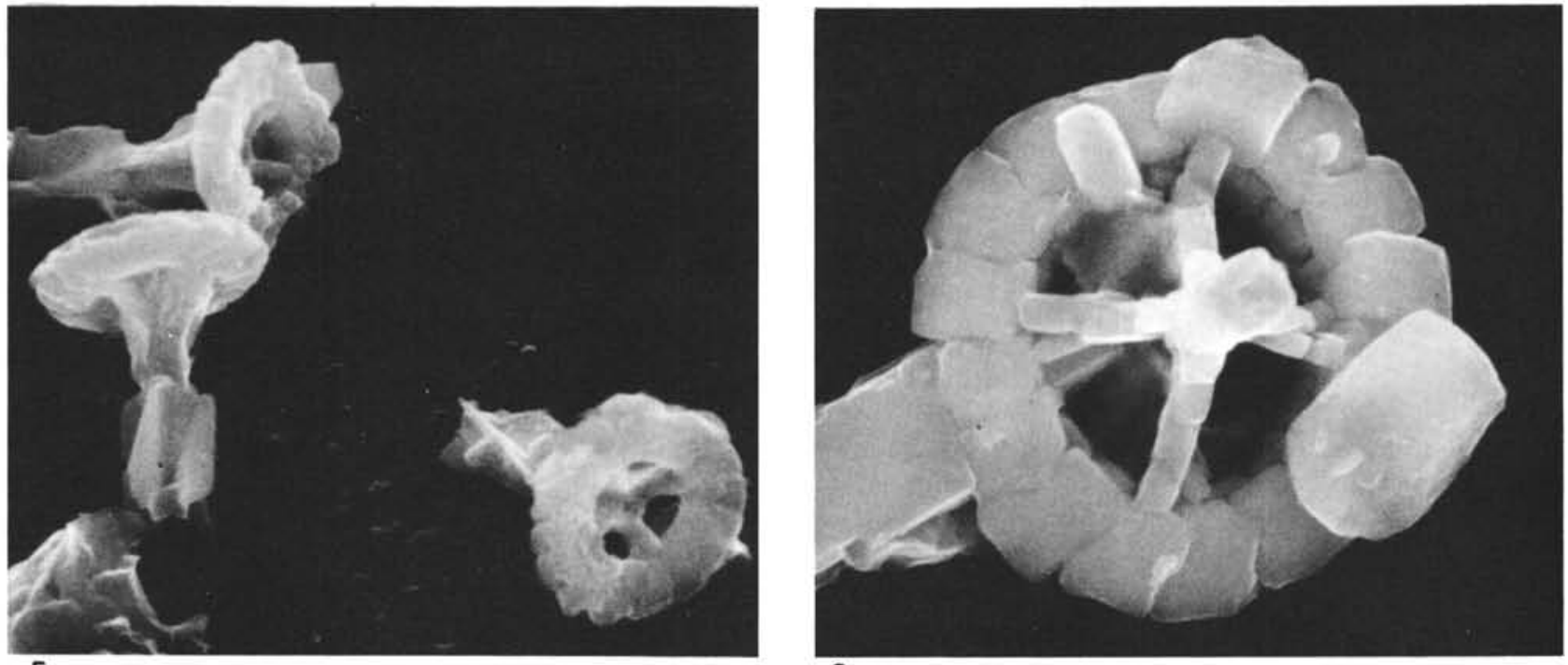
PLATE 59

(Albian; Campanian-Maestrichtian [Figure 2])

Figures 1, 2 Prediscosphaera cretacea (Arkhangelsky).

1. Distal view, Sample 327A-19-6, $38 \mathrm{~cm}, \times 8000$.

2. Distal view, Sample 327 A-13-2, $137 \mathrm{~cm}, \times 8000$.

Figures 3-6 Tetrapodorhabdus decorus (Deflandre and Fert) Wind and Wise, n. comb.

3. Distal view, Sample 327A-19-2, $15 \mathrm{~cm}$, $\times 10,000$.

4. Proximal view, Sample $327-16-5,20 \mathrm{~cm}, \times 8500$.

5. Proximal view, Sample 330-2-2, $141 \mathrm{~cm}$, $\times 12,000$.

6. Proximal view, Sample 330-2-2, $141 \mathrm{~cm}$, $\times 12,000$. 
PLATE 59

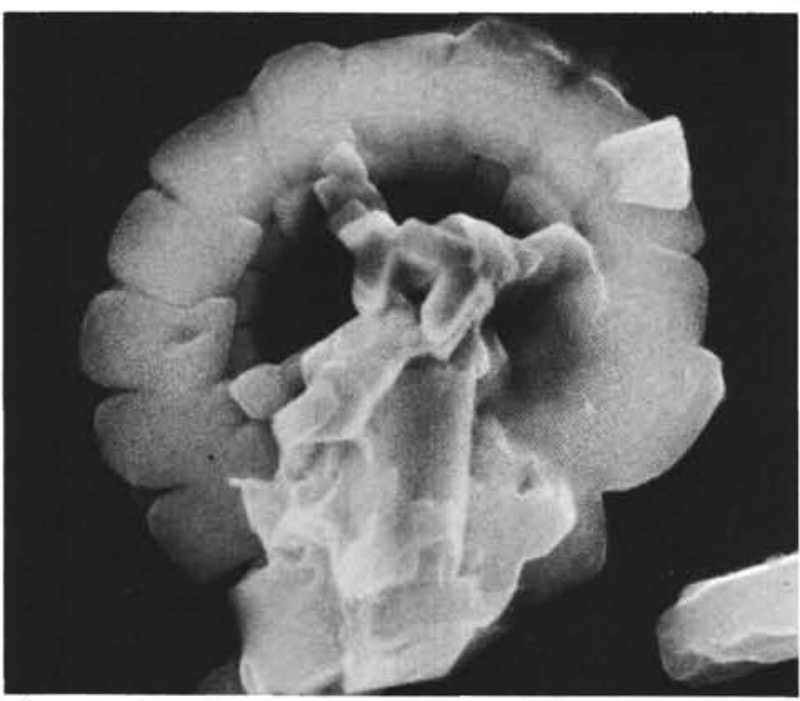

1

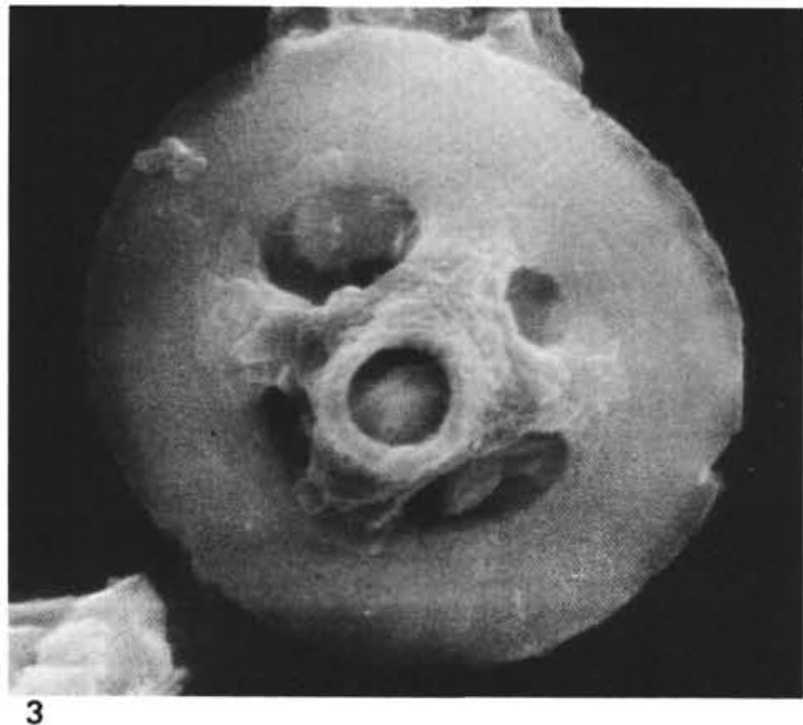

3

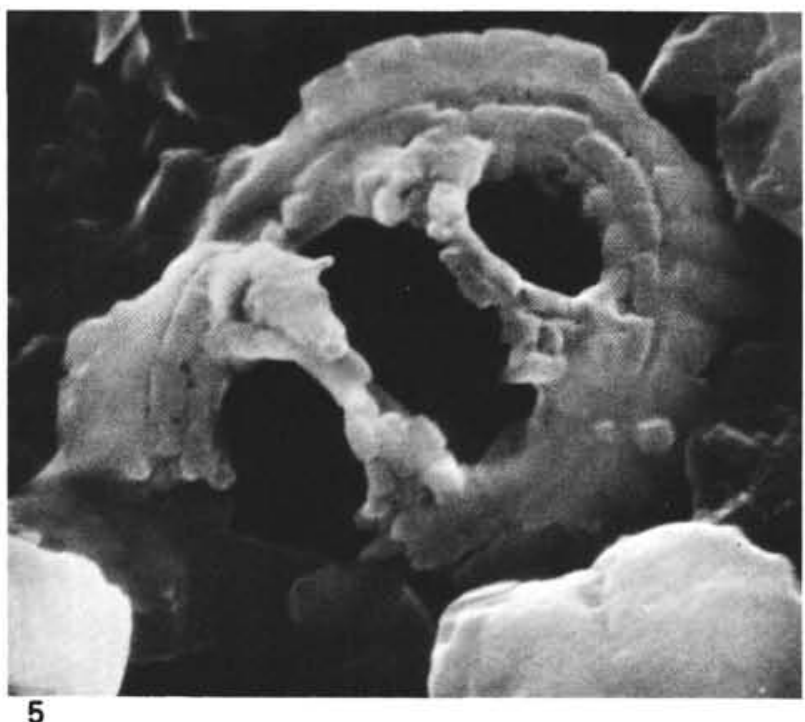

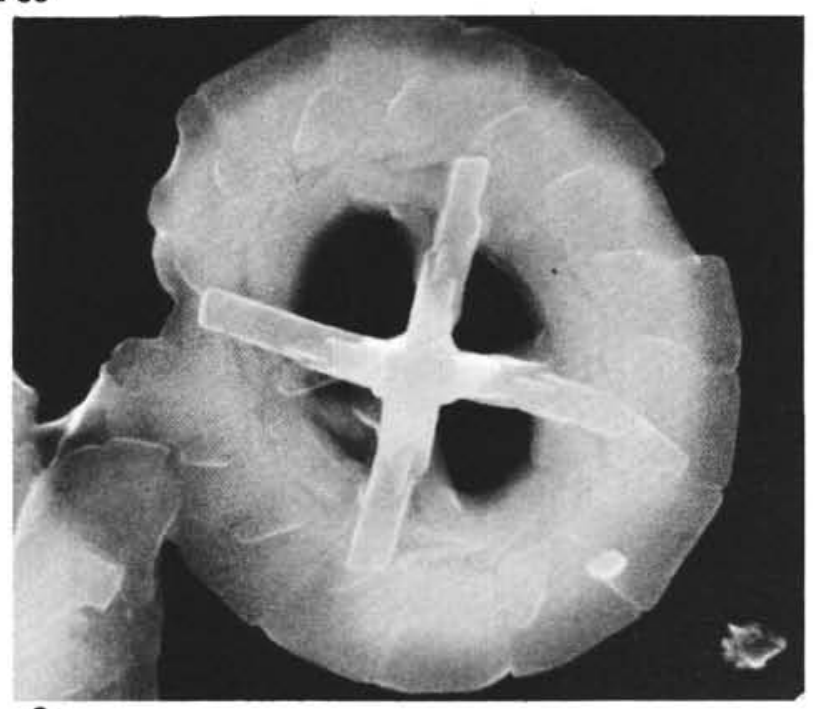

2
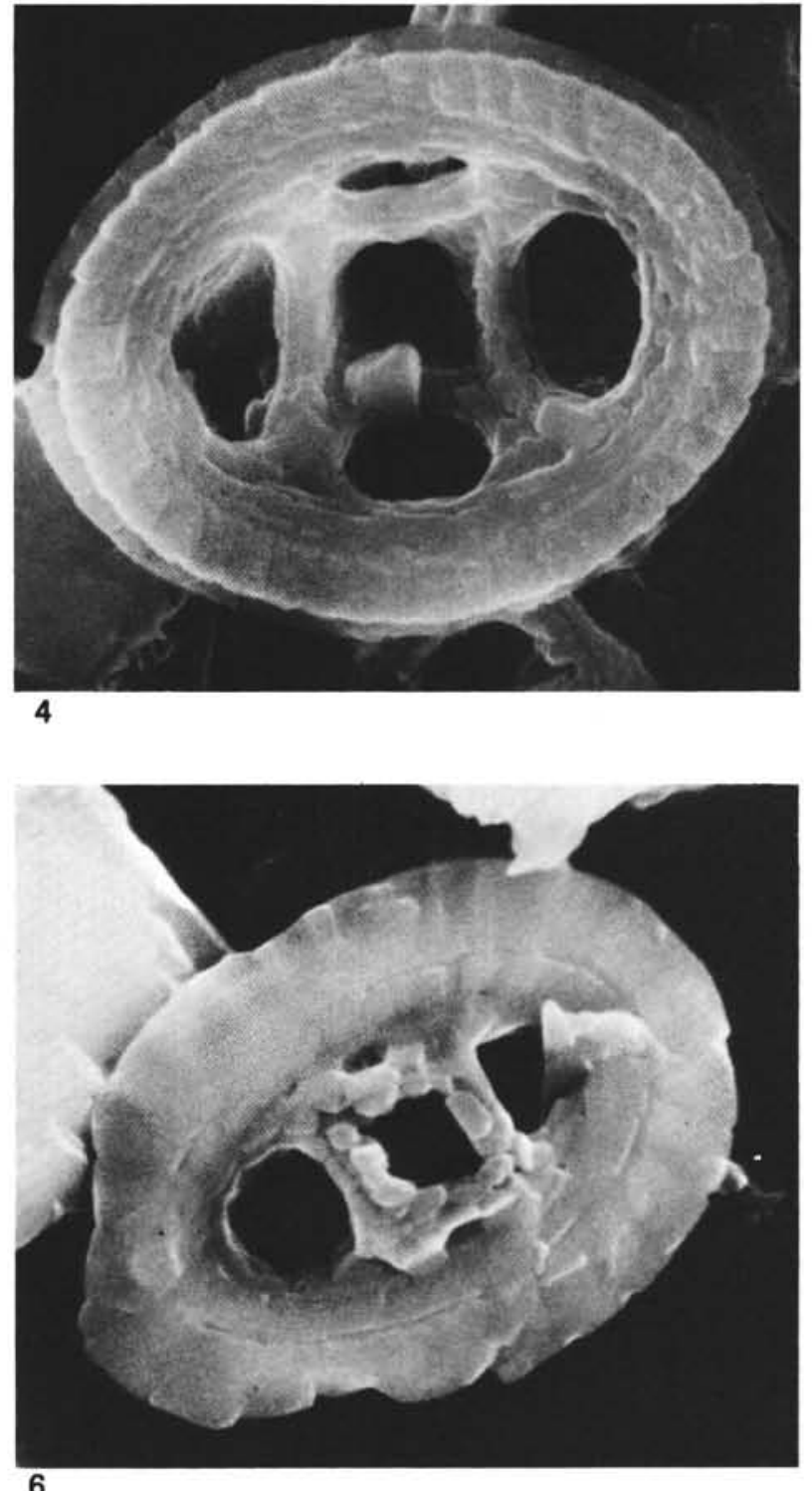


\section{PLATE 60}

(Albian, Aptian)

Figure 1 Corollithion achylosum (Stover), distal view (center, top); Stephanolithion laffittei Noël (bottom left), Albian Sample 330-2-2, $141 \mathrm{~cm}, \times 7500$.

Figure 2 Corollithion signum Stradner, proximal view, Albian Sample 327A-21-2, $36 \mathrm{~cm}, \times 18,000$.

Figures 3, 4 Corollithion geometricum (Gorka).

3. Proximal view, Aptian Sample 330-3-2, $115 \mathrm{~cm}$, $\times 26,000$.

4. Proximal view, Albian Sample 327-21-4, 107 $\mathrm{cm}, \times 18,000$.

Figures 5-7 Corollithion fragilis (Rood and Barnard) Wind and Wise, n. comb.

5. Proximal view, only seven bars present, Aptian Sample 330-3-2, $115 \mathrm{~cm}, \times 25,000$.

6. Distal view, Sample $330-3-2,115 \mathrm{~cm}, \times 25,000$.

7. Distal view, Sample 330-3-2, $115 \mathrm{~cm}, \times 9000$. 
PLATE 60
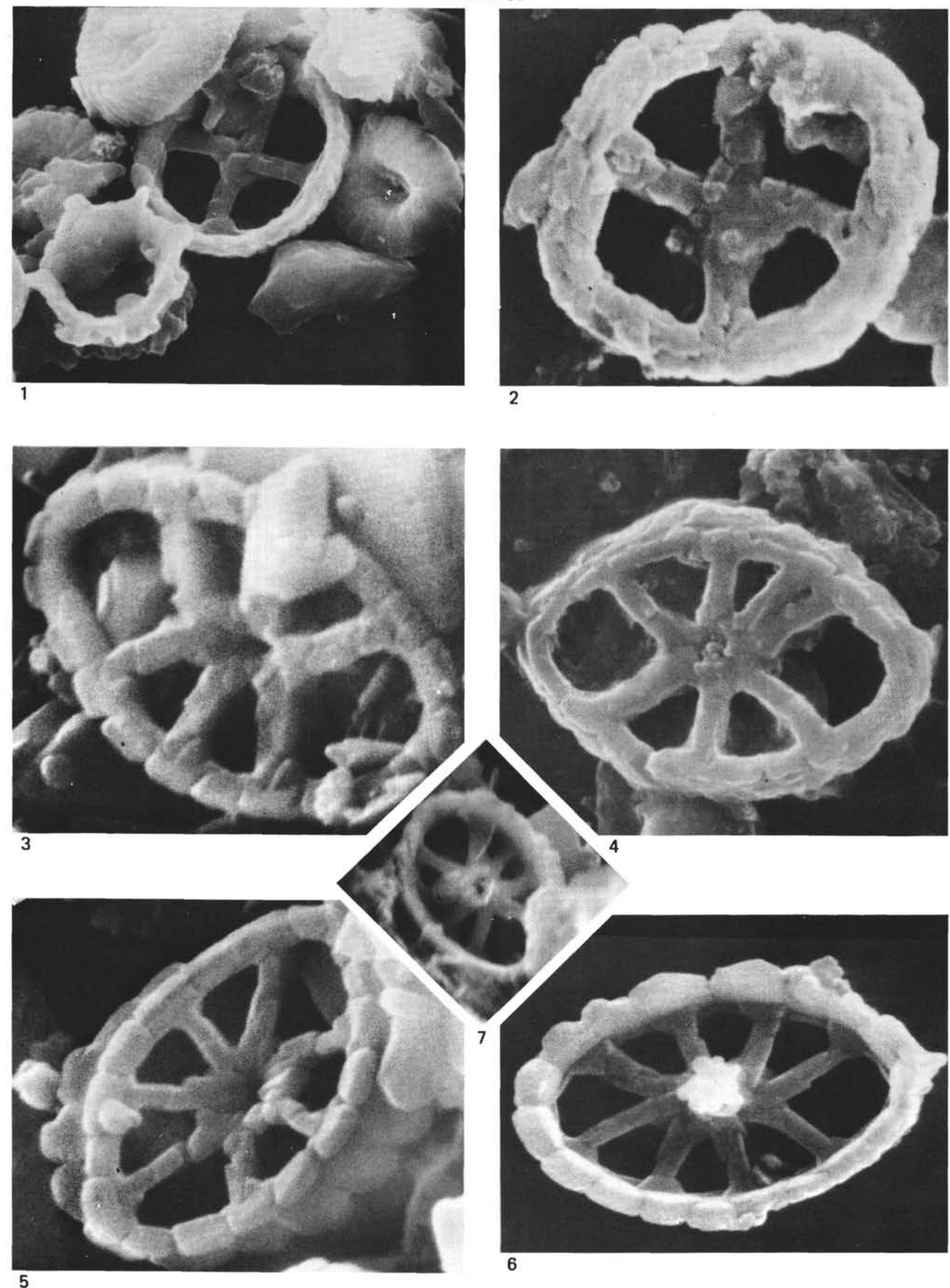


\section{PLATE 61}

(Aptian, Albian)

Figure 1 Corollithion rhombicum (Stradner and Adamiker), Sample 327A-16-5, $20 \mathrm{~cm}, \times 18,000$.

Figure 2 Assemblage predominantly of Corollithion fragilis (Rood and Barnard) Wise and Wind, n. comb., Sample 330-3-2, $115 \mathrm{~cm}, \times 4500$.

Figure 3 Corollithion perch-nielseni Filewicz, Wind, and Wise, n. sp., holotype USNM 240456 (upper specimen), paratype USNM 240457 (lower specimen), Sample 330-3-2, $115 \mathrm{~cm}, \times 12,000$.

Figures 4-6 Braarudosphaerid chalk, Sample 330-3-2, $115 \mathrm{~cm}$.

4. Note pentalith segments, $\times 4000$.

5. Framboidal pyrite, $\times 5000$.

6. Detail of Figure 5 above, $\times 10,000$. 


\section{PLATE 61}

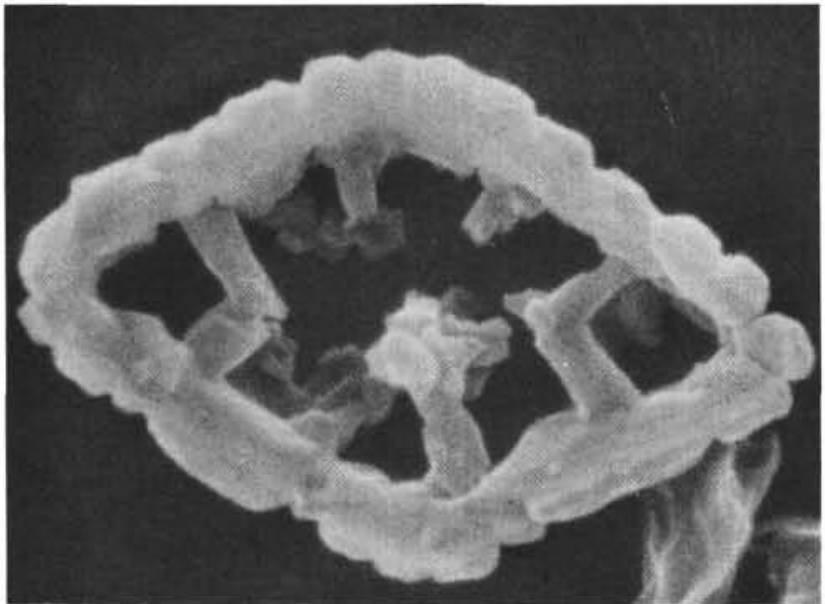

1

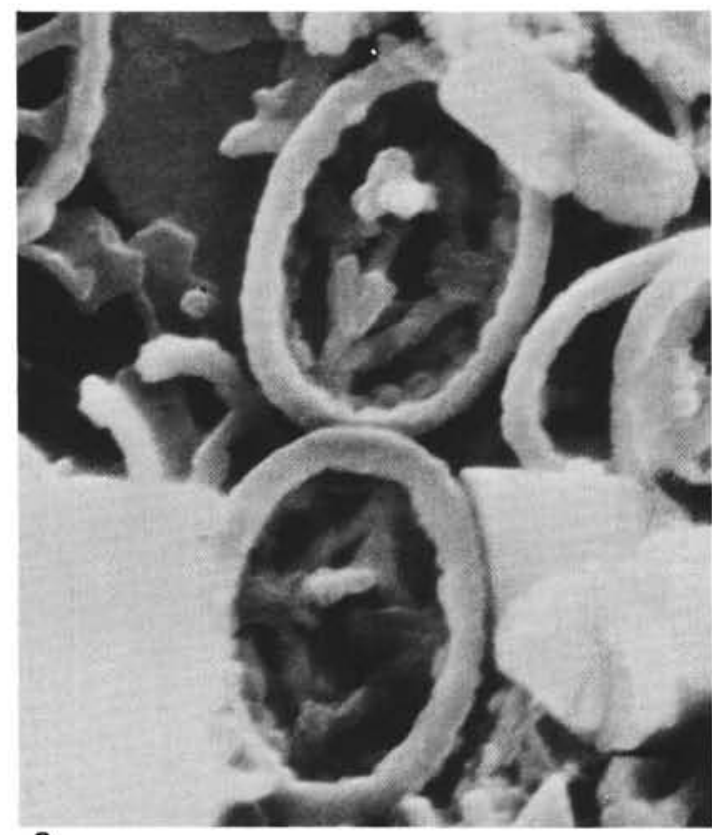

3

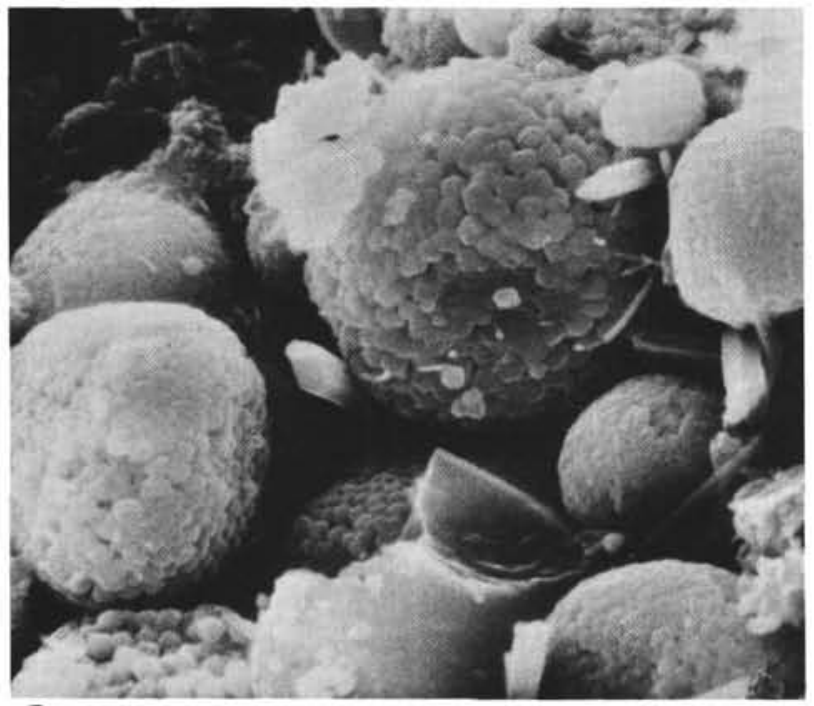

5

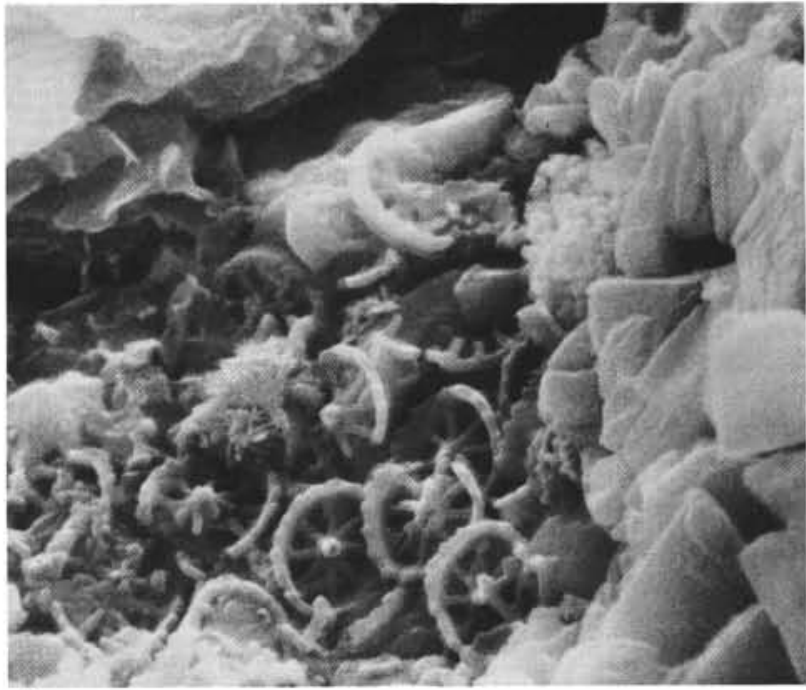

2
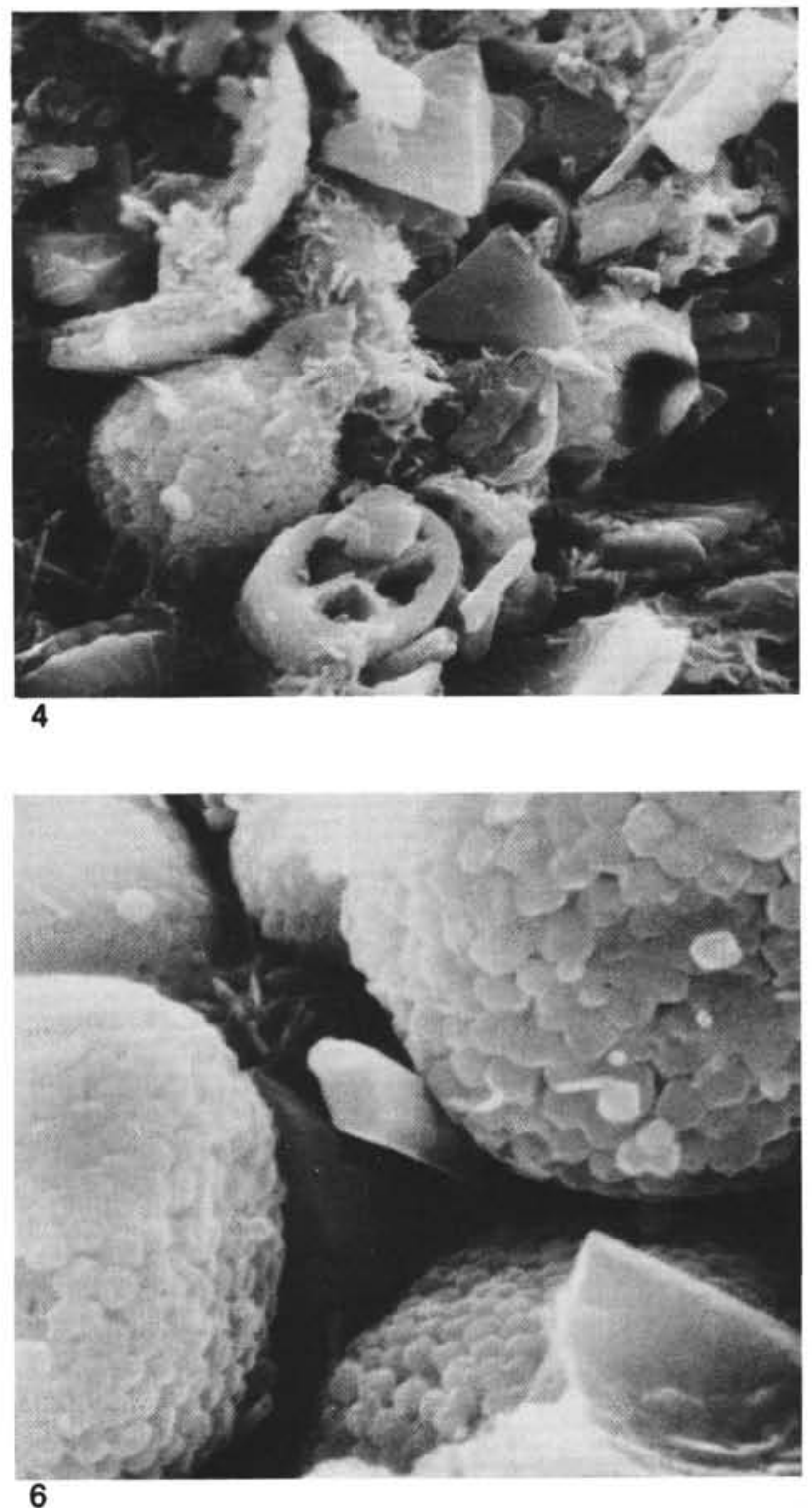


\section{PLATE 62}

(Aptian, Sample 330-3-2, $115 \mathrm{~cm}$ )

Figure $1 \quad$ Mixture of Vekshinella stradneri Rood, Hay, and Barnard, Wind and Wise, n. comb., and Corollithion silvaradion, Filewicz, Wind and Wise, n. sp., $\times 5000$.

Figures 2-6 Corollithion silvaradion, Filewicz, Wind, and Wise, n. sp.

2. Paratypes USNM $240451, \times 5000$.

3. Paratypes USNM $240452, \times 14,000$.

4. Paratypes USNM 240453, proximal and distal views, $\times 15,500$.

5. Paratypes USNM $240454, \times 10,000$.

6 . Holotype USNM 240455 , proximal view, $\times 24,000$. 


\section{PLATE 62}
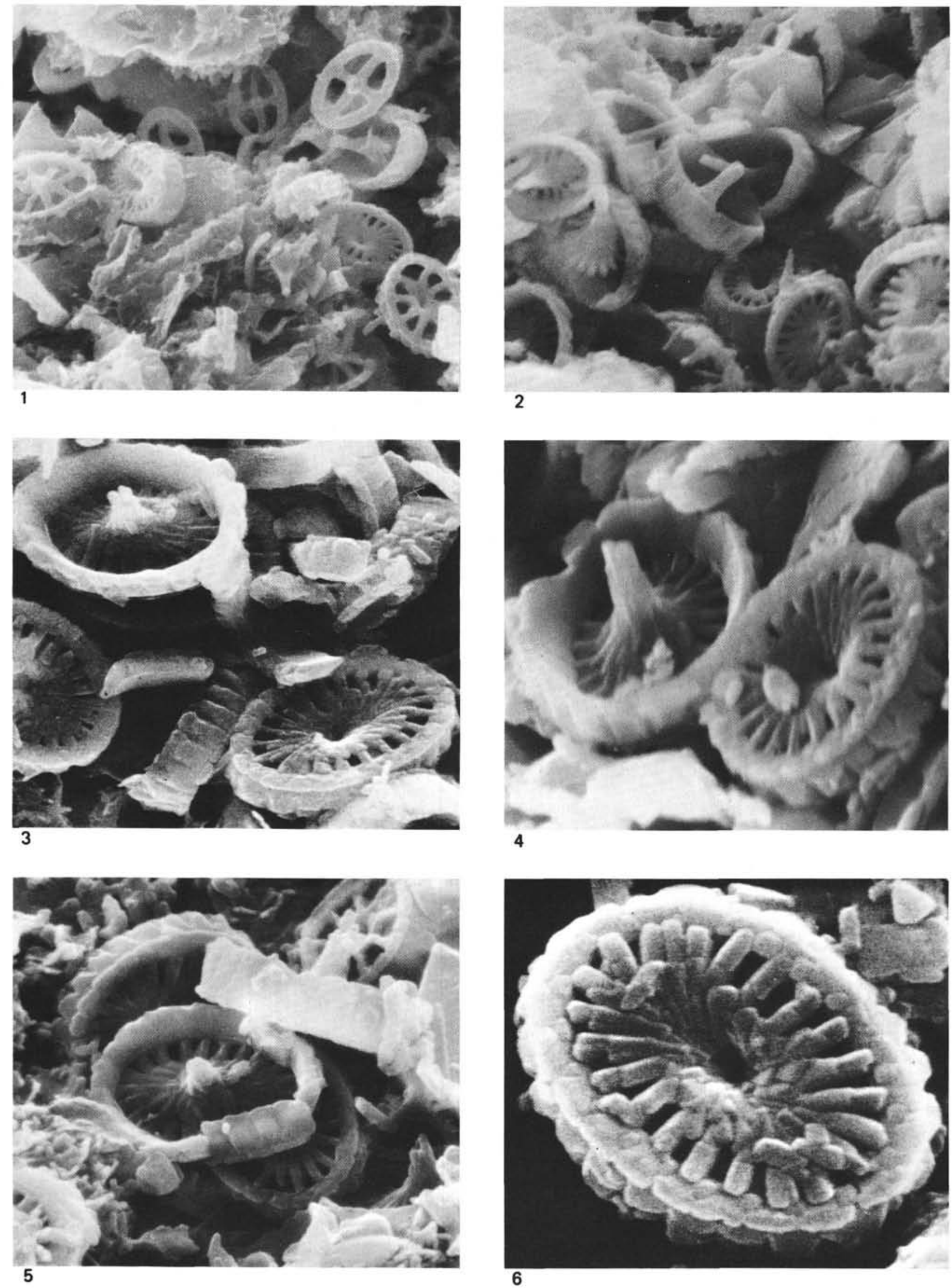


\section{PLATE 63}

(Aptian, phase-contrast, Sample 330-3-2, $105 \mathrm{~cm}, \times 4000$ )

Figures 1-4 Corollithion fragilis (Rood and Barnard) Wind and Wise, n. comb.

Figures 5, 6 Corollithion silvaradion, Filewicz, Wind, and Wise, n. sp.

5. Paratype USNM 240475.

6. Paratype USNM 240476.

Figures 7, 8 Seribiscutum bijugum, Filewicz, Wind, and Wise, n. sp.

7. Paratype USNM 240476.

8. Paratype USNM 240477.

Figure 9 Sollasites horticus (Stradner, Adamiker, and Maresch).

Figure $10 \quad$ Tranolithus gabulus Stover.

Figures 11, 12 Staurolithites matalosus (Stover). 


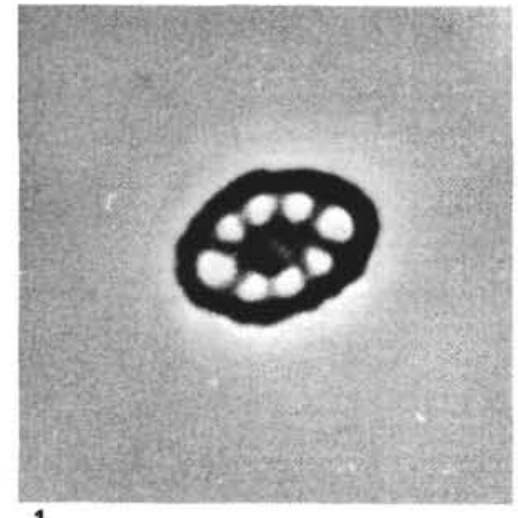

1
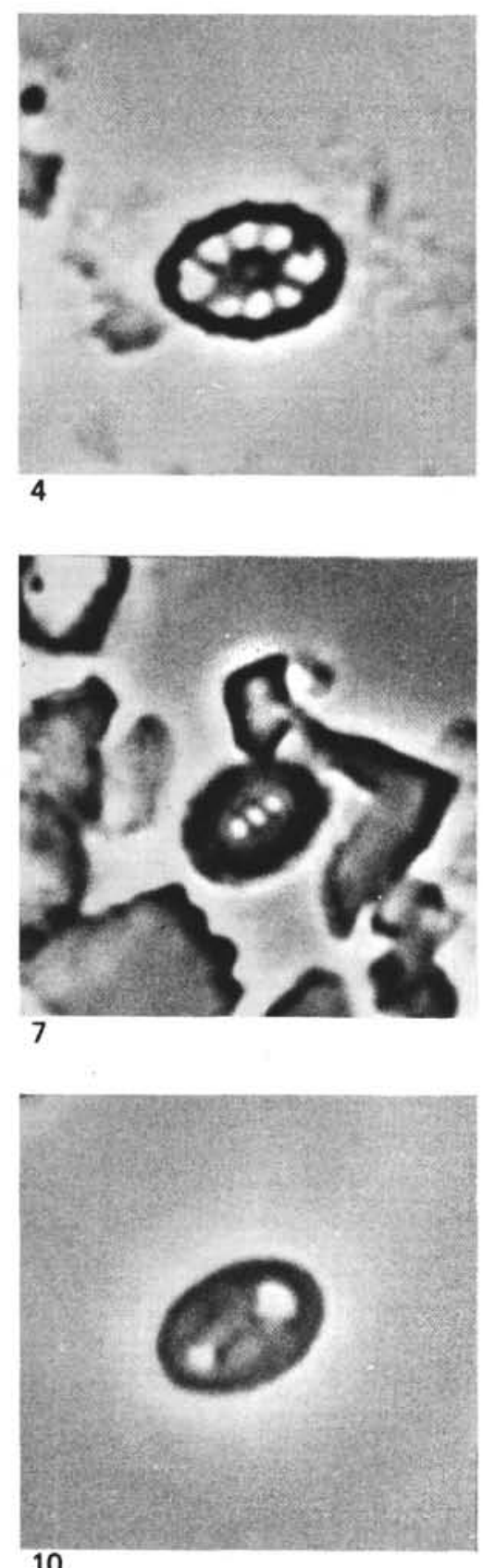

PLATE 63
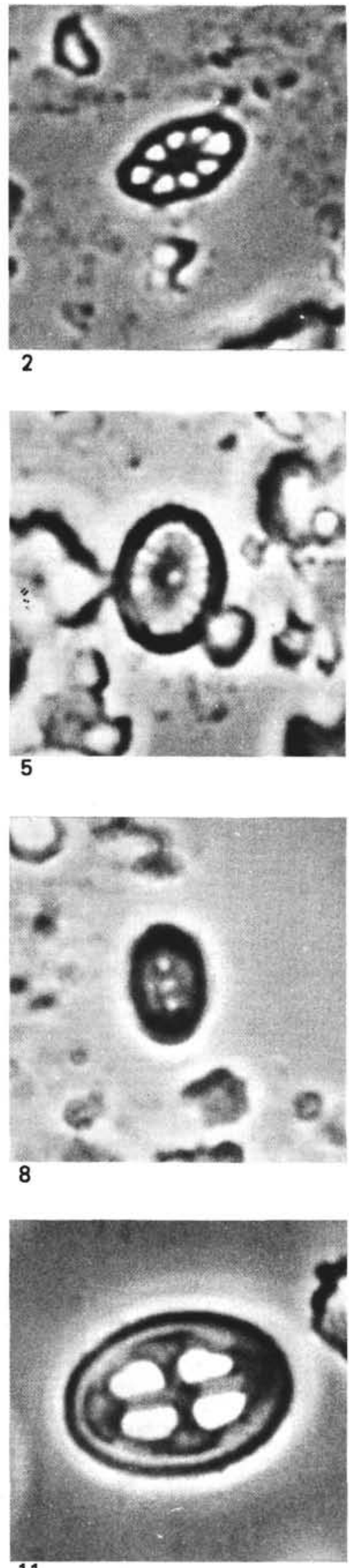
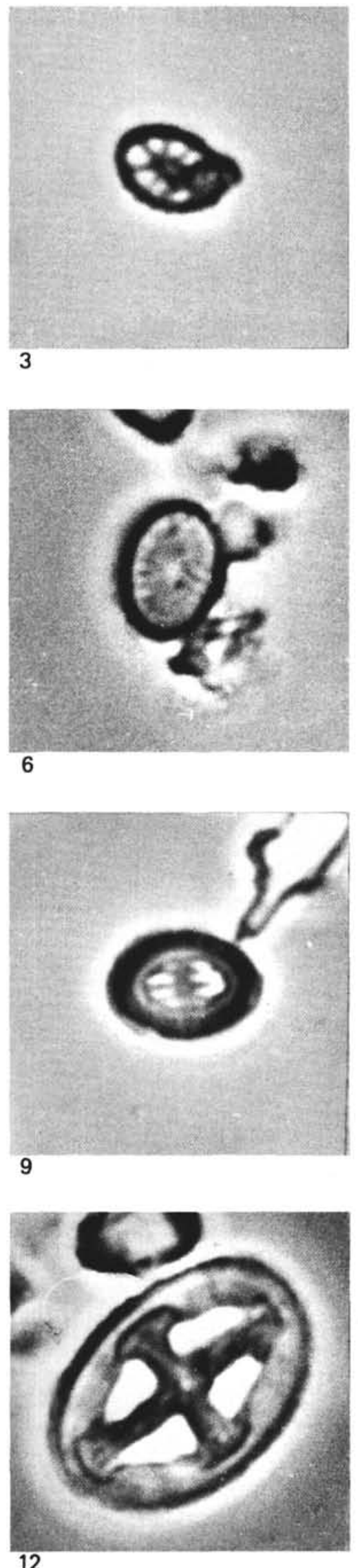
PLATE 64

(Aptian, Albian)

Figure 1 Sollasites horticus (Stradner, Adamiker, and Maresch), interior of coccosphere, Sample 330-3$2,115 \mathrm{~cm}, \times 5500$.

Figures 2-4 Sollasites falklandensis Filewicz, Wind, and Wise, n. sp.

2. Paratype USNM 240458, proximal view (center, right), Sample 330-2-3, $26 \mathrm{~cm}, \times 5000$.

3. Holotype USNM 240459, proximal view, Sample $327 \mathrm{~A}-19-2,15 \mathrm{~cm}, \times 7500$.

4. Paratype USNM 240460, distal view, Sample $327 \mathrm{~A}-19-2,120 \mathrm{~cm}, \times 7700$.

Figures 5, 6 Sollasites thiersteini Filewicz, Wind, and Wise, n. sp.

5. Holotype USNM 240477, interior of coccosphere, Sample 330-3-2, $115 \mathrm{~cm}, \times 5000$.

6. Same specimen, proximal view of two of the coccoliths, $\times 18,000$. 
PLATE 64
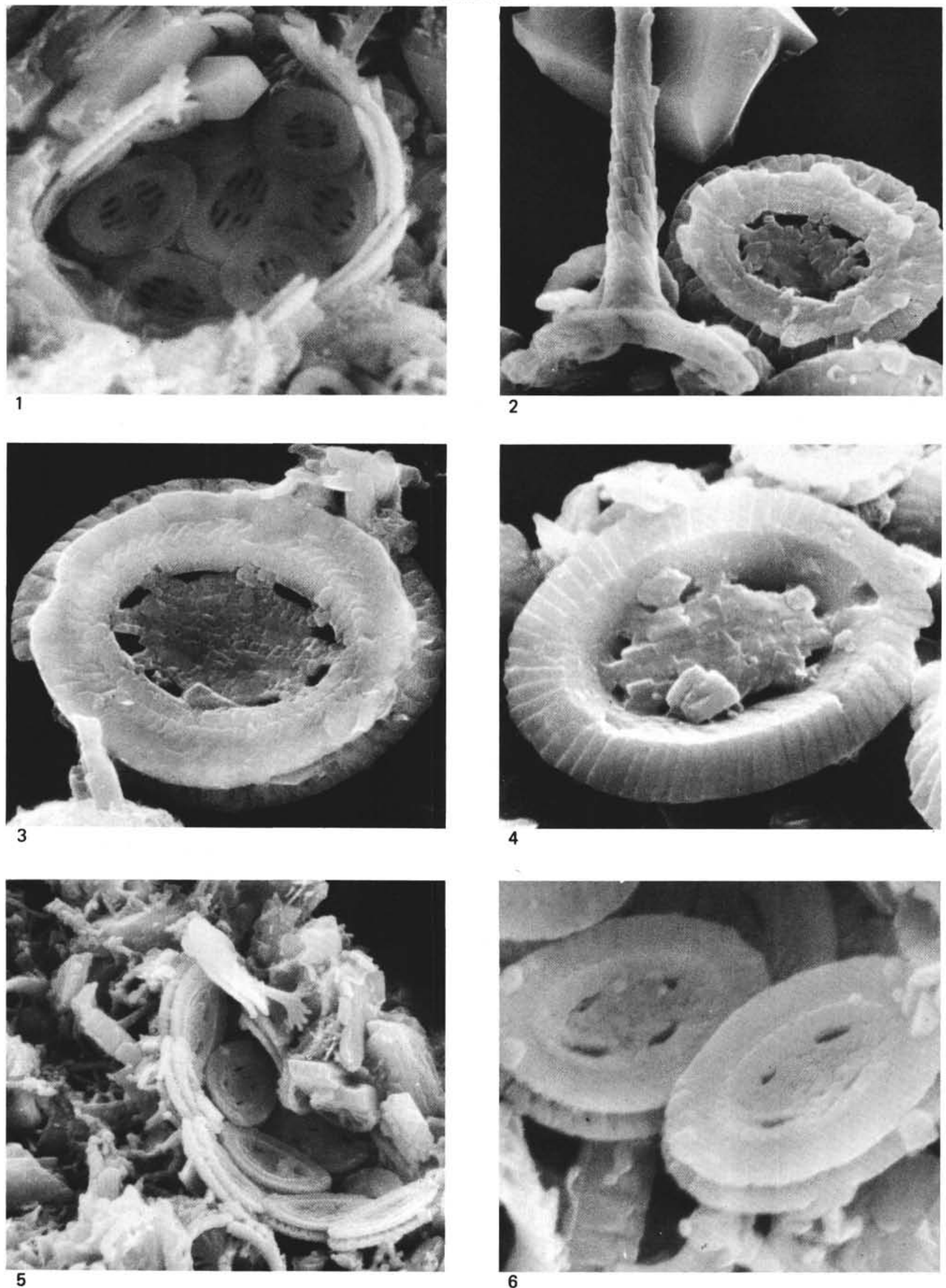


\section{PLATE 65}

(Aptian; Sample 330-3-2, $115 \mathrm{~cm}$ )

Figures 1,2 Sollasites thiersteini Filewicz, Wind, and Wise, n. sp.

1. Paratype USNM 240478, proximal view, $\times 15,000$.

2. Paratype USNM 240479 , distal view, $\times 15,000$.

Figures 3-6 Seribiscutum bijugum Filewicz, Wind, and Wise, n.

sp.

3. Paratype USNM 240461 , coccosphere, $\times 8500$. 4. Paratype USNM 240462, coccosphere interior, $\times 9500$.

5. Paratypes USNM 240463 , cluster, $\times 8500$.

6. Paratypes USNM 240464, distal view of a cluster, $\times 17,500$. 
PLATE 65
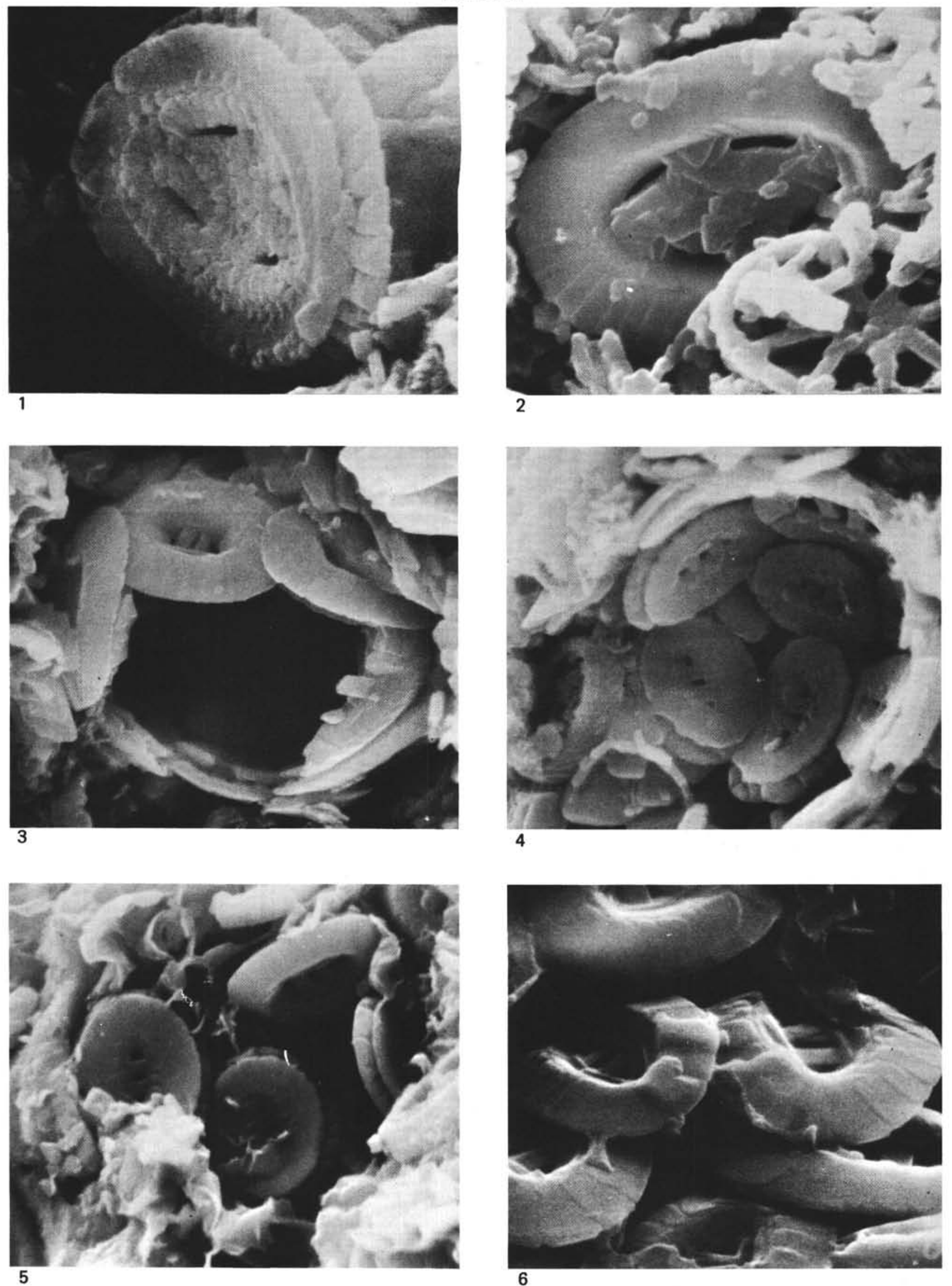


\section{PLATE 66}

(Albian, Albian-Cenomanian)

Figures 1-3 Seribiscutum bijugum Filewicz, Wind, and Wise, n. sp.

1. Paratypes USNM 240465, distal view of cluster, Sample 330-3-2, $115 \mathrm{~cm}, \times 18,000$.

2. Holotype USNM 240466, distal view, Sample $330-3-2,115 \mathrm{~cm}, \times 18,000$.

3. Paratypes USNM 240467 , proximal view, Sample $330-3-2,115 \mathrm{~cm}, \times 17,000$.

Figures 4-6 Seribiscutum primitivum (Thierstein) Filewicz, Wind, and Wise, n. comb.

4. Distal view, Sample 327 A-16-5, $20 \mathrm{~cm}$, $\times 10,000$.

5. Proximal view, Sample 330A-4, CC, $\times 17,500$.

6. Proximal view, Sample 330A-4, CC, $\times 12,000$. 
PLATE 66
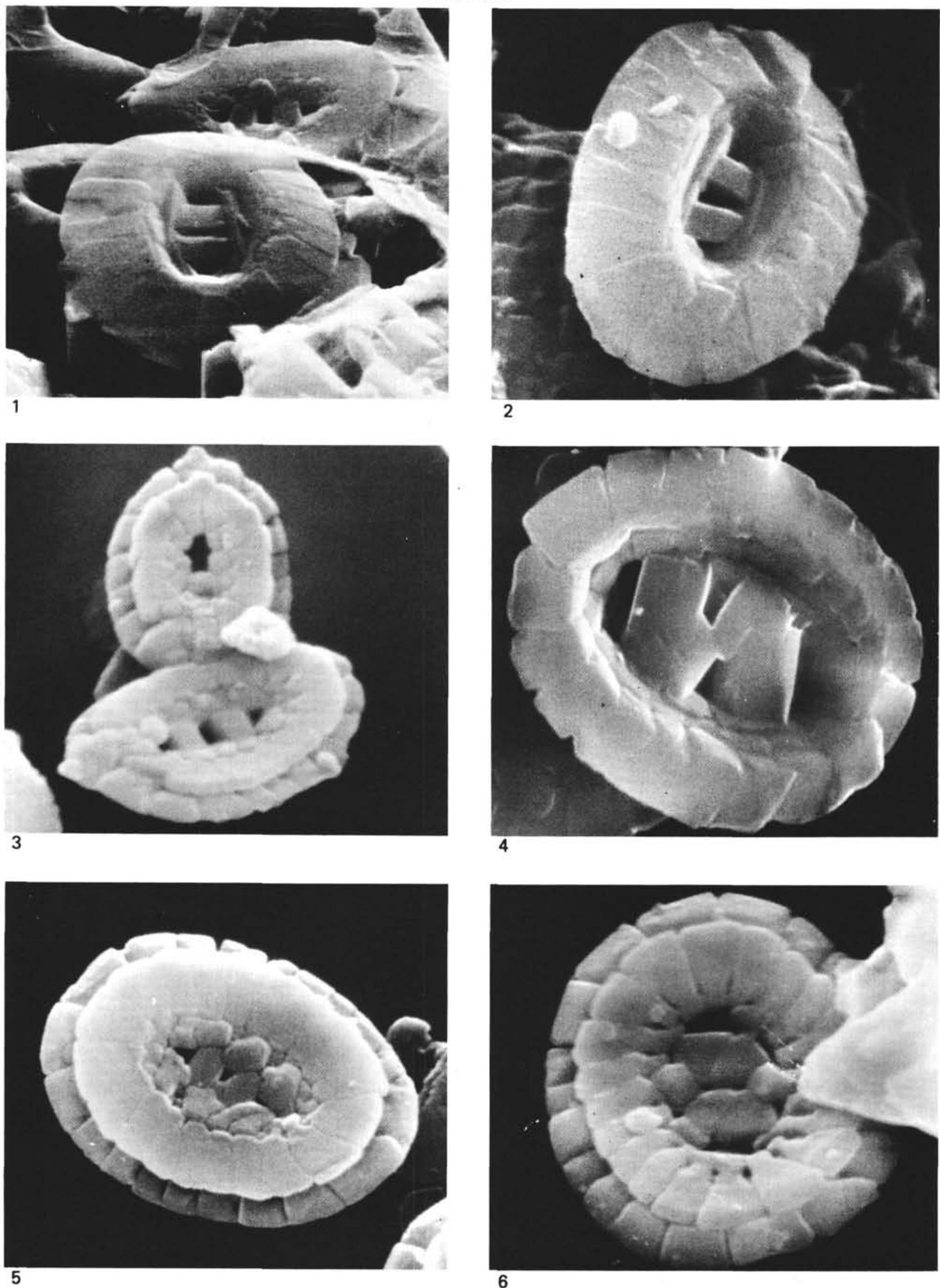
Figures 1-4 Seribiscutum primitivum (Thierstein) Filewicz, Wind, and Wise, n. comb.

1. Proximal view, Sample 330A-4, CC, $\times 10,000$.

2. Distal view, Sample $330 \mathrm{~A}-4, \mathrm{CC}, \times 12,000$.

3. Distal view, Sample 327A-14-6, $38 \mathrm{~cm}, \times 9500$. 4. Proximal and distal views, Albian Sample $327 \mathrm{~A}-15-1,146 \mathrm{~cm}, \times 7000$.

Figures 5,6 Tubodiscus sp. cf. T. verenae Thierstein.

5. Albian Sample 330-1-1, $70 \mathrm{~cm}, \times 5500$.

6. Albian Sample 327A-19-2, $120 \mathrm{~cm}, \times 7000$. 
PLATE 67
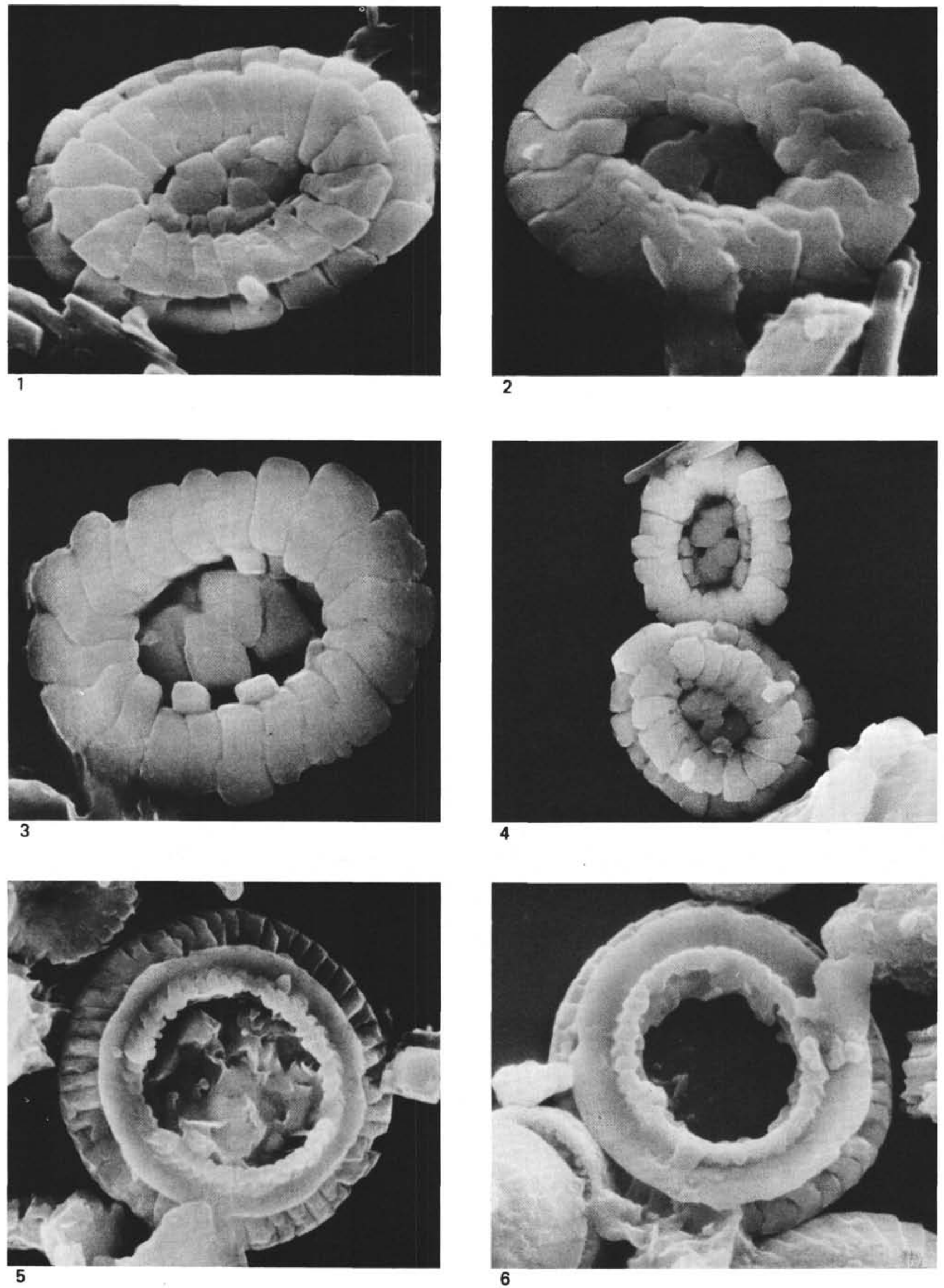
PLATE 68

(Albian-Cenomanian)

Figures 1,2 Repagulum parvidentatum (Deflandre and Fert). 1. Distal view, Albian Sample 327A-19-2, $120 \mathrm{~cm}$, $\times 20,000$.

2. Proximal view, Albian Sample 327A-21, CC, $\times 25,000$.

Figures 3,4 Watznaueria barnesae (Black).

3. Coccosphere, Sample 330A-4, CC, $\times 10,500$.

4. Distal view, Sample $330 \mathrm{~A}-4, \mathrm{CC}, \times 16,000$.

Figures 5-8 Watznaueria ovata Bukry.

5. Distal view, Albian Sample $327 \mathrm{~A}-21-2,36 \mathrm{~cm}$, $\times 11,000$.

6. Phase-contrast, proximal view, Albian Sample 327 A-16-3, $20 \mathrm{~cm}, \times 4400$.

7. Same specimen, crossed nicols at $0^{\circ}, \times 4400$.

8. Same specimen, crossed nicols at $45^{\circ}, \times 4400$. 


\section{PLATE 68}
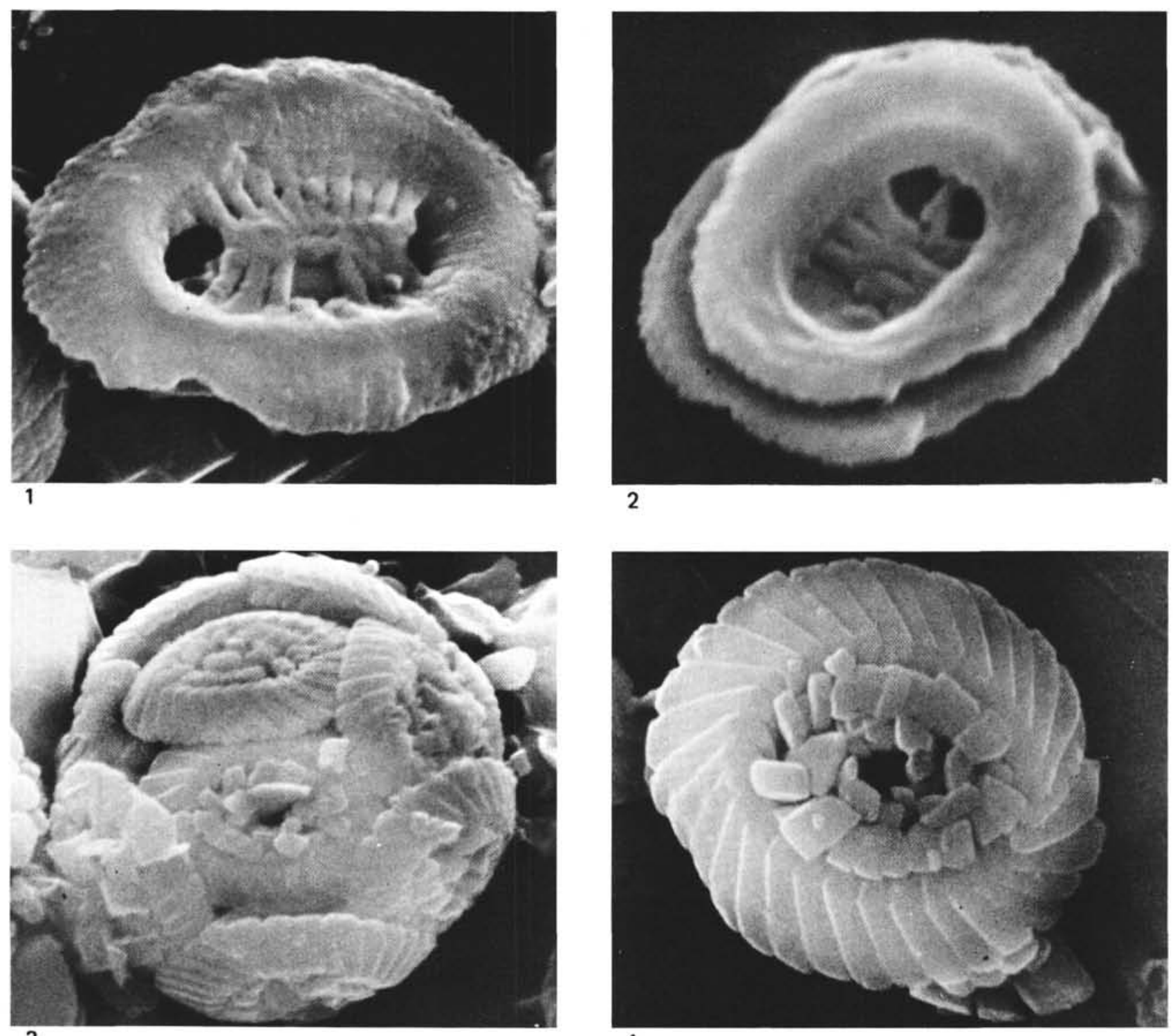

4
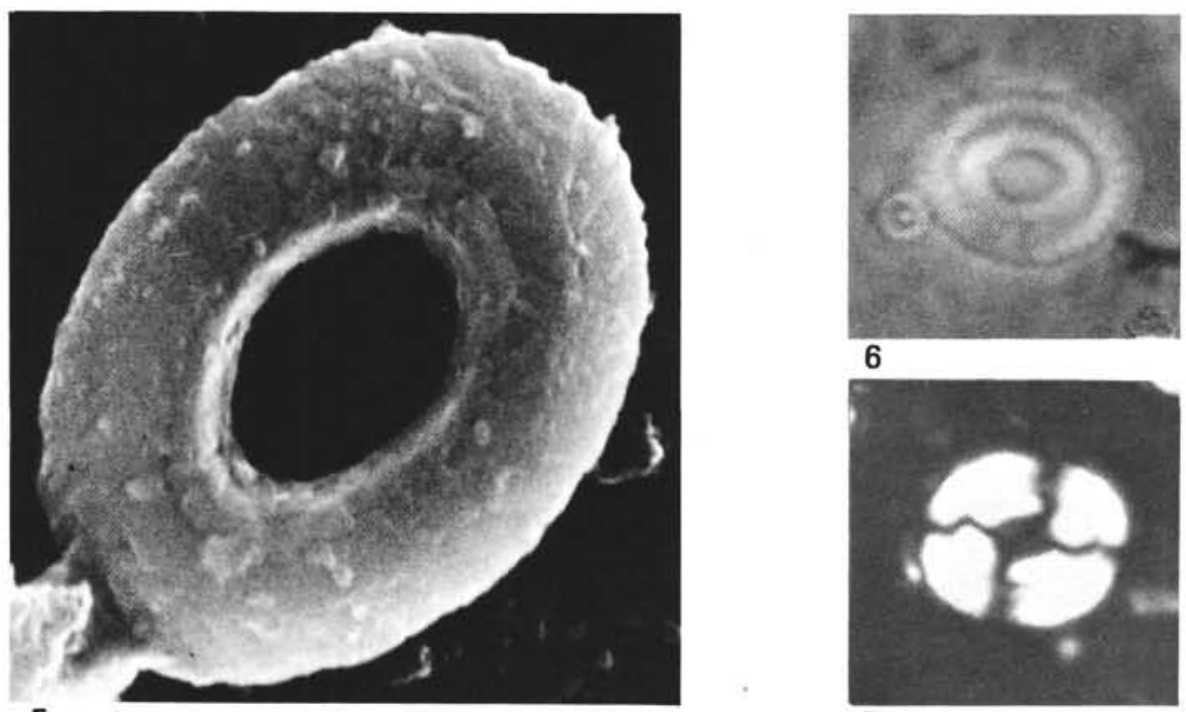

6
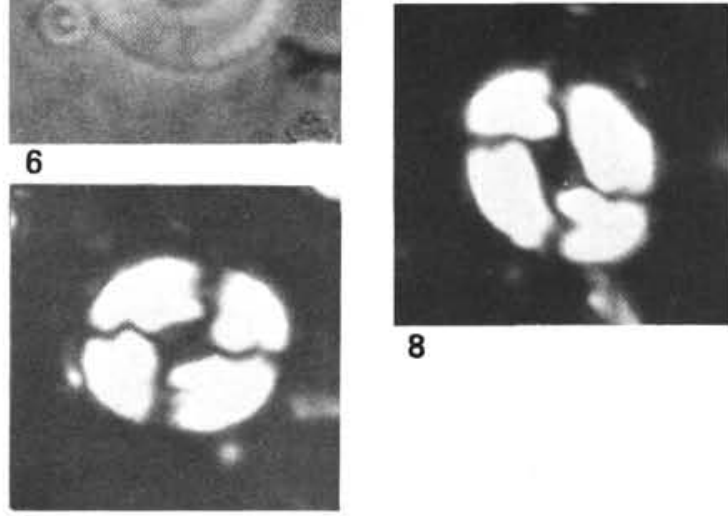

7 


\section{PLATE 69}

(Albian, Campanian-Maestrichtian)

Figure 1 Cretarhabdus surirellus (Deflandre), distal view, Albian Sample 327A-21-1, $142 \mathrm{~cm}, \times 10,000$.

Figures 2-6 Cretarhabdus conicus Bramlette and Martini, distal view.

2. Campanian-Maestrichtian Sample 327A-13-2, $54 \mathrm{~cm}, \times 13,500$.

3. Albian Sample 327A-17-2, $70 \mathrm{~cm}, \times 10,000$.

4. Albian Sample $330-2-2,26 \mathrm{~cm}, \times 9000$.

5. Albian Sample 330-2-2, $26 \mathrm{~cm}, \times 10,000$.

6. Albian Sample $327 \mathrm{~A}-17-2,70 \mathrm{~cm}, \times 10,000$. 


\section{PLATE 69}
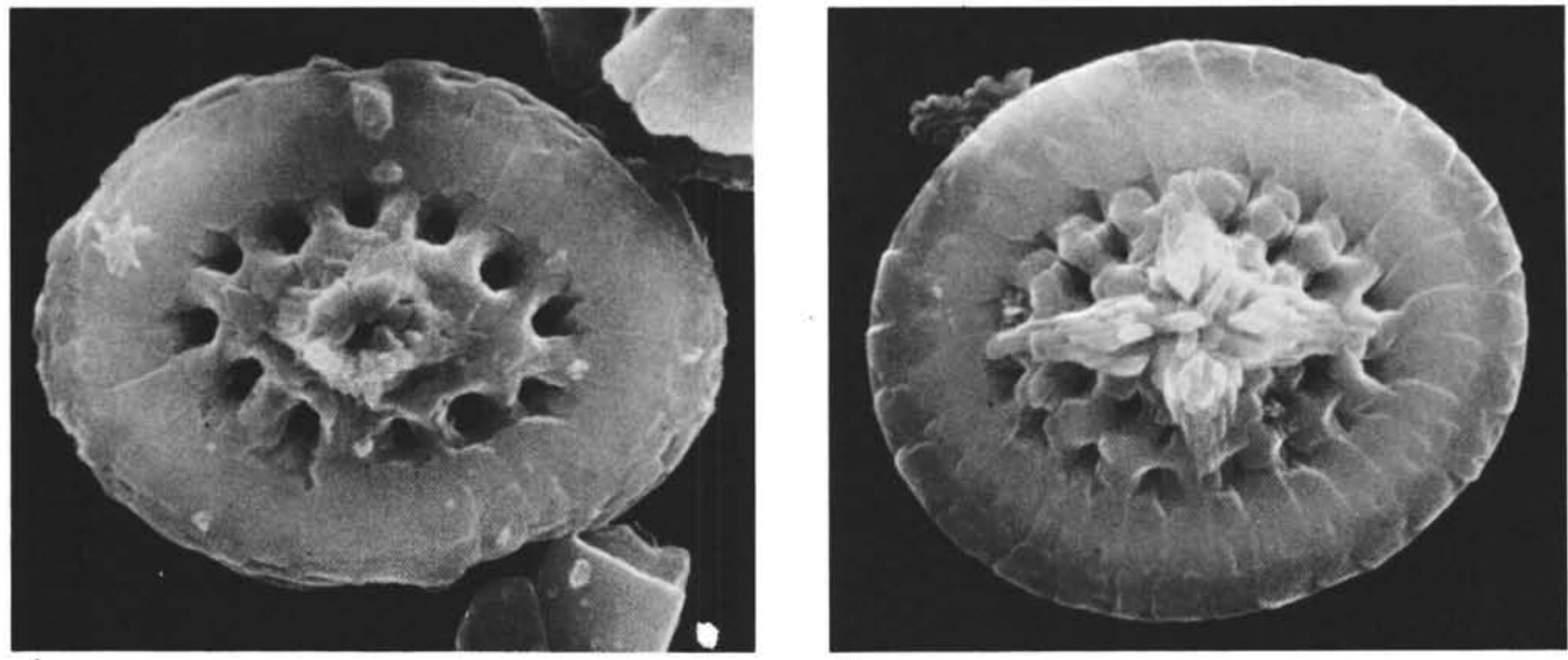

1
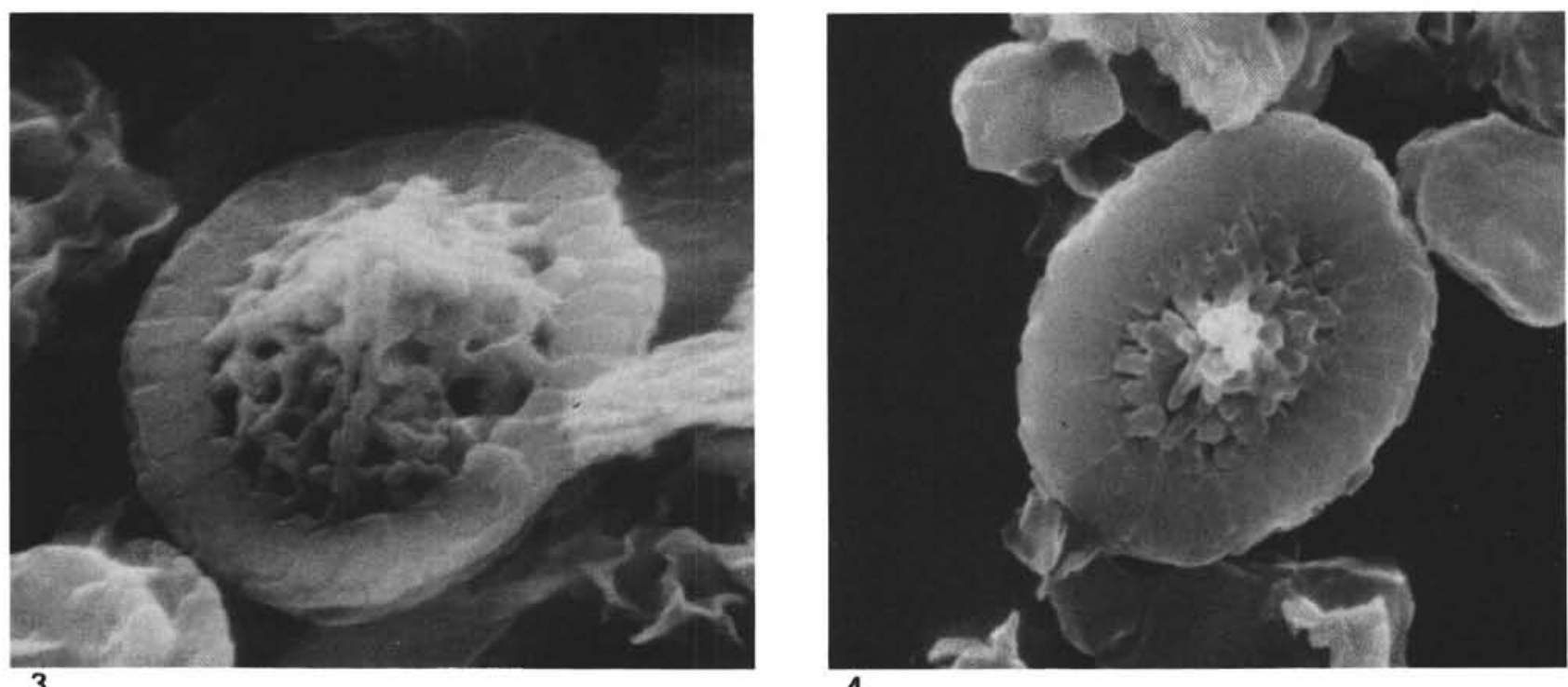

4
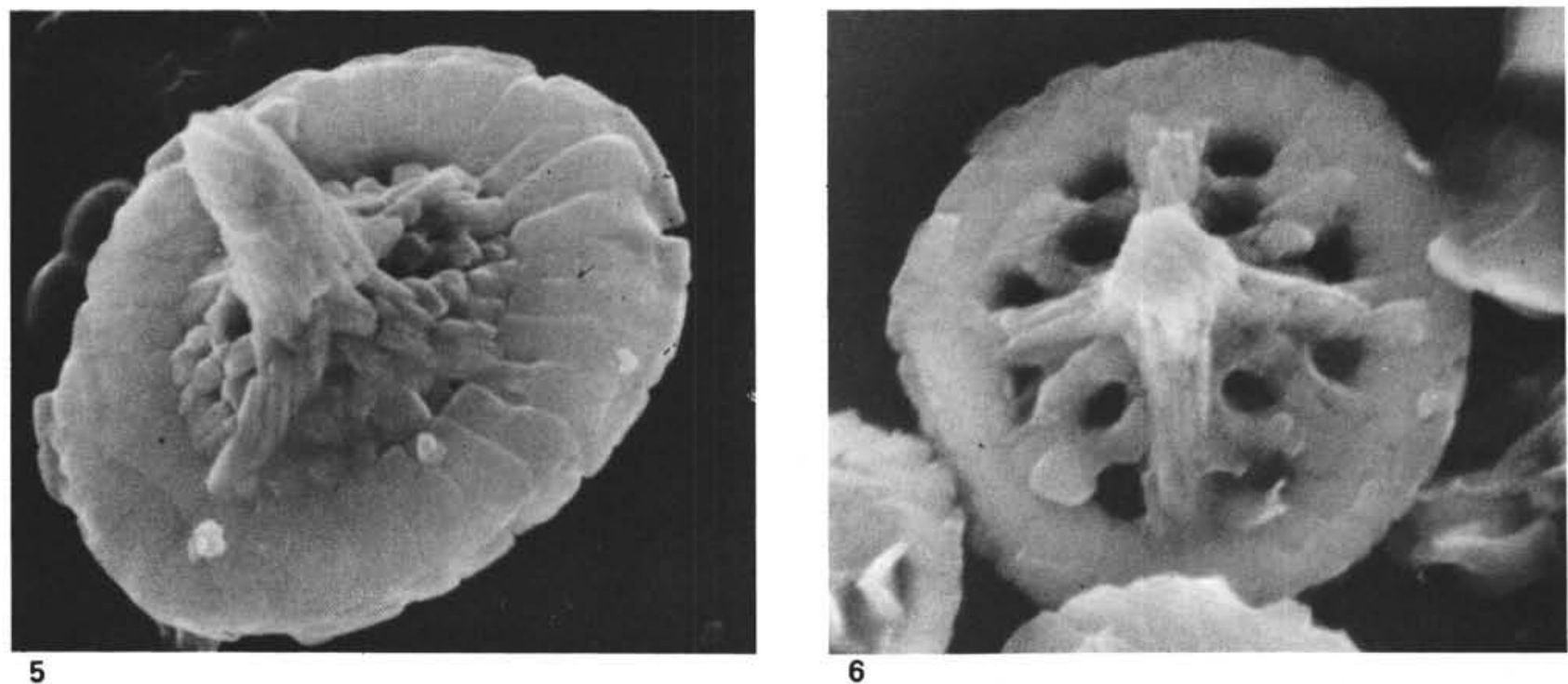


\title{
PLATE 70
}

\author{
(Aptian, Albian)
}

Figures 1,2 Cretarhabdus sp.

1. Proximal view, Sample 330-3-2, $105 \mathrm{~cm}$, $\times 14,000$.

2. Proximal view, Sample 330-3-2, $115 \mathrm{~cm}$, $\times 13,500$.

Figures 3, 4 Cretarhabdus coronadventalis Reinhardt.

3. Distal view, Sample 327A-21-3, $31 \mathrm{~cm}, \times 8000$.

4. Distal view, Sample 327 A-19-2, $120 \mathrm{~cm}, \times 7000$.

Figures 5,6 Stephanolithion laffittei Noël.

5. Proximal view, Sample 327A-18-2, $20 \mathrm{~cm}$, $\times 16,000$.

6. Distal view, Sample $330-2-2,26 \mathrm{~cm}, \times 10,000$. 
PLATE 70

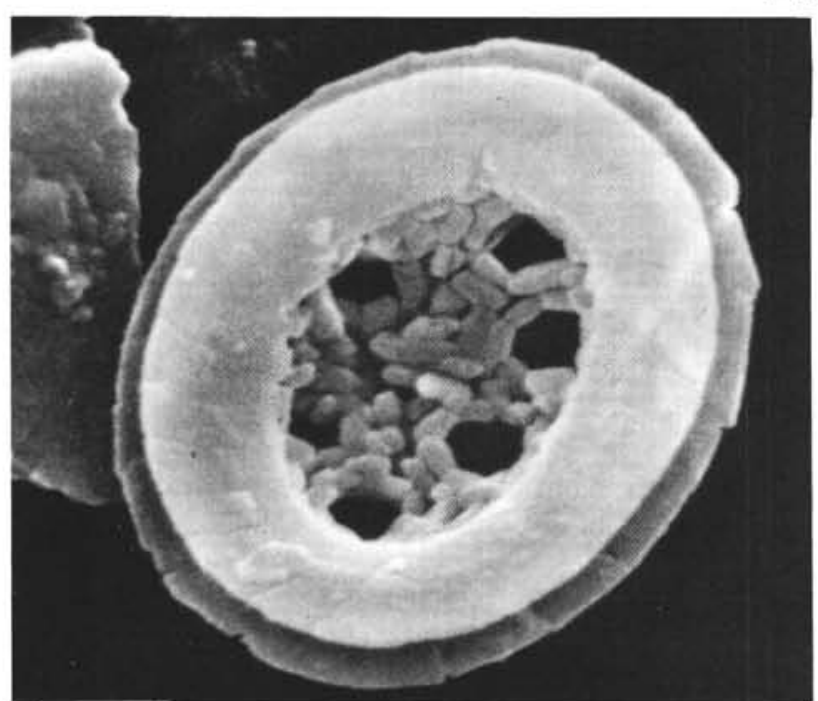

1

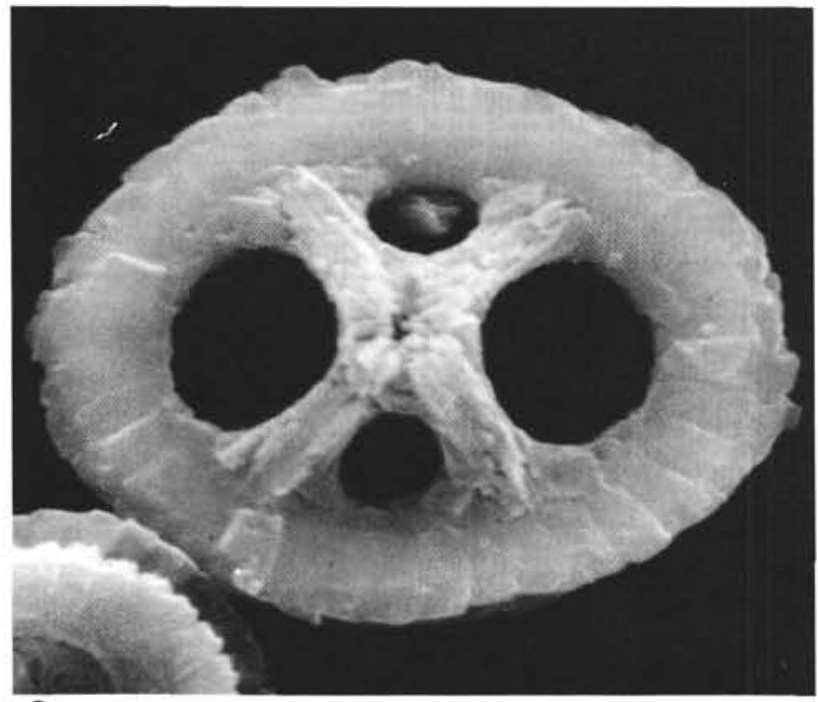

3

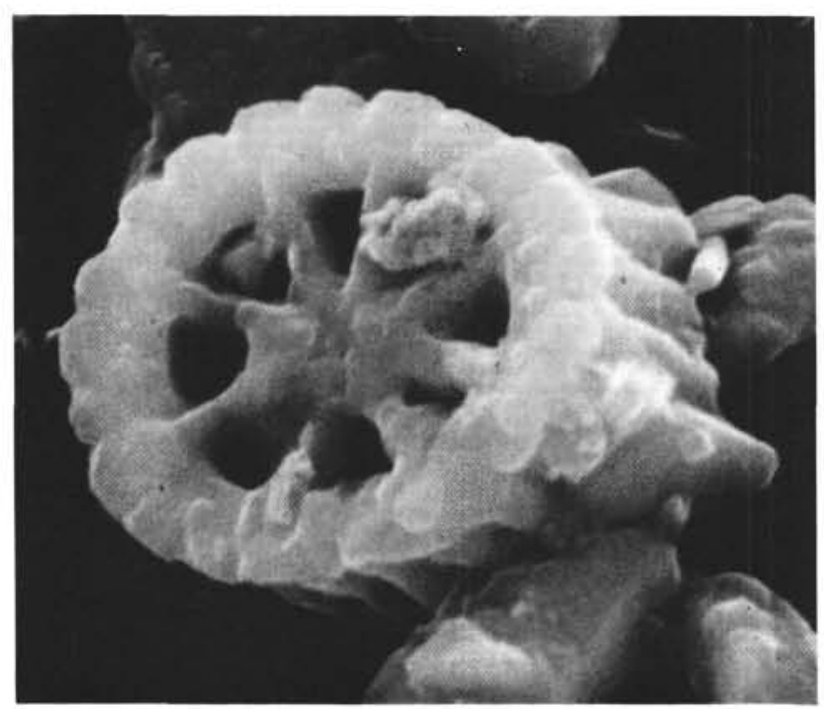

5

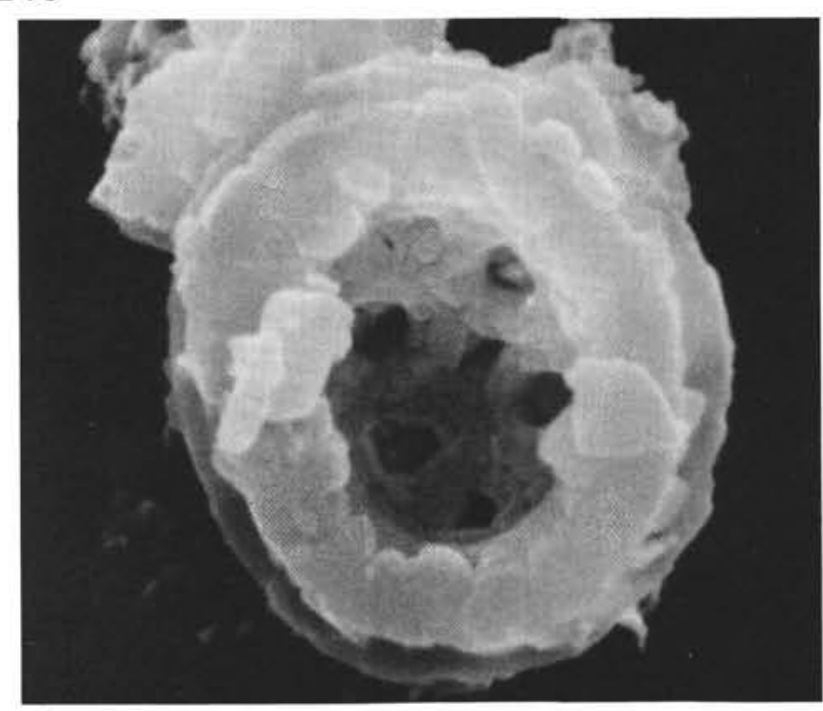

2

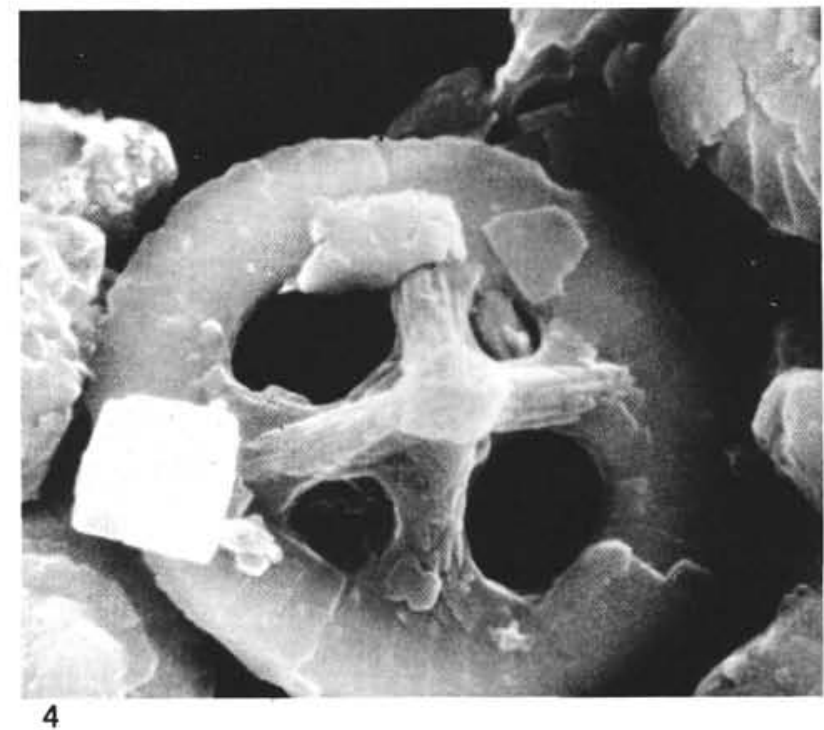

4

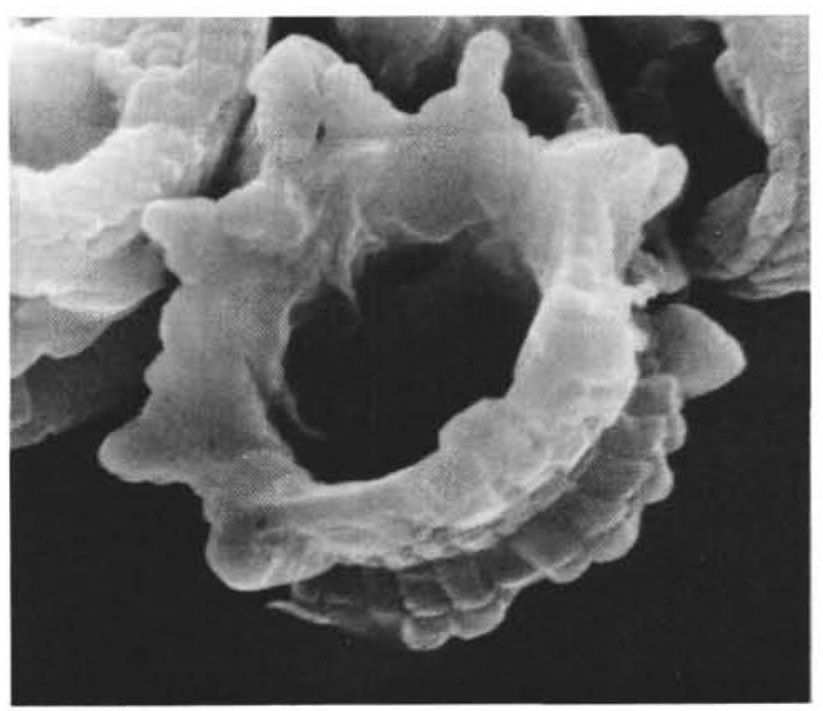

6 


\section{PLATE 71}

(Albian)

Figures 1-6 Stephanolithion laffittei Nöl.

1. Distal view, Sample 330-2-2, $26 \mathrm{~cm}, \times 8500$.

2. Proximal view, Sample $330-2-2,26 \mathrm{~cm}, \times 8500$.

3. Proximal view, Sample 330-2-2, $101 \mathrm{~cm}$, $\times 10,000$.

4. Oblique proximal view, Sample $330-2-2,26 \mathrm{~cm}$, $\times 8500$.

5. Same specimen as above, $\times 8500$.

6. Same specimen as above, proximal view, $\times 8500$.

Figures 7, 8 Parhabdolithus embergeri (Noël), Sample 330Abit.

7. Crossed-polarized light at $45^{\circ}, \times 3600$.

8. Same specimen as above crossed-polarized light at $0^{\circ}, \times 3600$.

Figure 9

Flabellites biforaminis Thierstein, crossedpolarized light at $45^{\circ}$, Sample $330 \mathrm{~A}-$ bit, $\times 4000$.

Figures 10-12 Nannoconus multicadus Deflandre and Deflandre, Sample 327A-18-3, $30 \mathrm{~cm}$.

10. Phase-contrast, $\times 4000$.

11. Crossed-polarized light at $0^{\circ}, \times 4000$.

12. Crossed-polarized light at $45^{\circ}, \times 4000$. 


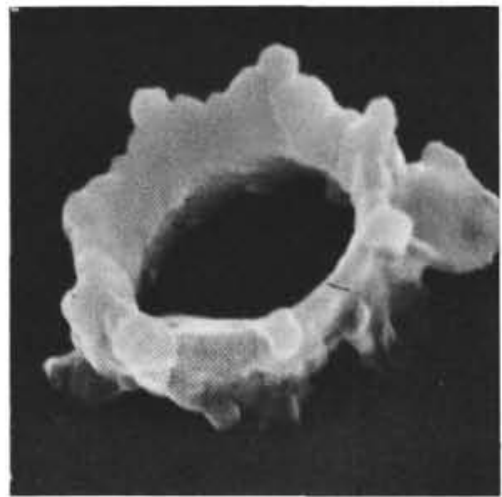

1

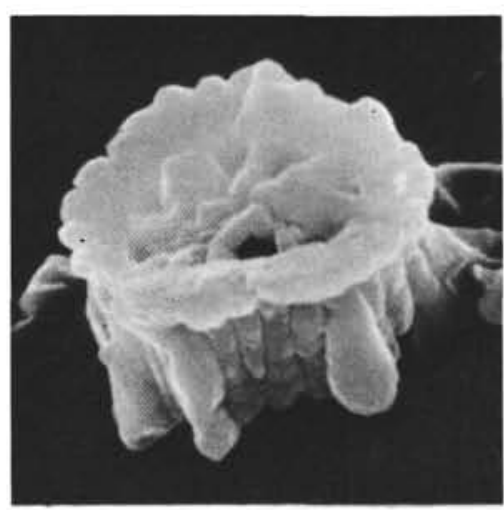

4

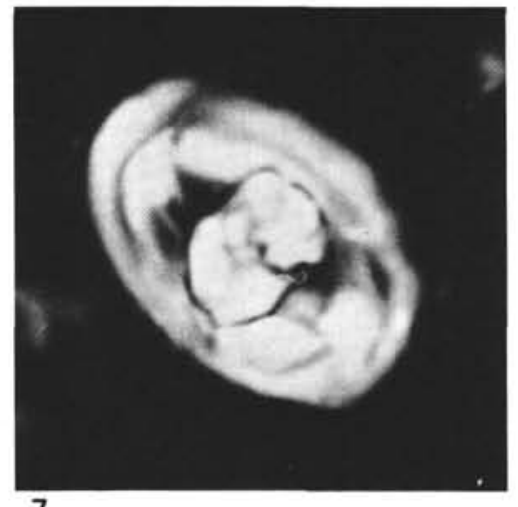

7

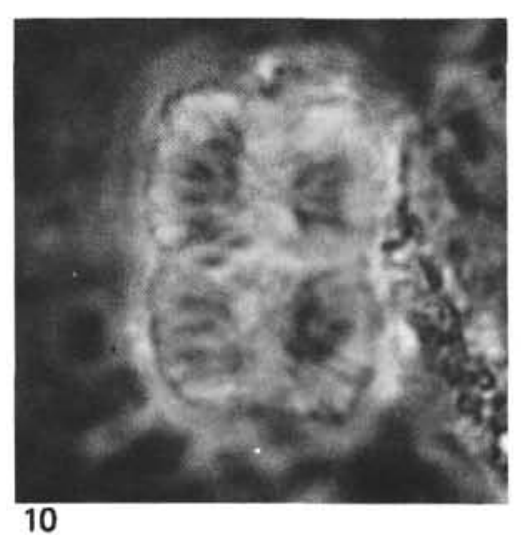

PLATE 71
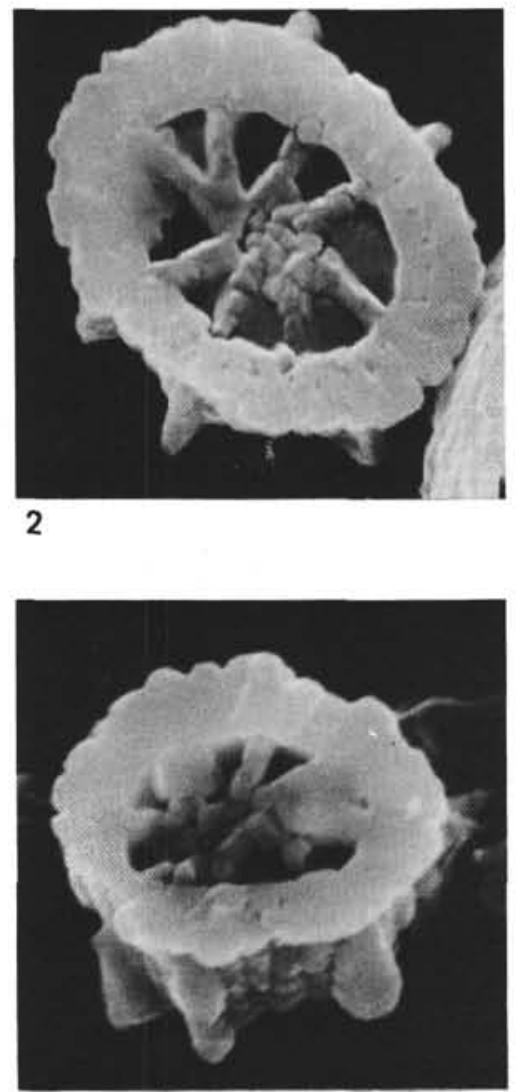

5
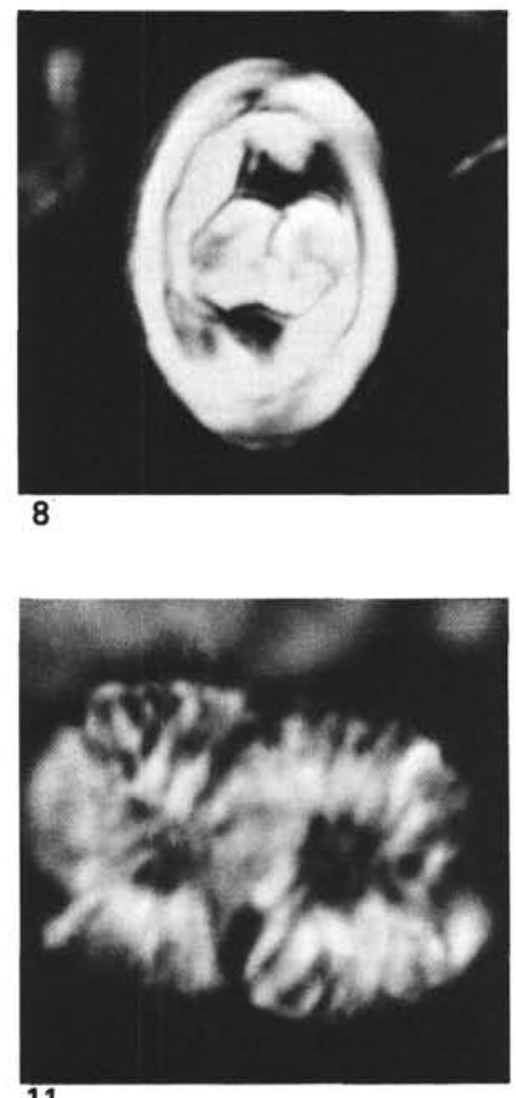

11

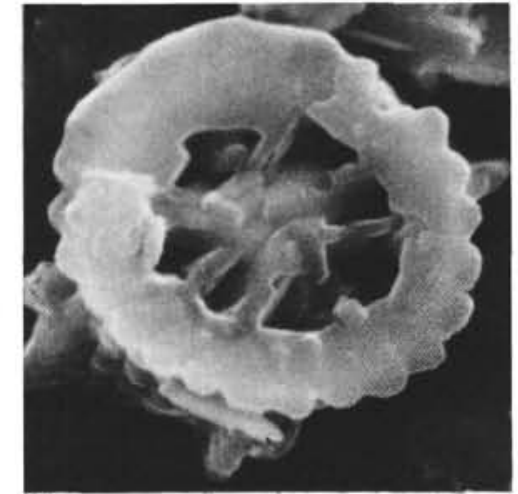

3

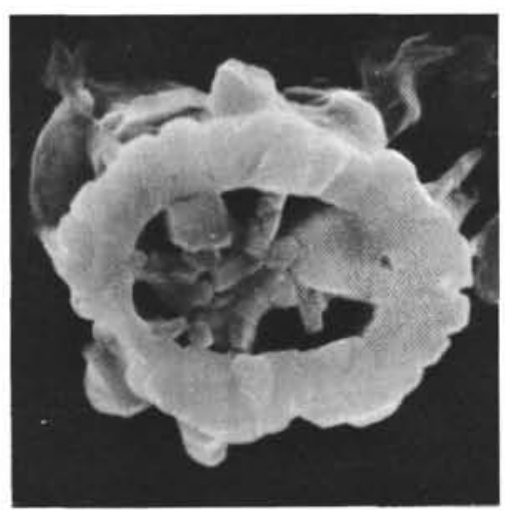

6

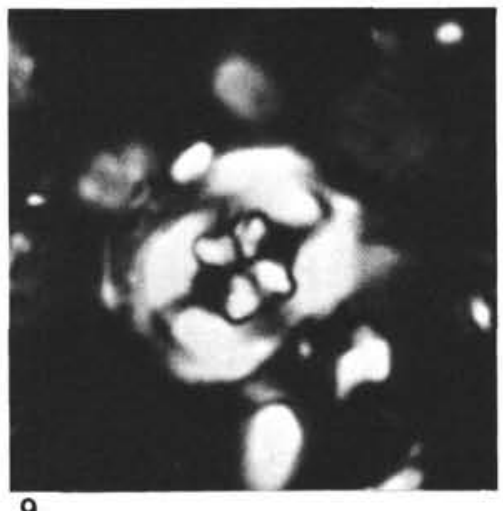

9

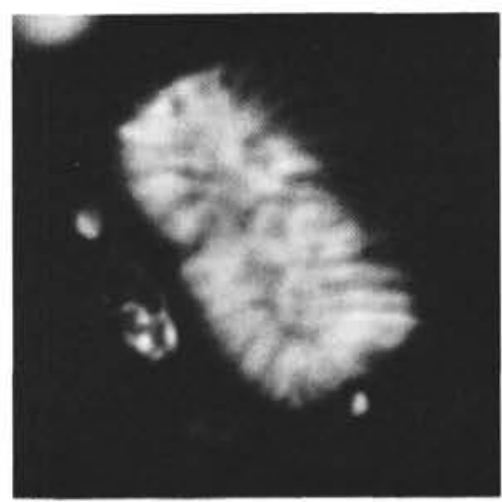

12 


\section{PLATE 72}

(Albian)

Figures 1-5 Nannoconus truitti Brönnimann.

1. Side view, Sample 327A-19-2, $15 \mathrm{~cm}, \times 6000$.

2. Oblique view, Sample 327A-19-2, $12 \mathrm{~cm}$, $\times 5000$.

3. Axial view of broken specimen, Sample 327A$21-1,142 \mathrm{~cm}, \times 9000$.

4. Same specimen as above, oblique view, Sample $327 \mathrm{~A}-21-1,142 \mathrm{~cm}, \times 11,000$.

5. Oblique view, Sample 327A-17-2, $70 \mathrm{~cm}$, $\times 6000$.

Figure 6 Nannoconus multicadus Deflandre and Deflandre, Sample 327A-21-2, $36 \mathrm{~cm}, \times 7500$. 
PLATE 72
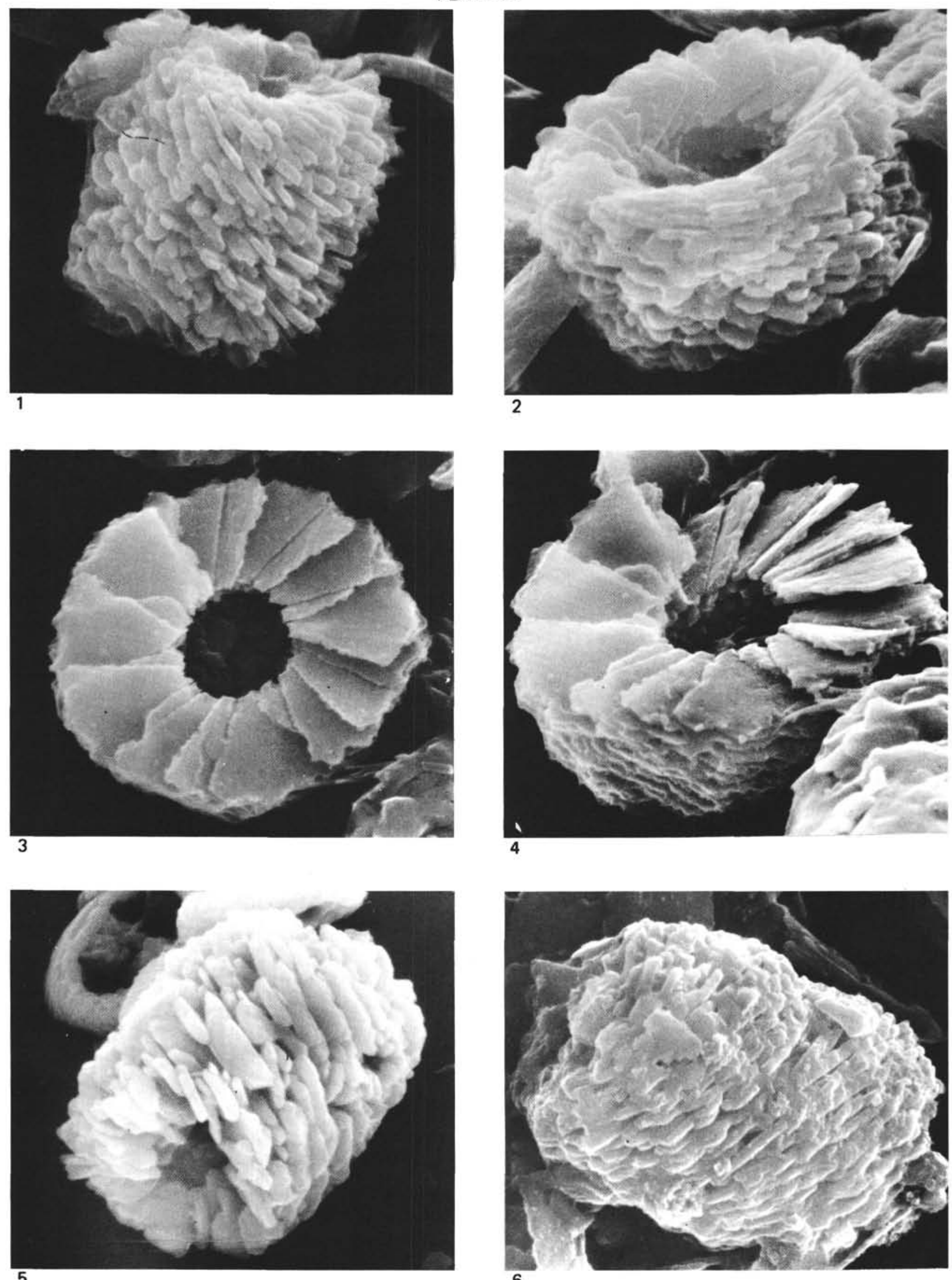


\section{PLATE 73}

(Albian)

Figures 1,2 Nannoconus truitti Brönnimann, oblique views, Sample $327 \mathrm{~A}-15-1,146 \mathrm{~cm}, \times 6500$.

Figures 3-7 Laguncula dorotheae Black, Sample 327A-18-5, $133 \mathrm{~cm}, \times 4000$.

3. Phase-contrast, medium focus.

4. Crossed-polarized light at $0^{\circ}$, medium focus.

5. Crossed-polarized light at $45^{\circ}$, high focus.

6. Crossed-polarized light at $45^{\circ}$, medium focus.

7. Crossed-polarized light at $45^{\circ}$, low focus.

Figure 8 Cyclagelosphaera margareli Noèl, crossedpolarized light, Sample 327A-16-3, $20 \mathrm{~cm}, \times 4000$.

Figures 9-11 Braarudosphaera minuta Filewicz, Wind, and Wise, n. sp., Sample 327A-21-2, $36 \mathrm{~cm}$.

9. Paratype USNM 240470, crossed-polarized light, $\times 4000$.

10. Paratype USNM $240471, \times 11,000$.

11. Holotype USNM 240472, $\times 9000$. 
PLATE 73
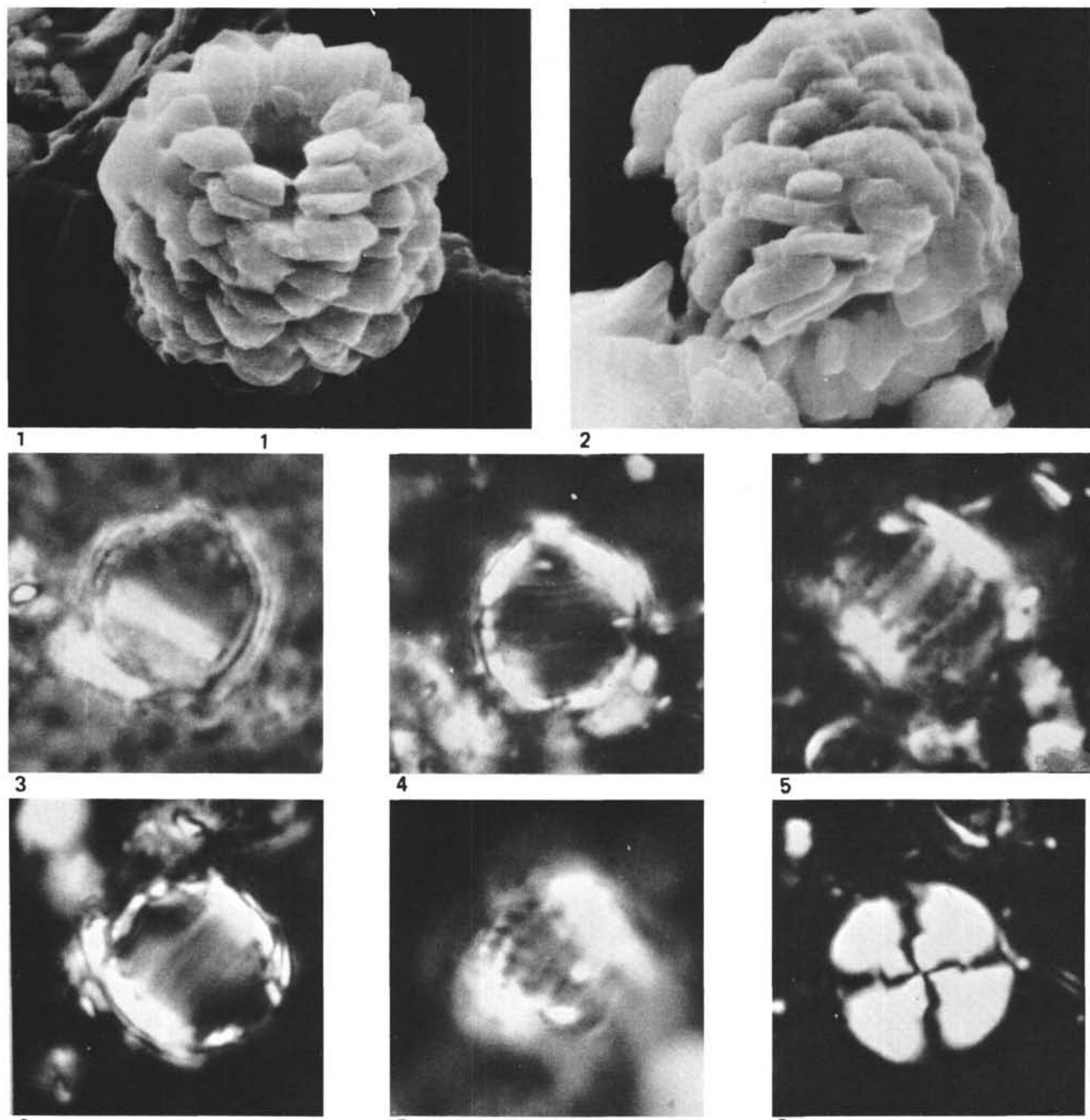

6
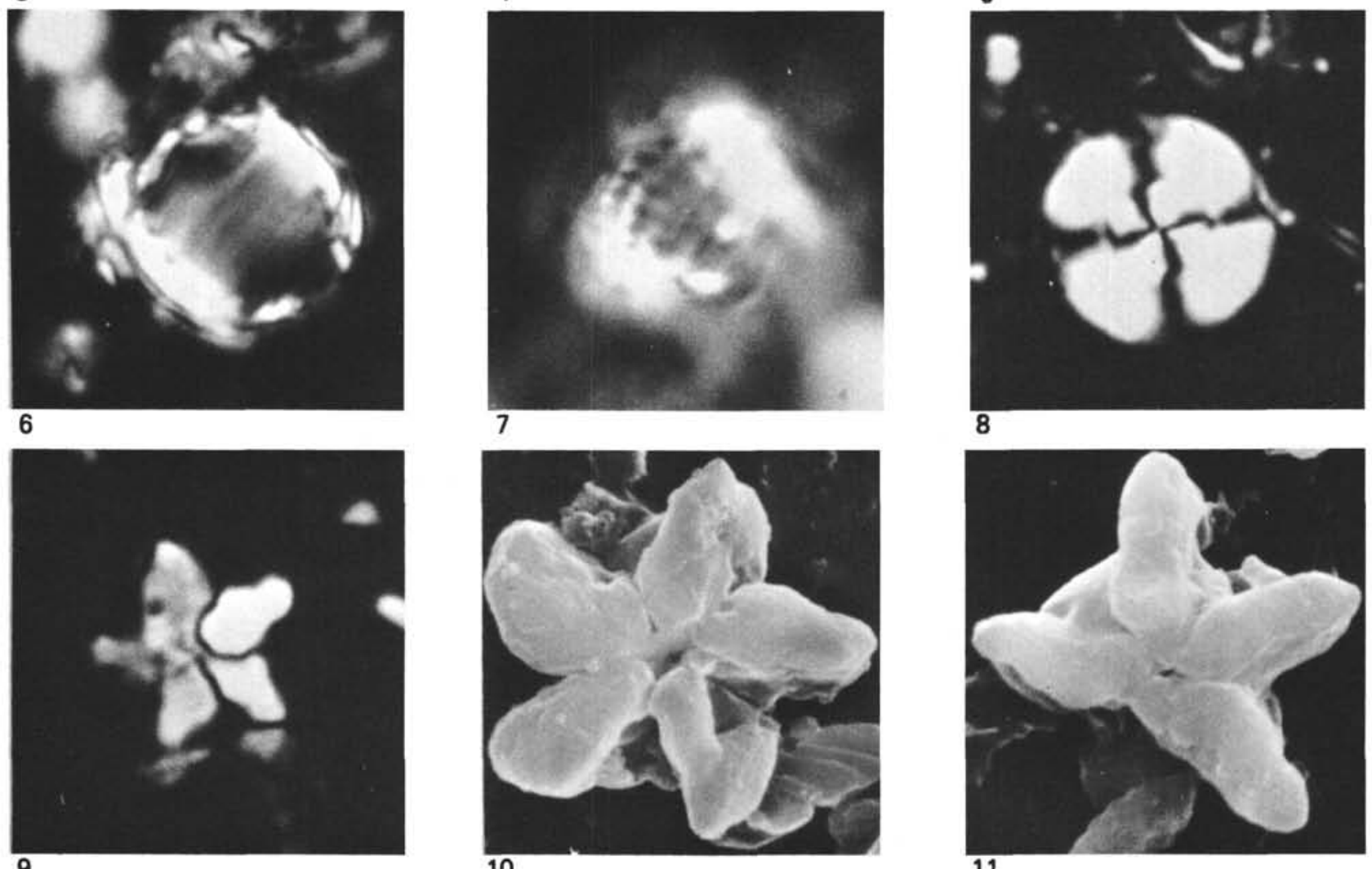


\section{PLATE 74}

\section{(Albian)}

Figure 1 Braarudosphaera bigelowi (Gran and Braarud), Sample 327A-19-2, $120 \mathrm{~cm}, \times 4500$.

Figures 2, $3 \quad$ Braarudosphaera africana Stradner.

2. Sample 327 A-19-2, $15 \mathrm{~cm}, \times 13,000$.

3. Sample $330-1-6,79 \mathrm{~cm}, \times 10,000$.

Figures 4, 5 Braarudosphaera gartneri Wind and Wise, n. sp. 4. Holotype USNM 240473, Sample 327A-19-2, $120 \mathrm{~cm}, \times 10,000$.

5. Paratype USNM 240474, Sample 327A-18-1, $79 \mathrm{~cm}, \times 10,000$.

Figure 6 Lithraphidites carniolensis Deflandre, Sample 330$2-2,26 \mathrm{~cm}, \times 10,000$. 


\section{PLATE 74}
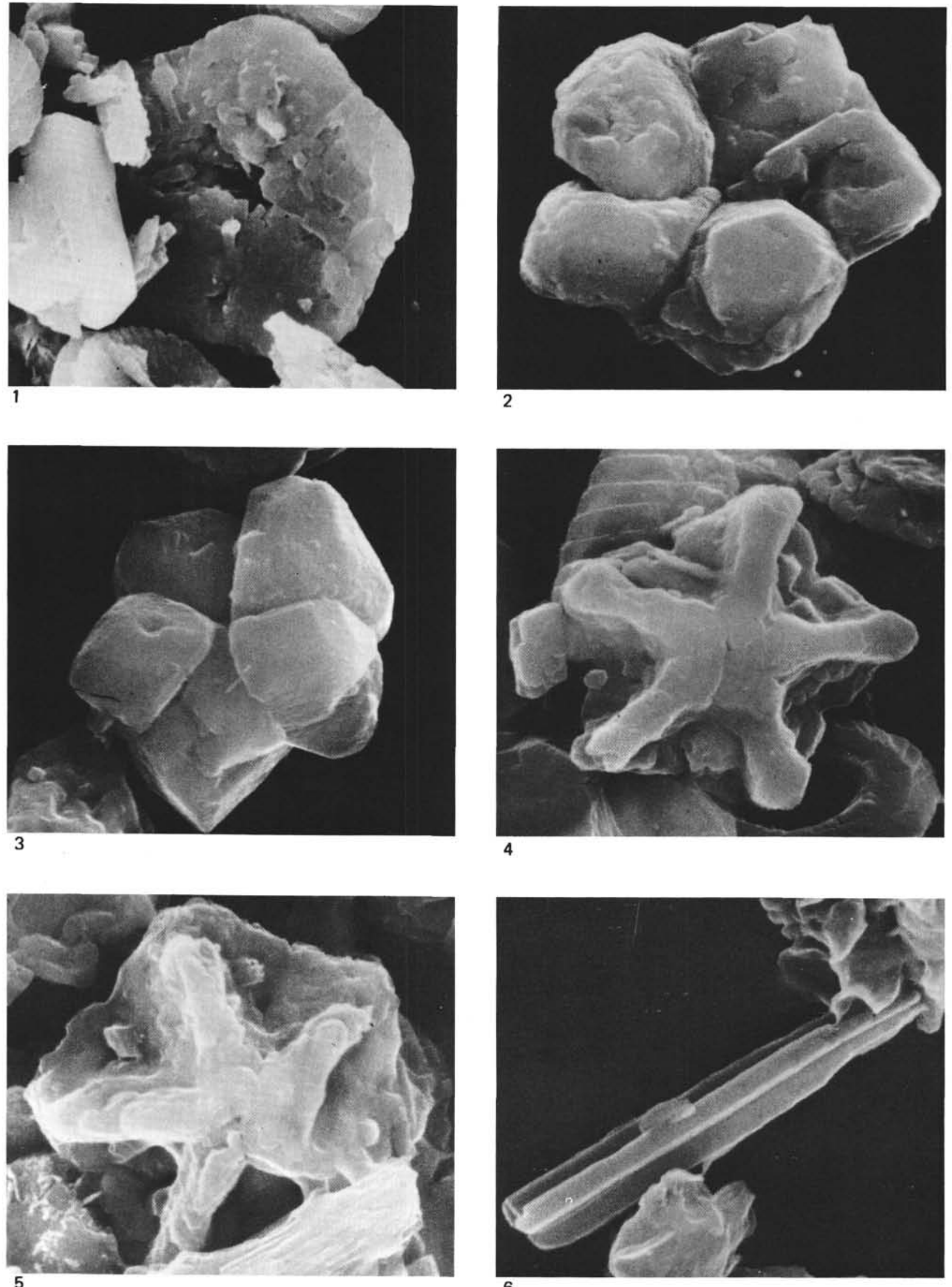
PLATE 75

(Albian-Santonian)

Figure $1 \quad$ Lithraphidites carniolensis Deflandre, Sample 330$2-2,141 \mathrm{~cm}, \times 6500$.

Figures 2-6 Lithastrinus floralis Stradner.

2. Plan view, Sample 330A-4, CC, $\times 17,000$.

3. Plan view, Sample $330-2-2,26 \mathrm{~cm}, \times 10,000$.

4. Plan view, Sample $327 \mathrm{~A}-21-3,31 \mathrm{~cm}, \times 10,000$.

5. Plan view, Sample 327 A-14-3, $29 \mathrm{~cm}, \times 10,000$; note diagenetic calcite overgrowth.

6. Side view, Sample 330A-4, CC, $\times 20,000$. 
PLATE 75
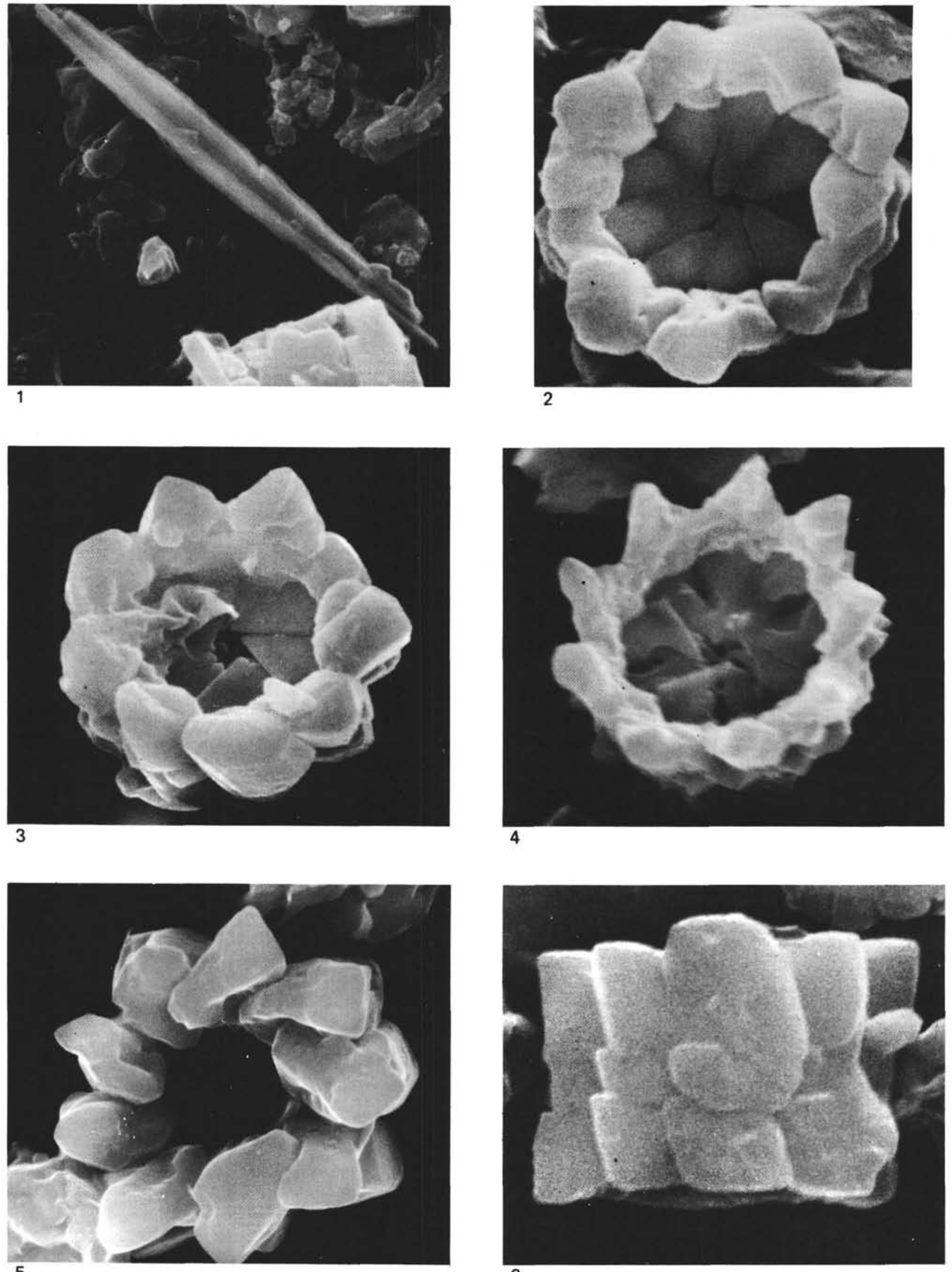


\section{PLATE 76}

(Oxfordian)

Figure 1 Ethmorhabdus? frondosus Wind and Wise, n. sp., holotype USNM 239530, distal view, Sample 330$8-1,107 \mathrm{~cm}, \times 14,000$.

Figure 2 Ethmorhabdus? frondosus Wind and Wise, n. sp., paratype USNM 239531, distal view, Sample 330$8-1,107 \mathrm{~cm}, \times 14,400$.

Figure 3 Retacapsa tridentata Wind and Wise, n. sp., holotype USNM 239532, distal view, Sample 330$7-5,120 \mathrm{~cm}, \times 10,000$.

Figure 4 Retecapsa tridentata Wind and Wise, n. sp., paratype USNM 239533, distal view, Sample 330$7-5,120 \mathrm{~cm}, \times 10,800$.

Figure 5 Retecapsa tridentata Wind and Wise, n. sp., paratype USNM 239534, distal view, Sample 330$7-5,120 \mathrm{~cm}, \times 13,000$.

Figure 6 Retecapsa angustiformata Black, 1971a, distal view, Sample 330-8-1, $107 \mathrm{~cm}, \times 14,800$. 


\section{PLATE 76}
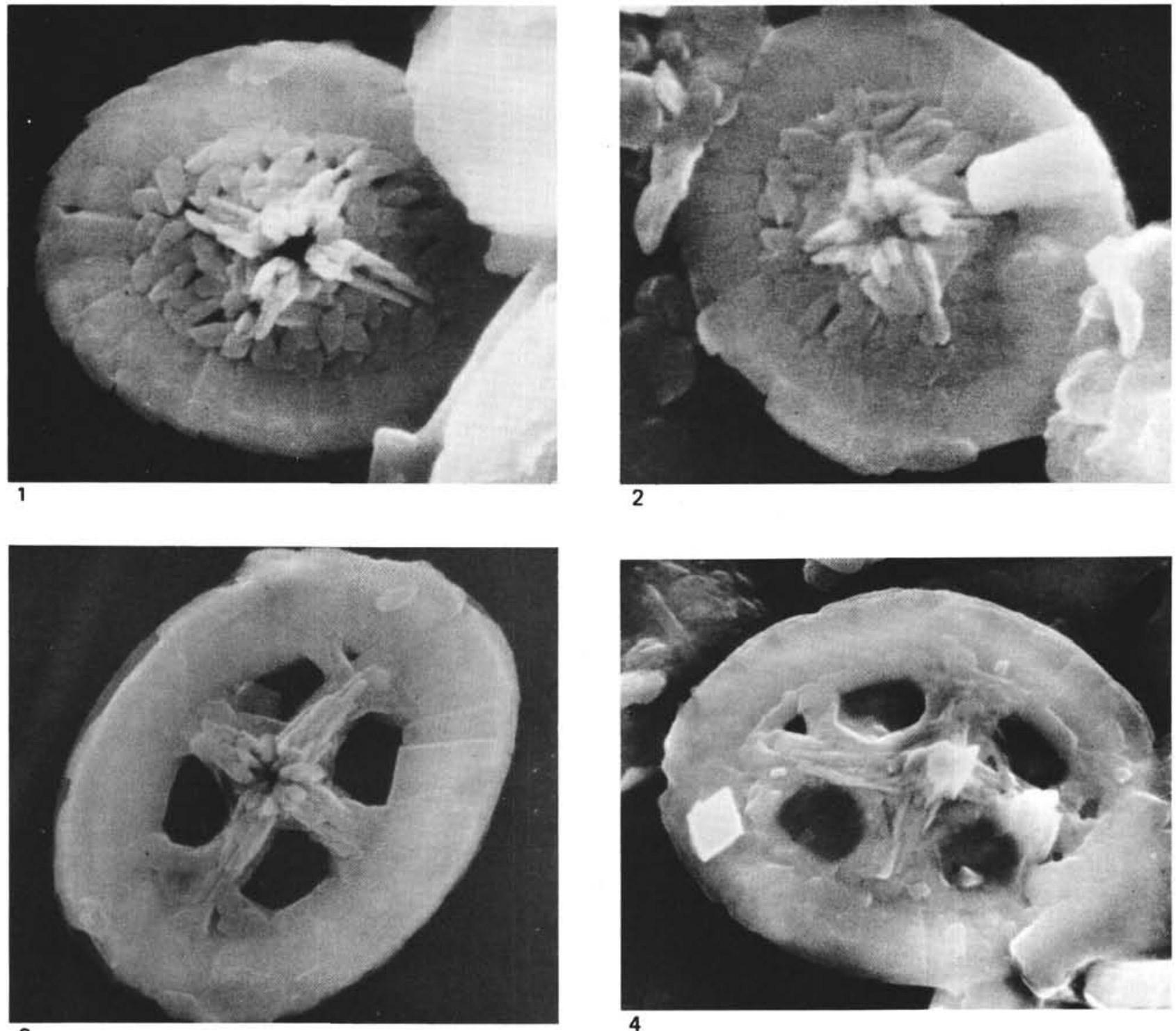

3
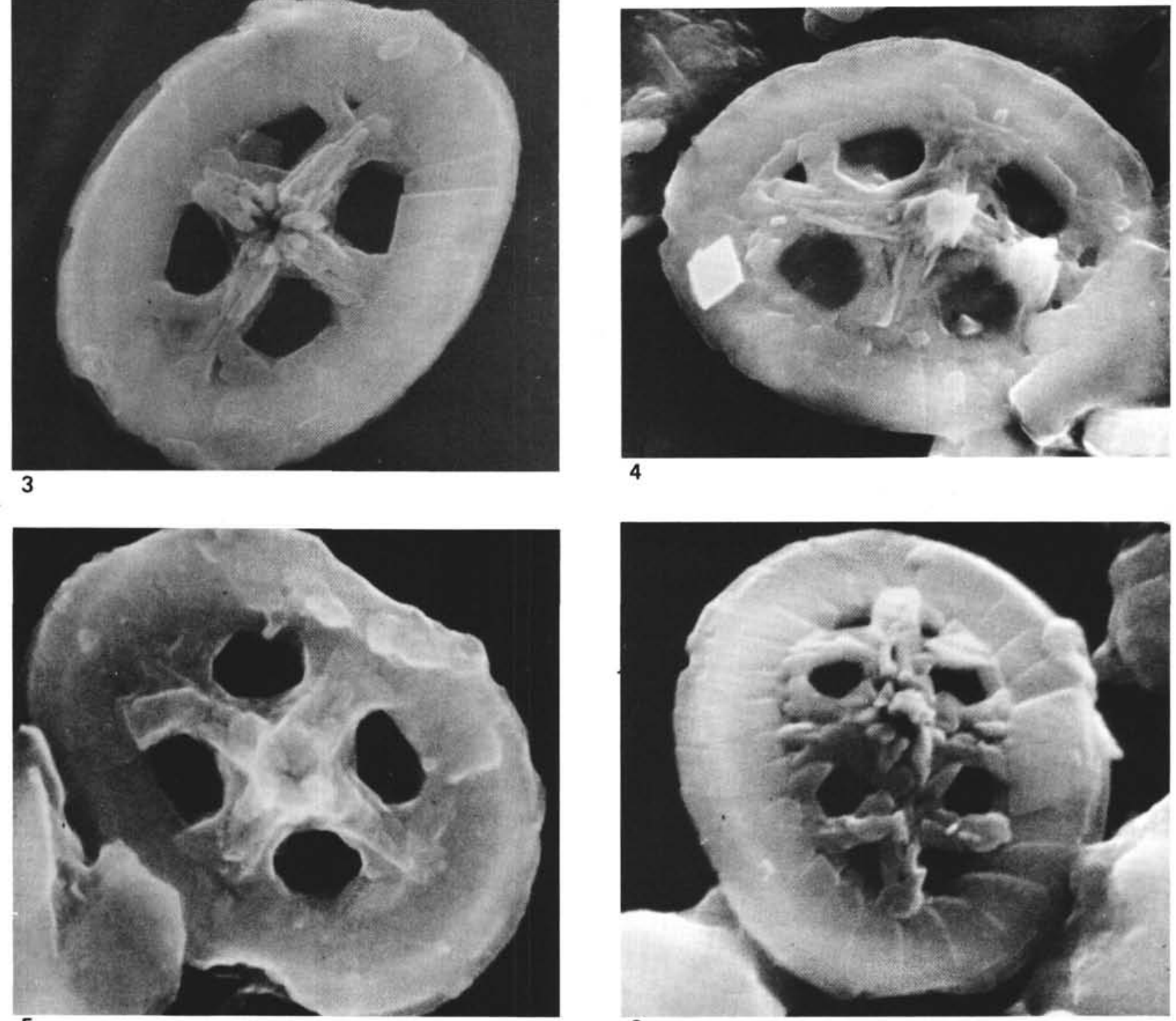

4

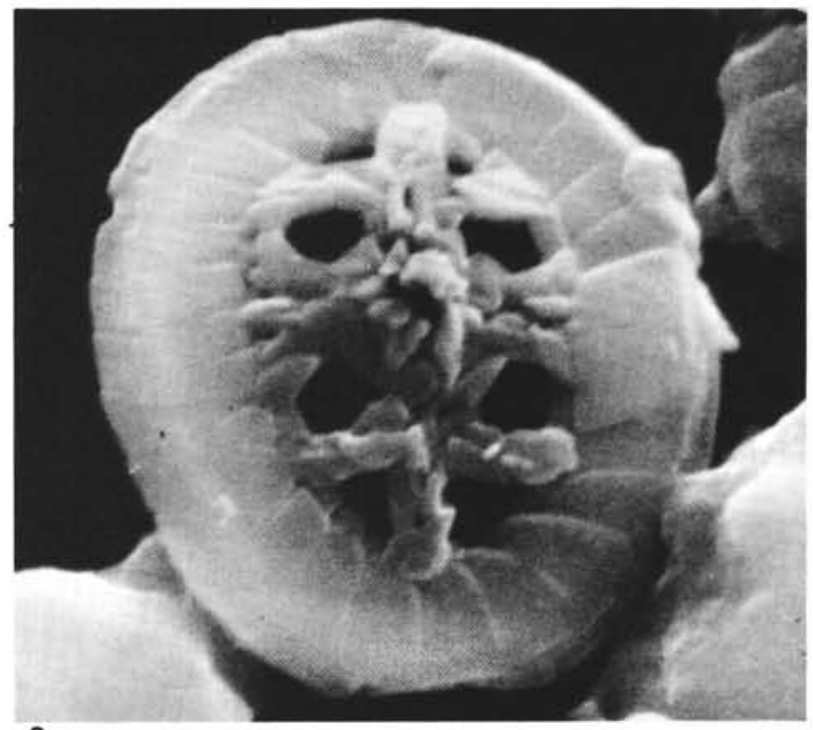




\section{PLATE 77}

\section{(Oxfordian)}

Figures 1,2 Polypodorhabdus escaigi, Noël, Sample 330-6-4, $149 \mathrm{~cm}$.

1. Lateral view, $\times 12,800$.

2. Distal view, $\times 13,000$.

Figure 3 Polypodorhabdus escaigi, Noël, distal view, Sample $330-7-5,120 \mathrm{~cm}, \times 13,000$.

Figure $4 \quad$ Polypodorhabdus sp. aff. P. escaigi Noël, proximal view, Sample 330-7-5, $120 \mathrm{~cm}, \times 11,500$.

Figure 5 Ethmorhabdus gallicus Noël, distal view, Sample $330-7-5,120 \mathrm{~cm}, \times 15,000$.

Figure 6 Ethmorhabdus gallicus Noël, proximal view, Sample $330-8-1,107 \mathrm{~cm}, \times 10,000$. 
PLATE 77
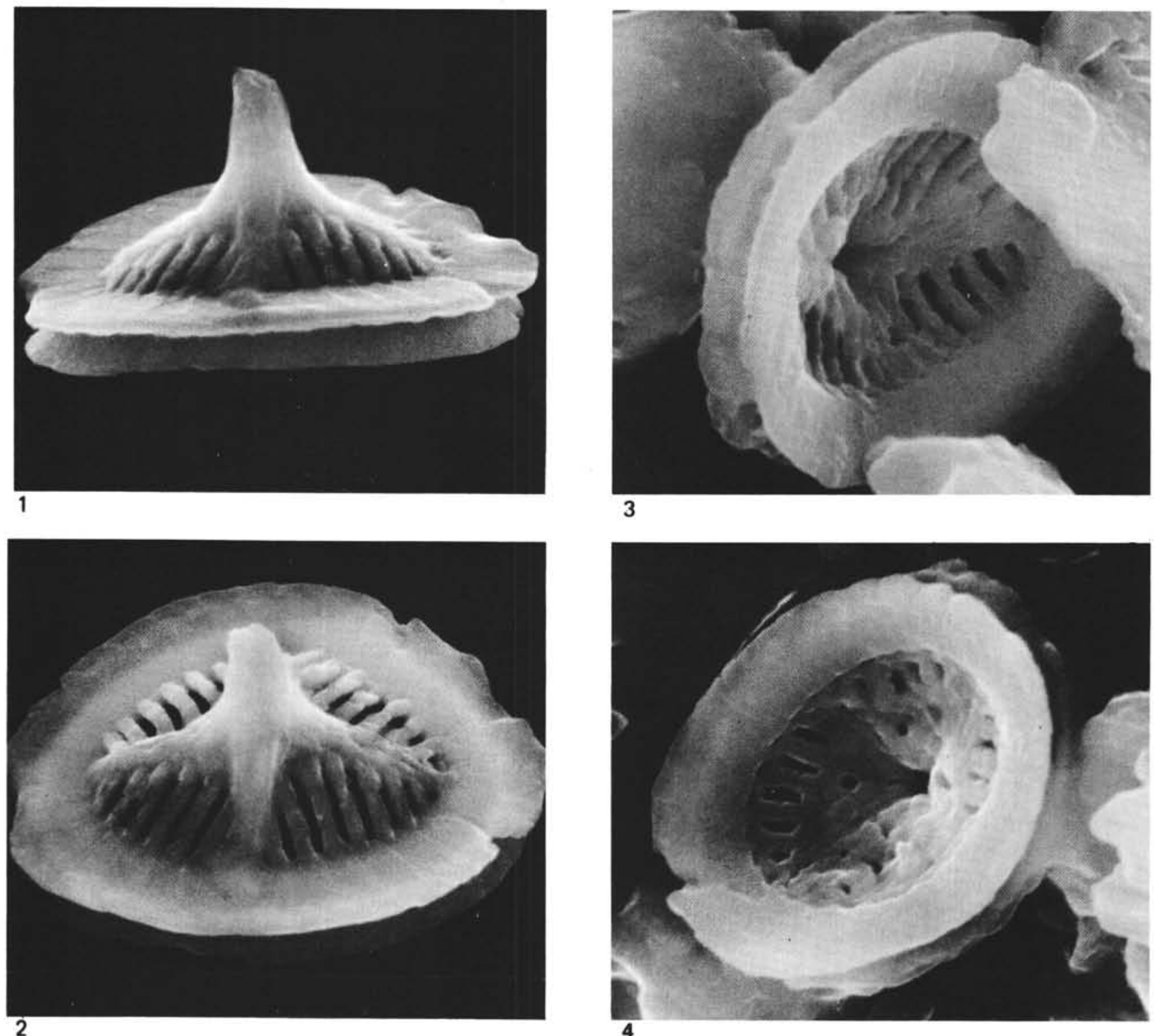

3
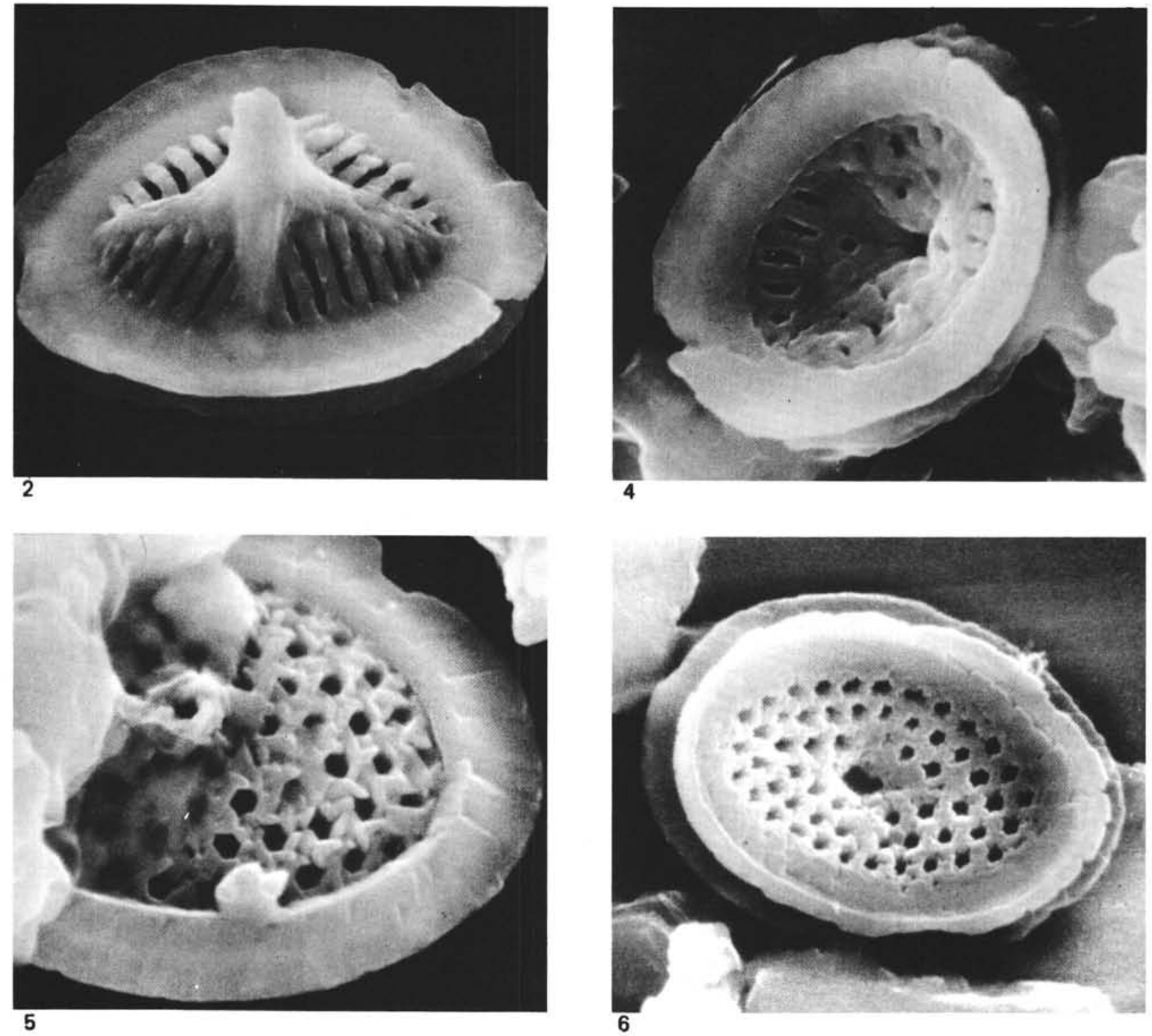


\section{PLATE 78}

(Oxfordian)

Figure 1 Retecapsa sp., Sample 330-8-1, $107 \mathrm{~cm}, \times 13,000$.

Figure 2 ?Corollithion senarius Wind and Wise, n. sp., distal view, Sample 330-7-5, $120 \mathrm{~cm}, \times 24,000$.

Figure 3 Corollithion senarius Wind and Wise, n. sp., holotype, USNM 239537, proximal view, Sample $330-7-5,120 \mathrm{~cm}, \times 18,600$.

Figures 4-6 Palaeopontosphaera erismata Wind and Wise, $\mathrm{n}$. sp., Sample 330-7-5, $120 \mathrm{~cm}$.

4. Holotype USNM 239538 , distal view, $\times 24,000$.

5. Paratype USNM 239539, distal view, $\times 21,000$.

6. Paratype USNM 239540, proximal view, $\times 21,000$. 


\section{PLATE 78}
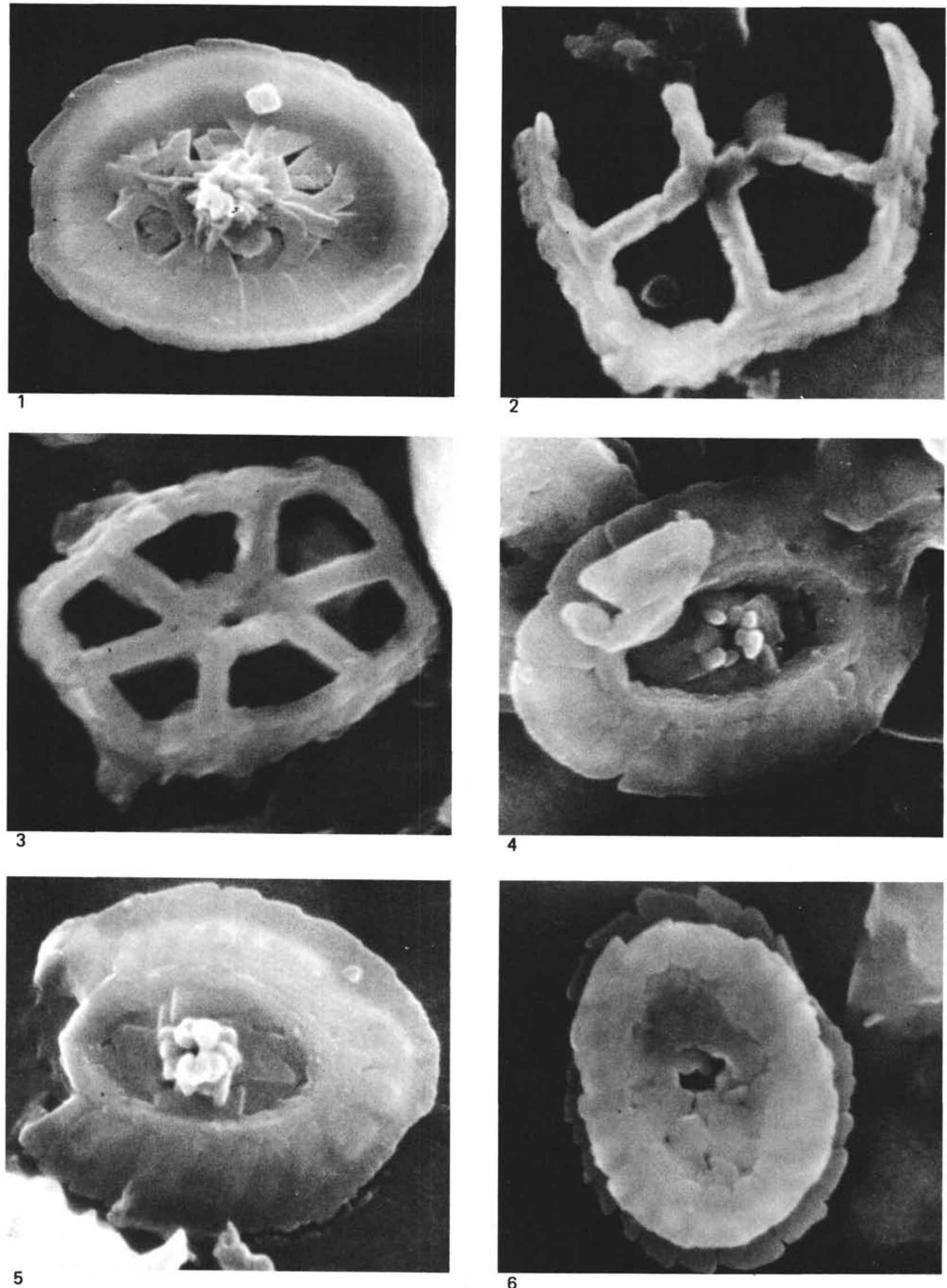


\section{PLATE 79}

(Oxfordian)

Figures 1-3 Stephanolithion bigoti Deflandre.

1. Proximal view, Sample 330-7-5, $120 \mathrm{~cm}$, $\times 14,000$.

2. Distal view, Sample $330-5-3,34 \mathrm{~cm}, \times 15,000$.

3. Proximal view, Sample 330-8-1, $107 \mathrm{~cm}$, $\times 15,000$.

Figures 4-6 Podorhabdus grassei Noël emend. Wind and Wise. 4. Proximal-lateral view, Sample $330-7-5,120 \mathrm{~cm}$, $\times 23,000$.

5. Lateral view, Sample $330-7-5,120 \mathrm{~cm}, \times 10,000$.

6. Lateral view, Sample $330-7-5,120 \mathrm{~cm}, \times 11,400$ 
MESOZOIC AND CENOZOIC CALCAREOUS NANNOFOSSILS

\section{PLATE 79}
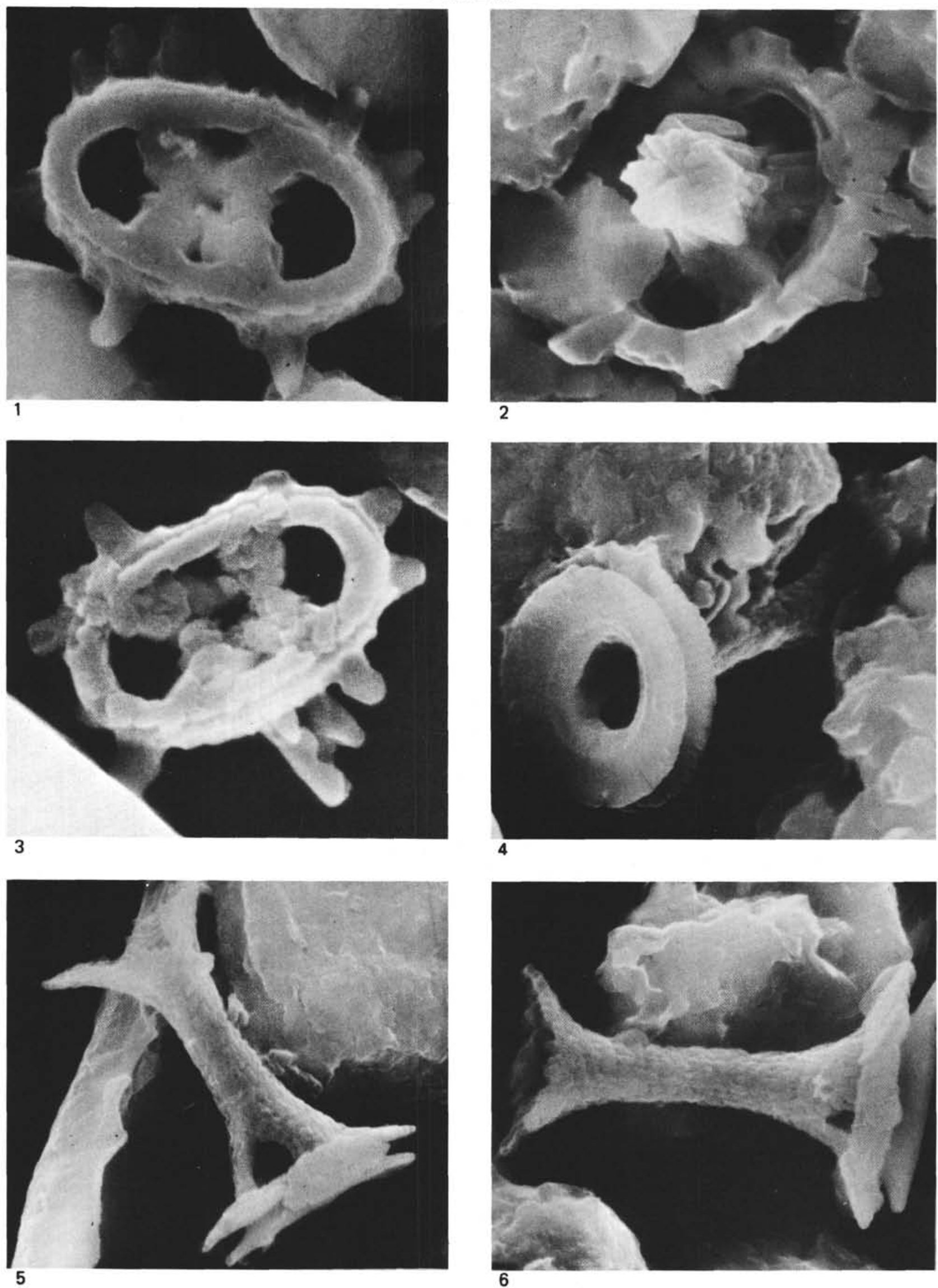


\section{PLATE 80}

(Oxfordian)

Figures 1, 2 Podorhabdus grassei Noël, emend. Wind and Wise, Sample 330-7-5, $120 \mathrm{~cm}$.

1. Proximal-distal view, $\times 10,000$.

2. Lateral view, $\times 9000$.

Figures 3,4 Podorhabdus grassei Noël, emend. Wind and Wise, Sample $330-7-5,120 \mathrm{~cm}$.

3. Proximal view, $\times 12,000$.

4. Lateral view, $\times 12,000$.

Figures 5,6 Axopodorhabdus cylindratus (Noël) Wind and Wise, n. comb., Sample 330-7-5, $120 \mathrm{~cm}$.

5. Proximal view, $\times 11,500$.

6. Lateral and distal views, Sample 330-8-1, 107 $\mathrm{cm}, \times 3000$. 
PLATE 80
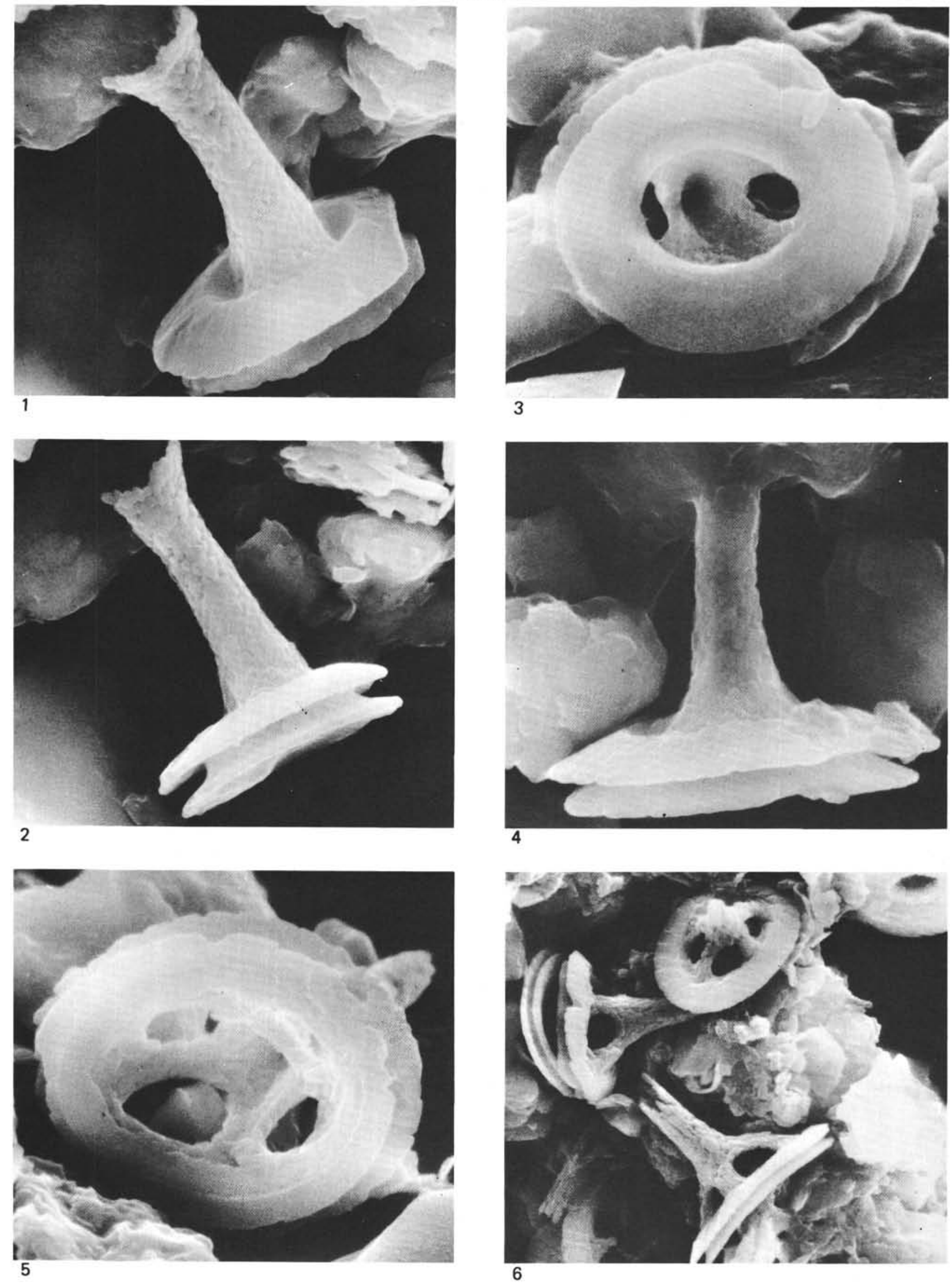


\section{PLATE 81}

\section{(Oxfordian)}

Figures 1-4 Axopodorhabdus cylindratus (Noël) Wind and Wise, n. comb.

1. Distal view, Sample $330-7-5,120 \mathrm{~cm}, \times 10,500$.

2. Lateral view, Sample 330-8-1, $107 \mathrm{~cm}, \times 8200$.

3. Proximal view, Sample $330-7-5,120 \mathrm{~cm}$, $\times 10,500$.

4. Distal-lateral view, Sample $330-7-5,120 \mathrm{~cm}$, $\times 9000$.

Figure 5 Hexapodorhabdus cuvillieri Noël, Sample 330-7-5, $120 \mathrm{~cm}, \times 13,000$.

Figure 6 ?Zeugrhabdotus erectus (Deflandre) Reinhardt, Sample $330-7-5,120 \mathrm{~cm}, \times 8500$. 
PLATE 81

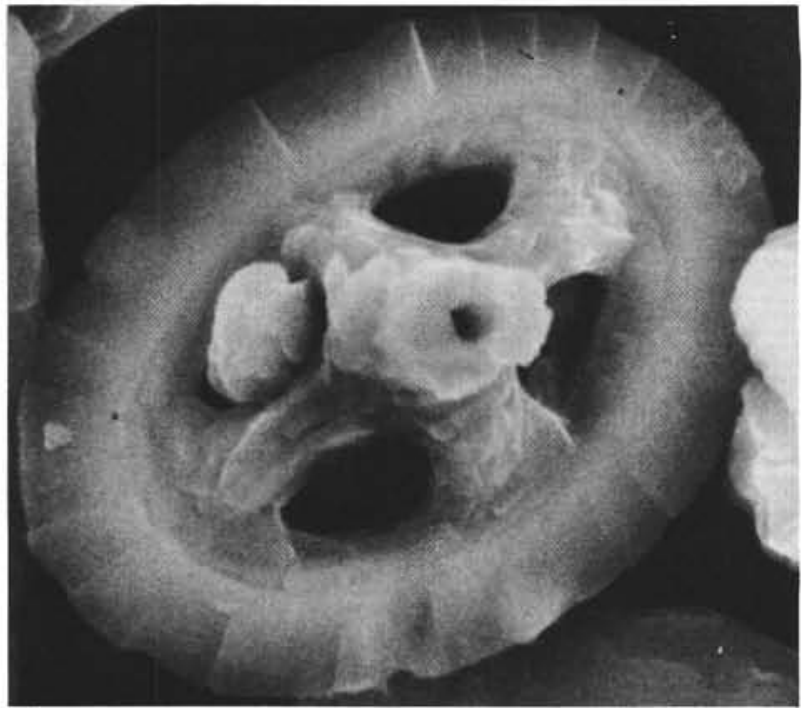

1

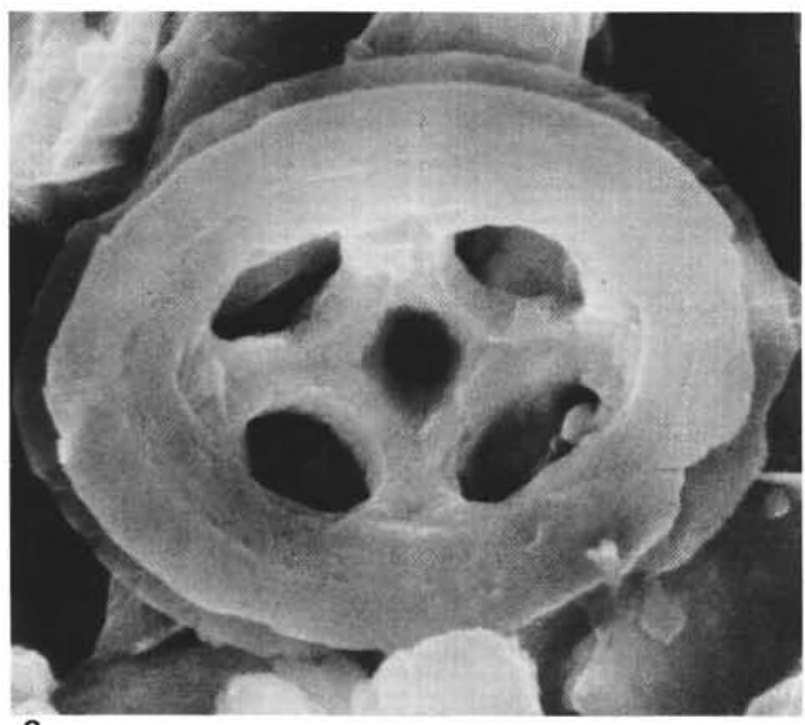

3

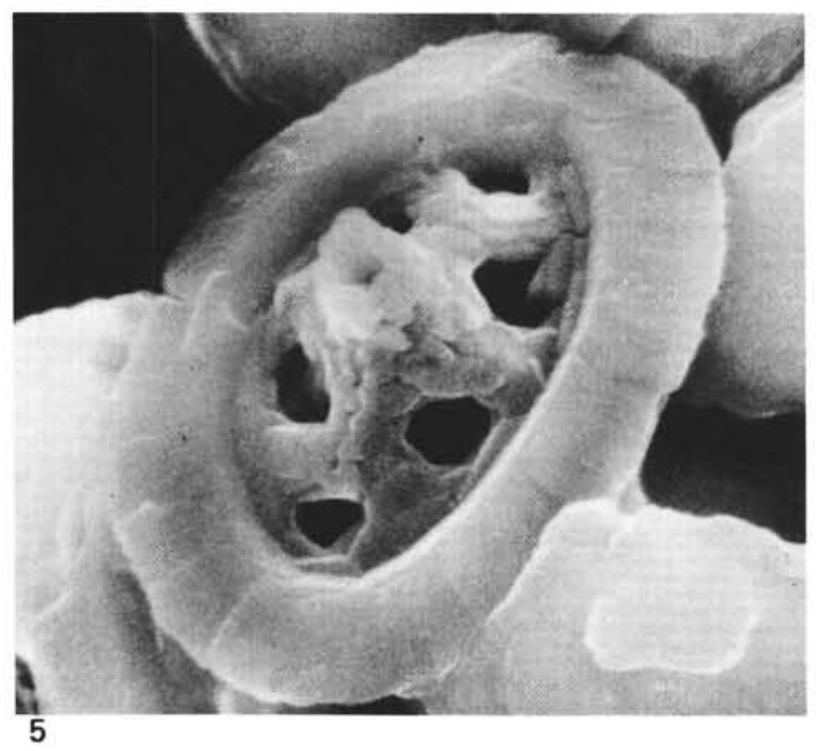

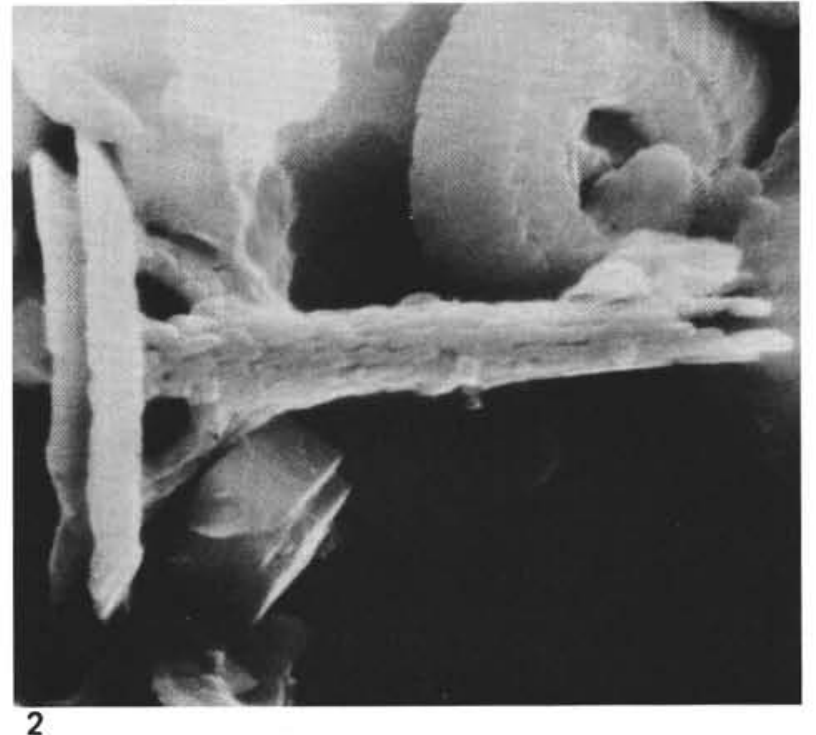

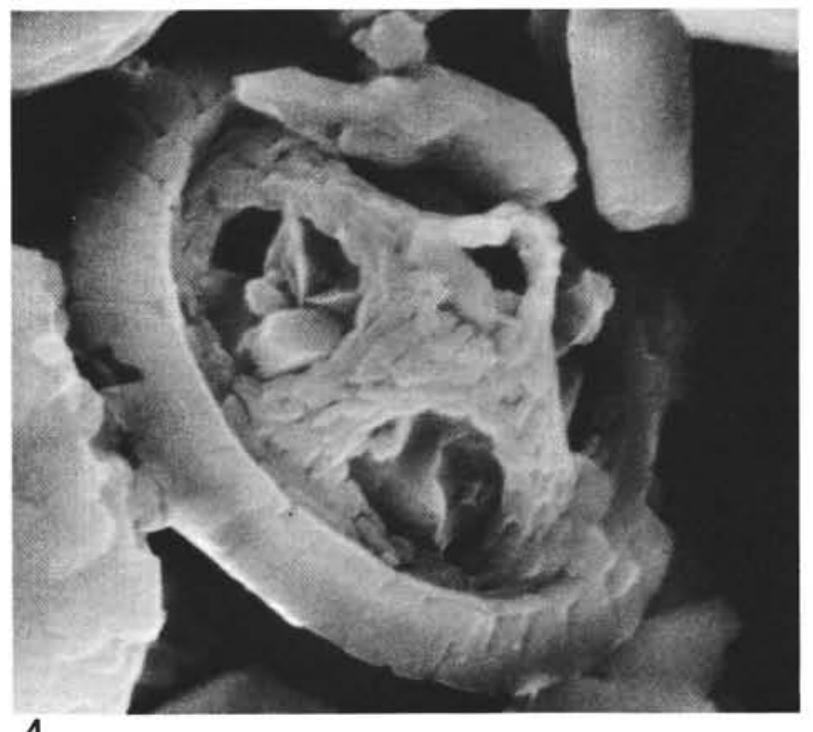

4

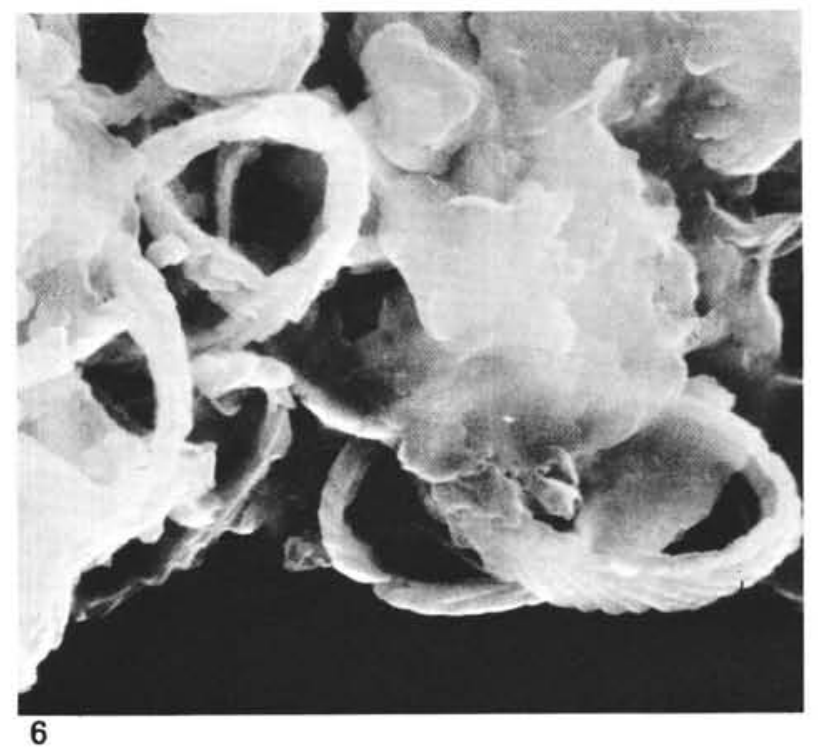




\section{PLATE 82}

(Oxfordian)

Figures 1-4, 6 Zeugrhabdotus noeli, Rood, Hay, and Barnard.

1. Sample $330-7-5,120 \mathrm{~cm}, \times 7500$.

2. Lateral-proximal view, Sample $330-7-5,120$ $\mathrm{cm}, \times 16,000$.

3. Lateral-proximal view, Sample 330-7-5, 120 $\mathrm{cm}, \times 16,500$.

4. Lateral view, Sample $330-7-5,120 \mathrm{~cm}, \times 16,000$. 6. Proximal view, Sample $330-6-4,23 \mathrm{~cm}$, $\times 17,000$.

Figure 5 ?Zeugrhabdotus choffati Rood, Hay, and Barnard, distal view, Sample 330-7-5, $120 \mathrm{~cm}, \times 20,000$. 
PLATE 82
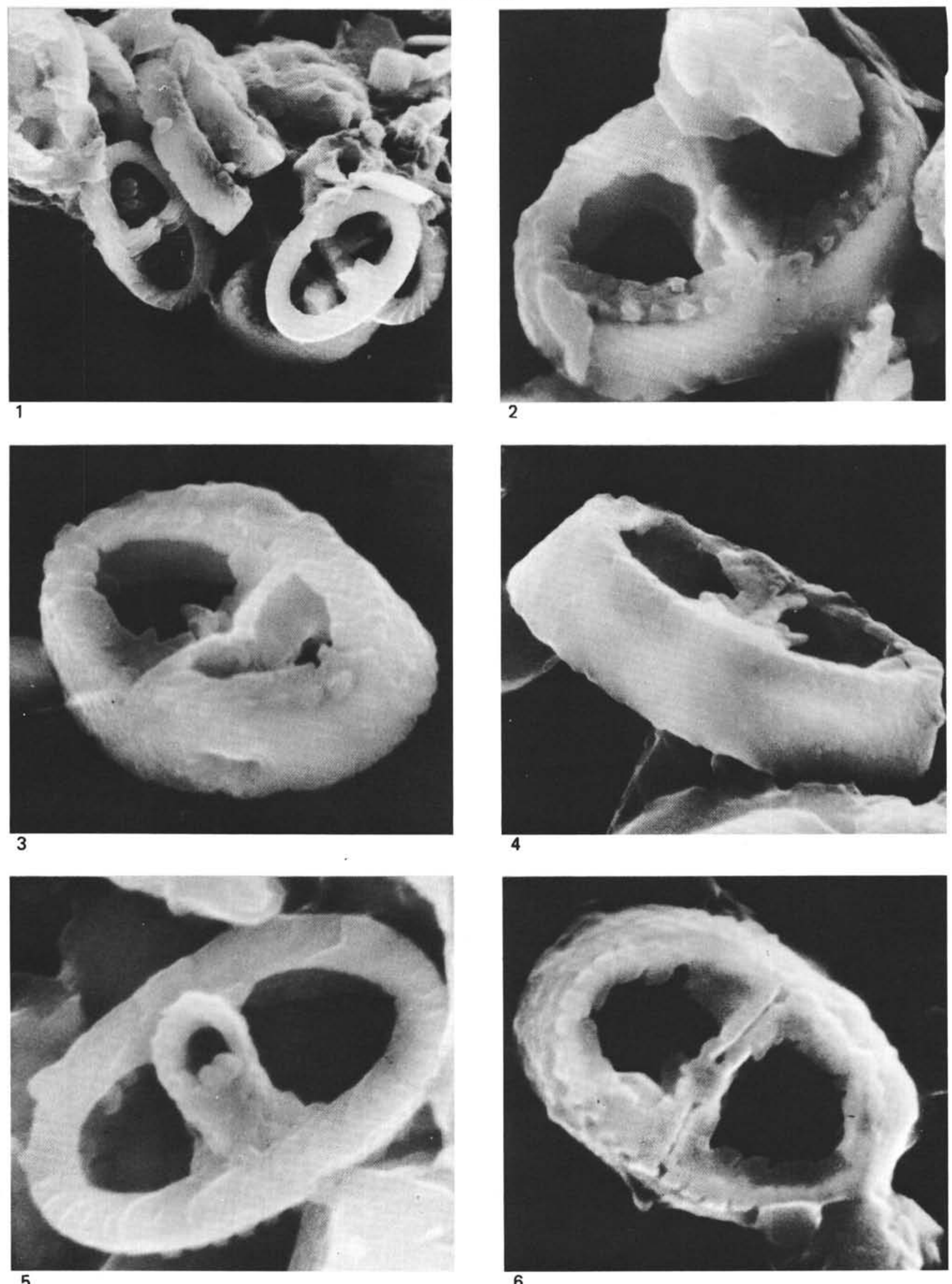


\section{PLATE 83}

\section{(Oxfordian)}

Figure 1 Zeugrhabdotus noeli, Rood, Hay, and Barnard, distal view, Sample 330-7-5, $120 \mathrm{~cm}, \times 17,000$.

Figure 2 ?Zeugrhabdotus erectus (Deflandre) Reinhardt, distal view, Sample 330-7-5, $120 \mathrm{~cm}, \times 15,000$.

Figures 3,4 Vekshinella quadriarculla (Noël) Rood, Hay, and Barnard, Sample 330-7-5, $120 \mathrm{~cm}$.

3. Proximal view, $\times 26,000$.

4. Distal view, $\times 21,000$.

Figure $5 \quad$ Vekshinella sp. aff. V. stradneri Rood, Hay, and Barnard, distal view, Sample 330-6-4, $149 \mathrm{~cm}$, $\times 16,000$.

Figure 6 Vekshinella stradneri Rood, Hay, and Barnard, distal view, Sample 330-7-5, $120 \mathrm{~cm}, \times 15,000$. 


\section{PLATE 83}

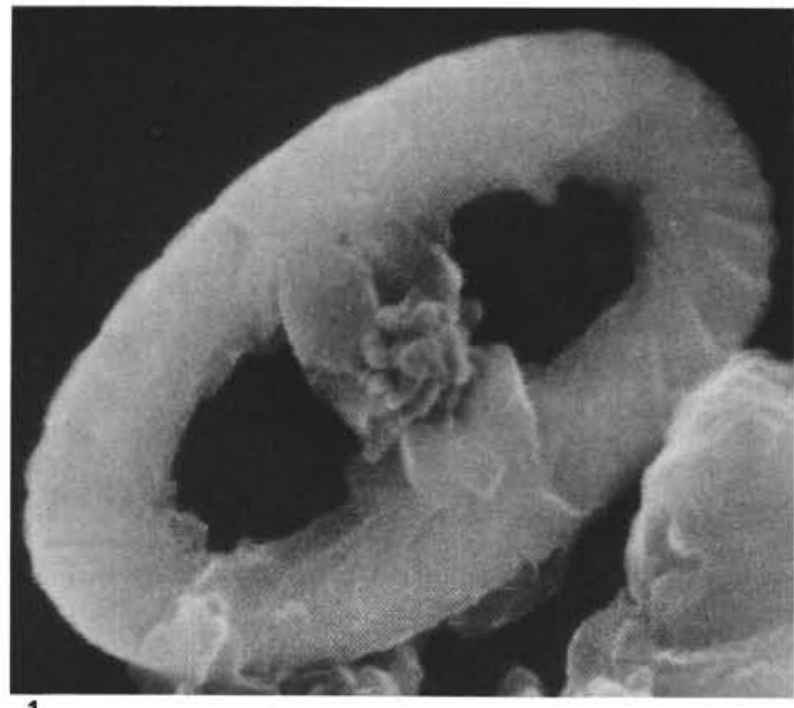

1

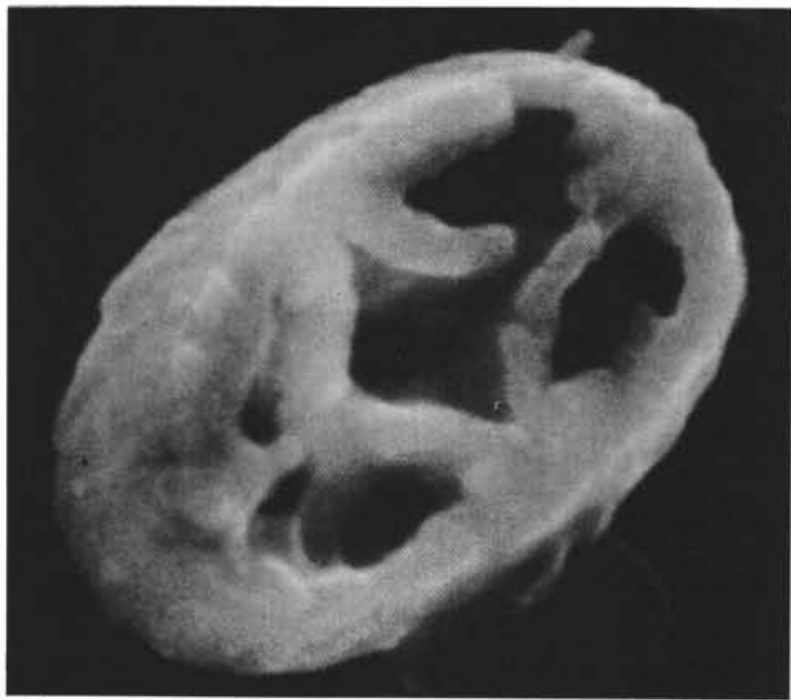

3

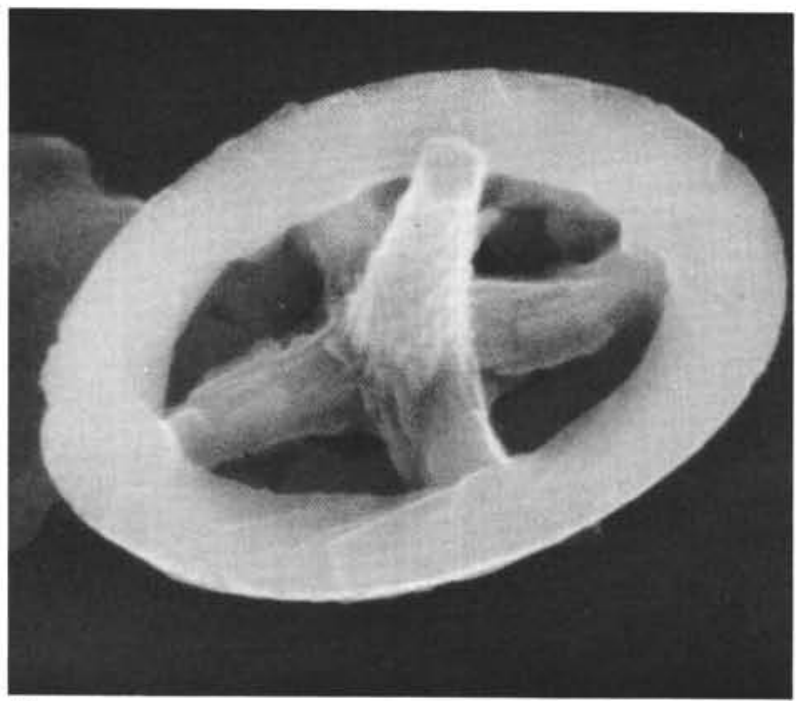

5

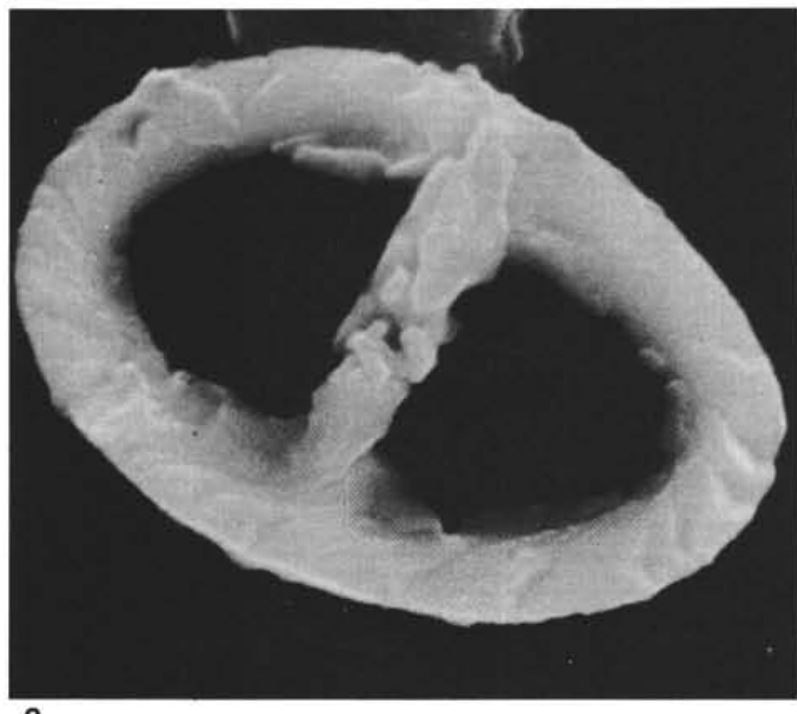

2
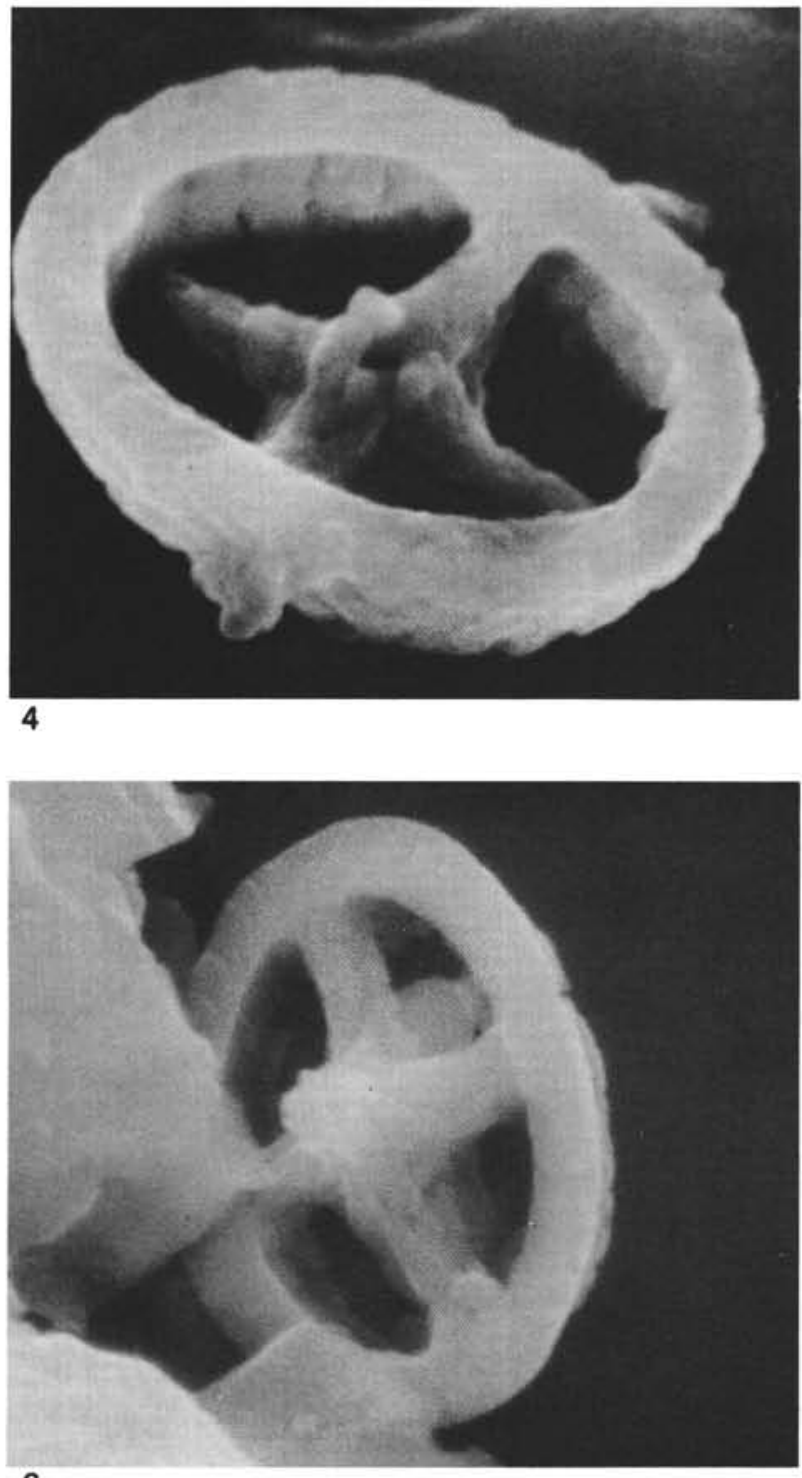


\section{PLATE 84}

(Oxfordian)

Figures 1, 3, 5, Vekshinella stradneri Rood, Hay, and Barnard, 6 Sample 330-7-5, $120 \mathrm{~cm}$.

1. Distal view, $\times 17,000$.

3. Distal view, $\times 25,000$, background of print retouched.

5. Proximal view, proximal surface veneer nearly completely removed, $\times 15,000$.

6. Proximal view, proximal surface veneer completely preserved, $\times 18,000$.

Figures 2, 4 Vekshinella quadriarculla (Noël) Wind and Wise, n. comb.

2. Distal view, Sample $330-7-5,120 \mathrm{~cm}, \times 28,000$.

4. Proximal-lateral view, Sample 6-4, $149 \mathrm{~cm}$, $\times 16,000$. 


\section{PLATE 84}
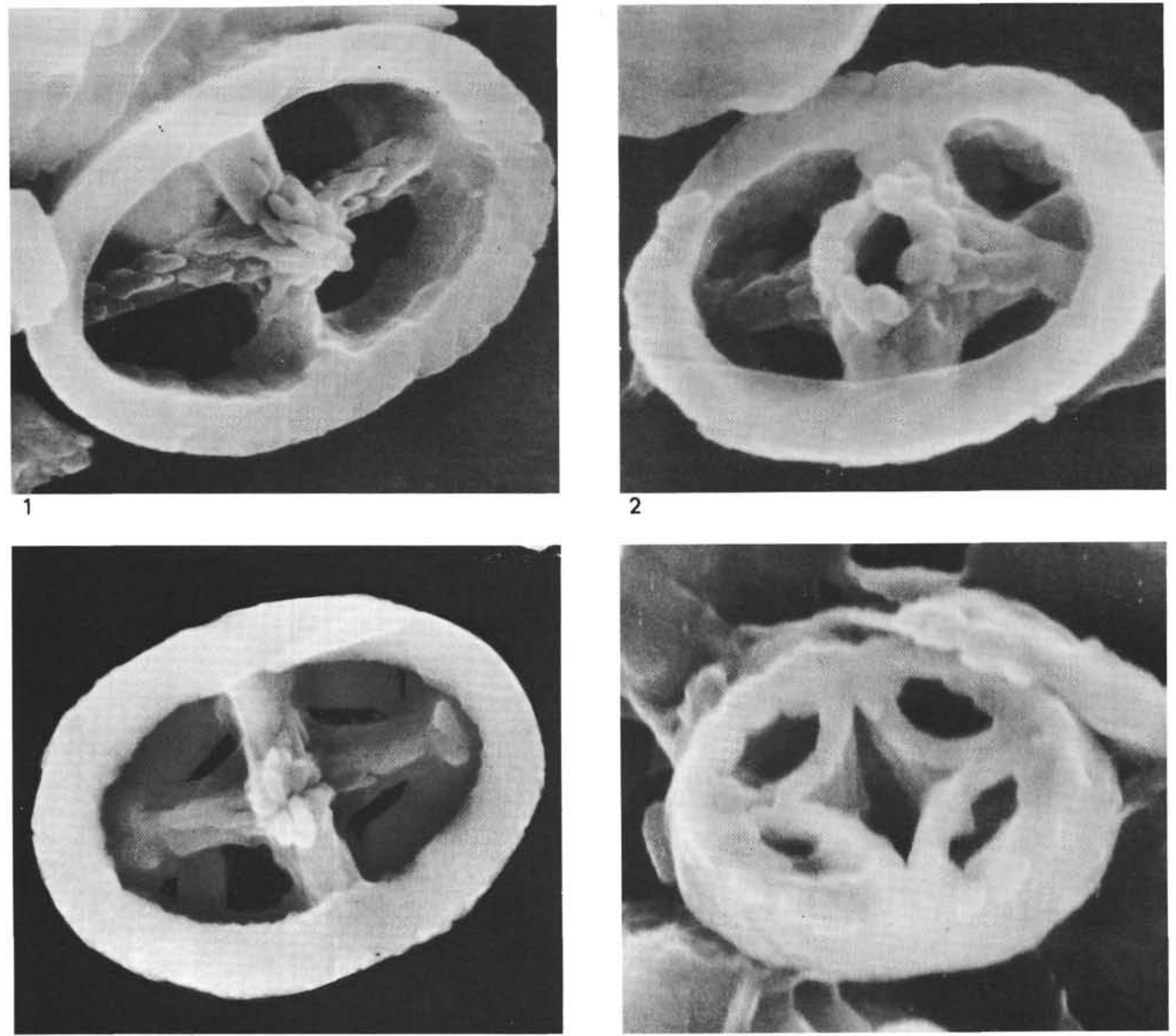

3

4
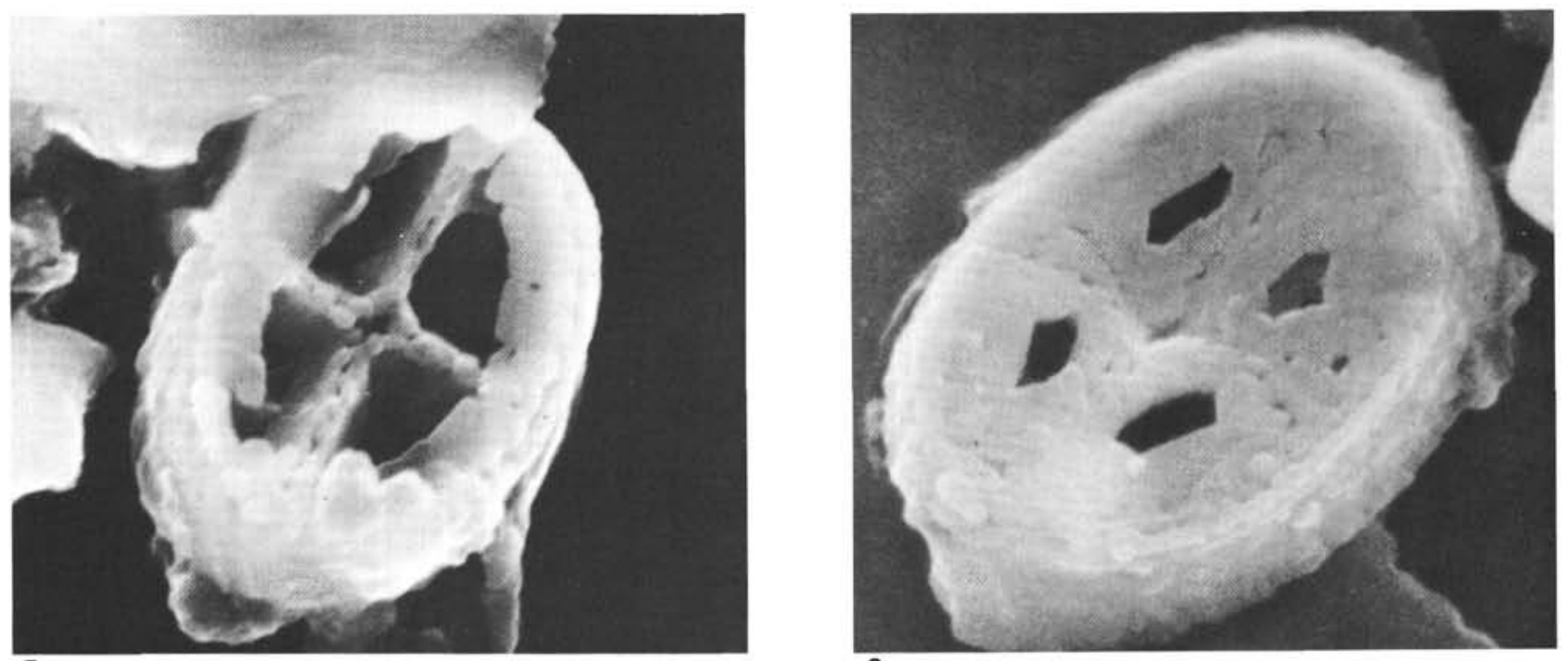

6 


\section{PLATE 85}

(Oxfordian)

Figures 1-5 Corollithion helotatus Wind and Wise, n. sp. 1-3. Holotype USNM 239535, lateral-proximal, lateral, and lateral-distal views, Sample 330-8-1, $107 \mathrm{~cm}$.

1. $\times 11,500$.

2. $\times 11,000$.

3. $\times 14,500$.

4. Paratype USNM 239541, lateral-distal view, Sample 330-7-5, $120 \mathrm{~cm}, \times 12,000$.

5. Paratype USNM 239542, distal view of spineless form, Sample $330-8-1,107 \mathrm{~cm}, \times 24,000$.

Figure 6 Cyclagelosphaera margareli Noël, distal view, Sample $330-7-5,120 \mathrm{~cm}, \times 12,000$. 


\section{PLATE 85}
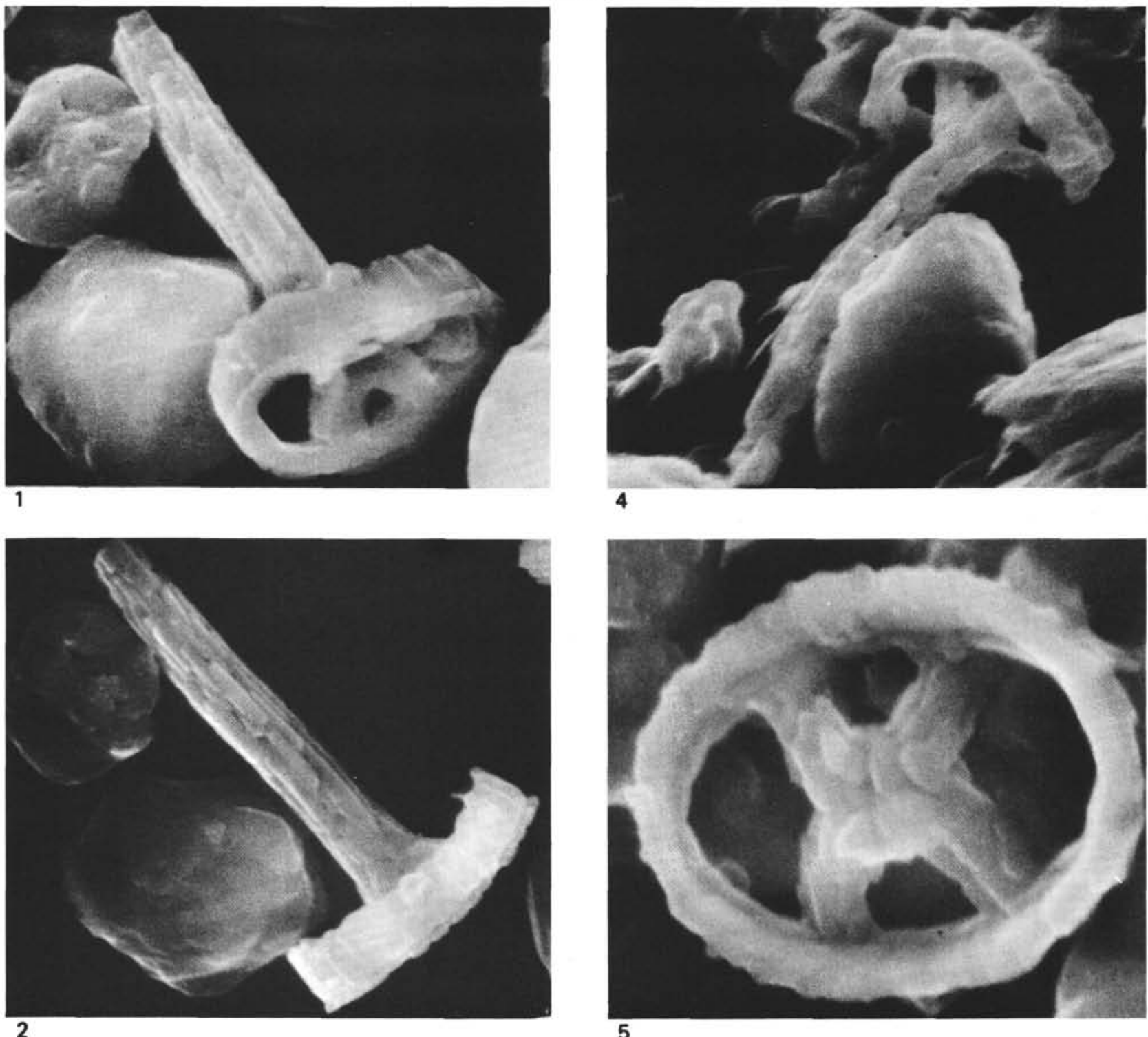

4
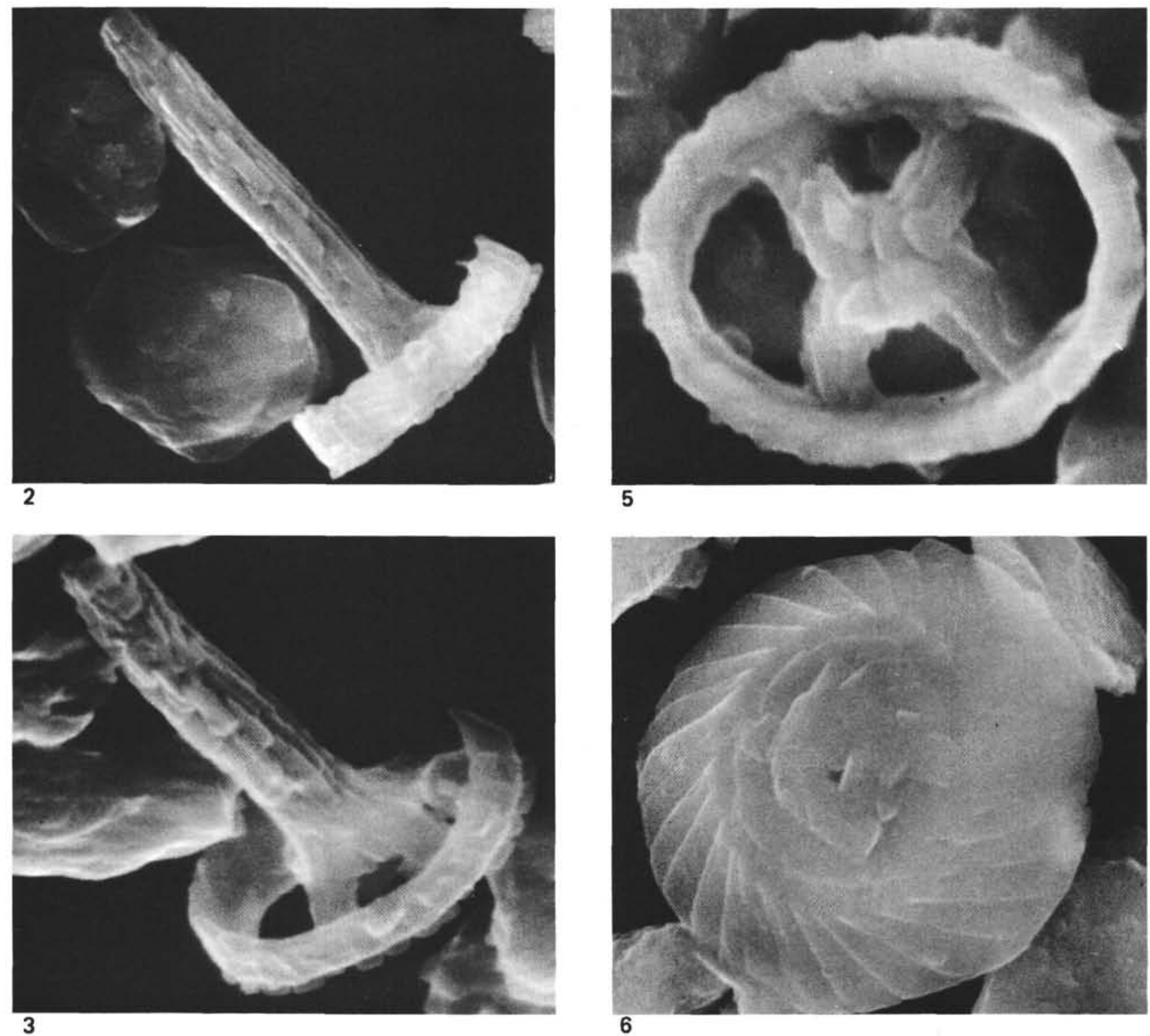


\section{PLATE 86}

(Oxfordian)

Figure 1

Watznaueria communis Reinhardt, coccosphere with placolith of $W$. britannica (arrow), Sample $330-7-5,120 \mathrm{~cm}, \times 4500$.

Figure 2 Watznaueria communis Reinhardt, distal view, Sample 330-7-5, $120 \mathrm{~cm}, \times 14,000$.

Figure 3 Watznaueria reinhardti, Rood, Hay, and Barnard, distal view, Sample 330-7-5, $120 \mathrm{~cm}, \times 13,000$.

Figure 4 Watznaueria britannica (Stradner) Reinhardt, proximal view, Sample 330-7-5, $120 \mathrm{~cm}, \times 12,000$.

Figure 5 Watznaueria communis Reinhardt, proximal view, Sample 330-7-5, $120 \mathrm{~cm}, \times 11,000$.

Figure $6 \quad$ Watznaueria sp., distal view (either W. communis Reinhardt or W. barnesae [Black] Bukry), Sample $330-8-1,107 \mathrm{~cm}, \times 12,000$. 


\section{PLATE 86}
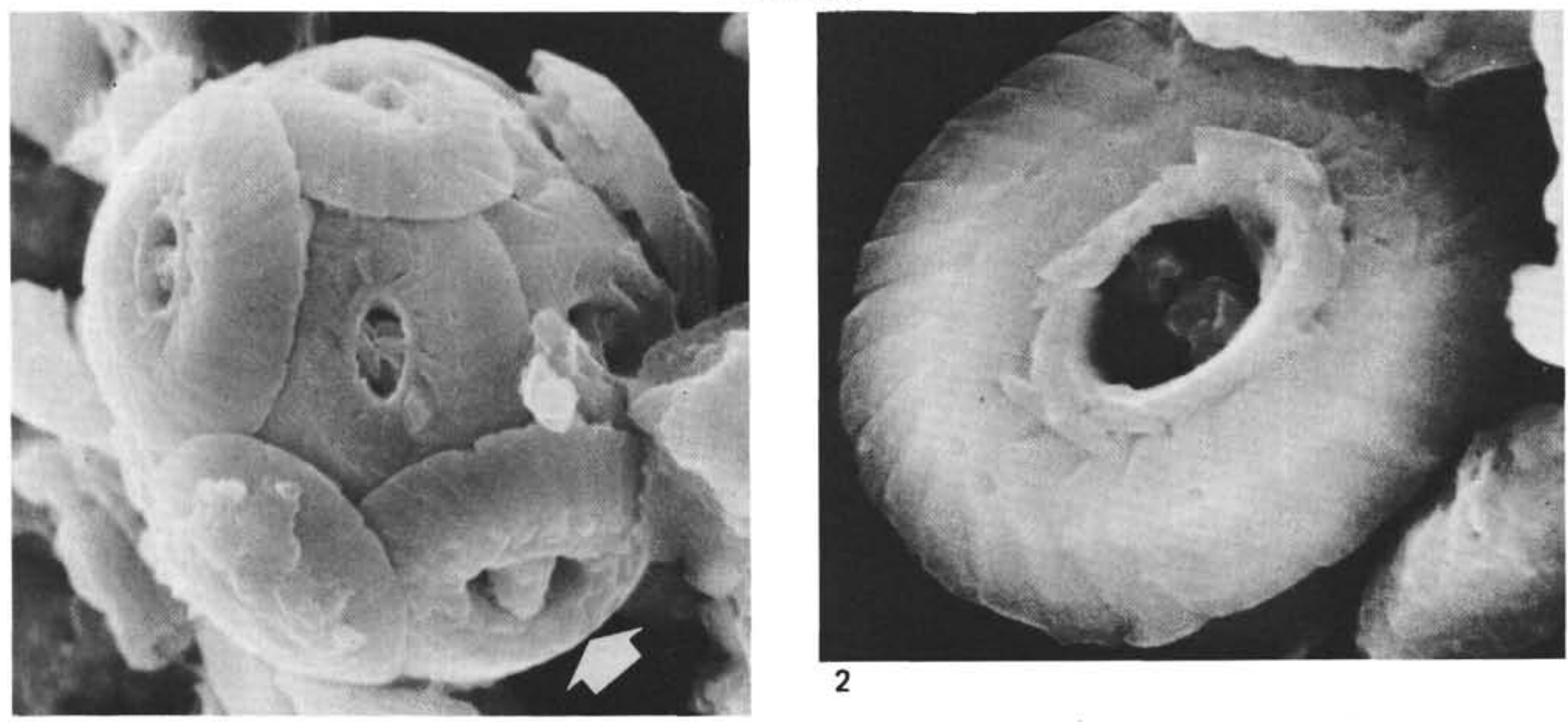

1
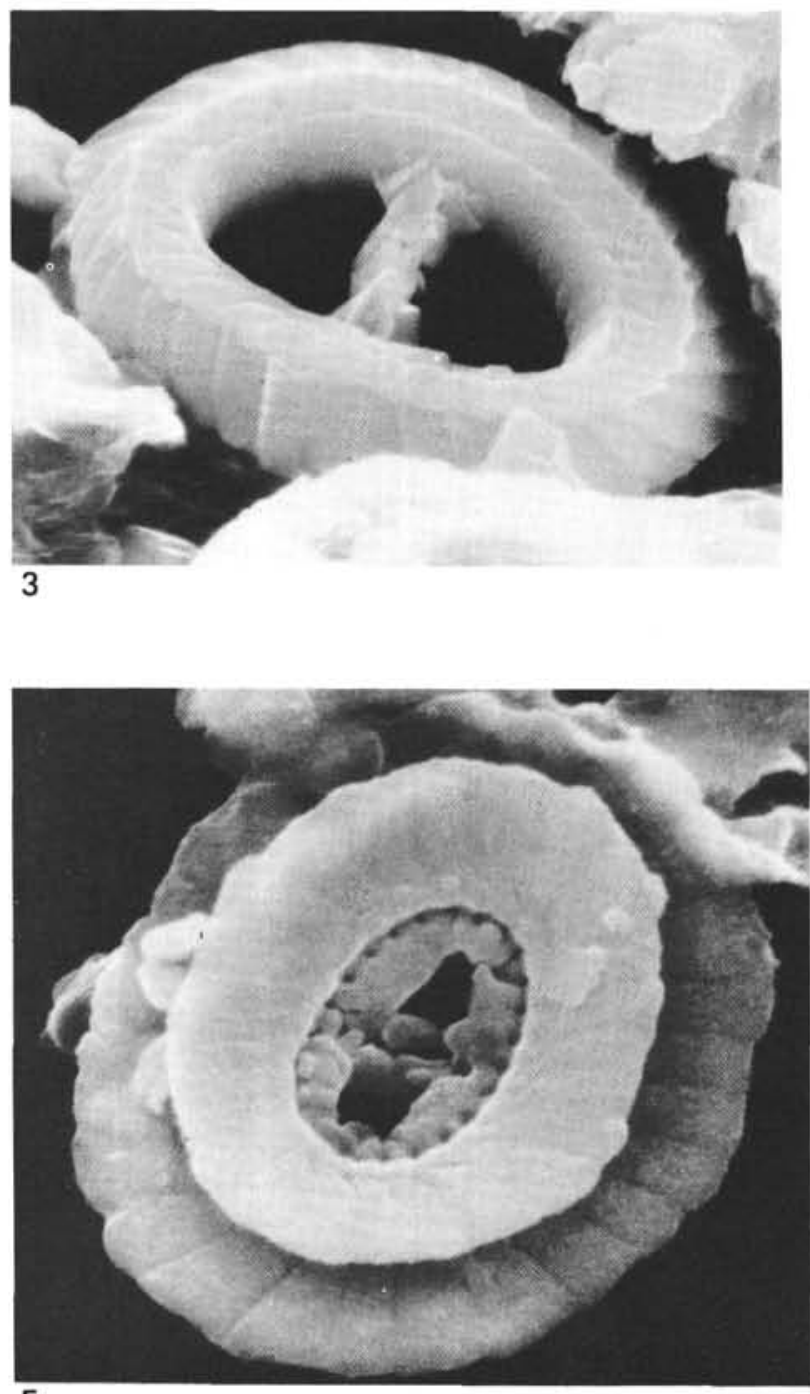

5
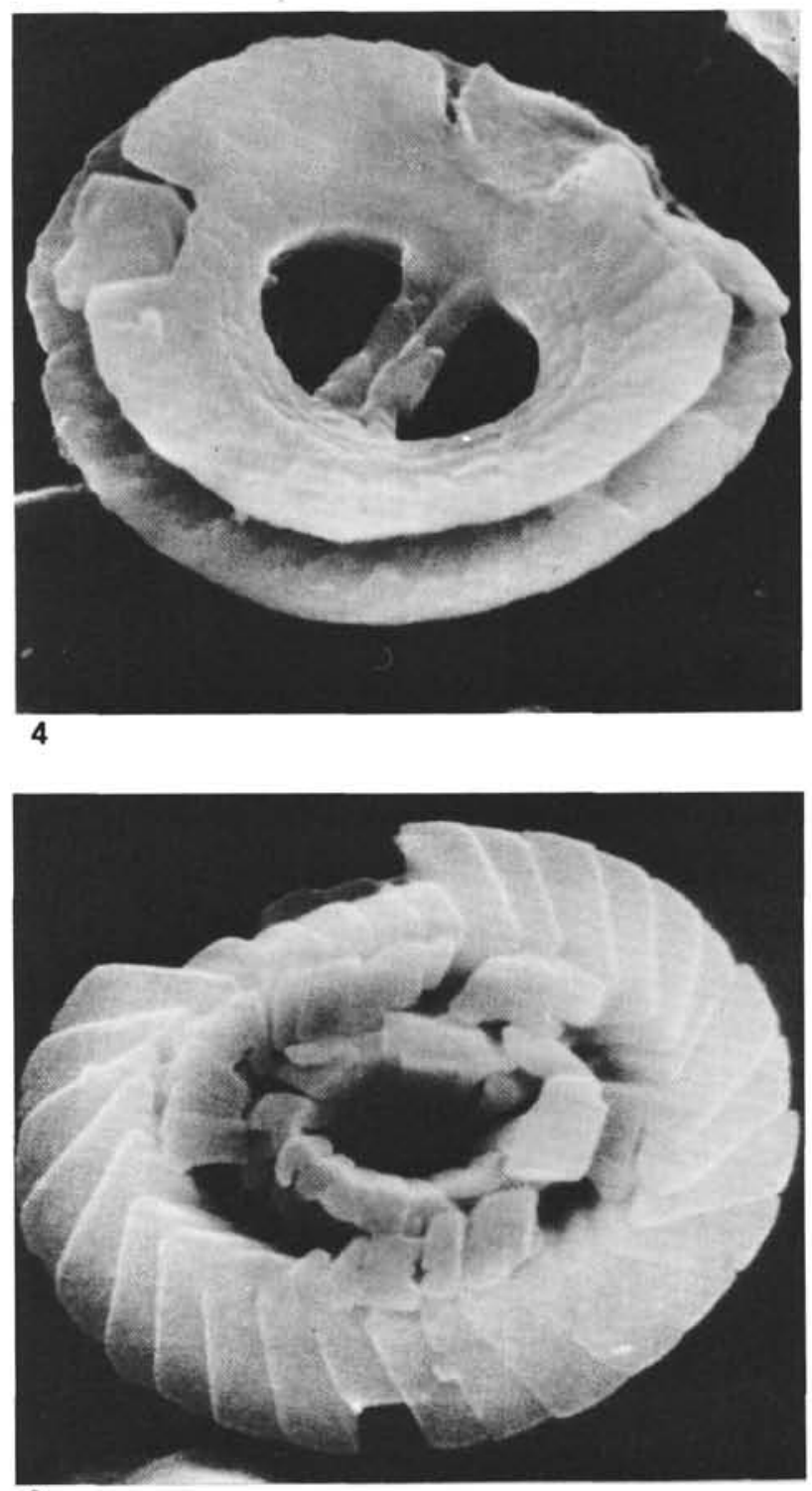

6 


\section{PLATE 87}

(Oxfordian)

Figures 1,2 Cyclagelosphaera margareli Noël, proximal view, Sample $330-7-5,120 \mathrm{~cm}$.

1. $\times 12,000$.

2. $\times 17,000$.

Figures 3, $4 \quad$ Watznaueria sp., proximal view.

3. Sample $330-7-5,120 \mathrm{~cm}, \times 10,000$.

4. Sample $330-7-4,118 \mathrm{~cm}, \times 12,000$.

Figure 5 Stereopair of specimens of Watznaueria and Cyclagelosphaera illustrating modes of preservation, Sample 330-9-2, $100 \mathrm{~cm}, \times 5000$. 


\section{PLATE 87}
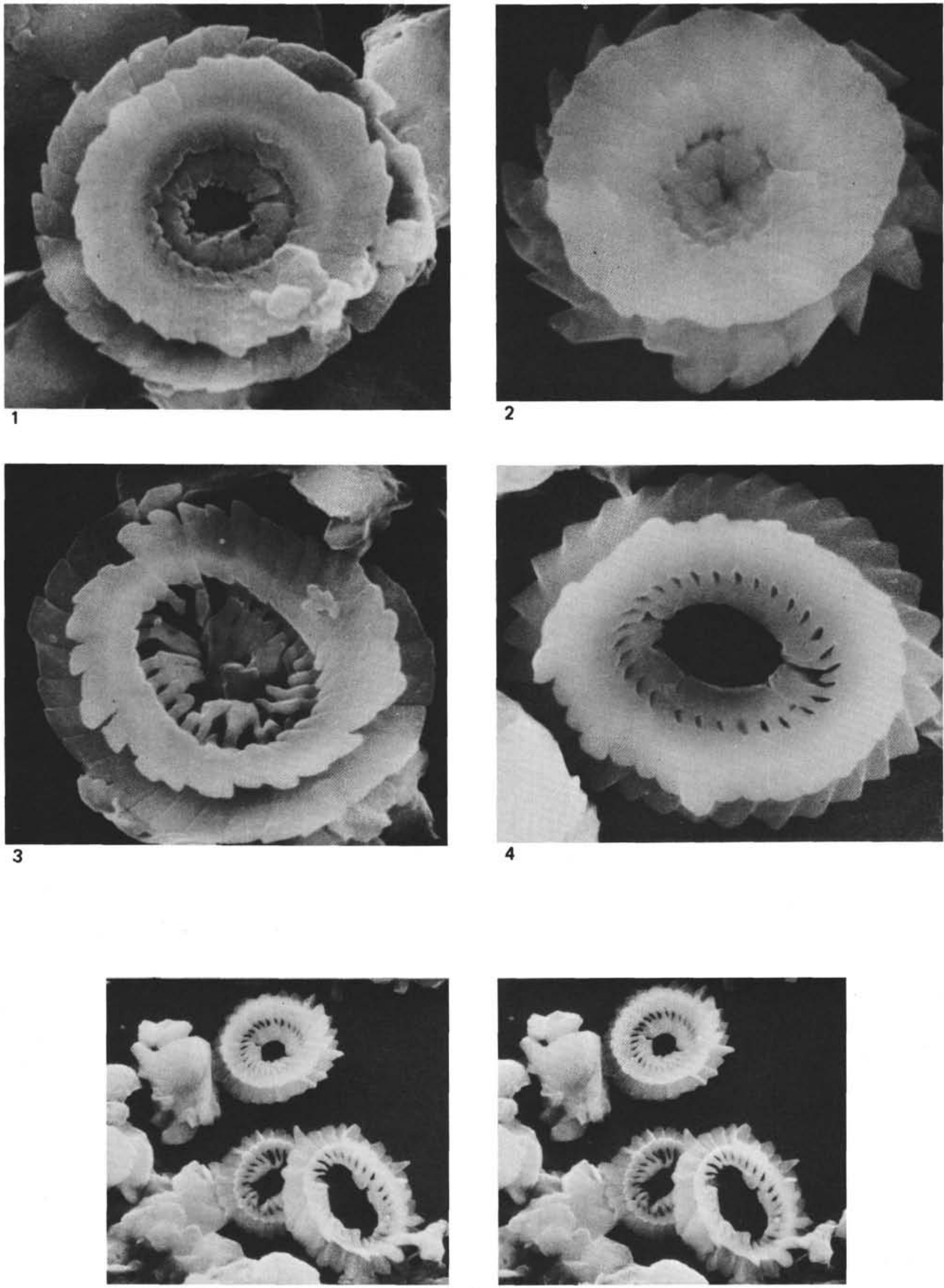

5 


\section{PLATE 88}

(Oxfordian; all figures are phase-contrast micrographs of carbonand gold-palladium-coated samples; magnification $\times 4800$ )

Figures 1, 2 Ethmorhabdus gallicus Noël, Samples 330-6-6, 62 $\mathrm{cm}$ and $330-6-3,25 \mathrm{~cm}$.

Figures 3, $4 \quad$ Polypodorhabdus escaigi Noël, Samples 330-6-6, 62 $\mathrm{cm}$ and $330-7-5,120 \mathrm{~cm}$.

Figures 5,6 Axopodorhabdus cylindratus (Noël) Wind and Wise, n. comb.

Figure 7 Watznaueria communis Reinhardt, Sample 330-6$3,25 \mathrm{~cm}$.

Figure 8 Watznaueria britannica (Stradner) Reinhardt, Sample 330-7-5, $120 \mathrm{~cm}$.

Figure 9 Watznaueria reinhardti Rood, Hay, and Barnard, Sample 330-6-3, $25 \mathrm{~cm}$.

Figure 10 Cyclagelosphaera margareli Noël, Sample 330-6-3, $25 \mathrm{~cm}$.

Figure $11 \quad$ Watznaueria barnesae (Black) Bukry, Sample 330$6-2,25 \mathrm{~cm}$.

Figure 12 Retecapsa tridentata Wind and Wise, n. sp., paratype USNM 239543, Sample 330-6-3, $25 \mathrm{~cm}$. 


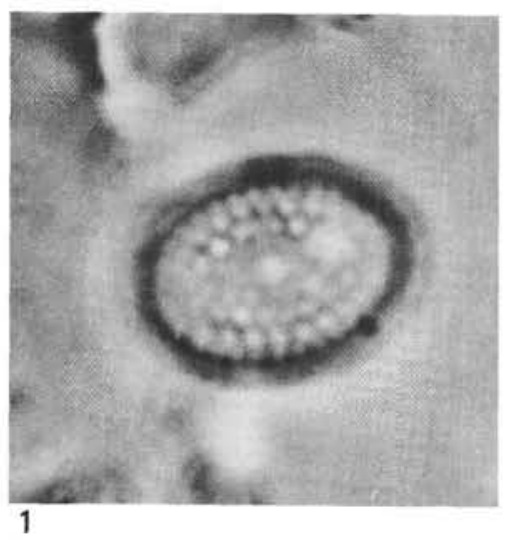

PLATE 88
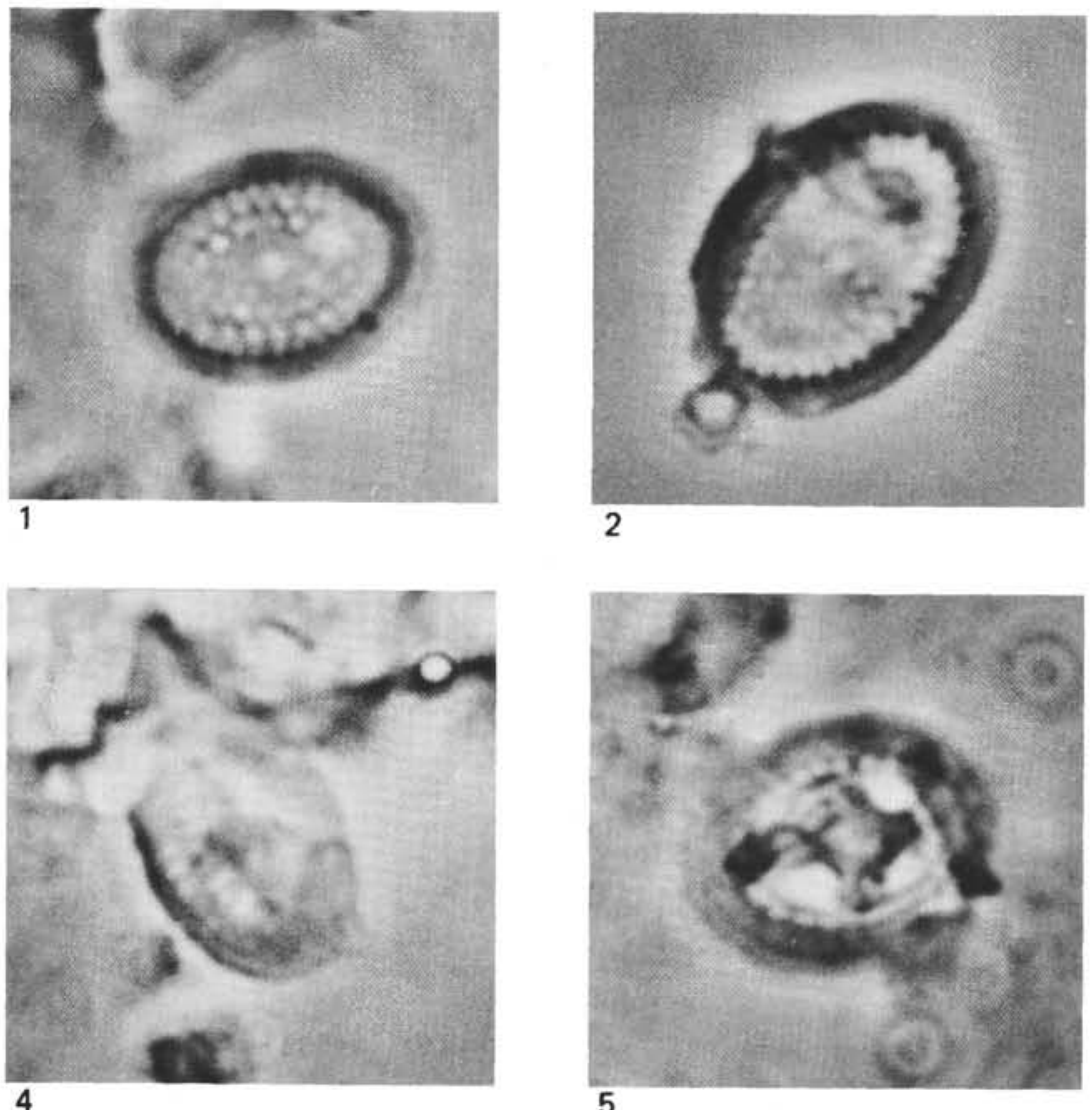

4
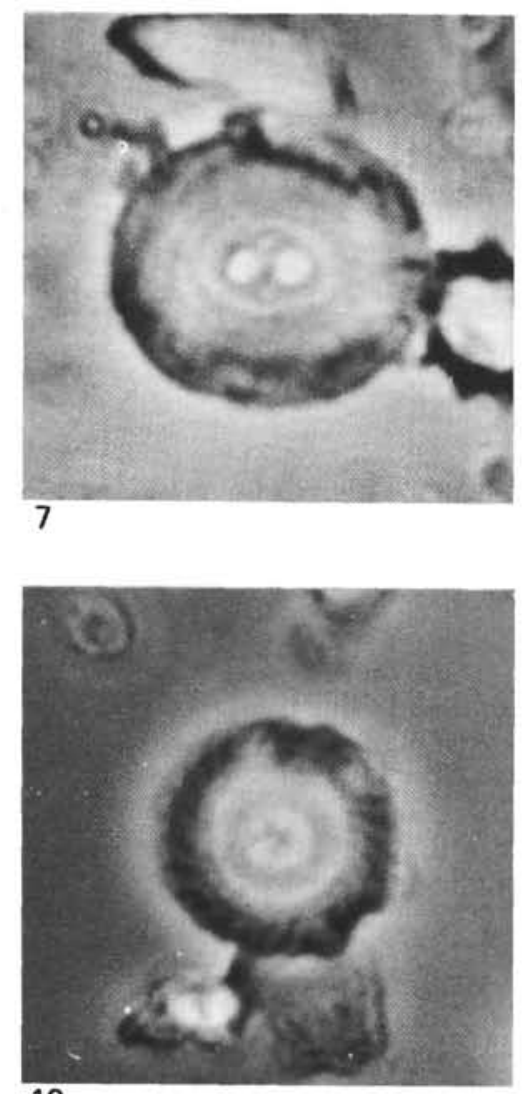
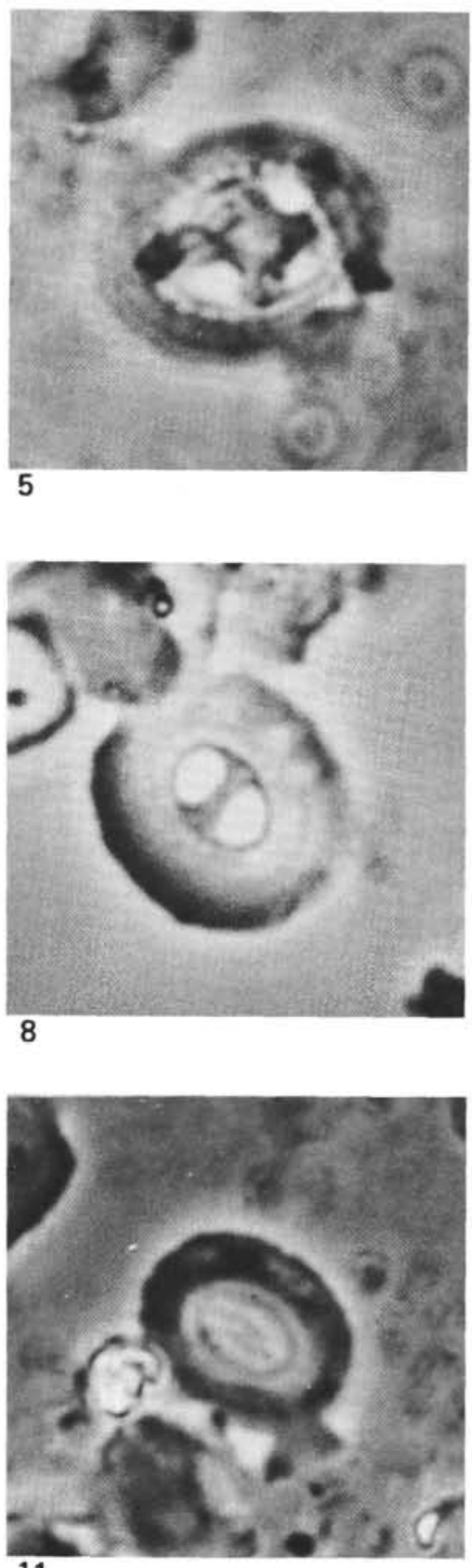

11
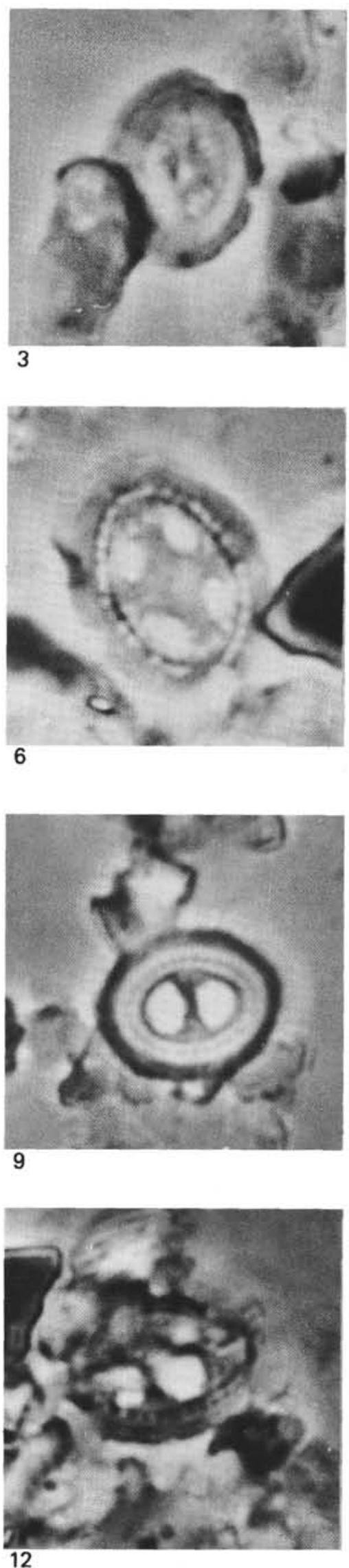


\section{PLATE 89}

(Oxfordian; all figures are phase-contrast light micrographs of carbon- and gold-palladium-coated samples; magnification, $\times 4800$ )

Figures 1-6 Stephanolithion bigoti Deflandre.

1. Sample 330-6-6, $62 \mathrm{~cm}$.

2, 3. Sample $330-5-2,14 \mathrm{~cm}$.

4, 5. Sample $330-8-1,107 \mathrm{~cm}$.

Figure 7

Vekshinella stradneri Rood, Hay, and Barnard, Sample 330-6-3, $25 \mathrm{~cm}$.

Figure 8 ?Corollithion helotatus Wind and Wise, n. sp., Sample 330-5-2, $14 \mathrm{~cm}$.

Figure 9 Corollithion ellipticum Bukry, Sample 330-3-2, 115 $\mathrm{cm}$.

Figures 10,11 Corollithion senarius Wind and Wise, n. sp., Sample $330-6-3,25 \mathrm{~cm}$.

10. Paratype USNM 239544.

11. Paratype USNM 240450.

Figure 12 Zeugrhabdotus noeli Rood, Hay, and Barnard, Sample 330-6-3, $25 \mathrm{~cm}$. 
PLATE 89
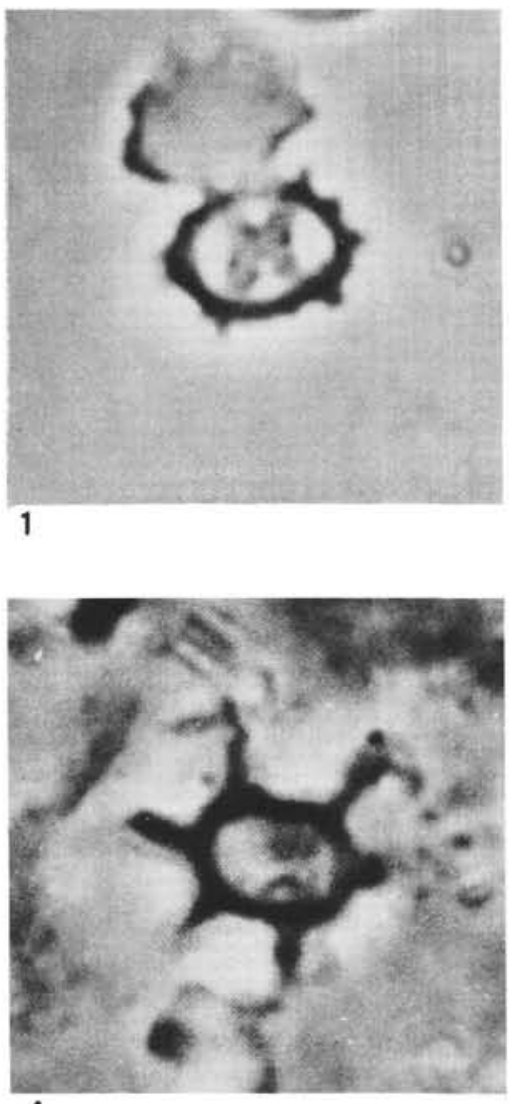

4
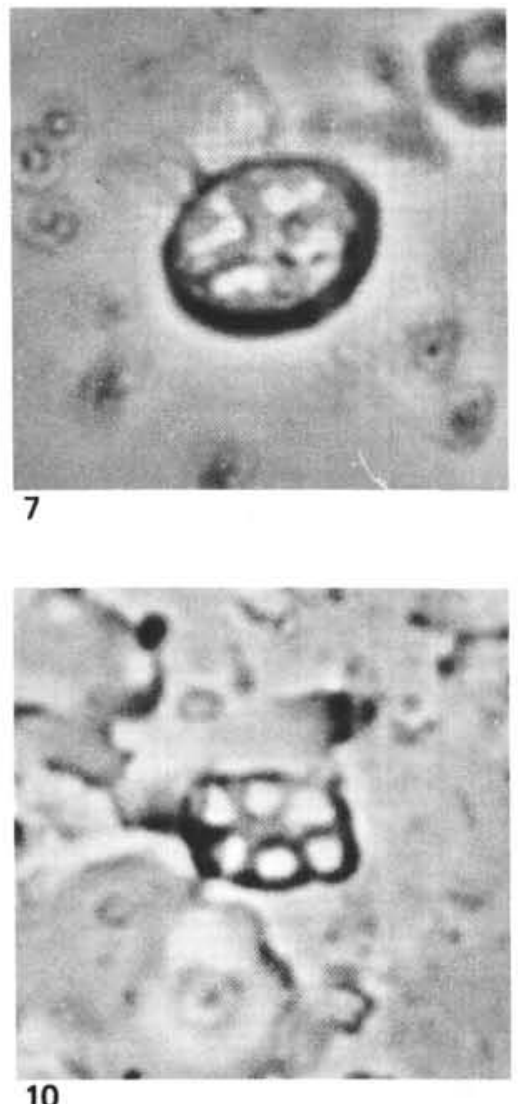

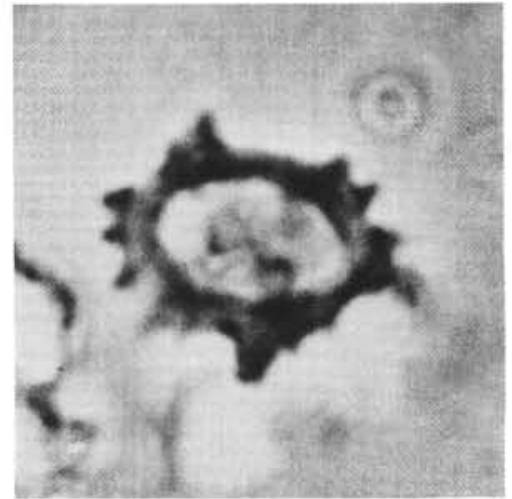

2

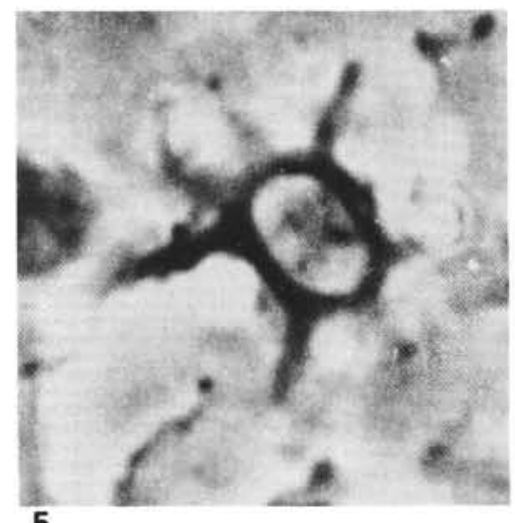

5
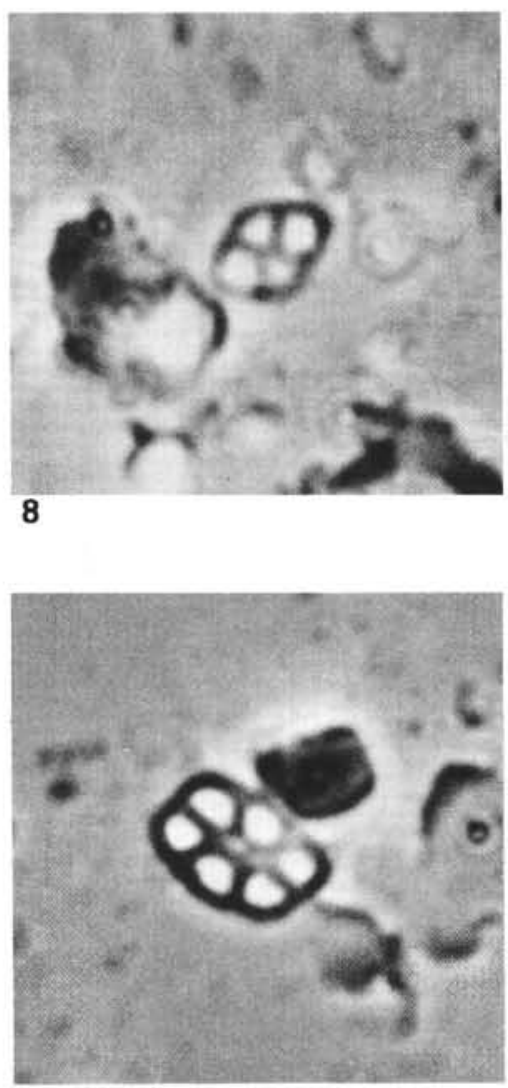

11

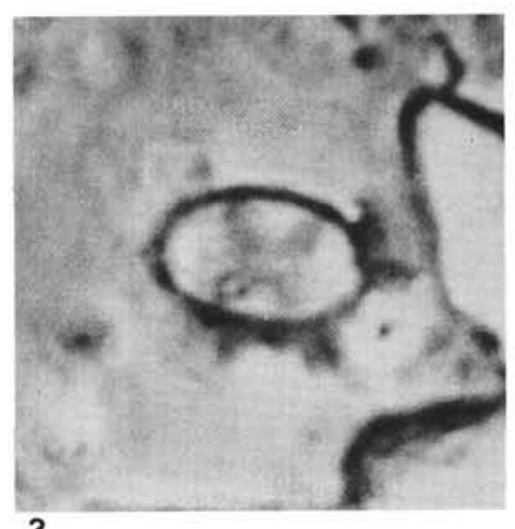

3
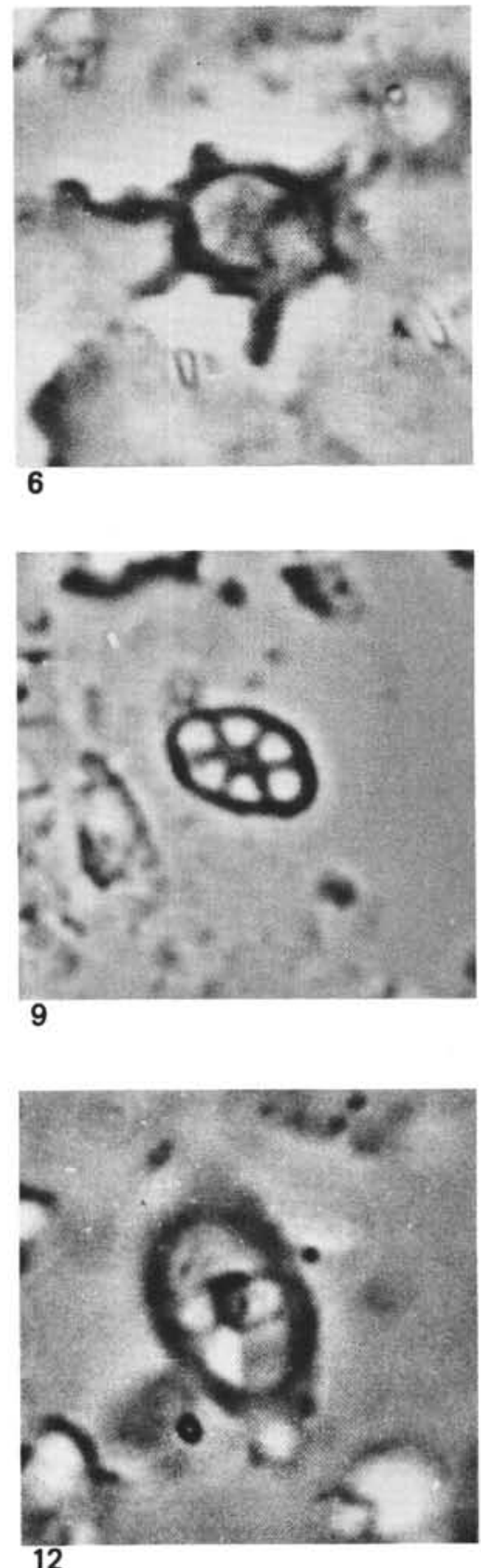